\title{
A TAXONOMIC REVISION OF THE GENUS \\ Dracophyllum Labill. (Ericaceae)
}

\author{
by \\ Stephanus Venter
}

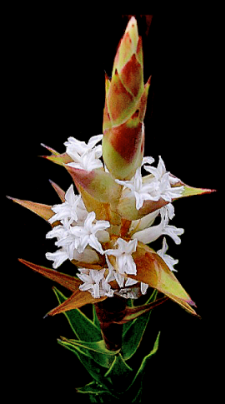

A thesis

Submitted to the Victoria University of Wellington in fulfillment of the requirements for the degree of Doctor of Philosophy in Botany

Victoria University of Wellington 2009 


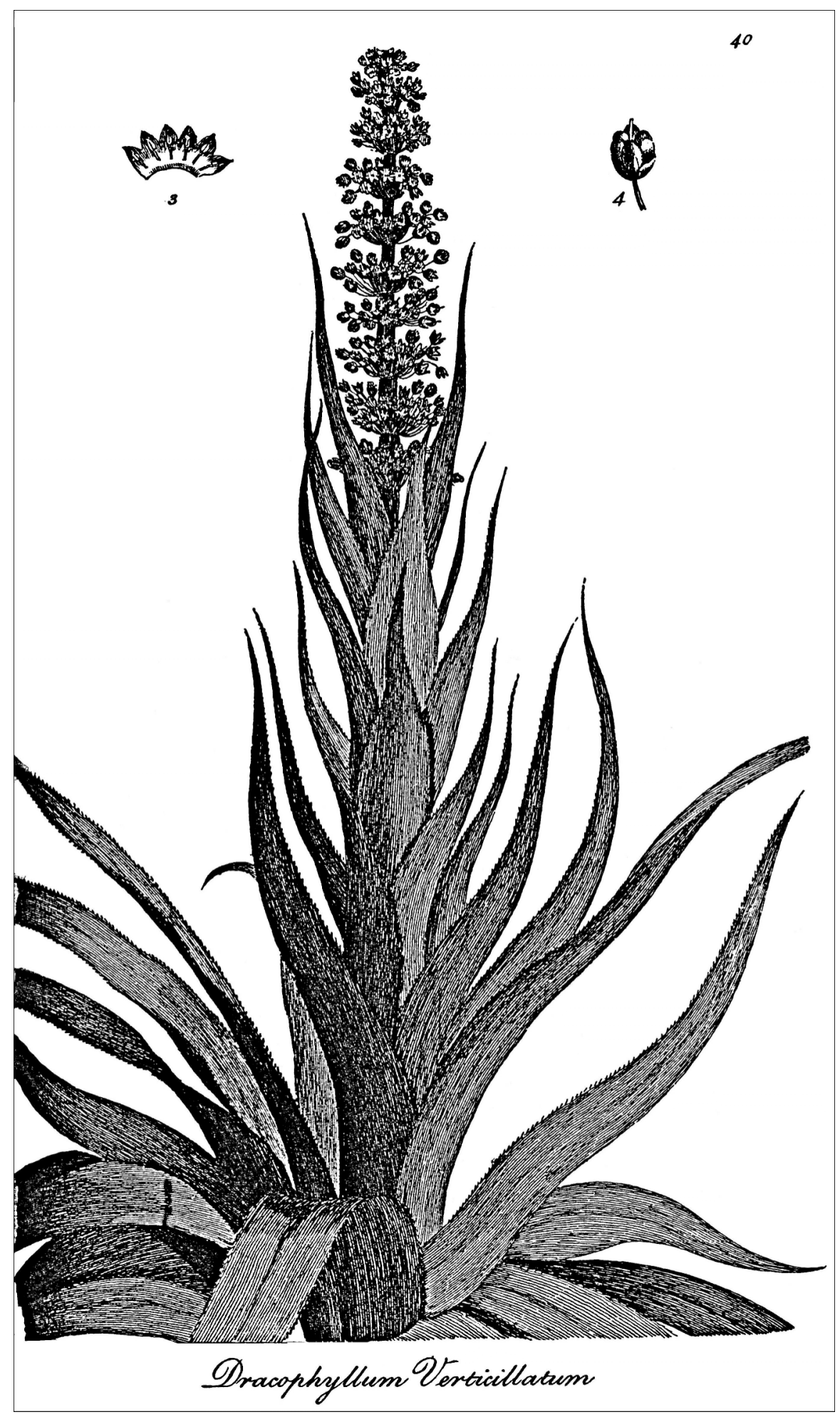

Dracophyllum verticillatum from Rèlation du voyage à la recherche de la Pérouse 2: t. 40 (1800) by J.J.H. de Labillardière. 


\section{CONTENTS}

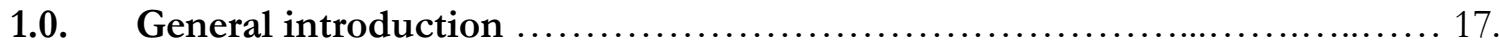

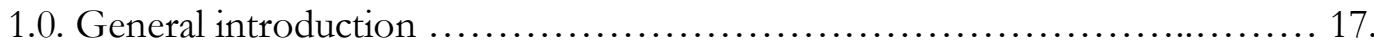

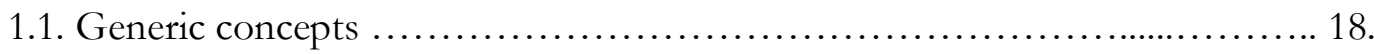

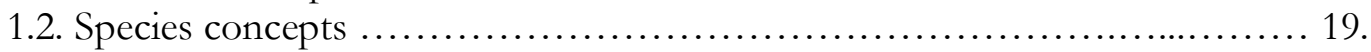

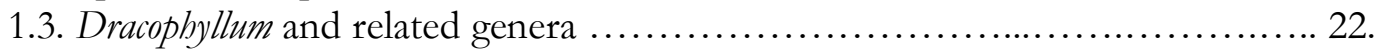

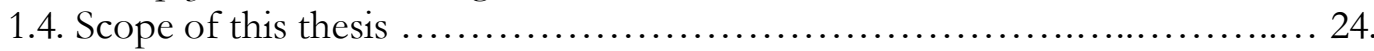

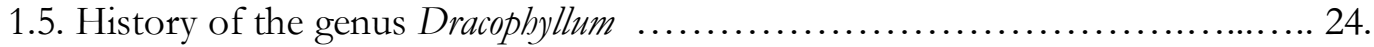

1.6. Familial placement of Dracophyllum ................................... 31 .

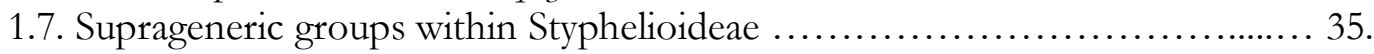

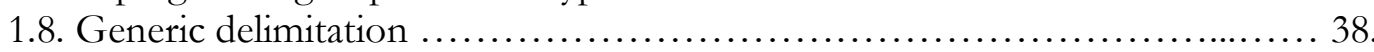

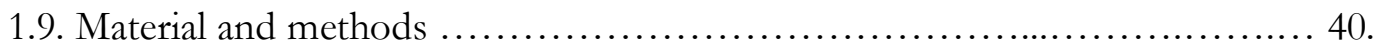

1.10. Aims of this thesis ............................................... 56.

2.0. Phylogenetic analysis of the Dracophyllum complex: evidence from morphology and anatomy ................................. 57.

2.1. Introduction .................................................... 57.

2.2. Materials and methods .................................................. 58.

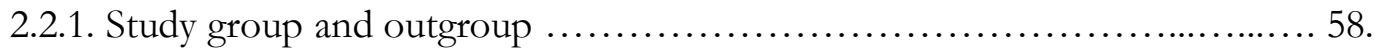

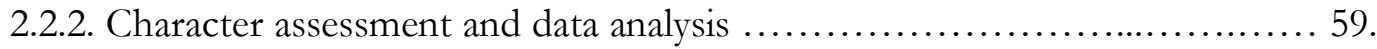

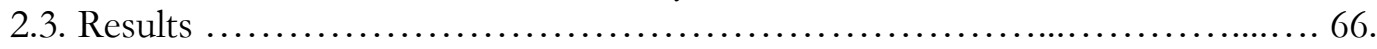

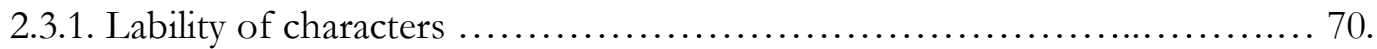

2.4. Discussion ....................................................... 71 .

2.4.1. Major clades of Dracophyllum, Richea and Sphenotoma ...................... 71.

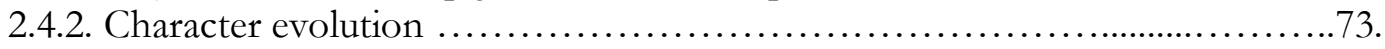

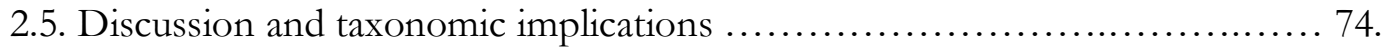

3.0. Classification, biogeography and endemism of the Dracophyllum

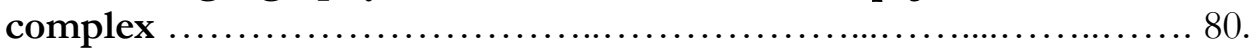

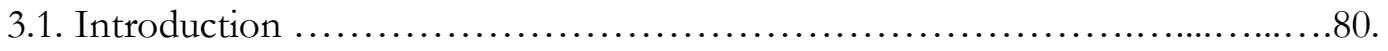

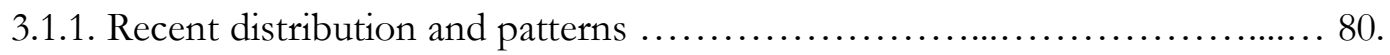

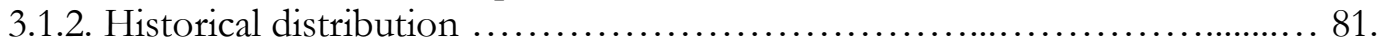

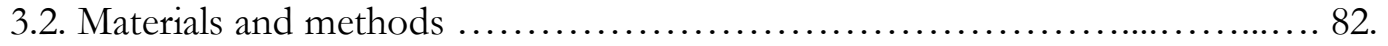

3.3. Results ......................................................... 83.

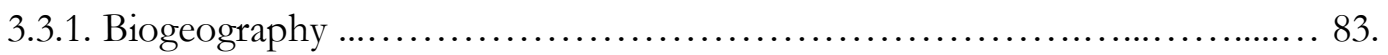

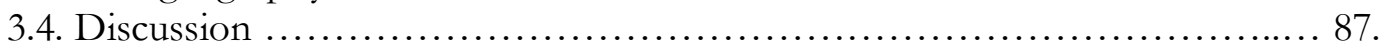

4.0. Species limits and variation in Dracopbyllum and Oreothamnus ................................................... 92.

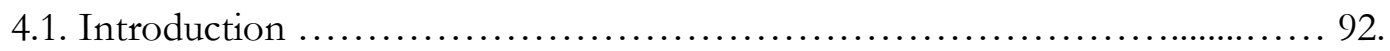

4.2. Materials and methods .............................................. 94.

4.3. Results ....................................................... 101.

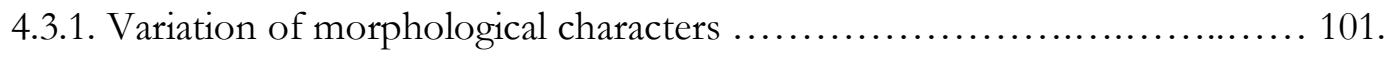

4.3.1.1. Oreothamnus rosmarinifolius .........................................

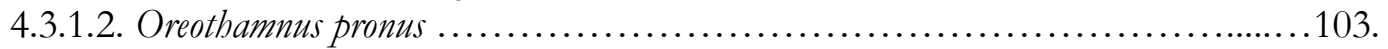


4.3.1.3. Oreothamnus urvilleanus ..........................................104.

4.3.2. Phenotypic responses and differences between ecotypes .................. 105.

4.3.3. Differences between species ....................................... 110.

4.3.3.1. Dracophyllum elegantissimum, D. latifolium and D. traversii .................. 110.

4.3.3.2. Oreothamnus muscoides, O. politus and O. pronus ........................... 111.

4.3.4. Phenetic study of similarity among Dracophyllum and Oreothamnus spp....... 112.

4.4. Discussion ................................................... 118.

\subsection{Taxonomic significance of anatomical characters of the leaf in} Dracopbyllum and Oreothamnus ........................... 119.

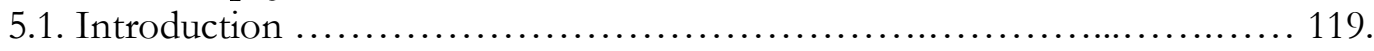

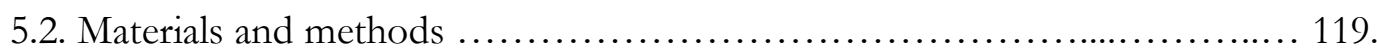

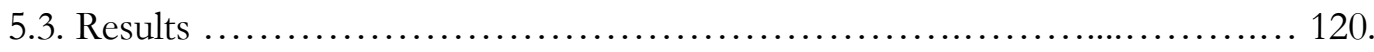

5.3.1. Cuticle ..................................................... 120.

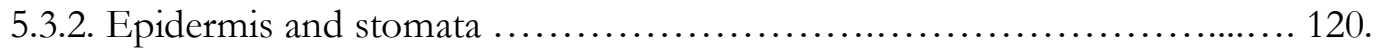

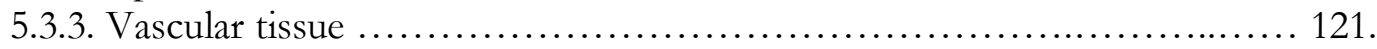

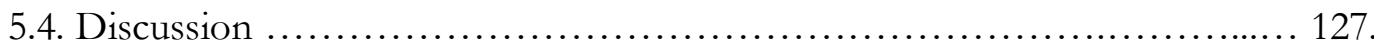

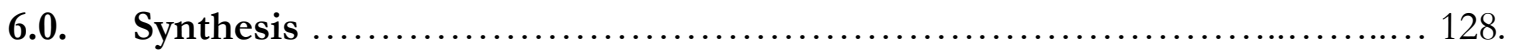

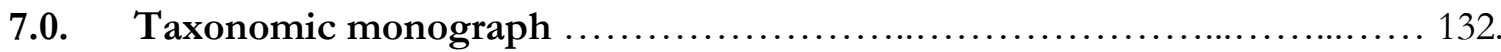

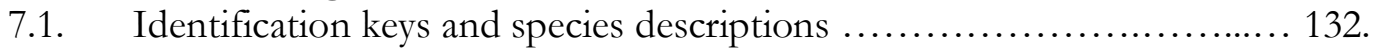

7.1.1. Key to the genera ............................................. 132.

7.2. Dracophyllum Labill. ............................................. 132.

7.2.1. Key to the genus Dracophyllum ................................... 135.

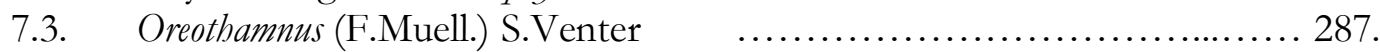

7.3.1. Key to the genus Oreothamnus .................................... 290.

7.4. NOMINA DUBIA AND NOMINA EXCLUSA ......................... 508.

7.5. References ................................................. 513.

\section{List of Appendices}

Appendix 1. Material used for leaf anatomical and epicuticular wax studies ............ 547.

Appendix 2. Material for SEM pollen studyies.................................. 548.

Appendix 3. Lamina length ( $\mathrm{mm}$ ) for 10 leaves per plant from a single plant in 10 widely separated populations of Oreothamnus rosmarinifolius ................. 548.

Appendix 4. Lamina length (mm) for 10 leaves per plant from 9 individual plants (A $\mathrm{J}$ ) in a population of Oreothamnus rosmarinifolius from Fiordland (Venter $13806)$....................................................... 548. 
Appendix 5. Lamina measurements ( $\mathrm{mm}$ ) for 95 leaves of Oreothamnus rosmarinifolius from a single population at Mt. Arthur ............................ 549.

Appendix 6. Oreothamnus urvilleanus. Leaf measurements ( $\mathrm{mm}$ ) for 37 leaves from the Kaiteriteri population and 11 leaves from the Whangamoa Saddle population

Appendix 7. Oreothamnus pronus. Leaf measurements ( $\mathrm{mm}$ ) for 15 leaves from Dun Mountain (Venter 13786) and 15 leaves from Foggy Peak (Venter 13755).

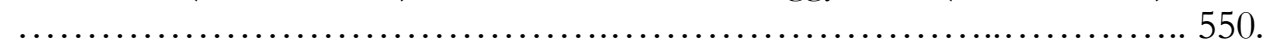

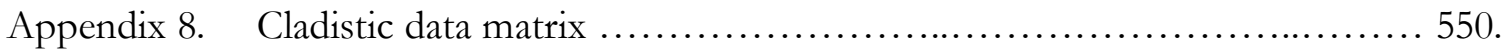

\section{List of figures}

Figure 1.1. The $14^{\circ}(15)$ square mapping system. The whole block is $1^{\circ}$ by $1^{\circ}$ and each small block is a $1 / 4^{\circ}$ by $1 / 4^{\circ}(15)$.

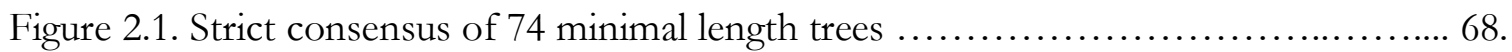

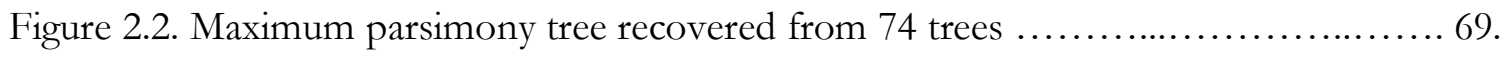

Figure 3.1. Known distribution of the genus Dracophyllum .......................... 84.

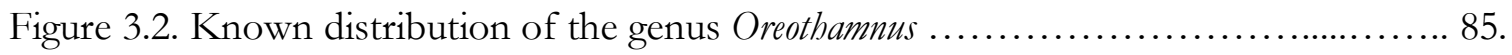

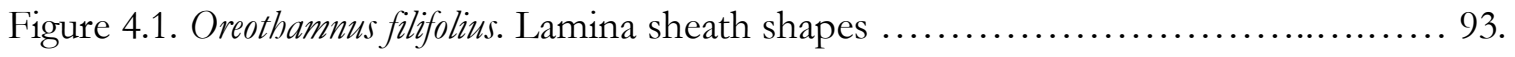

Figure 4.2. Survey of measurements of the leaf and inflorescence bracts ............... 95.

Figure 4.3. Pictorialized map showing variation in growth habit, shape and size of the lamina sheath and shape of the lamina apex in Oreothamnus rosmarinifolius. 100.

Figure 4.4. Leaf variation in Oreothamnus rosmarinifolius. Lamina length: width measured in 95 individuals from Mt. Arthur, South Island, New Zealand

Figure 4.5. Leaf variation in Oreothamnus rosmarinifolius. Lamina length : width measured in 95 individuals from Mt. Arthur, South Island, New Zealand. 102.

Figure 4.6. Variation in lamina length and width in Oreothamnus pronus. Lamina length : width measured from 15 individuals from an alpine habitat at Foggy Peak

Figure 4.7. Leaf variation in Oreothamnus urvilleanus. Lamina length:width measured from 39 individuals from Kaiteriteri 
Figure 4.8. Compact/complete linkage for the genus Dracophyllum s.l. 113.

Figure 5.1. Schematic representation of fibre bundle shapes in Dracophyllum and Oreothamnus 123.

Figure 5.2. Transverse sections through the adult lamina of Dracophyllum species 125.

Figure 5.3. Transverse sections through the adult lamina of Oreothamnus species 126.

Figure 7.1. Dracophyllum alticola figure 141.

Figure 7.2. Dracophyllum alticola plate 142.

Figure 7.3. Known distribution of Dracophyllum alticola 143.

Figure 7.4. Dracophyllum balansae figure 146.

Figure 7.5. Dracophyllum balansae plate 147.

Figure 7.6. Known distribution of Dracophyllum balansae ... 149.

Figure 7.7. Dracophyllum cosmelioides figure 153.

Figure 7.8. Dracophyllum cosmelioides plate 154.

Figure 7.9. Known distribution of Dracophyllum cosmelioides 155.

Figure 7.10. Dracophyllum elegantissimum figure 160.

Figure 7.11. Dracophyllum elegantissimum plate 161.

Figure 7.12. Known distribution of Dracophyllum elegantissimum 162.

Figure 7.13. Dracophyllum fiordense figure 165.

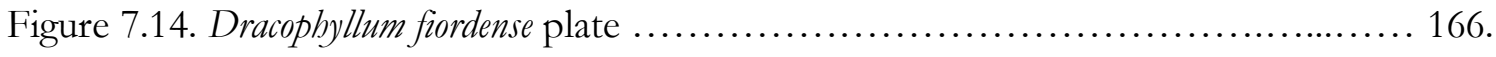

Figure 7.15. Known distribution of Dracophyllum fiordense ............................. 168.

Figure 7.16. Variation in Dracophyllum fiordense .................................... 169.

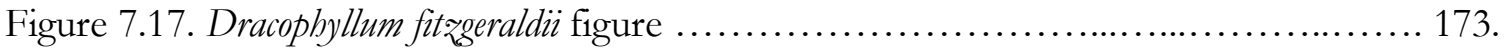

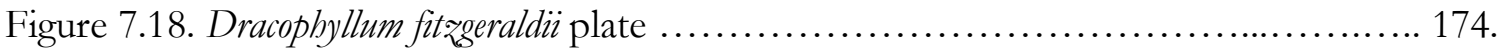

Figure 7.19. Known distribution of Dracophyllum fitggeraldii ............................ 176. 
Figure 7.20. Dracophyllum involucratum figure .................................... 180.

Figure 7.21. Dracophyllum involucratum plate .................................... 181.

Figure 7.22 Known distribution of Dracophyllum involucratum .......................... 182.

Figure 7.23 Dracophyllum latifolium figure ........................................ 187.

Figure 7.24. Dracophyllum latifolium plate ....................................... 188.

Figure 7.25. Known distribution of Dracophyllum latifolium ........................... 190.

Figure 7.26. Dracophyllum mackeeanum figure .................................. 195.

Figure 7.27. Dracophyllum mackeeanum plate ...................................... 196.

Figure 7.28. Known distribution of Dracophyllum mackeeanum .......................... 198.

Figure 7.29. Dracophyllum macranthum figure ................................... 202.

Figure 7.30. Dracophyllum macranthum plate ...................................... 203.

Figure 7.31. Known distribution of Dracophyllum macranthum .......................... 204.

Figure 7.32. Dracophyllum menziesii figure ..................................... 208.

Figure 7.33. Dracophyllum menqiesii plate ........................................ 209.

Figure 7.34. Known distribution of Dracophyllum menæiesii .......................... 210.

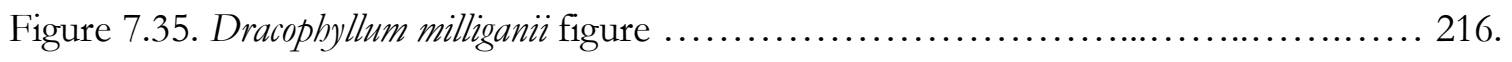

Figure 7.36. Dracophyllum milliganii plate ...................................... 217.

Figure 7.37. Known distribution of Dracophyllum milliganii ........................... 218.

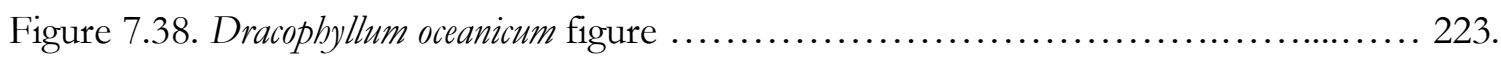

Figure 7.39. Dracophyllum oceanicum plate ....................................... 224.

Figure 7.40. Known distribution of Dracophyllum oceanicum ......................... 225.

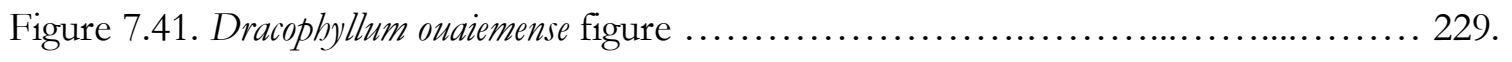

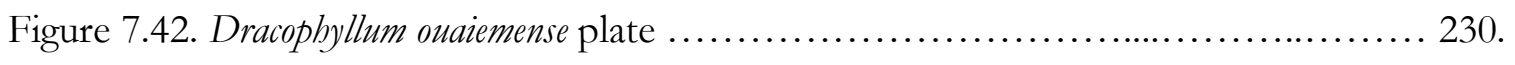

Figure 7.43. Known distribution of Dracophyllum ouaiemense ......................... 231. 


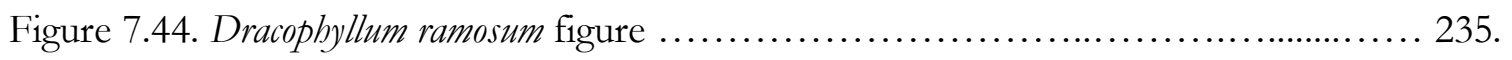

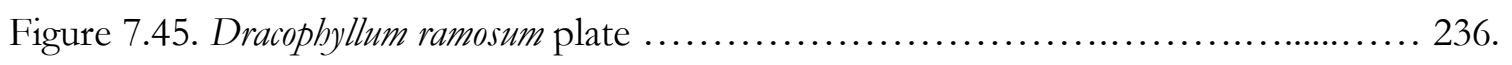

Figure 7.46. Known distribution of Dracophyllum ramosum .......................... 238.

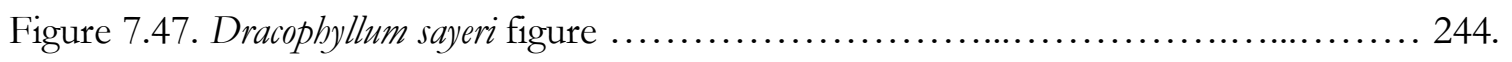

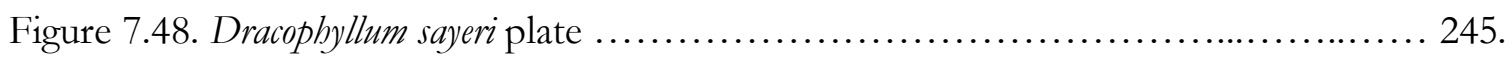

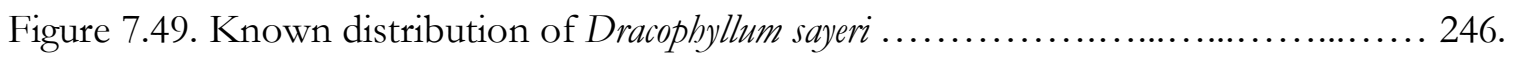

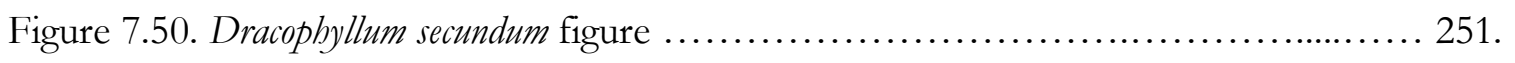

Figure 7.51. Dracophyllum secundum plate .................................... 252.

Figure 7.52. Known distribution of Dracophyllum secundum ......................... 253.

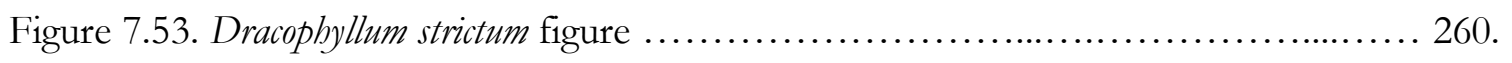

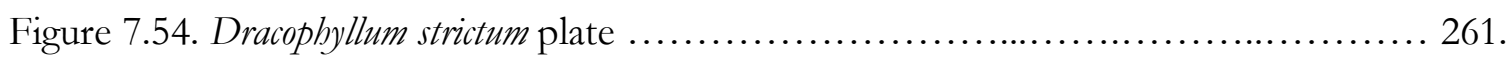

Figure 7.55. Known distribution of Dracophyllum strictum ........................... 262.

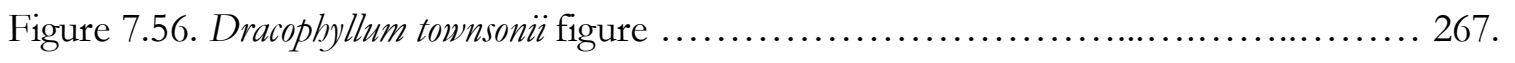

Figure 7.57. Dracophyllum townsonii plate ...................................... 268.

Figure 7.58. Known distribution of Dracophyllum townsonii ........................... 270.

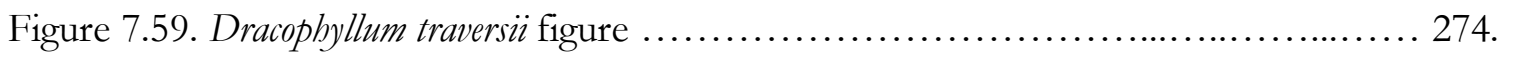

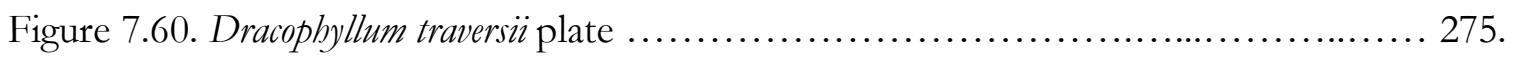

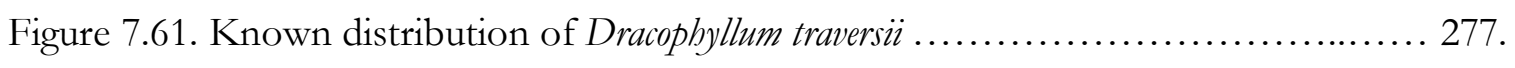

Figure 7.62. Dracophyllum verticillatum figure ................................... 282.

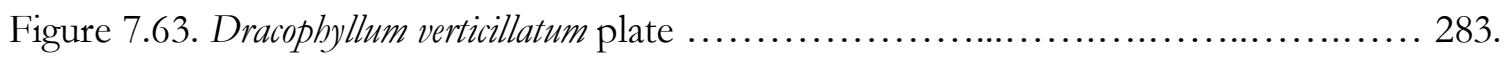

Figure 7.64. Known distribution of Dracophyllum verticillatum ........................ 284.

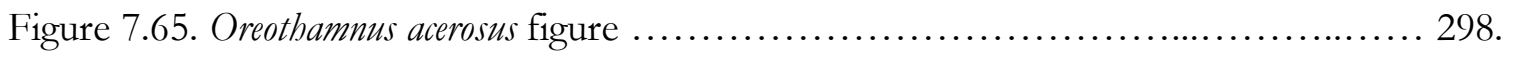

Figure 7.66. Oreothamnus acerosus plate ..................................... 299.

Figure 7.67. Known distribution of Oreothamnus acerosus in New Zealand ................. 301. 


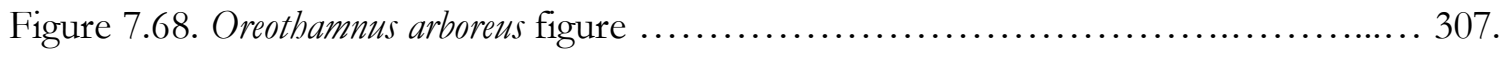

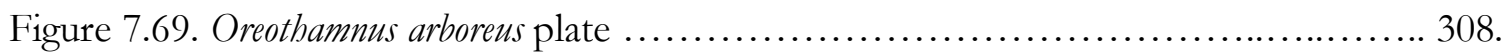

Figure 7.70. Known distribution of Oreothamnus arboreus ............................. 310.

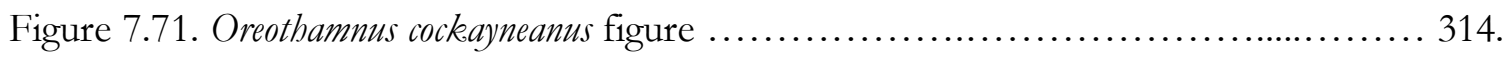

Figure 7.72. Oreothamnus cockayneanus. Habitat on Enderby Island ..................... 315.

Figure 7.73. Known distribution of Oreothamnus cockayneanus .......................... 316.

Figure 7.74. Oreothamnus densus figure ....................................... 320.

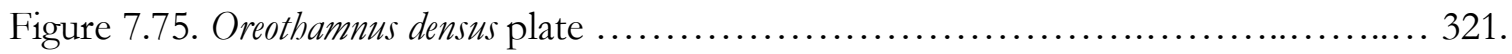

Figure 7.76. Known distribution of Oreothamnus densus. South Island,

New Zealand .................................................................. 323.

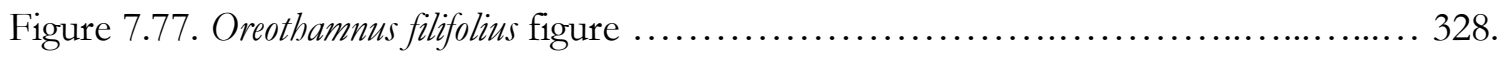

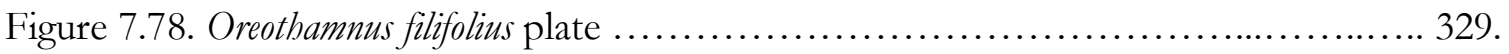

Figure 7.79. Peak nectar flow periods in Dracophyllum traversii ( ) and

Oreothamnus filifolius ( ) ............................................. 330.

Figure 7.80. Known distribution, growth habit and leaf variation in Oreothammus filifolius .............................................................. 331.

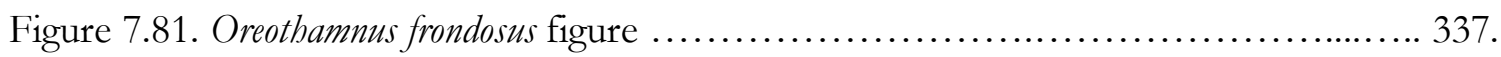

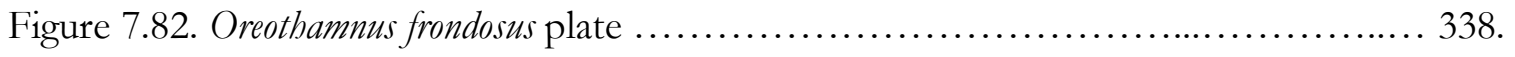

Figure 7.83. Known distribution of Oreothamnus frondosus ........................... 340.

Figure 7.84. Oreothamnus kirkii figure ....................................... 344.

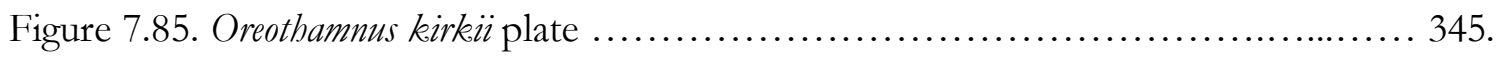

Figure 7.86. Known distribution of Oreothamnus kirkii .............................. 346.

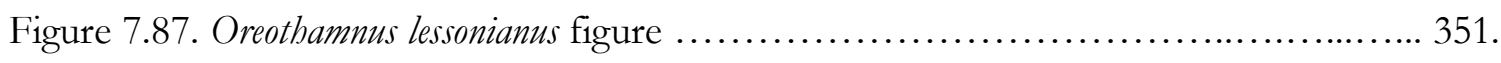

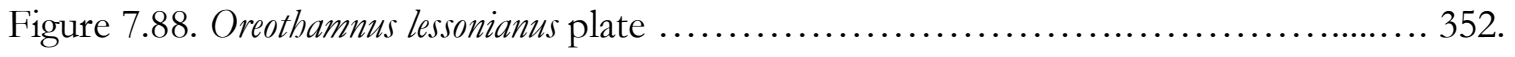

Figure 7.89. Known distribution of Oreothamnus lessonianus, North Island, New

Zealand ............................................................... 354. 


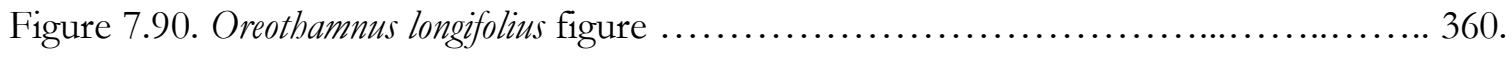

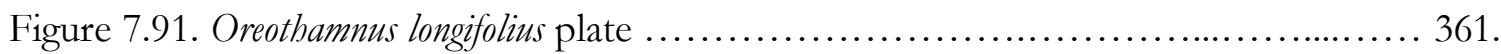

Figure 7.92. Known distribution, variation in growth habit and adult leaf in Oreothamnus longifolius ............................................... 363.

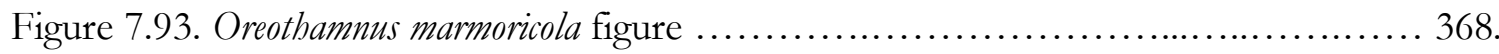

Figure 7.94. Oreothamnus marmoricola plate ....................................... 369.

Figure 7.95. Known distribution of Oreothamnus marmoricola, South Island, New

Zealand ................................................................ 370.

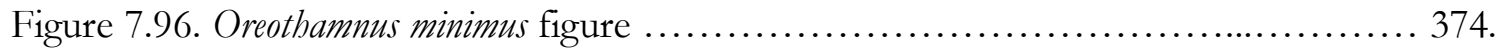

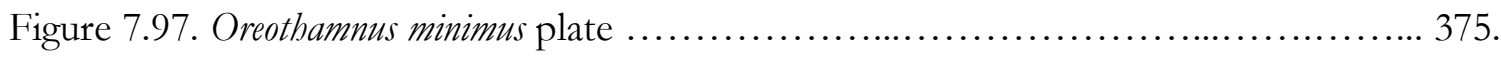

Figure 7.98. Known distribution of Oreothamnus minimus ........................... 377.

Figure 7.99. Oreothamnus muscoideus figure ......................................... 381.

Figure 7.100. Oreothamnus muscoideus plate ...................................... 382.

Figure 7.101. Known distribution of Oreothamnus muscoides ........................... 384.

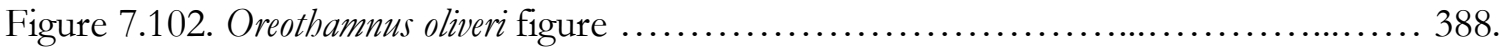

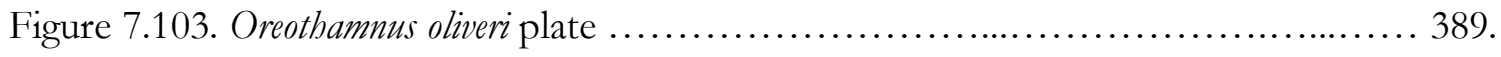

Figure 7.104. Known distribution, habit and leaf variation in Oreothamnus oliveri .......... 391.

Figure 7.105. Oreothamnus opbioliticus figure ...................................... 395.

Figure 7.106. Oreothamnus ophioliticus plate ..................................... 396.

Figure 7.107. Known distribution of Oreothamnus ophioliticus, South Island, New

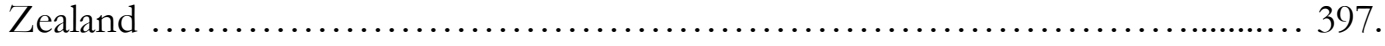

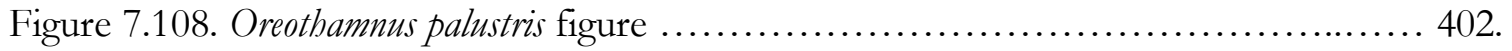

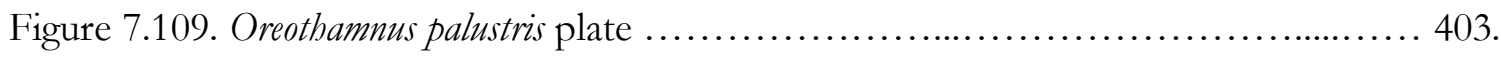

Figure 7.110. Known distribution of Oreothamnus palustris ........................... 404.

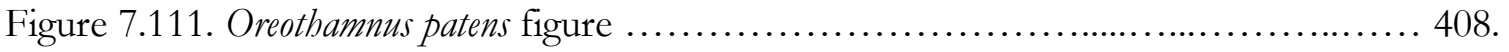

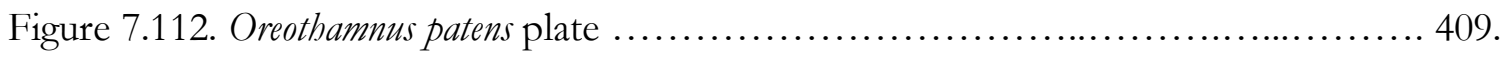




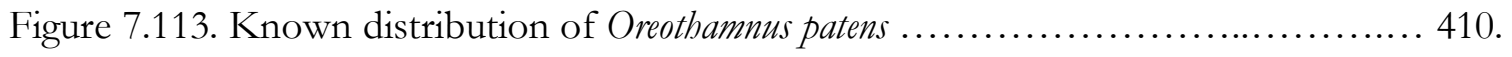

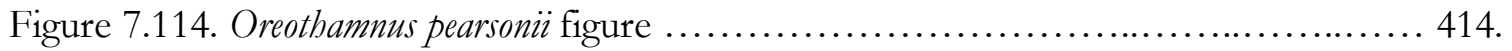

Figure 7.115. Oreothamnus pearsonii plate ....................................... 415.

Figure 7.116. Known distribution of Oreothamnus pearsonii-southern part of the

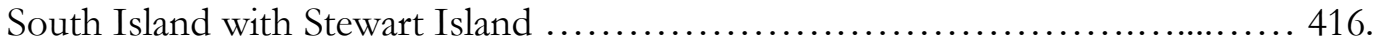

Figure 7.117. Oreothamnus politus figure ......................................... 420.

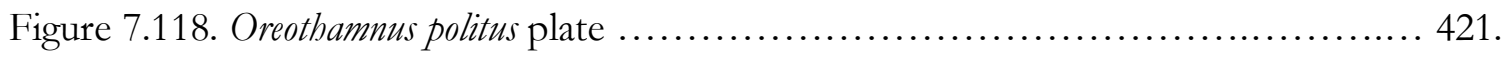

Figure 7.119. Known distribution, growth habit and leaf variation in Oreothamnus politus ............................................................ 422.

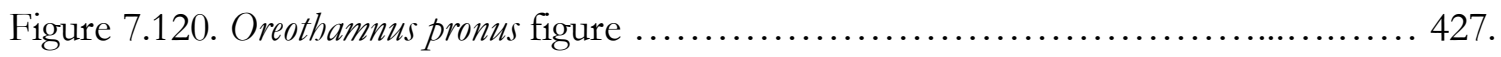

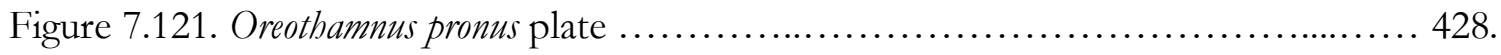

Figure 7.122. Known distribution, variation in growth habit and leaves of Oreothamnus pronus ............................................................... 429.

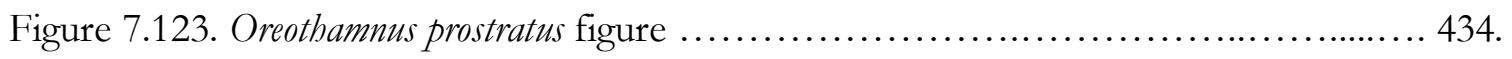

Figure 7.124. Oreothamnus prostratus plate ..................................... 435.

Figure 7.125. Known distribution of Oreothamnus prostratus ............................ 437.

Figure 7.126. Oreothamnus pubescens figure ..................................... 441.

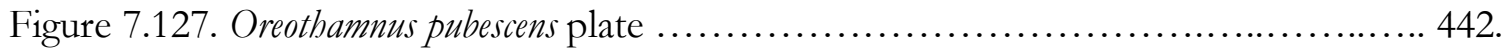

Figure 7.128. Known distribution of Oreothamnus pubescens ............................. 443.

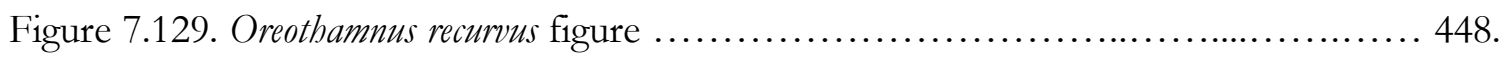

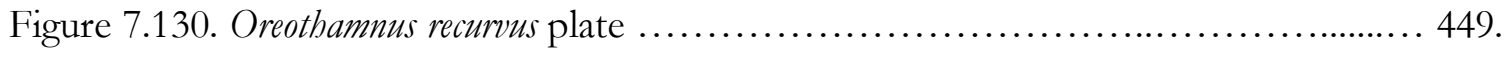

Figure 7.131. Known distribution of Oreothamnus recurvus, North Island, New Zealand ..................................................................... 450.

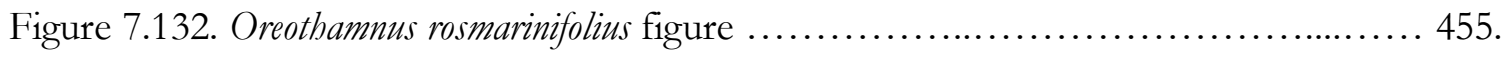

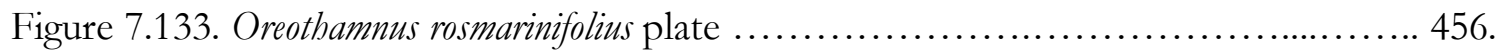

Figure 7.134. Known distribution of Oreothamnus rosmarinifolius ........................ 458. 


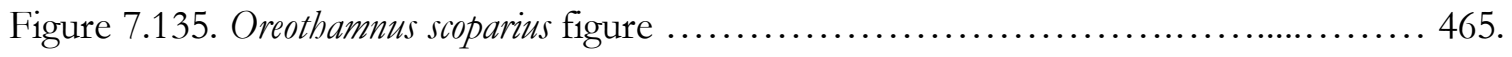

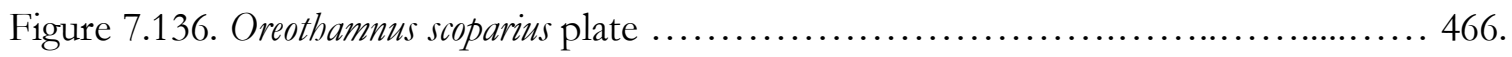

Figure 7.137. Known distribution of Oreothamnus scoparius .......................... 468.

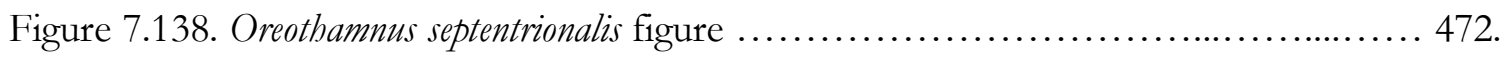

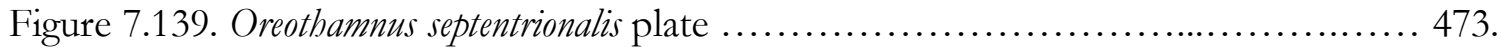

Figure 7.140. Known distribution of Oreothamnus septentrionalis, North Island, New Zealand ............................................................. 475.

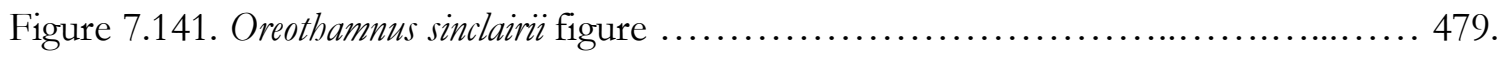

Figure 7.142. Oreothamnus sinclairii plate ....................................... 480.

Figure 7.143. Known distribution and variation in Oreothamnus sinclairii ................... 482.

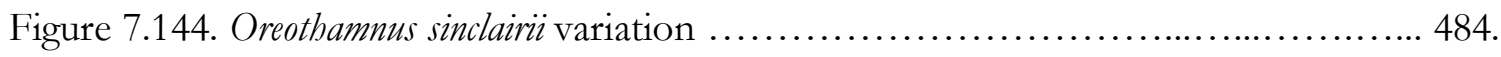

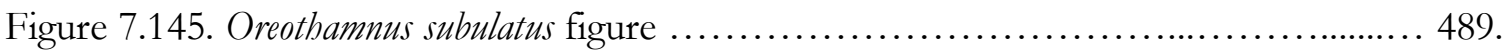

Figure 7.146. Oreothamnus subulatus plate ..................................... 490.

Figure 7.147. Known distribution of Oreothamnus subulatus .......................... 492.

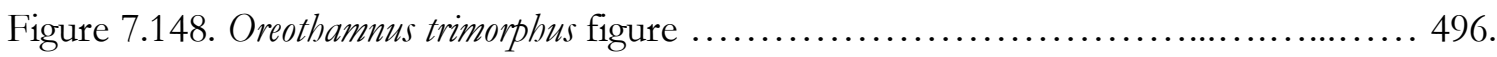

Figure 7.149. Oreothamnus trimorphus plate .................................... 497.

Figure 7.150. Known distribution of Oreothamnus trimorphus, top of the South Island, New Zealand .......................................................... 499.

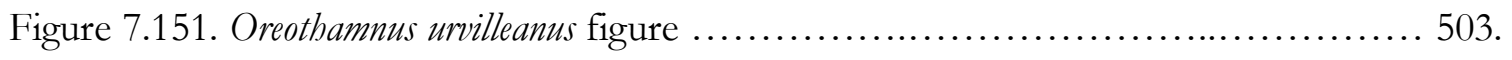

Figure 7.152. Oreothamnus urvilleanus plate ..................................... 504.

Figure 7.153. Known distribution of Oreothamnus urvilleanus, top of the South Island, New Zealand .......................................................... 505. 


\section{List of tables}

Table 1.1. Published history of the genus Dracophyllum Labill. s. l. ........................ 28.

Table 1.2. Traditional differences between the families Ericaceae and Epacridaceae ......... 32.

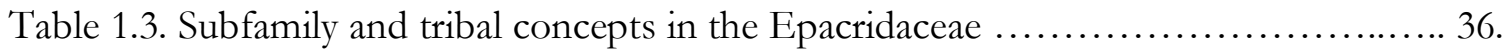

Table 1.4. Vegetation structural groups and formation classes $\ldots \ldots \ldots \ldots \ldots \ldots \ldots \ldots \ldots \ldots . \ldots 2$.

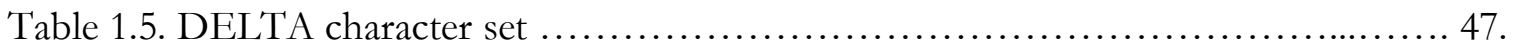

Table 2.1. Characters and character states used in the cladistic analysis .................. 60.

Table 4.0. Example of stepped characters. Portion of data matrix for Dracophyllum s.l. ...... 97.

Table 4.1. Character list for the phenetic clustering analysis $\ldots \ldots \ldots \ldots \ldots \ldots \ldots \ldots \ldots \ldots . . . . \ldots 8$.

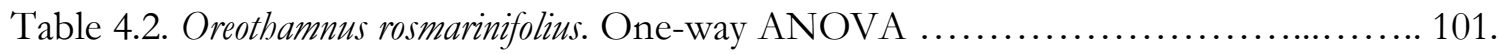

Table 4.3. Differences between Dracophyllum elegantissimum, D. latifolium and D. traversii.

Table 4.4. Differences between Oreothamnus muscoides, O. politus, O. pronus, and O. prostratus

Table 4.5. Differences between Oreothamnus filifolius, O. lessonianus, O. longifolius, O. oliveri and O. urvilleanus 112.

Table 4.6. Dracophyllum species groups according to Oliver $(1928,1952)$.............. 115.

Table 4.7. Concordance of names in the genus Dracophyllum ........................ 116.

Table 4.8. Concordance of names in the genus Oreothamnus ...........................117.

Table 5.1. Anatomical lamina vascular pattern (ALVP) code for the genus Dracophyllum and Oreothamnus ...................................... 124.

Table 7.1. Plant communities commonly associated with Dracophyllum alticola ............. 143.

Table 7.2. Differences between Dracophyllum balansae and D. cosmelioides ...................148.

Table 7.3. Plant communities commonly associated with Dracophyllum balansae ........... 149.

Table 7.4. Plant communities commonly associated with Dracophyllum cosmelioides .......... 156. 
Table 7.5. Diagnostic characters of Dracophyllum elegantissimum, D. traversii and D. latifolium 161.

Table 7.6. Plant communities commonly associated with Dracophyllum elegantissimum 162.

Table 7.7. Plant associations commonly associated with Dracophyllum fiordense ............. 170.

Table 7.8. Morphological differences between Dracophyllum fitzgeraldii,

D. milliganii, D. oceanicum, $D$. sayeri and $D$. verticillatum 175.

Table 7.9. Plant associations commonly associated with Dracophyllum fitrgeraldii 177.

Table 7.10. Plant communities commonly associated with Dracophyllum involucratum....... 183.

Table 7.11. Plant communities commonly associated with Dracophyllum latifolium 191.

Table 7.12. Major morphological differences between Dracophyllum mackeeanum

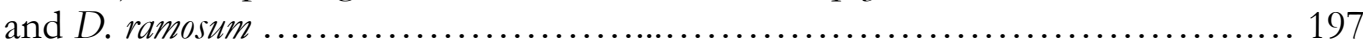

Table 7.13. Plant communities commonly associated with Dracophyllum mackeeanum. ....... 199.

Table 7.14. Plant communities commonly associated with Dracophyllum macranthum. ....... 205.

Table 7.15. Plant communities commonly associated with Dracophyllum menqiesii ........... 211.

Table 7.16. Plant communities commonly associated with Dracophyllum milliganii ........... 219.

Table 7.17. Plant communities commonly associated with Dracophyllum oceanicum .......... 226.

Table 7.18. Plant communities commonly associated with Dracophyllum ramosum ........... 238.

Table 7.19. Plant community commonly associated with Dracophyllum sayeri .............. 247.

Table 7.20. Plant associations commonly associated with Dracophyllum secundum ........... 254.

Table 7.21. Plant communities commonly associated with Dracophyllum strictum ........... 263.

Table 7.22. Plant communities commonly associated with Dracophyllum townsonii ............ 270.

Table 7.23. Differences between Dracophyllum traversii and D. latifolium ................... 276.

Table 7.24. Plant communities commonly associated with Dracophyllum traversii

Table 7.25. Plant communities commonly associated with Dracophyllum verticillatum 285. 
Table 7.26. Plant communities commonly associated with Oreothamnus acerosus ............ 302.

Table 7.27. Plant communities commonly associated with Oreothamnus arboreus ........... 310.

Table 7.28. Differences between Oreothamnus longifolius and O. cockayneanus ............... 315.

Table 7.29. Plant associations commonly associated with Oreothamnus cockayneanus ........ 317.

Table 7.30. Morphological differences between Oreothamnus densus and O. politus. ........... 322.

Table 7.31. Plant associations commonly associated with Oreothamnus densus. ............... 323.

Table 7.32. Plant communities commonly associated with Oreothamnus filifolius ........... 332.

Table 7.33. Differences between Oreothamnus rosmarinifolius and O. frondosus ............... 339.

Table 7.34. Plant communities commonly associated with Oreothamnus frondosus ............. 341.

Table 7.35. Plant communities commonly associated with Oreothamnus kirkii ............ 347.

Table 7.36. Plant communities commonly associated with Oreothamnus lessonianus ............................................................ 355 .

Table 7.37. Plant communities commonly associated with Oreothamnus longifolius ............. 364.

Table 7.38. Plant associations commonly associated with Oreothamnus marmoricola ......... 371.

Table 7.39. Morphological differences between O. minimus and O. muscoides. ............... 376.

Table 7.40. Plant associations commonly associated with Oreothamnus minimus ............ 378.

Table 7.41. Plant associations commonly associated with Oreothamnus muscoides ............. 385.

Table 7.42. Plant associations commonly associated with Oreothamnus oliveri .............. 392.

Table 7.43. Plant associations commonly associated with Oreothamnus ophioliticus ............ 398.

Table 7.44. Plant associations commonly associated with Oreothamnus palustris ........... 404.

Table 7.45. Plant associations commonly associated with Oreothamnus patens .............. 411.

Table 7.46. Plant associations commonly associated with Oreothamnus pearsonii ............ 417.

Table 7.47. Plant associations commonly associated with Oreothamnus politus ............ 423.

Table 7.48. Plant associations commonly associated with Oreothamnus pronus ............. 430.

Table 7.49. Plant associations commonly associated with Oreothamnus prostratus ............ 438. 
Table 7.50. Plant associations commonly associated with Oreothamnus pubescens ............ 444.

Table 7.51. Plant associations commonly associated with Oreothamnus recurvus ........... 451.

Table 7.52. Plant associations commonly associated with Oreothamnus rosmarinifolius ....... 459.

Table 7.53. Plant associations commonly associated with Oreothamnus scoparius ........... 469.

Table 7.54. Morphological differences between O. septentrionalis and O. oliveri. ............. 474.

Table 7.55. Plant associations commonly associated with Oreothamnus

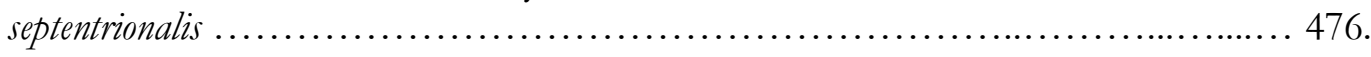

Table 7.56. Plant associations commonly associated with Oreothamnus sinclairii ............ 483.

Table 7.57. Plant associations commonly associated with Oreothamnus subulatus .......... 493.

Table 7.58. Plant associations commonly associated with Oreothamnus trimorphus ......... 500.

Table 7.59. Plant associations commonly associated with Oreothamnus urvilleanus ............ 506.

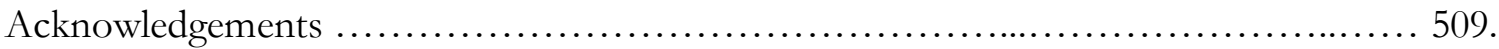




\section{Chapter 1: General introduction}

\subsection{Introduction}

In recent years the New Zealand biogeographic paradigm has shifted from 'Moa's Ark' (Bellamy et al. 1990) to the view that most biota has dispersed here in the last $\pm 10 \mathrm{My}$ (Fleming 1975, Pole 1994, McGlone et al. 2001). Large and widely distributed genera on island archipelagos and oceanic islands are important elements for the investigation of evolutionary processes such as dispersal from continents to islands and back, adaptive radiation and in some cases extinction. The genus Dracophyllum (Ericaceae: Richeeae) occurs on the Australian continent and the New Zealand archipelago as well as on many oceanic islands in the region. With its wide distribution, ecological importance and apparent taxonomic complexity, a monograph and phylogenetic study of Dracophyllum will make a valuable contribution towards the understanding of the above-mentioned processes.

There is still uncertainty about generic limits within tribe Richeeae (Dracophyllum Labill., Richea R. Br. and Sphenotoma R. Br. ex Sweet). Sphenotoma is geographically isolated (southwest Western Australia), monophyletic and forms a distinct evolutionary lineage that diverged early from Dracophyllum and Richea (Powell et al. 1996, Kron et al. 2002). The generic limits between Dracophyllum and Richea still need to be addressed, preferably by making use of DNA sequence data.

There are two fundamental aims of systematics: a) to discover, describe and name all species and $b$ ) to document the changes on the branches that have occurred during evolution and to transform these into a predictive classification system that reflects evolution (Systematics 
Agenda 2000). Systematics is therefore the study of the biological diversity that exists on earth today and its evolutionary history (Judd et al. 1999).

Taxonomic revisions, especially of large groups, need to focus on groups that are monophyletic (i.e. comprising an ancestor and all of its descendents) and not constrained by geography. Generic delimitation can become problematic when the flora of a specific region is studied in isolation. Many important aspects of genotypic and phenotypic variation are then not taken into consideration, resulting in a skewed and unrealistic representation of the genus as a whole. The long list of synonyms in the southern hemisphere for the genus Veronica L. is a reflection of this situation: Paederota L., Hebe Comm. ex Juss., Derwentia Raf., Pygmaea Hook.f., Detæneria Schltr. ex Diels, Parahebe W.R.B.Oliv., Chionohebe B.G.Briggs \& Ehrend., Leonohebe Heads, Heliohebe Garn.-Jones and Hebejeebie Heads.

\subsection{Generic concepts}

Taxonomists began to regard the genus as a natural unit from 1940 onwards. Anderson (1940) and Rollins (1953) established the view that a genus is made up of a group of species closely related in a natural way. According to Davis \& Heywood (1967) three important questions arise when one is deciding on generic concepts: 1) Is the group a natural one? Many modern authors regard monophyly as the most important criterion for generic delimitation and generic recircumscriptions are increasingly being published on the basis of monophyly. 2) Where to draw the line between closely allied genera - based on discontinuity and correlation of characters? 3) Is it practicable to recognise the group as a separate genus? 
Winston (1999) points out that genera are defined by a group of carefully chosen characters with at least some of them correlated functionally or genetically, thus they are present in all the members of the groups. He also states that one or more species in a genus might lack one or more of the diagnostic characters, or might have a character present but in a modified form.

Although monophyly provides an objective criterion for recognizing taxonomic groups, there is still no sensible objective criterion for deciding the rank of those groups. Judd et al. (1999) gave four sensible suggestions addressing this problem, 1) strength of evidence supporting the monophyly of the group; 2) presence of an obvious morphological character; 3) size of the group and 4) nomenclatural stability. The rankless PhyloCode System (a phylogenetic code of biological nomenclature http://www.ohiou.edu/phylocode/ website Valid on 01.10.2008) is another approach.

\subsection{Species concepts}

The patterns of variation in living biota are complex and diverse, and together with various evolutionary processes, resulted in the naming of at least five major species concepts in an attempt to group individuals (Wiley 1981; Stuessy 1990). These species concepts are really models, not definitions (Andersson 1990) and are mentioned below with their strengths and weaknesses.

The 'morphological species concept' defines species (morphospecies) as entities that are distinguished as sets of populations that are separated by a morphological discontinuity from other sets. According to Cronquist (1988): "Species are the smallest groups that are 
consistently and persistently distinct and, distinguishable by ordinary means". Thus, morphological similarity or dissimilarity is the main criterion for determining species. This concept is employed implicitly by all studies as a beginning point to identify units prior to analysis. The negative aspects are: i) it only fits loosely with genetic variation; ii) morphologically similar organisms might not be closely related genetically and iii) chromosomal variation might not be expressed in the morphology. This is the most oftenused species concept by practising taxonomists (Stuessy 1990).

The 'biological species concept' (Mayr 1942; 1969) defines species as a group of interbreeding populations that are reproductively isolated from other such groups. It also provides an important conceptual framework for speciation. The negative aspects are i) it is only really applicable to the present (Donoghue 1985); ii) does not apply to asexual organisms (Budd \& Mishler 1990); iii) there is no evolutionary dimension; iv) there are practical taxonomic difficulties with cryptic biological species and v) phenotypic divergence may exist in closely related species that can still interbreed (Donoghue 1985, Cracraft 1989).

The 'evolutionary species concept' (Simpson 1961) defines a species as “a single lineage of ancestor-descendant populations that maintain its identity from other such lineages and which has its own evolutionary tendencies and historical fate" (Wiley 1978). This concept is compatible with a greater range of reproductive modes than the biological species concept. It is applicable to extinct organisms and it is compatible with various modes of speciation. The evolutionary species concept addresses only the products of evolution. A major weakness of the evolutionary species concept is that it confuses process and pattern. It is 
necessary to understand relationships among various populations before this species concept can be applied.

The 'ecological species concept' (Van Valen 1976) defines a species as “a lineage (or a closely related set of lineages) that occupies an adaptive zone minimally different from that of any other lineage in its range and which evolves separately from all lineages outside its range". Disadvantages of this species concept are, i) it is only loosely connected to genetics; ii) it is rigidly tied to ecological niches; iii) it is difficult to define a niche and if so then by occupancy, but that introduces circularity to the argument; iv) its evolutionary dimension comes from the requirement to recognize a lineage, but this is overlooked by some proponents.

The 'phylogenetic species concept' (Cracraft 1983; Wiley 1978; Donoghue 1985; Stuessy 1990) describes a species as "a basal cluster of organisms that is diagnosably distinct from other such clusters and within which there is a parental pattern of ancestry and descent". According to De Queiroz \& Donoghue (1990), a species is the smallest monophyletic group of common ancestry and can be recognised by derived and shared characters. Problems with this concept are i) it requires discrete characteristics; ii) there is multiplication of species names; iii) one might find populations with almost but not completely fixed differences and iv) it is disconnected from population genetics and disallows paraphyletic species, which must be a reality if the peripheral isolates model is real.

To be able to give a stable and reliable classification for Dracophyllum, the morphological species concept (sensu Stuessy 1990) was adopted in this thesis. Species are regarded as 
distinct when at least two independent morphological characters (states) indicate significant differences. There are advantages to the morphological species concept. Selfing individuals do not need to be called new species, one of the criteria for the biological and the recognition species concepts (Mayr 1942; Patterson 1985). Evolutionary lineages can be identified by a specific morphologically based criterion, instead of only assumed to be there, like the evolutionary species concept (Simpson 1951; Gravendeel 2000). The fixation of two morphological characters is easier to recognize than monophyly, the criterion of the phylogenetic species concept (Cracraft 1983).

\subsection{Dracopbyllum and related genera}

Dracophyllum was until recently classified in the family Epacridaceae, which is now incorporated into the Ericaceae (Thorne 2000; Kron et al. 2002). The recognition of Epacridaceae as a family renders Ericaceae paraphyletic (Stevens 1971; Kron et al. 2002). This conclusion is supported by the nucleotide sequence data from the chloroplast genes rbcL (Kron \& Chase 1993) and matK (Kron et al. 2002). The former family Epacridaceae is now recognized as Ericaceae subfamily Styphelioideae (Kron et al. 2002) and consists of 35 genera and over 420 species (Copeland 1953; Crayn et al. 1996; Powell et al. 1996; Crayn et al. 1998; Menadue \& Crowden 2000). It is predominantly Australasian (Powell 1983) with some representatives in southeastern Asia (Leucopogon), Hawaii (Styphelia), Tierra del Fuego and Patagonia in South America (Lebetanthus).

Ericaceae is a large and widespread family comprising some 125 genera and $3000-4000$ species. Ericaceae has been divided up into several subfamilies and tribes (Stevens 1971; Anderberg 1993; Oliver 2000; Kron et al. 2002). Within the last 10 years various researchers 
have repeatedly studied the family Ericaceae and these studies, mostly cladistic, were based on selected morphological, anatomical, embryological characters and molecular data that shed new light on the classification and relationships within the family itself (Anderberg 1993; Judd \& Kron 1993; Kron et al. 2002).

Dracophyllum has been regarded as being closely related to Richea R. Br. and Sphenotoma (R. Br.) Sweet since Bentham's publication (1869). These three genera form a prominent clade in the strict consensus tree of Crayn et al. (1998) based on a molecular analysis using the plastid gene $r b c \mathrm{~L}$. This clade forms the Richea group, which corresponds with the tribe Richeeae of Powell (1983) and Powell et al. (1996).

Richea is endemic to southeastern Australia (nine species restricted to Tasmania and two to mainland south-eastern Australia) and Sphenotoma (six species) is restricted to south-western Western Australia. Richea appears somewhat similar to Dracophyllum. However its ovoid or conical corolla with united lobes that form an operculum easily distinguishes it. The operculum splits transversely and falls off as an entire unit leaving a persistent basal ring-like structure (Menadue \& Crowden 2000). Sphenotoma lacks a leaf sheath and has a narrow corolla tube with the throat almost closed by the presence of prominent longitudinal ridges that extend from the base of the corolla lobes down into the corolla tube (Bentham 1869).

Dracophyllum is traditionally divided into three subgenera: subgenus Dracophyllum (New Zealand 7 spp., Australia 4 spp., Tasmania 1 species, Lord Howe Island 1 species and New Caledonia 7 spp.), subgenus Cordophyllum with a single species in New Caledonia, and 
subgenus Oreothamnus (New Zealand 28 spp and Tasmania 1 species) (Oliver 1952). All species are endemic at the national level.

\subsection{Scope of this thesis}

Initially this research was to cover only the Dracophyllum species for New Zealand and its offshore islands, but for reasons outlined above I have chosen to enlarge the study to include the entire distribution area of the genus covering all the known species. In order to produce a comprehensive phylogeny and taxonomic revision, the entire natural distribution and all the known species of the genus Dracophyllum must be included. Only in this way could sufficient information be gathered and processed.

\subsection{History of the genus Dracopbyllum}

The descriptive history of the genus Dracophyllum began with two plant specimens collected in March 1773 by J.R. Forster and his son J.G.A. Forster at Dusky Bay in Fiordland, New Zealand (Table 1.1). These specimens were later described as two different species, one by father and son (Forster \& Forster 1776) as Epacris longifolia (= Dracophyllum longifolium) and the other by the son G. Forster (1786), as Epacris rosmarinifolia (= Dracophyllum rosmarinifolium). The genus name Epacris Cav. [1797], now attached to an endemic Australian genus of c. 40 species (Australian Plant Name Index [APNI] - www.anbg.gov.au/cgi-bin/apni accessed on 25.7.2005), is conserved against Epacris J.R. Forster et J.G.A. Forster. Epacris Cav. contains neither of the above species published by the Forsters.

The genus Dracophyllum was established by Labillardière (1800) for a plant that he collected in New Caledonia during April 1793. He named this plant D. verticillatum as he observed the 
flowers to be arranged in rings or verticels on the inflorescence. Labillardière gave a lengthy description and discussion of this plant and published it together with an illustration that shows all the diagnostic characteristics of the species. This became the type species of the genus.

Ten years later, Robert Brown (1810) divided Dracophyllum into sections Dracophyllum and Sphenotoma based on corolla shape, corolla lobe apex shape, and position of the stamens, inflorescence shape and the inflorescence bracts being persistent or deciduous. In the same publication, under the genus Dracophyllum, he mentioned (in nota) the two Epacris species of the Forsters as $D$. longifolium and $D$. rosmarinifolium respectively without citing basionyms or giving any discussion or detail. Index Kewensis gives Brown (1810) as the author who transferred the above-mentioned species to Dracophyllum; however the combinations were not validly made therein and according to Article 32.1 in the I.C.B.N. (Greuter et al. 2000) Roemer \& Schultes (1819) were the first to validly publish these two combinations.

Poiret (1811) based his Epacris section Dracophyllum on the number of bracts, shape of the corolla tube and position of the stamens. He gave extended descriptions of the Forsters' two species (D. longifolium and D. rosmarinifolium) but kept them in the genus Epacris. Sprengel (1825) had a different view of generic circumscriptions in the Epacridaceae. He did not accept Dracophyllum as a separate genus and kept D. longifolium, D. rosmarinifolium and Cosmelia R.Br. species in the genus Epacris. He regarded D. secundum as belonging to the genus Prionotes R. Br. 
Richard (1832) based his Dracophyllum publication on the New Zealand collections in the Muséum Nationale d'Histoire Naturelle in Paris $(\mathrm{P})$. The notes in Richard's publication give the impression that he had a modern concept of the circumscription and characteristics of Dracophyllum. This was the first revision of Dracophyllum. He mentioned four species (D. lessonianum A. Rich., D. longifolium, D. rosmarinifolium and D. urvilleanum A. Rich. of which two were described as new) and gave a lengthy discussion as to how the species differed from each other with particular reference to the flower characters.

A. Cunningham (1837) used his own manuscript names as well as those of Banks and Solander. None of the Banks and Solander manuscript names in Dracophyllum were however used in later descriptions by botanists.

De Candolle (1838) placed Dracophyllum in his family Epacrideae, remodelled the generic circumscription of Dracophyllum, and provided the first full description of the genus. He only included plants of Brown's (1810) first section, considering the species in the second section as belonging to a different genus, namely Sphenotoma. De Candolle mentioned seven species of Dracophyllum, five from New Zealand, one from Australia (D. secundum) and D. verticillatum from New Caledonia. These were also the first comprehensive descriptions of the species and he was the first author to mention species with a deciduous corolla, a characteristic of some species of Dracophyllum.

Endlicher (1836) ignored the views of Roemer \& Schultes (1819), Sprengel (1825) and De Candolle (1838) thus formulating his own concept of Dracophyllum. He described two sections for Dracophyllum, the new section Dacryanthus that is characterised by free stamens in 
order to accommodate D. secundum, and a remodelled section Dracophyllum Endl. non Benth. \& Hook. (1876) (as Eudracophyllum) characterised by stamens adnate to the corolla, to accommodate all the other known species. Later authors did not uphold Endlicher's sections.

Hooker (1844a) was the first author to give full descriptions of the species and to discuss species relationships and mentioned "- but none of these authors proposed any sectional characters for these species, which differ most materially from those of Mr. Brown's first section of the genus, in many of them having epipetalous stamens, as also in the flowers being spiked and the bracteae persistent, and which equally differ from Sphenotoma in habit and the form of the corolla". Hooker (1853) published the second revision of Dracophyllum wherein he discussed 14 species, of which nine were described as new. He placed the species in two unnamed sections based on inflorescence shape, inflorescence bracts being deciduous or persistent, and the length of the calyx lobes in relation to tube length. This was published as part of an account of the plants collected on the Antarctic voyage during 1839 - 1843.

Hooker was unsure about the differences between $D$. urvilleanum, D. lessonianum and $D$. filifolium thus starting the 72-year period of confusion pertaining to these three species.

Von Mueller (1858) proposed the section Oreothamnus in Dracophyllum encompassing species with the inflorescence in a raceme, spike or with a solitary flower, and stamens attached to the corolla tube for most of their length.

Hooker (1867) published his 'Handbook of New Zealand Flora' being the first publication that provided an identification key for Dracophyllum. Hooker divided the genus into three 
unnamed groups based on leaf characters and the structure of the inflorescence. Hooker's concept of $D$. urvilleanum differed markedly from that of Richard (1832) and he included $D$.

filifolium, D. lessonianum and D. scoparium in synonymy of $D$. urvilleanum.

Table 1.1. Published history of the genus Dracophyllum Labill. s. l.

\begin{tabular}{|l|l|l|c|}
\hline \multicolumn{1}{|c|}{ AUTHOR } & DATE & \multicolumn{1}{|c|}{ PUBLICATION } & NUMBER OF \\
\hline & & & SPECIES COVERED \\
\hline Forster, J.R. \& G. & 1776 & Characteres generum plantarum & 2 \\
\hline Forster, G. & 1786 & Florulae Insularum Australium Prodromus & 1 \\
\hline Labillardiére, J.J.H. & 1800 & Rélation du voyage à la recherche de la Pérouse & 3 \\
\hline Brow n, R. & 1810 & Prodromus Florae Novae Hollandiae & 1 \\
\hline Poiret, J.L.M. & 1811 & Encyclopédie Méthodique, Botanique, Supplement vol. 2. & 3 \\
\hline Roemer \& Schultes & 1819 & Systema Vegetabilium vol. 4. & 2 \\
\hline Sprengel, C. & 1825 & Systema Vegetabilium vol. 1. & 2 \\
\hline Sw eet, R. & 1830 & Hortus Britannicus & 4 \\
\hline Richard, A. & 1832 & Essai d'une Flore de la Nouvelle Zélande & 7 \\
\hline De Candolle, A.P. & 1838 & Prodromus Systematis Naturalis Regni Vegetabilis & 5 \\
\hline Cunningham, A. & 1838 & Annals of Natural History vol. 2 & 12 \\
\hline Hooker, J.D. & 1844 & Flora Antarctica & 11 \\
\hline Raoul, E. & 1846 & Choix de Plantes de la Nouvelle-Zélande & 2 \\
\hline Hooker, J.D. & 1853 & Flora Novae-Zelandiae vol. 2 & 5 \\
\hline Hooker, J.D. & 1860 & Flora Tasmaniae vol. 2 & 3 \\
\hline Brongniart \& Gris & 1864 & Bulletin Société Botanique de France vol. 2 & 1 \\
\hline Hooker, J.D. & 1867 & Handbook of the New Zealand Flora & 18 \\
\hline Bentham \& Mueller & 1869 & Flora Australiensis vol. 4 & 20 \\
\hline Mueller, F. von & 1870 & Fragmenta Phytographiae Australiae vol. 7 & 45 \\
\hline Cheeseman, T.F. & 1906 & Manual of the New Zealand Flora & 48 \\
\hline Cheeseman, T.F. & 1925 & Manual of the New Zealand Flora & 7 \\
\hline Oliver, W.R.B. & 1929 & Transactions of the New Zealand Institute vol. 59 & 2 \\
\hline Oliver, W.R.B. & 1952 & Transactions of the Royal Society of New Zealand vol. 80 & 2 \\
\hline Virot, R. & 1975 & Flore de la Nouvelle Calédonie et dépendances vol. 6 & 1 \\
\hline Brow n \& Streiber & 2000 & Telopea vol. 8 (3) & \\
\hline Venter, S. & 2002 & New Zealand Journal of Botany vol. 40 (1) & \\
\hline Venter, S. & 2004 & New Zealand Journal of Botany vol. 41 (4) & \\
\hline Venter, S. & 2004 & New Zealand Journal of Botany vol. 42 (4) & \\
\hline
\end{tabular}

The first publication to cover the New Caledonian Dracophyllum species was that of Brongniart \& Gris (1864b). They retained the name D. ramosum, and mentioned $D$. cosmelioides, both names written by Pancher onto the specimen sheets. D. cosmelioides was merely mentioned in nota but later validly published by Oliver (1952). 
The first revision of the Australian Dracophyllum species was by Von Mueller (1867). Unfortunately, the descriptions have little in the way of discussion. Bentham and Hooker (1876) gave a full generic description of Dracophyllum and divided the genus into two sections, Dracophyllum (as Eudracophyllum) and Sphenotoma, based on flower characters. This was despite the fact that Hooker mentioned earlier (1844b) that section Sphenotoma had been raised to genus level by Sweet (1827) as Sphenotoma R. Br. ex Sweet and it was retained as such by all future authors. Bentham and Hooker (1876) did not discuss or make mention of Von Mueller's section Oreothamnus.

Fifty-three years after Hooker's work, Cheeseman (1906) revised the genus for New Zealand wherein he recognised 18 species. He classified the species in two unnamed sections that correspond with Oliver's (1928) subgenera Eudracophyllum and Oreothamnus. Cheeseman brought some order to Dracophyllum taxonomy when he placed a number of Colenso's species in synonymy. Sadly though, he was unable to clear up the D. filifolium-D. urvilleanumD. lessonianum confusion that Hooker (1867) had begun. Cheeseman's concept of $D$. rosmarinifolium, D. scoparium and D. uniflorum also differed from that of Hooker's.

The next significant addition to Dracophyllum was the establishment of subgenera. Oliver (1928) raised the sections Dracophyllum (as Eudracophyllum) and Oreothamnus to subgenus level, described a third subgenus Cordophyllum to accommodate Dracophyllum involucratum from New Caledonia, and removed the section Sphenotoma from Dracophyllum. This was also the first major monograph of Dracophyllum and in it Oliver accepted 45 species. This publication gave the first comprehensive introduction to the genus with discussions on the macromorphology and grouping of the species. He brought order to the old D. filifolium-D. 
lessonianum-D. urvilleanum confusion, but in the process broke $D$. filifolium up into three varieties of which none is upheld in this study. Oliver's grouping of the species is not natural and differs markedly from that of the current study (Table 4.6.). This was nonetheless a commendable effort to resolve the taxonomy of Dracophyllum. Oliver (1952) later published a 'Supplement' to the revision wherein he regrouped the species and mentioned the types for all the species with many lectotypes chosen by him. In many cases, he did not write the word 'TYPE' on the specimen sheet or give any indication as to which specimen was the type. Subsequent research (Allan 1961; Virot 1975; Brown \& Streiber 2000; Venter 2002) has revealed serious shortcomings in the nomenclature and phylogeny.

The latest publication covering all Dracophyllum for New Zealand is that of Allan (1961) in which he stated that he followed the findings of Oliver $(1928 ; 1952)$ in a very large part and that no satisfactory key could be drawn up in the present state of our knowledge of the genus. In Allan's publication, he discussed 35 species and agreed that the D. rosmarinifolium D. uniflorum, the D. filifolium - D. urvilleanum and the D. longifolium groups remain unresolved. Allan seems to be unsure about the status of $D$. filifolium, D. longifolium, D. recurvum and $D$. strictum. He also published lengthy comments on Colenso's and Oliver's various species and varieties. These comments are in small type, apparently a procedure he used to report names but to make no judgment over their distinctness. He spent some time on the discussion of hybridism in the genus saying that it is a common phenomenon and that: ".......field evidence abundantly supports the view that hybrids occur freely between several members of the subgenus Oreothamnus" (Allan 1961). 
Virot (1975) revised the Dracophyllum species of New Caledonia and he mostly used material collected by the surgeons Vieillard and Déplanche (1853) but also made use of MacKee specimens from Missouri Botanical Gardens (MO). Virot accepted seven endemic Dracophyllum species for New Caledonia, six belonging to the subgenus Dracophyllum and $D$. involucratum to subgenus Cordophyllum. The species descriptions and the material studied are precise, but notes on the distribution, ecology and observations are scanty with hardly any mention being made of related species or how the species differ from each other. The most recent publication on Dracophyllum for Australia was by Brown and Streiber (2000) wherein they described two new species (D. macranthum and D. oceanicum) based on a morphometric

study. The latest publications on Dracophyllum for New Zealand and New Caledonia were by Venter $(2002 ; 2004)$ wherein three new species (D. marmoricola, D. ophioliticum and D. elegantissimum) were described from the northern part of the South Island and D. mackeeanum from New Caledonia.

\subsection{Familial placement of Dracopbyllum}

The close relationship between Ericaceae and Epacridaceae has been the subject of discussion for the past 124 years (Le Maout \& Decaisne 1868; Samuelsson 1913; Metcalf \& Chalk 1950; Copeland 1953; Paterson 1961; Stevens 1971; Cronquist 1981; Dahlgren 1983; Thorne 1992). Members of the Epacridaceae resemble some of the groups in the family Ericaceae making the distinction between the families somewhat unclear. The two families were primarily separated based on morphological differences (Table 1.2). These differences broke down in recent studies with no characters found that consistently distinguish all the members in this family from those of the Ericaceae (Stevens 1971; Judd \& Kron 1993; Kron et al. 2002). A single whorl of stamens (haplostemonous), although rare in the Ericaceae, is 
also present in the genus Loiseleuria Desv. ex Loisel. Free stamens are characteristic of Dracophyllum alticola, D. cosmelioides, D. fiordense, D. macranthum, D. milliganii and D. secundum, like the members of the Ericaceae. Powell et al. (1996) state that some species of 'Dracophyllum O' (the subgenus Oreothamnus) have free stamens but that statement is incorrect.

Table 1.2. Traditional differences between the families Ericaceae and Epacridaceae.

\begin{tabular}{|l|l|l|}
\hline Character & Ericaceae & Epacridaceae \\
\hline Stamens & choripetalous, in two whorls. & mostly epipetalous, single whorl. \\
\hline Anther dehiscence & by basal pores. & by longitudinal slits. \\
\hline Anther ornamentation & commonly with awns or spurs. & unornamented. \\
\hline Leaf venation & reticulodromous. & actinodromous/ parallelodromous \\
\hline Hairs & multicellular. & unicellular. \\
\hline
\end{tabular}

In the present survey, I found all species of the subgenus Oreothamnus to have epipetalous stamens. Epipetalous stamens are also present in Diplarche multiflora Hook.f. \& Thoms. and D. pauciflora Hook. f. \& Thoms. from the Ericaceae.

Anthers of most Ericaceae open by basal pores or short slits except in the genera Ledothamnus Meissn. and Leiophyllum Hedw.f. where they open with full-length slits. As a rule anthers in Styphelioideae open with full-length slits except in the genus Rupicola Maiden \& Betche where the anther slits are very short. The anthers are all without ornamentation whereas in the rest of the Ericaceae anthers are ornamented with awns and spurs except in the genera Ledothamnus and Leiophyllum. 
Ericaceae mainly have multicellular hairs but a combination of multicellular and unicellular hairs does occur, while Epacridaceae mostly have unicellular hairs. A combination of multicellular glandular hairs and unicellular hairs occurs in the Epacrid genera Lebetanthus and Prionotes, the so-called link between Ericaceae and Epacridaceae.

Camptodromous venation (secondary veins not terminating at the margin, Hickey 1973) based on a prominent midrib with pinnate secondary veins and inter-connecting reticulations is characteristic of Ericaceae and three Epacridaceae genera (Lebetanthus Endl., Lysinema R. Br. and Prionotes). The rest of the Epacridaceae have reticulo-actinodromous venation where there are three to five primary veins diverging from near the base of the leaf with or without secondary reticulations between them and/or branching towards the margin.

Watson et al. (1967) conducted a phenetic study, which they based on 38 morphological characters and concluded that the traditional distinction between the families Epacridaceae and Ericaceae is informative. Burtt et al. (1970) however criticized their view as did Stevens (1971), who presented a formal classification of the Ericaceae based on 60 anatomical, embryological, morphological and phytochemical characters. In a cladistic analysis of the Ericales based on 67 morphological, anatomical and phytochemical characters, Anderberg (1993) concluded that the Ericaceae is not monophyletic (Drude 1889; Stevens 1971; Cronquist 1981 \& Takhtajan 1986) and that the Epacridaceae is a derived offshoot from within the Ericaceae. He thus distinguished the Enkianthus, Rhododendroid and Vaccinioid subgroups, all within the Ericaceae. The Vaccinioid subgroup includes Epacridaceae, Pyrolaceae and Monotropaceae with the Epacridaceae linked to the Arbutoid-Vaccinoid taxa through characters present in the genera Prionotes and Lebetanthus. In the past (Stevens 
1971; Kron 1996), these two genera have been considered phenetically intermediate between the Ericaceae and Epacridaceae thus linking the two families. Kron et al. (1991) suggested that the Empetraceae and Epacridaceae are derived from within the Ericaceae based on the results of molecular work done on cpDNA rbcL gene sequences. Kron and Chase (1993) had much the same results based on an $r b c \mathrm{~L}$ sequence analysis of the Ericales and showed clearly that the members of the Epacridaceae are nested within the Ericaceae as sister group to a set of vaccinioid taxa. Placement of the Epacridaceae near the Andromedeae and Vaccinieae is in agreement with the views of Anderberg (1993), Kron and Chase (1993), Kron (1996) and Kron et al. (2002).

If the Empetraceae and Epacridaceae are kept separate as families, it would render Ericaceae paraphyletic and that would mean a number of Ericaceae tribes would have to be raised to familial rank (Anderberg 1993). To make Ericaceae monophyletic the best possible and most stable taxonomic treatment was to include the Epacridaceae as a subfamily in Ericaceae (Kron et al. 2002). Anderberg (1993) was the first to suggest that Epacridaceae must not be treated as a separate family but as a member of the Ericaceae s.l. and he emphatically stated this based on morphological characters, which he used in a cladistic study of the Ericales.

Based on afore-mentioned studies and that of Kron et al. (2002) the Ericaceae and Epacridaceae are neither phenetically nor cladistically justifiable and it is appropriate to state that the Epacridaceae is nested within the Ericaceae with the Vaccinioideae sister to the Styphelioideae (Judd et al. 2007). Under the ICBN (Greuter et al. 2000) the correct name for this clade at the rank of subfamily is Ericaceae subfamily Styphelioideae. 


\subsection{Suprageneric groups within Styphelioideae}

Various groupings of genera have been recognized within Styphelioideae, sometimes as tribes under Epacridaceae (Table 1.3), more recently within an enlarged Ericaceae. In this section, I address the various placements of Dracophyllum.

Brown (1810) was the first to divide the Epacridaceae into two groups, which were eventually made tribes. These were respectively the Styphelieae characterised by solitary ovules in each ovary locule, indehiscent fruit, drupes plus pyrenes, and the Epacrideae characterised by several ovules in each ovary locule and capsular fruits (Le Maout \& Decaisne 1868; Bentham 1869). Later Drude (1889) established a third tribe, the Prionoteae, based on the minute dentate leaves and free stamens. This was to accommodate the genera Prionotes and Lebetanthus, which were previously assigned to the tribe Epacrieae (as Epacreae). Burtt (1948) added Wittsteinia, an Australian endemic, to Prionoteae but Wittsteinia is now placed in the family Alseuosmiaceae (Van Steenis 1984).

Watson et al. (1967) based their re-organisation of Epacridaceae at the tribal level and above on a phenetic analysis for 193 species of Ericaceae and Epacridaceae using 38 morphological characters. They admit though that some of the data used in this study could be extrapolations from one or two observations coupled with faith in the current taxonomic scheme. The group forming the Epacridaceae separated convincingly from the Ericaceae. They divided the Epacridaceae into 'Subfamily I' consisting of the single 'Tribe 1' (Styphelieae) that corresponds with Crayn et al.'s (1998) Styphelieae and Oligarrheneae. Their 'Subfamily II' is divided into three unnamed tribes, 'Tribe 1' that corresponds to Crayn et al.'s Prionoteae and Archerieae, 'Tribe 2' with Cosmelieae and 'Tribe 3' with Richeeae. 
Table 1.3. Subfamily and tribal concepts in the Epacridaceae.

\begin{tabular}{|c|c|c|c|c|}
\hline Author & Date & Family & Subfamily & Tribe \\
\hline Bentham & 1869 & & & $\begin{array}{l}\text { Epacreae } \\
\text { Styphelieae }\end{array}$ \\
\hline Drude & 1889 & Epacridaceae & & \begin{tabular}{|l} 
Epacreae \\
Styphelieae \\
Prionoteae
\end{tabular} \\
\hline Copeland & 1953 & Epacridaceae & & \begin{tabular}{|l|} 
Epacrideae \\
Styphelieae \\
Prionoteae
\end{tabular} \\
\hline Watson et al. & 1967 & Epacridaceae & $\begin{array}{l}\text { Subfamily I } \\
\text { Subfamily II }\end{array}$ & \begin{tabular}{|l|} 
Styphelieae \\
Tribe 1 \\
Tribe 2 \\
Tribe 3 \\
\end{tabular} \\
\hline Powell & 1983 & Epacridaceae & $\begin{array}{l}\text { Richeoideae } \\
\text { Epacridoideae }\end{array}$ & \begin{tabular}{|l|} 
Richeeae \\
Cosmelieae \\
Epacrideae \\
Styphieleae \\
\end{tabular} \\
\hline Anderberg & 1993 & Epacridaceae & & \begin{tabular}{|l|} 
Epacrideae \\
Styphelieae \\
Prionoteae
\end{tabular} \\
\hline Takhtajan & 1997 & Epacridaceae & $\begin{array}{l}\text { Epacridoideae } \\
\text { Styphelioideae } \\
\text { Prionotoideae }\end{array}$ & \\
\hline Powell et al. & 1996 & Epacridaceae & & \begin{tabular}{|l} 
Richeeae \\
Epacrideae \\
Styphelieae \\
Cosmelieae
\end{tabular} \\
\hline Stace et al. & 1997 & Epacridaceae & $\begin{array}{l}\text { Richeoideae } \\
\text { Epacridoideae }\end{array}$ & \begin{tabular}{|l} 
Richeeae \\
Cosmelieae \\
Epacrideae \\
Styphelieae \\
\end{tabular} \\
\hline Crayn et al. & 1998 & Epacridaceae & & \begin{tabular}{|l} 
Richeeae \\
Epacrideae \\
Styphelieae \\
Cosmelieae \\
Archerieae \\
Oligarrheneae \\
Prionoteae
\end{tabular} \\
\hline Kron et al. & 2002 & Ericaceae & Styphelioideae & \begin{tabular}{|l} 
Prionoteae \\
Archerieae \\
Oligarrheneae \\
Richeeae \\
Epacrideae \\
Cosmelieae \\
Styphelieae
\end{tabular} \\
\hline
\end{tabular}

Powell (1983) based her division of the Epacridaceae on morphological characters and used the presence/absence of leaf scars to distinguish between the subfamilies Richeoideae and Epacridoideae. She used the name Richeoideae for the subfamily that included the genera Richea, Sphenotoma and Dracophyllum, which is the tribe Richeeae of Crayn et al. (1998). The 
rest of the tribes were placed in subfamily Epacridoideae. The genera Sphenotoma and Dracophyllum were separated from Richea based on the formation of a calyptra, structure of the inflorescence and of the flower, respectively.

A re-assessment was done by Powell et al. (1996) of the relationships within the Epacridaceae again based on morphological characters. The phylogenetic analysis showed a robust grouping into the Richea, Cosmelia and Styphelia clades. These three clades were well supported, and the Richea clade (genera Richea, Dracophyllum and Sphenotoma) received the highest $(88 \%)$ bootstrap support. These clades were regarded as the subfamilies Richeoideae and Cosmelieae of Watson (1967) and the tribe Styphelieae of Bentham and Hooker (1876). The Richea clade is defined by the possession of both adaxial and abaxial fibre caps that extend as a flange to contact each epidermis, multicellular nodes, heterogeneous pith, paracytic stomata, loculicidal capsules, broadly sheathing leaf bases and annular scars on the branches (Powell et al. 1996).

Crayn et al. (1998) divided the subfamily Epacridoideae (= Styphelioideae) of Ericaceae into seven tribes, Archerieae (Archeria), Cosmelieae (Andersonia, Cosmelia and Sprengelia), Epacrideae (Budawangia, Epacris, Lysinema, Rupicola and Woollsia), Oligarrheneae (Needhamiella and Oligarrhena), Prionoteae (Lebetanthus and Prionotes), Richeeae (Dracophyllum, Richea and Sphenotoma) and Styphelieae (Acrotriche, Astroloma, Brachyloma, Cyathodes, Leucopogon, Melichrus, Monotoca, Pentachondra, Styphelia and Trochocarpa) based on a molecular study using the plastid gene $r b c \mathrm{~L}$. The Richea clade is well defined by each of the support indices (decay +4 , parsimony jack-knife $72 \%$ ) and characterised by the fruit being a loculicidal capsule, leaf bases broadly sheathing and annular leaf scars on the stems. The three subgenera of 
Dracophyllum did not form a clade in the strict consensus tree; in the majority rule consensus tree, subgenera Dracophyllum and Cordophyllum were placed together as sister to genus Richea and not to subgenus Oreothamnus (Crayn et al. 1998). They acknowledged that their rbcL dataset suffered from too few uncontradicted synapomorphies to robustly cluster taxa, the same problem encountered in the morphological dataset of Powell et al. (1997). Part of this problem can be overcome by including a wider dataset based on observations of more, if not all, of the taxa per genus and not only on a few selected taxa. Powell et al.'s (1996) misinterpretation of free stamens and longitudinal folds in the corolla tube in Dracophyllum subgenus Oreothamnus is a good example of this.

\subsection{Generic delimitation}

Relationships within the Epacridaceae have received little taxonomic attention since Bentham (1869) and Mueller (1864, 1867, 1882, 1889) with no attempt made to assess the generic limits except Powell et al. (1987). Powell, Chapman and Doust (1987) were the first since Bentham (1869) to publish on the generic positions within the Epacridaceae. Their cladistic study based on 41 morphological characters showed that the genera Dracophyllum and Sphenotoma can readily be separated on the basis of stomatal distribution, style length and inflorescence type. They suggested that Dracophyllum subgenus Oreothamnus might be worthy of generic rank based on the number of apomorphies shown (stomatal distribution, inflorescence type and inflorescence being blastotelic/anthotelic and auxotelic/anauxotelic) in the cladogram. Powell et al. (1996) followed with their study in the re-assessment of relationships within Epacridaceae where they discussed the generic boundaries of some genera and suggested that the generic limits of Dracophyllum need to be re-assessed and that Oliver's (1982) subgenera do not form monophyletic groups in any of their most 
parsimonious trees. They indicated that the subgenus Oreothamnus clusters with the genus Sphenotoma rather than with the subgenera Dracophyllum and Cordophyllum. Likewise in Crayn et al. (1998), the majority rule consensus tree placed subgenus Dracophyllum as sister to Richea and the authors concluded that further study is needed on the genus.

Baumann-Bodenheim's (1989b) concepts of Dracophyllum and its subgenera are very different from all previous authors. He appears not to have accepted the subgenera as published by previous authors and proceeded to publish the genus Daenikeranthus to accommodate Dracophyllum alticola (as Daenikeranthus alticolus) providing no reason or discussion for taking this step. The basionym reference was not given and the author of Dracophyllum not stated. The combination is illegitimate and thus the generic name is illegitimate according to the International Code of Botanical Nomenclature (ICBN) Article 33.4 (Greuter et al. 2000). Baumann-Bodenheim (1989a,b) also erected the generic name Oreothamnus and referred to it as 'Oreothamnus Oliver (1852)'. Oliver changed the section Oreothamnus Mueller (1858) to subgenus Oreothamnus in 1928. No reference could be found to the date of 1852 with reference to Oreothamnus and it does not appear to be merely a typographical error for 1952. He used the genus name Oreothamnus to accommodate Dracophyllum amabile (a synonym of $D$. ramosum), D. cosmelioides and $D$. ramosum but failed to cite the correct author names, gave no Latin description nor mentioned the type or its reference for his genus Oreothamnus. This resulted in the generic name not being validly published according to the International Code of Botanical Nomenclature (ICBN) Article 33.4. (Greuter et al. 2000). None of the above Dracophyllum species belong to the subgenus Oreothamnus sensu Oliver and from this it appears that Baumann-Bodenheim's concept of Oreothamnus was directly in opposition to that of Von Mueller (1858); Oliver (1928, 1952); 
Virot (1975); Brown \& Streiber (2000) and Venter (2002; 2004). This whole exercise is most confusing because he gave no rationale as to why he used Oreothamnus in the first place. His circumscription excludes the type species of Dracophyllum section Oreothamnus F. Muell.

\subsection{Materials and methods}

\section{Herbaria and libraries}

This study has followed the standard methods for taxonomic revisions (Davis \& Heywood 1967). Relevant literature was consulted in libraries at Auckland Museum, University of Auckland, and Landcare Research at Lincoln, Lincoln University, Museum of New Zealand, Victoria University of Wellington, Nelson Public Library and Wellington Public Library. Herbarium material was received on loan from the following herbaria: AK, AKU, BM, BRIU, CANU, FI, GZU, HO, K, L, LINC, MEL, MPN, MW, NSW, NZFRI, O, OTA, P, S, TCD, UNSW, UPS, W, WAIK, WELT, WELTU and Z (abbreviations from Holmgren et al. 1990, Index Herbariorum). Abbreviations for periodicals follow Lawrence et al. (1968), those of books Stafleu \& Cowan (1976-1988), and for names of authors Brummitt \& Powell (1992). Terminology used is mainly in accordance with Stearn (1996).

\section{Typification}

Type material of all species and varieties of Dracophyllum and their synonyms was obtained from AK, BM, FI, GZU, HO, K, L, MEL, NSW, O, P, S, W, WELT and Z. All holotypes were checked with the respective protologues. Where lectotypification was necessary, Articles 7-10 of the ICBN (Greuter et al. 2000) were followed. In most instances, Oliver (1952) did not indicate on the type specimens that they were in fact the 'types'. All these type 
specimens were properly assigned and labelled as such in this study. Different names based on the same type specimen are homotypic synonyms and indicated by .

\section{Field studies}

Field studies were done on populations of all the New Zealand species of Dracophyllum and Oreothamnus in their natural habitat. This was done from as many different populations per species as possible to ascertain variability within species. Information on habitat and population characteristics was collected on 'Field Data' forms and stored in a database. Flowering and fruiting material was collected and preserved in specimen jars filled with preservative (F.A.G.) made up as follows: Formaldehyde (1 ml), Ethanol (10 ml), Glycerol (1 $\mathrm{ml}$ ) and Water $(8 \mathrm{ml})$. Glycerol is added to the mixture to keep the material soft and pliable, so that it can be handled under the microscope with ease without fear of breaking.

\section{Description of vegetation classes}

Plant associations that are commonly associated with the different Dracophyllum and Oreothamnus species are described according to a structural classification system (Table 1.4) based on that of Fosberg (1967), Eiten (1968, 1972), Specht (1981) and Edwards (1983). This broad-scale classification of vegetation can be applied to a variety of purposes. The aim here is to provide a definition of the broader structural classes of vegetation so that they may give a more precise and consistent meaning to these structural types of vegetation. A set of simple, basic terms for these structural classes and the use of terms for some common parameters of vegetation, especially cover and density, are given (Table 1.4). To determine structural classes a two-way matrix is established for a structural group (growth form $\times$ cover) and formation class (structural group $\times$ height). Primary growth forms are trees, 
shrubs, grasses and herbs. Cover is defined as the vertical projection of the crown area of the

plant to the ground as opposed to foliage cover that is most commonly used.

Table 1.4. Vegetation structural groups and formation classes.

\begin{tabular}{|c|c|c|c|c|}
\hline & \multicolumn{4}{|c|}{ Total plant cover } \\
\hline & \multicolumn{4}{|c|}{ FOREST } \\
\hline & \multicolumn{4}{|c|}{ Total tree cover $>75 \%$ and shrub cover $<10 \%$} \\
\hline & Subalpine forest & Upland forest & Sw amp forest & Low land forest \\
\hline Trees $>20 \mathrm{~m}$ & & High forest & High forest & High forest \\
\hline Trees $10-20 \mathrm{~m}$ & Tall forest & Tall forest & Tall forest & Tall forest \\
\hline Trees $5-10 \mathrm{~m}$ & Short forest & Short forest & Short forest & Short forest \\
\hline \multirow[t]{5}{*}{ Trees $2-5 \mathrm{~m}$} & Low forest & Low forest & Low forest & Low forest \\
\hline & \multicolumn{4}{|c|}{ WOODLAND } \\
\hline & \multicolumn{4}{|c|}{ Total tree cover $>0.1 \%$ and shrub cover $10 \%$ if $>1 \mathrm{~m}$ high } \\
\hline & \multicolumn{4}{|c|}{ Total tree cover $75-10 \%$ and shrub cover $<10 \%$} \\
\hline & & $75-10 \%$ & $10-1 \%$ & $1-0.1 \%$ \\
\hline Trees $>20 \mathrm{~m}$ & & High closed w oodland & High open w oodland & High sparse w oodland \\
\hline Trees $10-20 \mathrm{~m}$ & & Tall closed w oodland & Tall open w oodland & Tall sparse w oodland \\
\hline Trees $5-10 \mathrm{~m}$ & & Short closed w oodland & Short open w oodland & Short sparse w oodland \\
\hline \multirow[t]{5}{*}{ Trees $2-5 \mathrm{~m}$} & & Low closed w oodland & Low open w oodland & Low sparse w oodland \\
\hline & \multicolumn{4}{|c|}{ SHRUBLAND } \\
\hline & \multicolumn{4}{|c|}{ Total tree cover $<0.1 \%$ and shrub cover $>0.1 \%$} \\
\hline & \multicolumn{4}{|c|}{ Tree cover up to $1 \%$ and shrub cover $>10 \%$ and $>1 \mathrm{~m}$ high } \\
\hline & & $100-10 \%$ & $10-1 \%$ & $1-0.1 \%$ \\
\hline Shrubs $2-5 \mathrm{~m}$ & & High closed shrubland & High open shrubland & High sparse shrubland \\
\hline Shrubs $1-2 \mathrm{~m}$ & & Tall closed shrubland & Tall open shrubland & Tall sparse shrubland \\
\hline Shrubs $0.5-1$ & & Short closed shrubland & Short open shrubland & Short sparse shrubland \\
\hline \multirow[t]{5}{*}{ Shrubs $<0.5 \mathrm{~m}$} & & Low closed shrubland & Low open shrubland & Low sparse shrubland \\
\hline & \multicolumn{4}{|c|}{ GRASSLAND } \\
\hline & \multicolumn{4}{|c|}{ Total shrubs cover $<0.1 \%$ and herb cover $<0.1 \%$} \\
\hline & \multicolumn{4}{|c|}{ Grass cover dominant and $>10 \%$} \\
\hline & & $100-10 \%$ & $10-1 \%$ & $1-0.1 \%$ \\
\hline Shrubs $2-5 \mathrm{~m}$ & & High closed grassland & High open grassland & High sparse grassland \\
\hline Shrubs $1-2 \mathrm{~m}$ & & Tall closed grassland & Tall open grassland & Tall sparse grassland \\
\hline Shrubs $0.5-1$ & & Short closed grassland & Short open grassland & Short sparse grassland \\
\hline \multirow[t]{5}{*}{ Shrubs $<0.5 \mathrm{~m}$} & & Low closed grassland & Low open grassland & Low sparse grassland \\
\hline & \multicolumn{4}{|c|}{ HERBLAND } \\
\hline & \multicolumn{4}{|c|}{ Total tree cover $<0.1 \%$, shrub cover $<0.1 \%$} \\
\hline & \multicolumn{4}{|c|}{ Herb cover dominant and $>0.1 \%$} \\
\hline & & $100-10 \%$ & $10-1 \%$ & $1-0.1 \%$ \\
\hline Herbs $>2 \mathrm{~m}$ & & High closed herbland & High open herbland & High open herbland \\
\hline Herbs $1-2 \mathrm{~m}$ & & Tall closed herbland & Tall open herbland & Tall open herbland \\
\hline Herbs $0.5-1 \mathrm{~m}$ & & Short closed herbland & Short open herbland & Short open herbland \\
\hline Herbs $<0.5 \mathrm{~m}$ & & Low closed herbland & Low open herbland & Low open herbland \\
\hline
\end{tabular}




\section{Propagation}

Live seedlings and young plants of all the New Zealand species were collected by lifting the plant with as large a root ball as possible. These were planted into plastic plant pots in the following potting mix: 4 parts fine pine bark, 2 parts Flourish compost, 1 part frost grit, Dried blood $150 \mathrm{ml}$, Osmocote $8-9$ month release $5 \mathrm{~kg} / \mathrm{m}^{3}$ and Dolomite $125 \mathrm{ml}$. Fifty percent of each population sample was kept in a shade house under $40 \%$ shade netting and the other fifty percent in full sun to study the degree of variation in growth habit induced by shade and wind shelter.

\section{Herbarium material}

Herbarium material was dried in standard plant presses in the sun to make sure it could be used for epicuticular wax studies under the scanning electron microscope. Artificial heat sources (fire or heaters) were avoided because the excess heat may cause the wax structures (platelets, tubules) to either melt or deform. Vouchers were taken to verify identity of all observations reported and are housed in CHR and annotated accordingly. Other specimens used are cited with the necessary designations from the herbaria, which sent them as loan material.

\section{Photographs}

Colour slides $(35 \mathrm{~mm})$ were taken of all the New Zealand Dracophyllum and Oreothamnus species using both an Asahi Pentax MZ5 camera with Fuji 200 ISO film and a Fujifilm S5500, 4 mega pixel digital camera. 


\section{Preparation of material for SEM photography}

Scanning electron microscope (SEM) studies were performed on a Leica scanning electron microscope operating at $10 \mathrm{kV}$. Epicuticular waxes were studied from fresh and herbarium material (Appendix 2). Small pieces of mature leaves measuring $5 \times 5 \mathrm{~mm}$ were cut and fixed on aluminium stubs using double-sided adhesive tape and sputter coated with gold as above. The terminology used to describe the physical structure of the epicuticular waxes in Dracophyllum and Oreothammus is according to Barthlott et al. (1998). Pollen grains were removed from flowers of dried material (Appendix 2) brushed off onto aluminium stubs covered with double-sided adhesive tape and sputter-coated with $25 \mathrm{~nm}$ of gold in an Argon atmosphere.

Insects and pollen

Insects were caught on flowers of Dracophyllum and Oreothamnus making use of a suction tube, plastic vials $(10,15 \& 20 \mathrm{ml})$ and a butterfly net. The insects were killed by squeezing the thorax and transferring them to a paper envelope for later study (Elzinga 1978) and for identification by Dr. John Dugdale, Landcare Research, Nelson. The insects were inspected under a dissecting microscope and the pollen was transferred to microscope slides and viewed under a light microscope at $\times 1000$ magnification to search for pollen tetrads that are characteristic of Styphelioideae. 


\section{Distribution maps}

The distribution maps are based on herbarium specimens seen and material collected by myself during fieldwork. The $14^{\circ}\left(15^{\prime}\right)$ square mapping system based on Tarboton et al. (1987) was adopted for this study because New Zealand, New Caledonia and Australia operate on different mapping systems (Figure 1.1). The locality marked by the solid dot in Figure 1.1 is read as ' $42-172$ : DA' where $42-172$ refers to the one-degree square embraced by latitude $42^{\circ}$ and longitude $172^{\circ}$. DA is the subdivision of this into quarters and this divided again into quarters (half degree) 'D' being one of them and then the subdivision of each half-degree square into four quarter-degree squares with A being one of them.

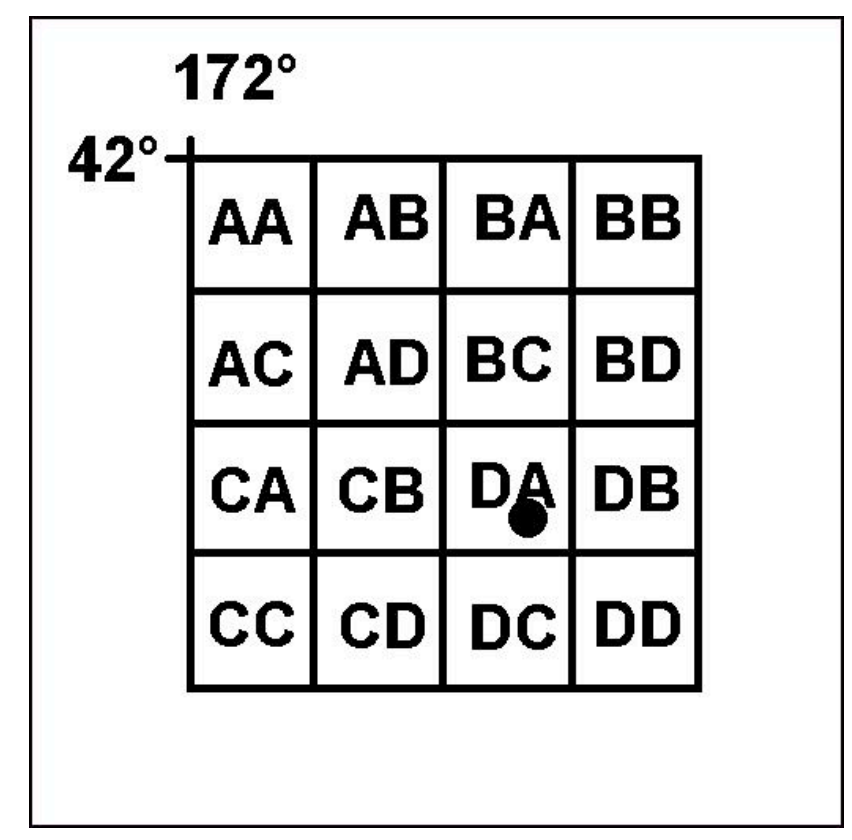

Figure 1.1 The $1 / 4^{\circ}(15)$ square mapping system. The whole block is $1^{\circ}$ by $1^{\circ}$ and each small block is a $14^{\circ}$ by $14^{\circ}(15)$. 
Specimens examined

"Specimens examined" is a partial list of specimens examined, selected on the basis of a) historical specimens used in previous revisions, b) complete fertile material and c) representative for the $14^{\circ}$ square distribution of the species. Mapped localities were plotted digitally, using the program Distribution Plotter Utility v. 2.0 (Pickard undated). All specimens studied have been annotated.

\section{Line drawings}

Line drawings were based on material in FAA, live material, and herbarium specimens. Drawings were made using Rotring Rapidograph ISO pens on Shamrock $120 \mathrm{~g}$ paper and the measurements were based on specific specimens mentioned with each illustration.

\section{Descriptions}

The program DELTA (Description Language for Taxonomy) (Dallwitz et al. 1993) is a general system for processing taxonomic descriptions and was used to compile the species descriptions by using the natural language description writing facility. The descriptions were slightly modified and some extra data added to improve the descriptions. Using DELTA for the descriptions thus ensured consistency (Table. 1.5.).

All the known variation was recorded with the diagnostic features of each species given and mentioned separately. All species descriptions are amplified compared to the original descriptions. 
Table 1.5. DELTA character set.

\#1. <Type description reference >/

\#2. <Type $>/$

\#3. $<$ Other types $>/$

\#4. $<$ Synonyms with references and types $>/$

$\# 5 .<$ Vernacular name $>$ /

\#6. $<$ Life form $>$ /

1. cushion forming $<1-5 \mathrm{~cm}>$ /

2. scrambler $<6-30 \mathrm{~cm}>$ /

3. sub-shrub $<31-50 \mathrm{~cm}>/$

4. shrub $<51-150 \mathrm{~cm}>$ /

5. small tree $<151-250 \mathrm{~cm}>$ /

6. tree $<251-1500 \mathrm{~cm}>$ /

\#7. $<$ Height of plant in $\mathrm{cm}>/$

$\mathrm{cm}$ tall/

\#8. Branches $<$ habit $>$ /

1. erect stemmed and sparingly branched/

2. erect stemmed and many branched/

3. spreading and sparingly branched/

4. spreading and many branched/

5. branches from one point/

6. open candelabra/

7. closed candelabra/

8. decumbent/

9. prostrate/

\#9. Stem at ground level $<$ habit $>/$

1. single stemmed/

2. many stemmed/

\#10. Stem at ground level $<$ diameter $>/$ mm wide/

\#11. Bark < colour $>$ /

1. grey/

2. dark grey/

3. greyish brown/

4. light brown/

5. brown/

6. reddish-brown/

7. dark brown/

8. blackish brown/

$\# 12$. Bark $<$ texture $>$ /

1. smooth/

2. finely fissured/

3. deeply fissured/
4. fibrous/

5. ridged/

6. rough/

7. flaky/

\#13. Bark on branchlet $<$ texture $>$ /

1. glabrous/

2. pubescent/

3. tomentose/

\#14. Bark on branchlet $<$ colour $>/$

1. grey/

2. yellowish brown/

3. brown/

4. reddish brown/

5. dark brown/

6. purplish brown/

7. blackish brown/

\#15. Leaves $<$ juvenile or adult only $>$ /

1. juvenile/

2. adult only/

\#16. Juvenile leaves < arrangement>/

1. crowded at tips of branches/

2. spirally along branches/

3. imbricate/

\#17. Juvenile lamina $<$ habit $>$ /

1. erect/

2. spreading/

3. recurved/

\#18. Juvenile lamina sheath $<$ colour $>$ /

1. yellowish green/

2. light green/

3. dark green/

4. olive-green/

5. glaucous/

6. brown/

\#19. Juvenile lamina sheath $<$ length in $\mathrm{mm}>$ / $\mathrm{mm}$ long/

\#20. Juvenile lamina sheath $<$ width in $\mathrm{mm}>$ / mm wide/

\#21. Juvenile lamina sheath shoulder $<$ shape $>$ /

1. tapering/

2. rounded/

3. truncate/

4. auricled/ 
$\# 22$. Juvenile lamina sheath margin $<$ texture $>$ /

1. entire/

2. ciliate in upper half/

3. ciliate /

\#23. Juvenile lamina <texture $>$ /

1. subcoriaceous/

2. coriaceous/

3. rigid and hard/

\#24. Juvenile lamina <colour $>$ /

1. glaucous/

2. light green/

3. deep green/

4. olive green/

5. green tinged red at base/

\#25. Juvenile lamina $<$ shape $>$ /

1. linear/

2. linear-subulate/

3. subulate/

4. linear-triangular/

5. lanceolate/

6. oblong/

7. ovate/

8. triangular/

\#26. Juvenile lamina adaxial surface $<$ texture $>$ /

1. glabrous/

2. patch of scabrid hairs at base/

3. scabrid/

4. pubescent/

5. tomentose/

\#27. Juvenile lamina abaxial surface $<$ texture $>$ /

1. glabrous/

2. scabrid/

3. pubescent/

4. tomentose/

\#28. Juvenile lamina $<$ length $>/$

$\mathrm{mm}$ long/

\#29. Juvenile lamina at base $<$ width in $\mathrm{mm}>$ / mm wide/

\#30. Juvenile lamina margin $<$ texture $>$ /

1. entire/

2. serrulate/

3. ciliate/

4. densely pubescent/

\#31. Juvenile lamina margin $<$ teeth $/ \mathrm{cm}>$ / number of teeth/
\#32. Juvenile lamina apex $<$ shape $>$ /

1. obtuse/

2. subacute/

3. acute/

4. acuminate/

\#33. Juvenile lamina adaxial apex $<$ texture $>/$

1. glabrous/

2. pubescent/

\#34. Adult leaves < arrangement $>$ /

1. crowded at tips of branches/

2. spirally along branches/

3. imbricate/

\#35. Adult leaves $<$ habit $>$ /

1. appressed to stem/

2. erect/

3. spreading/

4. recurved/

5. bromelioid/

\#36. Adult leaves below inflorescence $<$ decreasing in size $>$ /

1. not decreasing in size/

2. decreasing in size

\#37. Adult lamina sheath $<$ colour $>$ |

1. glaucous/

2. light green/

3. olive green/

4. dark green/

5. light brown/

\#38. Adult lamina sheath $<$ length in $\mathrm{mm}>$ / $\mathrm{mm}$ long/

\#39. Adult lamina sheath $<$ width in $\mathrm{mm}>$ / mm wide/

\#40. Adult lamina sheath $<$ texture $>$ /

1. membranous/

2. subcoriaceous/

3. coriaceous/

4. rigid and hard/

\#41. Adult lamina sheath $<$ striate or not $>$ /

1. not striate/

2. striate/

\#42. Adult lamina sheath margin $<$ membranous or not $>1$

1. not membranous/

2. membranous/ 
\#43. Adult lamina sheath shoulder $<$ shape $>$ /

1. tapering/

2. rounded/

3. truncate/

4. auricled/

\#44. Adult lamina sheath margin $<$ texture $>$ /

1. smooth/

2. top half ciliate/

3. ciliate/

\#45. Adult lamina $<$ texture $>/$

1. subcoriaceous/

2. coriaceous/

3. rigid and hard/

\#46. Adult lamina $<$ colour $>/$

1. glaucous/

2. light green/

3. mid green/

4. olive green/

5. dark green/

\#47. Adult lamina colour $<$ abaxially $>$ /

1. same colour as adaxial surface/

2. lighter than adaxial surface/

\#48. Adult lamina $<$ shape $>$ /

1. linear/

2. linear-subulate/

3. subulate/

4. linear-triangular/

5. lanceolate/

6. oblong/

7. ovate/

8. triangular/

\#49. Adult lamina <length>/ $\mathrm{mm}$ long/

\#50. Adult lamina $<$ width at base $>/$ mm wide/

\#51. Adult lamina adaxial surface in crosssection $<$ shape $>$ /

1. rounded/

2. flat/

3. slightly concave/

4. concave/

5. canaliculate/

\#52. Adult lamina abaxial surface in crosssection $<$ shape $>$ /

1. flat/

2. rounded

3. ridged/

\section{4. keeled/}

\#53. Adult lamina adaxial surface $<$ texture $>/$

1. glabrous/

2. rugose/

3. scabrid/

4. pubescent/

5. tomentose/

6. with tuft of hairs at base $>$ /

54. Adult lamina abaxial surface $<$ texture $>/$

1. glabrous/

2. scabrid hairs in upper half/

3. scabrid/

4. pubescent/

5. tomentose/

\#55. Adult lamina surface $<$ striation $>$ /

1. slightly striated/

2. prominently striated/

\#56. Adult lamina margin $<$ cartilaginous or not $>$ /

1. cartilaginous/

2. not cartilaginous/

\#57. Adult lamina margin $<$ texture $>/$

1. entire/

2. scabrid/

3. serrulate/

4. serrate/

5. denticulate/

6. ciliate/

7. densely pubescent/

\#58. Adult lamina margin $<$ teeth per $\mathrm{cm}$ in middle of leaf $>/$ number of teeth/

\#59. Adult lamina apex $<$ thickened or not $>/$ 1. thickened/

2. not thickened/

\#60. Adult lamina apex $<$ shape $>$ /

1. obtuse/

2. lobed/

3. acicular/

4. triquetrous/

5. acute/

6. acuminate/

\#61. Dry old leaves <present or absent>/

1. present/

2. absent/ 
\#62. Inflorescence <type $>$ /

1. solitary//
2. raceme//
3. panicle/

\#63. Inflorescence $<$ habit $>$ /

1. terminal on branches/

2. terminal on lateral branchlets/

3. near apices of branches/

4. below leaves/

\#64. Inflorescence $<$ longer or shorter than leaves $>$ /

1. longer than leaves/

2. shorter than leaves/

\#65. Inflorescence $<$ flowers maturing acropetally or basipetally $>$ /

1. acropetally/

2. basipetally/

\#66. Inflorescence <erect or drooping $>$ |

1. erect/

2. drooping/

\#67. Inflorescence $<$ dense or lax $>/$

1. lax/

2. dense/

\#68. Inflorescence $<$ length in $\mathrm{mm}>/$ $\mathrm{mm}$ long/

\#69. Inflorescence $<$ shape $>/$

1. linear-oblong/

2. oblong/

3. pyramidal/

\#70. Inflorescence < branching $>/$

1. sparingly branched/

2. densely branched/

$\# 71$. Inflorescence rachis and pedicels $<$ texture $>$ /

1. glabrous/

2. hirsute/

3. pubescent/

4. densely pubescent/

5. tomentose/

\#72. Inflorescence axis $<$ colour $>$ /

1. yellowish/

2. light green/

3. mid green/

4. dark green/

5. reddish brown/

6. reddish/
\#73. Inflorescence axis $<$ smooth or ribbed $>/$

1. smooth/

2. ribbed/

$\# 74$. Inflorescence axis $<$ diameter in $\mathrm{mm}$ at base $>$ /

mm diameter/

\#75. Inflorescence branch at base of inflorescence $<$ length in $\mathrm{mm}>/$ mm long/

\#76. Inflorescence branch $<$ habit $>$ /

1. suberect/

2. widely spreading/

3. at right angle with inflorescence axis/

\#77. Inflorescence bract $<$ caducous or persistent $>$ /

1. persistent/

2. caducous/

\#78. Inflorescence bract $<$ shorter or longer than flower $>$ /

1. shorter than flower/

2. equalling flower/

3. longer than flower/

\#79. Inflorescence bract $<$ texture $>/$

1. membranous/

2. subcoriaceous/

3. coriaceous/

4. rigid and hard/

\#80. Inflorescence bract $<$ colour $>$ |

1. light green/

2. dark green/

3. whitish at base/

4. glaucous/

5. pink tipped/

6. pink/

7. red/

\#81. Inflorescence bract $<$ shape $>$ /

1. subulate/

2. ovate-lanceolate/

3. narrowly ovate/

4. ovate/

5. broadly ovate/

6. ovate-triangular/

\#82. Inflorescence bract $<$ length in $\mathrm{mm}>/$ $\mathrm{mm}$ long/

\#83. Inflorescence bract $<$ width in $\mathrm{mm}>$ / mm wide/ 
\#84. Inflorescence bract adaxial surface $<$ texture $>$ /

1. glabrous/

2. rugose/

3. verrucose/

4. scabrid at base/

5. scabrid/

6. pubescent at apex/

7. pubescent/

8. sericeous/

\#85. Inflorescence bract abaxial surface $<$ texture $>$ /

1. glabrous/

2. rugose/

3. verrucose/

4. scabrid/

5. pubescent/

6. sericeous/

\#86. Inflorescence bract margin $<$ texture $>$ /

1. entire/

2. serrulate/

3. ciliate/

\#87. Inflorescence bract apex $<$ shape $>/$

1. obtuse/

2. subulate/

3. acute/

4. acuminate/

5. mucronate/

\#88. Flowers $<$ hidden by leaves or exposed $>$ / 1. hidden by leaves/

2. exposed/

\#89. Flowers $<$ number $>/$ I

\#90. Flowers < arrangement on inflorescence basally $>$ /

1. solitary/

2. in groups of two/

3. in groups of three/

4. in groups of four/

5. in groups of $5-10 /$

6 . ingroups of $>10 /$

\#91. Flower $<$ sessile or pedicellate $>$ /

1. sessile/

2. pedicellate/

\#92. Flower bract $<$ caducous or persistent $>$ /

1. persistent/

2. caducous/
\#93. Flower bract $<$ shorter or longer than

flower $>$ /

1. shorter than flower/

2. equalling flower/

3. longer than flower/

\#94. Flower bract $<$ lower bracts leaf like or not $>$ |

1. leaf like/

2. not leaf like/

\#95. Flower bract $<$ texture $>/$

1. membranous/

2. subcoriaceous/

3. coriaceous/

4. rigid and hard/

\#96. Flower bract at base $<$ shape $>$ /

1. linear/

2. ovate-lanceolate/

3. narrowly ovate/

4. ovate/

5. broadly ovate/

6. triangular/

\#97. Flower bract at apex $<$ shape $>$ /

1. subulate/

2. linear/

3. ovate-lanceolate/

4. narrowly ovate/

5. ovate/

6. broadly ovate/

7. triangular/

\#98. Flower bract $<$ length in $\mathrm{mm}>$ / $\mathrm{mm}$ long/

\#99. Flower bract at base $<$ wide in $\mathrm{mm}>$ / mm wide/

$\# 100$. Flower bract at apex $<$ wide in $\mathrm{mm}>$ / mm wide/

\#101. Flower bract adaxial surface $<$ texture $>$ /

1. glabrous/

2. with a tuft of scabrid hair at apex/

3. pubescent in upper third/

4. with a tuft of scabrid hair at base/

5. scabrid/

6. pubescent/

7. sericeous/

\#102. Flower bract abaxial surface $<$ texture $>$ /

1. glabrous/

2. scabrid/

3. pubescent/

4. sericeous/ 
5. with tuft of scabrid hair at apex/

6. with a tuft of scabrid hair at base/

\#103. Flower bract margin $<$ texture $>/$

1. entire/

2. ciliate/

\#104. Flower bract margin $<$ colour $>$ /

1. green/

2. white/

\#105. Flower bract apex <shape $>$ /
1. obtuse/
2. mucronate/
3. acuminate/
4. acute/
5. subulate/

\#106. Bracteole < caducous or persistent $>$ /

1. persistent/
2. caducous/

\#107. Bracteole $<$ shorter to longer than flower $>$ / 1. shorter than flower/

2. equalling flower/

3. longer than flower/

\#108. Bracteole $<$ shape $>/$

1. linear/

2. narrowly ovate/

3. ovate/

4. triangular/

\#109. Bracteole $<$ length in $\mathrm{mm}>$ / $\mathrm{mm}$ long/

\#110. Bracteole <width in $\mathrm{mm}>$ / mm wide/

\#111. Bracteole adaxial surface $<$ texture $>$ /

1. glabrous/

2. scabrid/

3. pubescent/

$\# 112$. Bracteole abaxial surface $<$ texture $>$ /

1. glabrous/

2. scabrid/

3. pubescent/

\#113. Pedicel $<$ habit $>$ /

1. straight/

2. curved/

\#114. Pedicel < colour >/

1. green

2. brown/
3. reddish brown/

$\# 115$. Pedicel $<$ length in $\mathrm{mm}>/$ mm long/

\#116. Pedicel surface $<$ texture $>$ /

1. glabrous/

2. pubescent/

3. tomentose/

\#117. Sepal < colour $>/$

1. green/

2. reddish brown/

3. rose-coloured/

4. red/

\#118. Sepal <shape $>$ /

1. lanceolate/

2. ovate-lanceolate/

3. oblong/

4. narrowly ovate

5. ovate/

6. broadly ovate/

7. triangular/

\#119. Sepal $<$ length in $\mathrm{mm}>$ / mm long/

\#120. Sepal < width in $\mathrm{mm}>/$ mm wide/

$\# 121$. Sepal $<$ shorter or longer than corolla tube $>$ /

1. shorter than corolla tube/

2. equalling corolla tube/

3. longer than corolla tube/

$\# 122$. Sepal $<$ striate or not $>/$

1. not striate/

2. striate/

\#123. Sepal adaxial surface $<$ texture $>$ /

1. glabrous/

2. top half pubescent/

3. patch of scabrid hairs at base/

4. scabrid/

5. pubescent/

\#124. Sepal abaxial surface $<$ texture $>$ /

1. glabrous/

2. top half pubescent/

3. patch of scabrid hairs at base/

4. scabrid/

5. pubescent/ 


\section{\#125. Sepal margin $<$ texture $>$ / \\ 1. smooth/ \\ 2. upper third toothed/ \\ 3. toothed/ \\ 4. ciliate in upper half/ \\ 5. ciliate/}

\#126. Sepal apex $<$ shape $>/$

1. acuminate/

2. acute/

3. subacute/

4. obtuse/

\#127. Corolla $<$ colour $>/$

1. white/

2. yellowish/

3. light pink/

4. dark pink/

5. red/

6. dark red/

\#128. Corolla tube $<$ shape $>/$

1. cylindrical/

2. slightly urceolate/

3. narrowly-campanulate/

4. campanulate/

5. broadly campanulate/

\#129. Corolla tube $<$ mouth narrowed or widened $>/$

1. narrowed at mouth/

2. widened at mouth/

$\# 130$. Corolla tube $<$ length in $\mathrm{mm}>$ / mm long/

\#131. Corolla tube $<$ width in $\mathrm{mm}>$ / mm wide/

\#132. Corolla tube exterior <texture $>/$ 1. glabrous/

2. pubescent/

\#133. Corolla lobe $<$ habit $>/$
1. spreading
2. spreading horizontally/
3. reflexed/

\#134. Corolla lobe $<$ shape $>/$

1. broadly lanceolate/

2. oblong/

3. ovate/

4. ovate-triangular/

5. broadly triangular/

6. triangular/
\#135. Corolla lobe $<$ shorter or longer than tube $>$ / 1. shorter than corolla tube/

2. equalling corolla tube/

3. longer than corolla tube/

\#136. Corolla lobe $<$ length in $\mathrm{mm}>$ / mm long/

\#137. Corolla lobe $<$ width in $\mathrm{mm}>/$ mm wide/

\#138. Corolla lobe <apical ridge absent or present $>$ /

1. apical ridge absent/

2. apical ridge present/

\#139. Corolla lobe <inflexed or not $>$ / 1. inflexed for entire length/

2. inflexed at apex/

3. not inflexed/

\#140. Corolla lobe apex $<$ shape $>/$

1. acute/

2. subacute/

3. obtuse/

\#141. Corolla lobe adaxial surface $<$ texture $>$ /

1. glabrous/

2. papillate/

3. rugose-verrucate/

$\# 142$. Corolla lobe abaxial surface $<$ texture $>$ /

1. glabrous/

2. pubescent/

\#143. Corolla lobe $<$ ratio of length compared to tube length $>$ / ratio/

\#144. Stamen insertion in corolla tube $<$ position $>$ /

1. top/

2. upper third/

3. middle/

4. lower third/

5. base/

\#145. Filament $<$ length in $\mathrm{mm}>$ / $\mathrm{mm}$ long/

\#146. Anther <exsertion>/

1. included/

2. slightly exserted/

3. exserted/ 


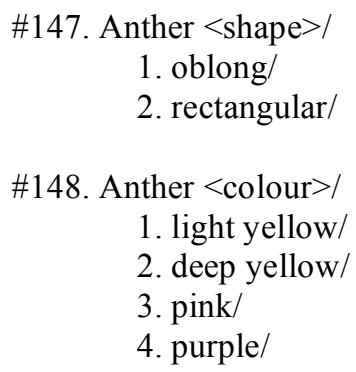

\#149. Anther $<$ length in $\mathrm{mm}>$ / $\mathrm{mm}$ long/

$\# 150$. Nectary scale $<$ connate at base or not $>/$ 1. not connate at base/

2. connate at base/

\#151. Nectary scale $<$ shape $>/$
1. rectangular/
2. oblong/
3. round/

$\# 152$. Nectary scale $<$ length in $\mathrm{mm}>/$ $\mathrm{mm}$ long/

$\# 153$. Nectary scale $<$ width in $\mathrm{mm}>$ / mm wide/

$\# 154$. Nectary scale apex $<$ shape $>/$

1. acute/

2. subacute/

3. obtuse/

4. retuse/

5. irregularly toothed/

\#155. Ovary < shape $>$ /

1. cylindrical/

2. ovate/

3. subglobose/

4. globose/

5. obovate/

6. oblong/

$\# 156$. Ovary <length in $\mathrm{mm}>$ / $\mathrm{mm}$ long/

\#157. Ovary < width in $m m>$ / mm wide/

\#158. Ovary length : width $<$ ratio $>/$ ratio/

\#159. Ovary apex $<$ shape $>/$

1. tapering/

2. round/

3. truncate/
$\# 160$. Ovary apex < surface texture $>$ /

1. glabrous/

2. apex pubescent/

3. pubescent/

$\# 161$. Style $<$ habit $>/$

1. enclosed/

2. exserted/

\#162. Style <length in $\mathrm{mm}>/$ mm long/

\#163. Style < surface texture $>/$

1. glabrous/

2. papillose distally/

3. pubescent/

\#164. Style $<$ lengthening in fruit or not $>$ /

1. lengthening in fruit/

2. not lengthening in fruit/

\#165. Stigma $<$ shape.>/

1. capitate/

2. clavate/

3. five-lobed/

$\# 166$. Fruit <enclosed in persistent sepals or not $>1$

1. enclosed/

2. not enclosed/

\#167. Fruit <pedicellate or sessile>/

1. pedicellate/

2. sessile/

\#168. Fruit <colour $>/$

1. light brown/

2. dark brown

3. reddish brown/

4. purplish brown/

\#169. Fruit $<$ length in $\mathrm{mm}>/$

mm long/

$\# 170$. Fruit $<$ diameter in $\mathrm{mm}>/$ mm diameter/

\#171. Fruit $<$ shape $>/$

1. depressed-globose/

2. depressed-obovoid/

3. obovoid/

4. broadly obovoid/

5. round/

6. oblong/ 
\#172. Fruit apex <shape>/

1. pointed/

2. round/

3. truncate/

\#173. Fruit apex <texture $>/$

1. glabrous/

2. pubescent/

\#174. Seed < colour $>/$

1. cream coloured/

2. yellowish brown/

3. light brown/

4. brown/

5. dark brown/

6. black/

\#175. Seed $<$ shape $>/$

1. filiform/

2. ovoid/

3. trigonous/

$\# 176$. Seed $<$ length in $\mathrm{mm}>$ / mm long/

$\# 177$. Seed surface $<$ texture $>/$ 1. slightly reticulate/

2. prominently reticulate/

\#178. Flowering $<$ months $>/$

1. January/

2. February/

3. March/

4. April/

5. May/

6. June/

7. July/

8. August/

9. September/

10. October/

11. November/

12. December/

\#179. Fruiting $<$ months $>$ /

1. January/

2. February/

3. March/

4. April/

5. May/

6. June/

7. July/

8. August/

9. September/

10. October/

11. November/

12. December/
\#180. Distribution/

1. Australia/

2. Tasmania/

3. Lord Howe Island/

4. New Caledonia/

5. New Zealand/

6. Chatham Islands/

7. Auckland Islands/

8. Cambell Island/

9. Three Kings Islands/

10. Great Barrier Island/

11. Little Barrier Island/

12. Stewart Island/

13. Mayor Island/ 


\subsection{Aims of this thesis:}

1. To test the monophyly of Dracophyllum and resolve the phylogenetic relationships among genera and species based on morphology. The generic circumscription of Dracophyllum is reviewed. This is the first cladistic study of the genus Dracophyllum and the first discussion on the evolutionary history not only of the genus but also the species. The importance and variation of several new morphological characters are described and discussed.

2. To conduct a full taxonomic revision of the genus Dracophyllum, including recognition, circumscription, description and nomenclature of all species. Species limits have been tested by attempting to falsify hypotheses of conspecificity (Garnock-Jones \& Lloyd 2004).

3. To consider the role of adaptation to substrates and other physical environments and/or adaptation to different pollinators leading to reproductive isolation, in speciation in Dracophyllum. The value and variation in flower biology and pollination is discussed.

4. To discuss the various habitats of the species with emphasis on the community associations, geology and pedology.

\section{Chapter 2: Phylogenetic analysis of the Dracophyllum complex: evidence from morphology and anatomy}




\subsection{Introduction}

A phylogeny can be regarded as an evolutionary chronicle (Gravendeel 2000) and provides an unambiguous hypothesis regarding the relationships and the naturalness of the taxa. Once the phylogeny is reconstructed it can be used to produce an unequivocal system of classification. In this thesis evolutionary relationships are inferred by cladistic analysis of morphological and anatomical characters (Fig. 2.1). A phylogenetic classification system is produced, i.e. monophyletic groups are recognized. Taxa are anchored by rank, but with reference to phylogenetic relationships with other taxa (De Queiroz \& Gauthier 1990). I used this system because the criterium of common descent is objective and makes the system defendable instead of intuitive (Van Welzen 1998).

Traditionally the genus Dracophyllum is classified into three subgenera; subgenus Dracophyllum (as Eudracophyllum) based on the inflorescence being a panicle (e.g., D. verticillatum), subgenus Cordophyllum characterized by the inflorescence being a panicle and the flowers in dense fascicles, each on a separate pedicel clothed in numerous bracts (D. involucratum), and subgenus Oreothamnus characterized by solitary flowers (e.g., D. muscoides), flowers in a simple raceme (e.g., D. urvilleanum) or in a spike (e.g., D. filifolium). Species groups in the last revision (Oliver 1928) and its amendment (Oliver 1952) were based on macro morphological characters.

The tribe Richeeae forms a monophyletic group in all analysis (Powell et al. 1987, Crayn et al. 1996, Powell et al. 1996, Crayn et al. 1998, Kron et al. 2002) but the generic boundaries in Richeeae are still unclear. The subgenus Oreothamnus in Dracophyllum forms a distinct morphological group and except for one species, all occur in New Zealand and its offshore islands. In this study the possibility that subgenus Oreothamnus is distinct enough to be raised to generic level and its relationship to subgenus Dracophyllum are investigated. 
Powell et al. (1987) in their cladistic study of the Epacridaceae was the first to suggest that subgenus Oreothamnus may be worthy of generic rank based on the number of apomorphies (stomatal distribution, inflorescence type and inflorescence being auxotelic or anauxotelic). They also mentioned that according to their analysis there is little reason for separating the two sections (Cystanthe and Dracophylloides) in Richea. The results of my cladistic study showed a noticeable distinction between Cystanthe and Dracophylloides.

\subsection{Materials and methods}

\subsubsection{Study group and outgroup}

The study group consists of Dracophyllum (50 species), Richea (11 species) and Sphenotoma (6 species). For the purpose of this study Dracophyllum sens. lat. includes the subgenera Dracophyllum, Cordophyllum (D. involucratum) and Oreothamnus. As wide a range of specimens as possible was used to cover variation. The tribe Cosmelieae, which consists of the genera Andersonia R. Br. (22+ species), Cosmelia R. Br. (1 species) and Sprengelia Sm. (4 species) was used as the outgroup. This tribe is defined by two unique synapomorphies (leaf scars absent and leaf vein fibre caps reaching the opposite epidermis, Crayn et al. 1998) and was chosen based on recent cladistic studies where it formed the sister clade to the tribe Richeeae (Powell et al. 1996; Crayn et al. 1998; Crayn \& Quinn 2000; and Kron et al. 2002).

\subsubsection{Character assessment and data analysis}

The morphological character set (Table 4.1.) of Dracophyllum was examined to find characters that would aid in defining natural groups and to postulate a possible phylogeny. Morphological and 
anatomical data was used in this study due to the near absence of DNA studies and lack of chemical data available: only Dracophyllum longifolium var. longifolium has been included in DNA analyses (Kron et al. 2002). Weiller et al. 1994 included 34 species in a study of the epicuticular wax morphology. Betts (1919) studied the anatomy of D. pronum and Gibson (1991) that of Dracophyllum minimum.

The next step in the phylogenetic study is the selection and assessment of characters using criteria of homology, which is the similarity due to common evolutionary origin (Stevens 1971; Hawkins et al. 1997). Stevens (1971) also stated that characters having an obvious continuous quantitative basis show a higher incidence of homoplasy, which may distort the analysis. I have tried to select mostly qualitative characters for the cladistic analysis and chose two multistate (chars 11 and 30), 29 binary (8 as present/absent) and three quantitative (chars 9, 23 and 25) characters.

A total of 31 characters covering vegetative and floral morphology and general anatomy of the leaves were scored for all the species (Appendix 8). One character is architectural, 10 taken from the leaves, seven from the inflorescence, and 11 from the flower and one from the seed. These characters are those that show possible usefulness in the phylogenetic analysis. Autapomorphies were excluded from the analysis because they provide no information about relationships. Several of the characters $(9-11,16,20,28$ and 31) used for the cladistic study are new and they are described in this thesis for the first time (Table. 2.1.). Characters are assessed in the following discussion as to the delimitation of their states.

Table 2.1. Characters and character states used in the cladistic analysis.

\begin{tabular}{|l|l|}
\hline Habit 1. growth habit & trees/shrubs (0) sprawling/cushion plants (1) \\
\hline
\end{tabular}




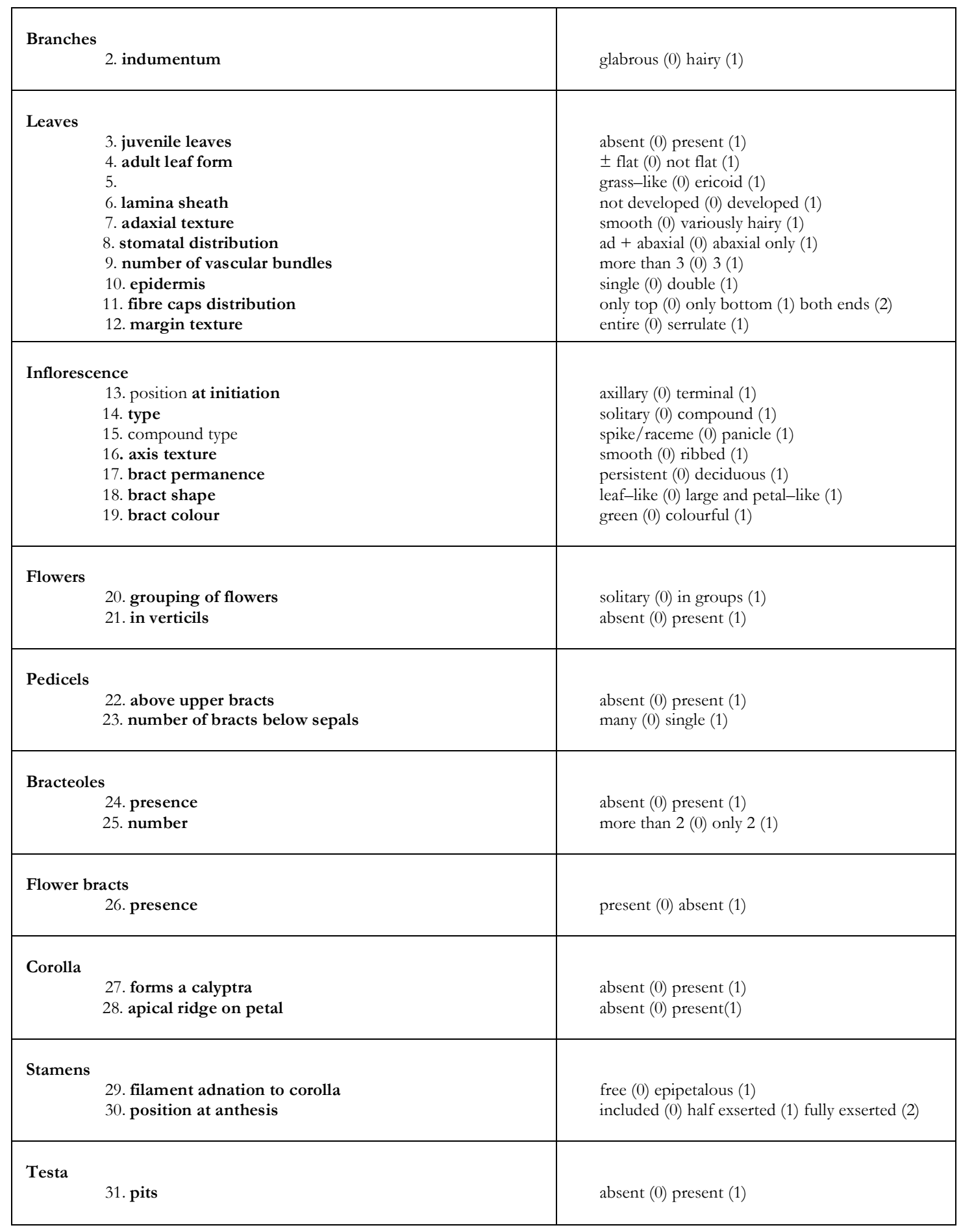

Growth habit (Character 1): Plants are woody perennial trees, shrubs or sub-shrubs with a few species (Dracophyllum densum, D. marmoricola, D. minimum, D. muscoides, D. politum, D. pronum, D. 
prostratum and D. recurvum) having a low sprawling or a cushion habit. The latter species are all associated with subalpine or alpine habitats.

Branch indumentum (Character 2): The presence of a well-developed indumentum on the young branches is present only in Dracophyllum alticola, D. balansae, D. cosmelioides and D. mackeeanum, species restricted to maquis vegetation in New Caledonia. This character appears to be constant for these four species based on material and fieldwork.

Juvenile leaves (Character 3): The occurrence of heteroblasty in Dracophyllum sens. lat. is well documented (Cockayne 1928, Oliver 1928, 1952) specifically leaf-heteroblastism (Philipson 1964) that refers to changes in leaf characters. Juvenile leaves in D. strictum and in subgenus Oreothamnus are larger and normally thinner in texture than the adult leaves. In most cases juvenile and adult phases persist together for a period of time, sometimes for years. In some cases the juvenile form is capable of reappearing in some part of the plant as a reversion shoot (Godley 1985). The leaf characters of the reversion shoot agree well with that of the juvenile leaves. Except for Dracophyllum strictum, the other 13 species with juvenile leaves all belong to subgenus Oreothamnus.

Adult leaf form (Characters 4-5): Leaves that are flat and wide are characteristic of subgenera Dracophyllum and Cordophyllum. The leaves are reasonably narrow in D. balansae $(2-3 \mathrm{~mm})$ and $D$. cosmelioides $(2.5-3.6 \mathrm{~mm})$ but still flat. In subgenus Oreothamnus the leaves are either prominently grass-like or ericoid (six species). The term ericoid refers to leaves that are needle-like semiterete to terete and not longer than $60 \mathrm{~mm}$. Species with ericoid leaves are associated with subalpine or alpine habitats. 
Lamina sheath development (Character 6): All species in subgenus Dracophyllum exhibit a weakly developed lamina sheath with no shoulders. In subgenus Oreothamnus the lamina sheath is well developed with the shoulders tapering to auriculate and variously decorated with hairs.

Lamina surface texture (Characters 7): Species of subgenus Dracophyllum with hairy leaves occur only in maquis vegetation on New Caledonia (D. balansae, D. cosmelioides and D. mackeeanum). Species in subgenus Oreothamnus with rugose leaves (D. acerosum, D. frondosum, D. marmoricola, D. recurvum, D. longifolium var. septentrionale) are from montane to subalpine areas and species with pubescent leaves (12 spp.) occur in a wide variety of habitats from coastal forest to subalpine areas.

Stomatal distribution on the lamina (Character 8): Species in subgenera Dracophyllum and Cordophyllum have stomata only on the abaxial surface but in subgenus Oreothamnus stomata occur on both surfaces.

Number of vascular bundles (Character 9): Anatomical characters have never been used in Dracophyllum sens. lat. taxonomy. I have distinguished between those species with only three vascular bundles per lamina and those with more than three.

Double epidermis (Character 10): There are two Dracophyllum species (D. fitzgeraldii, D. milliganii) with a double epidermis, a rare state in Ericaceae.

Sclereid distribution (Character 11): Watson (1967) gave four types of distribution of sclereids associated with the lamina veins namely i) Styphelia pattern, where the veins have an abaxial arc of sclereids touching the abaxial epidermis. ii) Epacris pattern, where the veins have an abaxial arc of sclereids embedded in the mesophyll and not adjacent to the epidermis. iii) Cosmelia pattern, 
where the veins have an abaxial arc of sclereids and are embedded in the mesophyll and touching the adaxial epidermis in the basal part of the leaf and Watson (1967) added a fourth, the Richea pattern, where the main veins are linked by sclereids to both upper and lower epidermis. Dracophyllum sens. lat. is traditionally classed in the Richea group (Watson 1967; Stevens 1971; Powell et. al. 1987; Kron et. al. 2002). During this study I found the Cosmelia, Richea and Styphelia patterns to be present in Dracophyllum sens. lat. showing that these characters cannot be upheld and used with confidence to group genera.

Leaf margin texture (Character 12): An entire or smooth lamina margin is present only in Dracophyllum alticola and D. sayeri and is regarded as a plesiomorphic state.

Position of the inflorescence (Character 13): In most species the inflorescence is situated at the apex of the branch (terminal), but there are species where the inflorescence is borne between the stem and a leaf (axillary).

Type of inflorescence (Characters 14-15): In subgenus Oreothamnus there are 11 species with solitary flowers. These plants are primarily associated with subalpine and alpine habitats. Twelve species have spikes and six species have racemes. Paniculate inflorescences are present only in subgenera Dracophyllum and Cordophyllum.

Texture of the inflorescence axis (Character 16): Three species have a prominently ribbed inflorescence axis (D. involucratum D. mackeeanum and D. milliganii).

Inflorescence bract permanence (Character 17): Inflorescence bracts are deciduous within species of subgenera Dracophyllum and Cordophyllum whereas they are persistent in subgenus Oreothamnus. 
Inflorescence bract shape and colour (Characters 18-19): In subgenera Dracophyllum and Cordophyllum the inflorescence bracts are large and mostly colourful but they are small and leaflike in subgenus Oreothamnus. Sometimes it is very difficult to distinguish between the leaves and the inflorescence bract in subgenus Oreothamnus but the texture of the lamina margin is different from that of the inflorescence bract. Flower bracts are green in all species of subgenus Oreothamnus.

Flower grouping (Character 20): Flowers are always borne singly in subgenus Oreothamnus but in subgenus Dracophyllum they are arranged in groups on the lower branches of the inflorescence.

Flowers arranged in verticils (Character 21): Dracophyllum involucratum and D. verticillatum from New Caledonia developed this flower arrangement, which the results indicate is an apomorphic condition, probably related to pollination.

Flowers pedicellate above upper bracts (Character 22): The bracts are inserted at a distance from the calyx in subgenera Dracophyllum and Cordophyllum.

Number of bracts below sepals (Character 23): Most species in subgenera Dracophyllum and Oreothamnus have only a single bract below the sepals but in D. involucratum and some Andersonia species there are more than one, sometimes up to 30.

Bracteole presence (Character 24-25): Bracteoles are present in subgenus Dracophyllum, Richea and Sphenotoma but absent in subgenus Oreothamnus. Bracteoles are normally two but there are species with more than two.

Flower bract presence (Character 26): Only present in subgenus Oreothamnus. 
Presence of a calyptra (Character 27): Only present in the genus Richea.

Presence of the apical ridge on the petal (Character 28): The value of this character state was only realised whilst visiting many populations of the alpine species in their natural habitat. A prominent apical ridge on the adaxial surface of the corolla lobe is present in 10 species in subgenus Oreothamnus. These species are all associated with subalpine to alpine habitats and except for three species, have a cushion-like growth habit.

Filament adnation to corolla (Character 29): Filaments are free in six species, all in subgenera Dracophyllum and Cordophyllum. Epipetalous stamens (inserted on the inside of the corolla tube) are present within all the other species. All species in subgenus Oreothamnus have epipetalous stamens.

Anther position at anthesis (Character 30): 10 Species in subgenera Dracophyllum and Cordophyllum have the anthers exserted from the mouth of the corolla at anthesis. It is clearly correlated with the various pollination syndromes.

Presence of testa pits (Character 31): A characteristic of the subgenera Dracophyllum and Cordophyllum. This is the first time that seed characters are being used in the taxonomy of the Styphelioideae.

Parsimony analyses were run in TNT (Tree Analysis Using New Technology, Goloboff et al. 2004) using a traditional search approach set for equal character weights, 100 random entry-order replicates. Because of the size of the data matrix, heuristic approaches of tree construction were used, set for TBR branch swapping with random taxon addition to recover multiple islands of equally parsimonious trees (Maddison 1991). Level of support for the clades identified in the 
parsimony analysis was inferred by standard bootstrap analysis (Felsenstein 1985) and parsimony jackknife analysis (Farris et al. 1996). The bootstrap approach places confidence estimates on groups contained in the most parsimonious trees and gives the investigator the ability to assign statistical confidence to hypotheses of relationship (Swofford \& Begle 1993). Bootstrap analysis used 10000 replicates. Clades supported by 50\% bootstrap values or more that are supported by morphological evidence and clades supported by $70 \%$ bootstrap values that are neither in support or in conflict with morphological evidence (Cantino et al. 1997) are indicated on the trees in Fig. 2.1. and 2.2. The parsimony jackknife analysis used 1000 replicates, each performing TBR branch swapping with 10 random entry orders saving one tree per replicate. TNT was also used to run Bremer support analyses, a synonym for the "decay index", as branch support (Mueller 2005) and the "Map characters onto trees" function to explore character state evolution.

\subsection{Results}

The strict consensus tree from the analysis is shown in Figure 2.1. and a maximum parsimony tree with the phylogenetically informative characters mapped on the branches, branch lengths indicated and the extant geographic distribution mapped in Figure 2.2. Most of the morphological features used in the analysis showed some level of homoplasy.

Results from the cladistic analysis show that none of the clades is strongly supported ( $90 \%$ bootstrap or more). There are two distinct divisions in the cladogram (Fig. 2.1.). The first clade represents the genus Oreothamnus and is supported by 64\% bootstrap and 68\% jackknife and with a Bremer support of six. The second clade is a heterogeneous group of 32 species representing the genera Dracophyllum and Richea. This clade is supported by $76 \%$ bootstrap and $78 \%$ jackknife with a Bremer support of six. The subclade representing Dracophyllum is moderately well supported with 75\% bootstrap; jackknife support of $81 \%$ and a Bremer support of six. Most of this subclade is unresolved except for $D$. verticillatum and $D$. involucratum from New Caledonia 
with a bootstrap support of $66 \%$, jackknife of $63 \%$ and a Bremer support of six. Dracophyllum milliganii and D. fitggeraldii are grouped together but the support is weak (bootstrap 51\% and Bremer support of one).

Richea is endemic to Australia with nine species restricted to Tasmania, and two to the state of Victoria on the mainland (Menadue \& Crowden 2000). The separation of Richea into two distinct grades corresponding to the sections Cystanthe and Dracophylloides was unexpected and supports Mueller's (1867) classification but appear paraphyletic. The two sections of Richea are grouped with Dracophyllum having a fairly strong support (76\% bootstrap) and form a grade basal to Dracophyllum in all the trees. Resolution is very low, but the few clades that are resolved within this grade are generally robust (Fig. 2.1.). 


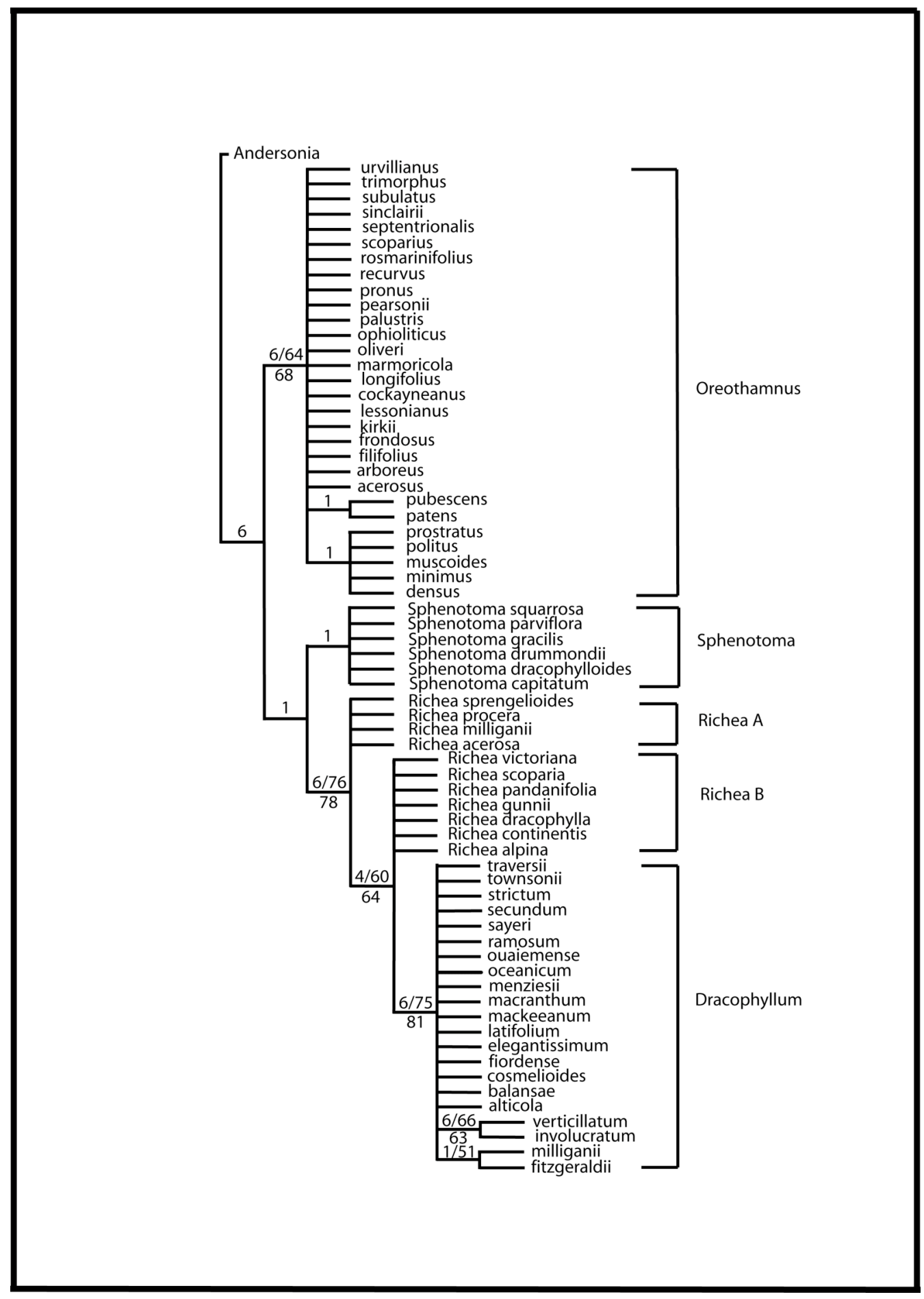

Figure 2.1. Strict consensus of 74 minimal length trees derived from the unweighted TNT parsimony analysis for the genera Dracophyllum, Richea and Sphenotoma. The numbers above the branches are the Bremer support value and the Bootstrap values, with the Jackknife values below the line. 


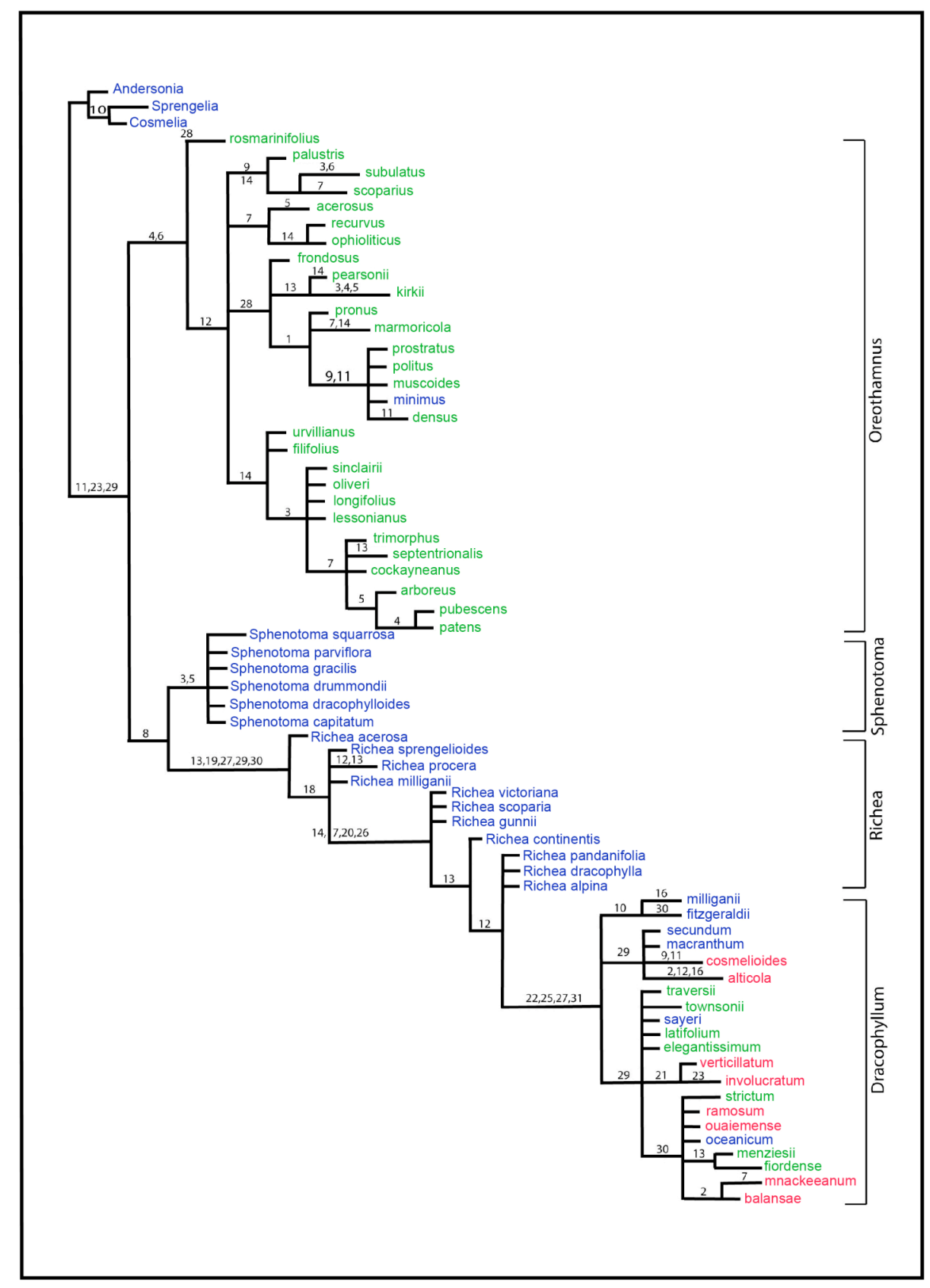

Figure 2.2. One of 74 equal-length maximum parsimony trees. $C I=0.4366$ and $\mathrm{RI}=0.9346$. Phylogenetically informative characters are mapped onto the branches. Branch lengths are proportional to the number of changes along each branch. Blue $=$ Australia, green $=\mathrm{New}$ Zealand, red $=$ New Caledonia taxa. 
The genus Sphenotoma forms a monophyletic group and within this study there is very little support for the clade but it corresponds well with the results of Powell et al. (1987), Crayn et al. (1996) and Powell et al. (1996). Sphenotoma is restricted to the South-West Botanical Province in Western Australia, separated by a gap of at least $2400 \mathrm{~km}$ from the nearest locality of Dracophyllum.

\subsubsection{Lability of characters}

The cushion growth habit (char. \#1) is a homologous state in the subalpine and alpine Oreothamnus species (O. densus, O. minimus, O. muscoides, O. politus, O. prostratus, O. pronus, O. marmoricola). Sometimes the growth habit is more carpet-like than cushion shaped especially in $O$. densus (Fig. 7.73B), O. politus and O. prostratus. Branches with a well-developed indumentum (char. \#2) characterize the Dracophyllum alticola, D. balansae, D. mackeeanum clade. This character has minimum variation in $D$. alticola but in $D$. balansae the indumentum can sometimes be quite sparse, and in D. mackeeanum it can be densely velutinous in plants at high elevations but hirsute at low elevations.

Of the 15 species with grass-like leaves (char. \#5), O. patens and O. pubescens have only the juvenile leaves grass-like with the adult leaves broad and flat. Distribution of the stomata (char. \#8) is a non-variable character and synapomorphy for the clade Dracophyllum + Richea + Sphenotoma where the stomata are restricted to the abaxial surface of the lamina. A double epidermis (char. \#10) is always present in D. fitzgeraldii and D. milliganii.

A paniculate inflorescence (char. \#15) is a synapomorphy of the genera Dracophyllum and Richea section Dracophylloides as well as the large (char. \#18) and colourful (char. \#19) caducous inflorescence bracts (char. \#17) and the flowers, which are arranged in groups on the lower inflorescence branches (char. \#20). The flowers are in groups of 3, 5- 10 or in groups of more 
than 10 . The flowers of $D$. involucratum and $D$. verticillatum are always in well-developed verticils (char. \#21). Only Dracophyllum has pedicels above the upper bracts (char. \#22). The absence of flower bracts is a non-variable character (char. \#26) for Dracopbyllum and Richea section Dracophylloides. The subalpine and alpine cushion species in Oreothamnus have a prominent apical ridge on the adaxial surface of the petals (char. \#28) and in some species (O. pronus and $O$. pearsonii) the apical ridge can sometimes be half the normal height. Well-developed testa pits (char. \#31) is a synapomorphy of Dracophyllum.

\subsection{Discussion}

\subsubsection{Major clades of Dracopbyllum, Richea and Sphenotoma}

The results of this study (Fig. 2.1.) support the monophyly of Oreothamnus (64\% bootstrap). The Oreothamnus clade consists of 29 species all from New Zealand except O. minimus, which is a Tasmanian endemic, and covers habitat types ranging from coastal forest to alpine grassland. Grass-like or ericoid leaves and well-developed lamina sheaths are synapomorphies that unite the clade. Stomata on the lamina surfaces, persistent inflorescence bracts and the presence of flower bracts are further supporting characters. Within the Oreothamnus clade there is little resolution but two sub-clades are prominent (Bremer support 1). The first includes two species, O. pubescens and O. patens, having the synapomorphy of well-developed broad and flat leaves. The second is the subclade with species (O. densus, O. minimus, O. muscoides, O. politus, O. prostratus) having only three vascular bundles and sclereid distribution with the bottom epidermis in the leaf as synapomorphies with additionally a prominent cushion growth habit and prominent apical ridges on the adaxial petal lobes. The rest of the species form an unresolved basal grade.

The Dracophyllum clade (75\% bootstrap) consists of 21 species growing in Australia (6 spp.), New Caledonia (8 spp.) and New Zealand (7 spp.). Most species occur in woodland or forest communities, with $D$. fiordense, D. menqiesii and $D$. traversii the only species recorded from 
subalpine vegetation. Pedicels above the upper bracts, presence of two bracteoles per flower and the presence of testa pits are synapomorphies that unite the clade. Leaves with a flat surface, weakly developed lamina sheath, stomata only on the abaxial lamina surface, paniculate inflorescence, deciduous large inflorescence bracts and flowers arranged in groups on the lower inflorescence branches are additional supporting characters. There appears to be some resolution in the Dracophyllum clade with two weakly supported (66\% and $51 \%$ bootstrap) sub-clades. The D. fitggeraldii - D. milliganii subclade with a Bremer support of one is characterized by the synapomorphy of a double epidermis, a rare character in the Ericaceae. Both are montane species but $D$. milliganii also occurs in subalpine areas. The D. involucratum - D. verticillatum subclade $(66 \%$ bootstrap and high Bremer support of six) has the synapomorphy of the inflorescence branches arranged in verticils along the inflorescence axis. Both species are from New Caledonia and grow in maquis and open forest vegetation. The rest of the species form an unresolved basal grade.

The Sphenotoma clade is characterized by the absence of distinct juvenile leaf morphology and flowers borne in contracted spikes. It has the autapomorphy of the corolla mouth nearly closed by many parallel folds in the corolla tube. Sphenotoma is sister to the Richea and Dracophyllum clade and consists of six species endemic to Western Australia occurring in heathland and woodland on nutrient poor sandy soils. Sphenotoma was originally assigned to Dracophyllum (Sweet 1828) and Bentham (1869) erected section Sphenotoma in Dracophyllum to accommodate the species but Mueller (1889) accepted it as a genus in its own right. Since then all subsequent studies, including this one with little support, showed Sphenotoma to be a distinct clade (Crayn et al. 1998). A more in-depth study needs to be done on Sphenotoma to determine if there is stronger support for its monophyly and to show the degree of resolution between the species. 


\subsubsection{Character evolution}

The high level of homoplasy as depicted in the cladograms based on morphology make it difficult to develop a hypothesis on the evolution of many of the characters with confidence.

Some indication of direction is present in the following characters (Fig. 2.1.): The adult leaves of O. patens, O. pubescens and O. kirkii morphologically resemble the leaves from Dracophyllum. Juvenile leaves are always present in these species and it is the first time this character has been used in the grouping of species. Sclereids that unite with the adaxial epidermis (Char. 9) developed in Oreothamnus densus and in Dracophyllum cosmelioides with sclereids that unite with the abaxial epidermis developed in O. minimus, O. muscoides, O. politus and O. prostratus. The rest of Dracophyllum (20 spp.), Oreothamnus (21 spp.), all Richea (11 spp.) and Sphenotoma (6 spp.) developed sclereids that unite with both epidermises.

Dracophyllum involucratum and $D$. verticillatum form a New Caledonian clade with good support (bootstrap 66\%, jackknife 63\% and Bremer support 6). The clade is characterized by the synapomorphy of flowers arranged in prominent verticils around the inflorescence axis (char. \#21). The two species look very similar but D. involucratum has the pedicels covered in multiple bracts. D. fitageraldii and D. milliganii form a clade with weak support (bootstrap 51\%, Bremer support 1). It is characterized by plants having a double epidermis (char. \#10), a character unique to these species.

Dracophyllum has flowers that are pedicellate above the upper bracts (Char. 22), a state common in Vaccinieae (Crayn et al. 1998) and it derived independently in Archeria, Prionotes, Brachyloma and Lissanthe sens. lat. (Powell et al. 1997). Many bracts that are situated below the flowers (Char. 23) are a unique character in Dracophyllum involucratum but common in all of Sphenotoma. Epipetalous stamens (Char. 29) are present in all Oreothamnus and in Dracophyllum (15 spp.). 
Relationships in Oreothamnus are less clear as a result of the low support for many of the characters and also the high level of homoplasy in the most parsimonious trees (Fig. 2.1.). The results of the phylogenetic hypothesis presented here give support (bootstrap 64\%, jackknife $68 \%$ and Bremer support of 6) for a monophyletic Oreothamnus group. No further formal division of Oreothamnus is recognized here.

Three vascular bundles per leaf is a character that occurs in Oreothamnus densus $+O$. minimus $+O$. muscoides + O. politus + O. prostratus + O. pronus subclade, primarily subalpine species with ericoid leaves. Oreothamnus prostratus, O. politus, O. muscoides, O. minimus and O. densus forms a clade supported by the synapomorphies: three vascular bundles per leaf (char. \#9) and sclereid distribution with the bottom epidermis (char. \#11). These similar species are characterized by their cushion growth habit (char. \#1), ericoid leaves (char. \#5), solitary flowers (char. \#14) and

prominent apical ridge on the petals (char. \#28). Oliver (1952) described these species as the 'Dracophyllum muscoides group' and mentioned that it was difficult to distinguish these species from each other in habitat. They differ nevertheless morphologically from each other and I regard them as separate species. The subclade of $O$. patens and O. pubescens share broad and flat leaves. The inclusion of a wider outgroup could possibly help to resolve many of the problems encountered in this analysis.

\subsection{Discussion and taxonomic implications}

Dracophyllum was established on the basis of leaves leaving annular scars on the stems and being imbricate and having semi-membranous leaf bases; corolla tubular with five corolla lobes, spreading and beardless; stamens epipetalous or free; nectary scales 5 and a loculicidal capsule with pendulous central placentae. Basal branches within Dracophyllum and Oreothamnus are short and indicate a reasonably rapid diversification in the early stages of evolution (Quinn et al. 2003). 
However there are a number of large clusters with support reflecting possible phylogenetic relationships. The high level of homoplasy makes it difficult to develop a hypothesis on the evolution of many of the characters with certainty.

This analysis concludes that the genus Dracophyllum sens. lat. is polyphyletic if Richea, which is paraphyletic, and Sphenotoma are recognized as genera. I include subgenus Cordophyllum into subgenus Dracophyllum for there is no support in the analysis to keep it separate. The flower with its many bracts is merely a strongly modified flowering branch of a panicle (eg. in D. verticillatum) where the apical flower remained and all that is left of the other flowers is their bracts. Synapomorphies for Dracophyllum are the presence of pedicels above the upper bracts, presence of bracteoles, absence of a calyptra and the exine prominently patterned with the cells of the testa prominently pitted. Further supporting characters are the weakly developed lamina sheaths with tapering shoulders, inflorescence a panicle, caducous inflorescence bracts, stomata only on the adaxial lamina surface and the epicuticular waxes either amorphous or a combination of amorphous and platelets. Synapomorphies for Oreothamnus are the well-developed lamina sheath with its sheath shoulders and the leaves that are not broad and flat. Additional supporting characters are inflorescences a raceme, spike or a solitary flower; inflorescence bracts persistent and not coloured; stomata on both lamina surfaces, epicuticular waxes platelet, ribbon or a combination of platelet and ribbon wax and the testa that is not prominently pitted.

An alternative approach would be to lump Dracophyllum and Richea into a broad circumscription of Dracophyllum and to recognize Oreothamnus and Sphenotoma as separate genera. To support this suggestion, DNA sequences need to be compared for the above-mentioned genera along with more distant relatives in the Ericaceae. The clade representing Dracophyllum and Richea is fairly robust with a Bremer support 6,76\% bootstrap and 78\% jackknife (Fig. 2.1.) supporting this view. 
Richea is morphologically similar to Dracophyllum and they share prominent annular scars from fallen leaves, leaves spirally arranged, parallel venation, bases sheathing, persistent sepals, anthers lacking appendages, 5-locular ovary with numerous ovules per loculus, axile placentation, style inserted in a depression in the ovary and the fruit a loculicidal capsule. The major difference between Richea and Dracophyllum is in the stamens that are enclosed in the corolla with its lobes fused until the anthers mature and they push the corolla off to be shed as an entire unit (an operculum). An operculum is also present in Dracophyllum (D. elegantissimum, D. latifolium, D. traversii) but here the stamens are epipetalous and shed with the operculum after pollination.

If Dracophyllum and Richea are lumped, all Richea (Brown 1810) species must then become Dracophyllum (Labillardière 1800), which is the nomenclaturally older of the two genera. In this case it is suggested that the two sections of Richea indicated as the clades Richea A and Richea B (Fig. 2.1.) become the subgenera Cystanthe and Dracophylloides of the genus Dracophyllum. The tribe Richeeae will then consist of the genera Dracophyllum, Sphenotoma and Oreothamnus. If Richea is included into Dracophyllum it will result in eight new name combinations. New names must be

given to three species ( $R$ acerosa, $R$ milliganii, $R$ scoparia) because these specific epithets are already in use in Dracophyllum: D. acerosum (Oreothamnus acerosus), D. scoparium (O. scoparius) and D. milliganii. This action will not cause a major nomenclatural upset.

The following is a proposed generic classification of the Richeeae clade (Crayan et al. 1998, Kron et al. 2002) if Richea is included in Dracophyllum.

\section{Genus Oreothamnus:}

All species formerly in Dracophyllum subgenus Oreothamnus (29 species). 
Genus Sphenotoma:

No change (11 species).

Dracopbyllum Labill.

Dracopbyllum subgenus Dracophyllum

No change (21 species).

Dracophyllum subgenus Cystanthe (R.Br.) S. Venter subg. nov. =Richea sect. Cystanthe (R.Br.) Benth. Flora Austr. 4: 258 (1868).

1. Dracopbyllum tasmanicum S. Venter nom. nud. =Richea milliganii (Hook.f.) F.Muell., Fragm. 6: 69 (1868).

=Cystanthe milliganii F.Muell., Fragm. 1: 38 (1858). =Pilitis milliganii Hook.f., Fl. Tasm. 1: 226, t.83 (1859).

2. Dracophyllum laciniatum S. Venter nom. nud. =Richea acerosa (Lindl.) F.Muell. Fragm. 6: 69 (1868). = Cystanthe acerosa F.Muell. Fragm. 1: 38 (1858).

=Pilitis acerosa Lindl. Introd. Nat. Syst. Edn 2: 443 (1836).

3. Dracophyllum procerum (F.Muell.) S.Venter comb. nud. =Richea procera (F.Muell.) F.Muell. Fragm. 6: 68 (1868). =Cystanthe procera F.Muell. Fragm. 1: 38 (1858).

4. Dracophyllum sprengelioides (R.Br.) S.Venter comb. nud. =Richea sprengelioides (R.Br.) F.Muell. 6: 68 (1868).

$=$ Cystanthe sprengelioides R.Br. Prod. 555 (1810).

Dracophyllum subgenus Dracophylloides (Benth.) S.Venter subg. nov. =Richea sect. Cystanthe (R.Br.) Benth. Flora Austr. 4: 258-259 (1868).

5. Dracophyllum victoriana (Y.Menadue) S.Venter comb. nud. =Richea victoriana Y.Menadue Austr. Syst. Bot. 13: 785 (2000).

=Richea gunnii sens. Walsh Victorian Nat. 104(3): (1987).

6. Dracopbyllum persistentifolium S. Venter nom. nud. =Richea scoparia Hook.f. Lond. Journ. 6: 273 (1847).

=Richea angustifolia B.L. Burtt, Curtis's Bot. Mag. Tab. 9632 (1941). 
7. Dracophyllum continentis (B.L. Burtt) S.Venter comb. nud

=Richea continentis B.L. Burtt Curtis's Bot. Mag. Lond., 163: subt.9632

(1941)

=Richea gunnii sens. str. Ewart, Flora Vict., 919 (1931). non Hook.f.

(1847).

8. Dracophyllum gunnii (Hook.f.) S. Venter comb. nud.

=Richea gunnii Hook.f. Lond. Journ. 6: 273 (1847).

9. Dracopbyllum pandanifolia (Hook.f.) S.Venter comb. nud.

$=$ Richea pandanifolia Hook.f. subsp. pandanifolia Fl. Antarctica 1: 50 (1844).

$=$ Richea pandanifolia Hook.f. subsp. ramulosa Y.Menadue Aust. Syst. Bot. 13: 795-796 (2000).

10. Dracophyllum atrosanguineum S. Venter nom. nud.

$=$ Richea dracopbylla R.Br. Prodr. 555 (1810).

11. Dracopbyllum alpinum (Y.Menadue) S.Venter comb. nud.

=Richea alpina Y.Menadue Aust. Syst. Bot. 13: 798-801 (2000).

Despite the lack in resolution, this cladistic study focused on important new hypotheses of relationships that can be tested by molecular systematic methods. Ultimately, molecular data should be used in a combined analysis (anatomy, morphology, molecular) to allow studies of congruence with morphological characters and their optimisation onto the trees produced (Wilkin 1999).

Oreothamnus minimus from Tasmania is the only representative of the genus outside New Zealand. Fleming (1963, 1976) and Wardle (1978) suggested, and I agree, that O. minimus is a recent natural introduction to the Tasmanian flora from New Zealand and it is likely to have dispersed relatively recently as it groups with the subalpine and alpine members of Oreothamnus (Figure 2.2). This implied direction of dispersal from New Zealand to Tasmania is against prevailing westerly winds but, as discussed by Wardle (1978), Barlow (1994) and Wagstaff et al. (2002), the direction of winds across the Tasman Sea can reverse. 
Without detailed DNA sequencing analysis of all species, a description of speciation in Dracophyllum and Oreothamnus is at best speculative but can be hypothesized from their intuitive relationships and from its recent distribution. Sequencing results no doubt will give a more complete and meaningful idea of dispersal patterns and age in Dracophyllum and Oreothamnus. 


\section{Chapter 3: Biogeography and endemism of the Dracophyllum complex}

\subsection{Introduction}

\subsubsection{Recent distribution and patterns}

Disjunct distributions can be long range, an example being the genus Bulbinella Kunth (Asphodelaceae) with seven species in New Zealand and 18 species in South Africa and the genus Cunonia L. (Cunoniaceae) with 16 species in New Caledonia and one species in South Africa. Three major mechanisms have been proposed to explain disjunct distributions. The first invokes fragmentation of land connections by plate tectonic events. The second invokes fragmentation of range by climatic changes (effectively climatic relicts), as in short-range disjunction. An example is Myosotis tenericaulis Petrie (Boraginaceae) (Heads 1998) that occurs in the south (area west of Dunedin) and in the north of the South Island (northwest Nelson) approximately $450 \mathrm{~km}$ apart. The third invokes the dispersal of species across geographic barriers. According to Carlquist (1967) and Wagstaff et al. (2002) longdistance dispersal has a major influence on the evolution of insular floras. The dispersal of a species over a fragmented space is made more feasible if it possesses an added degree of mobility in the disseminules being small, light, aerodynamic and/or buoyant. One of the paradoxes of biogeography is disjunct groups with no apparent means of dispersal e.g. Scleranthus (Smissen et al. 2003).

Based on macrofossil floras in Australia and New Zealand, Pole (1994) and McGlone et al. (2001) put forward an argument that the entire flora if not the entire biota, has arrived in New Zealand by transoceanic dispersal during the Tertiary. Accepting that long-distance dispersal is potentially occurring continuously, this argument implies that it has occurred recently and can be shown by the recent arrival of birds, butterflies and plants from Australia (Godley 1967; Pole 1994; McGlone et al. 2001). The Silvereye (Zosterops lateralis lateralis (Latham)) permanently colonized New Zealand from southeastern Australia in 1856 (Sibson 1990; Turbot 1990; Heather \& Robertson, 1996). Individuals of the Australian painted lady butterfly (Cynthia kershawi McCoy, 1868) turn up in New Zealand every year with occasionally a massive invasion (Gibbs 1980). Twelve of the New Zealand orchid species are 
thought to have arrived here by long-distance dispersal from Australia e.g., Cryptostylis subulata (Wilson \& Given 1989; St. George 1999; McGlone et al. 2001). Another example is Oreothamnus scoparius growing on the Chatham- and Campbell Islands for the past nearly 8000 years (Moar 1973; Wardle 1987). A Holocene dispersal from the Chatham Island southwards to Campbell Island is a possible explanation for its presence there. Pollen of Nothofagus and Podocarpus species in the Auckland Island peat areas is evidence of winds moving down from the north over the Auckland Islands (Wardle 1987).

Long-distance dispersal from New Zealand to Australia and Tasmania also occurred (Wagstaff

\& Garnock-Jones 1998, 2000). In the genus Aciphylla (44 species), A. glacialis and A. simplicifolia dispersed to Australia, and A. procumbens to Tasmania from New Zealand (Wardle 1978, Radford et al. 2001). Two species of Veronica (=Chionobebe) have dispersed independently, $V$. densiflora from the South Island, New Zealand to the Australian Alps and V. ciliolata from the South Island to Tasmania (Wagstaff \& Garnock-Jones 2000).

\subsubsection{Historical distribution}

During the Pliocene (5.3 - 1.6 Mya), the Kaikoura Orogeny became more intense pushing up blocks forming the main mountain ranges (Mildenhall 1980). The high mountains in New Zealand have existed since the Pliocene, and the alpine flora developed within this limited period (Wardle 1978; Godley 1975). These mountains brought about a fundamental change to the habitat, especially the soils of central South Island. High alpine endemics, of which Oreothamnus muscoides, O. palustris, O. pronus and O. prostratus are members, might date back to this period. Raven (1973) proposed that many of the ancestors of the alpine plant species entered via Australia following the late Pliocene, which contradicts Godley (1975) and Wardle (1978) who argued that the east to west dispersal routes are discounted and that other possible dispersal routes are ignored. The multiplicity of Oreothamnus species is characteristic of many alpine plant 
genera in New Zealand (e.g., Aciphylla, Anisotome, Celmisia, Coprosma, Veronica sect. Hebe, and Ranunculus) and they indicate recent, rapid and continuing evolution (Dawson 1961; Fisher 1965; Wagstaff et al. 2002).

Australia missed most of the Ice Age glaciation during the Pleistocene (1.6 Mya - later) but the effect on the flora of New Zealand was major and saw the disappearance of the last sub-tropical and tropical plants at the beginning of the Pleistocene (McGlone 1985). At least three interstadials occurred during the Last Glaciation ( \pm 100000 - 10000 years ago) when most of the surface of New Zealand was covered in forest (McGlone \& Topping 1983). The most recent of these periods occurred $25000-15000$ years ago (McGlone 1985) and during this period North and South Islands, Stewart Island and many offshore islands off New Zealand were united by dry land and experienced low temperatures with glaciers along the Southern Alps (McGlone \& Topping 1983; McGlone et al. 2001). The variety of environments and refugia for species that survived formed most of the modern vegetation patterns in New Zealand (White 1999; McGlone et al. 2001). Tasmania was affected by intense glaciation and during this period the Nothofagus forests retreated extensively being replaced by alpine grassland and subalpine heath communities with abundant epacrids e.g. Dracophyllum milliganii and Oreothamnus minimus (White 1999).

\subsection{Materials and methods}

Distribution maps from all known Dracophyllum and Oreothamnus localities were compiled from herbarium specimens from various herbaria worldwide (AK, AKU, BM, BRIU, CANU, FI, GZU, HO, K, L, LINC, MEL, MPN, MW, NSW, NZFRI, O, OTA, P, S, TCD, UNSW, UPS, W, WAIK, WELT, WELTU and Z). Acronyms follow Holmgren et al. (1990). Parsimony analyses were run in TNT (Tree Analysis Using New Technology of Goloboff et al. 2004) using a traditional search approach set for equal character weights and 100 random entry-order 
replicates. Heuristic approaches of tree construction were used, set for TBR branch swapping with random taxon addition to recover multiple islands of equally parsimonious trees (Maddison 1991). Support for the internal branches was conducted with parsimony jackknifing with 1000 replicates, each performing TBR branch swapping with 10 random entry orders saving one tree per replicate. Level of support for the clades identified in the parsimony analysis was inferred by standard bootstrap with 10000 replicates (Felsenstein 1985). Clades supported by 50\% bootstrap values or more that are supported by morphological evidence and clades supported by $70 \%$ bootstrap values that are neither in support or in conflict with morphological evidence (Cantino et al. 1997) are indicated on the trees in Fig. 2.1. and Fig. 2.2. TNT was also used to run Bremer support, as branch support (Mueller 2005) (Chapter 2).

\subsection{Results}

\subsubsection{Biogeography}

The genera Dracophyllum and Oreothamnus are restricted to the Northeast Australian, NeoCaledonian and the Neozeylandic floristic regions of Takhtajan (1986). All Dracophyllum species are endemic to the countries where they occur. They are distributed from New Caledonia (eight species), including the island, Île des Pins south of the main land (D. ramosum), Lord Howe Island (D. fitzgeraldii), east coast of Australia (four species), Tasmania (D. milliganii) and New Zealand including some small offshore islands (seven species) (Figure 3.1). Oreothamnus occurs in New Zealand and some of its offshore islands (29 species) with a single species (O. minimus) endemic to Tasmania (Figure 3.2). 


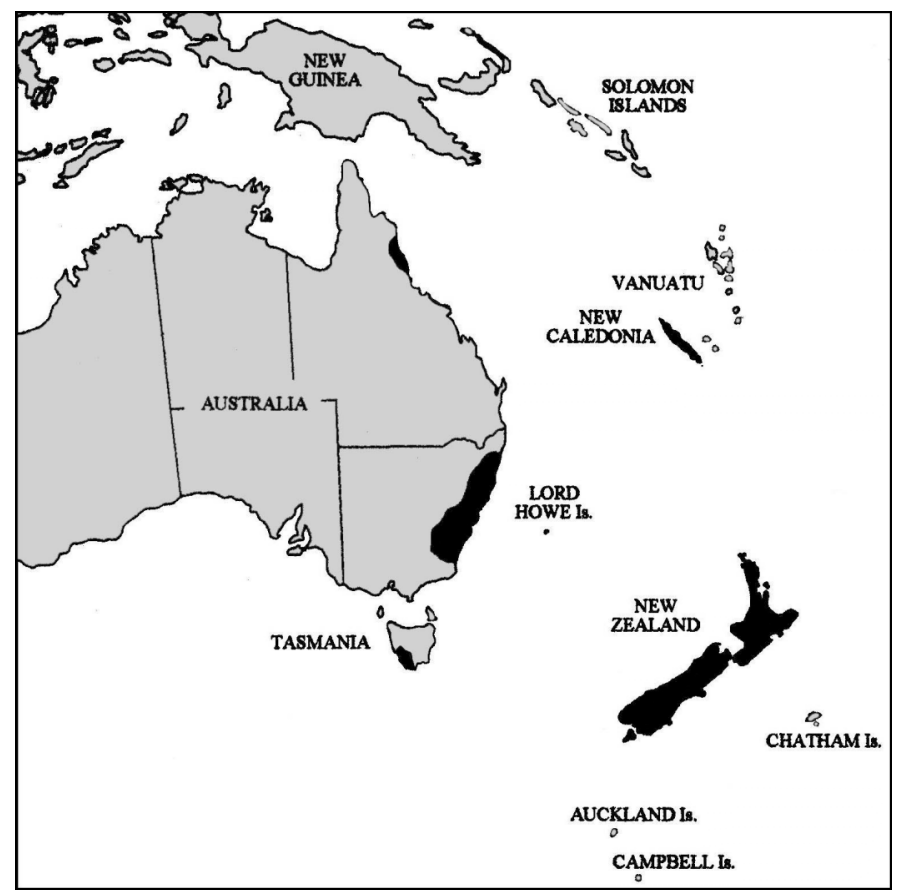

Figure 3.1. Known distribution of the genus Dracophyllum.

Several species are widespread, e.g., O. filifolius, O. kirkii, O. longifolius, O. oliveri, O. palustris, O. pronus and O. rosmarinifolius but most species are restricted in their distribution e.g., O. densus (Kahurangi National Park) O. patens (Coromandel area and Great Barrier Island), O. trimorphus (northernmost tip of the South Island), sometimes even to a specific mountain range e.g., $O$ marmoricola and O. ophioliticus on the Arthur Range.

According to Crisp et al. (2001) there are 12 centres of endemism in Australia with Dracophyllum occupying four of these centres. D. sayeri occurs in the Wet Tropics Centre and is restricted to the rain forest on the Bellenden-Ker, Mt. Bartle Frere and Mossman Ranges in Tropical northeastern Queensland. The Sydney Sandstone centre has two species, D. secundum with the widest 


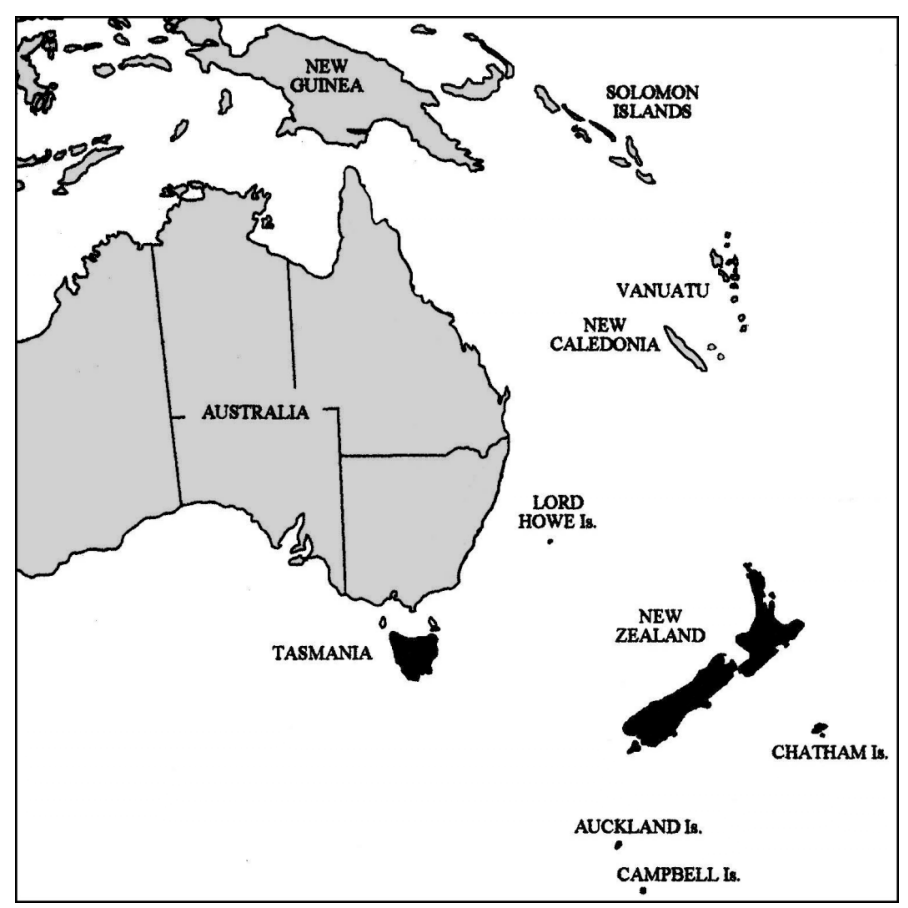

Figure 3.2. Known distribution of the genus Oreothamnus.

distribution (Central and Southern Tablelands in eastern New South Wales) and D. oceanicum restricted to the Jervis Bay area in New South Wales. D. macranthum occurs in the New England Dorrigo Centre and is restricted to the Coorabakh National Park area in northern New South Wales. D. milliganii is the only Dracophyllum in Tasmania and endemic to the Tasmania Centre. The cladistic results of this study (Fig. 2.1.) reflect the findings of Crisp et al. (2001) except for D. milliganii and D. fitageraldii that are grouped together. Crisp et al. did not include Lord Howe Island in their study but considering that $47 \%$ of the plant species are endemic (Hutton 2002), it may well qualify as a centre of endemism.

The closely related Dracophyllum balansae and D. mackeeanum have a sympatric distribution in maquis vegetation of New Caledonia. Dracophyllum elegantissimum and D. townsonii occur in $\mathrm{New}$ Zealand montane forest and normally they have an allopatric distribution except at Knuckle Hill near Collingwood (Venter 13752 \& Venter 13777) where both species occur together in a swampy habitat. Dracophyllum involucratum (Mt. Humboldt) is closely related to D. verticillatum and they 
occur together in lowland and montane maquis vegetation sometimes with a sympatric distribution.

Seven Oreothamnus species (O.densus, O. minimus, O. muscoides, O. politus, O. prostratus, O. marmoricola and O. pronus) form a clade (Fig. 2.2.) of subalpine species growing normally above the tree line. These plants are well adapted to survive snow conditions, low temperatures and high winds typical of their subalpine habitat with their cushion or mat-forming growth habit, short branches and short ericoid leaves. If one postulates that the present ecological requirements are indicative of the past, it can be inferred that early differentiation in Oreothamnus occurred in subalpine environments, and occupying the lowlands is then a secondary event as in Veronica sect. Hebe (Wagstaff et al. 2002).

Oreothamnus densus commonly occurs in subalpine grassland in Kahurangi National Park (1300 m) but on the Denniston Plateau $(800 \mathrm{~m})$ it grows as a much taller and open branched plant in open montane shrubland and herbfield. O. politus likewise grows on the Denniston Plateau but normally it is a common element of the subalpine grassland on Stuart Island and in Fiordland. The Denniston Plateau plants are much smaller with longer leaves and prostrate stems compared to the plants in subalpine areas. Oreothamnus prostratus and O. rosmarinifolius are common in the subalpine grasslands of Fiordland $(1300 \mathrm{~m})$ and Mt. Cook National Park (1800 m) but on Mt. Maungatua $(700 \mathrm{~m})$ it grows in montane grassland. Oreothamnus rosmarinifolius plants on Mt. Maungatua are much shorter with longer spreading leaves. Oreothamnus pronus is common in subalpine grassland but it also has representative populations at low altitude on Dun Mountain $(720 \mathrm{~m})$. Here the plants have a more sub shrub growth habit compared to the carpet-like growth habit of the Mt. Dobson $(1800 \mathrm{~m})$ populations growing in fell field. It appears if high temperatures and low elevation form an ecological barrier to restrict the distribution of these subalpine species (Cox \& Moore 2000). 
Oreothamnus frondosus occurs in southern Otago in the south and along the Wairau Valley in the northern part of the South Island, close to $650 \mathrm{~km}$ apart and, Oreothamnus oliveri that occurs in the northwest coast and in southern Otago to Fiordland in the South Island with nearly $100 \mathrm{~km}$ distance between the two distribution areas.

\subsection{Discussion}

The oldest known Dracophyllum sens. lat. fossil pollen record published is from New Zealand and recorded from the Upper Eocene \pm 40-37 Mya (Couper 1960; Fleming 1962). The Eocene climate was cool, temperate with marginal tropical coastal conditions but substantially warmer during the Late Eocene, probably sub-tropical to tropical (Mildenhall 1980; Douglas 1986). An Eocene locality in New Zealand produced macrofossils of the genera Brachychiton and Orites, showing the Australian relationships (Pole 1994).

A prominent period of drying in Australia occurred during the Miocene (23.7 - 5.3 Mya) and appeared first in central Australia. The increase in aridity during the Miocene resulted in the fragmentation of rainforest and the replacement by a drier and scleromorphic to xeromorphic vegetation (Truswell \& Harros 1982). In New Zealand the variable climates and rapid changes of vegetation within sequences sometimes resulted in shrub and grassland dominated vegetation

and grassland extended periodically to sea level in the northern part of the South Island of New Zealand by the middle Pliocene (Mildenhall 1980). To the north of New Zealand tectonism along the oceanic ridges created a topography that possibly helped in the migration of biota southwards from the Queensland-New Caledonia region (Hertzer 1998). According to palynological evidence, many plant species crossed the sea during the Tertiary Period mainly from Australia to New Zealand (Mildenhall 1980; Kershaw 1988; Pole 1993; McGlone et al. 2001). 
The progenitor of Dracophyllum s. str. probably originated in Australia. Dracophyllum most likely had a continual distribution pattern on the eastern part of the Australian continent whereas today with the exception of $D$. secundum, all species have a very restricted distribution. The ancestral species possibly had the following ancestral characters (Table 2.1): tree or shrub with flat and broad leaves with weakly developed lamina sheaths, a solitary axillary inflorescence with persistent inflorescence bracts, flowers with free stamens and having unspecialised pollination syndromes. At least one independent long distance dispersal event occurred from Australia to New Zealand and another from Australia to New Caledonia. Speciation followed these events as are evident in the reconstructed phylogeny (Fig. 2.2). Dracophyllum possibly dispersed to Lord Howe Island with D. fitrgeraldii surviving in the montane forests. The basalts of Lord Howe Island is dated at approximately six million years (Woodroffe et al. 2006) and gives us maximum age estimate for $D$. fitzgeraldii. It is remarkable though, given the period D. fitzgeraldii has been on the island, that there is so little variation evident in this species.

The genus Oreothamnus has a New Zealand origin and probably evolved from a montane ancestor. The mountains in New Zealand have been an important area of evolution and a centre for diversification in Oreothamnus with the uplift of the Southern Alps during the Pliocene creating mountain crests, large sub-arid areas and unstable scree slopes (Wagstaff \& GarnockJones 2000). The vertical range of Oreothamnus spans $0-2600 \mathrm{~m}$. Oreothamnus has 16 species on the South Island and six species on the North Island with O. filifolius and O. rosmarinifolius the only two species shared between the two islands. According to Ghani (1978) uplift of the North Island mountains occurred $\pm 0.2 \mathrm{Mya}$, much later than the South Island mountains indicating a recent dispersal of O. filifolius and O. rosmarinifolius to the North Island. It would appear that the initial radiation in Oreothamnus was stimulated by the uplift of the Southern Alps during the Pliocene. This radiation pattern is duplicated in other groups e.g. the Veronica section Hebe (Wagstaff \& Garnock-Jones 2000). 
Chatham Island and the other subantarctic islands are well known for their endemic vascular plant species (Wardle 1987). However the degree of endemism is low with six species for the Auckland Islands (3\%), three species for Campbell Island and 40 species $(12 \%)$ for the Chatham Islands (Glenny 2003). The endemic flora of the subantarctic islands compares well with those of New Zealand that have also radiated recently especially in the subalpine zone, and include the genera Veronica sect. Hebe (Wagstaff et al. 2002), Gentianella (Glenny 2003), Epilobium (Raven \& Raven 1976), Anisotome (Dawson 1961), Leptinella (1972) and Celmisia (=Damnamenia) (Given 1973).

Oreothamnus cockayneanus occurs on the Auckland Islands, Oreothamnus cockayneanus and O. scoparius on Campbell Island, and Oreothamnus arboreus and O. scoparius on Chatham Island. Unfortunately the low resolution in the Oreothamnus clade does not give a clear picture of the relationships of the species on the subantarctic islands and the discussion of the dispersal to and between the subantarctic islands is at best intuitive. One can however postulate that Oreothamnus could have reached Auckland and Campbell islands via two different routes. The first route was from the South Island via Auckland Island to Campbell Island. This infers that Oreothamnus dispersed southwards to the Auckland Island where O. cockayneanus developed and, at a later stage then dispersed to Campbell Island. The second route is where Oreothamnus dispersed from the South Island eastwards to the Chatham Island and from there southwest to Campbell Island. It is difficult to say which of $O$. arboreus or O. scoparius first developed on the Chatham Island or if they developed at the same time seen that their substrate requirements differ. Oreothamnus arboreus occurs on drier peaty soils where as O. scoparius occurs on boggy soils that are moist for prolonged periods.

It appears if O. scoparius dispersed to Campbell Island at a later stage. There is little variation between $O$. scoparius material from these two islands and it is possibly because it did not survive 
long enough on Campbell Island to be different from the Chatham Island populations and can be indicative of a recent dispersal. Both routes are quite feasible given the climatic conditions at the time. Fleming (1976) suggested that Phormeum tenax J.R. Forst. \& G. Forst. migrated from the lower South Island to Auckland Island in post-glacial times also from the South Island to Chatham Island, the same proposed routes as for Oreothamnus. Oreothamnus arboreus and $O$. scoparius most probably developed on the Chatham Islands and, later during the Holocene ( \pm $8000 \mathrm{BP}$ ), dispersed south to the Campbell Island group $\pm 1700 \mathrm{~km}$ to the south. There is proof of plant dispersal from the Chatham Islands south to the Auckland Islands as shown by the pollen record for Nothofagus and Podocarpus (Wardle 1987). According to Wardle (1987) there was much less glaciation on the Chatham Islands with more temperate to warm species e.g. Rhopalostylis sapida surviving there.

Oreothamnus arboreus is well suited for surviving in either protected areas or dense vegetation. The smaller stature, narrow and much smaller leaves of $O$. scoparius are most probably an adaptation to the ericoid habit suitable for surviving in peat. According to McGlone et al. (2000) O. cockayneanus only became prominent in the Auckland Island flora 10,000 years BP based on pollen analysis of peat cores.

Oreothamnus minimus from Tasmania is the only representative of the genus outside New Zealand. Fleming (1963, 1976) and Wardle (1978) suggested, and I agree, that O. minimus is a recent natural introduction to the Tasmanian flora from New Zealand and it is likely to have dispersed relatively recently as it groups with the subalpine and alpine members of Oreothamnus (Figure 2.2). This implied direction of dispersal from New Zealand to Tasmania is against prevailing westerly winds but, as discussed by Wardle (1978), Barlow (1994) and Wagstaff et al. (2002), the direction of winds across the Tasman Sea can reverse. 
Without detailed DNA sequencing analysis of all species, a description of speciation in Dracophyllum and Oreothamnus is at best speculative but can be hypothesized from their intuitive relationships and from its recent distribution. Sequencing results no doubt will give a more complete and meaningful idea of dispersal patterns and age in Dracophyllum and Oreothamnus. 


\section{Chapter 4: Species limits and variation in Dracophyllum and Oreothamnus.}

\subsection{Introduction}

In this thesis populations are considered to belong to different species if they differ by two or more putatively fixed independent qualitative differences and if there is convincing evidence that they represent independent lineages with preferably no genetic contact (Hedberg 1958; Gravendeel 2000, Garnock-Jones \& Lloyd 2004).

Many characters used in the past to determine species in Dracophyllum are very variable (e.g., shape of the lamina sheath and lamina size) and extensively used by Oliver $(1928,1952)$ and Allan (1961). Oliver $(1928,1952)$ valued the characters of the leaves in the genus Oreothamnus higher than those of the inflorescence. There is a distinct difference between the lamina and the lamina sheath in all Oreothamnus species in spite of the polymorphic shape and size. In the past, emphasis was placed on the shape of the lamina sheath to distinguish between different species (Allan 1961). This study shows that lamina sheath characters are unstable and variable especially in O. filifolius, making it impossible to use in any form to distinguish between species (Fig. 4.1).

This created two problems, first the description of too many species and secondly the creation of a few 'dustbin' species. The only way to define clear species limits is to make use of characters showing minimal or no variation. Also important are absolute minimum and maximum measurements e.g. (12-)18-36(-42) to incorporate variation and provide for accurate identification. The lack of knowledge of the extent of variation in species is one of the reasons authors described extreme forms and ecotypes as different species. To determine the extent of variation in different 


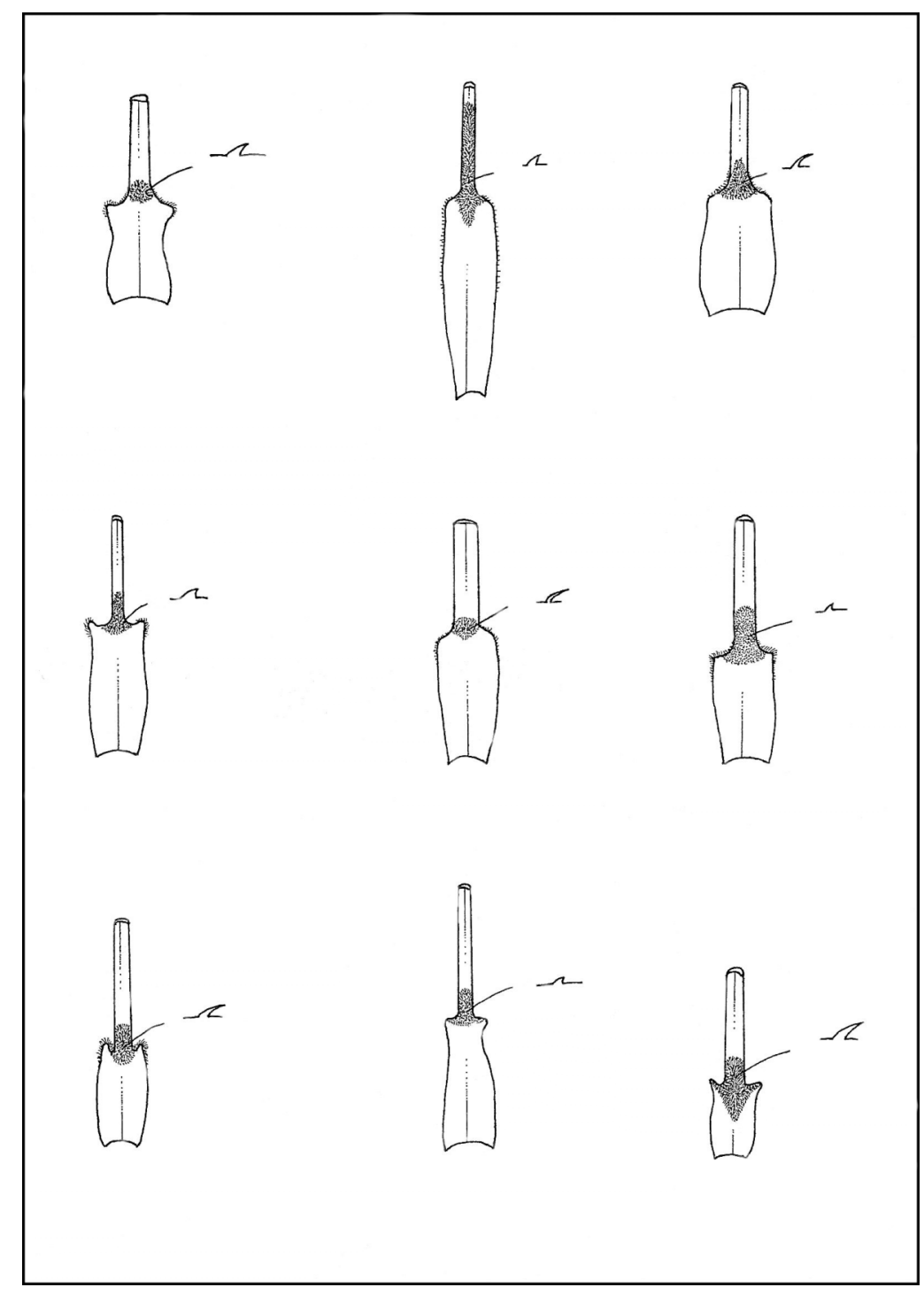

Figure 4.1. Oreothamnus filifolius. Lamina sheath shapes from nine different plants in the same population to show variation in shape and size (Venter 13785 Dun Mountain, Nelson, New Zealand).

Dracophyllum and Oreothamnus species, I studied as many specimens as possible and visited many populations in their natural habitat. Only when the degree of variation per taxon is known, can a full circumscription be given and sensible comparisons be made between taxa. This is why I regard doing extensive fieldwork on the group of plants you are working on as a priority requirement. 


\subsection{Materials and methods}

\section{Material}

Fresh leaves were collected in habitat and preserved in FAG (Formaldehyde - Ethanol Glycerol) to prevent shrinking.

\section{Measurements}

Measurements of the various morphological characters were taken at specific standard regions (Figure 4.2). The lamina in Oreothamnus was measured for width at a point directly above the lamina sheath (Figure 4.2Ad) and the length from a point directly above the lamina sheath to the apex (Figure 4.2Aa). In Dracophyllum the lamina length was measured from a point where the membranous margin of the lamina sheath stops to the lamina apex (Figure 4.2Ba). For both genera the inflorescence length was measured from the base of the inflorescence axis to its apex and likewise with the inflorescence branches. Inflorescence bracts and bracteoles were measured in a direct line from the apex to the point of insertion on the inflorescence stem or peduncle (Figure 4.2Ca \& Da) and the width at the widest point, irrespective if it was low down or above the middle of the bract (Figure 4.2Cb \& Db). Sepal and petal width were measured at the widest part irrespective of where it was situated on the lobes. Filament length was measured from the point of insertion either at the base of the ovary or at the insertion point on the corolla tube to the connecting point on the anther.

Ovary length was measured from the insertion point with the corolla to the top of the shoulders at the apex of the ovary. Nectary scale length was measured on the inside (adaxial) of the nectary scale from the insertion point with the ovary to the apex of the longest lobe on the nectary scale apex. 


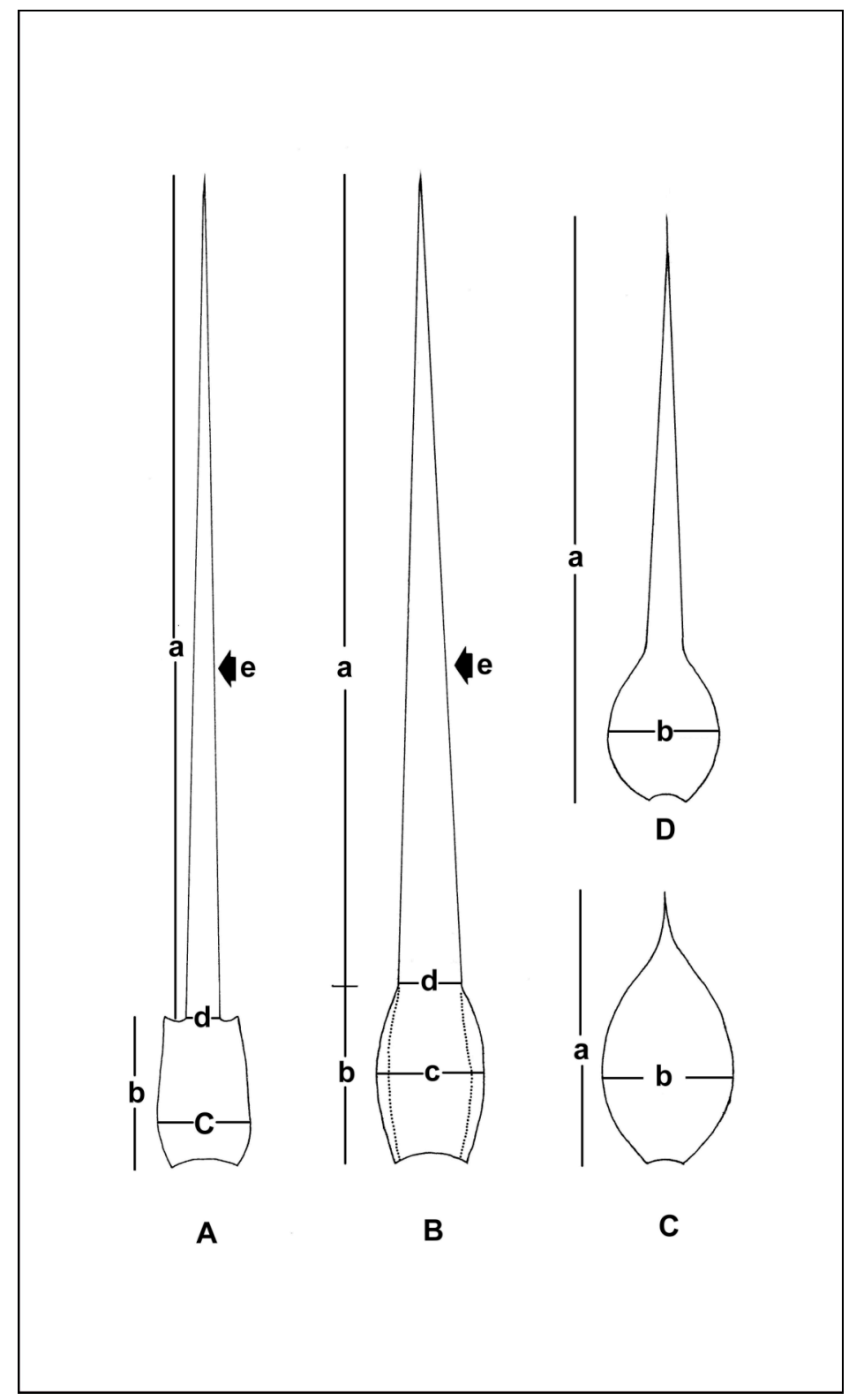

Figure 4.2. Survey of measurements of the leaf and inflorescence bracts. A. Oreothamnus leaf. $\mathbf{a}$, lamina length; $\mathbf{b}$, lamina sheath length; $\mathbf{c}$, lamina sheath width; $\mathbf{d}$, lamina width; $\mathbf{e}$, area for measuring teeth per $10 \mathrm{~mm}$; B. Dracophyllum leaf. a, lamina length; b, lamina sheath length; c, lamina sheath width; d, lamina width; e, area for measuring teeth per $10 \mathrm{~mm}$; C. Inflorescence bract of Oreothamnus. a, length; b, width; D. Inflorescence bract of Dracophyllum. a, length; b, width. 
Fruit length was measured from the merging point of the persistent sepals to the apex of the ovary, and the width along the widest point irrespective of where it was situated along the ovary. A minimum of 50 measurements but in most instances 100 measurements or more were taken for each character. Measurements were given in the format of (1.6-)3.0-8.5(-9.3) $\mathrm{mm}$ and should be interpreted as: rarely as small as $1.6 \mathrm{~mm}$, usual minimum $3.0 \mathrm{~mm}$, usual maximum 8.5 $\mathrm{mm}$ and rarely as long as $9.3 \mathrm{~mm}$. The standard international measuring system is used to first give the length and then the width e.g. 3.0-8.5 × 1.5-2.3 mm. Measurements of 10-150 mm were made making use of an 'Absolute digimatic' digital caliper (Mitutoyo Corp.) and measurements of less than $10 \mathrm{~mm}$ were measured with a Zeiss stereo-microscope equipped with a finely scaled $10 \times$ ocular.

\section{Characters}

The diagnostic value of the fibre cap and bundle shape and location, lamina margin texture, adaxial lamina surface texture, shape of the lamina apex; inflorescence axis texture, inflorescence bract adaxial surface and margin texture; flower grouping on the lower inflorescence branches; bracteole characters; corolla lobe spread, surface texture and apex shape; location of the stamens; ovary and nectary scale characters were grossly understated in the past and none of these characters were used in earlier revisions. In using the above characters, I was able to solve species limits in problem species groups.

\section{Statistical and phenetic analysis}

A statistical analysis on the leaves of Oreothamnus rosmarinifolius was carried out with the program PAST (Hammer et al. 2009). An ANOVA analysis was done to normalize the distribution of the data and to reduce skewness (Van Emden 2008) (Table 4.2.). 
A phenetic study of Dracophyllum s.l. based on 172 morphological characters (Table 4.1.) was conducted with S-Plus 4.5 (r2) (Wilton 1999) to test Oliver's $(1928,1952)$ revisions of the genus (Figure 4.8.). The 'Gower5' routine was used as it allows the use of mixed character types (quantative, qualitative, dichotomous, and stepped characters) within a dataset (Table 4.0.) and calculates the Gowers general coefficient of similarity. The routine will accept a matrix of OTUs (rows) x Characters (columns) if stepped characters are used.

Table 4.0. Example of stepped characters. Portion of data matrix for Dracophyllum s.l.

\begin{tabular}{|lcccccccc|}
\hline Name & Char14 & Char15 & Char23 & Char24 & Char33 & Char34 & Char44 & Char45 \\
Type & 1 & 1 & 1 & 1 & 1 & 1 & 1 & 1 \\
acerosum & NA & NA & NA & NA & $5-20$ & $3.5-6.5$ & $30-190$ & $0.7-1.5$ \\
alticola & NA & NA & NA & NA & $10-15$ & $10-11$ & $30-100$ & $10-30$ \\
arboreum & $9-17$ & $10.4-16.6$ & $100-220$ & $10-18$ & $6-12$ & $4-12$ & $25-90$ & $1-2$ \\
balansae & NA & NA & NA & NA & $6.7-10.0$ & $3-5$ & $30-180$ & $2-4$ \\
\hline
\end{tabular}

The jk.chars module was used to perform character based jackknife analysis on the phenetic data using Gower's General Coefficient of Similarity to provide an indication of degree of support for each of the clusters in the dendrogram.

It was important to include as many specimens per species (25-300+) to cover all morphological variation. The only species with less than 10 herbarium specimens were Dracophyllum ouaiemense, D. macranthum and Oreothamnus frondosus but the extent of variation was verified at the populations in the field. 
Table 4.1. Character list for the phenetic clustering analysis.

\begin{tabular}{|c|c|}
\hline 1 Life form: & 87 Flower bract persistence: \\
\hline 2 Plant height in $\mathrm{cm}$ : & 88 Flower bract shorter or longer than flower: \\
\hline 3 Branch habit: & 89 Flower bract leaf like or not: \\
\hline 4 Stem habit at ground level: & 90 Flower bract texture: \\
\hline 5 Stem diameter at ground level in $\mathrm{mm}$ : & 91 Flower bract shape at base: \\
\hline 6 Bark colour: & 92 Flower bract shape at apex: \\
\hline 7 Bark texture: & 93 Flower bract length in $\mathrm{mm}$ : \\
\hline 8 Bark texture on branchlet: & 94 Flower bract width at base in $\mathrm{mm}$ : \\
\hline 9 Bark colour on branchlet: & 95 Flower bract at apex width in $\mathrm{mm}$ : \\
\hline 10 Leaves juvenile or adult: & 96 Flower bract adaxial surface texture: \\
\hline 11 Juvenile leaf arrangement: & 97 Flower bract abaxial surface texture: \\
\hline 12 Juvenile lamina habit: & 98 Flower bract margin texture: \\
\hline 13 Juvenile lamina sheath colour: & 99 Flower bract margin colour: \\
\hline 14 Juvenile lamina sheath length in $\mathrm{mm}$ : & 100 Flower bract apex shape: \\
\hline 15 Juvenile lamina sheath width in $\mathrm{mm}$ : & 101 Bracteole persistence: \\
\hline 16 Juvenile lamina sheath shoulder shape: & 102 Bracteole shorter to longer than flower: \\
\hline 17Juvenile lamina sheath margin texture: & 103 Bracteole shape: \\
\hline 18 Juvenile lamina texture: & 104 Bracteole length in $\mathrm{mm}:$ \\
\hline 19 Juvenile lamina colour: & 105 Bracteole width in $\mathrm{mm}$ : \\
\hline 20 Juvenile lamina shape: & 106 Bracteole adaxial surface texture: \\
\hline 21 Juvenile lamina adaxial surface texture: & 107 Bracteole abaxial surface texture: \\
\hline 22 Juvenile lamina abaxial surface texture: & 108 Pedicel habit: \\
\hline 23 Juvenile lamina length in $\mathrm{mm}$ : & 109 Pedicel colour: \\
\hline 24 Juvenile lamina width at base in $\mathrm{mm}$ : & 110 Pedicel length in $\mathrm{mm}:$ \\
\hline 25 Juvenile lamina margin texture: & 111 Pedicel surface texture: \\
\hline 26) Juvenile lamina margin number of teeth per $\mathrm{cm}$ & 112 Sepal colour: \\
\hline 27Juvenile lamina apex shape: & 113 Sepal shape: \\
\hline 28 Juvenile lamina adaxial apex texture: & 114 Sepal length in mm: \\
\hline 29 Adult leaves arrangement: & 115 Sepal width in $\mathrm{mm}$ : \\
\hline 30 Adult leaves habit: & 116 Sepal shorter or longer than corolla tube: \\
\hline 31 Adult leaves below inflorescence decreasing in size: & 117 Sepal striation: \\
\hline 32 Adult lamina sheath colour: & 118 Sepal adaxial surface texture: \\
\hline 33 Adult lamina sheath length in $\mathrm{mm}$ : & 119 Sepal abaxial surface texture: \\
\hline 34 Adult lamina sheath width in $\mathrm{mm}$ : & 120 Sepal margin texture: \\
\hline 35 Adult lamina sheath texture: & 121 Sepal apex shape: \\
\hline 36 Adult lamina sheath striation: & 122 Corolla colour: \\
\hline 37 Adult lamina sheath margin texture: & 123 Corolla tube shape: \\
\hline 38 Adult lamina sheath shoulder shape: & 124 Corolla tube mouth narrowed or widened: \\
\hline 39 Adult lamina sheath margin texture: & 125 Corolla tube length in $\mathrm{mm}$ : \\
\hline 40 Adult lamina texture: & 126 Corolla tube width in $\mathrm{mm}$ : \\
\hline 41 Adult lamina colour: & 127 Corolla tube exterior texture: \\
\hline 42 Adult lamina colour abaxially: & 128 Corolla lobe habit: \\
\hline 43 Adult lamina shape: & 129 Corolla lobe shape: \\
\hline 44 Adult lamina length in $\mathrm{mm}$ : & 130 Corolla lobe shorter or longer than corolla tube: \\
\hline 45 Adult lamina width at base in $\mathrm{mm}$ : & 131 Corolla lobe length in $\mathrm{mm}$ : \\
\hline 46 Adult lamina shape of adaxial surface in cross-section: & 132 Corolla lobe width in $\mathrm{mm}$ : \\
\hline 47 Adult lamina shape of abaxial surface in cross-section: & 133 Corolla lobe apical ridge presence: \\
\hline 48 Adult lamina adaxial surface texture: & 134 Corolla lobe inflexed or not: \\
\hline 49 Adult lamina abaxial surface texture: & 135 Corolla lobe apex shape: \\
\hline 50 Adult lamina surface striation: & 136 Corolla lobe adaxial surface texture: \\
\hline 51 Adult lamina margin cartilaginous or not: & 137 Corolla lobe abaxial surface texture: \\
\hline 52 Adult lamina margin texture: & 138 Corolla lobe ratio of length compared to tube length: \\
\hline 53 Adult lamina margin number of teeth per $\mathrm{cm}$ in middle of leaf: & 139 Stamen insertion position in corolla tube: \\
\hline 54 Adult lamina apex thickening: & 140 Filament length in mm: \\
\hline
\end{tabular}




\begin{tabular}{|c|c|}
\hline 55 Adult lamina apex shape: & 141 Anther exsertion: \\
\hline 56 Presence of dry old leaves: & 142|Anther shape: \\
\hline 57 Inflorescence type: & 143 Anther colour: \\
\hline 58 Inflorescence habit: & 144 Anther length in $\mathrm{mm}$ : \\
\hline 59 Inflorescence longer or shorter than leaves: & 145 Nectary scale connate at base or not: \\
\hline 60 Inflorescence with flowers maturing acropetally or basipetally: & 146 Nectary scale shape: \\
\hline 61 Inflorescence erect or drooping: & 147 Nectary scale length in $\mathrm{mm}$ : \\
\hline 62 Inflorescence density: & 148 Nectary scale width in $\mathrm{mm}$ : \\
\hline 63 Inflorescence length in $\mathrm{mm}$ : & 149 Nectary scale apex shape: \\
\hline 64 Inflorescence shape: & 150 Ovary shape: \\
\hline 65 Inflorescence branching: & 151 Ovary length in mm: \\
\hline 66 Inflorescence rachis and pedicel texture: & 152 Ovary width in $\mathrm{mm}$ : \\
\hline 67 Inflorescence axis colour: & 153 Ovary length: width ratio: \\
\hline 68 Inflorescence axis smooth or ribbed: & 154 Ovary apex shape: \\
\hline 69 Inflorescence axis diameter in $\mathrm{mm}$ at base: & 155 Ovary apex surface texture: \\
\hline 70 Inflorescence branch at base of inflorescence length in $\mathrm{mm}$ : & 156 Style habit: \\
\hline 71 Inflorescence branch habit: & 157 Style length in $\mathrm{mm}:$ \\
\hline 72 Inflorescence bract persistence: & 158 Style surface texture: \\
\hline 73 Inflorescence bract shorter or longer than flower: & 159 Style lengthening in fruit or not: \\
\hline 74 Inflorescence bract texture: & 160 Stigma shape: \\
\hline 75 Inflorescence bract colour: & 161 Fruit enclosed in persistent sepals or not: \\
\hline 76 Inflorescence bract shape: & 162 Fruit pedicellate or sessile: \\
\hline 77 Inflorescence bract length in $\mathrm{mm}$ : & 163 Fruit colour: \\
\hline 78 Inflorescence bract width in $\mathrm{mm}$ : & 164 Fruit length in mm: \\
\hline 79 Inflorescence bract adaxial surface texture: & 165 Fruit diameter in $\mathrm{mm}:$ \\
\hline 80 Inflorescence bract abaxial surface texture: & 166 Fruit shape: \\
\hline 81 Inflorescence bract margin texture: & 167 Fruit apex shape: \\
\hline 82 Inflorescence bract apex shape: & 168 Fruit apex texture: \\
\hline 83 Flowers hidden by leaves or exposed: & 169 Seed colour: \\
\hline 84 Flower number per inflorescence: & 170 Seed shape: \\
\hline 85 Flower arrangement at basis of inflorescence: & 171 Seed length in $\mathrm{mm}:$ \\
\hline 86|Flower sessile or pedicellate: & 172|Seed surface texture: \\
\hline
\end{tabular}

The strength of phenetic analysis lies in the precise way it codes characters and their states and in the analysis method. The major weakness is that it does not take into account homoplasy (Glenny 2003) and that it relies on large numbers of characters to overcome the effects of a few unreliable characters (Sneath \& Sokal 1973). Conversely, characters that vary at random can mask signals from a few informative characters.

All the known variation was recorded with the diagnostic features of each species given and mentioned separately. All species descriptions are amplified compared to the original descriptions. 


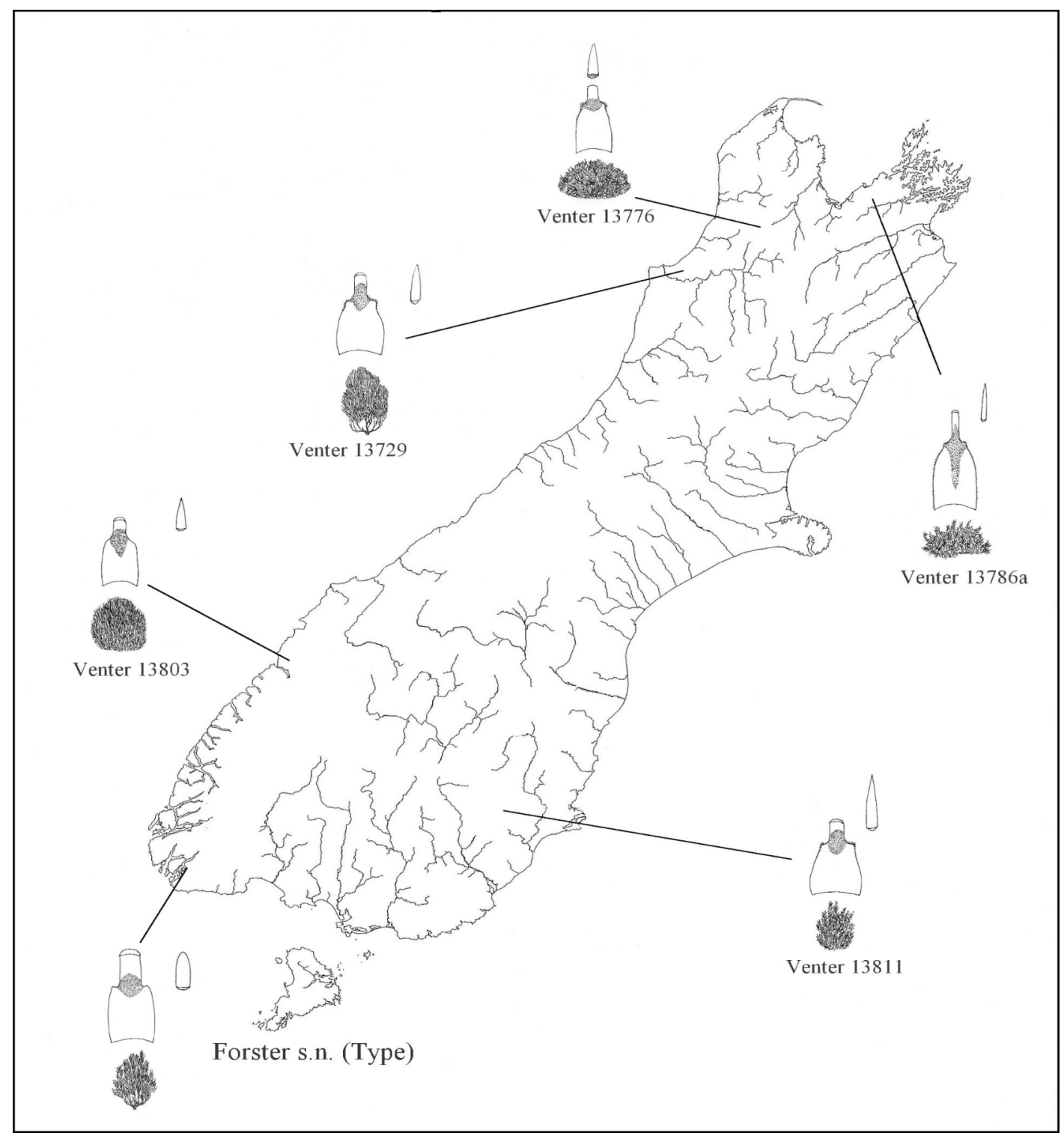

Figure 4.3. Pictorialized map showing variation in growth habit, shape and size of the lamina sheath and shape of the lamina apex in Oreothamnus rosmarinifolius. 


\subsection{Results}

\subsubsection{Variation of morphological characters}

\subsubsection{Oreothamnus rosmarinifolius}

By studying the populations of $O$. rosmarinifolius in their natural habitat it was found that there was not a large degree of variation between individuals in a single population (Table 4.2.) compared to that in widely distributed individual populations. Lamina length was chosen for it illustrates a higher degree of variation compared to that associated with lamina width (Figure 4.4). The size and shape of the patch of scabrid hairs at the base of the lamina also show a high degree of variation within a single population. Growth habit, branching architecture, height and flowering do not appear to be tied to altitude.

Table 4.2. Oreothamnus rosmarinifolius. One-way ANOVA analysis for lamina measurements $(\mathrm{mm})$ of 10 leaves per plant from a single plant in 6 populations and 10 leaves from 10 plants in a specific population from Mt. Arthur (Venter 13796).

\begin{tabular}{|l|ccccc|}
\hline & Sum of sqares & df & Mean Square & F & p(same) \\
\hline Between groups: & 0.0879147 & 1 & 0.0879147 & 4.948 & 0.02803 \\
Within groups: & 2.09665 & 118 & 0.0177682 & & \\
Total: & 2.18456 & 119 & & & \\
\hline
\end{tabular}

Levene's test for homogeneity of variance, based on means: $p$ (same) $=0.9176$

Based on medians: $p($ same $)=0.9558$

Welch $F$ test in the case of unequal variances: $F=4.948, d f=117.9, p=0.02803$

Even though the results from the one-way ANOVA (Table 4.2.) show that the degree of difference between the means in leaf measurements between plants in a single population from Mt. Arthur (Venter 13796) is different from that of six widely distributed populations, the graph in Fig. 4.4. shows a larger degree of variation between the individuals of the Mt. Arthur population than between the individual populations. 


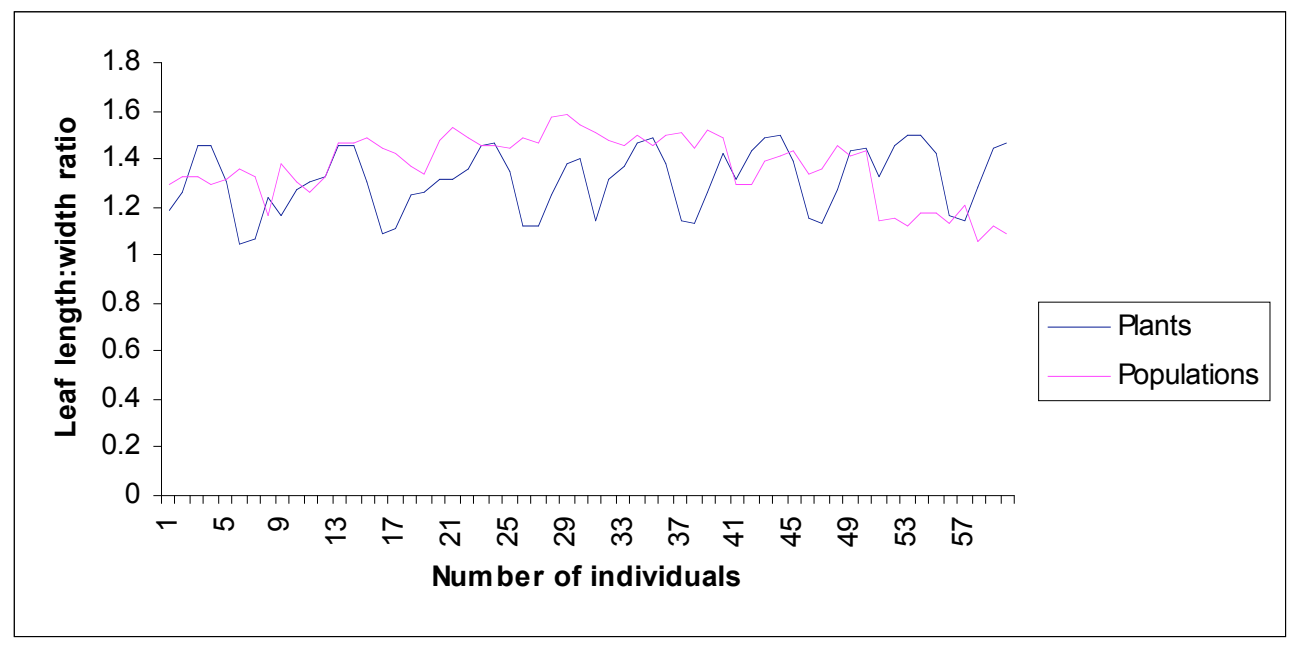

Figure 4.4. Leaf variation in Oreothamnus rosmarinifolius. Lamina length: width measured in 95 individuals from Mt. Arthur, South Island, New Zealand. ( $\mathrm{n}=95$; range $=8.84$ 38.01; mean $(\xi)=21.42$; SDEV $=7.16$; S.E. of 0.33). (Appendix 5).

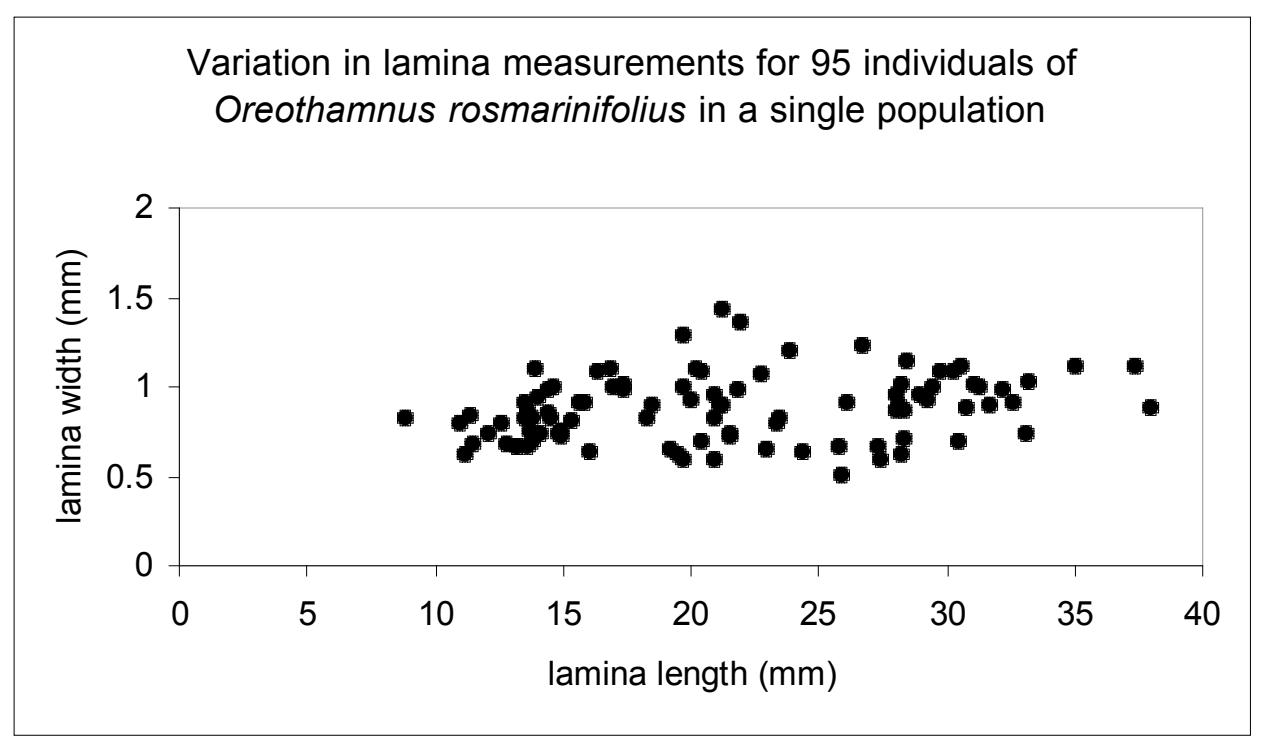

Figure 4.5. Leaf variation in Oreothamnus rosmarinifolius. Lamina length: width measured in 95 individuals from Mt. Arthur, South Island, New Zealand. ( $\mathrm{n}=95$; range $=8.84$ 38.01; mean $(\xi)=21.42$; SDEV $=7.16$; S.E. of 0.33). (Appendix 5). 


\subsubsection{Oreothamnus pronus}

At low altitude habitats on ultramafics, the leaves of $O$. pronus are nearly twice the length of those from alpine habitats but only slightly broader on average (Fig. 4.5). Low altitude plants tend to be sub shrubs with a bushier habit compared to the cushion and carpet growth habit of plants from subalpine and alpine habitats. There is hardly any difference between the flowers of plants from either area and the characteristic serrulate flower bracts that are shorter than the corolla tube and the apical ridge on the petal lobes tend not to vary. Oliver (1929) also noticed and discussed the subalpine and lower altitude forms but did not describe the two forms as different taxa.

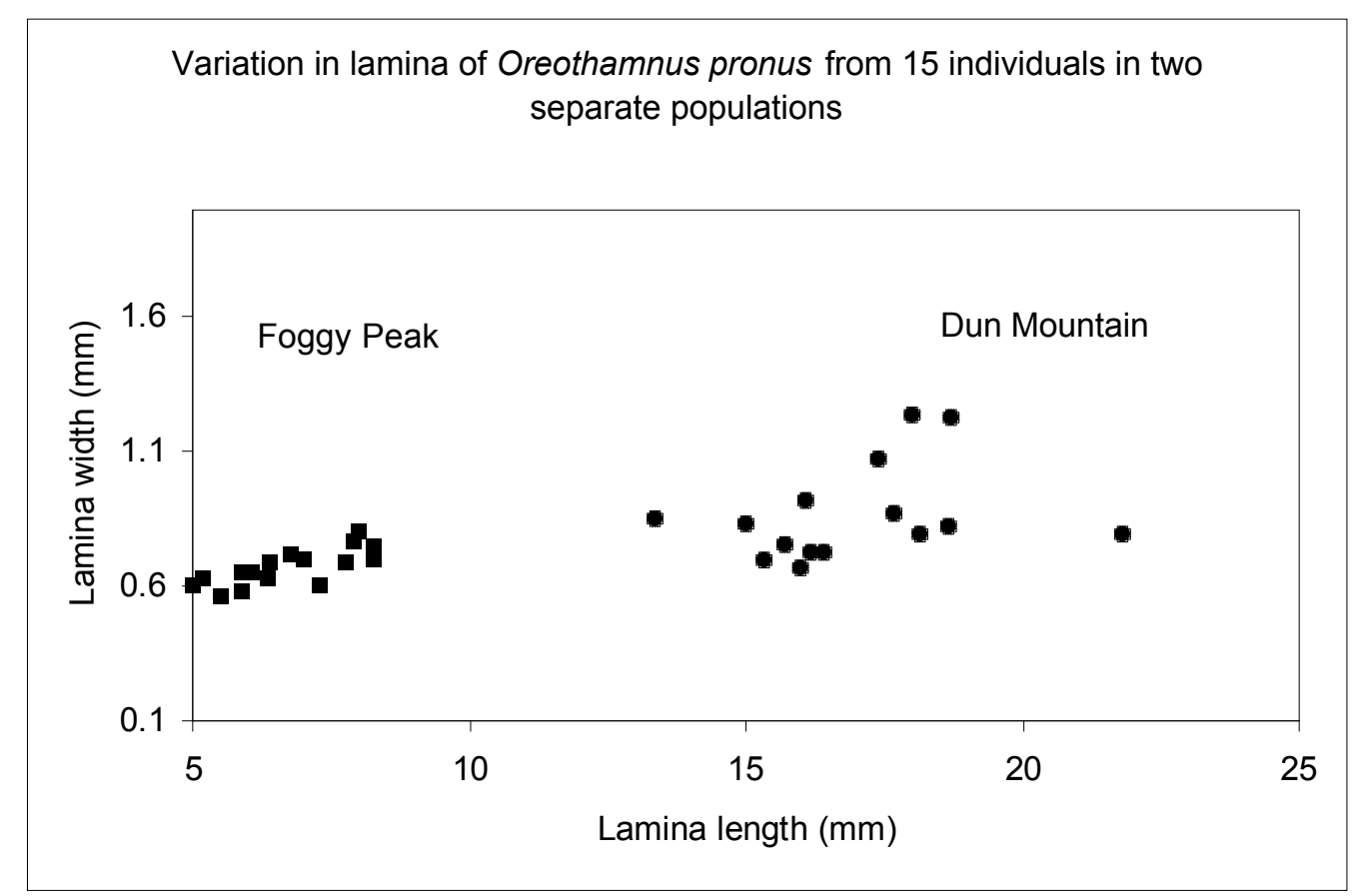

Figure 4.6. Variation in lamina length and width in Oreothamnus pronus. Lamina length : width measured from 15 individuals from an alpine habitat at Foggy Peak ( ) $(\mathrm{n}=15$; range $=5.0-8.0 ;(\xi)=20.28 ; \mathrm{SDEV}=3.84 ;$ S.E. $=0.99)$ and 15 individuals from a lowland habitat at Dun Mountain $(\bullet)(\mathrm{n}=15$; range $=14.41-27.59 ;(\xi)=8.68$; SDEV $=$ 1.56; S.E. $=0.40)$.

\subsubsection{Oreothamnus urvilleanus}


Oreothamnus urvilleanus also shows an extensive range of variation in lamina length. The lamina tends to be longer in populations situated inland (Whangamoa Saddle) compared to that of plants from coastal populations (Kaiteriteri) (Figure 4.7). This variation might be a plastic response to environmental factors. The coastal populations are subjected to longer periods of drought, higher temperatures and higher levels of sunlight. Plants of $O$. urvilleanus growing in full sun on an exposed ridge above Whangamoa Saddle have adult leaves much shorter and fleshier than their equivalent in the forest. This plastic response to full sun over a short period of time was observed in plants taken from the forest and grown under full sun conditions.

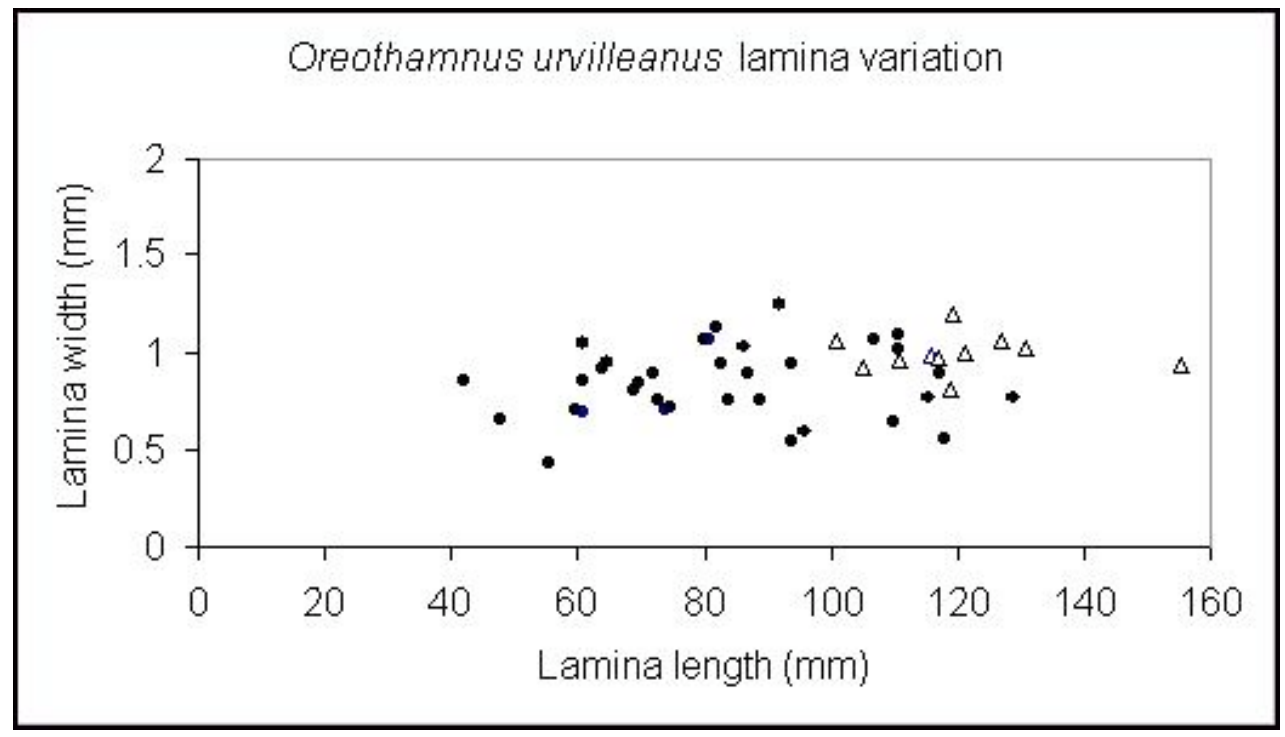

Figure 4.7. Leaf variation in Oreothamnus urvilleanus. Lamina length:width measured from 39 individuals from Kaiteriteri $(\bullet)(\mathrm{n}=39$; range $=42.23-129.0 ;(\xi)=83.02$; SDEV $=$ 21.82; S.E. $=0.26)$ and from 10 individuals from Whangamoa Saddle $(\Delta)(\mathrm{n}=10$; range $=100.85-155.52 ;(\xi)=111.06 ; \mathrm{SDEV}=14.6 ;$ S.E. $=0.13)$ South Island, New Zealand. (Appendix 6).

\subsubsection{Phenotypic responses and differences between ecotypes}


Dracophyllum mackeeanum has two distinct forms. Plants from lowland areas are shrubs up to $1.5 \mathrm{~m}$ tall and nearly glabrous with only the lamina margin and the abaxial lamina surface tomentose (Fig. 7.28C) and occur mostly under lower rainfall conditions. Plants from higher altitudes on the upper slopes of Mt. Humboldt experience lower temperatures, more and stronger winds and nearly $70 \%$ more moisture throughout the year and experience mist for many days of the year (Jaffré 1991).. These plants are smaller (maximum $20 \mathrm{~cm}$ tall) and covered in dense silvery hairs on all parts of the plant. The inflorescences and flowers of the upland form show little variation and especially with the intermediate forms, difficult to distinguish between the two. There are populations known of intermediate forms at intermediate altitudes.

The Tasmanian Dracophyllum milliganii occur normally as small single-stemmed plants (occasionally up to three branches) not taller than $30 \mathrm{~cm}$ in the open grassland, shrubland, moorland, heathland or sedgelands. There is a robust shrub-like form of this species recorded from the edges of open montane temperate rainforest with long leaves and a more robust inflorescence. There are specimens of intermediates linking the two forms and floristically there are no differences between the two forms except in the larger inflorescence of the shrub form. In view of the intermediate forms, it would be unwise to describe any infraspecific taxon.

Dracophyllum ramosum is a polymorphic species, with a great deal of variation in the leaves and inflorescence (Virot 1975). Plants recorded from the chert (phtanite) and limestone near Poum and on Mt. Tchingou grow as low shrubs scarcely one meter tall with a bromelioid head of small leathery leaves. Inflorescence and flower shape and size is the same as for the normal form. This form was described as Dracophyllum amabile by Brongniart and Gris (1864b) from the mountains near Kanala. Lenormand described the 
form with longer and thinner textured leaves growing in forest margins as D. vieillardii in 1911. There is a gradual variation linking all these forms.

What are regarded in this treatment as ecotypes were described as species $(=D$. pyramidale) by Oliver (1952) for a form of $D$. traversii with a slightly more robust pyramidal-shaped inflorescence that occurs on Little Barrier Island, Mt. Pirongia and Mt. Kaitarakihi areas, North Island. He described this North Island form as Dracophyllum pyramidale based on a single difference, the more robust pyramidal-shaped inflorescence. I studied the type material and plants in their natural habitat and regard $D$. pyramidale as a form of $D$. traversii adapted to grow on exposed slopes and therefore included it under Dracophyllum traversii.

Colenso $(1888,1890,1896,1899)$ described four different forms of Oreothamnus recurvus (=Dracophyllum recurvum) as species. D. rubrum (1888) is a form with reddish flowers, $D$. tenuicaulis (1890) a form with thin branches and compact inflorescences, D. brachyphyllum (1896) a form with short, narrow leaves and D. brachycladum (1899) a form with short branchlets. Different habitats can keep species of Dracophyllum and Oreothamnus apart. Certain species are restricted to specific substrates for example O. ophioliticus the only species from unstable serpentinite areas and in New Caledonia, D. onaiemense is the only species there growing on schist with the geographically closest species (D. ramosum) on serpentinite $300 \mathrm{~m}$ lower in altitude.

Another example of a species with two isolated regional variants is Dracophyllum fiordense with populations of Fiordland and Westland that differ in leaf length, stem branching, and fruit size. The Westland populations tend to be shorter and more branched with shorter leaves (400-550 $\mathrm{mm}$ ) and smaller fruit. A possible explanation is the higher 
elevation (900-1300 m) lower rainfall and relatively higher temperatures especially during the summer months. Plants from the southern population grow at lower elevation (20$600 \mathrm{~m}$ ), tend to be mostly unbranched or rarely branched with thicker stems, longer leaves $(600-700 \mathrm{~mm})$ and with larger fruit $(2.5-2.8 \times 3.0-4.0 \mathrm{~mm}$ compared to $2.0-2.5 \times$ 2.5-3.0 mm). The habitat of the area between the two distribution areas is superficially the same with no obvious ecological barrier. This in between area needs to be searched for more $D$. fiordense populations even with the help of a helicopter as $D$. fiordense is easily spotted due to its growth habit and large heads of leaves.

Oreothamnus filifolius is another variable species that occurs on both North and South Islands. It shows various ecotypes with plants from the serpentinite band in northwest Nelson being the most distinct. This form is much smaller with more upright branching and erect coriaceous leaves (Fig. 7.76E) this being the most distinct form. Plants collected on Dun Mountain (Venter 13785) and cultivated under controlled conditions for two years grew leaves and branching comparable to plants growing on other geological formations. The only area where O. filifolius grows as a substantial tree is on Stewart Island with plants at least four meters tall.

A dwarf form of Oreothamnus longifolius grows in moist montane grassland on the Mt. Maungatua plateau with most of the plants along tarns and along creeks with their roots in water. The plants are dwarfed, up to $1.5 \mathrm{~m}$ tall with much smaller leaves (juvenile and mature) and represent one end of the morphological variation spectrum for the species (Fig. 7.92D). Small populations of O. longifolius growing up to three meters tall and resembling the populations growing close to the coast grow along the eastern slopes of the mountain. Along the West Coast of South Island O. longifolius commonly grows as a shrub with upright branches and with broad juvenile leaves turning purplish during the 
winter (Venter 13750), not a common characteristic for the species. Along the coast of Stewart Island (Venter 13787) and at Alex Knob (Venter 13802) plants of this species grow as trees eight meters and 12 meters tall respectively.

Normally Oreothamnus recurvus occur as a carpet-like plant or as a low cushion plant in the subalpine zone on the volcanic plateau. In the Rangipo desert to the east of Mt. Ruapehu and Mt. Ngauruhue it grows as a dense cushion shrub up to $1 \mathrm{~m}$ tall but the inflorescence and flowers vary minimally from the subalpine form (Fig. 7.131A \& D). Some specimens growing in protected areas between large rock boulders and along creeks are up to $90 \mathrm{~cm}$ tall with an open branching pattern.

The growth habit in Oreothamnus densus varies from a flat compact shrublet to small shrubs up to $50 \mathrm{~cm}$ tall with trailing branches. Plants on Mt. Garibaldi grow as flat cushions or carpets not taller than the short Poa grassland wherein it occurs (Fig. 7.73B \& C). These plants experience colder conditions and higher winds throughout the year and during the winter months they are covered in a deep layer of snow for several months. This form of $O$. densus is very similar to the large-leaved form of $O$. prostratus from Fiordland (Fig. 7.125D) but it differs in the size and shape of the lamina sheath and the flower. On Stewart Island and in Southland Oreothammus politus grows as a tall cushion plant (Fig. 7.119E). Plants on Mt. Anglem grow as cushions $50 \mathrm{~cm}$ tall compared to the northern populations that grow as dense carpets especially on the Denniston Plateau. In spite of the different growth habit, the inflorescence is the same. Whereas the Stewart Island plants are very dense cushions one can stand on, the Denniston plateau plants are small open cushions up to $20 \mathrm{~mm}$ tall with some trailing branches. 
The Oreothamnus species with the most ecotypes is O. rosmarinifolius (Chapter 4.2.1.). These various ecotypes are all connected via intermediate forms.

The examples above show how important it is to know the extent of variation in a species before any circumscription can be given or any form of discussion of the different species can take place. The use of infraspecific categories has varied greatly from Linnaeus's days with little uniformity in their adoption today. Du Rietz (1930) did much to help stabilize concepts for subgeneric ranks and his proposals have been widely accepted. The use of subspecies and especially varieties in the New Zealand concept has a history that started in the last century with British practises and continued through with the popular use of varieties by Allan (1961) in the New Zealand Flora and later (19651997) only the rank of subspecies was preferred and this is also true for Australia where only the rank of subspecies is used in the Flora of Australia (Glenny 2003). A recent trend not only in New Zealand but also in southern Africa and Australia is the avoidance of using infraspecific ranks in spite of recognizing various degrees of differentiation and the existence of geographical variants (Glenny 2003).

My view is to recognize broad species much along the same lines as Fisher (1965) for the genus Ranunculus and to discuss the various ecotypes or forms under the species I recognize. 


\subsubsection{Differences between species}

\subsubsection{Dracophyllum elegantissimum, D. latifolium and $D$. traversii}

The group of species containing Dracophyllum elegantissimum, D. latifolium and D. traversii has always been difficult to define. These species differ in the following characters (Table 4.3.):

Table 4.3. Differences between Dracophyllum elegantissimum, D. latifolium and D. traversii.

\begin{tabular}{|c|c|c|c|}
\hline & D. elegantissimum & D. latifolium & D. traversii \\
\hline $\begin{array}{l}\text { Fibre bundles between vascular bundles } \\
\text { Epidermal layer } \\
\text { Ovary shape } \\
\text { Ovary size in mm } \\
\text { Ovary shape of the apex } \\
\text { Nectary scale length compared to ovary }\end{array}$ & $\begin{array}{c}\text { absent } \\
\text { very thick } \\
\text { globose } \\
1.0-1.5 \times 1.3-1.5 \\
\text { tapered } \\
\text { shorter }\end{array}$ & $\begin{array}{c}\text { present } \\
\text { thin } \\
\text { ovate } \\
0.8-1.0 \times 1.0-1.5 \\
\text { indented } \\
\text { equalling or longer }\end{array}$ & $\begin{array}{c}\text { present } \\
\text { thin } \\
\text { subglobose } \\
1.4-1.5 \times 1.8-2.0 \\
\text { indented } \\
\text { shorter }\end{array}$ \\
\hline
\end{tabular}

The ovary and nectary scale characters and the anatomical characters of the cross-section of the lamina show that the three species are distinct (Table 7.5). The ovary of $D$. latifolium is ovate and smaller $(0.8-1.0 \times 1.0-1.5 \mathrm{~mm})$ with the nectary scales equalling the ovary or sometimes slightly longer. A cross-section of the lamina shows distinct small bundles of fibres spaced between the vascular bundles. The ovary of $D$. traversii is subglobose and larger $(1.4-1.5 \times 1.8-2.0 \mathrm{~mm})$ with very wide nectary scales $(1.0-1.5 \mathrm{~mm}$ long and wide). The epidermis layer is thinner in $D$. traversii and there is elongated fibre bundles spaced between the vascular bundles except for the vascular bundles next to the lamina margin. The globose ovary $(1.0-1.5 \times 1.3-1.5 \mathrm{~mm})$ in D. elegantissimum has the apex strongly tapering into the style, a unique character for the genus. The very thick epidermal layer can clearly be seen in a cross-section of the lamina. There is also an extra fibre bundle present between the first and second vascular bundles and the fibre caps on 
the secondary vascular bundles are long and narrow, a character lacking in both $D$. latifolium and D. traversii.

\subsubsection{Oreothamnus muscoides, O. politus, O. pronus and O. prostratus}

All taxonomists in the past experienced problems in defining the group of subalpine to alpine cushion species (Oreothamnus muscoides, O. politus, O. pronus and O. prostratus). These species differ in the following characters (Table 4.4.):

Table 4.4. Differences between Oreothamnus muscoides, O. politus, O. pronus, and O. prostratus.

\begin{tabular}{|c|c|c|c|c|}
\hline & O. muscoides & O. politus & O. pronus & O. prostratus \\
\hline Number vascular bundles per leaf & 3 & 3 & 5 & 3 \\
\hline Vascular bundle shape & round & elongate & elongate+extension & round \\
\hline Vascular bundle distribution & 1 central +2 lateral & 1 central +2 lateral & 3 central +2 lateral & 1 central +2 lateral \\
\hline Lateral vascular bundles & present & absent & present & absent \\
\hline Fibre caps encircle vascular bundle & present & absent & absent & absent \\
\hline Dead leaves on stems & present & present & absent & present \\
\hline Apex of the nectary scale & irregularly toothed & irregularly toothed & retuse & irregularly toothed \\
\hline Sepal texture in upper half & glabrous & pubescent & glabrous & glabrous \\
\hline
\end{tabular}

The shape and distribution of the vascular bundles and the fibre caps and bundles are different for each species. O. politus and O. prostratus both have three vascular bundles per leaf but the basal fibre cap in O. politus is much larger and the fibre caps of the two lateral vascular bundles in $O$. prostratus do not connect with the abaxial epidermis. O. pronus has five vascular bundles with only the middle three having the fibre caps reaching both epidermis layers. There are also two lateral fibre bundles, a character it shares with $O$. muscoides. The shape of the fibre caps in O. muscoides is different from those in the other species in that it fully encircles the vascular bundles. O. pronus lacks the presence of old and dead leaves which remain on the plant for a long period and the apex of the nectary scales are retuse not irregularly toothed as in the other three species. In O. politus the 
upper half of the adaxial surface of the sepal is pubescent whereas it is glabrous in the other three species.

Another group of species, which became a 'dustbin' for botanists and ecologists, is the group containing Oreothamnus filifolius, $O$. lessonianus, $O$. longifolius, $O$. oliveri and $O$. urvilleanus. Oliver (1952) was the first to bring order to this group of species. These species are easily distinguished from each other based on the characters in Table 4.5.

Table 4.5. Differences between Oreothamnus filifolius, O. lessonianus, O. longifolius, O. oliveri and $O$. urvilleanus.

\begin{tabular}{|l|ccccc|c|}
\cline { 2 - 5 } \multicolumn{1}{c|}{} & O. filifolius & O. lessonianus & O. longifolius & O. oliveri & O. urvilleanus \\
\hline Juvenile leaves & absent & present & present & present & present \\
Juvenile lamina width $(\mathrm{mm})$ & 0 & $1.6-1.8$ & $2.5-8.0(-10.0)$ & $1.3-1.5$ & $(1.5-) 2.3-3.7$ \\
Adult lamina striation & slightly & none & prominently & smooth & smooth \\
Adaxial lamina surface & not striated & not striated & striated & not striated & not striated \\
Inflorescence shape & spike & spike & raceme & raceme & raceme \\
Inflorescence bract margin & ciliate & entire & serrulate & serrulate & serrulate \\
Inflorescence bract texture & coriaceous & rigid and hard & coriaceous & coriaceous & coriaceous \\
Inflorescence bract texture & glabrous & glabrous & glabrous & glabrous & rugose \\
Inflorescence bract length $(\mathrm{mm})$ & 8.5-17.0 & 6.0-17.5 & (17-)30.0-35.0 & $(0.6-) 13.0-20.0$ & $(15.4-) 31.0-35.0$ \\
Colour of flower bract margin & green & white & green & green & green \\
Flower shape & cylindrical & cylindrical & cylindrical & cylindrical & campanulate \\
\hline
\end{tabular}

Populations of $O$. filifolius and O. urvilleanus occur next to each other at two localities (Whangamoa Saddle and Cobb Reservoir) with no hybrids recorded. Using the above mentioned characters it was easy to distinguish between the two species. This shows that the two species were genetically separated for long enough to form two distinct taxa.

\subsubsection{Phenetic study of similarity among Dracopbyllum and Oreothamnus species.}

The phenetic study of Dracophyllum sens. lat. conducted here, based on morphological and anatomical characters, shows little congruence with Oliver's studies on the genus (Table 4.4. \& 4.5.). The 0.4 similarity phenon line indicates two 


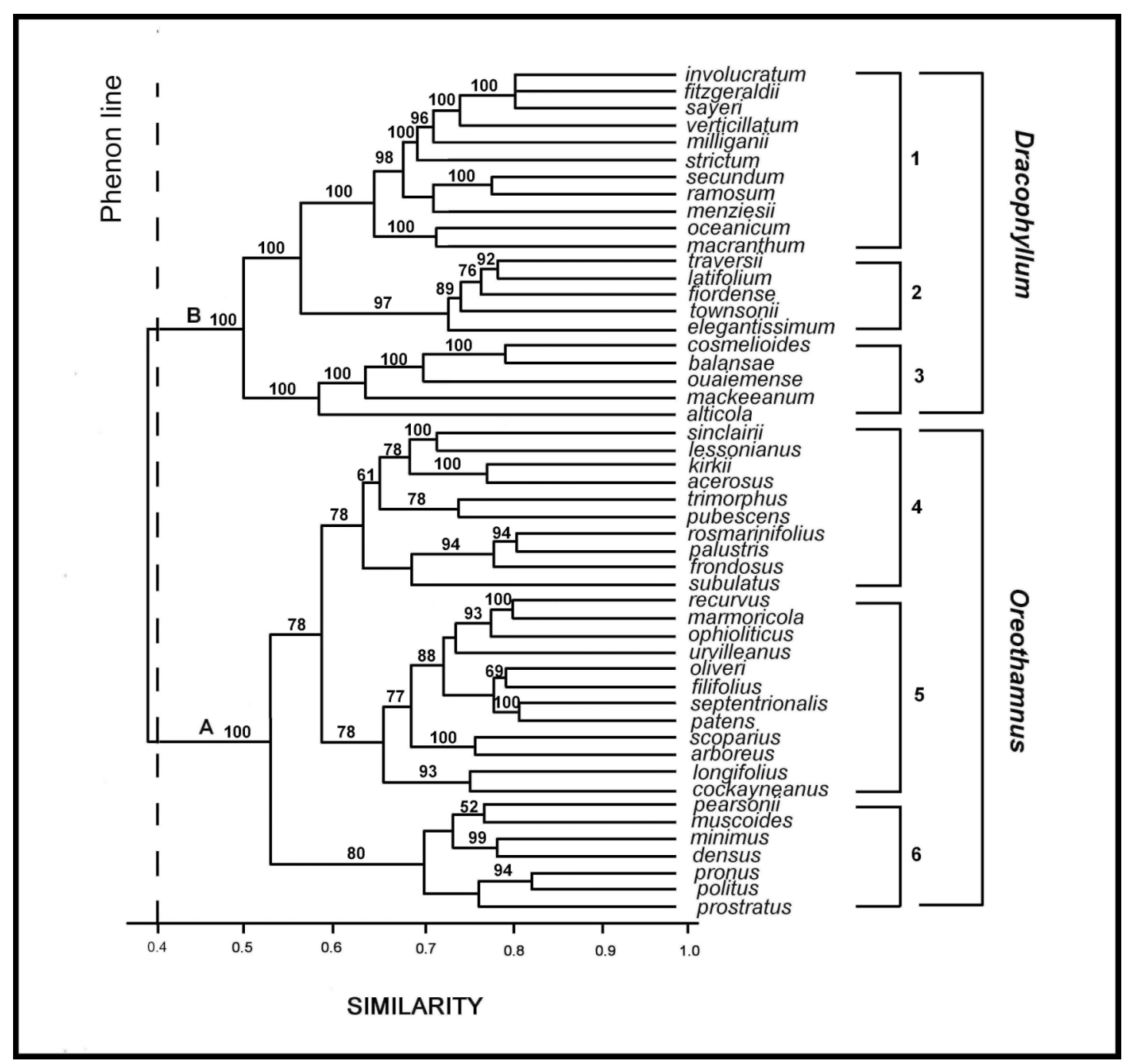

Figure 4.8. Compact/complete linkage for the genus Dracophyllum s.l. Overall Cophenetic correlation coefficients - Spearman Rank: 0.80014; Pearson: 0.79949. The 0.4 phenon line is indicated with a broken line. The numbers above the line are the jackknife values only values over $50 \%$ are shown. 
major groupings with $100 \%$ Bootstrap support, group A corresponds to Oliver's (1952) subgenus Oreothamnus and group B to subgenus Dracophyllum (as Eudracophyllum), but subgenus Cordophyllum got no recognition (Fig. 4.8.). There is some agreement in three of his 14 groups in his 1928 and one of his 18 groups in his 1952 study.

The phenetic study shows three prominent groupings in Dracopbyllum based on the following characters:

Group 1: reflexed corolla lobes; obovate to subglobose ovary and the stamens that are inclosed in the corolla tube $(100 \%$ Bootstrap support).

Group 2: A New Zealand group of trees characterised by flaky bark; leaves arranged in bromelioid heads; leaves prominently striated; acute inflorescence bracts; flowers arranged in groups of five or more; flowers campanulate; exserted anthers and short and broad sepals (97\% Bootstrap support). A well-defined group easily identified in its natural habitat and from herbarium material.

Group 3: A New Caledonia group characterised by deeply fissured bark; leaves crowded at the apices of the branches; inflorescence a panicle which is longer than the leaves, lax, sparingly branched and the style enclosed in the corolla tube (100\% Bootstrap support).

The three groupings in Oreothamnus is based on the following characters: 
Group 4: shrubs with leaves having a tuft of scabrid hairs at the base of the lamina; inflorescence shorter than the leaves; corolla lobes shorter than the corolla tube and the stamens inserted in the upper third of the corolla tube (78\% Bootstrap support).

Table 4.6. Dracophyllum species groups according to Oliver $(1928,1952)$.

\begin{tabular}{|c|c|c|c|}
\hline \multicolumn{2}{|r|}{ Oliver 1928} & \multicolumn{2}{|c|}{ Oliver 1952} \\
\hline Species groups & Species & Species groups & Species \\
\hline \multirow[t]{3}{*}{ minimum } & \multirow{3}{*}{$\begin{array}{l}\text { minimum } \\
\text { muscoides } \\
\text { pearsonii } \\
\text { politum } \\
\text { pronum } \\
\text { prostratum }\end{array}$} & minimum & minimum \\
\hline & & muscoides & $\begin{array}{l}\text { muscoides } \\
\text { pronum } \\
\text { prostratum }\end{array}$ \\
\hline & & \multirow[t]{2}{*}{ pearsonii } & $\begin{array}{l}\text { densum } \\
\text { pearsonii }\end{array}$ \\
\hline \multirow[t]{2}{*}{ rosmarinifolium } & \multirow{2}{*}{$\begin{array}{l}\text { acerosum (= peninsulare) } \\
\text { palustre } \\
\text { rosmarinifolium } \\
\text { subulatum }\end{array}$} & & politum \\
\hline & & rosmarinifolium & $\begin{array}{l}\text { acerosum } \\
\text { rosmarinifolium } \\
\text { rosmarinifolium (= uniflorum) }\end{array}$ \\
\hline kirkii & $\begin{array}{l}\text { kirkii } \\
\text { pubescens }\end{array}$ & subulatum & $\begin{array}{l}\text { palustre } \\
\text { subulatum }\end{array}$ \\
\hline scoparium & $\begin{array}{l}\text { arboreum } \\
\text { scoparium } \\
\text { scoparium (= paludosum) }\end{array}$ & kirkii & $\begin{array}{l}\text { kirkii } \\
\text { pubescens } \\
\text { trimorphum } \\
\end{array}$ \\
\hline \multirow[t]{2}{*}{ urvilleanum } & \multirow{2}{*}{$\begin{array}{l}\text { filifolium } \\
\text { filifolium (= collinum) } \\
\text { lessonianum } \\
\text { urvilleanum }\end{array}$} & scoparium & scoparium \\
\hline & & urvilleanum & $\begin{array}{l}\text { filifolium } \\
\text { lessonianum } \\
\text { urvilleanum }\end{array}$ \\
\hline sinclairii & $\begin{array}{l}\text { patens } \\
\text { sinclairii } \\
\text { sinclairii (= viride) }\end{array}$ & sinclairii & $\begin{array}{l}\text { arboreum } \\
\text { patens } \\
\text { sinclairii } \\
\text { sinclairii (= viride) }\end{array}$ \\
\hline recurvum & recurvum & recurvum & recurvum \\
\hline \multirow[t]{2}{*}{ longifolium } & \multirow[t]{2}{*}{$\begin{array}{l}\text { longifolium } \\
\text { sinclairii (= adamsii) }\end{array}$} & longifolium & $\begin{array}{l}\text { longifolium } \\
\text { oliveri }\end{array}$ \\
\hline & & adamsii & sinclairii (= adamsii) \\
\hline menziesii & $\begin{array}{l}\text { fiordense } \\
\text { menziesii } \\
\text { townsonii }\end{array}$ & menziesii & $\begin{array}{l}\text { fiordense } \\
\text { menziesii } \\
\text { townsonii }\end{array}$ \\
\hline secundum & $\begin{array}{l}\text { cosmelioides (= gracile) } \\
\text { ramosum } \\
\text { ramosum (= amabile) } \\
\text { ramosum (= vieillardii) } \\
\text { secundum } \\
\text { strictum } \\
\text { verticillatum (= thiebautii) }\end{array}$ & secundum & $\begin{array}{l}\text { alticola } \\
\text { cosmelioides } \\
\text { ramosum } \\
\text { ramosum (= amabile) } \\
\text { ramosum (= vieillardii) } \\
\text { secundum } \\
\text { strictum } \\
\text { verticillatum (= thiebautii) }\end{array}$ \\
\hline milliganii & $\begin{array}{l}\text { fitzgeraldii } \\
\text { milliganii } \\
\text { sayeri } \\
\text { verticillatum (= dracaenoides) }\end{array}$ & milliganii & $\begin{array}{l}\text { fitzgeraldii } \\
\text { milliganii } \\
\text { sayeri } \\
\text { verticillatum (= dracaenoides) }\end{array}$ \\
\hline latifolium & $\begin{array}{l}\text { latifolium } \\
\text { latifolium (= mathewsii) } \\
\text { traversii } \\
\text { traversii (= recurvatum) }\end{array}$ & latifolium & $\begin{array}{l}\text { latifolium } \\
\text { latifolium (= mathewsii) } \\
\text { traversii } \\
\text { traversii (= recurvatum) }\end{array}$ \\
\hline verticillatum & verticillatum & verticillatum & verticillatum \\
\hline involucratum & involucratum & involucratum & involucratum \\
\hline
\end{tabular}


Group 5: leaves spreading, linear-triangular; flower bracts longer than the flowers and the corolla lobes reflexed (78\% Bootstrap support).

Group 6: A subalpine/alpine group characterised by the ericoid leaves; membranous margins of the lamina sheaths; smooth sepals; ovate triangular corolla lobes with a prominent apical ridge; style enclosed in the corolla tube and ovoid seeds $(80 \%$ Bootstrap support). A group morphologically well defined.

In the phenetic study the 'D. minimum group' of Oliver (1928) matches 'Group 6' in the phenogram except for $O$. densus $(=D$. densum) published in 1952. In spite of Oliver's different views in grouping of species in Dracophyllum sens. lat. (Table 4.6.) he had a good concept of the species with most of them recognized in this study.

Table 4.7. Concordance of names in the genus Dracophyllum.

\begin{tabular}{|c|c|c|c|c|}
\hline Cheeseman 1925 & Oliver 1928 & Oliver 1952 & Allan 1961 & Venter this revision \\
\hline D. Iatifolium var. latifolium & D. latifolium & D. latifolium & D. latifolium & D. Iatifolium \\
\hline D. latifolium var. matthewsii & D. matthewsii & D. matthewsii & D. matthewsii & D. latifolium \\
\hline D. traversii & D. traversii & D. traversii & D. traversii & D. traversii \\
\hline D. townsonii & D. townsoni & D. townsoni & D. townsonii & D. townsonii \\
\hline D. menziesii & D. menziesii & D. menziesii & D. menziesii & D. menziesii \\
\hline \multirow[t]{20}{*}{ D. strictum } & D. strictum & D. strictum & D. strictum & D. strictum \\
\hline & D. fiordense & D. fiordense & D. fiordense & D. fiordense \\
\hline & D. recurvatum & D. Iatifolium & D. Iatifolium & D. Iatifolium \\
\hline & & D. pyramidale & D. pyramidale & D. traversii \\
\hline & & & & D. elegantissimum \\
\hline & D. ramosum & D. ramosum & & D. ramosum \\
\hline & D. secundum & D. secundum & & D. secundum \\
\hline & D. vieillardii & D. vieillardii & & D. ramosum \\
\hline & D. amabile & D. amabile & & D. ramosum \\
\hline & D. gracile & D. cosmelioides & & D. cosmelioides \\
\hline & D. thiebautii & D. thiebautii & & D. verticillatum \\
\hline & D. sayeri & D. sayeri & & D. sayeri \\
\hline & D. dracaenoides & D. dracaenoides & & D. verticillatum \\
\hline & D. milligani & D. milligani & & D. milliganii \\
\hline & D. fitzgeraldi & D. fitzgeraldi & & D. fitzgeraldii \\
\hline & D. verticillatum & D. verticillatum & & D. verticillatum \\
\hline & D. involucratum & D. involucratum & & D. involucratum \\
\hline & & D. alticolum & & D. alticola \\
\hline & & D. compactum & & D. involucratum \\
\hline & & & & D. mackeeanum \\
\hline
\end{tabular}


Table 4.8. Concordance of names in the genus Oreothamnus.

\begin{tabular}{|c|c|c|c|c|}
\hline Cheeseman 1925 & Oliver 1928 & Oliver 1952 & Allan 1961 & Yenter this revision \\
\hline D. sinelairii & D. squarrosum & & & 8. sinetalutilita \\
\hline D. recurvumm & D. recurvum & D. recurvum & R.rectinum & Q. \\
\hline D. longifolium & D. Iongifolium & D. longifolium var. Iongifolium & B. tomgifollumv var. longitollum & O. Homginotitus \\
\hline D. urvilleanum var. urvilleanum & D. urvillianum & D. urvilleanum & D. urvilleanum & O urvilleanus \\
\hline D. urvilleanum var. filifolium & D. filifolium & D. filifolium & D. filifolium & O. filifolius \\
\hline D. urvilleanum var. lessonianum & D. Iessonianum & D. Iessonianum & D. Iessonianum & O. lessonianus \\
\hline D. urvilleanum var. montanum & & & & O. filifolius \\
\hline D. pearsonii & D. pearsoni & D. pearsoni & D. pearsonii & O. pearsonii \\
\hline D. scoparium & D. scoparium & D. scoparium & D. scoparium & O. scoparius \\
\hline D. arboreum var. arboreum & D. arboreum & D. arboreum & D. arboreum & O. arboreus \\
\hline D. arboreum var. paludosum & D. paludosum & D. paludosum & D. paludosum & O. scoparius \\
\hline D. subulatum & D. subulatum & D. subulatum & D. subulatum & O. subulatus \\
\hline D. pubescens & D. pubescens & D. pubescens & D. pubescens & O. pubescens \\
\hline D. kirkii & D. kirkii & D. kirkii & D. kirkii & O. kirkii \\
\hline D. uniflorum var. uniflorum & & D. uniflorum & D. uniflorum var. uniflorum & O. rosmarinifolius \\
\hline D. uniflorum var. acicularifolium & & & & O. acerosus \\
\hline D. uniflorum var. virgatum & D. palustre & & & O. palustris \\
\hline D. politum & D. politum & D. politum & D. politum & O. politus \\
\hline D. rosmarinifolium & D. pronum & D. pronum & D. pronum & O. pronus \\
\hline D. prostratum & D. prostratum & D. prostratum & D. prostratum & O. prostratus \\
\hline \multirow[t]{17}{*}{ D. muscoides } & D. muscoides & D. muscoides & D. muscoides & O. muscoides \\
\hline & D. minimum & D. minimum & & O. minimus \\
\hline & D. rosmarinifolium & D. rosmarinifolium & D. rosmarinifolium & O. rosmarinifolius \\
\hline & D. peninsulare & D. acerosum & D. acerosum & O. acerosus \\
\hline & D. palustre & D. palustre & D. palustre & O. palustris \\
\hline & D. collinum & D. filifolium & D. filifolium & O. filifoius \\
\hline & D. patens & D. patens & D. patens & O. patens \\
\hline & D. viride & D. viride & D. viride & O. sinclairii \\
\hline & D. adamsii & D. adamsii & D. adamsii & O. sinclairii \\
\hline & & D. densum & D. densum & O. densus \\
\hline & & D. acerosum & D. acerosum & O. acerosus \\
\hline & & D. trimorphum & D. trimorphum & O. trimorphus \\
\hline & & D. Iongifolium var. septentrionale & & O. septentrionalis \\
\hline & & D. Iongifolium var. pluviale & & O. longifolius \\
\hline & & D. longifolium var. cockayneanum & D. longifolium var. cockayneanum & O. cockayneanus \\
\hline & & D. oliveri & D. oliveri & O. oliveri \\
\hline & & D. sinclairii & D. sinclairii & O. sinclairii \\
\hline
\end{tabular}




\subsection{Discussion}

Oliver (1928) was the only person who attempted to arrange Dracophyllum species into species groups and he arranged it into 14 groups (Table 4.6) based on leaf and inflorescence characters. Later in a supplement to his 1928 revision (1952), he added three additional species and regrouped all the species into 18 species groups, which differed considerably from his first grouping unfortunately with little discussion and reasons for this new grouping (Table 4.6). The high level of homoplasy and the subsequent weakly resolved phylogeny in the cladistic study makes it difficult to place the species into robust species groups. At this stage grouping of species can only be intuitive, but I strongly suggest leaving the final species grouping till after DNA sequencing has been done for all the species in the ingroup. 


\section{Chapter 5: Taxonomic significance of anatomical characters of the leaf in Dracopbyllum and Oreothamnus.}

\subsection{Introduction}

Few publications until now have used leaf anatomy in systematic work on Dracophyllum and Oreothamnus. Anatomical work done by Simon (1891) covered the Styphelioideae with a few references to Dracophyllum and Oreothamnus. A study by Betts (1919) is the only detailed anatomical work on Oreothamnus in New Zealand and she gave a detailed description of the anatomy of O. filifolius (as Dracophyllum urvilleanum) and O. pronus (as D. rosmarinifolium). Gibson (1991) in a study of four Tasmanian cushion species discussed the anatomy of O. minimus in some detail. Watson (1967) did an anatomical study of the leaf fibres, nodal anatomy and pith structure in the Styphelioideae (as Epacridaceae) including the genera Dracophyllum and Oreothamnus and described four leaf fibre patterns: Styphelia, Epacris, Cosmelia and Richea patterns.

Leaf material of Dracophyllum and Oreothamnus was studied to confirm whether all the species fall within Watson's Richea pattern.

\subsection{Materials and methods}

Preparation and examination of leaf sections

Fresh leaf material was available for all the New Zealand and two of the Australian species (Dracophyllum sayeri \& D. secundum). Fresh material was fixed and preserved in FAA (formalin-acetic acid-alcohol). When fresh material was not available dried material was rehydrated by immersion in commercial 'Windolene' (Reckitt \& Colman) for 10 minutes and then immersed into boiling water for another 10 minutes. 'Windolene' is added to reduce surface tension and to help with water penetration. Material treated in 
this way can easily be sectioned. Fresh and dried leaf material was sectioned by hand with a scalpel blade under a Wild stereomicroscope at $25 \times$ magnification. The sections, approximately $25 \mu \mathrm{m}$ thick, were mounted unstained in water and studied with a stereo microscope on a black background to lighten up the white sclerenchyma sheaths, and to show the colour contrast between the vascular bundles and green chlorenchyma. Fifty samples per species representing five populations throughout its geographical range were studied for Oreothamnus and all the New Zealand species of Dracophyllum with twenty samples studied for the other Dracophyllum species.

\section{Material}

Species names and voucher specimens for samples studied are listed in Appendix 1.

\subsection{Results}

\subsubsection{Cuticle}

The internal structure of the cuticle in Dracophyllum and Oreothamnus is of limited taxonomic value. In Dracophyllum it is normally thicker on the adaxial surface with the exception of D. oceanicum and D. secundum where it is of equal thickness and in O. minimus where it is thin (Gibson 1991). In Oreothamnus there are 10 species with the adaxial and abaxial cuticle of the same thickness (Fig. 5.3.).

\subsubsection{Epidermis and stomata}

In Dracophyllum and Oreothamnus the stomata are rubiaceous/paracytic (stoma bordered on both sides by one or more subsidiary cells whose long axes lie parallel with the long axis of the guard cells). In Dracophyllum stomata are present only on the adaxial lamina surface, but present on both surfaces of the sepals unlike Oreothamnus where the stomata are present on both lamina and sepal surfaces. and is of systematic value (Stace 1965; 
Watson 1962). Betts (1919) found that in O. filifolius stomata are more numerous on the adaxial surface, with the guard cells and the opening protected by guard-cell ridges that have thickened walls. Sunken stomata are present in all Dracophyllum and Oreothamnus species except in $O$. frondosus where the stomata are prominently raised. Sunken stomata is a feature usually associated with plants from xeric habitats and according to Stace (1965) the amount of ornamentation of the guard cells is usually proportional to the degree of thickening of the cell walls and again related to the degree of xeromorphism. Stomata in O. minimus are very small with sunken guard cells (Gibson 1991).

Oliver (1917) gave a detailed description of the adaxial leaf epidermis of D. fitzgeraldii. He stated that the epidermal cells are large, in a single layer and slightly deeper than wide. The hypodermis consists of two layers of sclerenchymatous cells that are twice as long as broad in cross section. The abaxial epidermis consists of a single layer of cells that are smaller than those of the adaxial epidermis. In $O$. filifolius the adaxial epidermis cells are small and round with thickened and slightly lignified walls. Some of these cells are produced as single-celled hairs with thick cutinized walls. The epidermal cells on the abaxial leaf surface are slightly smaller than those of the adaxial epidermis (Betts 1919). The shape of the epidermal cells in O. muscoides is isodiametric (Simon 1891) and the epidermis of $O$. minimus consists of a single layer of cells.

\subsubsection{Vascular tissue}

Leaves of Dracophyllum and Oreothamnus have conspicuous groups of fibres associated with the veins and Simon (1891) suggested that the different arrangement patterns of the fibrous tissue could be used as taxonomic criteria. Watson (1967) built on this idea and described four different patterns: 
a) Styphelia pattern - veins with an abaxial arc of fibres touching the lower epidermis of the lamina.

b) Epacris pattern - veins with a conspicuous abaxial arc of fibres embedded in mesophyll and not touching the abaxial part of the lamina.

c) Cosmelia pattern - veins with an abaxial arc of fibres, which are embedded in mesophyll and touching the abaxial part of the lamina.

d) Richea pattern - veins linked by fibres to both lamina epidermal surfaces.

Watson (1967) included the genera Richea, Dracophyllum and Oreothamnus in the Richea pattern. Simon (1891) suggested that the closely situated I-shaped sclerenchyma bundles gave support to the leaves. Features of the leaf morphology, nodal anatomy and pith structure are narrowly correlated with patterns of fibre arrangement (Watson 1967).

The results from this study are markedly different from those of Simon (1891) and Watson (1967) in that all four of the fibre arrangement patterns occur in Dracophyllum and Oreothamnus limiting the taxonomic value to subgeneric ranks.

The overall pattern formed by the veins and the associated fibres, I call 'anatomical lamina vascular pattern' (ALVP) as shown by a transverse section made through adult leaves of Dracophyllum (Figure 5.2) and Oreothamnus (Figure 5.3) species. This pattern is made up of the different shapes of the fibre bundles and their associated veins. There are five different shapes of veinless fibre bundles that are either scattered between the veins or located next to the lamina margin (Figure 5.1, a - e), and 13 shapes of veins (dark shading) plus the associated fibres bundles (not shaded) (Figure 5.1, A - M). 


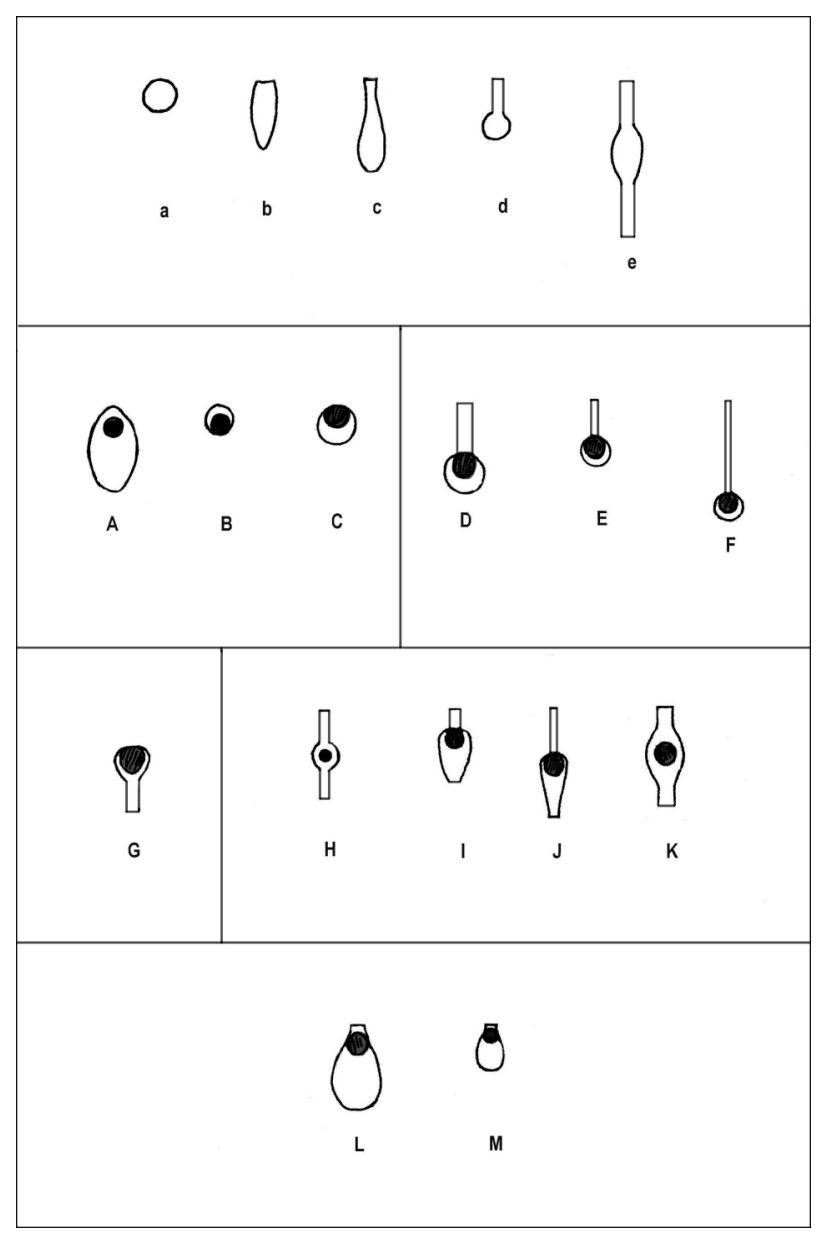

Figure 5.1. Schematic representation of fibre bundle shapes in Dracophyllum and Oreothamnus (For explanation see text).

The shape of the fibre bundles and veins was coded according to the shapes in figure 5.1 starting from the margin working towards the middle of the lamina. These patterns are called code strings and given for all the species (Table 5.1). The ALVP in Dracophyllum differs for all the species except in $D$. ouaiemense and $D$. sayeri where the pattern is the same and can thus be used to successfully identify species by comparing the ALVP of the specimen with that depicted in Table 5.1. By giving a separate code to the different types of vascular bundles with the associated terminal and diffuse sclerenchyma, different code-strings were compiled for Dracophyllum and Oreothamnus depicting the ALVP (Table 
Table 5.1. Anatomical lamina vascular pattern (ALVP) code for the genus Dracophyllum and Oreothamnus.

\begin{tabular}{|c|c|c|c|c|c|c|c|c|c|c|}
\hline \multicolumn{11}{|c|}{ Dracophyllum species } \\
\hline D. alticola & a & A & $\mathrm{a}$ & $\mathrm{a}$ & A & $\mathrm{a}$ & $\mathrm{a}$ & A & $\mathrm{a}$ & $\mathrm{a}$ \\
\hline D. ouaiemense $+D$. sayeri & a & $\mathrm{D}$ & $\mathrm{D}$ & $\mathrm{D}$ & $\mathrm{D}$ & $\mathrm{D}$ & $\mathrm{D}$ & D & $\mathrm{D}$ & $\mathrm{D}$ \\
\hline D. townsonii & $a$ & $E$ & $a$ & $E$ & a & $E$ & $a$ & E & a & D \\
\hline D. strictum & a & $E$ & $\mathrm{~b}$ & $\mathrm{E}$ & c & $E$ & $\mathrm{C}$ & E & c & $E$ \\
\hline D. traversii & $a$ & $E$ & $E$ & $E$ & $\mathrm{e}$ & $E$ & $\mathrm{e}$ & $E$ & e & $E$ \\
\hline D. milliganii & a & $E$ & $\mathrm{E}$ & $\mathrm{E}$ & $E$ & $E$ & $E$ & $\mathrm{E}$ & $E$ & $E$ \\
\hline D. latifolium & a & $\mathrm{F}$ & $\mathrm{F}$ & $\mathrm{a}$ & $\mathrm{F}$ & a & $\mathrm{F}$ & a & $\mathrm{F}$ & a \\
\hline D. elegantissimum & a & I & $\mathrm{b}$ & 1 & $\mathrm{~J}$ & $\mathrm{~J}$ & 1 & $\mathrm{~J}$ & $\mathrm{~J}$ & I \\
\hline D. menziesii & a & $\mathrm{J}$ & $a$ & $\mathrm{~J}$ & $a$ & $\mathrm{~J}$ & $a$ & $\mathrm{~J}$ & a & $\mathrm{J}$ \\
\hline D. fiordense & $a$ & $\mathrm{~J}$ & 1 & $\mathrm{~J}$ & 1 & $\mathrm{~J}$ & 1 & $\mathrm{~J}$ & I & $\mathrm{J}$ \\
\hline D. fitzgeraldii & $\mathrm{b}$ & $\mathrm{b}$ & $E$ & $E$ & $E$ & $E$ & $E$ & $E$ & $E$ & $E$ \\
\hline D. balansae & B & $\mathrm{H}$ & $\mathrm{H}$ & $\mathrm{H}$ & $\mathrm{H}$ & $\mathrm{H}$ & $\mathrm{H}$ & $\mathrm{H}$ & $\mathrm{H}$ & $\mathrm{H}$ \\
\hline D. involucratum & C & A & $A$ & $A$ & A & A & A & A & A & A \\
\hline D. oceanicum & $\mathrm{C}$ & $\mathrm{D}$ & $\mathrm{D}$ & $\mathrm{D}$ & $\mathrm{D}$ & $\mathrm{D}$ & D & $\mathrm{D}$ & $\mathrm{D}$ & D \\
\hline D. verticillatum & $\mathrm{C}$ & $E$ & $\mathrm{~L}$ & $\mathrm{C}$ & $\mathrm{L}$ & $\mathrm{L}$ & $\mathrm{L}$ & $L$ & $\mathrm{~L}$ & L \\
\hline D. secundum & $E$ & $\mathrm{D}$ & $\mathrm{D}$ & $\mathrm{D}$ & $\mathrm{D}$ & $\mathrm{D}$ & $\mathrm{D}$ & $\mathrm{D}$ & $\mathrm{D}$ & $\mathrm{D}$ \\
\hline D. cosmelioides & $E$ & $\mathrm{D}$ & $\mathrm{E}$ & & & & & & & \\
\hline D. mackeeanum & $E$ & $E$ & $\mathrm{E}$ & $E$ & $E$ & $E$ & $E$ & $E$ & $E$ & $E$ \\
\hline D. ramosum & $E$ & I & 1 & 1 & 1 & 1 & 1 & 1 & I & I \\
\hline \multicolumn{11}{|c|}{ Oreothamnus species } \\
\hline O. kirkii & $\mathrm{a}$ & $\mathrm{a}$ & $\mathrm{H}$ & $\mathrm{H}$ & $\mathrm{H}$ & $\mathrm{H}$ & $\mathrm{H}$ & $\mathrm{H}$ & $\mathrm{H}$ & $\mathrm{H}$ \\
\hline O. ophioliticus & a & $A$ & G & $\mathrm{H}$ & $\mathrm{H}$ & $\mathrm{H}$ & $\mathrm{H}$ & $\mathrm{H}$ & $\mathrm{H}$ & $\mathrm{H}$ \\
\hline O. oliveri & a & $\mathrm{C}$ & $A$ & $A$ & $A$ & $A$ & $A$ & $A$ & $A$ & $A$ \\
\hline O. cockayneanus & a & $\mathrm{C}$ & $\mathrm{D}$ & $\mathrm{D}$ & $\mathrm{D}$ & $\mathrm{D}$ & $\mathrm{D}$ & $\mathrm{D}$ & $\mathrm{D}$ & $\mathrm{D}$ \\
\hline O. subulatus & a & C & 1 & $\mathrm{C}$ & a & & & & & \\
\hline O. recurvus & a & C & 1 & C & 1 & C & 1 & $\mathrm{C}$ & I & C \\
\hline O. lessonianus + O. urvilleanus & a & $\mathrm{C}$ & 1 & 1 & 1 & 1 & 1 & 1 & I & I \\
\hline O. marmoricola & a & C & 1 & 1 & 1 & C & $a$ & & & \\
\hline O. pronus & a & $\mathrm{C}$ & $\mathrm{J}$ & $\mathrm{J}$ & $\mathrm{J}$ & C & a & & & \\
\hline O. longifolius & $a$ & C & $\mathrm{K}$ & $\mathrm{C}$ & $\mathrm{K}$ & C & $\mathrm{K}$ & $\mathrm{C}$ & $\mathrm{K}$ & C \\
\hline O. rosmarinifolius & a & $\mathrm{C}$ & $\mathrm{K}$ & $\mathrm{K}$ & $\mathrm{K}$ & $\mathrm{C}$ & a & & & \\
\hline O. sinclairii & a & $E$ & a & $\mathrm{D}$ & a & $\mathrm{D}$ & $\mathrm{E}$ & $\mathrm{D}$ & $\mathrm{E}$ & $\mathrm{D}$ \\
\hline O. trimorphus & a & G & $\mathrm{H}$ & a & $\mathrm{H}$ & a & a & $\mathrm{H}$ & a & a \\
\hline O. septentrionalis & $a$ & I & 1 & 1 & 1 & a & & & & \\
\hline O. filifolius + O. pubescens & a & 1 & 1 & 1 & 1 & 1 & 1 & 1 & I & I \\
\hline O. acerosus & a & $\mathrm{K}$ & $\mathrm{K}$ & $\mathrm{K}$ & $\mathrm{K}$ & $\mathrm{K}$ & a & & & \\
\hline O. arboreus & a & $\mathrm{K}$ & $\mathrm{K}$ & $\mathrm{K}$ & $\mathrm{K}$ & $\mathrm{K}$ & $\mathrm{K}$ & $\mathrm{K}$ & $\mathrm{K}$ & $\mathrm{K}$ \\
\hline O. minimus + O. muscoides + O. politus $+O \cdot$ prostratus & C & $\mathrm{C}$ & $\mathrm{C}$ & & & & & & & \\
\hline O. patens & $\mathrm{C}$ & $\mathrm{D}$ & $\mathrm{D}$ & $\mathrm{D}$ & $\mathrm{D}$ & $\mathrm{D}$ & $\mathrm{D}$ & $\mathrm{D}$ & $\mathrm{D}$ & $\mathrm{D}$ \\
\hline O. frondosus + O. palustris + O. scoparius & C & $\mathrm{K}$ & $\mathrm{C}$ & & & & & & & \\
\hline O. pearsonii & $\mathrm{C}$ & $\mathrm{K}$ & $\mathrm{C}$ & $\mathrm{K}$ & $C$ & $\mathrm{~K}$ & C & & & \\
\hline O. densus & $M$ & $\mathrm{~L}$ & $M$ & & & & & & & \\
\hline
\end{tabular}




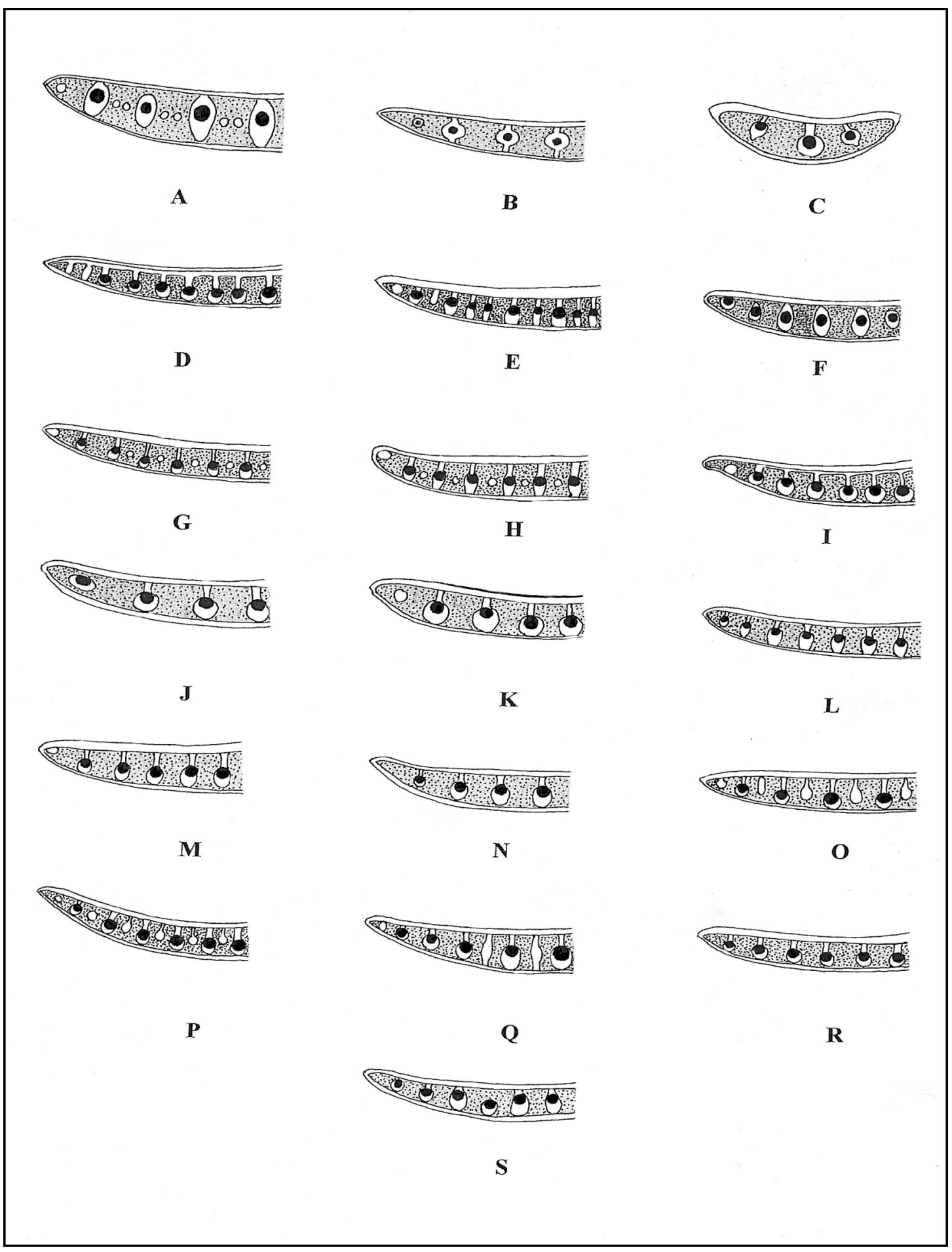

Figure 5.2. Transverse sections through the adult lamina of Dracophyllum species ( $\mathrm{n}=25$ for each species). A, D. alticola; $\mathbf{B}, D$. balansae; C, D. cosmelioides; D, D. fitrgeraldii; $\mathbf{E}, D$. elegantissimum; $\mathbf{F}, D$. involucratum; $\mathbf{G}, D$. latifolium; $\mathbf{H}, D$. menziesii; $\mathbf{I}, D$. milliganii; $\mathbf{J}, D$. oceanicum; $\mathbf{K}, D$. ouaiemense; $\mathbf{L}, D$. ramosum; $\mathbf{M}, D$. sayeri; $\mathbf{N}, D$. secundum; $\mathbf{O}, D$. strictum; $\mathbf{P}$, D. townsonii; $\mathbf{Q}, D$. traversii; $\mathbf{R}, D$. mackeeanum and $\mathbf{S}, D$. verticillatum. (Magnification $\times 40$ ). 


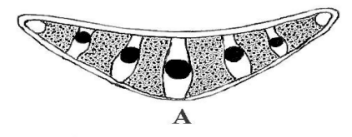

are 900

D
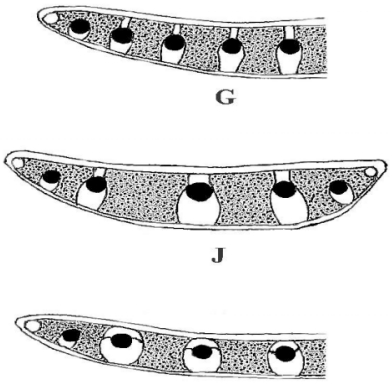

M
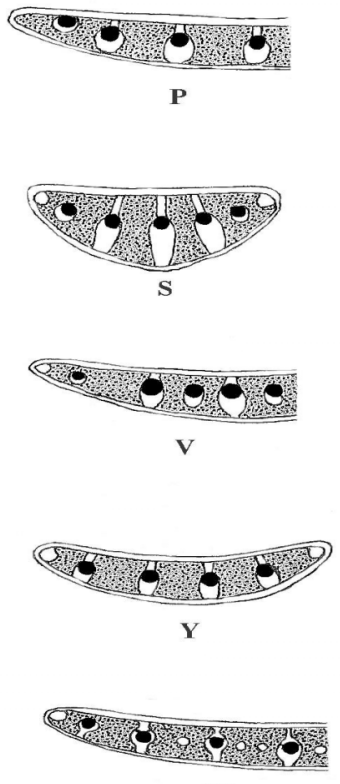

AB
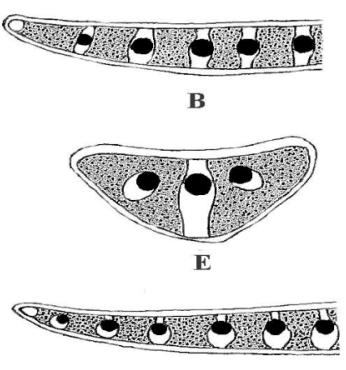

$\mathbf{H}$
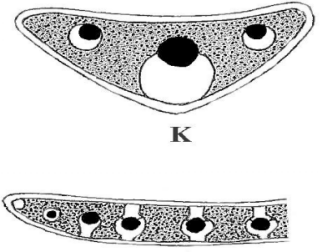

N
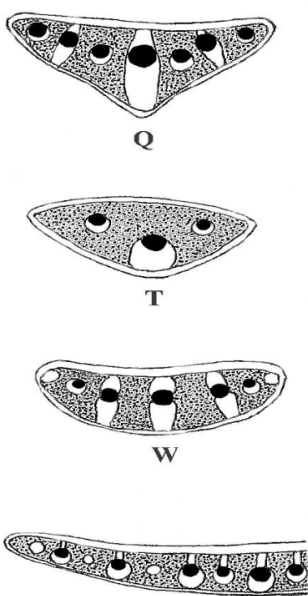

Z

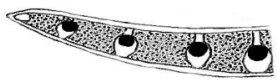

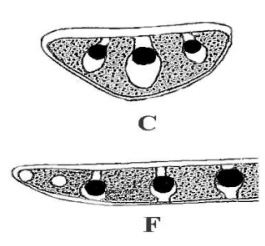

(10)

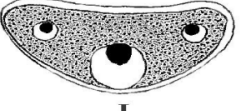

L
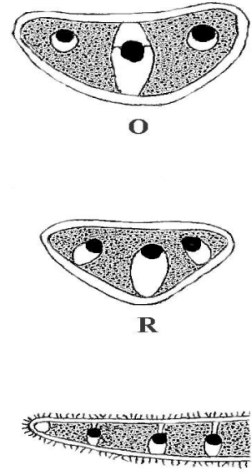

$\mathbf{U}$
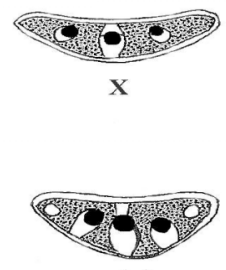

Figure 5.3. Transverse sections through the adult lamina of Oreothamnus species ( $\mathrm{n}=25$ for each species). A, O. acerosus; $\mathbf{B}$, O. arboreus; $\mathbf{C}$, O. densus; $\mathbf{D}$, O. filifolius; $\mathbf{E}$, O. frondosus; $\mathbf{F}$, O. kirkii; $\mathbf{G}$, O. lessonianus; $\mathbf{H}$, O. cockayneanus; $\mathbf{I}$, O. longifolius; $\mathbf{J}$, O. marmoricola; $\mathbf{K}, O$. minimus; L, O. muscoides; $\mathbf{M}$, O. oliveri; $\mathbf{N}$, O. ophioliticus; $\mathbf{O}$, O. palustrus; $\mathbf{P}$, O. patens; $\mathbf{Q}, O$. pearsonï; $\mathbf{R}$, O. politus; $\mathbf{S}$, O. pronus; $\mathbf{T}$, O. prostratus; $\mathbf{U}$, O. pubescens; $\mathbf{V}$, O. recurvus; $\mathbf{W}, O$. rosmarinifolius; $\mathbf{X}$, O. scoparius; $\mathbf{Y}$, O. septentrionalis; $\mathbf{Z}$, O. sinclairii; $\mathbf{A A}$, O. subulatus; $\mathbf{A B}, O$. trimorphus and AC, O. urvilleanus. (Magnification $\times 40$ ). 
5.1). These code-strings showed that in Oreothamnus, there are four species groups with the same ALVP for species in the respective groups.

Group 1. O. lessonianus and O. urvilleanus.

Group 2. O. pubescens and O. filifolius.

Group 3. O. minimus, O. muscoides, O. politus and O. prostratus.

Group 4. O. frondosus, O. palustris and O. scoparius.

\subsection{Discussion}

I am in full agreement with Watson (1962) that the presence of stomata on the lamina can be a useful taxonomical tool to separate certain genera in the Styphelioideae (=Epacridaceae). Stomata are present only on the abaxial surface of the lamina in Dracophyllum whereas they are present on both surfaces in Oreothamnus.

The different arrangement patterns of the conspicuous groups of fibres associated with the veins of the Dracophyllum and Oreothamnus leaves is of limited taxonomic value and could not be used to confidently separate Richeeae from the Styphelieae, Epacrideae or the Cosmelieae.

The anatomical lamina vascular pattern (ALVP) is a new formula-based system developed during this study where the shape of the fibre bundle patterns was coded as code strings. These code strings are of taxonomic value in separating different species in Dracophyllum and Oreothamnus. There is the exception in Dracophyllum with D. ouaiemense and D. sayeri having the same pattern. Most of the species in Oreothamnus can be separated using the ALVP system and it shows that there are four distinct species groups in the genus. 


\section{Chapter 6: Synthesis}

In spite of knowing that a cladistic study based on morphological characters will result in recognition of high levels of homoplasy, I did see the value of such a study. The cladistic study was undertaken to assess the currently accepted genera in the tribe Richeeae (Kron et al. 2002) and to locate any well-supported clades. The analysis resulted in cladograms with moderately low consistency indices indicating the level of homoplasy being present in the morphological data set. The strict consensus tree (Fig. 2.1) resulted with the subgenus Oreothamnus and the genus Sphenotoma clades. The results of the phylogenetic hypothesis presented here give support (bootstrap 64\%, jackknife 68\% and Bremer support of 6) for a monophyletic Oreothamnus.

The genera Dracophyllum sens. strict. and Richea are polyphyletic. The subgenus Cordophyllum in Dracophyllum received recognition in either the phenetic or the cladistic study and therefore not recognized. Richea was split into two distinct clades (Fig. 2.1.) that correspond with the sections Cystanthe and Dracophylloides - an unexpected result.

A few sub clades in Dracophyllum were supported; the D. involucratum $+D$. verticillatum sub clade with $66 \%$ and the D. fitrgeraldii + D. milliganii sub clade with $51 \%$ bootstrap support. There was overall more resolution in Dracophyllum than in Oreothamnus. All other clades are supported by homoplastic synapomorphies (convergences plus subsequent reversals and convergences). The phylogenetic relationships in neither Dracophyllum nor Oreothamnus are resolved as is clearly shown in the cladogram (Fig. 2.1 \& Fig. 2.2) and I could not give a complete and robust phylogeny. To render Dracophyllum monophyletic it is suggested that Richea be included into Dracophyllum (Fig. 2.1.). However, from the results of the cladistic study I have decided to give subgenus Oreothamnus generic status and this necessitated giving a new circumscription of genus Dracophyllum. 
In some cases an intuitive approach was adopted with the reduction of Dracophyllum pyramidale into D. traversii, D. matthewsii into D. latifolium, Oreothamnus viride and O. adamsii into $O$. sinclairii and D. uniflorum into O. rosmarinifolius. Some infrageneric taxa were raised to species level: O. cockayneanus ( $=D$. longifolium var. cockayneanum), O. septentrionalis $(=D$. longifolium var. septentrionale) and $O$. frondosus ( $=D$. uniflorum var. frondosum).

At this stage no recognition is given to any formal division of the genera and it must await DNA sequencing studies of all species in the ingroup, outgroup and related genera.

During the course of this study two new Dracophyllum species (D. elegantissimum and D. mackeeanum) and Oreothamnus species (O. marmoricola and O. ophioliticus) were described.

The genus Oreothamnus has a New Zealand origin and probably evolved from a montane or subalpine ancestor during the uplift of the Southern Alps during the Pliocene and was accompanied by cooler climates. Radiation took place in Oreothamnus especially during the uplift and thereafter of the major mountain ranges in New Zealand during the Pleistocene with glaciation and erosion that created a large variety of habitats. Oreothamnus possibly dispersed from the South Island to the Chatham Islands and from thereon southwards to the Auckland and Campbell Island groups. O. scoparius most likely developed on the Chatham Islands and, later during the Holocene $( \pm 8000 \mathrm{BP})$ (Wardle 1987), dispersed south to the Campbell Island group $\pm 1700 \mathrm{~km}$ to the south. A possible single dispersal from New Zealand to Tasmania followed with O. minimus. All species are endemic to the countries where they occur. Oreothammus filifolius and O. rosmarinifolius are shared between the North and South Islands of New Zealand. Both these distributions indicate later dispersals. 
In this thesis the rank of species is given to taxa if they differ by two or more putatively fixed independent qualitative differences and if there is convincing evidence that they represent independent lineages with preferably no genetic contact (Hedberg 1958; Gravendeel 2000, Garnock-Jones \& Lloyd 2004). Many characters used in the past to determine species in Dracophyllum were very variable (e.g., shape of the lamina sheath and lamina size). Many ecotypes were also described as separate species. The only way to define clear species limits is to make use of characters showing minimal or no variation.

A much wider view of $O$. rosmarinifolius was taken in this study to include all the different forms and ecotypes (Fig. 4.3) and this necessitated the inclusion of D. uniflorum into $O$. rosmarinifolius.

Four species of Dracophyllum and seven Oreothamnus have ecotypes. To describe them as varieties will tell us little about variation in the species and it will be difficult to define the se varieties. In describing variation it is very difficult to define the cut-off point between the varieties making it difficult to name a specimen. It is for this reason that I refrained from describing varieties in Dracophyllum and Oreothamnus and rather gave a full description of variation in the different species.

Oliver $(1928,1952)$ was the only person that attempted to arrange the subgenera of Dracophyllum into species groups. The high level of homoplasy and the subsequent weakly resolved phylogeny makes it difficult to place all the species into robust species groups. At this stage grouping of species can only be intuitive, but I strongly suggest leaving the final species grouping till after DNA sequencing has been done for all the species in the ingroup. 
The presence of stomata proved to be of taxonomic value with Oreothamnus the only genus in the ingroup with stomata on both lamina surfaces. Simon (1891) and Watson (1967) described four arrangement patterns of the groups of fibres with the veins (Styphelia, Epacris, Cosmelia and Richea patterns). Till recently (Kron et al. 2002) the subgenera of Dracophyllum were included in the Richea pattern. The results from my study are markedly different from those of Simon (1891) and Watson (1967) in that all four fibre arrangement patterns occur in Dracophyllum and Oreothamnus rendering their four patterns of limited taxonomic value. The anatomical lamina vascular pattern (ALVP) is a new formula-based system developed during this study where the shape of the fibre bundle patterns was coded as code strings. These code strings are of taxonomic value in separating different species in Dracophyllum and Oreothamnus.

The next step in research on the phylogenetic relationships and evolution within Dracophyllum, Oreothamnus and Richea is to be based on additional morphological data and molecular studies preferably DNA sequences for the genes matK and $r b c \mathrm{~L}$. 


\section{Chapter 7: Taxonomic monograph}

\subsection{Identification keys and species descriptions}

\subsubsection{Key to the genera}

Inflorescence a panicle with coloured and deciduous inflorescence bracts; flower bracts absent; bracteoles present; lamina sheath poorly developed; testa prominently pitted Dracophyllum

Inflorescence a solitary flower, spike or raceme with persistent non coloured inflorescence bracts; flower bracts present; bracteoles absent; lamina sheath well-developed; testa smooth Oreothamnus

\subsection{Dracopbyllum Labill.}

Dracopbyllum Labill., Rel. Voy. Rech. la Pérouse 2: 210-211 (1800). Type species Dracophyllum verticillatum Labill.

Brown, Prodr. Fl. Nov. Holl: 555-556 (1810); De Candolle, Prodr. Syst. Nat.: 769 (1839); Endlicher, Gen. Plant.: 750 (1839); Hooker, Fl. Ant. 1: 45 (1844); Hooker, Fl. Nov. Zel. 2: 167 (1853); Hooker, Fl. Tasm. 3: 367 (1860); Hooker, Handb. N.Z. Fl: 180 (1864); Bentham, Fl. Austr. 4: 261 (1869); Hooker, Gen. Plant. 2 (2): 618 (1876); Rodway, Tasm. Fl.: 126 (1903); Cheeseman, Man. N.Z. Fl.: 418 (1906); Allan, Fl. N.Z. 1: 521 (1961); Virot, Fl. Nouv. Caléd. et Depend. 6: 106 (1975); Green, Fl. Austr. 49 (1): 145-146 (1994).

= Subgenus Dracophyllum Hooker, Gen. Plant. 2 (2): 618 (1876). (As Eudracophyllum). Type species: Dracophyllum verticillatum Labill., designated by Virot (1975). 
= Subgenus Cordophyllum W.R.B. Oliv., Trans. N.Z. Inst. 59: 714 (1928). Type species: Dracophyllum involucratum Brongn. \& Gris

Trees, shrubs or sub-shrubs up to $14 \mathrm{~m}$ tall. Leaves crowded at the ends of or spirally arranged along branches; base of lamina sheathing and leaving ringed scars on branches when falling away forming a sheath; with tapering shoulders, smooth to ciliate; lamina coriaceous to rigid and hard, linear-triangular to triangular, $15-1000 \times 0.5-50.0 \mathrm{~mm}$, surfaces glabrous, rugose, scabrid, pubescent to tomentose sometimes with a tuft of hairs at the base on adaxial surface, sometimes striated; lamina margin entire, serrate, serrulate or thickly covered in hairs, sometimes cartilaginous; lamina apex thickened, obtuse, lobed, acicular, triquetrous to acuminate. Juvenile leaves present in D. strictum only. Inflorescence a terminal or lateral panicle; flowers opening acropetally, rarely basipetally (D. macranthum), 10-460 mm long, linear-oblong to pyramidal in outline; inflorescence bracts caducous, longer than flowers and overtopping, light green to red, subulate to ovatetriangular, $4.5-67.0 \times 1.5-45.0 \mathrm{~mm}$, surfaces glabrous to sericeous, entire, serrulate to ciliate, apex obtuse to mucronate. Flowers 5-5000+ per inflorescence, pedicellate. Bracteoles persistent or caducous, shorter or longer than flower, linear to triangular, $0.5-$ $8.0 \times 0.1-1.7 \mathrm{~mm}$, glabrous to pubescent; pedicels straight to curved, $0.2-20.0 \mathrm{~mm}$ long, glabrous to tomentose. Calyx 5-lobed, persistent, polysepalous; sepals green to red, lanceolate to broadly ovate, $0.7-17.0 \times 0.8-2.5 \mathrm{~mm}$, shorter to longer than the corolla tube, surfaces glabrous to pubescent, sometimes with the top half pubescent or with scabrid hairs at base; margin smooth, upper half toothed or ciliate; apex obtuse to acuminate. Corolla white or yellowish or light pink to dark red; corolla tube cylindrical, slightly urceolate to broadly campanulate, mouth of tube narrowed to widened, 1.0-22.0 $\times$ 0.8-5.0 mm, exterior surface glabrous to pubescent; corolla lobes 5 , free, imbricate in bud, spreading to strongly recurved, broadly lanceolate to triangular, white to dark red, 
shorter to longer than corolla tube, $0.8-5.0 \times 0.8-4.0 \mathrm{~mm}$, sometimes with the margin inflexed, apex acute to obtuse, adaxial surface glabrous or papillate to slightly rugoseverrucate, abaxial surface glabrous or pubescent. Stamens 5, hypogynous or adnate to the corolla tube; filaments $0.3-20.0 \mathrm{~mm}$ long; anthers included or exserted, dorsifixed, oblong to rectangular in outline, light yellow to purple, $0.4-3.0 \mathrm{~mm}$ long. Ovary 5locular with pendulous placentae; cylindrical to oblong, $0.5-4.5 \times 0.5-3.0 \mathrm{~mm}$, apex tapering to truncate, glabrous to pubescent; nectary scales 5 , free, rarely fused to form a ring (D. verticillatum), rectangular to round, $0.2-2.0 \times 0.3-2.0 \mathrm{~mm}$, apex acute to obtuse, bifid to variously toothed; style inserted in a depression at the apex of the ovary, 0.5-19.0 $\mathrm{mm}$ long, glabrous, papillose distally or pubescent, sometimes lengthening in fruit; stigma included or exserted, obscurely to prominently 5-lobed. Fruit a dry capsule, loculicidely 5-valved, mostly included in persistent sepals, pedicellate, light brown to purplish brown, 1-5 mm long and wide, depressed-globose to oblong, apex pointed to truncate, glabrous or pubescent. Seeds many, filiform to trigonous, $0.2-1.3 \mathrm{~mm}$ long, testa variously reticulate, cells pitted. Chromosome number $n=13$.

Species 20; restricted to the western Pacific, extending from Australia, Lord Howe Island, New Caledonia, New Zealand and its off-shore islands (Figure 3.1). 


\subsubsection{Key to the genus Dracopbyllum}

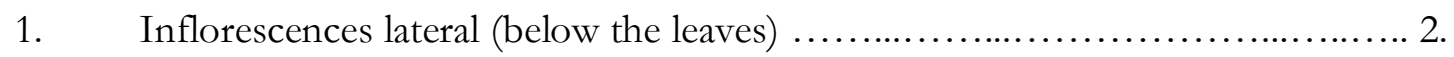

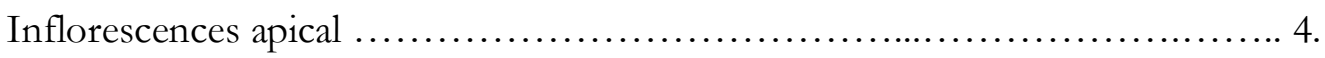

2. Pedicel glabrous; stamens hypogynous; fruit not enclosed in persistent sepals; lamina $40-50 \mathrm{~mm}$ wide D. fiordense

Pedicel pubescent to tomentose; stamens epipetalous; fruit enclosed in persistent sepals; lamina 4-18 $\mathrm{mm}$ wide 3.

3. Plants erect-stemmed and sparingly branched; flowers arranged in groups of 3 on the lower inflorescence branches; stamens and style included

D. menziesii

Plants with branches forming an open candelabrum; flowers arranged in groups of 5-10 on lower inflorescence branches; stamens and style exserted

D. townsonii

4. Flower maturation basipetal; style $14 \mathrm{~mm}$ or longer

D. macrantbum

Flower maturation acropetal; style shorter than $5 \mathrm{~mm}$ 5.

5. Branchlets glabrous 9.

Branchlets pubescent or tomentose 6. 
6. Inflorescence axis prominently ribbed; stamens inserted in the lower half of the corolla tube

D. mackeeanum

Inflorescence axis smooth; stamens either inserted in the upper third of the

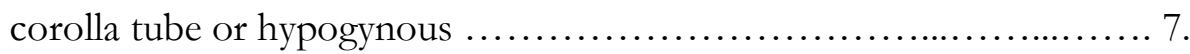

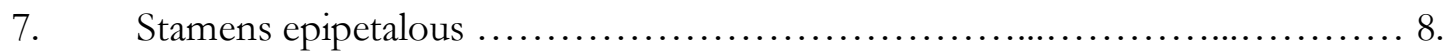

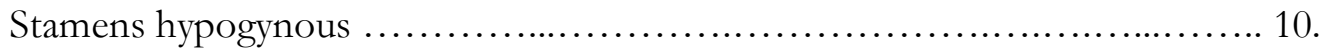

8. Lamina $2-5 \mathrm{~mm}$ wide; sepals longer than the corolla tube; flowers in groups of three on lower inflorescence branches ............ D. balansae

Lamina 5-8 $\mathrm{mm}$ wide; sepals shorter than the corolla tube; flowers in groups of 5-10 on lower inflorescence branches

D. strictum

9. Lamina margin smooth; leaves below inflorescence imbricating; corolla 9-17 mm long; outer surface of corolla tube densely pubescent D. alticola Lamina margin serrulate; leaves below inflorescence not imbricating; corolla (2-) 4-6 mm long; outer surface of corolla tube glabrous .... D. cosmelioides

10. Inflorescence axis prominently ribbed 11. Inflorescence axis smooth 12.

11. Pedicel covered in dense overlapping bracts D. involucratum Pedicel without bracts D. milliganii 
12. Flowers arranged in groups of 3 on the lower inflorescence branches

D. ouaiemense

Flowers arranged in groups of 5 or more on the lower inflorescence

branches

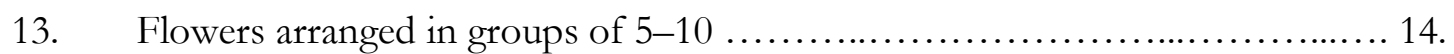

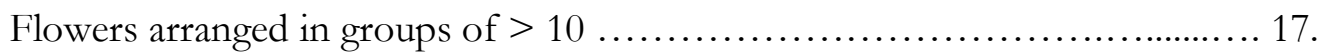

14. Flowers borne in clusters (verticils) at close intervals

D. verticillatum

Flowers not in clusters (verticils) .................................... 15.

15. Stamens hypogynous, $>3.7 \mathrm{~mm}$ long; inflorescence rachis glabrous

D. secundum

Stamens epipetalous, $\leq 1.75 \mathrm{~mm}$ long; inflorescence rachis pubescent to

tomentose 16.

16. Stamens exserted; leaves below inflorescence not different from the other leaves; corolla lobes longer than the corolla tube; corolla campanulate D. latifolium

Stamens included; leaves below inflorescence different from sterile leaves; corolla lobes shorter than the corolla tube; corolla tube narrowed at mouth D. ramosum 
17. Flowers cylindrical; abaxial surface of inflorescence bract scabrid; apex

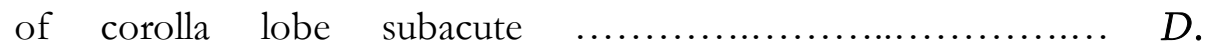

\section{fitrgeraldii}

Flowers narrowly to broadly campanulate; abaxial surface of

inflorescence bract glabrous; apex of corolla tube obtuse

18.

18. Lamina margin entire; bracteoles equalling flower in length; nectary

scales connate at base

D. sayeri

Lamina margin serrulate; bracteoles shorter than flower; nectary scales

separate

19.

19. Corolla tube 4-7 $\mathrm{mm}$ long; inflorescence bract 10-65 $\mathrm{mm}$ long;

pedicel glabrous

D. oceanicum

Corolla tube shorter than $3.5 \mathrm{~mm}$; inflorescence bract 129-615 mm

long; pedicel pubescent to tomentose

20. Corolla lobe shorter than corolla tube; margin of inflorescence bract

entire; sepal shorter than corolla tube; apex of ovary tapering

D. elegantissimum

Corolla lobe longer than corolla tube; margin of inflorescence bract

ciliate; sepal equalling corolla tube; apex of ovary round ...... D. traversii 


\section{Dracophyllum alticola Däniker}

Dracophyllum alticola Däniker, Viert. Nat. Ges. Zürich. 78 (19): 339 - as alticolum (1933). Oliver, Trans. Roy. Soc. N.Z. 80 (1): 15 - as alticolum (1952); Virot, Fl. Nouv. Caléd. et Dépend. 6: 125 (1975). Type: New Caledonia, Mt. Humboldt, 5.xi.1924. A.U. Däniker D509 (Z, lecto.!), designated by Oliver (1952). Mt. Humboldt. A.U. Däniker 509a (Z, lectopara.!), designated by Virot (1975).

Icones: Oliver, Trans. Roy. Soc. N.Z. 80 (1): t. 5 (1952); Virot, Fl. Nouv. Caléd. et Dépend. 6: t. 18 (1975).

\section{Description}

Multi-stemmed shrub, 0.2-1.0 m tall. Branches: Bark on old branches grey, smooth, on young stems pubescent and yellowish brown. Leaves crowded at tips of branches, spreading, light green to grey, sometimes reddish at base, decreasing in size below inflorescence; lamina sheath 10-15 × 10-11 mm, coriaceous, striate, tapering, and margin smooth; lamina triangular, 30-100 × 10-30 mm, slightly concave, surfaces glabrous, prominently striated; margin entire; apex thickened, lobed. Inflorescence a panicle subtended by $5-9$ short, imbricating leaves; overtopping the leaves, erect, lax, 80-250 mm long, sparsely branched; rachis and pedicels densely white pubescent to tomentose; inflorescence axis 3-5 $\mathrm{mm}$ in diameter; basal inflorescence branch 1-5 $\mathrm{mm}$ long, suberect; inflorescence bracts overtopping flowers, subcoriaceous, light green with the tips pink, ovate-triangular, $12-30 \times 9-10 \mathrm{~mm}$, surfaces glabrous, striate, margins entire. Flowers 45-50, in groups of three at base of inflorescence, pedicellate; bracteoles caducous, recaulescent, with one bracteole situated just below the perianth and the other 
in the middle of the pedicel, shorter than flower, $3-5 \times 0.2-0.3 \mathrm{~mm}$, pubescent, straight and reddish brown; pedicels reddish brown, (2-)5-20 $\mathrm{mm}$ long, pubescent. Sepals lanceolate to ovate-lanceolate, $9-17 \times 2.5-3.5 \mathrm{~mm}$, longer than the corolla tube, striate, adaxial surfaces glabrous, abaxial surfaces pubescent; margins toothed. Corolla light to dark pink; corolla tube cylindrical, narrowed at mouth, (7-)9-17 $\times 2.0-3.5 \mathrm{~mm}$, exterior pubescent; corolla lobes spreading, ovate-triangular, shorter than corolla tube, (3-)4-5 $\times$ (1.5-)2.0-4.0 mm, apices subacute; adaxial surface papillate, abaxial surface pubescent. Stamens Hypogynous, filaments 5.0-6.5 mm long; anthers included, oblong, purple, and $1.0-1.3 \mathrm{~mm}$ long. Ovary ovoid, (1.5-)2-4 $\mathrm{mm} \times(1.5-) 2-3 \mathrm{~mm}$, densely pubescent, apex truncate; nectary scales rectangular, $0.5-0.8 \times 0.5-1.0 \mathrm{~mm}$, apex obtuse to irregularly toothed; style included, 3-4 mm long, pubescent; stigma capitate. Fruit 3-4 mm long and wide, broadly obovoid, apex round, variously pubescent. Seeds ovoid, 0.5-0.6 mm long, testa slightly reticulate. Flowering September-November (-May). (Figure 7.1).

\section{Diagnostic features and discussion}

Dracopbyllum alticola is a diagnostic species characterized by its low $(20-100 \mathrm{~cm}$ tall) shrubby habit; light green to grey triangular and striated leaves with prominently lobed apices, 5-10 imbricating bract-like leaves below the inflorescence; large pink flowers (9$17 \mathrm{~mm}$ long) with sepals longer than the corolla tube and their abaxial surfaces densely pubescent, corolla tube pubescent on the outside, pedicels 5-20 $\mathrm{mm}$ long and pubescent, the ovary, style and fruit densely pubescent.

\section{Distribution}

A New Caledonia endemic restricted to the upper slopes of Mt. Humboldt and Massif de Kouakoue (Fig. 7.3). D. alticola appears to be uncommon and restricted in distribution. 


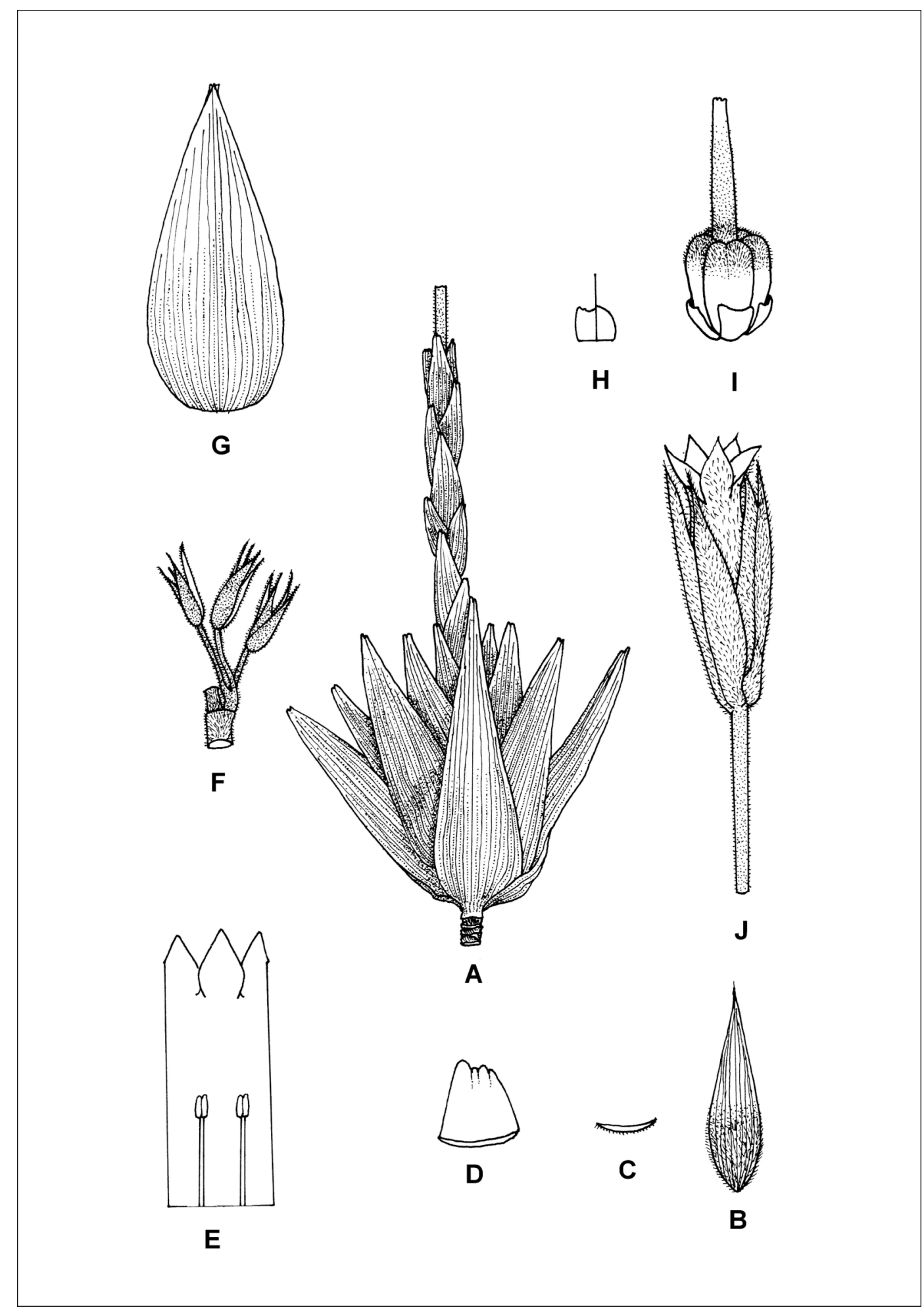

Figure 7.1. Dracophyllum alticola. A, flowering branch $(\times 1)$; $\mathbf{B}$, sepal abaxial surface $(\times 3)$; C, sepal - cross-section $(\times 3)$; $\mathbf{D}$, lamina apex $(\times 10)$; E, laid out flower $(\times 3) ; \mathbf{F}$, lower inflorescence branch $(\times 1.5)$; $\mathbf{G}$, lamina $(\times 3)$; $\mathbf{H}$, nectary scale $(\times 10)$; I, ovary $(\times$ 5); J, flower ( $\times 3)$; Drawn from Däniker 509 . 

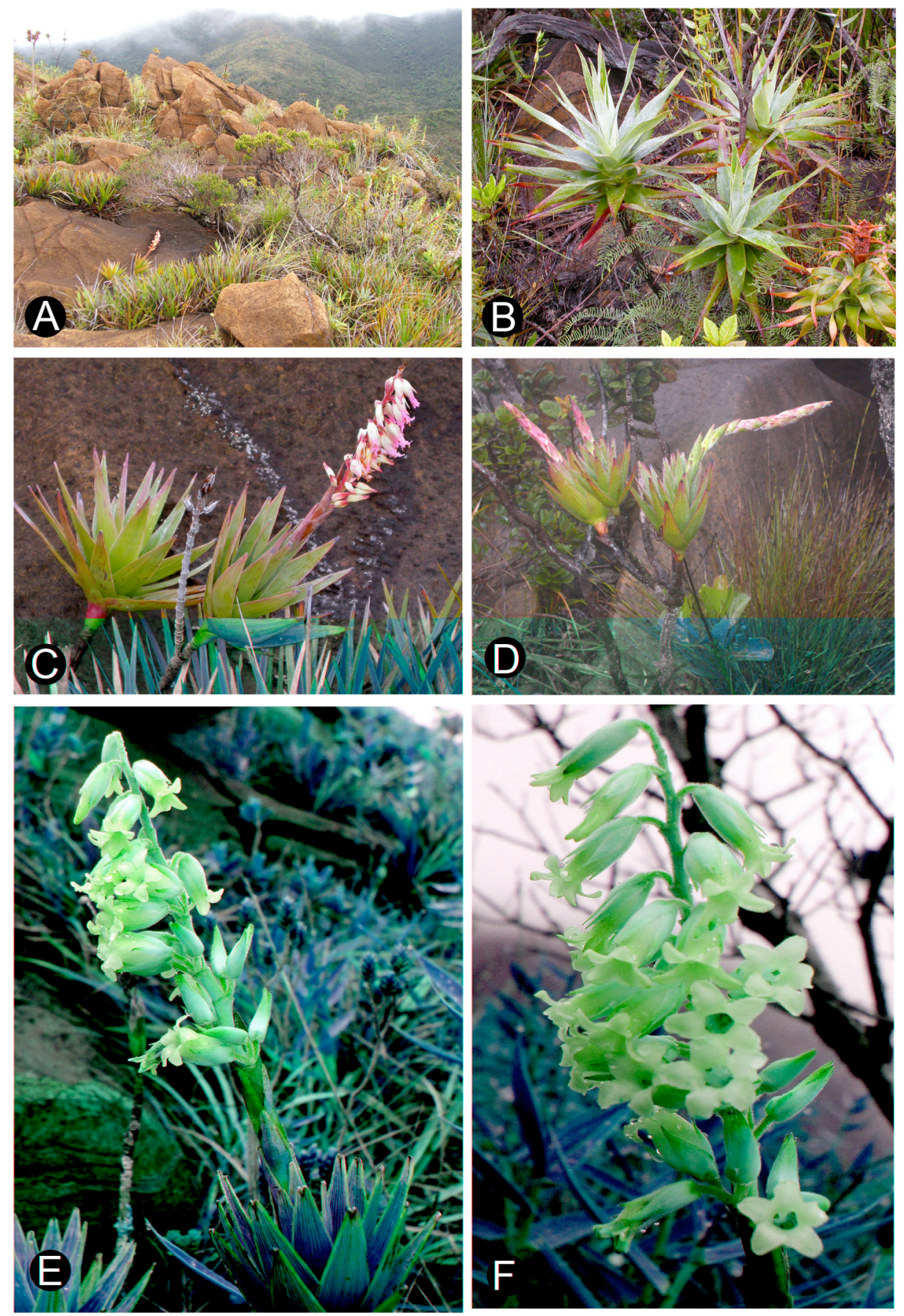

Figure 7.2. Dracopbyllum alticola. A, habitat on Mt. Humboldt; B, plant showing the leaf shape and silvery wax on the lamina surfaces; C, large-leaved plant with creamcoloured calyx; $\mathbf{D}$, young inflorescences showing the overlapping inflorescence bracts; $\mathbf{E}$, flowering plant with rigid green leaves $\mathbf{F}$, flowering plant at the type locality (Venter 13850). 


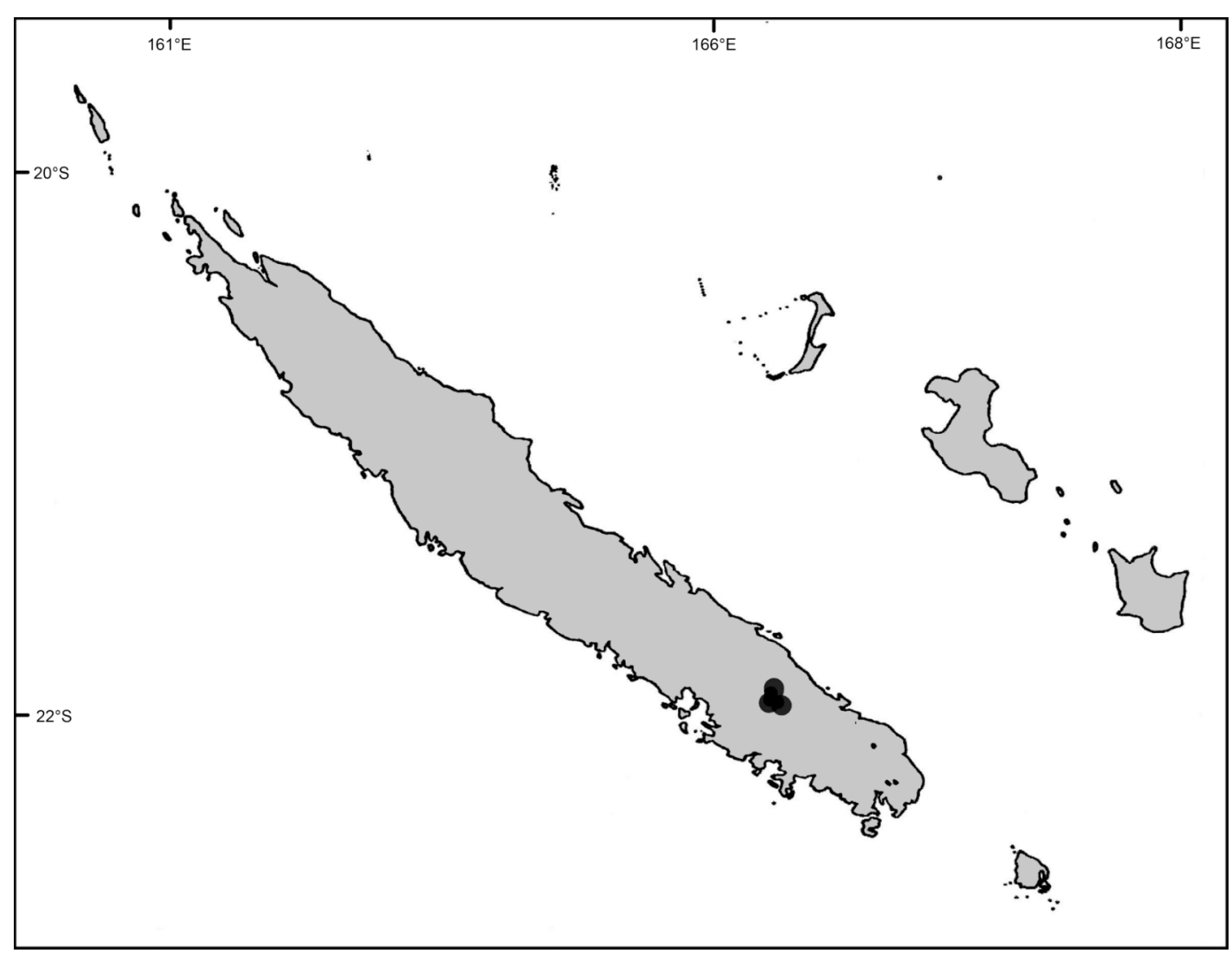

Figure 7.3. Known distribution of Dracophyllum alticola, New Caledonia.

\section{Habitat}

Dracophyllum alticola occurs on gentle $\left(5^{\circ}-20^{\circ}\right)$ southern and south-eastern mountain slopes at 1,000 - 1,634 $\mathrm{m}$ altitudes and is restricted to open maquis vegetation on ultrabasic substrate (Jaffré 1991). It sometimes grows in the forest margin but mostly in open grassy areas amongst low shrubs (Table 7.1). The soil is brown to reddish brown loam or clay loam derived from peridotite and serpentinite.

Table 7.1. Plant communities commonly associated with Dracophyllum alticola. 


\section{Variation}

D. alticola is a species that shows little variation. The young leaves are distantly pubescent but they soon lose this and become glabrous.

\section{Specimens examined}

NEW CALEDONIA. 21-166: Mt. Humboldt (-CD), 23.xi.1951. Baumann-Bodenheim 15505 (P, Z); ibid., 17.v.2005. Venter 13855 (CHR, NOU); ibid., 17.v.2005. Venter 13856 (NOU); ibid., 5.xi.1924. Däniker 509 (Z); ibid., Däniker 509A (Z); ibid., 13.x.1956. MacKee 5412 (L); ibid., 19.ix.1980. Hoff 2645 (NOU, P); ibid.,1.viii.1993. Cherry 344 (NSW); ibid., 18.ix.1980. McPherson 3098 (NOU); ibid., 26.iv.1973. Veillon 2849 (NOU); ibid., 17.v.2005. Venter 13855 (CHR, NOU); Massif de Kouakoue, vii.1955. Chevalier 11 (NOU).

\section{Dracophyllum balansae Virot}

Dracophyllum balansae Virot, Fl. Nouv. Caléd. et Dépend. 6: 138 (1975). Type: New Caledonia, Port-Bouquet. xi.1869. B. Balansa 2194 (P, holo.!; P!).

Icon: Virot, Fl. Nouv. Caléd. et Dépend. 6: t. 23 (1975).

\section{Description}

Multi-stemmed shrub, 0.6-1.0 m tall. Brancbes: Bark on old branches grey to dark brown, deeply fissured, on young stems pubescent and yellowish brown. Leaves erect to spreading; lamina sheath $6.7-7.0(-22) \times 3-5(-9) \mathrm{mm}$, subcoriaceous, tapering with the top half ciliate, and margin membranous; lamina coriaceous, linear, (30-)40-80(-180) $\times 2-3(-$ 6) $\mathrm{mm}$, flat, surfaces glabrous, sometimes with a tuft of scabrid hairs at base of adaxial 
surface, slightly striated; margin serrulate with 60-100 teeth per $10 \mathrm{~mm}$; apex rarely obtuse. Inflorescence slightly overtopping the leaves, erect, lax, 20-81 mm long, linearoblong and sparsely branched; rachis and pedicels mostly tomentose; inflorescence axis smooth, $1.0-1.5 \mathrm{~mm}$ in diameter; basal inflorescence branch $0.5-1.0 \mathrm{~mm}$ long, widely spreading; inflorescence bracts caducous, overtopping flowers, red, ovate-lanceolate to ovate, $8.0-16.4 \times 3.0-6.8 \mathrm{~mm}$, surfaces glabrous, margins ciliate. Flowers hidden by leaves, 25-50, in groups of three at base of inflorescence, pedicellate; bracteoles caducous, recaulescent, with one bracteole situated just below the perianth and the other in the middle of the pedicel, shorter than flower, $2-3 \times 0.2-0.25 \mathrm{~mm}$, glabrous to pubescent; pedicels $0.5-2.0(-3.0) \mathrm{mm}$ long, glabrous to pubescent. Sepals rose-coloured to red, lanceolate to triangular, $3.0-5.2 \times 1.0-1.7 \mathrm{~mm}$, equal to or longer than the corolla tube, striate, surfaces glabrous; margins ciliate. Corolla white tipped pink to red; corolla tube narrowly campanulate, $3-4 \times 0.8-1.0 \mathrm{~mm}$; corolla lobes spreading, ovate-triangular to triangular, shorter than corolla tube, 1.2-1.8 $\times 1.0-1.2 \mathrm{~mm}$, apices subacute to obtuse; adaxial surface papillate. Stamens inserted in upper third of corolla tube, filaments 0.3$0.32 \mathrm{~mm}$ long; anthers included, oblong, light yellow and $0.5 \mathrm{~mm}$ long. Ovary subglobose, 1.0-1.5 × 0.5-0.8 mm, glabrous, apex round; nectary scales oblong, $0.5-1.2 \times 0.4-0.5 \mathrm{~mm}$, apex retuse; style included, 0.7-1.5 mm long, glabrous; stigma capitate. Fruit reddish brown, 1.5-1.7 × 1.5-2.0 mm, obovoid, apex round and glabrous. Seeds yellowish brown, filiform, $0.2-0.3 \mathrm{~mm}$ long, testa slightly reticulate. Flowering May-December. (Figure 7.4). 


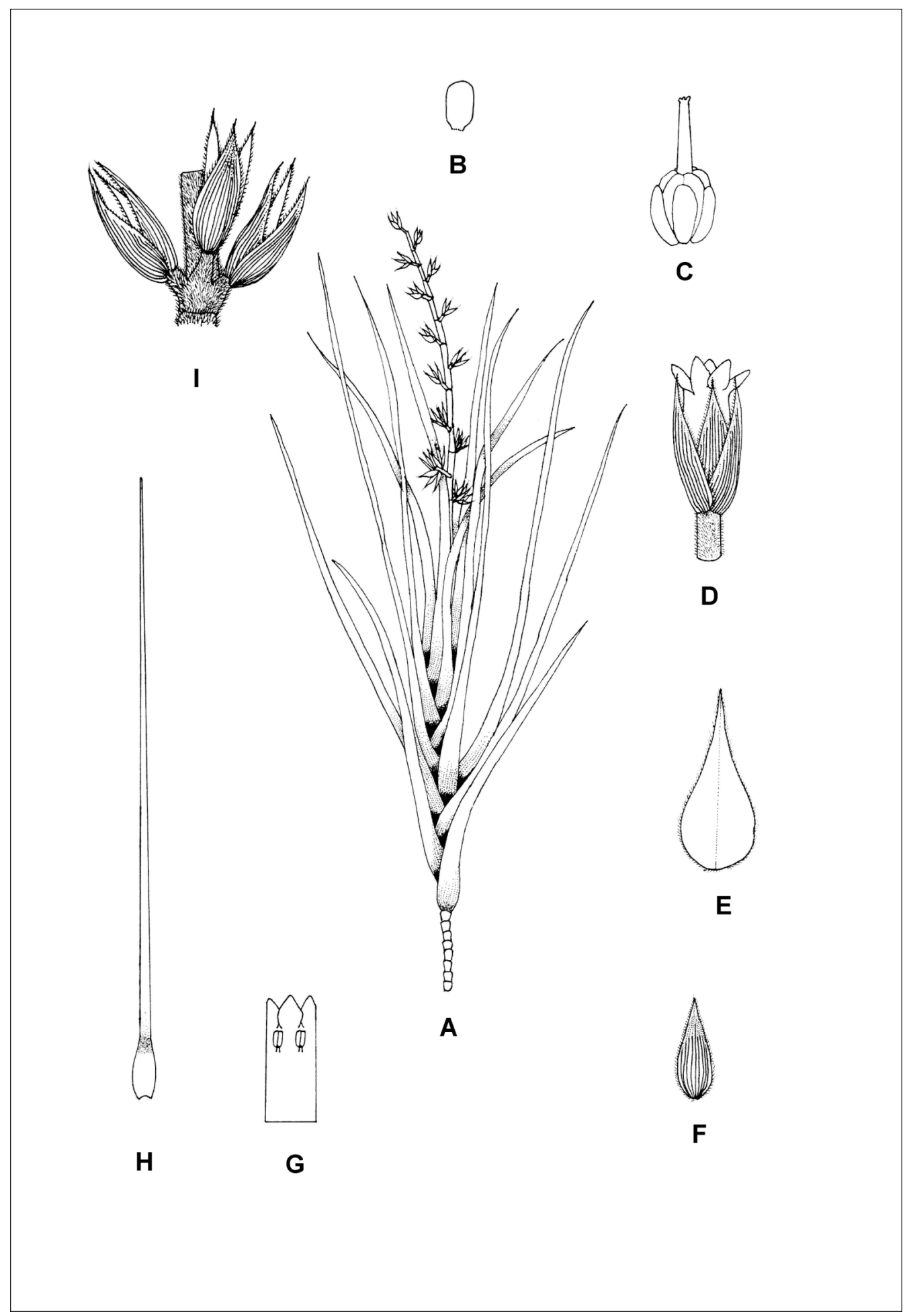

Figure 7.4. Dracopbyllum balansae. A, flowering branch $(\times 1)$; $\mathbf{B}$, nectary scale $(\times 10)$; $\mathbf{C}$, gynoecium $(\times 10) ; \mathbf{D}$, flower $(\times 6)$; $\mathbf{E}$, inflorescence bract abaxial surface $(\times 3) ; \mathbf{F}$, sepal abaxial surface $(\times 5) ; \mathbf{G}$, laid out flower $(\times 5) ; \mathbf{H}$, leaf $(\times 1)$; I, lower inflorescence branch (× 6). Drawn from MacKee 18158 . 

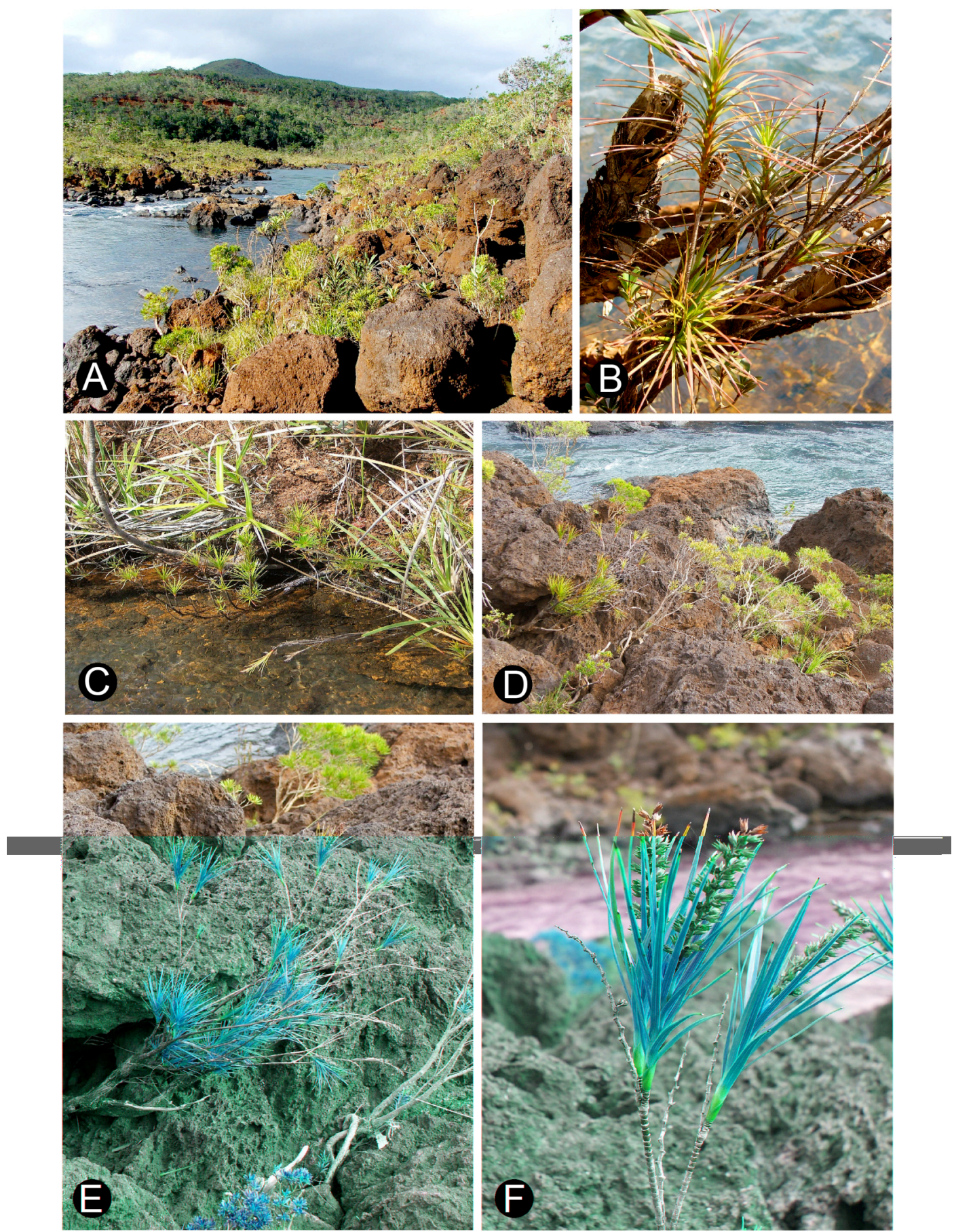

Figure 7.5. Dracopbyllum balansae. A, habitat along the Creek Pernod, B, plant with fruiting branches; $\mathbf{C}$, fruiting branch showing the spreading leaves; $\mathbf{D}$, adult plant growing in minimum soil between rocks in creek bed; E, adult plant (Venter 13845); F, branch showing the many-flowered inflorescence and the red leaf sheaths. 


\section{Diagnostic features and discussion}

Dracophyllum balansae is characterized by its shrubby habit $(0.6-1.0 \mathrm{~m}$ tall) with erect branches; erect narrow and long $(40-80 \times 2-3 \mathrm{~mm})$ leaves with the abaxial surfaces finely pubescent; inflorescence included in the foliage, flowers arranged in groups of three at the base of the inflorescence, short peduncles $(0.5-1.0 \mathrm{~mm})$, pedicels $0.5-2.0 \mathrm{~mm}$ long, calyx red with the white corolla tipped pink, corolla tube hypocrateriform and 4-5 mm long with spreading corolla lobes, stamens included and the capsule $1.5-2.0 \mathrm{~mm}$ in diameter.

Dracophyllum balansae is similar to $D$. cosmelioides in the long narrow leaves, the inflorescence being shorter than the leaves and the sepals longer than the corolla tube but differs in lamina, inflorescence and flower characters (Table 7.2).

Table 7.2. Differences between Dracophyllum balansae and D. cosmelioides.

\begin{tabular}{|l|l|l|}
\hline \multicolumn{1}{|c|}{ Character } & \multicolumn{1}{|c|}{ D. balansae } & \multicolumn{1}{c|}{ D. cosmelioides } \\
\hline Lamina width $(\mathrm{mm})$ & $2-3$ & $0.8-1.5$ \\
Inflorescence bract size $(\mathrm{mm})$ & $8.0-16.4 \times 3.0-6.8$ & $4.5-6.0 \times 1.5-2.0$ \\
Number of flowers/inflorescence & $25-50$ & $5-13$ \\
Corolla tube size $(\mathrm{mm})$ & $3-4 \times 0.8-1.0$ & $4-6 \times 1.0-1.5$ \\
Filament habit & epitepalous & hypogynous \\
Ovary length $(\mathrm{mm})$ & $1.0-1.5$ & $0.5-1.0$ \\
\hline
\end{tabular}

\section{Distribution}

New Caledonia endemic, restricted to the southern part of Grande Terre. Most known localities are east of Nouméa (Fig. 7.6). 


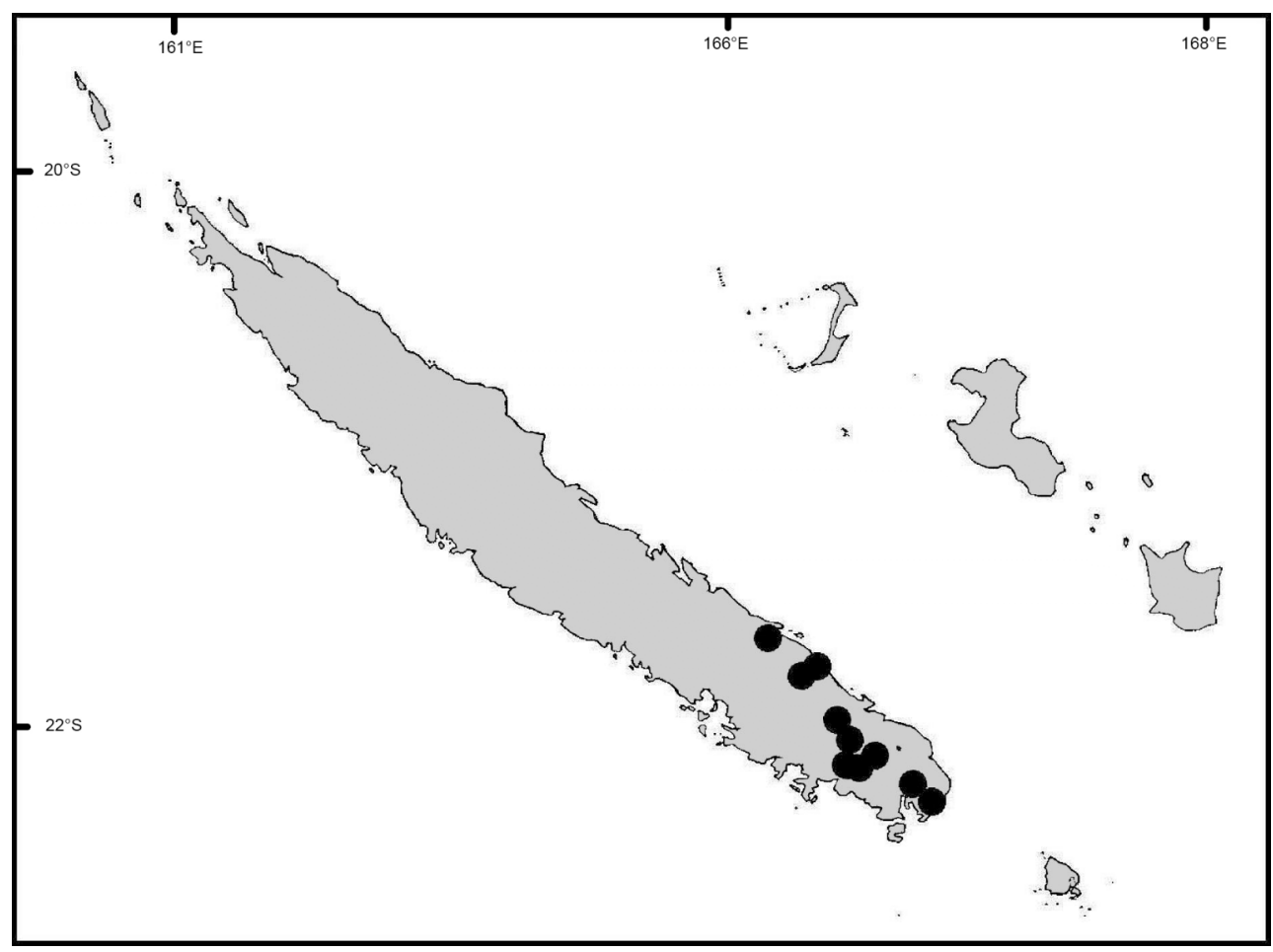

Figure 7.6. Known distribution of Dracophyllum balansae.

\section{Habitat}

Dracophyllum balansae occurs at altitudes of 50-700 $\mathrm{m}$ and grows along small streams and rivers, sometimes among rocks in streambeds. The vegetation consists of maquis (Table 7.3) growing on ferrous soils derived from serpentinite. Most plants of $D$. balansae grow in full sun but plants in shaded conditions have slightly larger, thinner, lighter green and more pubescent leaves.

Table 7.3. Plant communities commonly associated with Dracophyllum balansae.

\section{MAQUIS}

Low open evergreen Xanthostemon aurantiacus - Melaleuca brongniartii - Styphelia albicans maquis Tall open evergreen Melaleuca brongniartii - Styphelia albicans - Xyris pancheri maquis 


\section{Variation}

The lamina is glabrous but a patch of scabrid hairs is sometimes present at the base on the adaxial surface. Some variation occurs in the length $(20-81 \mathrm{~mm})$ and hairiness of the inflorescence axis, which is mostly glabrous, but can be shortly tomentose in some populations. The bracteole and pedicel can be either glabrous or pubescent. Sepals vary from lanceolate to triangular on a single plant.

\section{Specimens examined}

NEW CALEDONIA. 21-166: Hill at Ngoye (-DC), 27.xi.1902. Schlechter 15103 (L, P, W, Z); ibid., 1.vii.1965. Bernardi 9331 (L); Ouinné, 29.xi.1984. Jaffré 2668 (NOU). 22-166: Rivière Bleu (-BA), 1.vii.1965. Bernardi 9331 (L); ibid., 14.xi.1977. Schmid 3479 (NOU); Route to Yaté (-BB), 25.xii.1967. MacKee 18158 (K, L); North of Val des Pins, (-BD), 30.iii.1951. Guillamin \& Baumann-Bodenheim 11722 (Z); Bleue River, 07.xii.1966. Schmid 824 (NOU, P); ibid., 6.xi.1979. Hartley 14839 (NOU, L); Along the Bleue River, 5.viii.1951. Baumann-Bodenheim 15053 (Z); ibid. near pass, 21.v.1997. Musselman, Delzell \& Rich 5305 (BM); Creek Pernod at bridge, 12.v.2005. Venter 13845 (NOU); 4 km from Prony to Mt. Kouré, 14.v.2005. Venter 13848 (NOU); Creek Pernod, 4.xi.2003. Brown 2003/153, Crayn \& Quinn (CHR, NOU, NSW).

3. Dracophyllum cosmelioides Pancher ex W.R.B.Oliv.

Dracophyllum cosmelioides Pancher ex W.R.B. Oliv., Trans. Roy. Soc. N.Z. 80 (1): 15 (1952); Brongniart \& Gris, Ann. Sci. Nat. Bot. 2: 156 (1864a); Brongn. \& Gris, Ann. Sci. Nat. Bot. 3: 238 (1865b); Oliver, Trans. Proc. N.Z. Inst. 59: 708 (1928); Däniker, Viert. Nat. Ges. Zürich. 78 (19): 340 (1933); Virot, Fl. Nouv. Caléd. \& Dépend. 6: 143 (1975). Type: New 
Caledonia, Lac Arnaud, 1860. E. Vieillard 828 (P, lecto.!; isolecto.!), designated by Oliver (1952); New Caledonia. Plaine des Lacs. Deplanche 363 (P!); s. loc. Pancher 214 (P, para.!), designated by Virot (1975).

= Dracophyllum gracile Brongniart \& Gris, Ann. Sci. Nat. Bot. 2: 156 (1864a). nom. inval. (non R. Br.).

= Dracophyllum thiebautii Brongn. \& Gris, Ann. Sci. Nat. Bot. 3: 238 (1865b). Type:

New Caledonia, montagnes d'Arama, 1865. C. Thiebaut 339 (P, holo.!).

Icon: Virot, Fl. Nouv. Caléd. et Dépend. 6: t. 24 (1975). The nectary scales are incorrectly illustrated as being fused at the base.

\section{Description}

Single to multi-stemmed shrub $0.2-1.0 \mathrm{~m}$ tall. Branches. Bark on old branches grey to blackish brown, finely to deeply fissured, young stems tomentose to pubescent and dark brown. Leaves erect; lamina sheaths 4-8 $\times(1.5-) 2.5-3.6 \mathrm{~mm}$, membranous, tapering and margin ciliate; lamina linear, rarely linear-triangular, $15-70 \times 0.8-1.5 \mathrm{~mm}$, slightly concave, surfaces glabrous with a tuft of scabrid hairs at base of adaxial surface; slightly striated; margin serrulate with $50-70$ teeth per $10 \mathrm{~mm}$; apex obtuse, sometimes semiacute. Inflorescence overtopping the leaves, erect, lax, 10-50 $\mathrm{mm}$ long, oblong and sparsely branched; rachis and pedicels tomentose; inflorescence axis $0.5-1.0 \mathrm{~mm}$ in diameter; basal inflorescence branch $0.5-1.0 \mathrm{~mm}$ long, suberect; inflorescence bracts caducous, overtopping flowers, pink to red, ovate-lanceolate, $4.5-6.0 \times 1.5-2.0 \mathrm{~mm}$, adaxial surface pubescent at the apex, margins ciliate. Flowers hidden by leaves, 5-13, in groups of three at base of inflorescence, pedicellate; bracteoles caducous, recaulescent, with 
one bracteole situated just below the perianth and the other in the middle of the pedicel, shorter than flower, $2-3 \times 0.2 \mathrm{~mm}$, glabrous; pedicels straight to curved, reddish brown, 0.5-2.5 mm long, tomentose. Sepals rose-coloured to red, lanceolate to ovate, 2.5-4.0(8.0) $\times$ 1.5-2.0 mm, equaling corolla tube, striate, glabrous; margins ciliate. Corolla light pink to red; corolla tube narrowly campanulate, narrowed at mouth, (2-) $4-6 \times 1.0-1.5$ $\mathrm{mm}$; corolla lobes spreading, ovate-triangular, shorter than corolla tube, 0.8-1.0 mm long and wide, apices obtuse; glabrous. Stamens hypogynous, filaments $2.5-3.0 \mathrm{~mm}$ long; anthers included, oblong, light yellow and $0.40-0.45 \mathrm{~mm}$ long. Ovary subglobose, $0.5-1.0$ $\mathrm{mm}$ long and wide, glabrous, apex round; nectary scales rectangular, 0.5-0.7 $\times 0.3-0.5 \mathrm{~mm}$, apex retuse; style included, $0.5-0.7 \mathrm{~mm}$ long, glabrous; stigma clavate. Fruit pedicellate, reddish brown, 1.5-3.0 mm long and wide, broadly obovoid, apex round, glabrous. Seeds brown, filiform, $0.20-0.21 \mathrm{~mm}$ long, testa slightly reticulate. Flowering May-December. (Figure 7.7).

\section{Diagnostic features and discussion}

Dracophyllum cosmelioides is characterized by the low shrubby habit; linear leaves having blunt apices; inflorescence equal or slightly longer than the leaves, sepals and rachis shortly pubescent, sepals pink to red and striate equalling the corolla tube in length, corolla pink to red and the filaments hypogenous.

Oliver (1952) chose a new name for Dracophyllum gracile because Brown (1810) transferred Epacris gracilis to the genus Dracophyllum, but the name now belongs to the genus Sphenotoma. Oliver (1952) chose as the new name, the Pancher manuscript name $D$. cosmelioides. Virot (1975) placed D. cosmelioides close to D. alticola and D. ouaiemense based on the general morphology of the inflorescence however, D. cosmelioides is similar to 


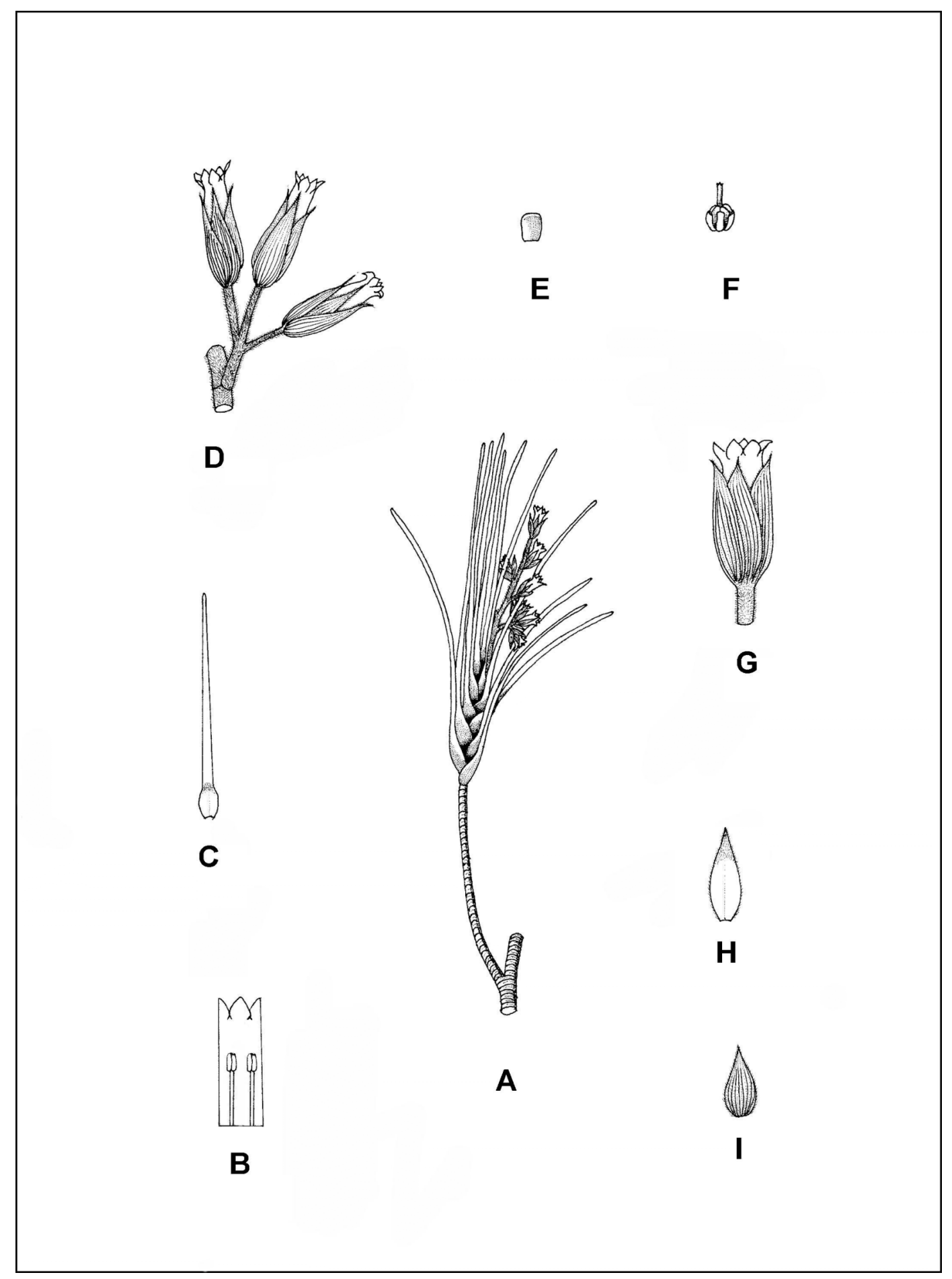

Figure 7.7. Dracophyllum cosmelioides. A, habit $(\times 1)$; B, laid out corolla $(\times 5)$; C, leaf $(\times 1)$; $\mathbf{D}$, flower arrangement on inflorescence $(\times 5)$; $\mathbf{E}$, nectary scale $(\times 20) ; \mathbf{F}$, gynoecium $(\times 10)$; $\mathbf{G}$, flower $(\times 5) ; \mathbf{H}$, inflorescence bract adaxial surface $(\times 3)$ and $\mathbf{I}$, sepal abaxial surface $(\times 5)$. Drawn from Vieillard 828 . 

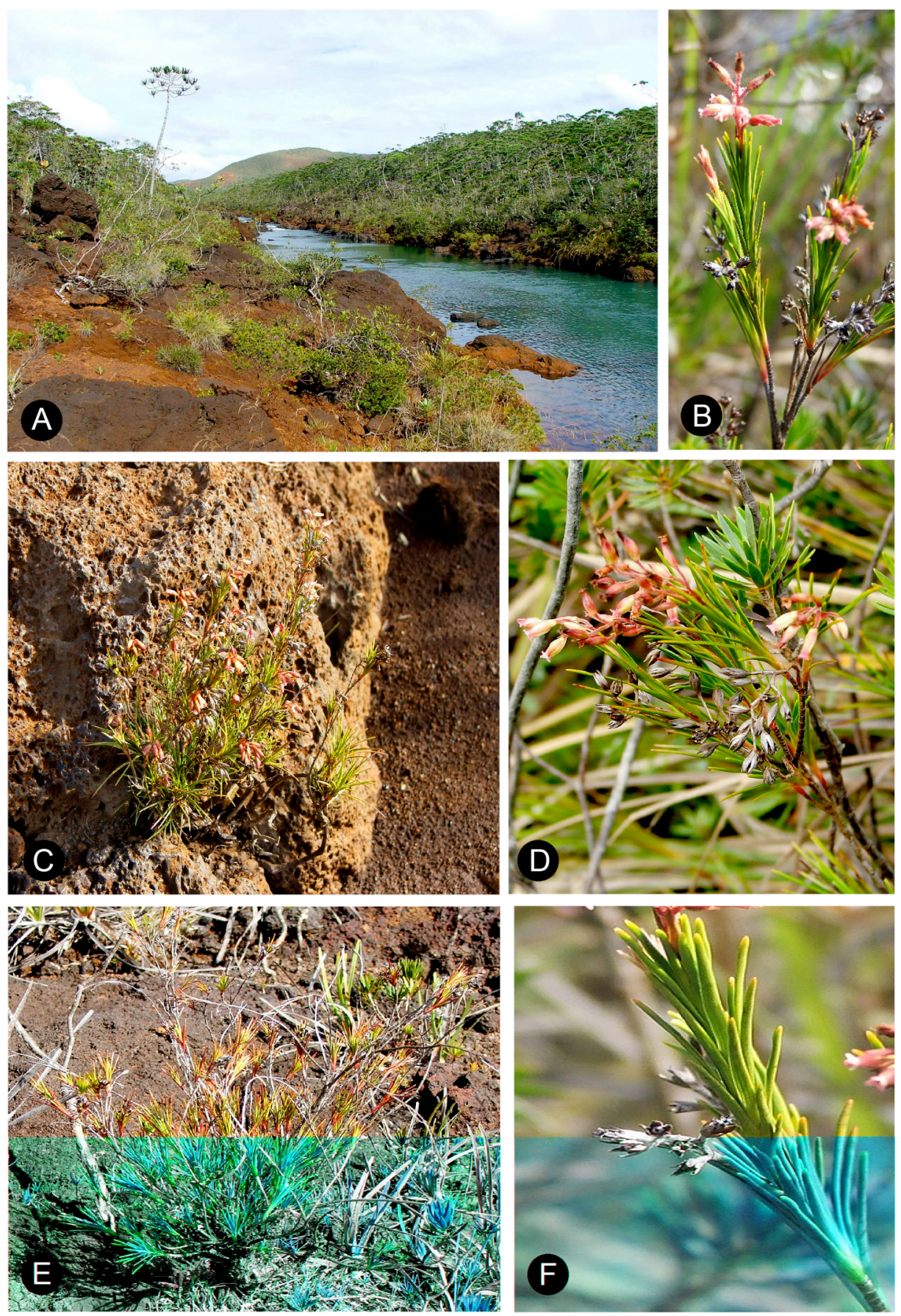

Figure 7.8. Dracophyllum cosmelioides. A, habitat along Creek Pernod; B, flowering branch showing the horizontally spreading flowers; C, mature plant growing in rock cracks devoid of soil; $\mathbf{D}$, flowering branch showing the erect linear leaves and the fewflowered inflorescence, $\mathbf{E}$, plant showing the tufts of leaves at the banch apices; $\mathbf{F}$, the erect leaves with blunt apices. (B-C, D \& F Venter 13844). 
D. balansae in general appearance. For differences between D. balansae and D. cosmelioides see under $D$. balansae.

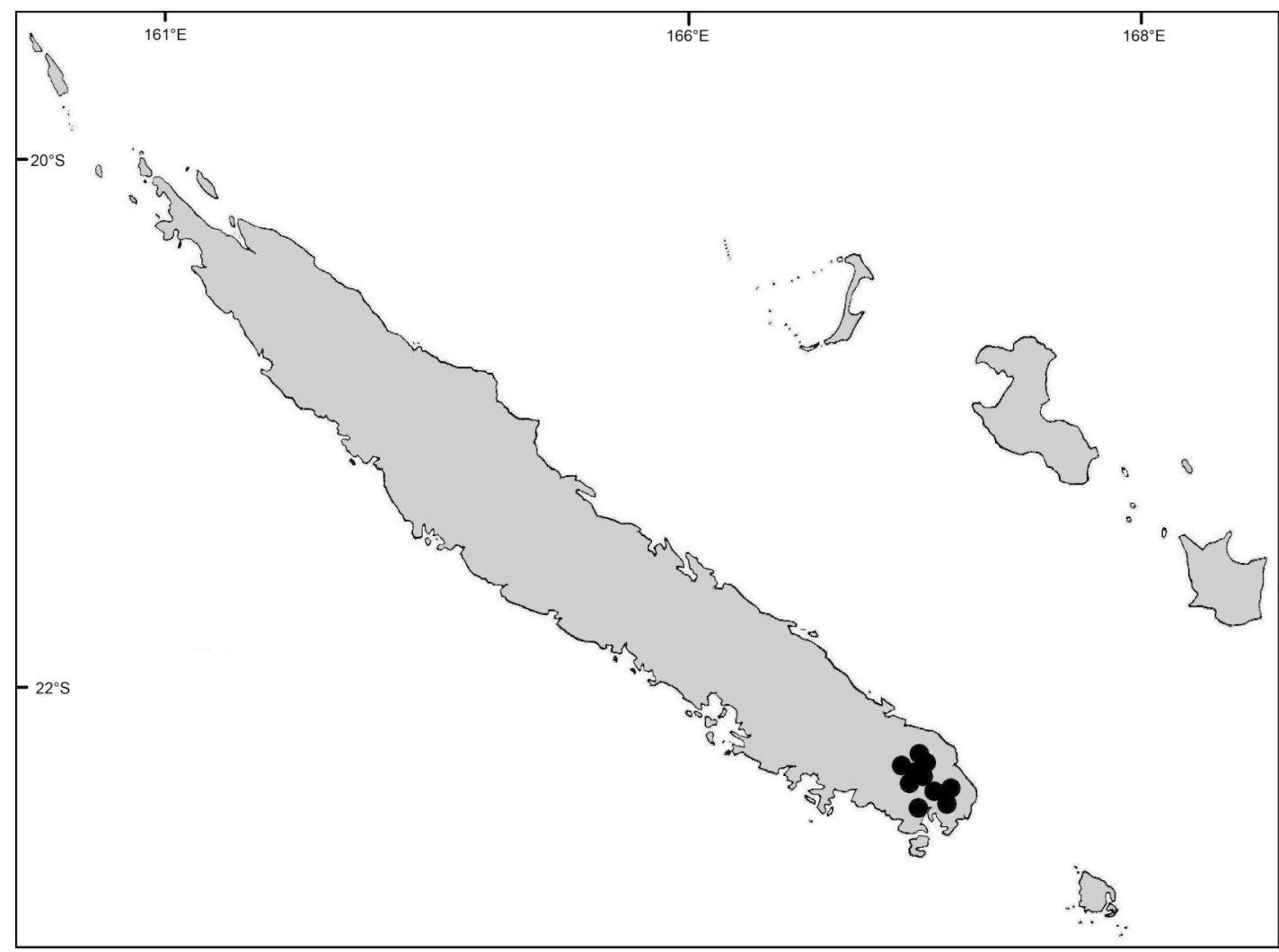

Figure 7.9. Known distribution of Dracophyllum cosmelioides.

\section{Distribution}

A New Caledonia endemic and appears to be restricted to the mountains in the southeast, mostly in the Plain des Lacs area (Fig. 7.9).

\section{Habitat}

Dracophyllum cosmelioides occurs on flat areas or on gentle $\left(0^{\circ}-10^{\circ}\right)$ slopes at altitudes of 160-200 m. It grows in open areas in riparian vegetation along streams and rivers that run through maquis vegetation (Table 7.4). Soils are lithosols derived from serpentinite 
or laterite. In certain populations, plants grow between rocks in streambeds with their roots permanently wet.

Table 7.4. Plant communities commonly associated with Dracophyllum cosmelioides.

Low open evergreen Xanthostemon aurantiacus - Melaleuca brongniartii - Styphelia albicans maquis Tall open evergreen Melaleuca brongniartii - Styphelia albicans - Xyris pancheri maquis

\section{Variation}

Pedicel length is variable ranging from $0.5-2.5 \mathrm{~mm}$ on a single plant.

\section{Specimens examined}

NEW CALEDONIA. 22-167: Goro-nickel, Rivière Kwé, 18.v.2002. Dagostini \& Rigault 616 (NOU). 21-166: Ngoye (-DC), 27.xi.1902. Schlechter 15103 (K, L, NSW, W). 22-166: River Yaté (-BB), 6.x.1924. Däniker 223 (Z). Plaine des Lacs, La Chute River (-BD), 25.vi.1963. Blanchon 207 (NOU, P); Valley of River des Lacs, 5.x.1950. Guillaumin \& Baumann 6542 (Z); Near junction of River des Lacs and Ruisseau Pernod, 24.ix.1963. Green 1192 (K, L, MEL, NOU, Z); Rivière des Lacs, 14.v.2005. Venter 13849 (NOU); Prony, x.1913. Franc 1825 (L, NBI, Z); l’Odjijoni, 19.viii.1958. Hürliman 3346 (Z); 100 m from turnoff to Chute de la Madeleine along Creek Pernod, 12.v.2005. Venter 13844 (NOU); 


\section{Dracopbyllum elegantissimum S. Venter}

Dracophyllum elegantissimum S. Venter, N.Z. Journ. Bot. 42 (1): 37 - 43 (2004). Type: New Zealand, Abel Tasman National Park, Rameka Track, 28.i.2001. S. Venter 13827 (CHR, holo.!; AK, K, NSW, P, WELT).

\section{Description}

Single-stemmed tree 5-14 m tall. Branches form a closed candelabrum-shaped crown. Bark on old branches light brown, flaky, on young stems yellowish brown. Leaves at tips of branches in a bromelioid manner, old leaves present; lamina sheath $22-58 \times 13-43 \mathrm{~mm}$, light brown, coriaceous, striate, tapering, margin smooth; lamina coriaceous, light to mid green, linear to linear-triangular, 330-1000 × 10-20(-32) mm, surfaces glabrous, prominently striated; margin cartilaginous, serrulate with $15-24$ teeth per $10 \mathrm{~mm}$; apex acute and prominently curled. Inflorescence shorter than the leaves, erect, dense, 190$320 \mathrm{~mm}$ long, pyramidal and densely branched; rachis and pedicels tomentose, sometimes hirsute to pubescent, light green; inflorescence axis 7.6-13.5(-14.0) $\mathrm{mm}$ in diameter; basal inflorescence branch $38-42(-55) \mathrm{mm}$ long, widely spreading $\left(50^{\circ}-80^{\circ}\right)$ to right angles with the inflorescence axis; inflorescence bracts caducous, overtopping flowers, light green, ovate-triangular at base, 270-610 × 30-45 mm, surfaces glabrous, margins entire. Flowers 600-1000+, in groups of more than 10 at base of inflorescence, pedicellate; bracteoles caducous, both bracteoles shorter than the perianth and situated in the middle of the pedicel, 2.0-6.5(-8.0) $\times 0.5-1.0(-1.5) \mathrm{mm}$, glabrous; pedicels straight, $0.5-2.0 \mathrm{~mm}$ long, tomentose. Sepals broadly ovate, $1-2 \times 1.0-1.5 \mathrm{~mm}$, shorter than corolla tube, striate, surfaces glabrous; margins ciliate; apices subacute to obtuse. Corolla light to dark pink; corolla tube campanulate, widened at mouth, 1-2 × 1.3-2.0 mm, sometimes white; corolla lobes spreading horizontally to reflexed, ovate-triangular, shorter 
than corolla tube, $1.2-1.4 \times 1.0-1.3 \mathrm{~mm}$, apices obtuse; surfaces glabrous. Stamens inserted at top of corolla tube, filaments $0.3-0.5 \mathrm{~mm}$ long; anthers exserted, rectangular, young anthers pink, deep yellow when mature and 0.9-1.3 mm long. Ovary globose, 1.0$1.5 \times 1.3-1.5 \mathrm{~mm}$, glabrous, apex tapering; nectary scales rectangular, $0.6-1.0 \times 0.5-1.0$ $\mathrm{mm}$, apex subacute to irregularly toothed; style exserted, $1.5-1.7 \mathrm{~mm}$ long, glabrous, lengthening in fruit; stigma clavate. Fruit not included in persistent calyx, reddish brown, 1.2-1.5 × 1.5-1.8 mm, depressed-globose, apex round, glabrous. Seeds yellowish brown, filiform, $0.7-0.8 \mathrm{~mm}$ long, testa slightly reticulate. Flowering December-February. (Figure 7.10).

\section{Diagnostic features and discussion}

Dracophyllum elegantissimum is characterized by the columnar and closed candelabra-shaped crown, bark flaking in large pieces, smooth glossy leaves that are narrow and thinly textured with prominently curled apices, stout and hirsute panicle with small dark pink flowers, sepals and corolla lobes shorter than the corolla tube, nectary scales very small and the capsule 1.5-1.8 $\mathrm{mm}$ in diameter. Dracophyllum elegantissimum is separated from similar species, with which it sometimes co-occurs, by a suite of vegetative inflorescence, floral, and seed characters, which constitute evidence that it is not conspecific with them (Table 7.5).

Superficially, D. elegantissimum resembles $D$. traversii but it lacks the glaucous waxy bloom so characteristic of $D$. traversii. Cockayne (1928) confused D. elegantissimum with $D$. latifolium and so all other people after him. 


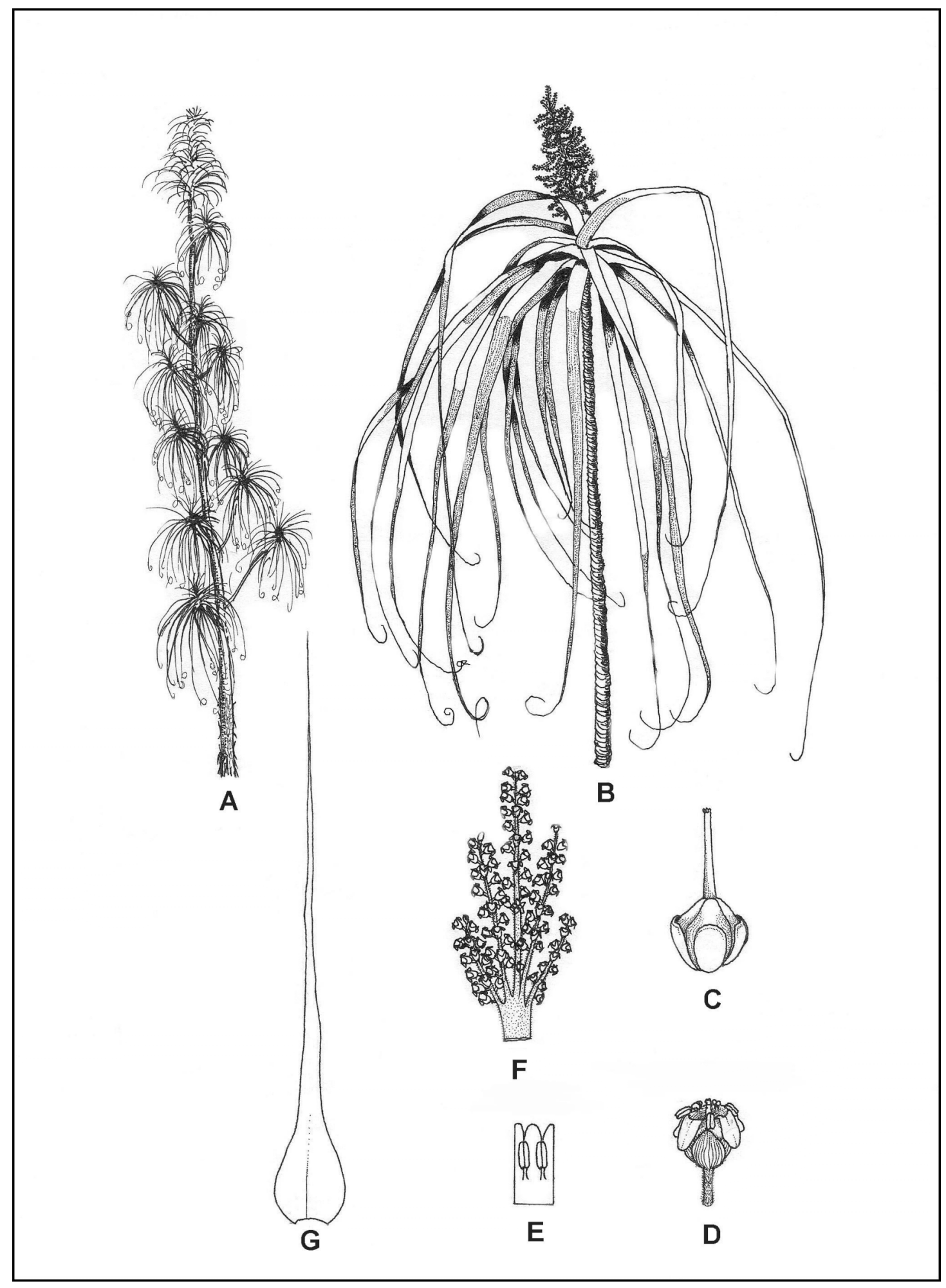

Figure 7.10. Dracophyllum elegantissimum. A, habit $(\times 0.12)$; B, flowering branch $(\times$ $0.25)$; $\mathbf{C}$, gynoecium $(\times 10) ; \mathbf{D}$, flower $(\times 5)$; $\mathbf{E}$, laid out corolla $(\times 5) ; \mathbf{F}$, inflorescence branch $(\times 1)$; G, inflorescence bract $(\times 0.3)$. Drawn from Venter 13827 . 

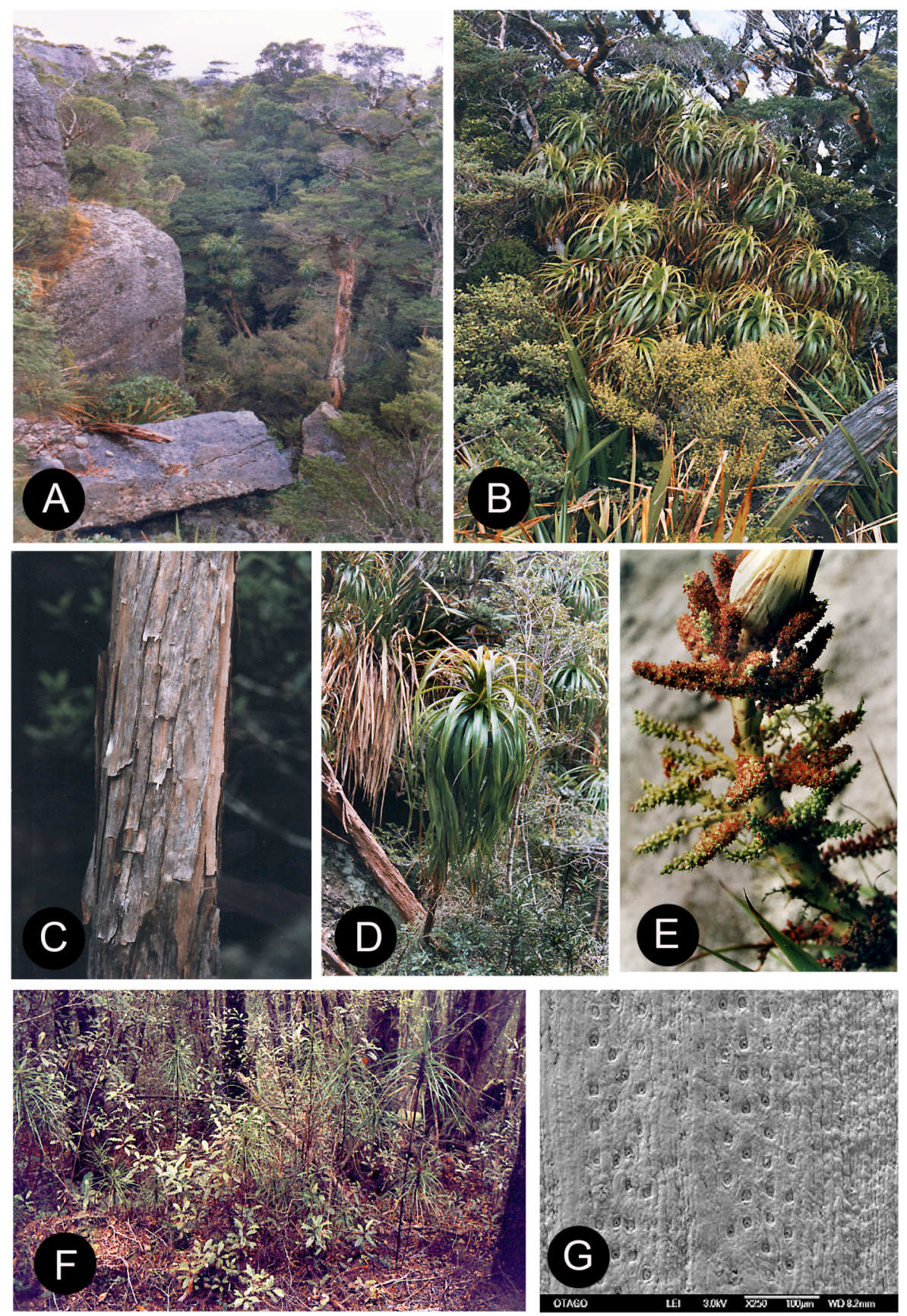

Figure 7.11. Dracopbyllum elegantissimum. A, Nothofagus menæiesii forest habitat on Mt. Rochfort; B, mature plant on Mt. Rochfort; C, characteristic peeling bark; D, plant in forest on Takaka Hill showing the characteristic long, narrow leaves with coiled leaf tips. $\mathbf{E}$, inflorescence showing the small flowers; F, seedlings on forest floor, Mt. Rochfort; $\mathbf{G}$, SEM micrograph of the adaxial lamina surface (Scale bar $=10 \mu \mathrm{m}) . \quad B, C, E$, Venter13732 and D, Venter13827. 
Table 7.5 . Diagnostic characters of Dracophyllum elegantissimum, D. traversii and D. latifolium.

\begin{tabular}{|c|c|c|c|}
\hline Character & D. elegantissimum & D. traversii & D. latifolium \\
\hline Crown habit & closed candelabrum/columnar & open candelabrum & open candelabrum \\
\hline Leaf size $(\mathrm{mm})$ & $330-1000 \times 10-20(-32)$ & $90-300 \times 40-50$ & $45-500 \times 12-30$ \\
\hline Rachis and pedicel & tomentose & pubescent & pubescent/tomentose \\
\hline Inflorescence axis diam. (mm) & $7.6-13.5(-14.0)$ & $13.0-16.5$ & $15-20$ \\
\hline Inflorescence bract length ( $\mathrm{mm})$ & $270-610$ & $130-240$ & $105-180$ \\
\hline Bracteole size $(\mathrm{mm})$ & $2.0-6.5 \times 0.5-1.0$ & $4.0-4.8 \times 0.5-0.7$ & $2.0-5.5 \times 0.5-1.7$ \\
\hline Sepal size $(\mathrm{mm})$ & $1-2 \times 1.0-1.5$ & $2-3 \times 2.0-2.5$ & $0.7-1.5 \times 1.0-1.7$ \\
\hline Sepal length & $<$ corolla tube & equaling corolla tube & $<$ corolla tube \\
\hline Corolla tube size (mm) & $1-2 \times 1.3-2.0$ & $2.7-3.0 \times 4-51$ & $5-2.0 \times 1.5-2.5$ \\
\hline Corolla lobe size (mm) & $1.2-1.4 \times 1.0-1.3$ & $2.5-2.8 \times 2.0-2.5$ & $1.5-2.0 \times 1.5-2.0$ \\
\hline Corolla lobe length & $<$ corolla tube & $>$ corolla tube & $>$ corolla tube \\
\hline Filament length (mm) & $0.3-0.5$ & $1.0-1.2$ & $1.0-1.2$ \\
\hline Anther length (mm) & $0.9-1.3$ & $1.8-2.0$ & $1.3-1.5$ \\
\hline Nectary scale size (mm) & $0.6-1.0 \times 0.5-1.0$ & $1.0-1.5 \times 1.0-1.5$ & $0.6-1.2 \times 0.8-1.0$ \\
\hline Nectary scale apex & subacute to irregularly toothed & retuse & irregularly toothed \\
\hline Ovary size (mm) & $1.0-1.5 \times 1.3-1.5$ & $1.4-1.5 \times 1.8-2.0$ & $0.8-1.0 \times 1.0-1.5$ \\
\hline Style length (mm) & $1.5-1.7$ & $2.0-2.2$ & $1.0-1.7$ \\
\hline Fruit size (mm) & $1.2-1.5 \times 1.5-1.8$ & $1.9-2.0 \times 2.8-3.0$ & $1-2 \times 2-3$ \\
\hline Seed shape & filiform & ovoid & ovoid \\
\hline Seed length (mm) & $0.7-0.8$ & $1.0-1.2$ & $1.2-1.3$ \\
\hline
\end{tabular}

\section{Distribution}

Endemic to the north-west Nelson area on the South Island of New Zealand. Most localities are in the Abel Tasman and Kahurangi National Parks with a few scattered localities southwards to Charleston (Fig. 7.12).

\section{Habitat}

Dracophyllum elegantissimum occurs from 10 to 1064 m altitudes in light to deep shade (rarely in full sun) in lowland to montane forest communities (Table 7.6). It is common in the small tree tier of the high altitude conifer/broad-leaved forest. All the known populations occur on gentle to steep $\left(5^{\circ}-45^{\circ}\right)$ south-west to north-west facing mountain slopes. Soils are dark brown humus-rich loam to gritty brown sandy loam derived from granidiorite, calcareous sandstone and conglomerate (Mt. Rochfort) or from limestone (Gouland Downs). 


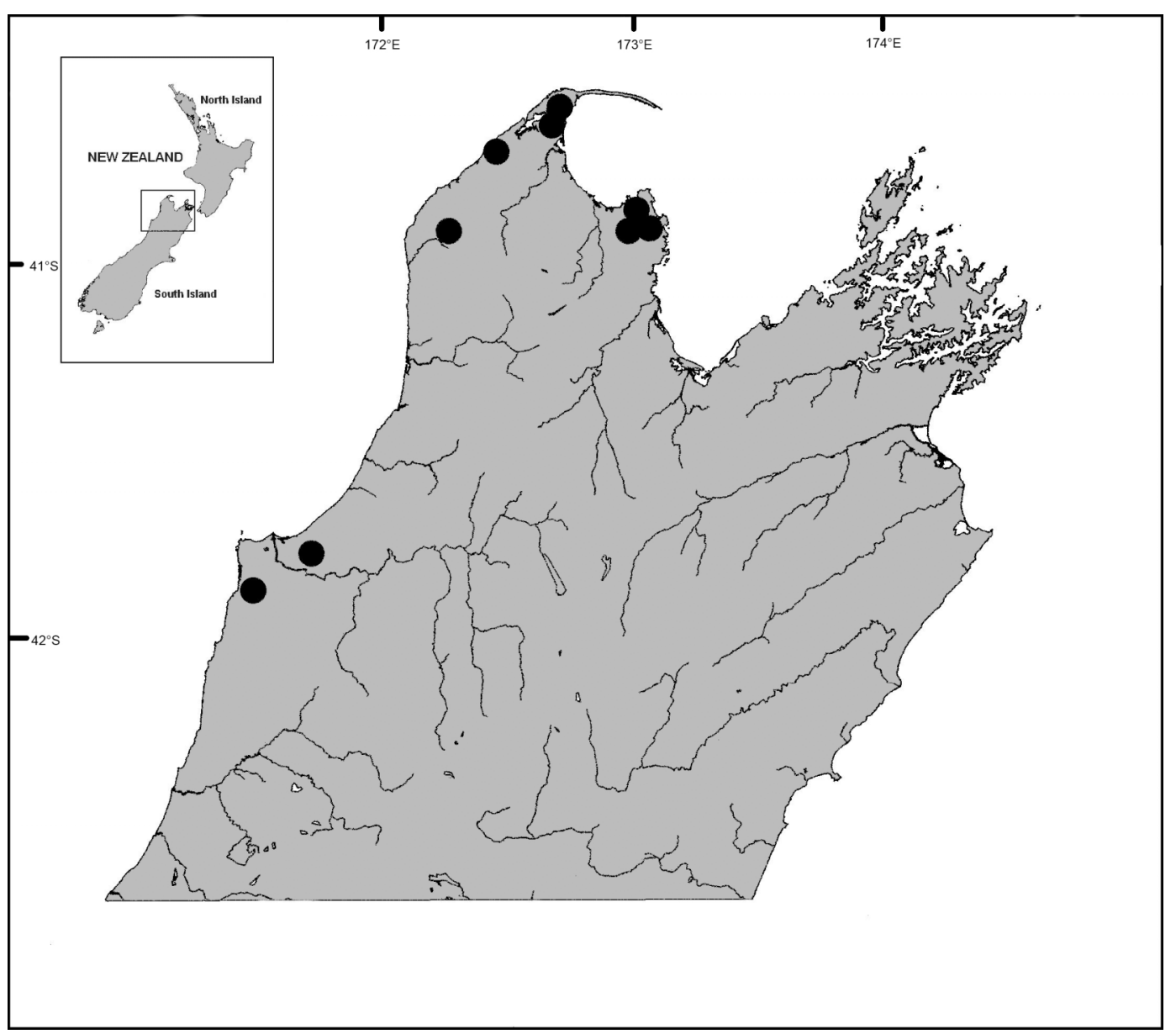

Figure 7.12. Known distribution of Dracophyllum elegantissimum.

Table 7.6. Plant communities commonly associated with Dracophyllum elegantissimum.

\section{FOREST}

Low open evergreen Weinmannia racemosa - Nothofagus menziesii - Blechnum discolor forest High closed evergreen Nothofagus menziesii - Libocedrus plumosa - Coprosma microcarpa forest

High closed evergreen Weinmannia racemosa - Griselinia littoralis - Pseudowintera traversii forest

\section{Variation}

Mature plants display crown shapes that vary from columnar to closed-candelabrashaped but plants growing in forest openings can sometimes have a more open crown resembling that of $D$. traversii. Leaf length varies in a single population from 330-1000 
$\mathrm{mm}$ with the lamina width $10-20(-32) \mathrm{mm}$ but most plants have leaves $500-700 \times 15-$ $20 \mathrm{~mm}$. The inflorescence bracts vary in shape and length $(270-610 \mathrm{~mm})$ even on an individual plant.

\section{Specimens examined}

NEW ZEALAND. South Island - northwest Nelson - 40-172: Along the Anatori River (-CD), 26.ii.2002, Courtney s.n. (CHR); Kahurangi National Park, Gouland Downs, 14.ii.2002, Courtney s.n. (CHR); Knuckle Hill (-DA), 28.iii.1999. Venter 13778 (CHR); Abel Tasman National Park, near Moa Park (-DD), Druce s.n. (CHR); Wainui Falls, 22.xii.2002. Venter 13837 (CHR). 41-171: Charleston, Ananui Caves, along the Nile River (-CD), 07.i.1999, Venter 13749 (CHR); Westport, Mt. Rochfort (-DC), 25.xi.1998, Venter 13732 (CHR).

\section{Dracophyllum fiordense W.R.B. Oliv.}

Dracophyllum fiordense W.R.B. Oliv., Trans. Proc. N.Z. Inst. 59: 705 (1928); Oliver, Trans. Proc. N.Z. Inst. 52: 11 (1920) as D. townsonii; Oliver, Trans. Roy. Soc. N.Z. 80 (1): 14 (1952); Allan, Fl. N.Z. 1: 536 (1961); Eagle, Trees \& Shrubs of N.Z. $2^{\text {nd }}$ Ed.: 292 (1982); Salmon, Native Trees of N.Z.: 272 (1989); Poole \& Adams, Trees and Shrubs of N.Z.: 164 (1994). Type: New Zealand - Wilmot Pass on Wilmot Saddle, iii.1927. W.R.B. Oliver s.n. (WELT 55115, lecto.!), designated by Oliver (1952).

Icones: Oliver, Trans. Proc. N.Z. Inst. 59: t. 15 (1928); Eagle, Trees \& Shrubs of N.Z. $2^{\text {nd }}$ Ed.: t. 130 (1982); Salmon, Native Trees of N.Z.: 272 (1989). 


\section{Description}

A tree $1.5-5.0 \mathrm{~m}$ tall. Branches erect and sparsely branched. Bark on old branches greyish-brown, deeply fissured to flaky at the base on old stems and branches, young stems yellowish brown. Leaves crowded on tips of branches in a bromelioid manner; lamina sheath 60-87 × 30-43 mm, coriaceous, striate, tapering and margin smooth; lamina coriaceous, linear-triangular to lanceolate, $400-700 \times 40-50 \mathrm{~mm}$, surfaces glabrous, prominently striated; margin denticulate with 10-15 teeth per $10 \mathrm{~mm}$; apex acute and often spiralling. Inflorescence an axillary panicle some distance below the leaves; much shorter than the leaves, drooping, dense, 100-120(-150) mm long, pyramidal, densely branched; rachis and pedicels glabrous; inflorescence axis 5.6-7.7 $\mathrm{mm}$ in diameter; basal inflorescence branch 20-25(-50) mm long, widely spreading; inflorescence bracts caducous, overtopping flowers, light green, ovate-triangular at base, 40-51 × 18-21 mm, surfaces glabrous, margins ciliate. Flowers hidden by leaves, 113-120, in groups of more than 10 at base of inflorescence; bracteoles caducous, longer than the perianth and situated in the middle of the pedicel, $4.5-5.0 \times 0.8-1.0 \mathrm{~mm}$, glabrous; pedicels straight, $0.8-1.5 \mathrm{~mm}$ long, glabrous. Sepals ovate, $2.0-2.5 \times 2.0-3.0 \mathrm{~mm}$, shorter than the corolla tube, striate, surfaces glabrous; margins ciliate. Corolla light to dark pink; corolla tube broadly campanulate, widened at mouth, 2.0-2.5 long and wide; corolla lobes reflexed, oblong, equaling the corolla tube, $1.5-2.0 \times 1.3-1.5 \mathrm{~mm}$, apices obtuse; surfaces glabrous. Stamens hypogynous, filaments 2.3-2.5 mm long; anthers exserted, oblong, light yellow and 1.5-2.0 mm long. Ovary subglobose, 0.9-1.0 × 1.3-1.5 mm, glabrous, apex round; nectary scales rectangular, 0.6-0.7 mm long and wide, apex retuse; style exserted, 1.8-2.0 mm long, glabrous; stigma five-lobed. Fruit reddish brown, $2.0-2.8 \times 2.5-4.0 \mathrm{~mm}$, depressedglobose, apex round, glabrous. Seeds brown, ovoid, 0.55-0.6 mm long, testa slightly reticulate. Flowering January-March. (Figure 7.13). 


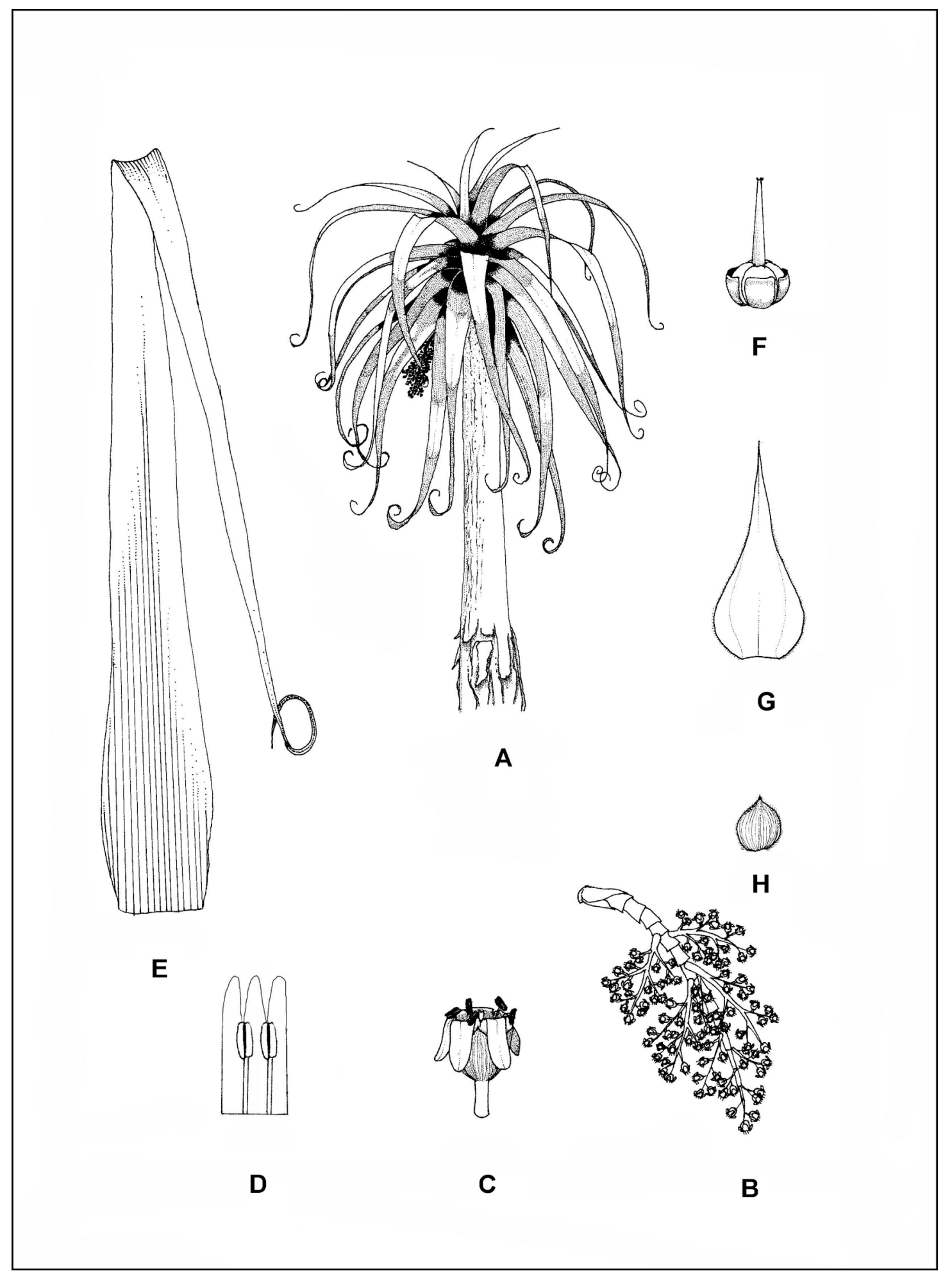

Figure 7.13. Dracopbyllum fiordense. A, habit $(\times 0.25)$; $\mathbf{B}$, inflorescence $(\times 0.5)$; C, flower $(\times 5)$; $\mathbf{D}$, laid out corolla $(\times 5) ; \mathbf{E}$, leaf $(\times 0.5) ; \mathbf{F}$, ovary $(\times 10) ; \mathbf{G}$, inflorescence bract $(\times 1)$; H, sepal $(\times 5)$. Drawn from Venter 13801 . 

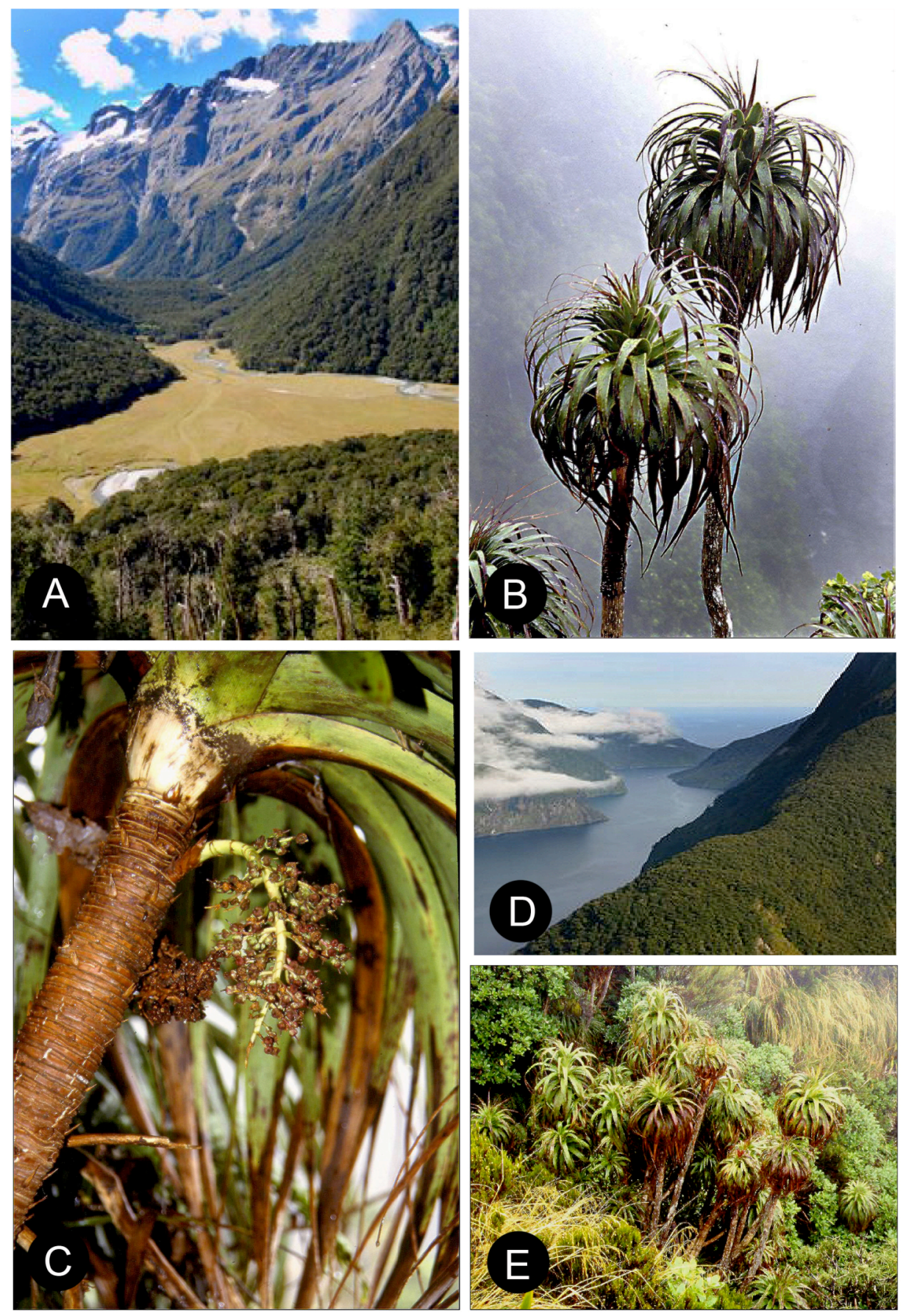

Figure 7.14. Dracophyllum fiordense. A, steep mountain slope habitat, Fiordland; B, mature plant showing the typical bromelioid growth habit of the leaves; $\mathbf{C}$, inflorescence below the leaves; D, Nothofagus forest with D. fiordense, Fiordland; E, subalpine forest habitat on Alex Knob, Franz Josef Glacier. B, C \& E, Venter13801. 


\section{Diagnostic features and discussion}

Dracophyllum fiordense is characterized by the unbranched (occasionally only once) stems, very large and long leaves with narrowed lamina bases and prominently spiralled apices, the panicle situated below the leaves, sepals shorter than the corolla tube with spaced cilia on the margin, bracteoles longer than the flower with a few teeth at the apex and the anthers exserted with the capsule short and very broad.

Dracophyllum fiordense is related to D. menziesii and D. townsonii (Oliver 1928) in the axillary panicles situated below the leaves. It resembles $D$. traversii but differs in the unbranched to sparsely branched stems, the large leaves with spiralled apices and the inflorescences situated below the leaves. The panicles are more branched than those of D. menziesii but closely resemble those of $D$. townsonii in size and shape.

\section{Distribution}

Endemic to the Western Otago and Fiordland areas of New Zealand. There are two distribution areas, the one surrounding the Mt. Cook and Westland National Parks and the other in Fiordland National Park (Fig. 7.15).

\section{Habitat}

Dracophyllum fiordense is common on steep $\left(50^{\circ}-80^{\circ}\right)$ northern, north-western and northeastern slopes from near sea level $(50 \mathrm{~m})$ to areas of high altitude $(1,280 \mathrm{~m})$. The vegetation consists 


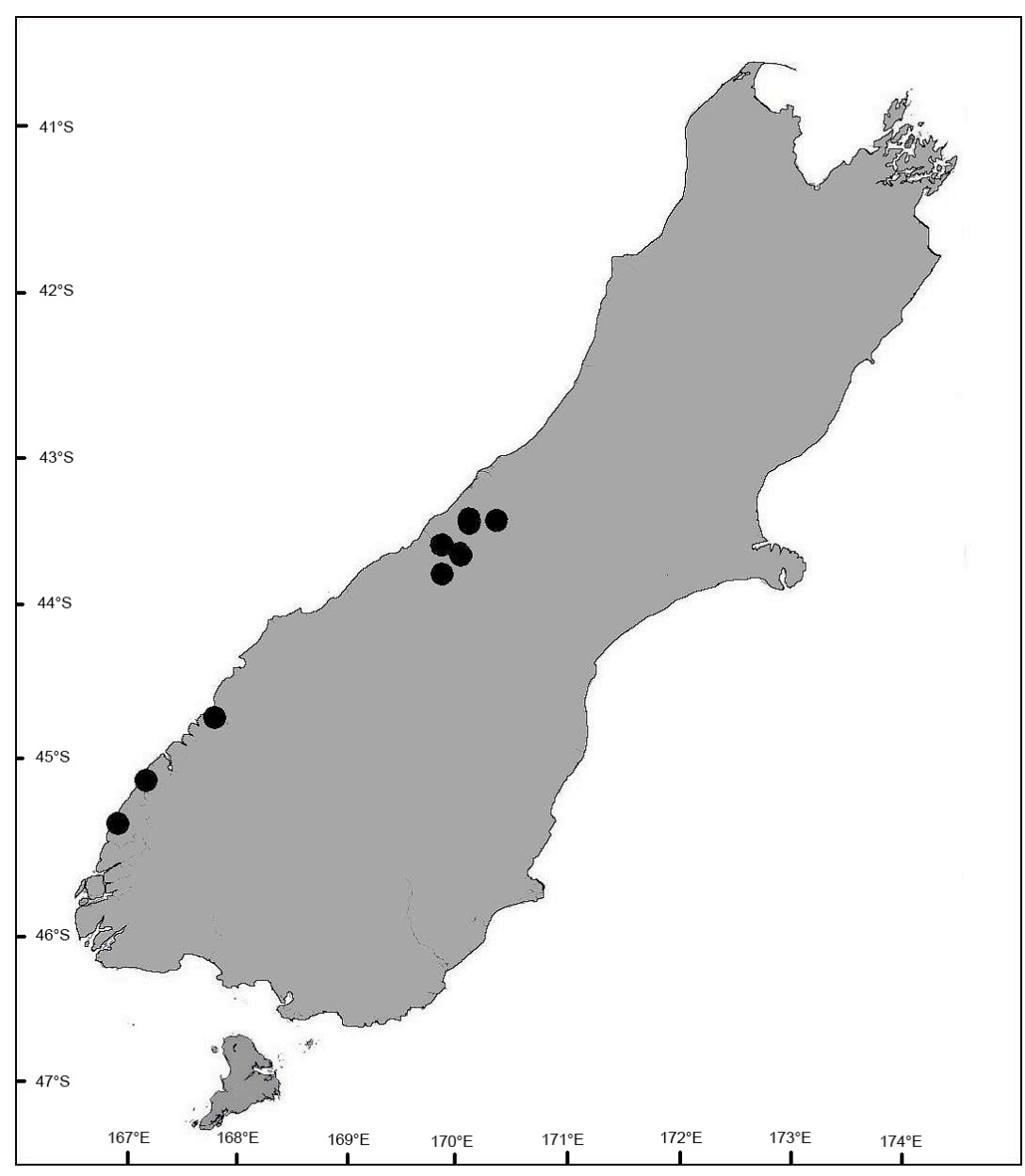

Figure 7.15. Known distribution of Dracophyllum fiordense. South Island, New Zealand.

sometimes of moist to permanently moist lowland but mostly subalpine forest, subalpine woodland and shrubland or tussock grassland (Table 7.7) in mountain gullies, ravines, on ridges or on bluffs. The soil is humus rich brown clay loam derived from schist and gneiss. Most populations grow in full sun but occasionally some individuals grow in light shade although this does not alter their external appearance. Plants occur in high rainfall areas and receive additional moisture from mist. 


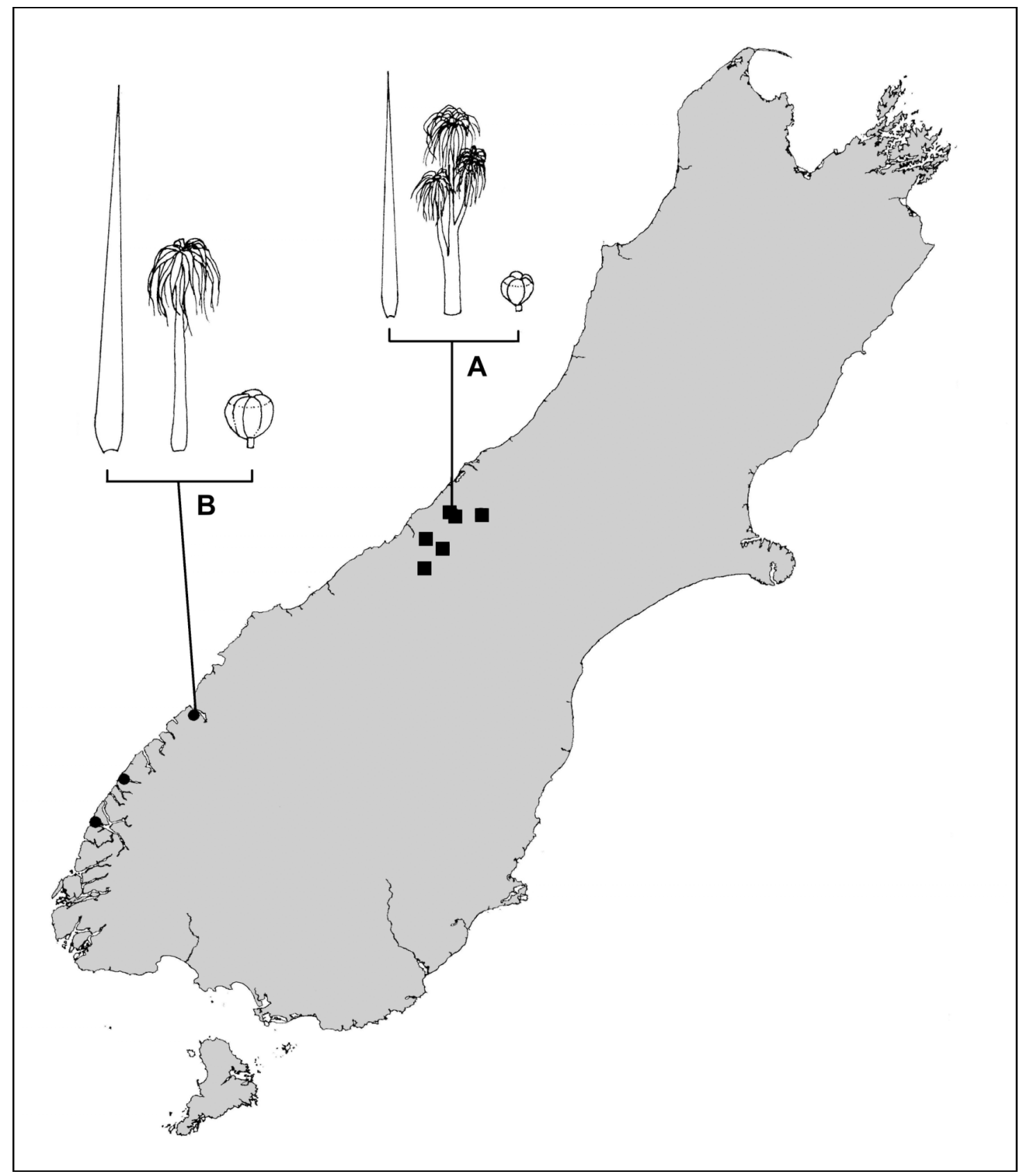

Figure 7.16. Variation in Dracophyllum fiordense. Plants from northern populations ( ) tend to have branched main stems, small leaves and fruit (A, Westland National Park, Alex Knob, Venter 13801) compared to the southern populations ( ) with unbranched main stems, much longer leaves and larger fruit (B, Fiordland National Park, Sinbad Gulley, Johnson s.n.) 
Table 7.7. Plant associations commonly associated with Dracophyllum fiordense.

\begin{tabular}{|c|}
\hline FOREST \\
\hline Low open evergreen Nothofagus menziesii forest \\
\hline WOODLAND \\
\hline Low closed evergreen Olearia colensoi - Phormium cookianum - Chionochloa alpine woodland \\
\hline
\end{tabular}

\section{Variation}

Leaves collected from populations of D. fiordense in the Franz Josef area (Figure 7.16) are nearly $50 \%$ shorter, with the main stems more branched than the plants from further south. This can possibly be attributed to the higher elevation, lower rainfall and higher temperatures of the northern populations. Plants from protected valleys on Mt. Alexander attain a height of five metres compared to plants from exposed areas at high altitude that are not taller than $50 \mathrm{~cm}$. Fruit size varies $(2.0-2.8 \times 2.5-4.0 \mathrm{~mm})$ with the largest fruit found in the southern populations.

\section{Specimens examined}

NEW ZEALAND. South Island. 43-169: Alex Knob, gully between Alex Knob and Louisa Peak (-AC), 19.iii.2000. Venter 13801 (CHR); ibid., 17.i.1951. Oliver s.n. (WELT 13767); Westland Nat. Park, head of Architect Creek (-DB), 7.ii.1971. Wardle s.n. (CHR); Westland Nat. Park, between Twain Col and Douglas River (-DD), 3.ii.1971. Wardle s.n. (CHR); 43-170: Westland Nat. Park., between Mt. Moltke and Cape Defiance, Castle Rocks (-AC), 9.ii.1971. Wardle s.n. (CHR); Whataroa Valley, Rocky Creek (-AD), v.1998. Giller s.n. (CHR); Westland Nat. Park, Copland Valley head, near Copland Glacier Lake (-CA), 18.xi.1975. Wilson \& Verboef s.n. (CHR); 44-167: Cleddau Valley (-DB), 20.xii.1944. Oliver s.n. (WELT 55113); Karangarua River, between Top Flat and Twain Saddle, 29.iii.1969. Wardle \& Fryer s.n. (CHR); Fiordland, Sinbad Gulley (-DB), 27.ii.1975. Johnson s.n. (CHR); 45-166: Thompson Sound, mountains above Lyall Bay (- 
BD), i.1958. Metcalf s.n. (CHR); 45-167: Caswell Sound, Mt. Alexander (-AB), 29.iii.1949, Zotov s.n. (CHR); Wilmot Pass, Wilmot Saddle (-CA), iii.1927. Oliver s.n. (WELT).

6. Dracophyllum fitzgeraldii Moore \& F. Muell.

Dracophyllum fitzgeraldii Moore \& F. Muell., Fragm. Phytogeogr. Austr. 7: 27 (1869). (As 'Fitggeraldi); Hemsley, Ann. Bot. 10: 241 (1896); Maiden, Proc. Linn Soc. N.S.W. 23: 120 (1898); Oliver, Trans. Proc. N.Z. Inst. 49: 146 (1917); Oliver, Trans. Proc. N.Z. Inst. 59: 711 (1928); Oliver, Trans. Roy. Soc. N.Z. 80 (1): 16 (1952); Recher \& Clark, Environmental Survey of Lord Howe Is.: 26 (1974); Hutton, Lord Howe Is.: 123 (1986); Green, Oceanic Islands. Fl. of Austr: 49 (1): 145 (1994); Streiber et al., Telopea 8 (3): 389 (1999). Type: Australia - In insula Lord Howe's Island. 1869. Rob D. Fitggerald 43 (MEL, holo.!).

Icones: Oliv, Trans. Proc. N.Z. Inst. 59: t. 21 (1928); Recher \& Clark, Environmental Survey of Lord Howe Is: 26 (1974); Hutton, Lord Howe Is.: 123 (1986); Green, Oceanic Islands. Fl. of Austr: 49 (1): t. 42 (H) (1994).

\section{Description}

A shrub to tree (1-)3-13 m tall. Branches. Bark on old branches dark brown to blackish brown, rough to deeply fissured, young stems reddish brown. Leaves crowded on tips of branches in a bromelioid manner; lamina sheath light brown, 23-29 × 15-21 mm, coriaceous, striate, membranous, tapering, top half minutely ciliate; lamina coriaceous, light to mid green, abaxial surface lighter coloured, linear-triangular, rarely lanceolate $(150-) 205-335(-350) \times(7-) 9-11(-25) \mathrm{mm}$, surfaces glabrous, prominently striated; margin cartilaginous, serrate to serrulate with 16-38 teeth per $10 \mathrm{~mm}$; apex acute. 
Inflorescence shorter than the leaves, erect, dense, 100-150 (-280) mm long, densely branched; rachis and pedicels pubescent; inflorescence axis $3.0-5.5 \mathrm{~mm}$ in diameter; basal inflorescence branch 10-12 mm long, widely spreading; inflorescence bracts caducous, overtopping flowers, light green, ovate-lanceolate at base, 29-49 $\times 11.8-15.2 \mathrm{~mm}$, adaxial surfaces glabrous; abaxial surfaces scabrid, margins serrulate. Flowers 100-600+, in groups of more than 10 at base of inflorescence, pedicellate; bracteoles persistent, recaulescent with one bracteole situated just below the perianth and the other in the middle of the pedicel, shorter than flower, $4.5-6.0 \times 0.5-0.7 \mathrm{~mm}$, glabrous; pedicels straight, 1-2 mm long, pubescent. Sepals lanceolate to ovate-lanceolate, (3.0-)4.4-5.0(6.0) $\times 1.5-2.5 \mathrm{~mm}$, shorter than the corolla tube, white, striate, surfaces glabrous; margins ciliate. Corolla white, occasionally pale pink; corolla tube cylindrical, widened at mouth, $(4,0-) 5.3-6.0 \times 2.0-2.3 \mathrm{~mm}$; corolla lobes reflexed, triangular, shorter than corolla tube, $2.0-2.5 \times 1.3-1.6 \mathrm{~mm}$, apices subacute; surfaces glabrous. Stamens adnated to top of corolla tube, filaments $0.3-0.5 \mathrm{~mm}$ long; anthers slightly exserted, oblong, light yellow and $0.8-0.9 \mathrm{~mm}$ long. Ovary subglobose, $1.0-1.5 \times 1.2-1.25 \mathrm{~mm}$, glabrous, apex round; nectary scales rectangular, $0.6-0.7 \times 0.3-0.5 \mathrm{~mm}$, apex retuse to irregularly toothed; style included, 0.9-1.0 mm long, glabrous; stigma five-lobed. Fruit pedicellate, dark brown, (3.9-)4.4-5.0 × 1.8-2.0 mm, broadly obovoid, apex round, glabrous. Seeds yellowish brown, ovoid, $0.6-0.65 \mathrm{~mm}$ long, testa slightly reticulate. Flowering OctoberFebruary (-April). (Figure 7.17).

\section{Diagnostic features and discussion}

Dracophyllum fitggeraldii is characterized by the spreading crowns, deeply fissured and rough bark, lamina sheath $23-29 \times 15-21 \mathrm{~mm}$, lamina 205-335 × 9-11 mm with prominent striation and drawn out lamina apices, panicle shorter than the leaves with 


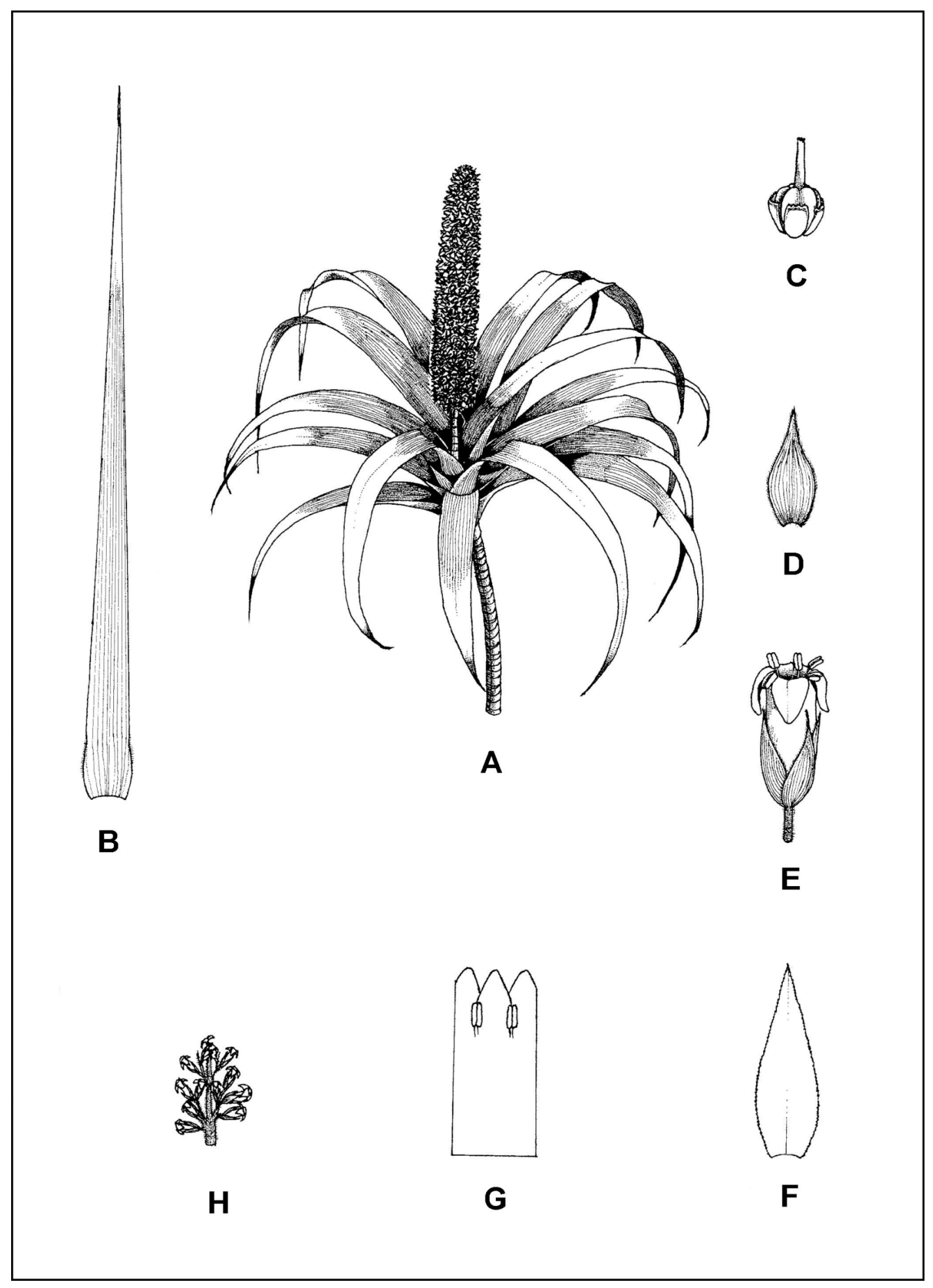

Figure 7.17. Dracophyllum fitzgeraldii. A, flowering branch $(\times 0.25) ; \mathbf{B}$, leaf $(\times 0.5)$; $\mathbf{C}$, ovary $(\times 10)$; $\mathbf{D}$, sepal abaxial surface $(\times 5)$; $\mathbf{E}$, flower $(\times 5) ; \mathbf{F}$, inflorescence bract adaxial surface $(\times 1)$; G, laid out corolla $(\times 5)$; H, bottom inflorescence branch $(\times 2)$. Drawn from Green 1656. 

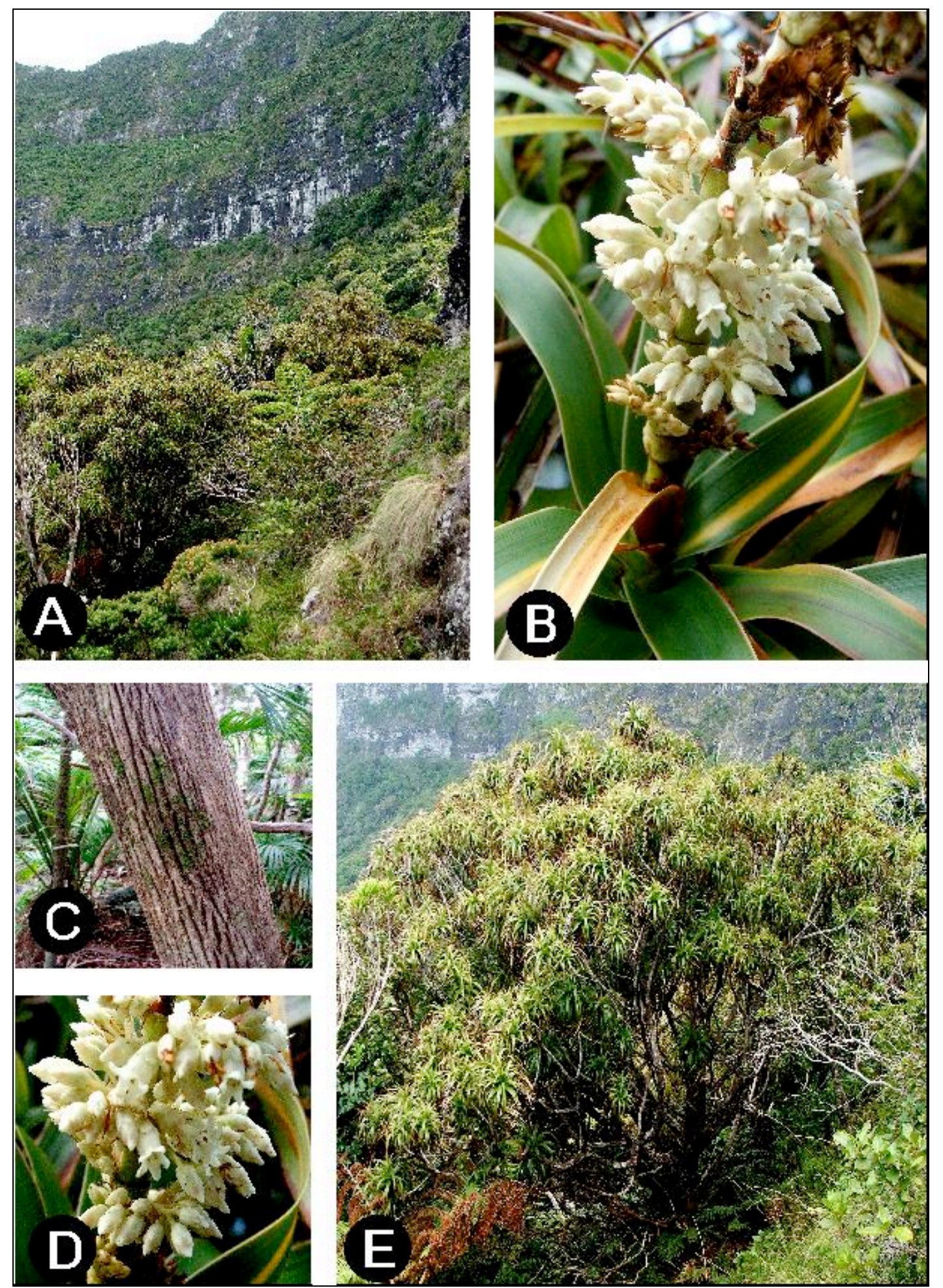

Figure 7.18. Dracophyllum fitzgeraldii. A, habitat on slopes of Mt. Lidgebird; B, flowering branch; C, deeply fissured and rough bark; D, flowers; E, mature plant. B-E from Venter 13863. 
flowers arranged in groups of $>10$ at the base of the inflorescence, sepals shorter (4.4 $5.0 \times 1.5-2.5 \mathrm{~mm})$ than the 5.3-6.0 $\mathrm{mm}$ long corolla tube, anthers slightly exserted with the ovary subglobose and the style included.

Dracophyllum fitrgeraldii is related to species in Northern Queensland (D. sayeri) and New Caledonia (D. verticillatum) (Oliver 1952; Green 1994; Streiber et al.1999). Dracophyllum fitrgeraldii is similar to D. milliganii, D. sayeri, D. oceanicum and D. verticillatum but differs in the characters mentioned in Table 7.8.

Table 7.8. Morphological differences between Dracophyllum fitrgeraldii, D. milliganii, $D$. oceanicum, D. sayeri and D. verticillatum.

\begin{tabular}{|l|c|c|c|c|c|}
\hline & D. fitggeraldii & D. milliganii & D. oceanicum & D. sayeri & verticillatum \\
\hline Lamina sheath length $(\mathrm{mm})$ & $23-29$ & $30-40$ & $12-17$ & $20-27$ & $17.3-25.2$ \\
\hline Lamina margin texture & serrulate & serrulate & serrulate & smooth & serrate/serrulate \\
Number of teeth/cm & $16-20$ & $15-70$ & $10-20$ & absent & $20-32$ \\
Inflorescence length $(\mathrm{mm})$ & $100-150$ & $130-460$ & $70-100$ & $160-210$ & $190-400$ \\
Inflorescence axis texture & smooth & ribbed & smooth & smooth & smooth \\
Inflorescence bract length $(\mathrm{mm})$ & $24-49$ & $40-180$ & $10-65$ & $85-110$ & $42-43$ \\
\hline Inflorescence bract margin & serrulate & serrulate & entire/serrulate & entire & ciliate \\
Sepal to corolla tube length & shorter & equaling & shorter/equaling & shorter & shorter \\
Corolla tube length $(\mathrm{mm})$ & $5-6$ & $2.5-3.0$ & $4-7$ & $3-5$ & $2-3$ \\
Stamen fusion & top & free & middle & top & upper third \\
Filament length (mm) & $0.3-0.5$ & $2.5-5.0$ & $3.0-4.5$ & $1.0-1.3$ & $1.0-1.5$ \\
Nectary scales fusion & free & free & free & fused at base & fused at base \\
\hline
\end{tabular}

\section{Distribution}

Endemic to Lord Howe Island and restricted to the upper slopes of Mt. Gower and Mt. Lidgbird. (Fig. 7.19). 


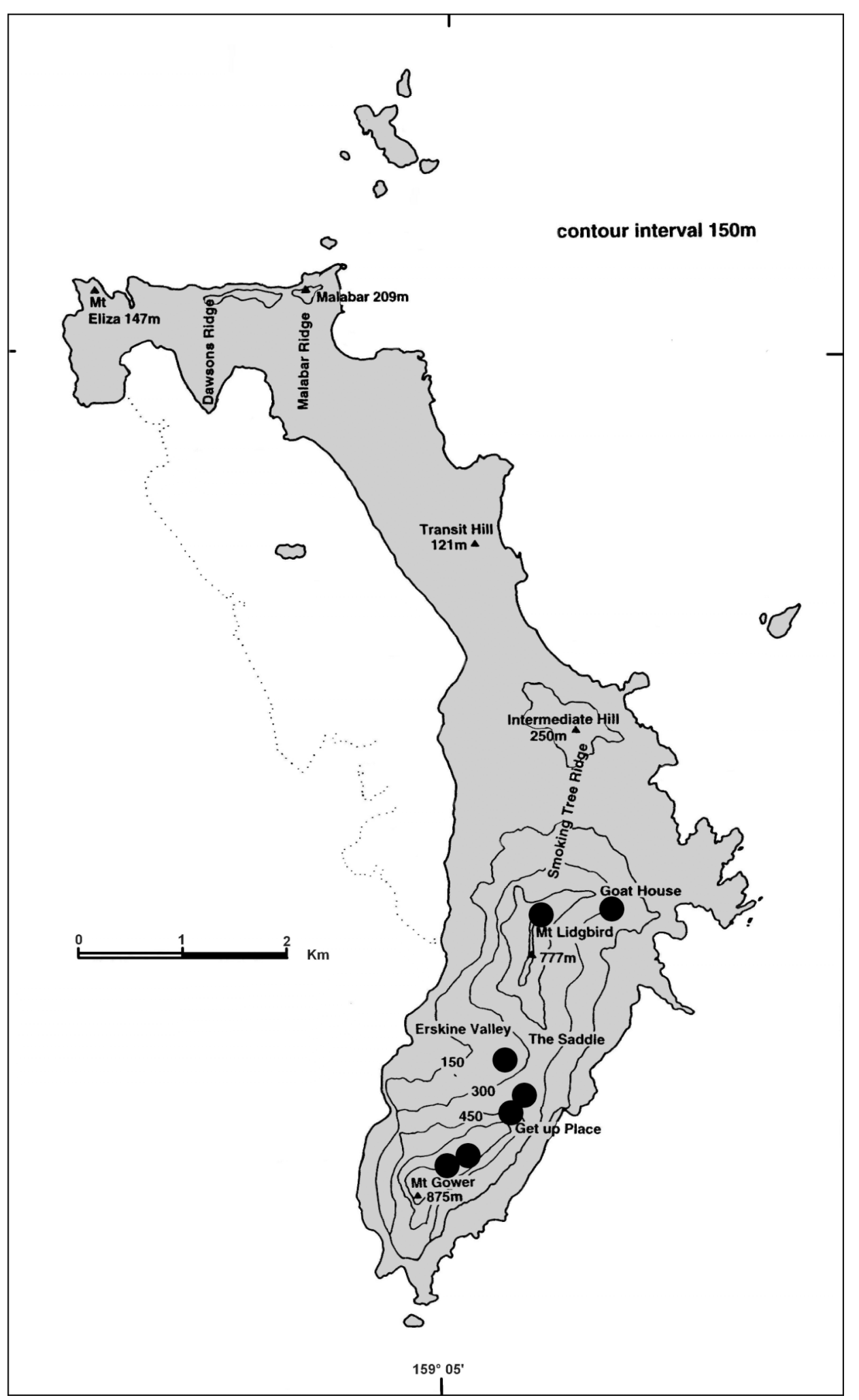

Figure 7.19. Known distribution of Dracophyllum fitzgeraldii. 


\section{Habitat}

Dracophyllum fitgrgeraldii occurs on gentle to steep $\left(10^{\circ}-70^{\circ}\right)$ northern to north-western slopes at 200-1000 m altitudes, which are covered in dense oceanic montane cloud forest and shrubland (Table 7.9). The soil is clay loam derived from basalt.

Table 7.9. Plant associations commonly associated with Dracophyllum fit:geraldii.

\section{FOREST}

Tall closed evergreen Metrosideros nervulosa - Drypetes deplanchei - Cryptocarya triplinervis forest

Tall closed evergreen Howea belmoreana - Linociera quadristaminea forest

Tall closed evergreen Dracophyllum fitzgeraldii - Metrosideros nervulosa forest

Low open evergreen Metrosideros nervulosa - Howea forsteriana - Pandanus forsteri forest

Low open evergreen Melaleuca howeana - Metrosideros nervulosa - Nephrolepis cordifolia forest Low closed evergreen Zygogynum howeanum - Dracophyllum fitzgeraldii forest SHRUBLAND

Tall closed evergreen Dracophyllum fitzgeraldii - Metrosideros nervulosa shrubland

Tall closed evergreen Coprosma - Melicope contermina - Negria rhabdothamnoides shrubland

\section{Variation}

On the slopes of Mt. Gower and in the Erskine Valley, D. fitzgeraldii grows as a tree (up to $13 \mathrm{~m}$ tall). Where the habitat is more exposed the vegetation changes from forest to closed shrubland where Dracophyllum plants rarely exceed two meters in height especially on the high plateau. Inflorescence length varies from plant to plant $(100-150 \mathrm{~mm})$ and most corolla lobes have subacute apices but there are some specimens with obtuse apices. The apices of the nectary scales vary from retuse to irregularly toothed.

\section{Specimens examined}

LORD HOWE ISLAND. 31-159: Eastern side of Mt. Lidgbird, near the Goat House (CA), 28.viii.1969. Game 69/248 (K); Beyond Goat House around Mt. Lidgebird, 2.xii.1993. Beard s.n. (HO, WAIK); Near Goathouse Cave, 1.ix.1981. Rodd 3714 (NSW); along footpath south of Goat House cave, 7.iv.2006. Venter 13863 (CHR, NSW);

Northern spur of Mt. Gower, Johnson \& Rodd 1366 (K, NSW); Summit of Mt. Gower, 
Green 1656 (K, MEL); ibid., Fullager s.n. (BM, MEL); Mt. Gower, Get Up Place, 17.ix.1998. Parkes s.n. (CHR); Mt. Gower, 6.vi.1882. Duff s.n. (MEL); Erskine Valley, Mt. Gower Track, 27.xi.1980. Rodd 3591 (NSW); The Saddle, 14.iv.1999. Hutton s.n. (NSW); along Erskine Creek on The Saddle, 9.iv.2006. Venter 13862 (CHR, NSW); Mt. Lidgebird, 22.vii.1965. Van Balgooy 1076 (L); Erskine Valley, Von Mueller 17 (BM); Erskine Valley to summit of Mt. Gower, 17.v.1920. Boorman s.n. (NSW).

\section{Dracopbyllum involucratum Brongn. \& Gris}

Dracophyllum involucratum Brongn. \& Gris, Ann. Sci. Nat. Bot. (Fr.) 2: 157 (1864); Moore, Journ. Linn. Soc. Bot. 45: 349 (1921); Oliver, Trans. Proc. N.Z. Inst. 59: 714 (1928); Däniker, Viert. Nat. Ges. Zürich 78: 340 (1933); Oliver, Trans. Roy. Soc. N.Z. 80 (1): 17 (1952); Virot, Fl. Nov. Caléd. et Dépend. 6: 121 v(1975). Types: New Caledonia, montagne d'Yate. Vieillard 832 (P!, lecto., NSW!, P!) designated by Oliver (1952); New Caledonia, s. loc. Pancher 367 (P, lectopara.) designated by Virot (1975).

= Dracophyllum compactum S. Moore, Journ. Linn. Soc. Bot. $45: 349$ (1921). Type: New Caledonia, Plaine des Lacs, 23.ii.1914. R.H. Compton 371 (BM!).

Icones: Oliver, Trans. Proc. N.Z. Inst. 59: t. 25 (1928); Virot, Fl. Nov. Caléd. et Dépend. 6: t. 17 (1975).

\section{Description}

Trees 2-4 m tall. Branches spreading, sparsely branched. Bark on old branches grey to brown, smooth, young stems yellowish brown. Leaves spreading to recurved; lamina 
sheath light green to light brown, 40-48 $\times 25-30 \mathrm{~mm}$, coriaceous, striate, tapering and margin smooth or with the top half minutely ciliate; lamina with lower surface lighter green, linear-triangular to sometimes lanceolate, $(150-) 250-300(-500) \times 15-25(-30)$ $\mathrm{mm}$, surfaces glabrous, prominently striated; margins serrulate with 6-8 teeth per $10 \mathrm{~mm}$; apex acute to rarely obtuse. Inflorescence overtopping the leaves, erect, dense, 220-400 $\mathrm{mm}$ long, linear-oblong and densely branched; rachis and pedicels tomentose; inflorescence axis prominently ribbed, 4-7 $\mathrm{mm}$ in diameter; basal inflorescence branch 1-2 mm long, widely spreading; inflorescence bracts caducous, overtopping flowers, light green, ovate-lanceolate at base, $25-30(-40) \times 10-12 \mathrm{~mm}$, surfaces glabrous, margins ciliate. Flowers 400-600+, in groups of more than 10 at base of inflorescence, pedicellate; flower bracts persistent, shorter than flowers, coriaceous, ovate to broadly ovate, $2.5-4.0 \times 1.5-2.5 \mathrm{~mm}$, surfaces glabrous, striate, margins ciliate; apices acute; bracteoles caducous, situated at the base of the pedicel and the pedicel above the bracteoles covered in persistent bracts, shorter than the flower, $0.5-1.0 \times 0.1-0.2 \mathrm{~mm}$, glabrous; pedicels straight, (1.5-)4-12 mm long, tomentose. Sepals lanceolate to occasionally ovatelanceolate, $2.5-5.0 \times 2.0-2.5 \mathrm{~mm}$, shorter than the corolla tube, striate, surfaces glabrous; margins ciliate. Corolla white to greenish white; corolla tube narrowly campanulate; (2-)4$5 \times 1.4-1.5 \mathrm{~mm}$; corolla lobes reflexed, ovate-triangular, shorter than corolla tube, $1-2 \times$ 1.2-1.5 mm, apices obtuse; surfaces glabrous. Stamens adnate to top of corolla tube, filaments 1.0-1.5 mm long; anthers exserted, oblong and purple when young turning light yellow when mature and 1.2-1.5 mm long. Ovary subglobose to mainly obovate, 1.0-1.2 $\times 1.0-1.3 \mathrm{~mm}$, glabrous, apex round; nectary scales rectangular, $0.5-0.6 \mathrm{~mm}$, apices retuse to irregularly toothed; style included, 1.5-2.0 mm long, glabrous; stigma five-lobed. Fruit dark to reddish brown, 2-3 mm long and wide, obovoid, apex round, glabrous. Seeds brown, filiform, 0.9-1.0 mm long, testa slightly reticulate. Flowering October-April. (Figure 7.20). 


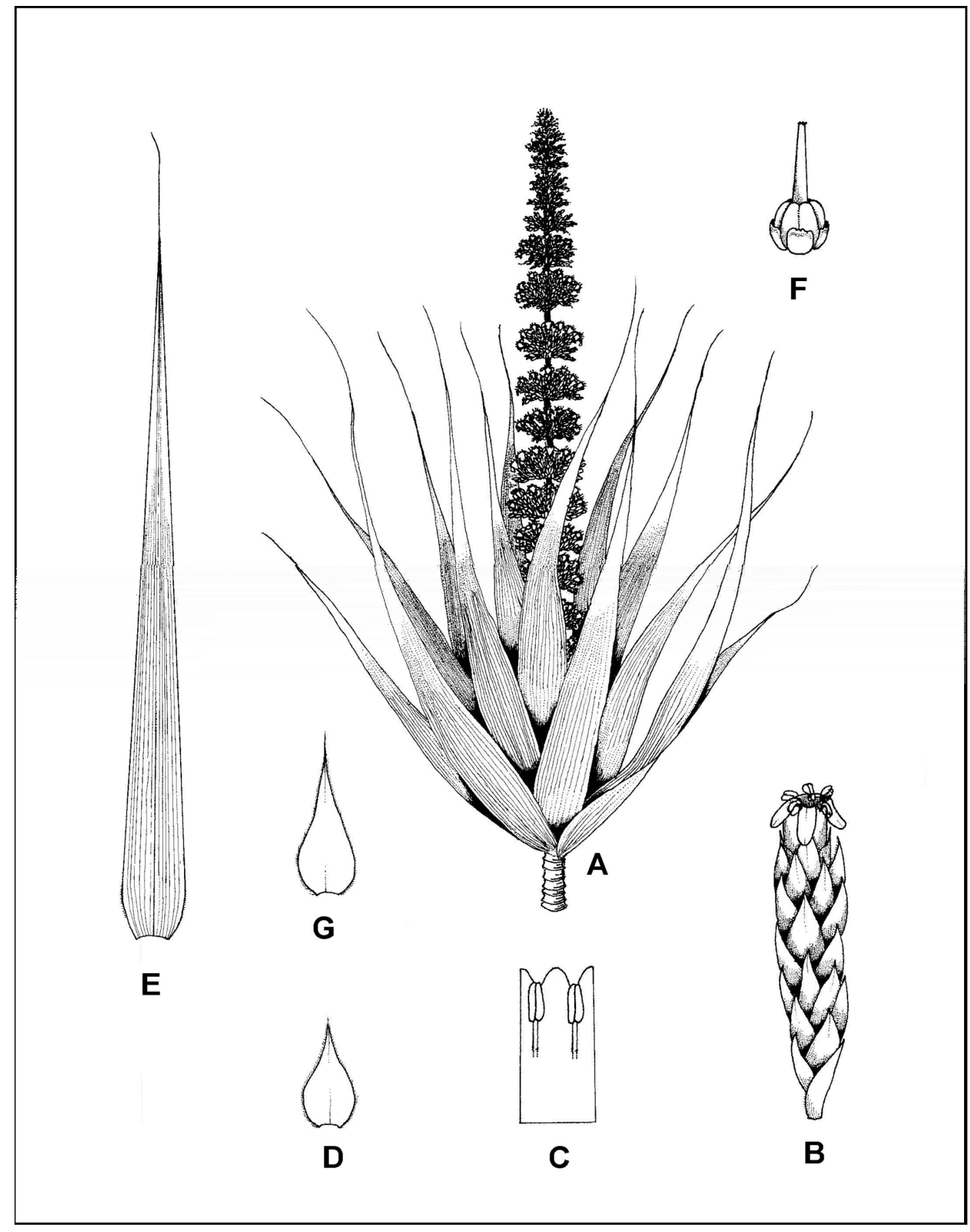

Figure 7.20. Dracophyllum involucratum. A, flowering branch $(\times 0.25)$; $\mathbf{B}$, flower $(\times$ 5); C, laid out corolla $(\times 5)$; $\mathbf{D}$, sepal adaxial surface $(\times 5)$; $\mathbf{E}$, leaf $(\times 0.5)$; F, ovary $(\times$ 10); G, inflorescence bract ( $\times 5)$. Drawn from MacKee 21621. 



Figure 7.21. Dracophyllum involucratum. A, habitat at Pic du Pin; B, adult plant in habitat, Pic du Pin; $\mathbf{C}$, the characteristic involucres with young fruit; mature plant in fruit showing the open branching habit and the dense flower bracts; $\mathbf{D}$, fruiting plant, Pic du Pin. C-D, Venter 13850. 


\section{Diagnostic features and discussion}

Dracophyllum involucratum is characterized by leaves having long drawn apices, remote minute teeth on the lamina margin, ribbed and densely tomentose rachis with flowers arranged in dense contracted clusters surrounding the rachis at regular intervals, peduncles clothed in persistent imbricating bracts and the narrow corolla tube.

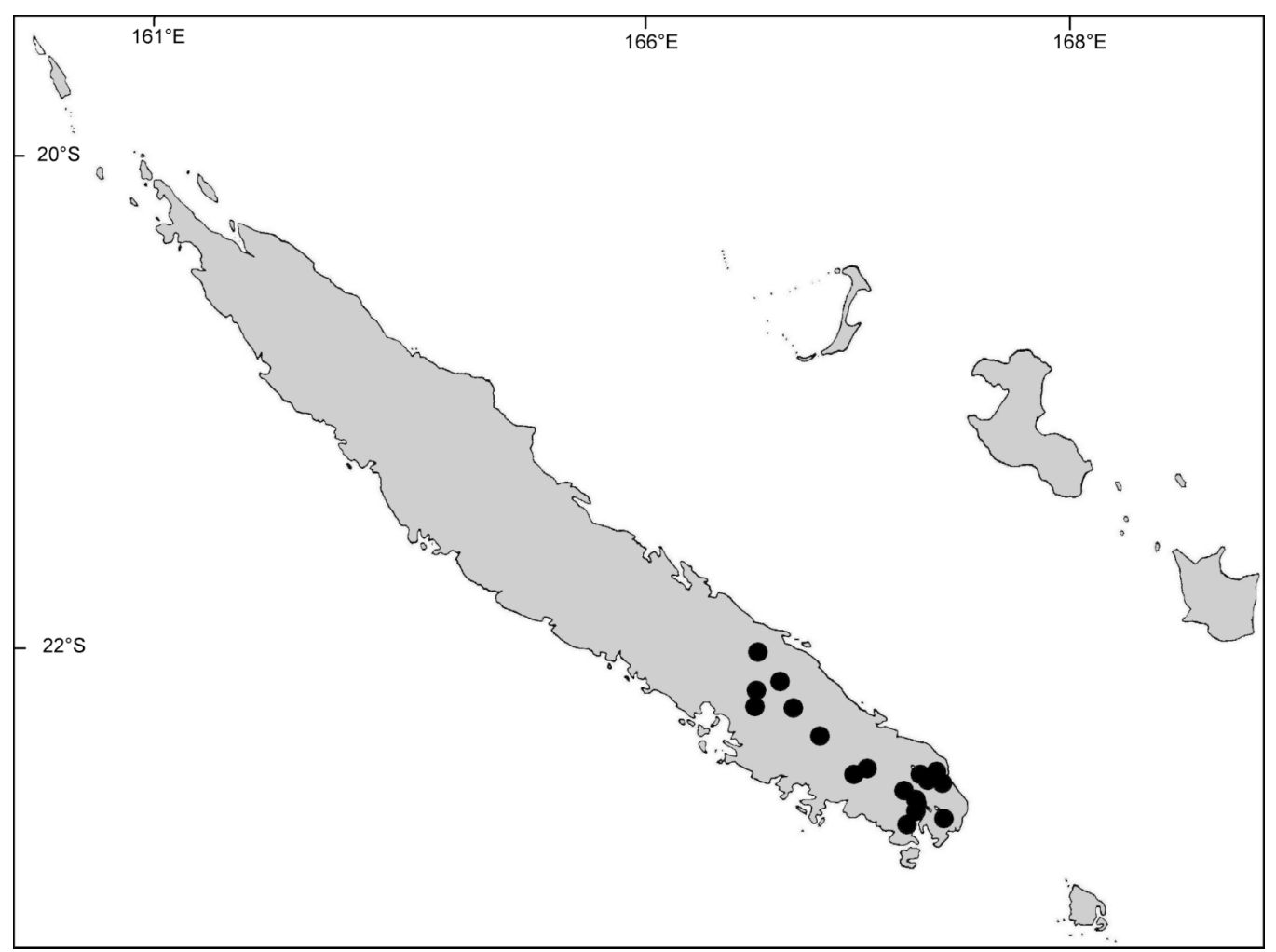

Figure 7.22. Known distribution of Dracophyllum involucratum.

D. involucratum is similar to D. sayeri, D. elegantissimum and D. fitggeraldii but can be distinguished by the flowers being in involucres and the pedicel of each individual flower covered with tightly overlaid persistent bracts. These characters prompted Oliver (1952) to describe the subgenus Cordophyllum to accommodate D. involucratum. The results of the cladistic (Fig. 2.1) and phenetic (Fig. 4.9) studies showed no support for the subgenus and it can thus not be kept separate. 


\section{Distribution}

New Caledonia endemic. Restricted to the montane areas east of Tontouta (Figure 7.22).

\section{Habitat}

Dracophyllum involucratum grows on mountain slopes, plateaus and in valley floors at altitudes of 150-1400 m. The vegetation consists of maquis and forest (Table 7.10). Soils are ferruginous, mostly rocky loam to clay loam and derived from peridotite or serpentinite. Plants grow mostly in full sun but some populations occur in light shade inside the forest.

Table 7.10. Plant communities commonly associated with Dracophyllum involucratum..

\section{MAQUIS}

Low open evergreen Tristaniopsis glauca - Xanthostemon aurantiacus - Pteridium esculentum maquis Low open evergreen Babingtonia leratii - Lomandra insularis - Hibbertia pancheri maquis

\section{Variation}

Dracophyllum involucratum is a species showing limited variation. Some variation occurs in inflorescence length $(220-400 \mathrm{~mm})$, flower bract size $(2.5-4.0 \times 1.5-2.5 \mathrm{~mm})$, sepal length $(2.5-5.0 \mathrm{~mm})$ and nectary scale apices that are either retuse or irregularly toothed.

\section{Specimens examined}

NEW CALEDONIA - 21-166: Mt. Kouakoué, 20.xi.1981. MacKee 39946 (NOU); ibid., 1.xii.2002. Tronchet 609 (NOU, MO). 22-166: Montagne des Sources (-BA), 01.iv.1968. Bernardi 12464 (K); ibid. 31.xii.1967. MacKee 18217 (L); Yate (-BB), 18.iii.1969. Jaffré 175 (NOU, P); ibid., 12.i.1951. Hürlimann 682 (Z); 4 km SE of S2 TER on road to Carenage, 19.vii.1977. Whaite 3697-11 (NSW); Track, c. $0.3 \mathrm{~km}$ off Carenage road, $2 \mathrm{~km}$ directly ENE of Pic du Pin, Weston 1685 (NOU, NSW); Creek Pernod, 22.iii.1967. Nothis 333 
(NOU); Vallée du Pernod, 9.iii.1967. Schmid 1956 (NOU); Chute de la Madeleine, 28.vi.1966. Schmid 1358 (NOU); Prony (-BD), xii.1913. Franc 1518 (Z); Plaine des Lacs, 06.ii.1926. Däniker 3074 (Z); ibid., 23.ii.1914. Compton 371 (BM); Plaine des Lacs, Ruisseau Pernod, 02.xi.1967. MacKee 17841 (L, NOU); ibid., 25.xii.1967. MacKee 18161 (K, L, NOU); Vallée des Lacs, 07.x.1950. Guillaumin \& Baumann-Bodenheim 6747 (Z); Ouénarou, 22.ii.1970. MacKee 21621 (K, L, NOU); Ouenghi, E de la Dent de Saint-Vincent (-CC), 22.xii.1970. MacKee 23100 (L); Pic du Pin, 14.v.2005. Venter 13850 (NOU).

\section{Dracopbyllum latifolium A.Cunn.}

Dracophyllum latifolium A.Cunn., Ann. Nat. Hist. 2: 48 (1839); De Candolle, Prodr. Syst. Nat. 7: 770 (1839); Hooker, Fl. Antart.: 48 (1844); Hooker, Fl. Nov. Zel. 2: 167 (1853); Hooker, Handb. N.Z. Fl.: 181 (1864); Kirk, Forest Fl. N.Z.: 251 (1889); Colenso, Trans. Proc. N.Z. Inst. 21: 92 (1889); Cheeseman, Man. N.Z. Fl.: 419 (1906); Cheeseman, Illustr. N.Z. Fl., t. 129 (1914); Cheeseman, Man. N.Z. Fl.: 701 (1925); Oliver, Trans. Proc. N.Z. Inst. 59: 711-712 (1928); Oliver, Trans. Roy. Soc. N.Z. 80 (1): 16 (1952); Allan, Fl. N.Z. 1: 537 (1961); Eagle, Trees \& Shrubs of N.Z.: 292 (1982); Salmon, Native Trees of N.Z.: 273 (1989); Poole \& Adams, Trees \& Shrubs of N.Z.: 164 (1994). Type: New Zealand, Bay of

Islands, dry woods on the Kana Kana [Kawakawa] River, 1826. A. Cunningham s.n. (BM, lecto.!; MEL!; WELT 79400! ), designated by Oliver (1952).

= Dracophyllum recurvatum Colenso, Trans. Proc. N.Z. Inst. 21: 92 (1889). Type: New Zealand, hills around Lake Waikare [Lake Waikaremoana], on high grounds, 2,000’-3,000', 1888. H.T. Hill \& T. Kirk s.n. (WELT 23606, holo.!; AK 6904!; K!; WELT!). 
= Dracophyllum latifolium A.Cunn. var. matthewsii Carse, Trans. Proc. N.Z. Inst. 48: 238

(1916). Type: New Zealand, near Kaitaia, Taumatamahoe, 1,900’, 2.x.1913.

H. Carse \& H.B. Matthews s.n. (CHR 332571, lecto.!, AK 6910!, AK6911!), designated by Oliver (1952).

$=$ Dracophyllum matthewsii Carse, Trans. Proc. N.Z. Inst. 56: 86 (1926); Oliver, Trans. Roy. Soc. N.Z. 80 (1): 16 (1952).

Icones: Kirk, Forest Fl. N.Z.: t. 123 (1889); Cheeseman, Illustr. N.Z. Fl., t. 129 (1914); Eagle, Trees \& Shrubs of N.Z.: tt. 129A \& 129B (1982); Salmon, Native Trees of N.Z.: 271 (1989).

\section{Description}

Tree 3-10 m tall. Branches form an open candelabrum-shaped crown. Bark on old branches greyish-brown to brown, rough or flaky, young stems yellowish brown. Leaves crowded at tips of branches in a bromelioid manner; lamina sheath 30-65 $\times 18-55 \mathrm{~mm}$, striate, membranous, tapering and margin smooth; lamina linear-triangular to rarely lanceolate, $(100-) 145-700(-800) \times 12-30 \mathrm{~mm}$, surfaces glabrous, prominently striated; margins serrate to denticulate with 2-4 teeth per $10 \mathrm{~mm}$; apex thickened. Inflorescence shorter than leaves, erect to drooping, dense, 100-340(-400) $\mathrm{mm}$ long, oblong to pyramidal and densely branched; rachis and pedicels pubescent to tomentose; inflorescence axis yellowish to light green, 15-20 $\mathrm{mm}$ in diameter; basal inflorescence branch 30-60 mm long, sub erect to at right angles with inflorescence axis; inflorescence bracts caducous, overtopping flowers, whitish at base and pink tipped, broadly ovate to ovate-triangular at base, 105-180(-210) × 20-35 mm, surfaces glabrous, margins ciliate, apices acute. Flowers 600-2000+, in groups of 5-10 at base of inflorescence, pedicellate; 
bracteoles caducous, recaulescent, with one bracteole situated just below the perianth and the other in the middle of the pedicel, shorter than flower, (1.5-)2.0-5.5 $\times 0.5-1.7 \mathrm{~mm}$, glabrous; pedicels straight, $1.0-2.5 \mathrm{~mm}$ long, pubescent to tomentose. Sepals broadly ovate to triangular, $0.7-1.5 \times 1.0-1.7 \mathrm{~mm}$, shorter than the corolla tube, striate, adaxial surfaces glabrous; abaxial surfaces pubescent; margins with upper third toothed. Corolla dark pink to dark red; corolla tube campanulate to broadly campanulate, widened at mouth, 1.5-2.0 $\times 1.5-2.5 \mathrm{~mm}$; corolla lobes reflexed, oblong to ovate-triangular, longer than corolla tube, 1.5-2.0 long and wide, apices obtuse, rarely subacute; surfaces glabrous. Stamens inserted at top of corolla tube, filaments (0.5-)1.0-1.2 mm long; anthers exserted, rectangular, pink turning light yellow with age and 1.3-1.5 mm long. Ovary ovate, $0.8-$ $1.0 \times 1.0-1.5 \mathrm{~mm}$, glabrous, apex round; nectary scales rectangular to oblong, $0.6-1.2 \times$ 0.8-1.0 mm, apex retuse to irregularly toothed; style exserted, 1.0-1.7 mm long, glabrous; stigma clavate to five-lobed. Fruit not included in persistent calyx, reddish to purplish brown, 1-2 $\times 2-3(-4) \mathrm{mm}$, depressed-globose, apex round and glabrous. Seeds yellowish brown, ovoid, $1.2-1.3 \mathrm{~mm}$ long, testa slightly reticulate. Flowering September-May. (Figure 7.23).

\section{Diagnostic features and discussion}

Dracophyllum latifolium is characterized by the rough to flaky bark; leaves recurved in a bromelioid manner, glabrous, thinly textured; panicle slender, erect or drooping with the pubescent branches at 


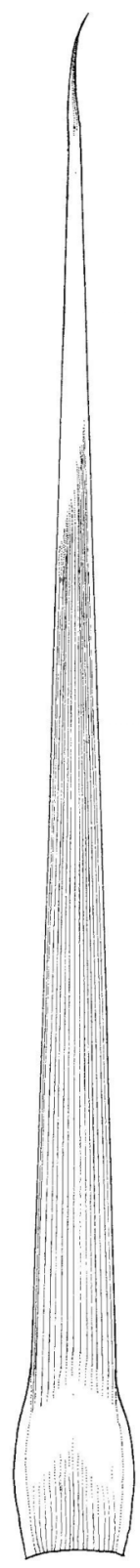

E

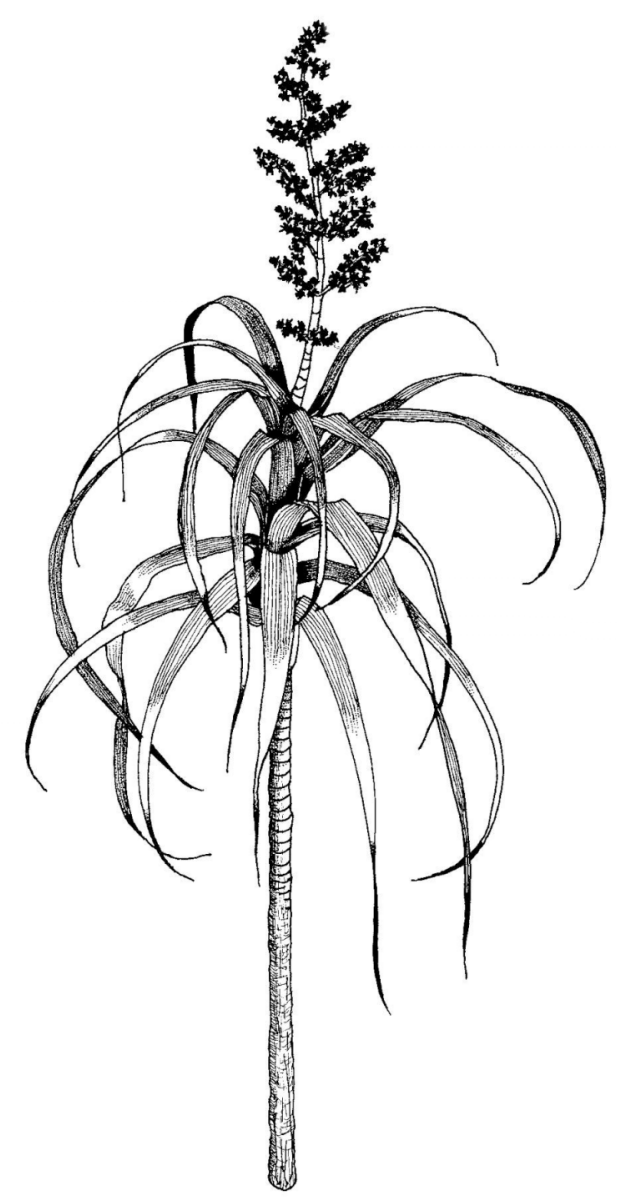

A

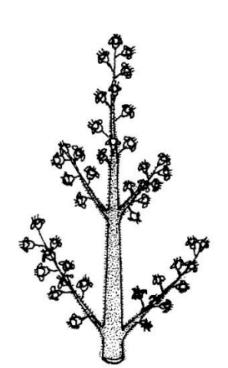

D

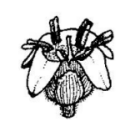

C

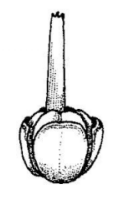

$\mathbf{F}$

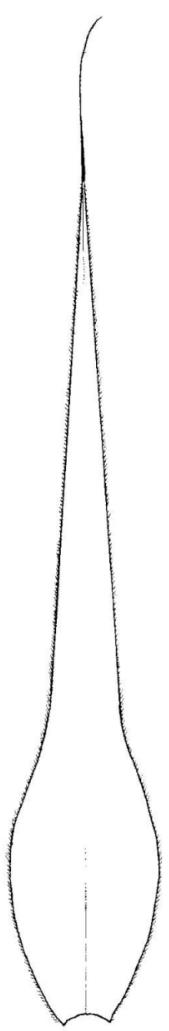

B

Figure 7.23. Dracopbyllum latifolium. A, flowering branch $(\times 0.25)$; $\mathbf{B}$, inflorescence bract $(\times 1)$; $\mathbf{C}$, flower $(\times 5)$; $\mathbf{D}$, lower inflorescence branch $(\times 1) ; \mathbf{E}$, leaf adaxial surface $(\times 0.5) ; \mathbf{F}$, ovary $(\times 10)$. Drawn from Venter 13764 . 

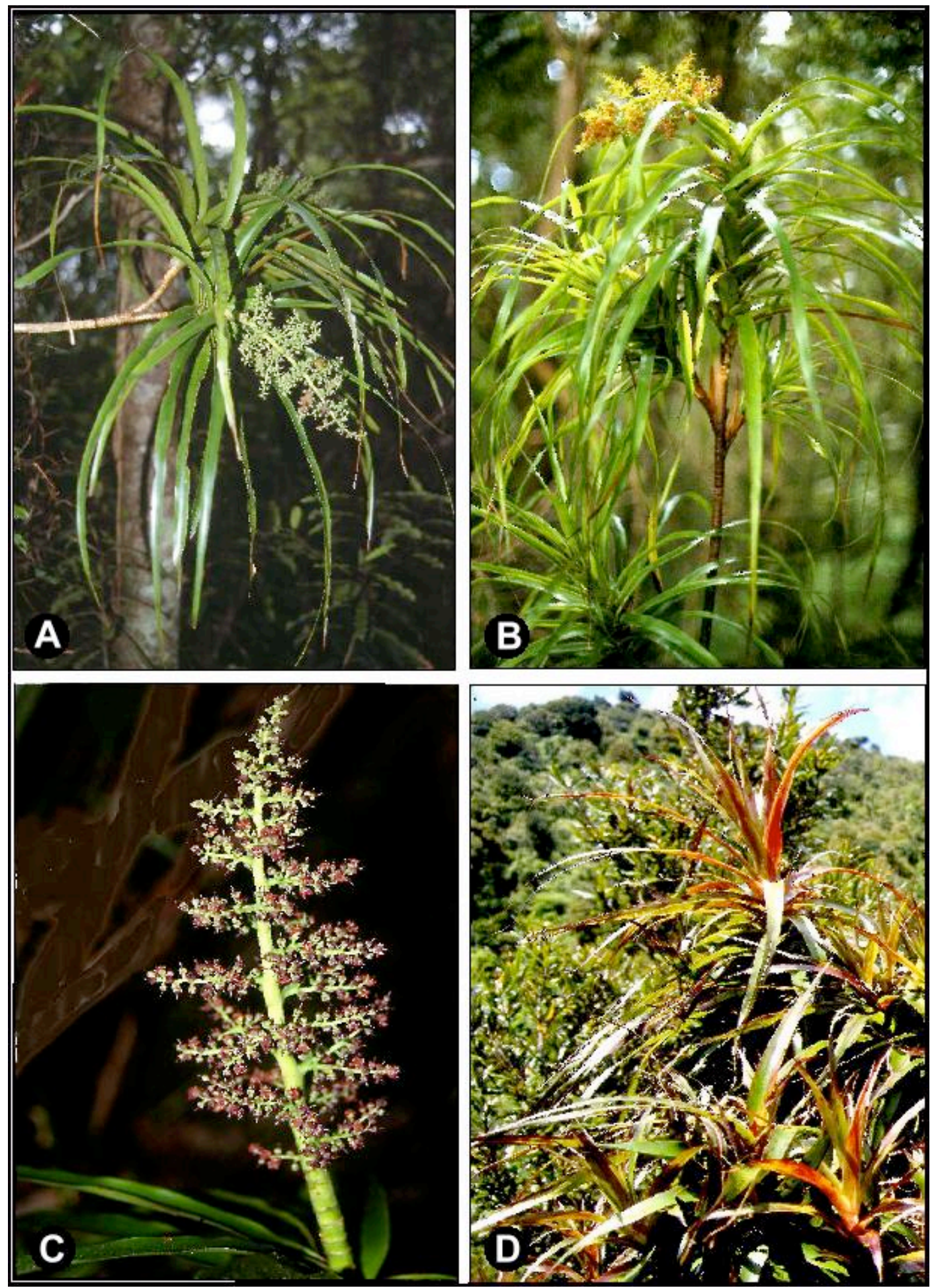

Figure 7.24. Dracopbyllum latifolium. A, plant with drooping inflorescence $(=D$. matthewsii) from Mt. Kaitarakihi on the Coromandel Peninsula; B, flowering plant from Mt. Rowe; C, inflorescence from a specimen growing on Mt. Kaitarakihi; D, plant growing in full sun in an exposed habitat with shorter and wider leaves. $\mathbf{A}$ and $\mathbf{C}$, Venter 13764. 
acute angles, flowers purplish-red, capsules $2.0-2.5 \mathrm{~mm}$ in diameter with the pedicels 1.5-2.5 mm long. Young plants form erect unbranched stems with a tuft of leaves at the top, a character shared with $D$. fiordense, D. fitzgeraldii, D. elegantissimum, D. involucratum, $D$. ramosum, $D$. townsonii, $D$. traversii and $D$. verticellatum. Dracophyllum latifolium is similar to $D$. traversii but differs in having narrower leaves (12-30 mm compared to $40-50 \mathrm{~mm}$ ), lamina margin serrate to denticulate (not serrulate) and having fewer teeth on the lamina margin (2-4 compared to 18-20 per $10 \mathrm{~mm}$ ). The flowers are in groups of 5-10 (compared to more than 10), sepals shorter than the corolla tube longer with the upper half distinctly toothed not ciliate, corolla tube shorter and narrower, ovary ovate and much smaller with the seeds larger than that of D. traversii.

Oliver (1928; 1952) and Allan (1961) kept D. matthewsii separate from D. latifolium on the basis of the drooping inflorescence. In many $D$. latifolium populations drooping inflorescences occur together with erect inflorescences making this an unreliable character to separate species.

\section{Distribution}

Endemic to the North Island of New Zealand (Fig. 7.26). The known localities are north of a line from Mt. Egmont to Hawke's Bay.

\section{Habitat}

Dracophyllum latifolium occurs on gentle to steep $\left(0^{\circ}-70^{\circ}\right)$ slopes in river valleys, along stream banks and on mountain slopes from sea level to 1,100 m altitude. Most localities known are from low altitude areas and covered in lowland to montane forest, woodland or shrubland (Table 7.11). D. latifolium is an important element of the small tree and 
shrub tier of the low altitude conifer/broad-leaved forest (Wardle 1964, 2002). Soils are brown sandy loam derived from calcareous sandstone and greywacke or dark brown clay loam or clay derived from andesite, basalt, rhyolite, siltstone and

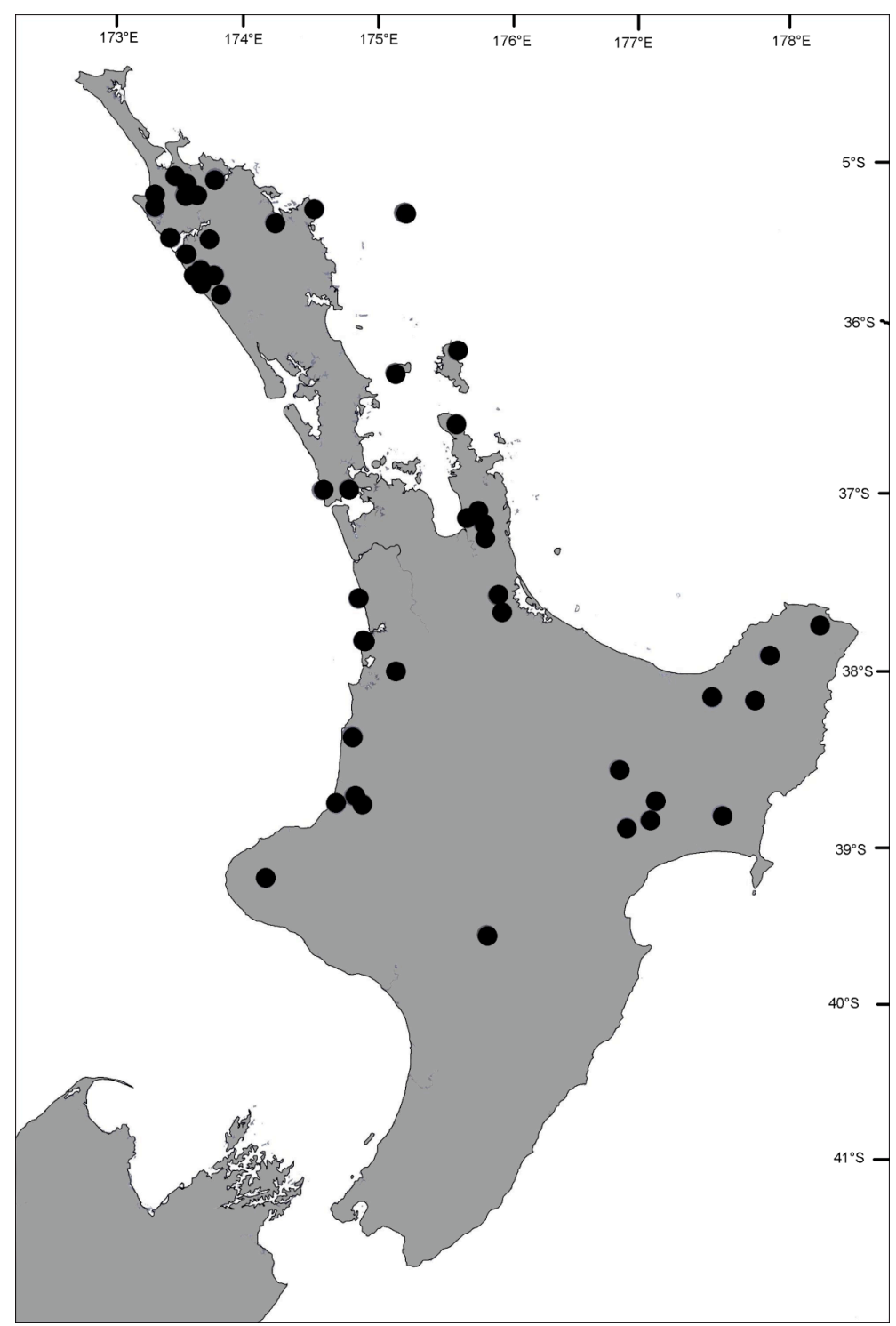

Figure 7.25. Known distribution of Dracophyllum latifolium. North Island, New Zealand. 
mudstone. D. latifolium sometimes grows in full sun but is primarily a shade lover of forest communities. It is not known to occur in areas that are exposed to salt spray.

Table 7.11. Plant communities commonly associated with Dracophyllum latifolium.

\begin{tabular}{|l|}
\hline FOREST \\
\hline High closed evergreen Dysoxylum spectabile - Agathis australis forest \\
Tall closed evergreen Knightia excelsa - Freycinetia baueriana subsp. banksii - Astelia fragrans forest \\
Tall closed evergreen Weinmannia silvicola - Beilschmiedia tawa forest \\
Tall closed evergreen Quintinia serrata - Weinmannia silvicola forest \\
Tall open evergreen Nothofagus menziesii forest \\
Low closed evergreen Melicytus ramiflorus - Freycinetia baueriana ssp. banksii - Dicksonia squarrosa \\
Low open evergreen Nothofagus truncata forest \\
\hline WOODLAND \\
\hline High closed evergreen Dysoxylum spectabile - Agathis australis woodland \\
\hline
\end{tabular}

\section{Variation}

Inflorescences are erect in the southern populations but drooping in some northern populations. Carse described plants with drooping inflorescences under the name Dracophyllum matthewsii. Inflorescence bracts vary from broadly ovate to ovate-triangular and can sometimes be short and narrow, especially in populations growing in full sun. Sepal size varies $(0.7-1.5 \times 1.0-1.7 \mathrm{~mm})$ with corolla lobes being oblong to ovatetriangular and this does not seem to be associated with specific populations. The nectary scales show variation in shape (rectangular to oblong), size $(0.6-1.2 \times 0.8-1.0 \mathrm{~mm})$ and shape of the apices (retuse to irregularly toothed).

\section{Specimens examined}

NEW ZEALAND. North Island. 35-173: Near Kaitaia (-AA), i.1913. Matthews \& Carse s.n. (CHR); Manganui County, Kaiaka (-AB), 3.i.1904. Carse s.n. (CHR); Pukepoto (AD), 1.x.1915. Carse \& Matthews s.n. (CHR); Maungataniwha (-BA), xi.1920. Carse 7573 (K); Puketi State Forest, Pukatea Ridge Track. 9.x.1973. Orchards 4075 (AK); North of Whangaroa Harbour. 27.ix.1990. Wright 10520 (AK, HO); Mokau Range, Puketi Forest 
Reserve (-BB), 9.iv.1973. Van Steenis 22347 (L); Puketi forest, leading ridge $\mathrm{N}$ of Opaopao Stream (-BC), 15.viii.1984. Bellingham s.n. (AK); Bay of Islands, Kerikeri (-BD), ix.1977. Bartlett \& O’ Brien s.n. (CHR); Waima Forest (-CB), ix.1991, Druce 627 (CHR); Waipoua State Forest, 2 miles S of Headquarters (-DA), 12.iv.1972. Rawlings, Esler, Smith \& Astridge 3830 (CHR); Otaua, xi.1874. Berggren s.n. (W). 35-174: Bay of Islands, E of Paihia, near Nagiotonga, 19.iv.1966. Lamoureux 3700 (CHR); Bay of Islands, Cape Brett (-AD), ix.1964. Collett s.n. (CHR). 36-174: Little Barrier Island (-BB), vii.1949. Parkin s.n. (CHR); Wayby (-BC), 31.i.1944. McKenqie s.n. (AK); Piha Valley, Kauri Forest (-CD), 14.ii.1965. Moore s.n. (CHR); Auckland, Piha Road (-CD), 26.ii.1973. Gardner 572 (CHR); Te Aroha Mountain, Swanson (-DC), ix.1944. Carnahan s.n. (MPN). 36-175: Little Barrier Island (-AA), Shakespear 129 (AK, K); Great Barrier Island (-AB), T. Kirk s.n. (CHR); Coromandel Peninsula, Port Charles (-CB), i.1948. Hutson s.n. (CHR); 37-175: Mt. Kohukohunui summit (-AA), 3.xi.1939. Molesworth s.n. (AK); Thames (-BA), Petrie s.n. (Z); Thames, Mt. Kaitarakihi, 12.ii.1999. Venter 13763 (CHR); Thames, First Lookout, iii.1970. Druce s.n. (CHR); Kauaeranga Valley, Table Mountain, iv.1971. Druce s.n. (CHR); Upper Kauaeranga Valley. 17.viii.1966. Chinnock s.n. (WELTU); Mt. Te Aroha, near top (-DA), 2.vii.1939. Molesworth s.n. (AK); Kaimai Range, Ngatamahinerua (-DB), vii.1977. Bartlett s.n. (CHR); 37-174: Huia, Rickard's Bush (-CA), 6.viii.1949. Wood s.n. (AK). 37176: Tauranga, McLaren's Falls (-CC), Simpson 1960 (CHR); 37-177: Raukumara Range, Mt. Honokawa (-DD), ii.1969. Druce s.n. (CHR); 37-178: Pukeamaru (-CB), i.1983. Druce s.n. (CHR); Raukumara Range, Mt. Aorangi (-CC), i.1983. Druce s.n. (CHR). 38-174: Herangi Range, Mangatoa Road near Saddle (-BC), iii.1972. Druce s.n. (CHR); E of Pehimatea, 2 km inland, Garrick s.n. (CHR); Marokopa, Waitomo. 5.ii.1957. Franklin s.n. (WELTU); Herangi Range, near Te Kuiti (-DB), ii.1983. Druce s.n. (CHR); Tongaporutu River W bank, near Ahititi turnoff (-DC), 16.v.1978. Ogle s.n. (CHR); Hutiwai Valley, 15.ii.1996. Heaphy s.n. (CHR); Waitaanga Plateau (-DD), ii.1967. Druce s.n. (CHR); 38- 
175: Pirongia (-AA), ii.1968. Bell s.n. (CHR); Mt. Pirongia peak. 31.iii.1940. Molesworth s.n. (AK); Pukeatua (-BA), Reischeck s.n. (W). 38-177: Raukamara Range, SW spur leading to Arowhana (-BB), 15.x.1964. Fryer s.n. (CHR); Urewera National Park, Lake Waikareiti, Sandy Bay (-CA), iv.1973. Druce s.n. (CHR); Waikaremoana, between Lake House and Aniwahiwa (-CC), 28.viii.1966. Lambrechtsen s.n. (CHR); Mt. Whakapunake (-DC), xii.1967. Druce s.n. (CHR); Raukamara Range, Mt. Honokawa (-DD), ii.1969. Druce s.n. (CHR). 39-176: Mt. Hikurangi (-CC), 14.ii.1966. Burke s.n. (WELTU).

\section{Dracopbyllum mackeeanum S. Venter}

Dracophyllum mackeeanum S. Venter, N.Z. Journ. Bot. 42: 747-751 (2004). Virot, Fl. Nov. Caléd. et Dépend. 6: 147-151 p.p. (1975). Type: New Caledonia, Province Sud, Upper Rivière Tontouta, near Mine Gallieni, 25.xii.1960, H.S. MacKee 7745 (holo.!, NSW 461862, CANB, L!).

Icon: Virot, Fl. Nov. Caléd. et Depend. 6: t. 26 (1975) (as D. ramosum); Venter, N.Z. Journ. Bot. 42: 748, t. 1 (2004).

\section{Description}

A fairly compact and multi-stemmed shrub, up to $1.5 \mathrm{~m}$ tall Branches. Bark on old stems greyish brown with spaced deep furrows, young stems yellowish to reddish brown, smooth and covered with fine whitish antrorse, multicellular hairs. Leaves erectspreading; lamina sheath slightly wider than the lamina, light brown to reddish brown, 10$16 \times 7.0-9.6(-13.35) \mathrm{mm}$, coriaceous, striate, shoulder tapering with the top half shortly ciliate; lamina coriaceous, light green to dark green above and lighter beneath, elongate- 
triangular, $27.8-58.6(-128) \times 3.8-7.8(-11.53) \mathrm{mm}$, flat, adaxial surface glabrous to pubescent but abaxial surface tomentose, prominently striated; margins serrulate with 22-40 teeth per $10 \mathrm{~mm}$; apex subacute to obtuse. Inflorescence exceeding the leaves, erect, dense, $72.0-81.5 \mathrm{~mm}$ long, linear-oblong and sparingly branched; rachis and pedicels white pubescent; inflorescence axis prominently ribbed, $2.0-2.7 \mathrm{~mm}$ in diameter at base; basal inflorescence branch 5- $12 \mathrm{~mm}$ long, sub erect; inflorescence bracts caducous, longer than flowers, straw yellow tinged pink to light red, broadly ovate at the base with apices drawn-out, 15-23 × 10-15 mm; adaxial surfaces glabrous, apices pubescent, abaxial surfaces white tomentose, margins ciliate. Flowers 26-32, arranged in groups of three on the basal inflorescence branches, pedicellate; bracteoles persistent, recaulescent with one bracteole situated just below the perianth and the other in the middle of the pedicel, shorter than flower, weakly keeled, 3-4 $30.2-0.5 \mathrm{~mm}$, ciliate; pedicels fused at base and flattened, middle pedicel longest, $1.5-3.0 \times 0.5 \mathrm{~mm}$, tomentose, lateral pedicels $1.5-2.0 \times 0.5 \mathrm{~mm}$. Sepals rose to light pink, ovate-lanceolate, $4-6 \times 1.5-1.7$ $\mathrm{mm}$, equal to or longer than corolla tube, striate, adaxial surface glabrous, abaxial surface pubescent; margin ciliate. Corolla white; corolla tube cylindrical, 4.5-5.0 × 1.2-1.3 mm, exterior pubescent in distal part, slightly verrucose inside; corolla lobes spreading to horizontal, broadly lanceolate, shorter than corolla tube, $2.0-2.7 \times 1.2-1.5 \mathrm{~mm}$, margin laciniate; adaxial surface papillate, abaxial surface pubescent, apex obtuse. Stamens inserted at mid-point of corolla tube; filaments 1.0-1.5 mm long; anthers included, oblong, light yellow, 0.5-0.7 mm long. Ovary ovate, $0.9-1.0 \mathrm{~mm}$ long and wide, glabrous, apex round; nectary scales rectangular, 0.6-0.7 $\times 0.4-0.5 \mathrm{~mm}$, apices retuse; style included, 0.95$1.0 \mathrm{~mm}$ long, glabrous; stigma included, 5-lobed. Fruit light to dark brown, 1.5-2.0 mm long and wide, apex round, glabrous. Seed yellowish brown, ovoid, 0.75-0.8 mm long, with slightly reticulate testa. Flowering October-December. (Figure 7.26). 


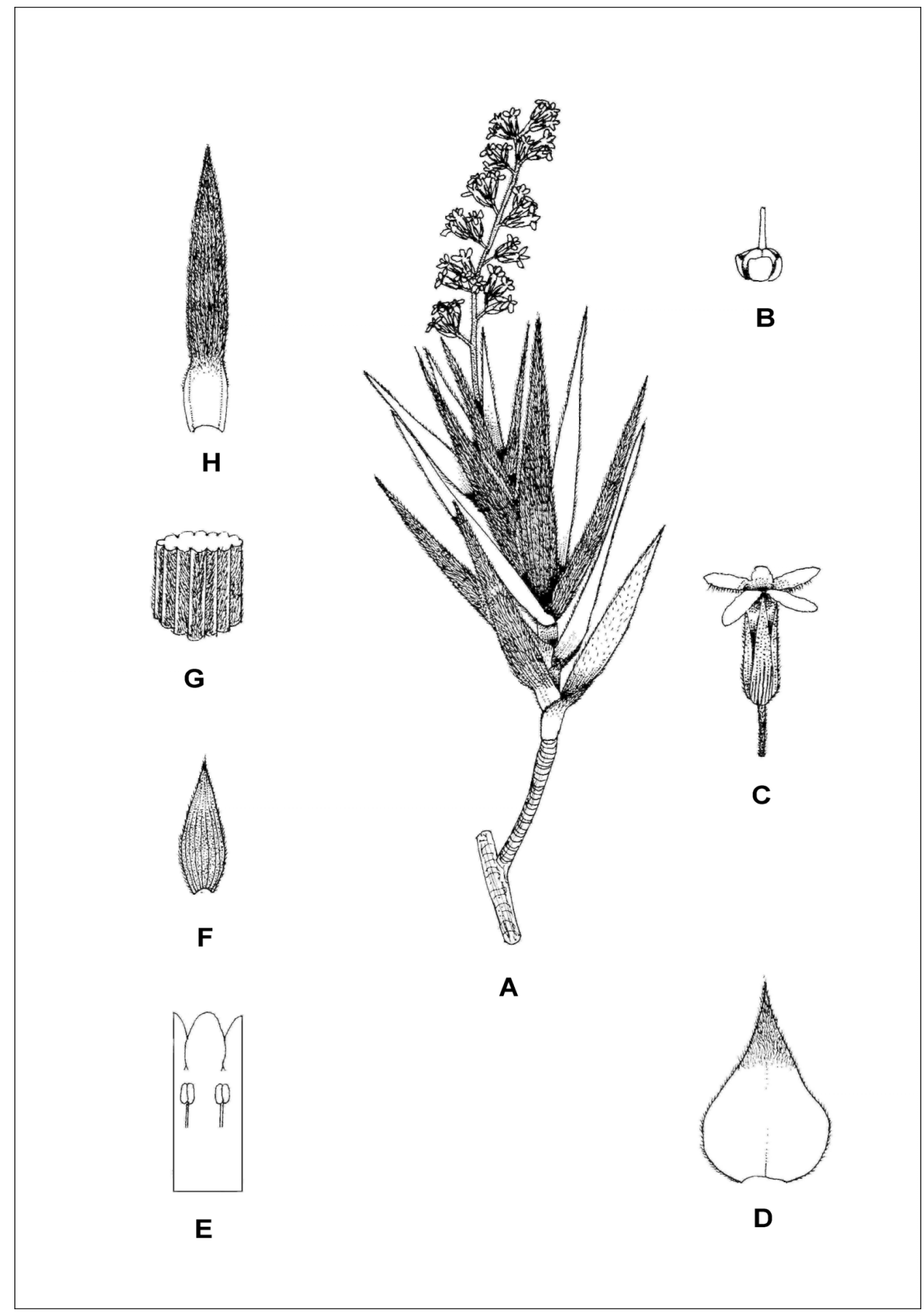

Figure 7.26. Dracopbyllum mackeeanum. A, flowering branch $(\times 1)$; $\mathbf{B}$, ovary $(\times 10)$; $\mathbf{C}$, flower $(\times 5)$; $\mathbf{D}$, inflorescence bract adaxial surface $(\times 2) ; \mathbf{E}$, laid out corolla $(\times 5) ; \mathbf{F}$, calyx $(\times 5)$; G, cross-section through inflorescence axis $(\times 10) ; \mathbf{H}$, leaf $(\times 1)$. Drawn from MacKee 7745 . 


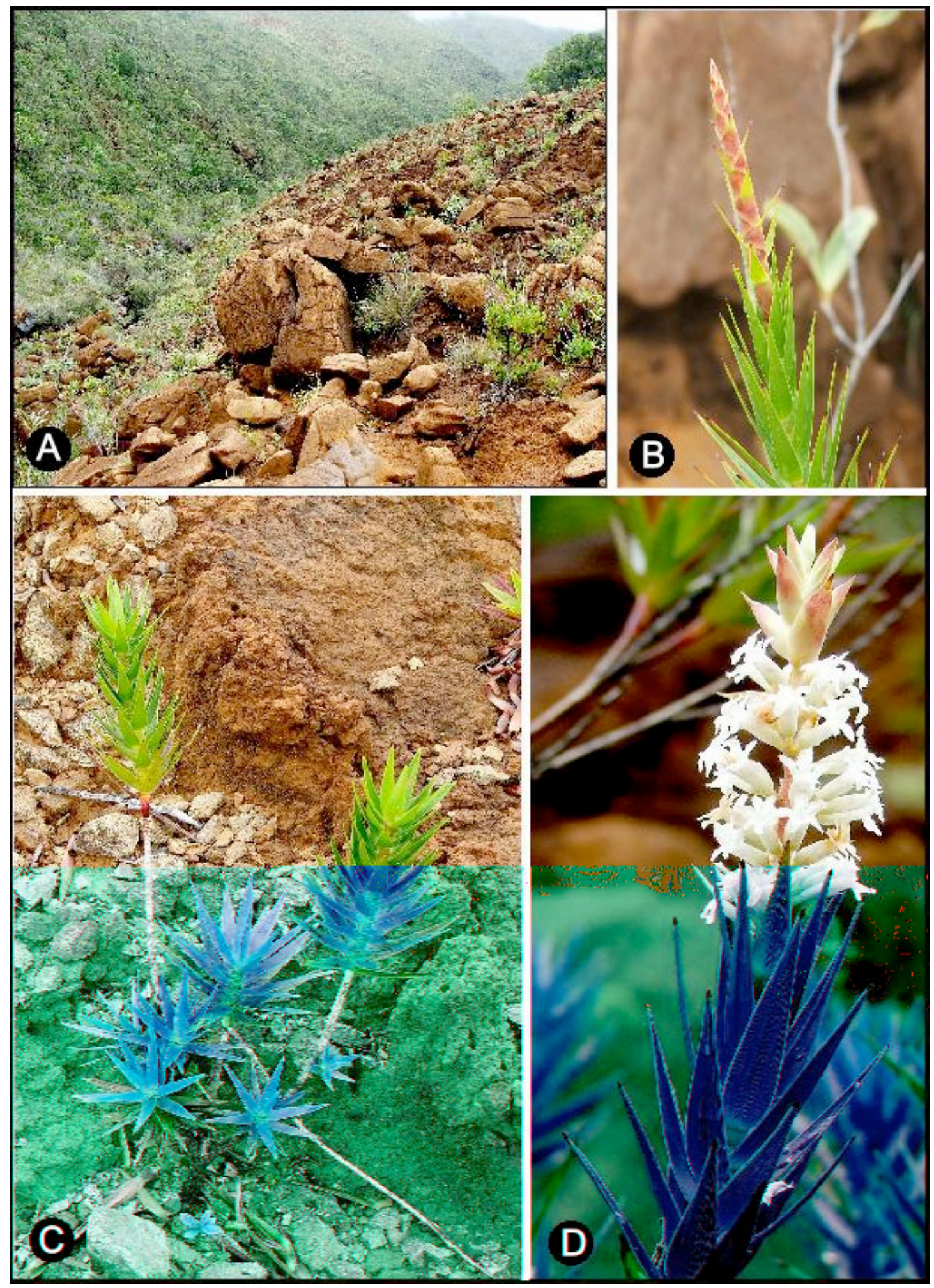

Figure 7.27. Dracopbyllum mackeeanum. A, habitat along the To De River near Thio; $\mathbf{B}$, young inflorescence showing the shape of the inflorescence bracts; $\mathbf{C}$, mature plant; D, flowering branch (Venter 13847). 


\section{Diagnostic features and discussion}

Dracophyllum mackeeanum is characterized by the young stems covered in fine whitish hairs lying flat on the surface, leaves glabrous to pubescent adaxially and tomentose abaxially, striate and light green; prominently ribbed and white pubescent inflorescence axis, abaxially whitish tomentose inflorescence bracts with flowers arranged in groups of three on the basal inflorescence branches, base of pedicels fused and flattened, cylindrical corolla tube being $4.5-5.0 \mathrm{~mm}$ long with the distal part of the outer surface pubescent, broadly lanceolate corolla lobes that are abaxially pubescent with laciniate margins and stamens inserted in the mid-point of the corolla tube.

Table 7.12. Major morphological differences between Dracophyllum mackeeanum and D. ramosum.

\begin{tabular}{|l|l|l|}
\hline \multicolumn{1}{|c|}{ Character } & \multicolumn{1}{|c|}{ D. mackeeanum } & \multicolumn{1}{c|}{ D. ramosum } \\
\hline & & \\
Lamina size (mm) & $28-59 \times 4-8$ & $65-125 \times 6-11$ \\
Inflorescence axis & ribbed & smooth \\
Basal inflorescence branches (mm) & $5-12$ & $0.8-1.0$ \\
Inflorescence bracts length (mm) & $15-23$ & $(10-) 22-70$ \\
Inflorescence bract adaxial surface & pubescent at apex & glabrous \\
Inflorescence bract length & $14.5-23.0$ & $22-70$ \\
Number of flowers/ inflorescence & $25-33$ & $65-350$ \\
Abaxial surface of sepal & pubescent & glabrous \\
Corolla tube diameter (mm) & $1.2-1.3$ & $2.3-2.5$ \\
Corolla lobe size (mm) & $2.0-2.7 \times 1.2-1.5$ & $1.5-1.7 \times 1.0-1.1$ \\
Stamen fusion & lower third of tube & upper third of tube \\
Filament length & $1.0-1.5$ & $1.5-1.7$ \\
Nectary scale apices & retuse & irregularly toothed \\
Seed length (mm) & $0.75-0.8$ & $0.48-0.5$ \\
\hline
\end{tabular}

Dracophyllum mackeeanum is similar to D. ramosum (Table 7.12.) but there is no marked difference between the leaves of the vegetative branch and that of the flowering branch. Virot (1975) confused D. mackeeanum with D. ramosum and thought it to be just another 
variation in branching, leaf and inflorescence characters, not realizing the stability of these characters.

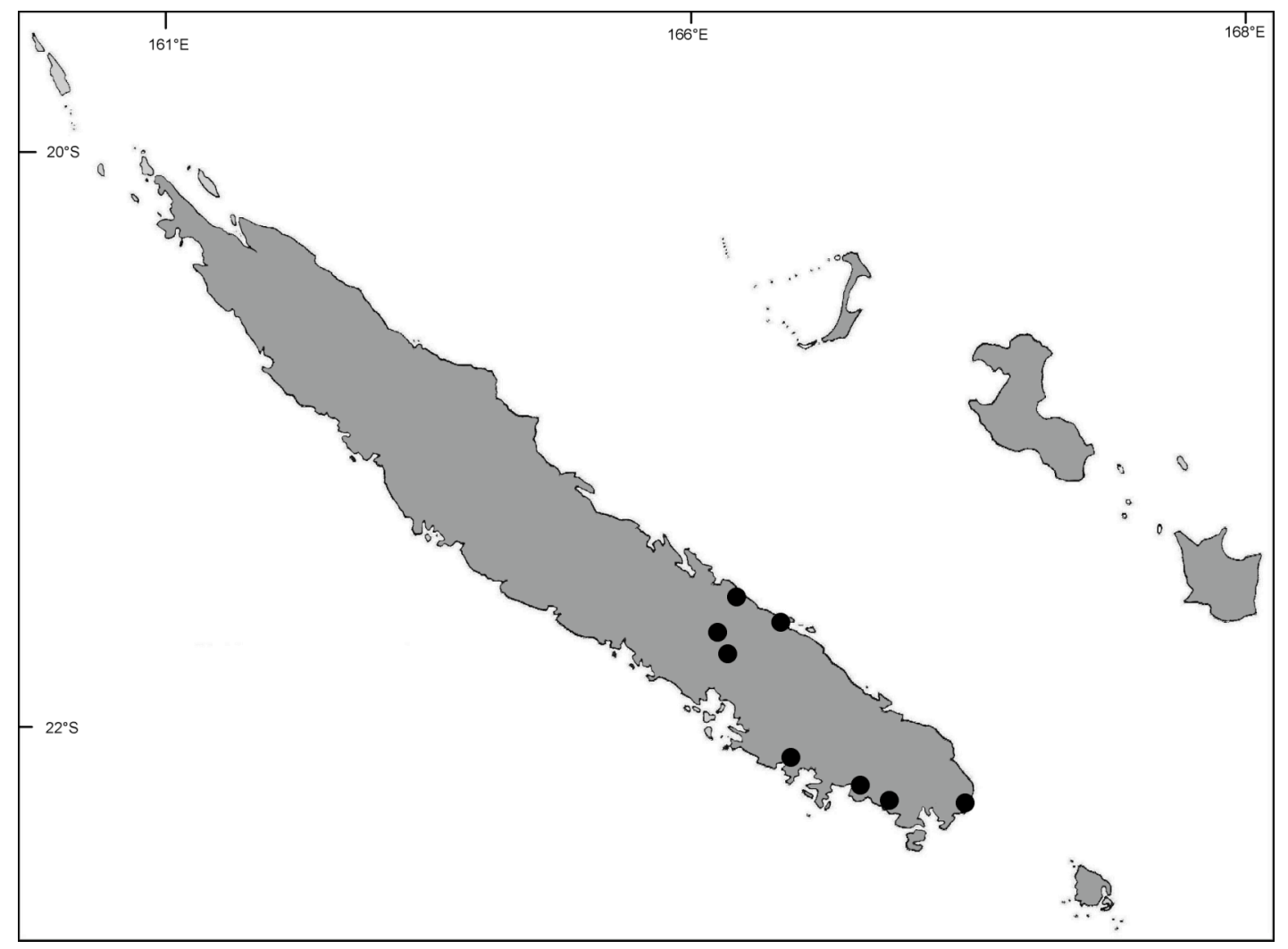

Figure 7.29. Known distribution of Dracophyllum mackeeanum

\section{Distribution}

New Caledonian endemic. Restricted to the Thio, Tontouta and Dombea Valleys (Fig. 7.29).

\section{Habitat}

Dracophyllum mackeeanum occurs on gentle $\left(5^{\circ}-15^{\circ}\right)$ to steep $\left(40^{\circ}-50^{\circ}\right)$ hill slopes at 200 $600 \mathrm{~m}$ altitudes. It is restricted to low maquis vegetation (Table 7.13) in exposed open areas. Soils are rocky clay loam derived from serpentinite. 
Table 7.13. Plant communities commonly associated with Dracophyllum mackeeanum..

MAQUIS
Low open evergreen Pancheria vieillardii - Styphelia albicans - Scaevola beckii maquis
Low open evergreen Oxanthera neocaledonica - Dracophyllum ramosum - Costularia pubescens maquis
Short open evergreen Xeronema moorei - Metrosideros tetrasticha - Drosera neocaledonica maquis

\section{Variation}

Dracophyllum mackeeanum is a species having some variation in the leaf size $(27.8-58.6 \times$ $3.8-7.8 \mathrm{~mm}$ ) and with $22-40$ teeth per $10 \mathrm{~mm}$ on the lamina margin. Basal inflorescence branches can vary from 5-12 $\mathrm{mm}$ long and the inflorescence bract size is $15-23 \times 10-15$ $\mathrm{mm}$. Occasionally one or two plants in a population have flowers with sepals equaling the corolla tube in length (MacKee 3480).

\section{Specimens examined}

New Caledonia. 21-166: Montagnes de la Dombea (-AB), Vieillard 2831 (NSW); 5 miles NW of Thio on road to Canala (-CA), 25.vii.1952. McMillan 5159 (L); Combui Concession SLN, 18.xii.2002. Dagostini \& Rigault 575 (NOU); Thio-Canala, vallée de la Nekuitourou, 29.xii.1977. Bamps 6099 (NOU); Valley of the Dothio River, c. 12 km NW of Thio, 17.xii.1973. Webster 19349 (NOU); Route de Port-Bouquet, $10 \mathrm{~km}$ from Thio, 06.xii.1965. MacKee 14017 (NOU); Thio area, c. $2 \mathrm{~km}$ upstream along the To De River, 13.v.2005. Venter 13847 (NOU); Upper Tontouta Valley, hillside (-CD), 20.xi.1955, MacKee 3480 (L); Col de Vulcain, 24.ix.1951. Baumann-Bodenheim 15540 (Z); Bord de la Tontouta, mine Liliane, 15.xii.1964. Blanchon 1297 (NOU); Mt. Humboldt, 17.v.2005. Venter 13854 (NOU). 22-166: Col de Ouirange (-BA), 14.v.2005. Venter 13852 (NOU). 
Dracophyllum macranthum E.A. Br. \& N. Streiber, Telopea 8 (3): 394 (1999).

Type: Australia, New South Wales, North Coast, Coorabakh National Park, track to Newbeys Cave c. 100 m from Newbeys Creek Road, on Newbeys Creek, 270 m, 12.viii.1997. E.A. Brown 97/51, N. Streiber \& D.M. Cryan (NSW 411514, holo.!; CHR!, MEL!, NY).

Icon: Telopea 8 (3): t. 1. (1999).

\section{Description}

Shrub to small tree 0.6-2.0(-3.0) $\mathrm{m}$ tall. Branches frequently pendant. Bark on old branches grey, deeply fissured, young stems reddish-brown. Leaves spirally arranged along young branches but crowded at tips of old branches, spreading; lamina sheath light brown, 7-8 $\times 10-12 \mathrm{~mm}$, membranous, striate, tapering and the top half ciliate; lamina coriaceous, abaxial side lighter green, linear-triangular, (85-)140-200 × 6-9 mm, surfaces glabrous, prominently striated; margins serrulate with 8-13 teeth per $10 \mathrm{~mm}$; apex acute. Inflorescence overtopping the leaves, erect, dense, 100-160 $\mathrm{mm}$ long, oblong and sparsely branched; flowers maturing basipetally; rachis and pedicels glabrous; inflorescence axis reddish brown, $1.0-1.5 \mathrm{~mm}$ in diameter; basal inflorescence branch 0.5-1.0 mm long, suberect; inflorescence bracts caducous, overtopping flowers, pink tipped to pink, broadly ovate at base, $40-50 \times 8-11 \mathrm{~mm}$, surfaces glabrous, margins ciliate. Flowers 15-38, in groups of three at base of inflorescence, pedicellate; bracteoles persistent, recaulescent with one bracteole situated just below the perianth and the other in the middle of the pedicel, shorter than flower, $5-8 \times 0.45-0.5 \mathrm{~mm}$, glabrous; pedicels straight, 1-3 mm long, glabrous. Sepals rose-coloured, ovate-lanceolate, (6-)9-10(-11) 
$\times(1.2-)$ 2.0-2.5 mm, shorter than corolla tube, striate, surfaces glabrous, margins ciliate in upper half. Corolla light to dark pink becoming red with age; corolla tube cylindrical, widened at mouth, (10-)18-22(-25) $\times(2-) 3.0-3.5(-4) \mathrm{mm}$; corolla lobes spreading, ovate to ovate-triangular, shorter than corolla tube, $2.2-4.0 \times 1.2-3.0 \mathrm{~mm}$, apices obtuse; adaxial surface mostly papillate, sometimes minutely rugose verrucate. Stamens hypogynous, sometimes loosely adnated to the wall of the corolla tube, filaments (12-)18$20 \mathrm{~mm}$ long; anthers included, oblong, pink and $2-3 \mathrm{~mm}$ long. Ovary cylindrical, $2-3 \times$ 1-2 mm, glabrous, apex round; nectary scales rectangular to oblong, $1.0-1.5 \times 0.5-0.6 \mathrm{~mm}$, apices irregularly toothed, sometimes retuse; style enclosed, (14-)17-19 mm long, sometimes distally papillose; stigma five-lobed. Fruit light to reddish brown, $2.5-4.5 \times$ 2-3 mm, oblong, apex round, glabrous. Seeds light brown, ovoid, 0.8-1.0 mm long, testa prominently reticulate. Flowering August-October. (Figure 7.29).

\section{Diagnostic features and discussion}

Dracophyllum macranthum has the autapomorphy of flowers maturing basipetally. The corolla tube is pink to dark pink with white corolla lobes. The corolla tube is $18-22 \mathrm{~mm}$ long and it is also longer than the sepals.

In the past, D. macranthum has been confused with $D$. secundum and is similar in general appearance. It differs in the leaves being wider $(6-9 \mathrm{~mm})$ with fewer teeth (8-13 per 10 $\mathrm{mm}$ ) on the lamina margin. The inflorescence matures basipetally not acropetally, a unique feature in the genus Dracophyllum. Flowers in D. macranthum are arranged in groups of three on the basal inflorescence branches. The sepals are ovate-lanceolate not broadly ovate triangular and are larger $(9-10 \times 2.0-2.5 \mathrm{~mm})$. The mouth of the corolla tube is widened and the corolla tube (18-20 $\mathrm{mm}$ compared to $4-8 \mathrm{~mm}$ in D. secundum $)$ and the corolla lobes (2.2.-4.0 mm) are longer. The adaxial surfaces of the corolla lobes are 


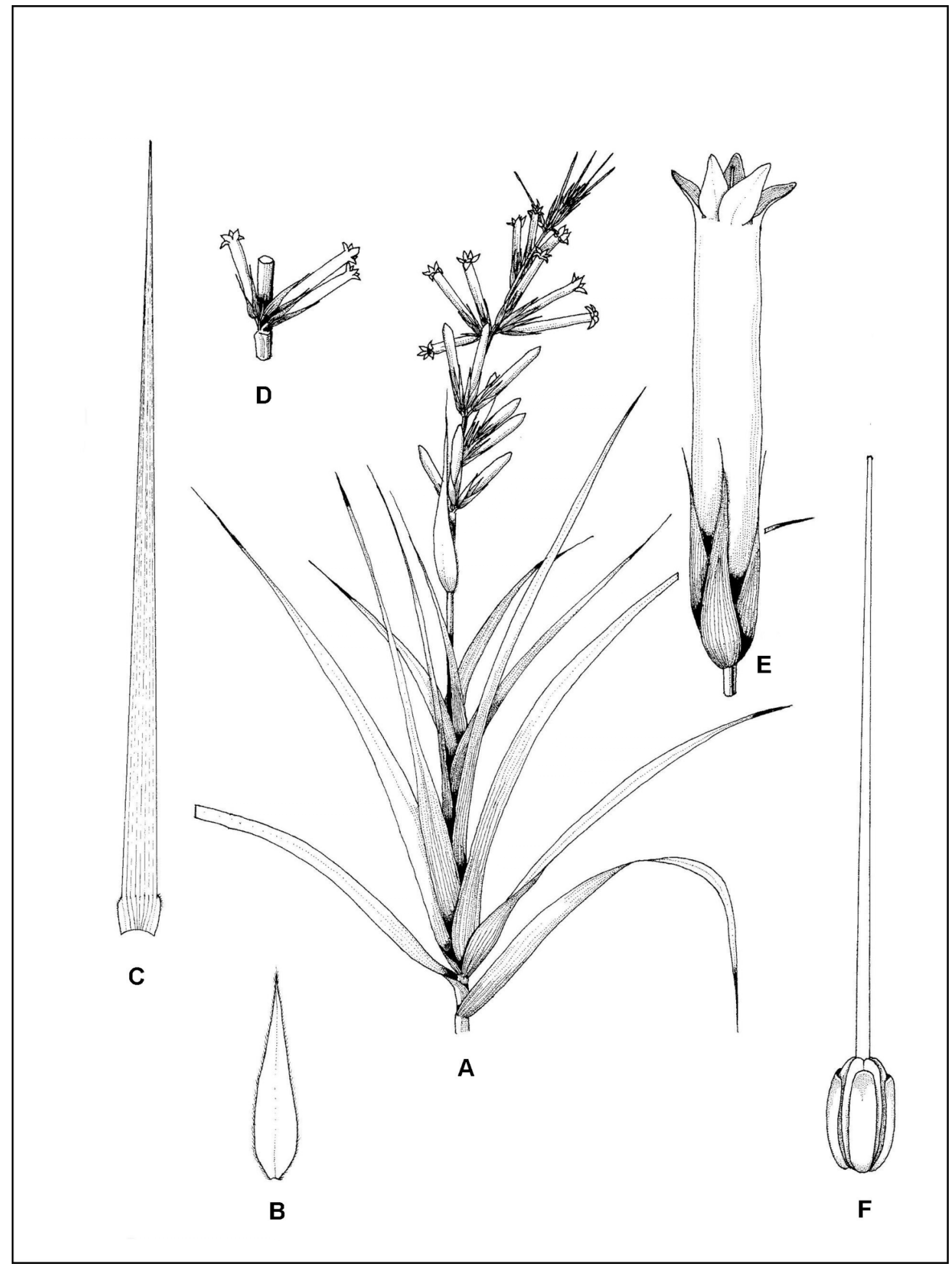

Figure 7.29. Dracophyllum macrantbum. A, flowering branch $(\times 1)$; $\mathbf{B}$, inflorescence bract $(\times 1)$; $\mathbf{C}$, leaf $(\times 1) ; \mathbf{D}$, lower branch of inflorescence $(\times 1) ; \mathbf{E}$, flower $(\times 5) ; \mathbf{F}$, ovary $(\times 10)$. Drawn from Brown 97/50. 

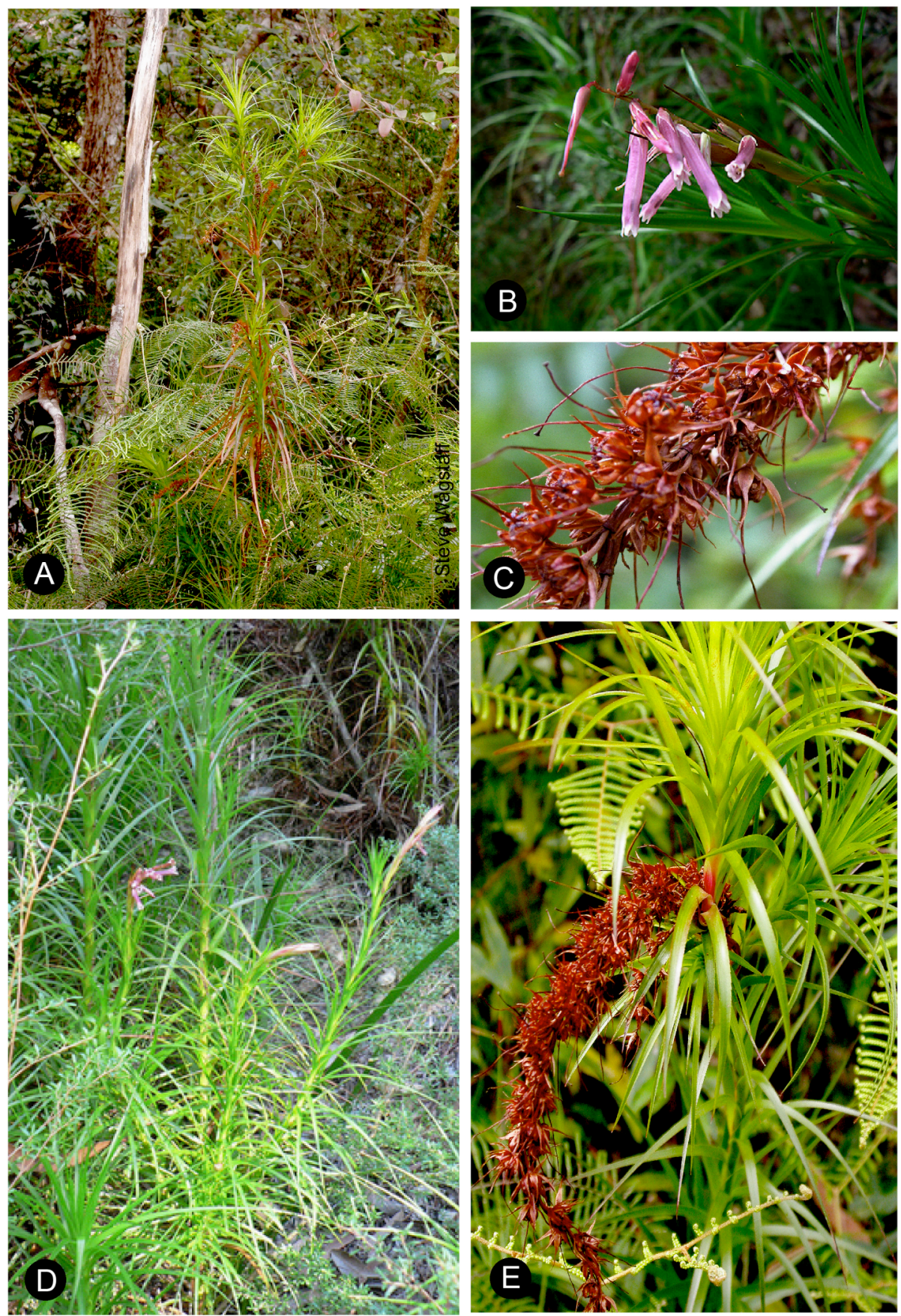

Figure 7.30. Dracophyllum macrantbum. A, mature plant in habitat; B, flowering branch showing the long corolla tubes and light coloured corolla lobes; $\mathbf{C}$, fruit showing the persistent long styles; D, plant coming into flower; $\mathbf{E}$, fruiting branch. Photos A,C,E by S. Wagstaff. and B \& D by E. Brown. 
glabrous and the filaments are longer. The nectary scales are larger $(1.0-1.5 \times 0.5-0.6$ $\mathrm{mm})$. The fruit is also wider $(2-3 \mathrm{~mm})$ and the seed longer $(0.8-1.0 \mathrm{~mm})$.

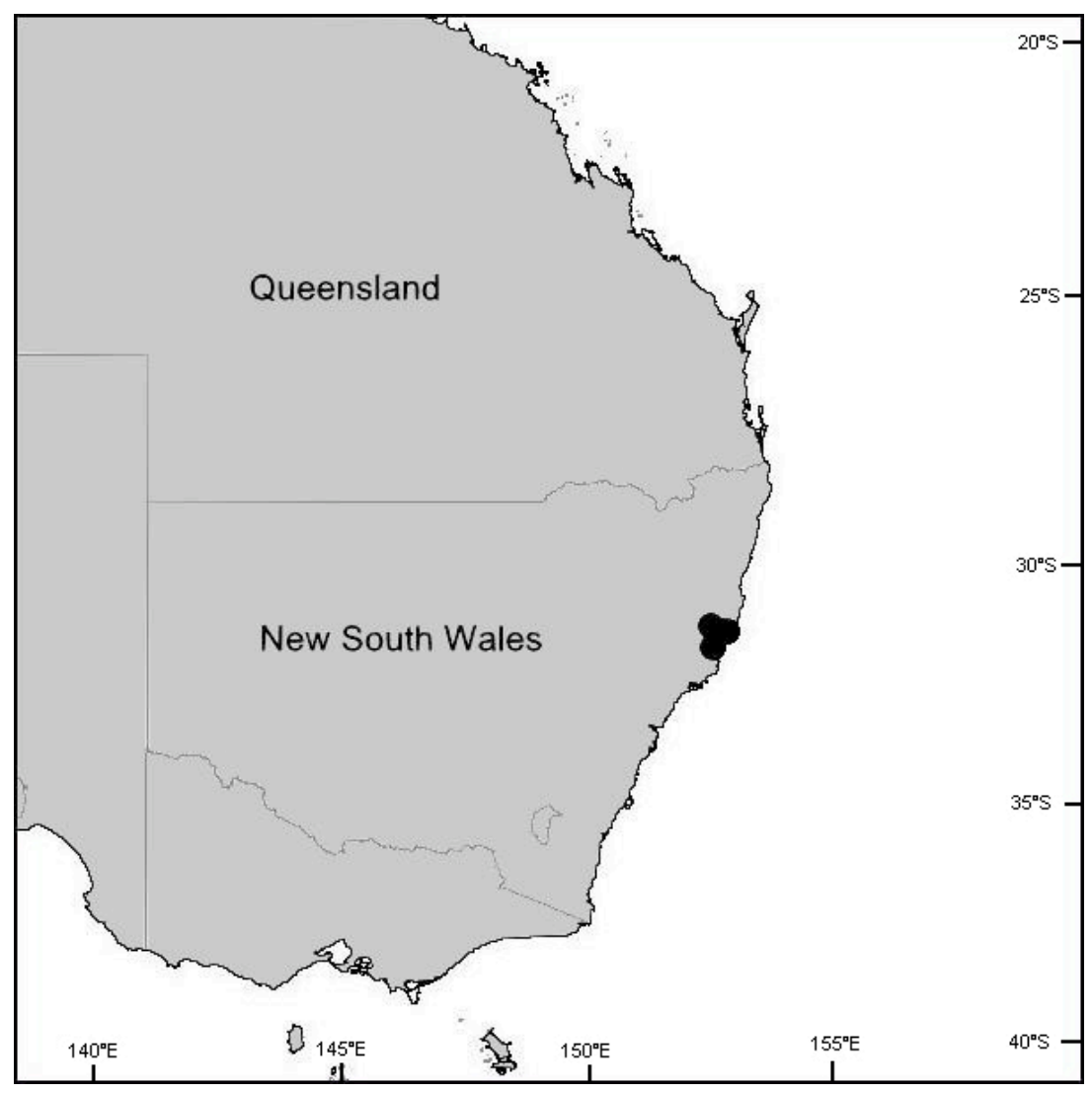

Figure 7.31. Known distribution of Dracophyllum macranthum.

\section{Distribution}

Endemic to the Coorabakh National Park in New South Wales, Australia (Fig. 7.31).

\section{Habitat}

Dracophyllum macranthum occurs along forested (Table 7.14) stream gullies, low cliffs and on rock outcrops and faces at altitudes of $800-900 \mathrm{~m}$. The annual rainfall varies between 
$1200-1600 \mathrm{~mm}$. The soil is a sandy loam or clay loam derived from conglomerate and sandstone.

Table 7.14. Plant communities commonly associated with Dracophyllum macranthum.

\begin{tabular}{l} 
Tall open semi-deciduous Eucalyptus - Corymbia - Allocasuarina forest \\
Tall open semi-deciduous Eucalyptus - Allocasuarina - Ceratopetalum apetalum forest \\
Low open semi-deciduous Callicoma serratifolia - Sticherus lobatus forest \\
\hline
\end{tabular}

\section{Variation}

There is some variation in leaf size $(140-200 \times 6-9 \mathrm{~mm})$ and in inflorescence length (100-160 mm). Flower number per inflorescence can vary from 15-38 and minor variation in flower size $(18-22 \times 3.0-3.5 \mathrm{~mm})$ but variation in corolla lobe size is more prominent $(2.2-4.0 \times 1.2-3.0 \mathrm{~mm})$. The corolla lobes can sometimes be white.

\section{Specimens examined}

AUSTRALIA. New South Wales. 31-152: North Coast, Track to Newbeys Cave c. 100 m from Newbeys Creek Road, on Newbeys Creek (-CD), 12.viii.1997. Brown 97/51, Streiber \& Cryan (NSW). Starrs Creek Catchment, South of Big Nellie (-DA), 13.viii.1997. Brown 97/59, Streiber \& Crayn (NSW).

11. Dracopbyllum menziesii Hook. f.

Dracophyllum menæiesii Hook. f., Fl. Nov. Zel. 2(1): 168 (1853); Hooker, Handb. N.Z. Fl. 1:181 (1864); Cheeseman, Man. N.Z. Fl.: 420 (1906); Cheeseman, Man. N.Z. Fl. $2^{\text {nd }}$ Edn.: 703 (1925); Oliver, Trans. Proc. N.Z. Inst. 59: 705 (1928); Oliver, Trans. Roy. Soc. N.Z. 80 (1): 13 (1952); Allan, Fl. N.Z. 1: 535 (1961); Eagle, Trees \& Shrubs of N.Z. $2^{\text {nd }}$ series.: 292 
(1982); Poole \& Adams, Trees \& Shrubs of N.Z.: 164 (1994). Type: New Zealand, Dusky Sound, 1791. A. Menzies s.n. (K, lecto!; BM 577674!), designated by Oliver (1952).

Allan (1961) did not find the Menzies specimen that Oliver (1952) chose as the type in the type folder at Kew and mentioned that the only specimens in the type folder were two specimens collected by Lyall at Port Preservation. I found two perfectly good Menzies specimens that agree with the protologue, the one held at Kew in the type folder, and the other specimen from BM.

Icones: Oliver, Trans. Proc. N.Z. Inst. 59: t. 14 (1928); Eagle, Trees \& Shrubs of N.Z. $2^{\text {nd }}$ series.: t. 132 (1982) - the habit specimen drawn is atypical; Smith-Dodsworth, N.Z. Native Shrubs \& Climbers.: t. 60, P1. 24C \& 24D (1991).

\section{Description}

Shrub 0.5-1.0 m tall. Branches. Bark on old branches grey, smooth, rarely deeply fissured at base, young stems brown. Leaves crowded at tips of branches in a bromelioid manner; lamina sheath light brown, 10-20 × (7-)17.2-20.4, coriaceous, striate; tapering, margins membranous and smooth; lamina coriaceous, linear-triangular to occasionally triangular, 90-220 × 9-17 mm, surfaces glabrous, prominently striated; margins cartilaginous, serrate, thickened, with 20-32 teeth per $10 \mathrm{~mm}$; apex thickened, acute. Inflorescence an axillary panicle situated below the leaves; shorter than the leaves, drooping, dense, 50 $150 \mathrm{~mm}$ long, oblong and sparsely branched; rachis and pedicels pubescent; inflorescence axis mid green to reddish brown, $1.5-2.4 \mathrm{~mm}$ in diameter; basal inflorescence branch 11.0-12.4 mm long, widely spreading; inflorescence bracts caducous, overtopping the flowers, dark green to red, broadly ovate at base, 12.0-19.2 × 6.0-8.8, adaxial surfaces glabrous to sericeous in basal half; abaxial surfaces glabrous, margins 
ciliate. Flowers 8-38, in groups of three at base of inflorescence, pedicellate; bracteoles caducous, recaulescent, with one bracteole situated just below the perianth and the other in the middle of the pedicel, shorter than flower, $4-5 \times 0.8-1.0 \mathrm{~mm}$, glabrous; pedicels straight, $1.5-5.5 \mathrm{~mm}$ long, tomentose. Sepals ovate to broadly ovate, (2.5-)3.0-3.5 $\times$ (1.5-)2.0-2.5 mm, shorter than the corolla tube, striate, surfaces glabrous; margins ciliate. Corolla white to red; corolla tube campanulate, widened at mouth, (4-)6-7 $\times 3-5 \mathrm{~mm}$; corolla lobes reflexed, ovate-triangular, shorter than corolla tube, $2.0-4.5 \times 1.1-1.6 \mathrm{~mm}$, apices obtuse; surfaces glabrous. Stamens inserted at top of corolla tube, filaments (0.5)1.0-1.2 mm long; anthers included, oblong, light yellow and $1.3-1.5 \mathrm{~mm}$ long. Ovary obovate, 1.3-1.5 × 1.7-2.0, glabrous, apex round; nectary scales rectangular, 0.7-0.8 long and wide, apices retuse; style included, $2.5-3.5 \mathrm{~mm}$ long, glabrous, lengthening in fruit; stigma five-lobed. Fruit reddish brown, 1.5-2.5 × (2.5-)4.0-5.0 mm, depressed-globose, apex round, glabrous. Seeds dark brown, ovoid, (0.55-)0.8-0.6(-1.3) mm long, testa slightly reticulate. Flowering November-February. (Figure 7.32)

\section{Diagnostic features and discussion}

Dracophyllum menqiesii is characterized by its shrubby habit, mostly unbranched stems, leaves crowded in a bromelioid fashion, lamina short and broad (90-220 $\times 9-17 \mathrm{~mm})$, short and Dracophyllum menziesii is a well-defined species, readily distinguished from other Dracophyllum species. It is similar to $D$. townsonii but can easily be separated by the unbranched stems and the shorter and wider leaves. The distribution of the two species al does not overlap. 


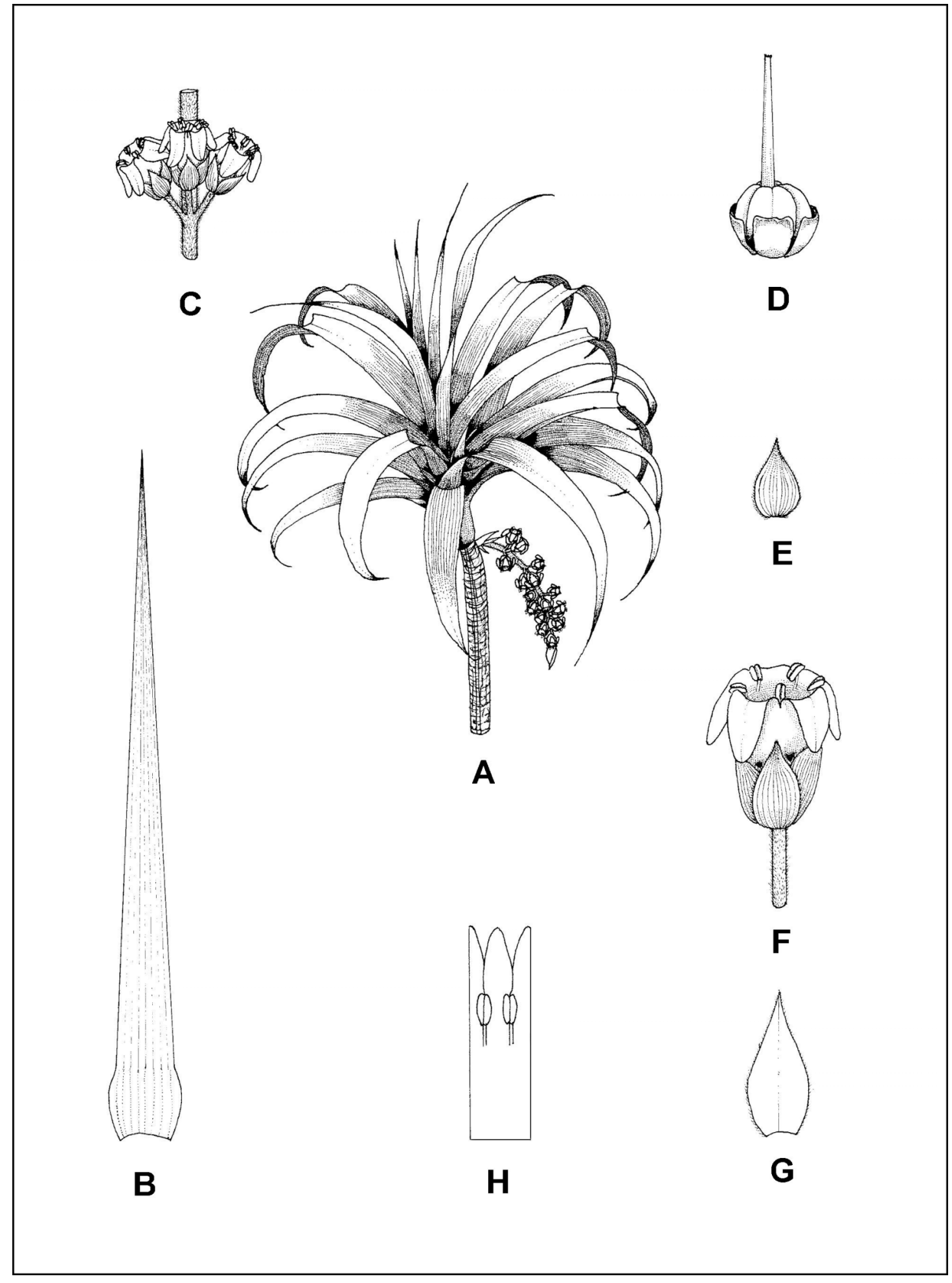

Figure 7.32. Dracopbyllum menziesii. A, flowering branch $(\times 0.5)$; B, leaf $(\times 1)$; C, bottom branch of inflorescence $(\times 2)$; $\mathbf{D}$, ovary $(\times 10)$; $\mathbf{E}$, sepal $(\times 5) ; \mathbf{F}$, flower $(\times 5)$; $\mathbf{G}$, inflorescence bract $(\times 2) ; \mathbf{H}$, laid out corolla $(\times 5)$. Drawn from Venter 13788 . 


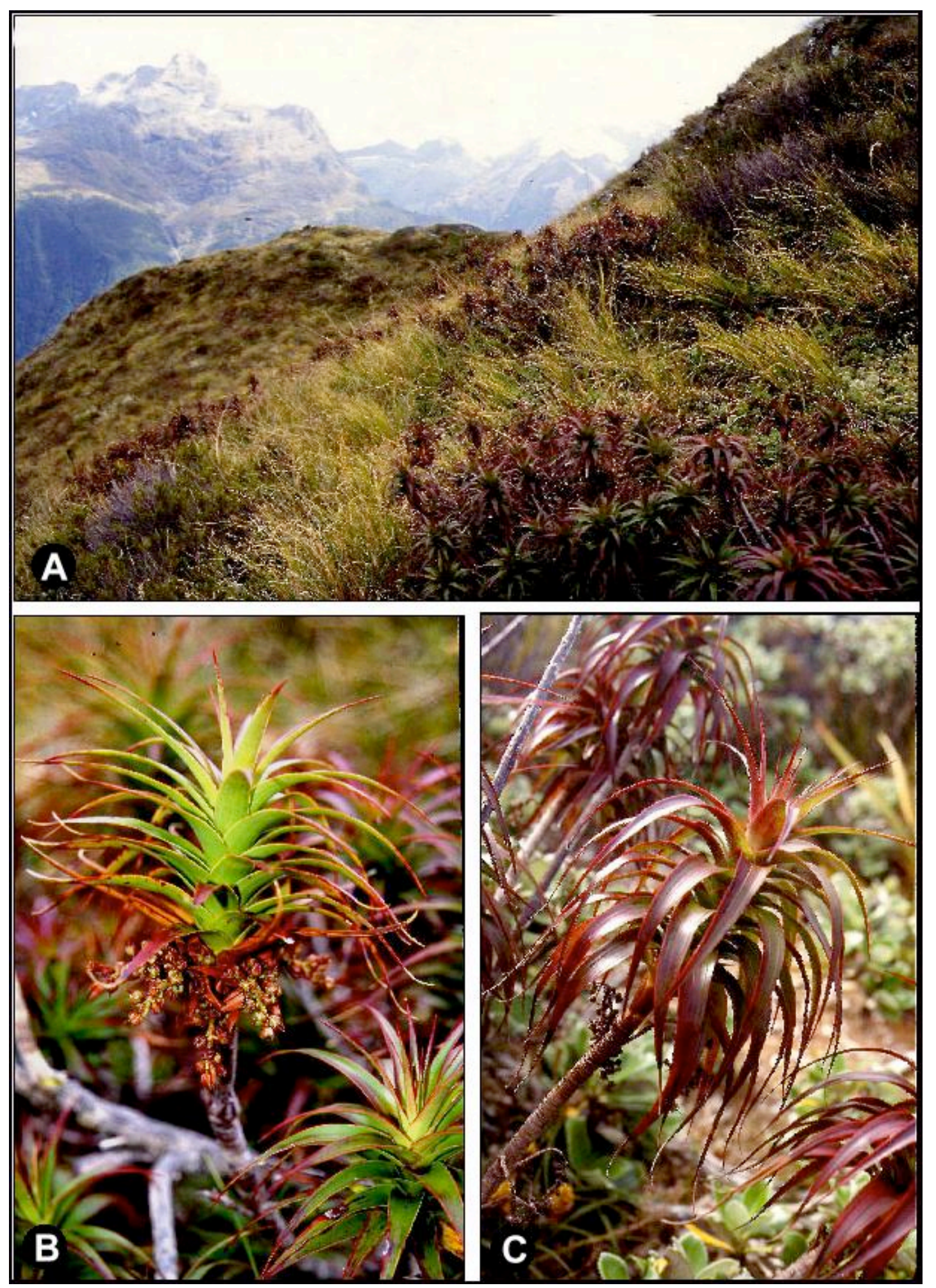

Figure 7.33. Dracopbyllum menziesii. A, habitat near Milford Sound, Fiordland; B, mature plant showing the inflorescences situated below the leaves; $\mathbf{C}$, fruiting branch. BC, Venter 13788 . 


\section{Distribution}

Endemic to the South Island of New Zealand (Fig. 7.34). Occurs west of a line from Haast to Invercargill and Hafmoon Bay on Stewart Island.

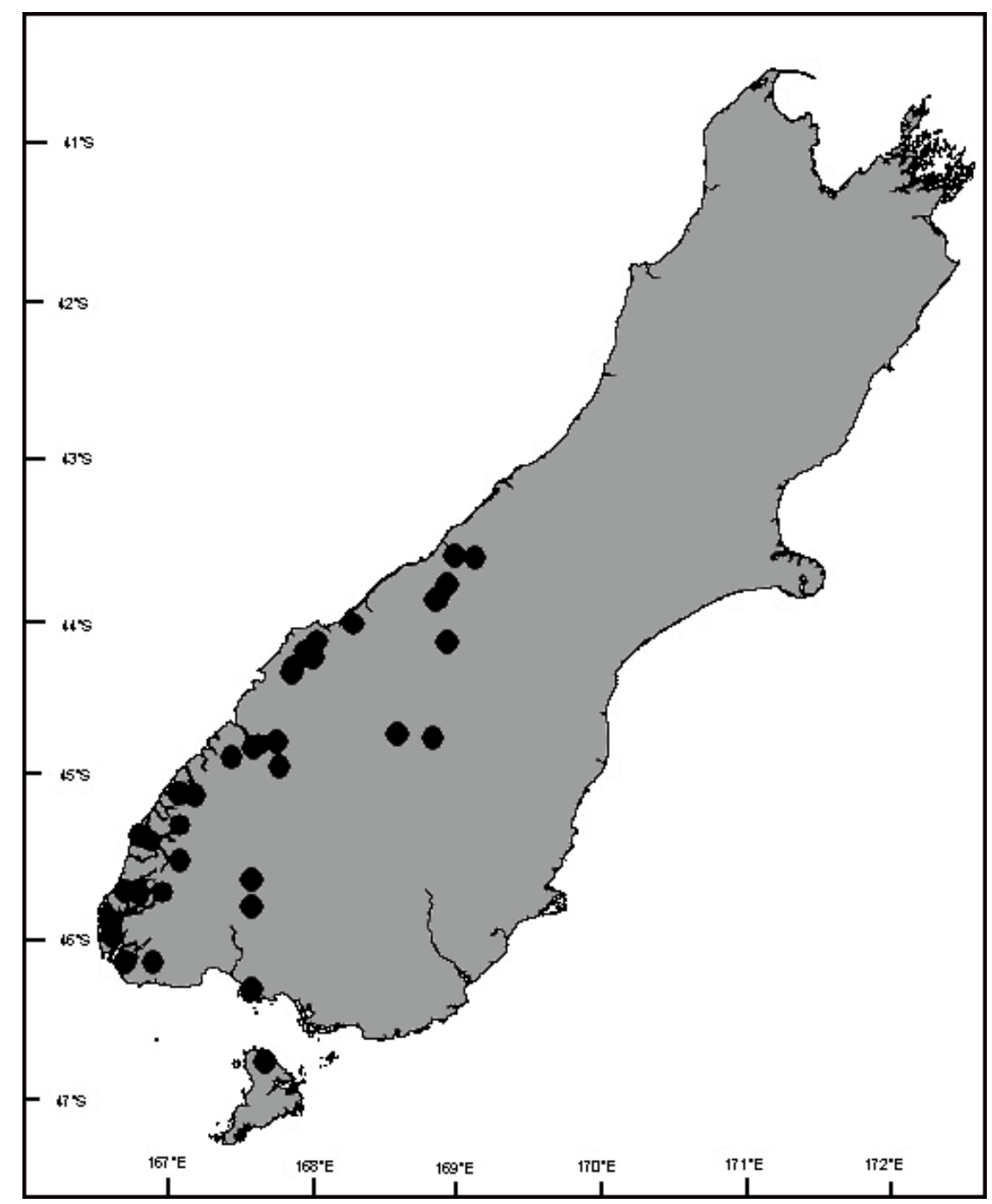

Figure 7.34. Known distribution of Dracophyllum menziesii. 


\section{Habitat}

Dracophyllum menziesii grows from close to sea level up to $1,500 \mathrm{~m}$ altitude on mountain slopes of $10^{\circ}-50^{\circ}$ and on Stewart Island occasionally on cliffs, also on bluffs and rock outcrops. Vegetation consists of montane to subalpine woodland, montane and subalpine shrubland, grassland and herbfield or snow-tussock herbfield (Table 7.15). D. menziesii is not recorded from forest communities and is the only true grassland species in the genus. The soil is brownish grey gritty sandy loam derived from granidiorite, schist, argillite, diorite gneiss or occasionally peridotite. All populations visited were recorded as growing fully exposed and covered in a thick layer of snow during the winter.

Table 7.15. Plant communities commonly associated with Dracophyllum menziesii.

\begin{tabular}{|c|}
\hline WOODLAND \\
\hline Low open evergreen Halocarpus biformis woodland \\
\hline SHRUBLAND \\
\hline Low closed evergreen Olearia colensoi shrubland \\
\hline GRASSLAND \\
\hline Tall open Chionochloa crassiuscula - C. rigida subsp. amara subalpine grassland \\
\hline
\end{tabular}

\section{Variation}

Bark on mature stems can vary from smooth to deeply fissured and the lamina shape is very variable, from linear-triangular to triangular in a single population. Leaf size is also variable $(90-220 \times 9-17 \mathrm{~mm})$. Plants in subalpine habitats display short inflorescences (50-78 mm) compared to inflorescences from plants growing at lower altitudes (80-150 $\mathrm{mm}$ long). The inflorescence bracts vary in size $(12.0-19.2 \times 6.0-8.8 \mathrm{~mm})$, with a number of populations on Stewart Island having the inflorescence bracts red, not the normal green. The corolla can either be white with pink lobes, light pink or red depending on the population. Corolla lobes of subalpine plants are larger than those from lower altitudes. 


\section{Specimens examined}

NEW ZEALAND. South Island. 43-168: South Westland, Okuru District, Woolsack (DD), 01.iv.1979. Williams \& Wardle s.n. (CHR). 43-169: South Westland, Mataketake Range, Mt. Clarke (-CD), 7.iii.1980. Wardle s.n. (CHR); Head of Clarke River, Kea Cliffs (-DA), 09.iv.1978. W ardle s.n. (CHR); Copland Range, Ngataus Knob (-DB), 08.xii.1967. Wardle \& Fryer s.n. (CHR); Karangarua River, route from Top Flat to Twain Saddle, 30.iii.1969. Wardle \& Fryer s.n. (CHR); Fiordland, head of Clarke tributary of Landsborough River, Marks Flat (-DC), 19.ii.1972. Wardle s.n. (CHR); South Westland, Mt. Hooker, lower slopes above Marks Flat, 31.xii.1948. Mason s.n. (CHR); Karangarua River, between Cassel and Lame Duck Flat (-DD), 31.iii.1969. Wardle \& Fryer s.n. (CHR). 43-170: Westland National Park, Fox Range, McKenna Creek (-CA), 22.iii.1970. Wardle s.n. (CHR); Ben Ohau Range, head of Fred Stream (-CC), 08.vi.1969. Wilson 456 (CHR). 44-167: Fiordland, Tutoko Valley, Tutoko high bench, Leader Creek (-DB), 13.i.1976. Morris s.n. (CHR); Fiordland, Homer Saddle (-DD), 06.iii.1962. Simpson 3874 (CHR); Fiordland National Park, Milford Track, Mackinnon Pass, 19.xii.1969. Palmer s.n. (CHR); Lake Te Anau, head of Clinton Valley, MacKinnon Pass, Petrie s.n. (CHR); Saints Creek. 18.xi.1969. Matthews s.n. (WELTU). 44-168: South Westland, Gorge Plateau area, Red Hills (-AB), 02.i.1970. Rowley s.n. (CHR); Cascade Valley, Mt. Delta, 08.iii.1878. Wardle, Lee \& Johnson s.n. (CHR); Fiordland, north end of Olivine Range (-BA), 05.i.1977. Webb 77016 (CHR); Jackson River catchment N of Mt. Beta, 27.iii.1979. Wardle \& Williams s.n. (CHR); Fiordland National Park, Lake Harris (-CA), 21.iii.2000. Venter 13809 (CHR); Fiordland, Gertrude Saddle, 27.xii.1939. Cranwell \& Moore s.n. (CHR); Lake Harris (-CC), 27.ii.1927. Petrie s.n. (CHR); Kinloch, Bold Peak, ii.1923. Wall s.n. (CHR); Milford Sound, Cascade Creek, 4.xi.1973. Van Steenis 22643 (L). 44-169: South Canterbury, Hopkins River, head of North Temple Stream (-BB), 7.i.1986. Metcalf s.n. (CHR). 45-166: Fiordland, Doubtful Sound, Secretary Island, Blanket Bay (-BD), 
13.xii.1962. Morice s.n. (CHR); Thompson Sound, mountains above Lyell Bay, i.1958. Metcalf s.n. (CHR); Dusky Sound, Woodhen Cove (-CB), 08.xii.1946. Allan s.n. (CHR); (CD), Fiordland National Park, near West Cape, 05.ii.1972. Mark s.n. (CHR); Fiordland, valley S of Mt. Anderson (-DB), ii.1972. Given 72650 (CHR): Fiordland, Dusky Sound, Cascade Valley (-DC), 02.i.1969. Dorizac s.n. (CHR); Fiordland, Dusky Sound, Pickersgill Harbour to Lake Forester, 03.i.1969. Dorizec s.n. (CHR). 45-167: Caswell Sound, above Leslie Clearing, Expectation Stream (-AB), 08.iii.1949. Murie s.n. (CHR); Caswell Sound, Mt. Alexander, 27.ii.1978. Purdie \& Meyers s.n. (CHR); Fiordland, George Sound, Henry Saddle [Henry Pass], 17.iv.1949. Mason s.n. (CHR); Fiordland, Mount Gorge, above hut at head of Elizabeth Burn (-AC), iii.1977. Garnock-Jones, Lee, Anderson \& Given 10308 (CHR); Mountains head of Lake Hauroko between Hay River and Hauroko Burn (-CC), 11.i.1926. Thomson s.n. (CHR); Fiordland National Park, South Caroline Burn, 24.xi.1975. Sutcliffe, Craighead \& Williams s.n. (CHR): Takitimu Range, head of Aparima River (-DD), 31.i.1962. Wardle s.n. (CHR). 46-166: Preservation Inlet, Useless Bay (-BA), 27.i.1946. Allan s.n. (CHR); Fiordland, Lake Monk (-BB), 22.i.1960. Simpson 2013 (CHR). Stewart Island. 46-167: Mt. Anglem (-DB), 17.ii.1962. Melville \& Melville 6381 (AK, CHR, K); ibid. near top, 11.i.2000. Venter 13788 (CHR); ibid. Kirk s.n. (AK).

\section{Dracophyllum milliganii Hook.f.}

Dracophyllum milliganii Hook. f., Icon. Plant. 9: t. 845 (1852). (As 'Milligani'). Hooker, Fl. Tasm. 3: 367 (1860); Mueller, Fragm. Phytogr. Austr. 6: 65 (1864); Bentham, Fl. Austr. 4: 262 (1869); Rodway, Tasmanian Fl: 126 (1903); Oliver, Trans. Proc. N.Z. Inst. 59: 710 (1928); Oliver, Trans. Royal Soc. N.Z. 80 (1): 16 (1952); Curtis, The Student's Flora of Tasmania 2: 461 (1963); Jackes, Australian Plants 5: 207 (1969). Type: Tasmania, Mt. Sorel, 
Macquarrie Harbour, 15.i.1846. J.M. Milligan 747 (MELB 2064389, holo.!; BM!; HO!; K!; NSW!; W!).

Icones: Hook. f., Icon. Plant. 9: t. 845 (1851); Oliver, Trans. Proc. N.Z. Inst. 59: t. 20 (1928); Jackes, Australian Plants 5: t. 3 (1969).

\section{Description}

A shrub to small tree, $0.2-3.0 \mathrm{~m}$ tall. Branches. Bark on old stems brown, deeply fissured, young stems reddish brown. Leaves spreading to recurved; lamina sheath light green to light brown, (24-)30-40 $\times(9-) 15-20 \mathrm{~mm}$, coriaceous, striate, tapering, top half of margin ciliate; lamina coriaceous, linear-triangular to lanceolate, $140-300(-900) \times 5.1-$ $7.0 \mathrm{~mm}$, with scabrid hairs restricted to veins on abaxial surface, slightly striated; margins serrulate with 50-70 teeth per $10 \mathrm{~mm}$; apex acute, coils often. Inflorescence overtopping the leaves, erect, dense, 130-460 mm long, oblong and densely branched; rachis and pedicels pubescent; inflorescence axis mid green, reddish brown to reddish, prominently ribbed, 3.8-8.2 $\mathrm{mm}$ in diameter; basal inflorescence branch 14-25(-101) $\mathrm{mm}$ long, widely spreading; inflorescence bracts persistent for a long period, overtopping flowers, light green, pink or with only the apices pink, ovate to broadly ovate at base, 40-180(-320) $\times$ 6-19; adaxial surface scabrid at apex; abaxial surfaces scabrid on veins to pubescent, margins serrulate, ciliate. Flowers $150-500+$, in groups of more than 10 at base of inflorescence, pedicellate; bracteoles persistent, recaulescent with one bracteole situated just below the perianth and the other in the middle of the pedicel, shorter than flower, 2.0 $2.5 \times 0.1-0.2 \mathrm{~mm}$, glabrous; pedicels straight, 0.5-1.5 mm long, tomentose. Sepals reddish brown to rose coloured, lanceolate to oblong, $(2-) 3-4 \times 0.8-1.5 \mathrm{~mm}$, equaling corolla tube, striate, surfaces glabrous; margins ciliate in upper half. Corolla white to light pink; corolla tube narrowly campanulate, narrowed at mouth, (2-)2.5-3.0 $\times 1.5-2.0 \mathrm{~mm}$; corolla 
lobes spreading horizontally to reflexed, oblong to ovate-triangular, shorter than corolla tube, $1.0-1.5 \times(0.9-) 1.0-1.2 \mathrm{~mm}$, apices obtuse; surfaces glabrous. Stamens hypogynous, filaments 2.5-5.0 mm long; anthers exserted, oblong, papillate, pink turning deep yellow with age and (0.5-)0.8-1.0 mm long. Ovary subglobose, 1.3-1.5 × 1.5-2.0 $\mathrm{mm}$, glabrous, apex round; nectary scales appears to be connate, rectangular, $0.2-0.25 \times$ 0.6-0.8 mm, apices retuse; style included, 0.9-1.0(-1.1) mm long, glabrous; stigma fivelobed. Fruit reddish brown, 2.2-2.5 × 1.5-2.0 mm, depressed-globose, apex round, glabrous. Seeds yellowish brown, ovoid, $0.47-0.5 \mathrm{~mm}$ long, testa slightly reticulated. Flowering January-May. (Figure 7.35.).

\section{Diagnostic features and discussion}

Dracophyllum milliganii is characterized by its unbranched stems, leaves $140-300 \mathrm{~mm}$ long with thin drawn out apices and finely crenulated lamina margins, panicle 130-460 mm long having the rachis prominently ribbed and hairy, inflorescence bracts broadly sheathing and abruptly contracted into long and attenuated apices, sepals and corolla tube the same length, anthers exserted and the bilobed apices of the nectary glands.

Dracophyllum milliganii is to some extent similar to $D$. involucratum but easily distinguished from the latter on account of the flowers not in involucres and the inflorescence bracts that are persistent till the flowers are fully open. 


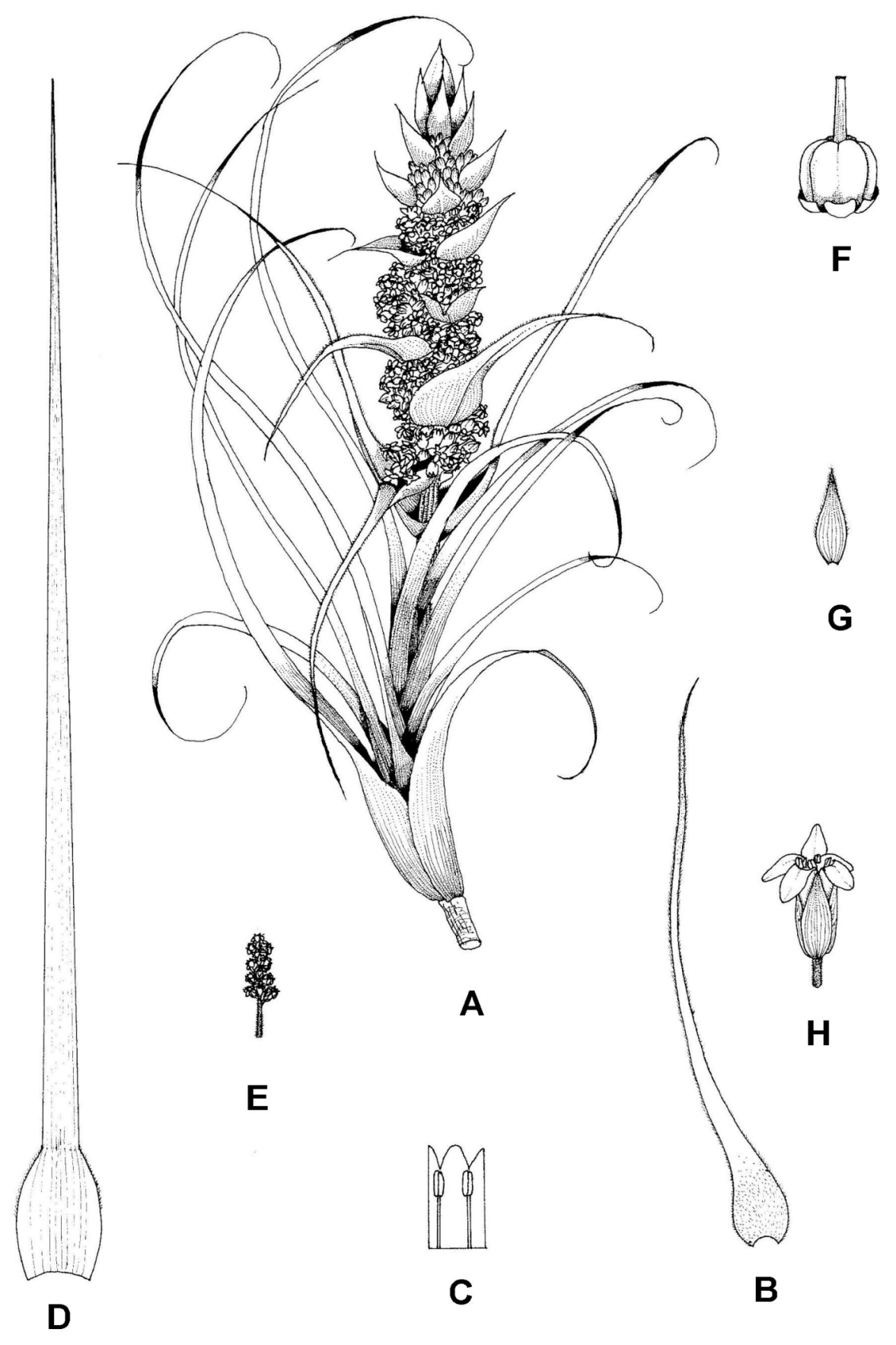

Figure 7.35. Dracopbyllum milliganii. A, flowering branch $(\times 0.5)$; $\mathbf{B}$, inflorescence bract adaxial surface $(\times 1)$; C, laid out corolla $(\times 5)$; $\mathbf{D}$, leaf $(\times 1)$; $\mathbf{E}$, lower inflorescence branch (× 1); F, ovary (× 10); G, sepal $(\times 5) ; \mathbf{H}$, flower $(\times 5)$. Drawn from Croft 10070 . 


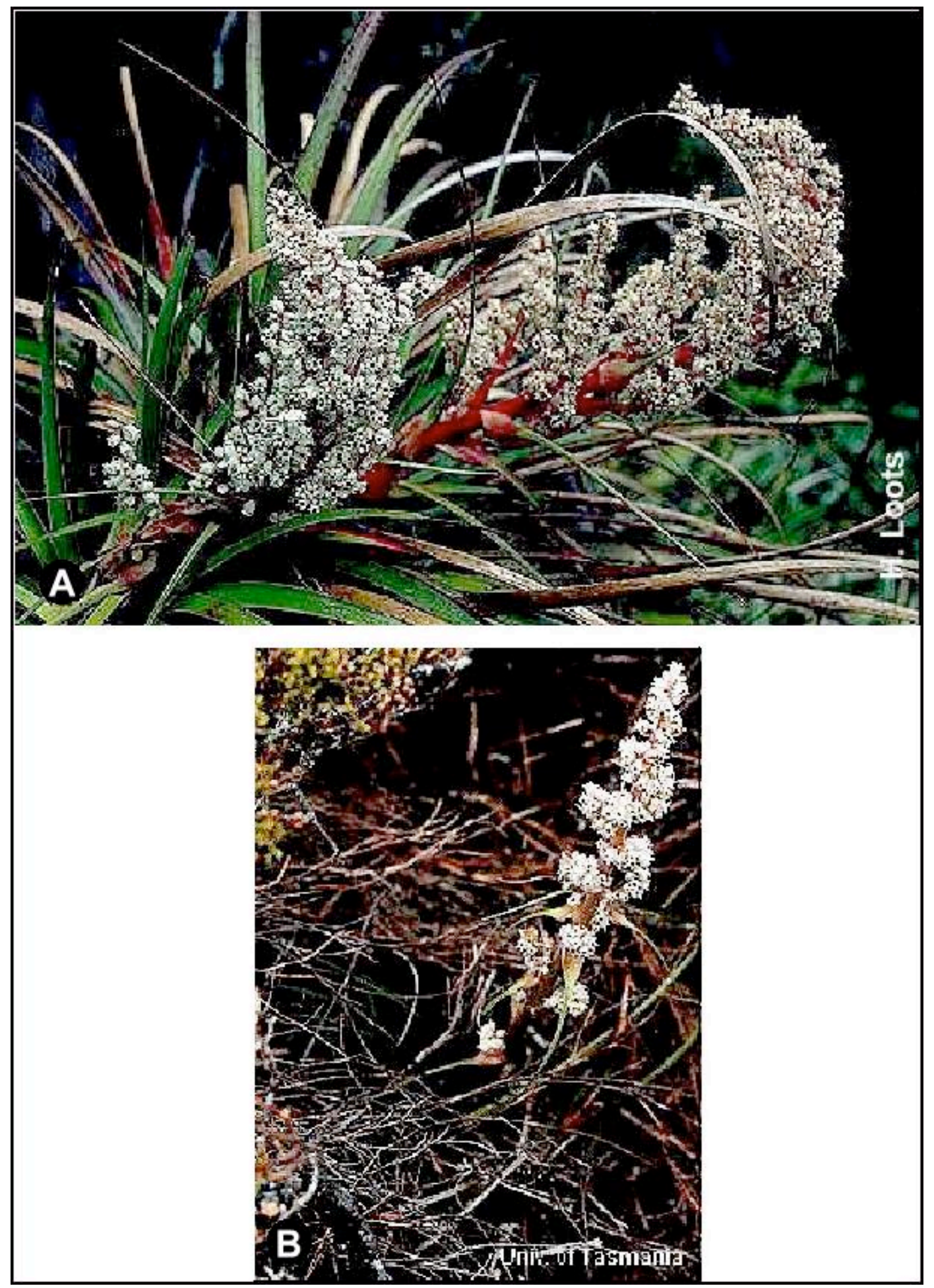

Figure 7.36. Dracophyllum milliganii. A, flowering specimen of the 'shrub form' from a forest habitat on Mt. Counsel; B, flowering specimen of the normal form from a subalpine habitat. 


\section{Distribution}

Endemic to Tasmania. Most known localities are in the Cradle Mountain-Lake St. Clair

National Park in the north, Wals of Jerusalem National Park, Franklin-Gordon Wild Rivers National Park, Mount Field National Park and the Southwest National Park in the south. Most common in the quartzite mountains of the west and south-west (Fig. 7.37).

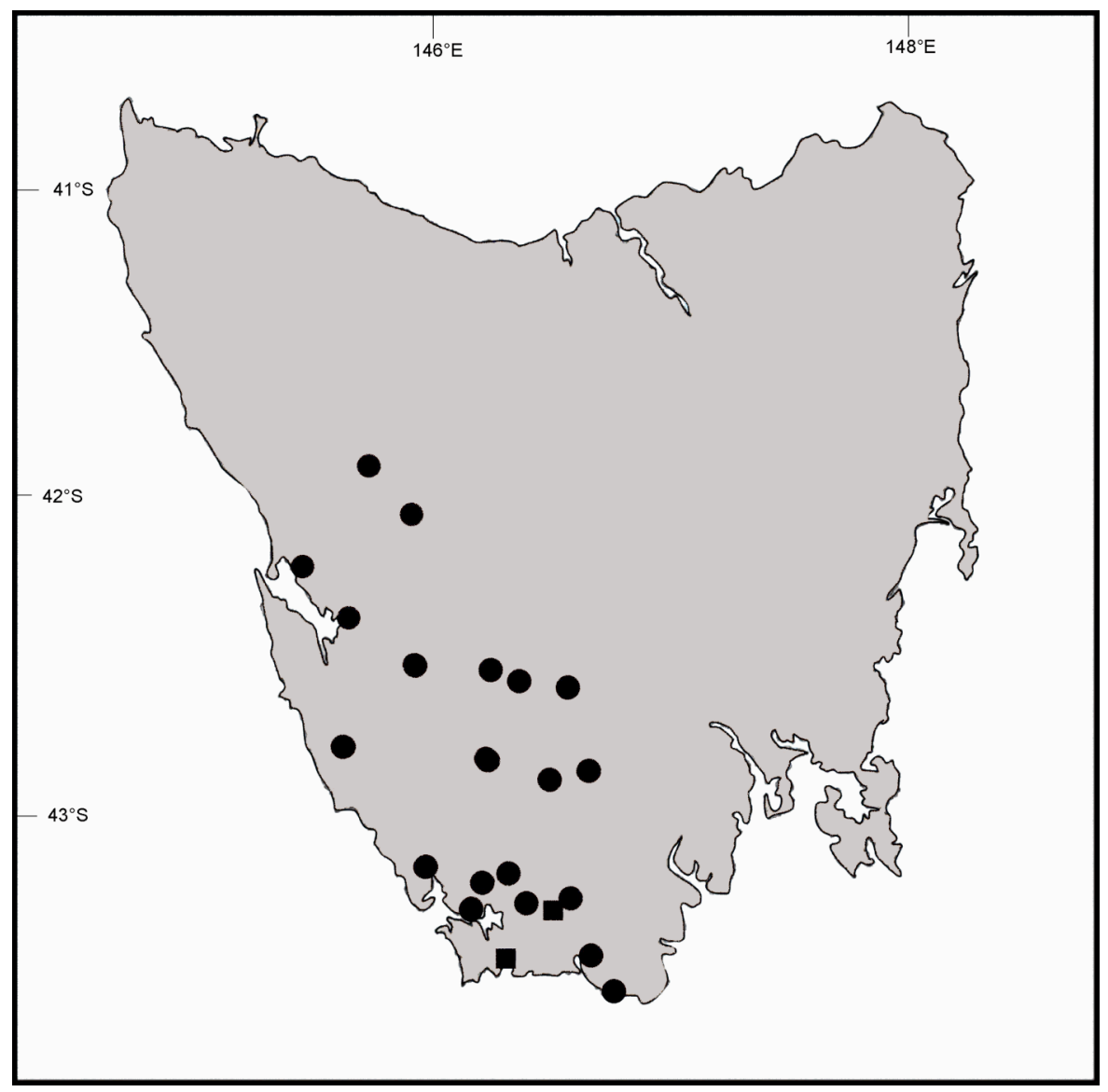

Figure 7.37. Known distribution of the normal form of Dracophyllum milliganii ( ) and the shrub form ( ).

\section{Habitat}

Dracophyllum milliganii occupies a wide altitudinal range, from almost near sea level in the perhumid western cold lowlands to $1,050 \mathrm{~m}$. altitude on Mt. Field West. It grows in 
mountain gullies or on mountain slopes and ridges that are covered in shrubland, moorland, heathland or sedgelands, with the shrub form on the edges of open montane temperate rainforest (Table 7.16). The soil is usually shallow yellowish-brown to brown stony clay loam, low in nutrients, and derived from Precambrian or Ordovician quartzites and quartzitic conglomerates. It occasionally occurs on granite and dolorite. Lithosols and shallow fibrous peats cover the glacially and periglacially eroded areas occupied by the alpine vegetation (Kirkpatrick 1983).

Table 7.16. Plant communities commonly associated with Dracophyllum milliganii.

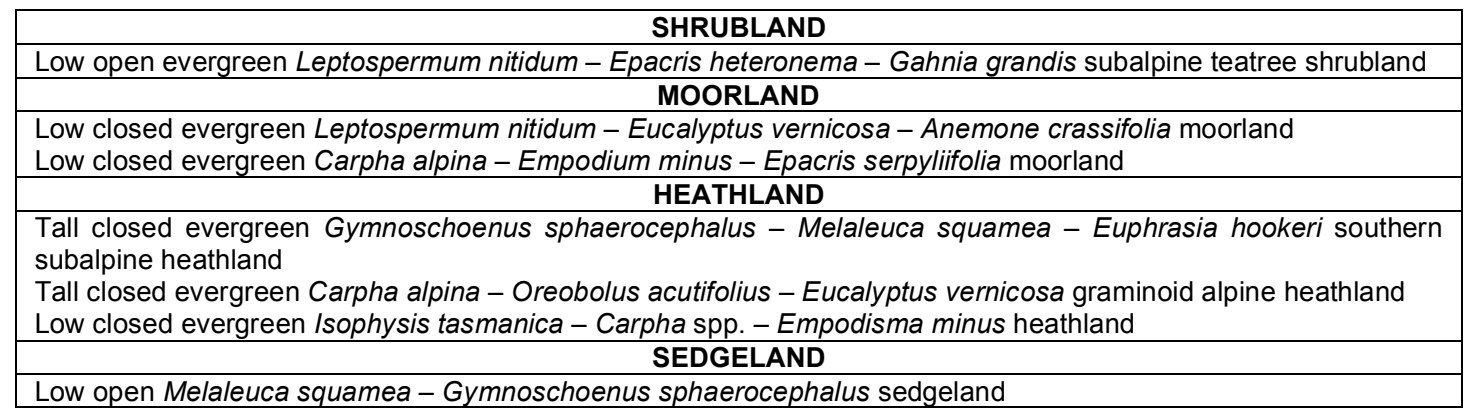

\section{Variation}

Dracophyllum milliganii differs from other Dracophyllum species in the inflorescence bracts that persist deep into the flowering period. There appears to be two different forms. The common form is a small plant with subterranean stem growing in exposed sites and the other, a tall plant with a stem up to $3 \mathrm{~m}$ tall, long leaves and a more robust inflorescence. This large form is found growing in more protected areas in dense shrub or in forest. There are specimens of intermediates linking the two forms and floristically there are no differences between the two forms except in the larger inflorescence of the shrub form. D. milliganii has leaves that vary from $140-300 \times 5-10 \mathrm{~mm}$ depending on the locality and habitat. The colour of the inflorescence axis varies from green, reddish brown to red. Plants growing in open subalpine areas have short inflorescence bracts (40-90 mm 
compared to $98-180 \mathrm{~mm})$. Flower colour varies from white to pink with the white forms sometimes intermingled with the pink. The sepals are variable in shape and size, ranging from lanceolate to oblong and 3-4 $\times 0.8-1.5 \mathrm{~mm}$. Corolla lobes are oblong to ovatetriangular with the filaments $2.5-5.0 \mathrm{~mm}$ long.

\section{Specimens examined}

AUSTRALIA - Tasmania. 41-145: North of Lake Huntley (-DC), 23.ix.1985. Brown 1261 (HO). 42-145: Strahan (-AB), i.1913, Rodway s.n. (HO); Queenstown, Mt. Sedgewick (-BA), 28.ii.1930. Comber 2162 (K); Macquarie Harbour, Mt. Sorell (-BC), Von Mueller s.n. (W); Frenchmans Cap, Barron Pass (-BD), 29.xii.1966. Olsen 37 (NSW).

42-146: Twelve Trees Range, $1 \mathrm{~km}$ NE of Strathgordon (-CA), 19.ii.1989. Croft 10224 (HO, NSW); Clear Hill (-CB), 3.xii.1997. Buchanan 14990, (HO); Mt Cullen, Summit area (-CC), 13.iv.1986. Moscal 12874 (HO, NSW); Mt. Humboldt, Mt. Field West (-DA), 25.xii.1896. Rodway s.n. (HO); Lake Seal, Tarn Shelf, 15.xii.1928. Comber s.n. (HO); Tarn Shelf, 2 km NW of Lake Dobson, NE of Rodway Range, 15.ii.1989. Croft 10070 (HO, NSW). 43-146: Western Arthur Range, Moraine A (-AA), 7.xii.1986. Collier 1999 (HO); South West National Park, Schnells Ridge (-AB), 11.i.1998. Rozefelds 658 (HO); Port Davy, Cox Bight, near Kings Mine (-AC), 15.xii.1939. King s.n. (HO); Mt. Councel, 23.iii.1984. Brown 383 (HO); Between Mt. La Perouse and Maxwell Ridge (-BC), 21.iii.1984. Buchanan 3025 (HO, NSW); Mt. La Perouse (-DA), xii.1926. Rodway s.n. (HO); Ridge between Mt Brady \& Mt La Perouse (-DB), xii.1898. Rodway s.n. (NSW).

13. Dracophyllum oceanicum E.A. Br. \& N. Streiber

Dracophyllum oceanicum E.A. Br. \& N. Streiber, Telopea. 8 (3): 397 (1999); Type: Australia, New South Wales, South Coast, cliffs c. $300 \mathrm{~m} \mathrm{~N}$ of Point Perpendicular, Beecroft 
Peninsula, Jervis Bay. 9.ix.1997. E.A. Brown 97/80, N. Streiber \& C.C. Simpson (NSW 412,483, holo.!; BRI; CANB!; CHR!; NY).

Icon: Telopea. 8 (3): t.2 (1999).

\section{Description}

A shrub to small tree $0.4-2.0(-2.5) \mathrm{m}$ tall with a scrambling habit. Branches erect to spreading and many branched. Bark on old branches grey, deeply fissured, young stems reddish brown. Leaves crowded at tips of branches, spirally arranged along stem in young plants, spreading to recurved; lamina sheath olive green to light brown, 12-17 $\times$ 14-21 mm, coriaceous, striate, membranous, tapering to rounded and the top half minutely ciliate; lamina coriaceous, adaxial surface lighter coloured, linear-triangular, (90)150-200(-230) × (9-)10-15(-18) mm, surfaces glabrous, prominently striated; margins serrulate with 10-20 teeth per $10 \mathrm{~mm}$; apex thickened, obtuse. Inflorescence shorter than the leaves, erect, dense, 70-100 mm long, oblong and densely branched; rachis and pedicels glabrous, reddish brown; inflorescence axis $3.0-3.6 \mathrm{~mm}$ in diameter; basal inflorescence branch 0.5-1.0 mm long, widely spreading; inflorescence bracts caducous, overtopping flowers, whitish at base and pink tipped to pink, ovate-triangular at base, 10-65 × 1.5-15.0 mm, surfaces glabrous, margins entire to serrulate. Flowers 300-700+, in groups of more than 10 at base of inflorescence, pedicellate; bracteoles persistent, recaulescent with one bracteole situated just below the perianth and the other in the middle of the pedicel, shorter than flower, linear to triangular, $4-8 \times 0.2-0.6 \mathrm{~mm}$, glabrous; pedicels straight, $1.5-2.0 \mathrm{~mm}$, glabrous. Sepals green to rose-coloured, lanceolate to ovate-lanceolate, $4.5-7.0 \times 1-2 \mathrm{~mm}$, shorter to equaling corolla tube, striate, surfaces glabrous; margins ciliate in upper half. Corolla white; corolla tube narrowly campanulate, widened at mouth, 4-7 $\times 2.5-3.5 \mathrm{~mm}$; corolla lobes spreading horizontally to 
reflexed, ovate, shorter than corolla tube, 1.5-2.5 $\times(1-) 1.5-2.0 \mathrm{~mm}$; apices obtuse; adaxial surface papillate and rugose. Stamens inserted in middle of corolla tube, filaments 3.0-4.5 mm long; anthers included, rectangular, pink and 1.5-2.0 $\mathrm{mm}$ long. Ovary obovate, 1.5-3.0 × 1-2 mm, glabrous, apex round; nectary scales oblong, 1.8-2.0 × 0.5-1.5 (-2.0) $\mathrm{mm}$, apex subacute to obtuse; style included, 2 - $3 \mathrm{~mm}$ long, glabrous,; stigma fivelobed. Fruit dark brown, 1.5-3.0 × 1.5-2.5 mm, obovoid, apex round, glabrous. Seeds yellowish brown, trigonous, $0.5-0.6 \mathrm{~mm}$ long, testa prominently reticulate. Flowering August-December. (Figure 7.38).

\section{Diagnostic features and discussion}

Dracophyllum oceanicum is characterized by the scrambling growth habit, roughly fissured bark, leaves mostly bronzed green and $150-200 \times 10-15 \mathrm{~mm}$, primary axis of the inflorescence reddish brown with flowers on the basal inflorescence branches arranged in groups of 20-30, pedicels $1.5-2.0 \mathrm{~mm}$ long, sepals shorter or equalling the cylindrical corolla tube, obtuse corolla lobes, hypogynous filaments and the trigonous seed.

Dracophyllum oceanicum shows affinities with $D$. fitzgeraldii and D. sayeri in the many flowers per inflorescence node, wide coriaceous leaves and floral measurements showing overlap (Streiber et al. 1999). The stigma is capitate and the corolla lobes are of a similar shape in 


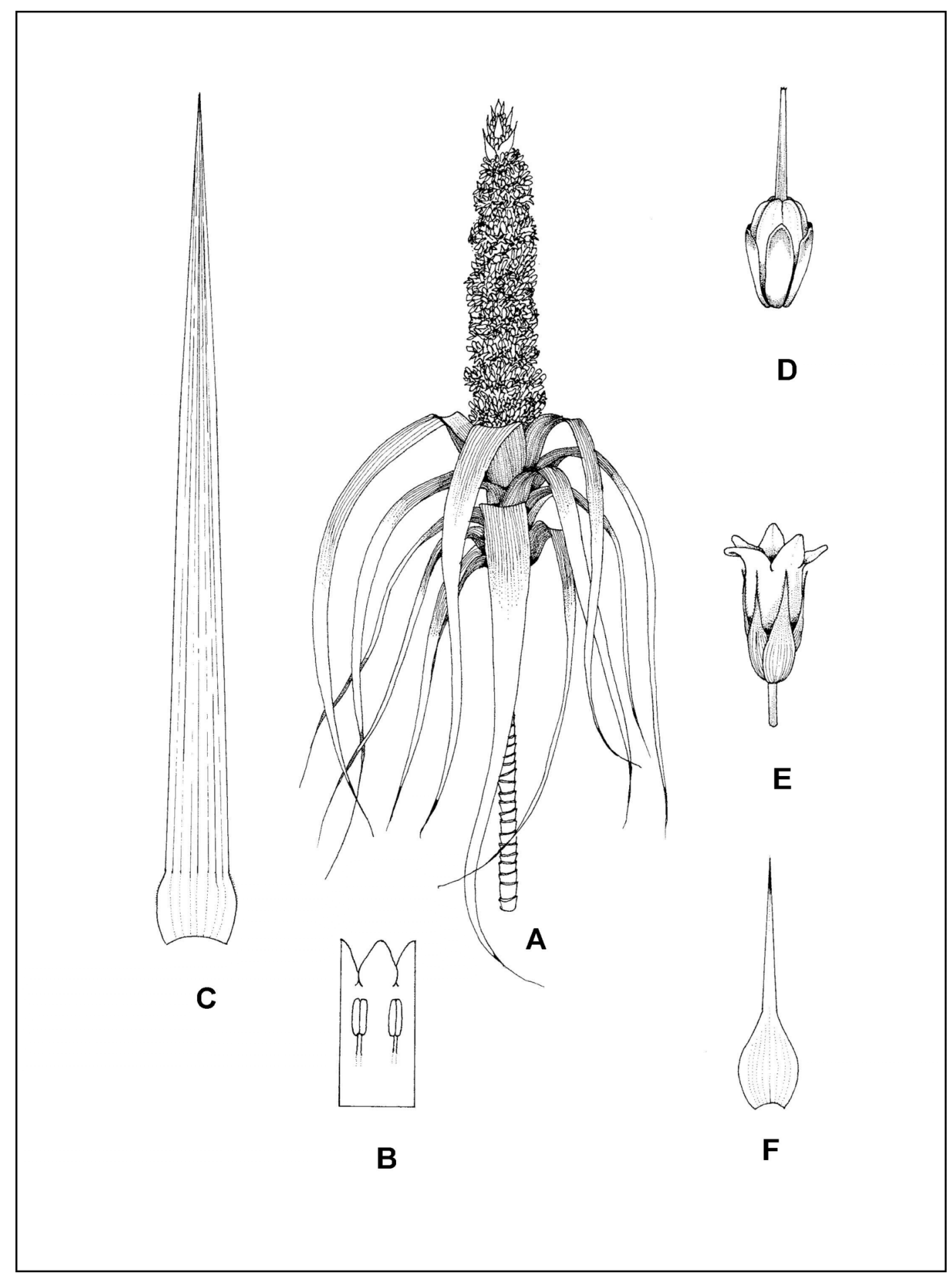

Figure 7.38. Dracopbyllum oceanicum. A, flowering branch $(\times 0.25) ; \mathbf{B}$, laid out corolla $(\times 5)$; $\mathbf{C}$, leaf $(\times 1) ; \mathbf{D}$, ovary $(\times 10) ; \mathbf{E}$, flower $(\times 5) ; \mathbf{F}$, inflorescence bract $(\times 1)$. Drawn from Brown 97/82. 


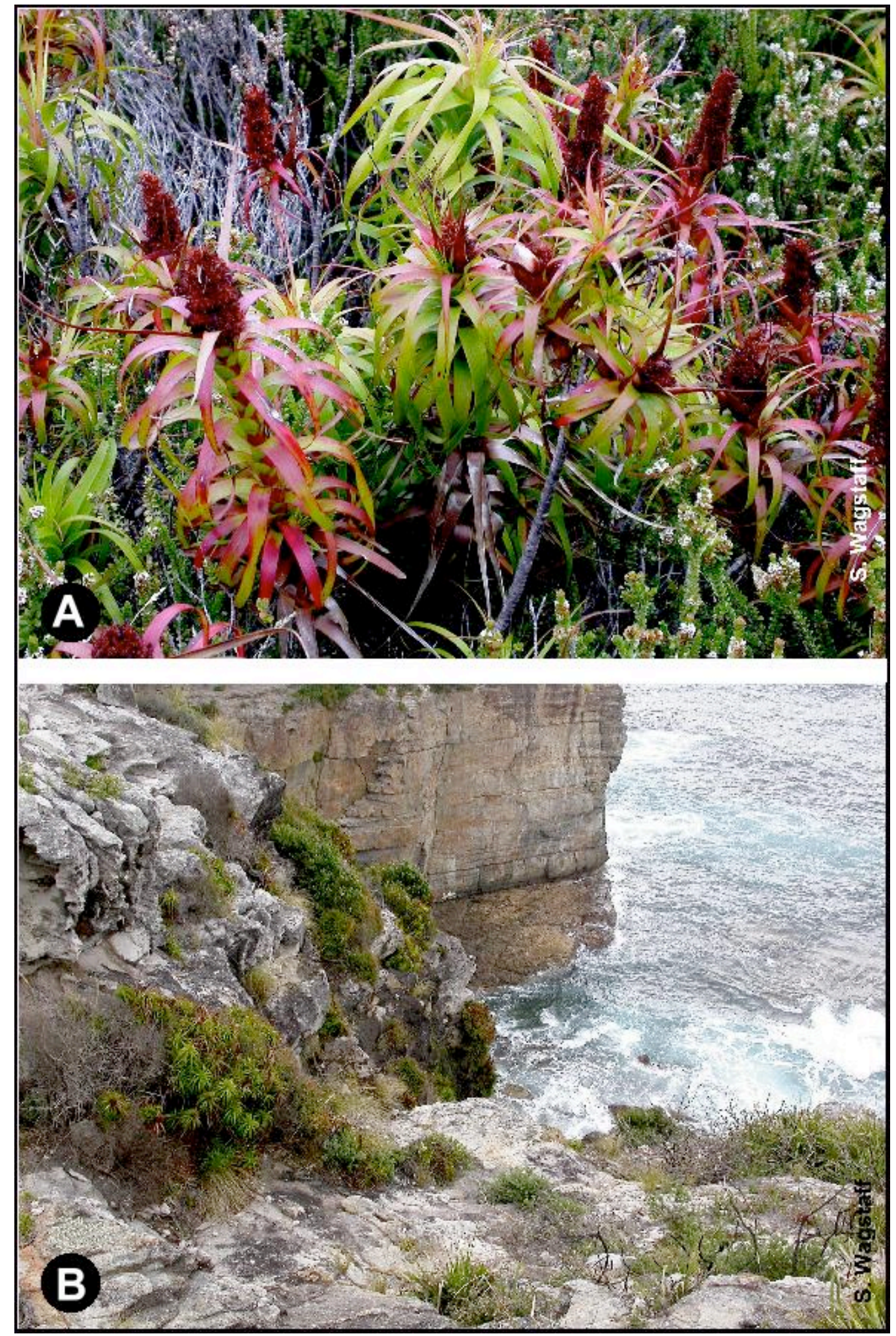

Figure 7.39. Dracopbyllum oceanicum. A, Mature plant showing the scrambling habit; B, typical cliff habitat at Jarvis Bay. 
D. oceanicum and D. fitzgeraldii. Dracophyllum oceanicum and D. sayeri have glabrous peduncles and pedicels but they are hairy in D. fitggeraldii (Brown et al., 1999). For differences between D. oceanicum and D. fitggeraldii see Table 7.8.

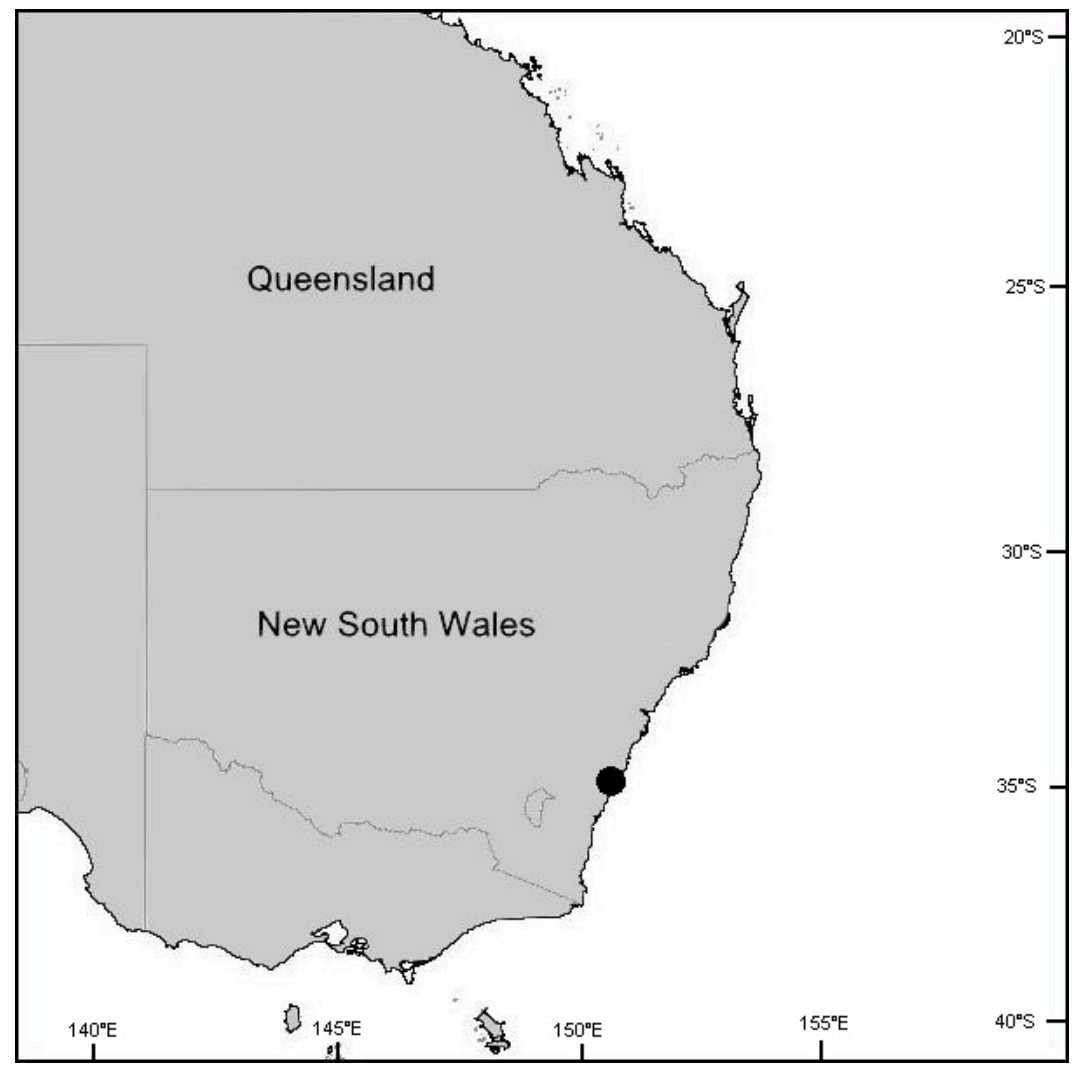

Figure 7.40. Known distribution of Dracophyllum oceanicum.

\section{Distribution}

Australian endemic restricted to the Jervis Bay area in New South Wales (Fig. 7.41).

\section{Habitat}

Dracophyllum oceanicum grows in full sun to light shade at low altitudes (10-50 m altitude), on or at bases of coastal cliffs and along stream margins in sheltered bays. It rarely grows more than $50 \mathrm{~m}$ from the sea. The surrounding vegetation is open heathland to dry 
sclerophyll woodland (Table 7.17). The soil is sand or sandy loam derived from sandstone.

Table 7.17. Plant communities commonly associated with Dracopbyllum oceanicum.

\section{Variation}

Leaf size varies from $150-200 \times 10-15 \mathrm{~mm}$ and the lamina might be either flat or channelled in cross-section. The inflorescence varies in length from 70-100 mm, with the green inflorescence bracts varying in size $(10-65 \times 1.5-15 \mathrm{~mm})$, having a whitish base or it can be pink-tipped or wholly pink. Plants in a population occasionally have the margin of the inflorescence bracts entire not serrulate. Bracteoles may vary in shape from linear to triangular on the same inflorescence. Sepal size varies from 4.5-7.0 $\times 1-2 \mathrm{~mm}$ and the corolla tube $4-7 \times 2.5-3.5 \mathrm{~mm}$ with the corolla lobes $1.5-2.5 \times 1.5-2.0 \mathrm{~mm}$. The adaxial surface of the corolla lobes can either be papillate or slightly rugoseverrucate. Ovary size varies from $1.5-3.0 \times 1-2 \mathrm{~mm}$ and fruit size from $1.5-3.0 \times 1.5-$ $2.5 \mathrm{~mm}$.

\section{Specimens examined}

AUSTRALIA - 35-150: New South Wales, South Coast, Beecroft Peninsula (-BB), 9.ix.1997. Brown 97/82, Streiber \& Simpson (AK, HO, NSW), ibid. Brown 97/84, Streiber \& Simpson (AK, CANB, NSW); ibid., 22.x.1994. Buchanan 13818 (HO); ibid., 7.ix.1997. Brown 97/87, Streiber \& Simpson (HO, NSW); ibid., 13.ix.1930. Rodway 49 (HO); Beecroft Peninsula, c. $500 \mathrm{~m} \mathrm{~W}$ of Beecroft Head, at Eves Ravine, 27.viii.1991. Lyne 374 (BISH, 
NSW, P); $1 / 4$ mile N of Point Perpendicular, (first gully), northern head of Jervis Bay, 7.x.1960. Constable s.n. (HO, K, NSW); Beecroft Peninsula, Gumgetters Inlet, 9.ix.1997. Brown 97/83, Streiber \& Simpson (NSW); East end of Steamers Bush, 7.ix.1997. Brown 97/90, Streiber \& Simpson (NSW). Drum and Drumsticks, near Point Perpendicular, Jervis Bay (-CD), 23.x.1932. Rodway 917 (HO, K, NSW).

\section{Dracophyllum ouaiemense Virot}

Dracophyllum ouaiemense Virot, Fl. Nov. Caléd. et Dépend. 6: 156 (1975). Type: New Caledonia, Roche Ouaième (massif de Ton-Non), 900 m, 7.i.1968. H.S. MacKee 18230 (P, holo.!; NOU; P.).

Icon: Virot, Fl. Nov. Caléd. et Dépend. 6: t. 27 (1975).

\section{Description}

A shrub $30-50 \mathrm{~cm}$ tall. Branches erect stemmed and sparsely branched. Bark on old branches grey to brown, deeply fissured, young stems reddish brown. Leaves erect to spreading; lamina sheath light green, 5-6 $\times 6-8 \mathrm{~mm}$, coriaceous, striate, membranous, tapering and margin ciliate; lamina coriaceous, linear-triangular to triangular, 15-60 $\times 4$ $12 \mathrm{~mm}$, surfaces glabrous, slightly striated; margins denticulate with $20-30$ teeth per 10 $\mathrm{mm}$; apex thickened, acute. Inflorescence overtopping the leaves, erect, lax, 20-100 mm long, oblong and sparsely branched; rachis and pedicels pubescent; inflorescence axis reddish, $0.8-2.0 \mathrm{~mm}$ in diameter at base; basal inflorescence branch 2-3 $\mathrm{mm}$ long, widely spreading; inflorescence bracts caducous, longer than flowers, light green to reddish, ovatelanceolate to ovate, $6-12 \times 4-8 \mathrm{~mm}$, surfaces glabrous, margins ciliate, apices obtuse. 
Flowers 20- 35, in groups of three at base of inflorescence, pedicellate; bracteoles caducous, both bracteoles shorter than the perianth and situated in the middle of the pedicel, 1.8-2.0 × 1.0-1.3, abaxial surface pubescent; pedicels curved, (2-)3-11, pubescent. Sepals rose-coloured to red, ovate to broadly ovate, $(3.5-) 4-6 \times 2.0-2.5$, shorter than the corolla tube, striate, adaxial surfaces glabrous, abaxial surfaces with minute scattered papillae; margins ciliate. Corolla red; corolla tube narrowly campanulate to sub-urceolate, narrowed at mouth, 7-9 $\times 0.8-1.0 \mathrm{~mm}$, exterior apically pubescent; corolla lobes spreading, ovate, shorter than corolla tube, $2.3-2.5 \times 1.2-1.5 \mathrm{~mm}$, apices obtuse; adaxial surface papillate; abaxial surface pubescent. Stamens implanted at middle of corolla tube, filaments 1-2 mm long; anthers included, rectangular, 0.7-1.5 mm long. Ovary globose, 0.8-1.0 mm long and wide, glabrous, apex round; nectary scales rectangular, $0.4-0.5 \mathrm{~mm}$ long and wide, apex retuse to irregularly toothed; style included, $0.7-1.0 \mathrm{~mm}$ long, glabrous; stigma capitate. Fruit reddish brown, $1.2-1.5 \times 2-4 \mathrm{~mm}$, obovoid to broadly obovoid, apex round, glabrous. Seeds light brown, ovoid, $0.55-0.6 \mathrm{~mm}$ long, testa slightly reticulate. Flowering January-July. (Figure 7.41).

\section{Diagnostic features and discussion}

Dracophyllum ouaiemense is characterized by its low (up to $50 \mathrm{~cm}$ tall) growth habit, thick stems with the leaves $15-60 \times 4-12 \mathrm{~mm}$ and glabrous, short inflorescence $(20-100 \mathrm{~mm}$ long) normally carried above the leaves, 7-9 $\mathrm{mm}$ long flowers arranged in groups of three at the base of the inflorescence, 3-11 $\mathrm{mm}$ long filiform pedicels, flexuose and caducous filiform bracteoles, glabrous sepals 4-6 $\mathrm{mm}$ long, red suburceolate 7-9 $\mathrm{mm}$ long corolla tube, obtuse oval-shaped corolla lobes and the included stamens. 


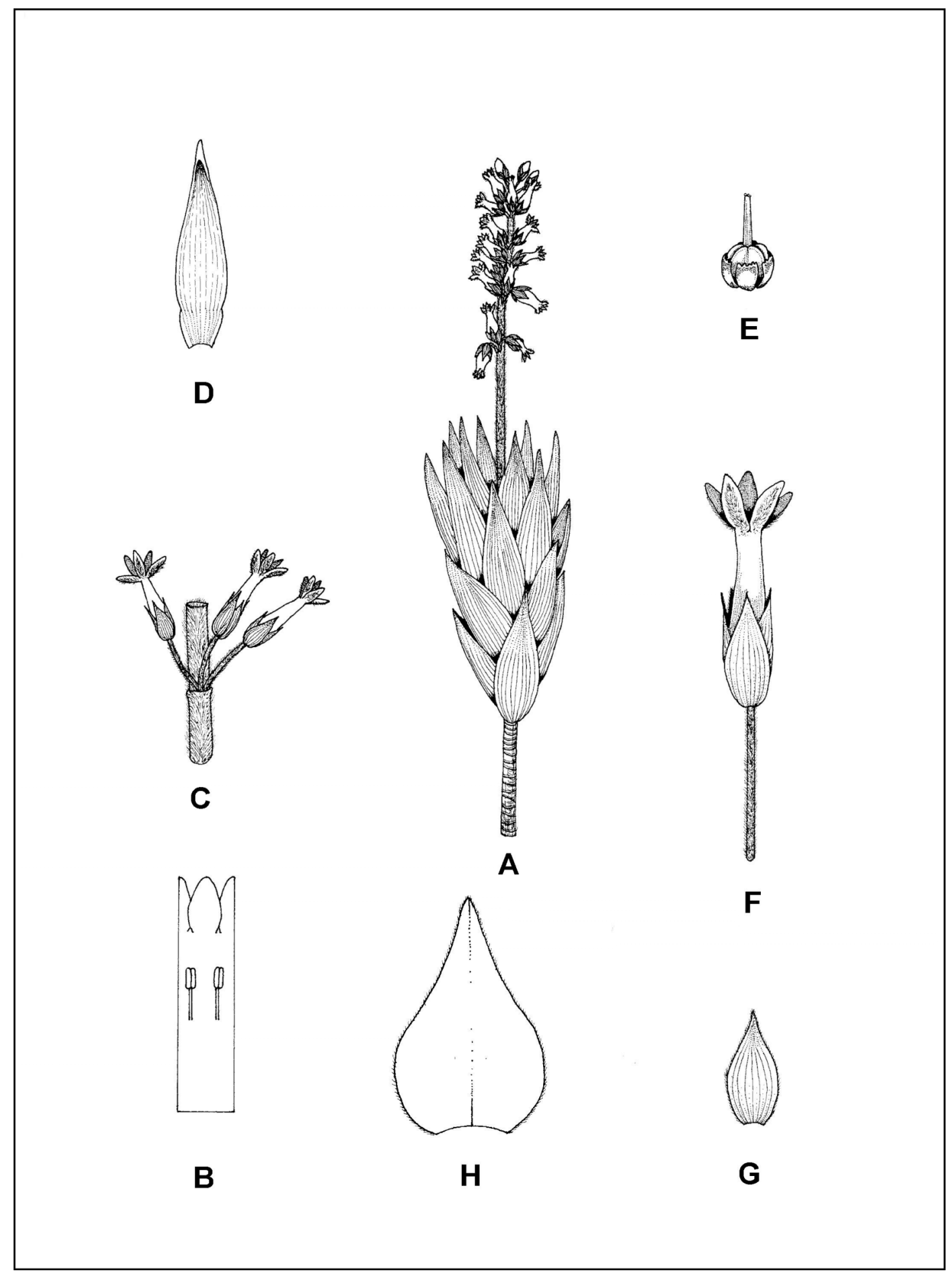

Figure 7.41. Dracopbyllum ouaiemense. A, flowering branch $(\times 1)$; $\mathbf{B}$, laid out corolla $(\times 5)$; C, bottom inflorescence branch $(\times 2)$; $\mathbf{D}$, leaf $(\times 1)$; $\mathbf{E}$, ovary $(\times 10) ; \mathbf{F}$, flower $(\times$ $5)$; $\mathbf{G}$, sepal abaxial surface $(\times 5), \mathbf{H}$, inflorescence bract $(\times 5)$. Drawn from MacKee 18230. 


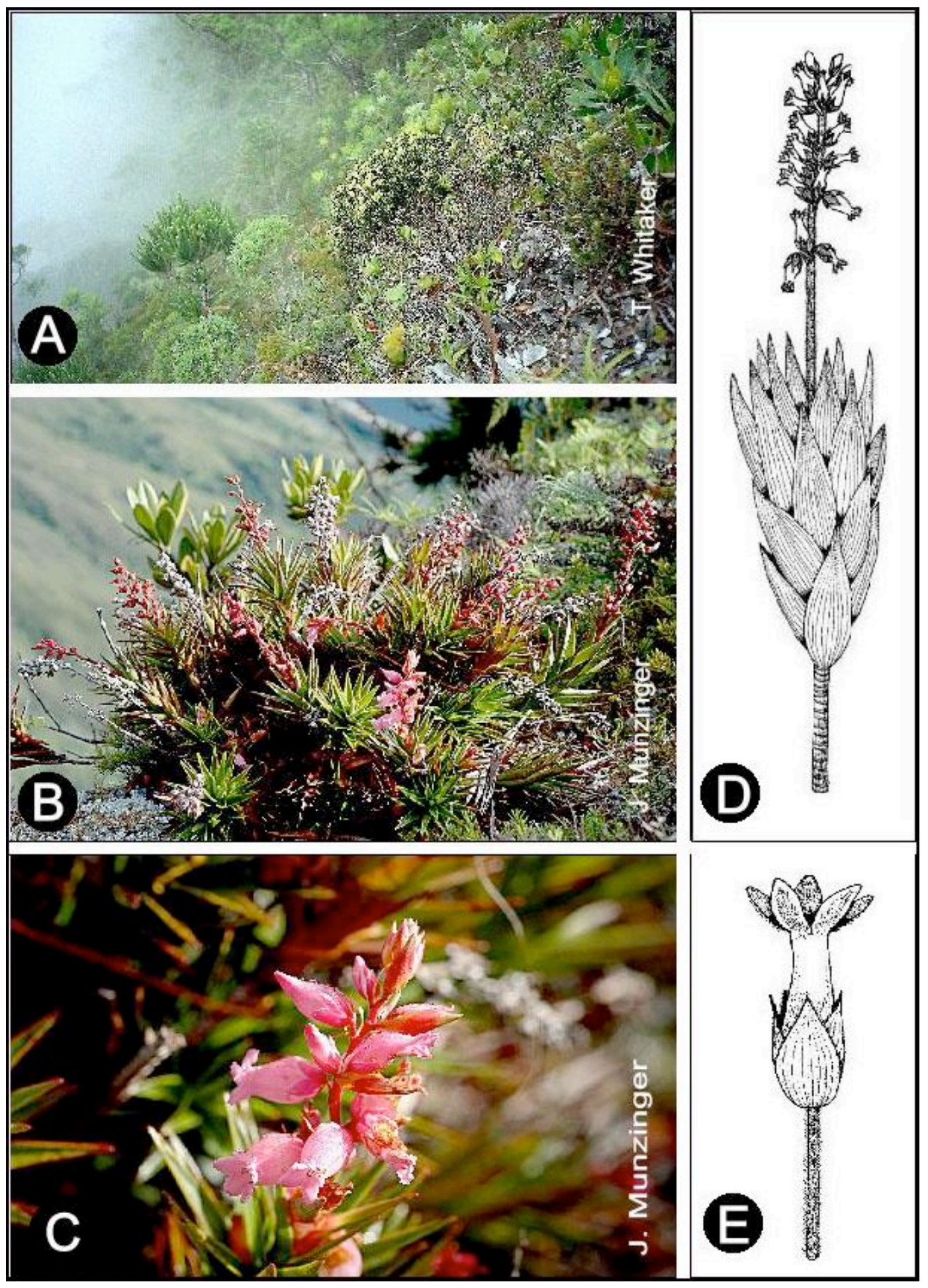

Figure 7.42. Dracophyllum onaiemense. A, habitat on Roche Ouaième at the type locality; B, adult flowering plant; $\mathbf{C}$, flowering branch showing the urceolate flowers; $\mathbf{D}$, flowering branch showing the striated leaves; $\mathbf{E}$, flower showing the pubescent abaxial corolla lobe surface. 
Virot (1975) placed D. onaiemense close to D. alticola and D. cosmelioides but it differs from them mainly in the inflorescence characters. D. ouaiemense is superficially similar to $D$. balansae and D. cosmelioides but differs from them in the glabrous branchlets, wider lamina (4-12 mm) and denticulate lamina margin with $20-30$ teeth per $10 \mathrm{~mm}$. The rachis is pubescent with the basal branches of the inflorescence longer $(2-3 \mathrm{~mm})$. The inflorescence bracts have obtuse apices and the pedicel is much longer (3-11 mm). The sepals are shorter than the corolla tube and the corolla tube is longer (7-9 $\mathrm{mm}$ ) with the outer surface pubescent. The corolla lobes are longer $(2.3-2.5 \mathrm{~mm})$ with pubescent abaxial surfaces and the stamens are inserted in the middle of the corolla tube with the ovoid seed being longer $(0.5-0.6 \mathrm{~mm})$.

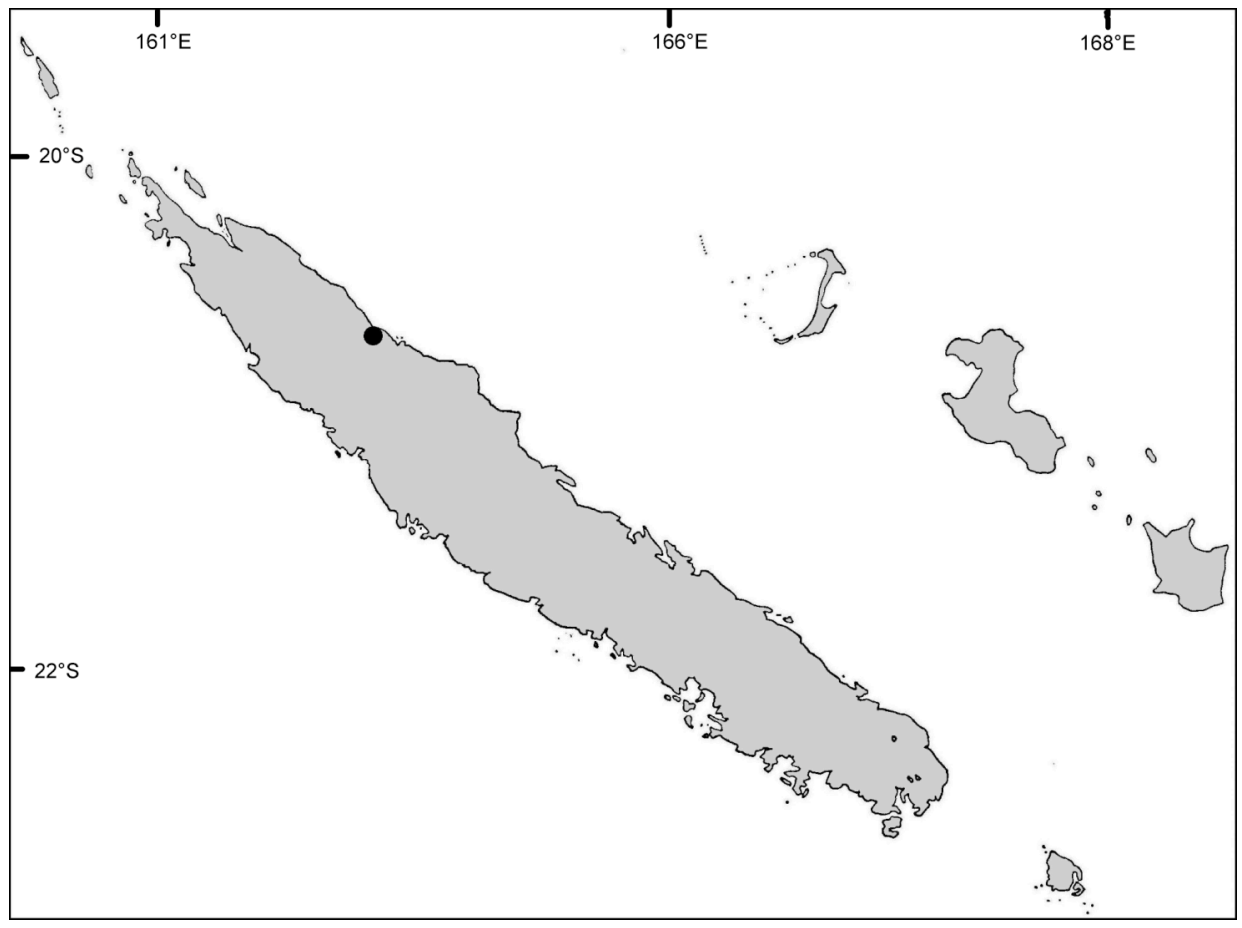

Figure 7.43. Known distribution of Dracophyllum ouaiemense. 


\section{Distribution}

New Caledonia endemic restricted to the Roche Ouaième area of Grande Terre in the north (Fig. 7.43).

\section{Habitat}

Dracophyllum onaiemense occurs in full sun on mountain tops and gentle to steep $\left(10^{\circ}-40^{\circ}\right)$ slopes at $850-900 \mathrm{~m}$ altitude. The vegetation is typical maquis and D. ouaiemense grows in close association with Xeronema moorei on clay loam derived from schist. This habitat is usually moist during the rainy season but receives mist throughout the year especially over the summer months.

\section{Variation}

The leaves of $D$. ouaiemense show variation in shape from linear-triangular to triangular and in size $(15-60 \times 4-12 \mathrm{~mm})$. The inflorescence bracts vary from ovate-lanceolate to ovate at the base and also in size $(6-12 \times 4-8 \mathrm{~mm})$. The flowers at the base of the inflorescence are sometimes arranged in groups of two, a rare reduction from the normal groups of three on the basal inflorescence branches. The apices of the nectary scales are normally retuse but occasionally they are irregularly toothed.

\section{Specimens examined}

\section{NEW CALEDONIA}

20-164: (-DD), Roche Ouaième (massif de Ton-Non), 13.vii.1968. MacKee 19135 (P); ibid., 7.i.2003. Tronchet 714 (MO, NOU, P). 
15. Dracophyllum ramosum Pancher ex Brongn. \& Gris.

Dracophyllum ramosum Pancher ex Brongn \& Gris, Ann. Sci. Nat. Bot. 2: 156 (1864a); Moore, Journ. Linn. Soc. Bot. 45: 349 (1921); Oliver, Trans. Proc. N.Z. Inst. 59 : 707 (1928);

Däniker, Vierteljabrsschr. Nat. Ges. Zürich 78 (19): 341 (1933); Oliver, Trans. Roy. Soc. N.Z. 80 (1): 14 (1952); Virot, Fl. Nov. Caléd. et Dépend. 6: 152 (1975) p.p.. Types: New Caledonia, Montagne de M’bée. 1861. E. Vieillard 830 (L, lecto.!; GH; NSW; W!; Z!), New Caledonia, Kanala. J.A.I. Pancher s.n. (P, lectopara.!), designated by Virot (1975).

$=$ Dracophyllum amabile Brongn. \& Gris, Bull. Soc. Bot. Fr. 11: 68 (1864b). Type: New Caledonia, Montagnes de Kanala. 1855. E. Vieillard 829 (P, lecto.!; K!; L!; LY!; W!; Z!.), designated by Oliver (1952). Type: New Caledonia, s. loc. J.A.I. Pancher 215 (K, syn.!); s. loc. Pancher 4292 (NOU, syn.!; P!).

= Dracophyllum vieillardii Lenorm. ex Guill., Ann. Mus. Col. Marseille 9 (2): 181 (1911). nom. nud. Type: New Caledonia, Dombéa, E. Vieillard s.n. (P, holo.!; P!; W!; Z!).

Icones: Oliver, Trans. Proc. N.Z. Inst. 59: t. 17 \& 18 (1928); Oliver, Trans. Roy. Soc. N.Z. 80 (1): t. 17 \& 18 (1952); Virot, Fl. Nov. Caléd. et Dépend. 6: t. 25 (1975) p.p..

\section{Description}

A shrub or tree, $0.5-5.0 \mathrm{~m}$ tall. Branches spreading and sparsely branched, branches having side branches growing from the same point. Bark on old branches greyish to blackish brown, finely to deeply fissured, young stems reddish brown. Leaves spirally arranged on young plants, spreading to recurved, decreasing in size below inflorescence; lamina sheath light green to light brown, 19-28 $\times 10-14 \mathrm{~mm}$, coriaceous, striate, 
membranous, tapering and margin smooth; lamina coriaceous, linear-triangular to lanceolate, $65-125 \times 6-11 \mathrm{~mm}$, surfaces glabrous, prominently striated; margins serrulate with 40-60 teeth per $10 \mathrm{~mm}$; apex obtuse to acute. Inflorescence overtopping the leaves, erect, dense, 40-200 mm long, linear-oblong and sparsely branched; rachis and pedicels pubescent; inflorescence axis light to mid green, $1-2 \mathrm{~mm}$ in diameter; basal inflorescence branch $0.8-1.0 \mathrm{~mm}$ long, widely spreading; inflorescence bracts caducous, overtopping flowers, coriaceous, pink tipped, pink or red, narrowly ovate to ovatetriangular at base, $(10-) 22-70 \times 10-15 \mathrm{~mm}$, surfaces glabrous, margins ciliate. Flowers 70-250+, in groups of 5-10 at base of inflorescence, pedicellate; bracteoles persistent, both bracteoles situated at a basal position on the pedicel with the top bracteole longer than the perianth and the lower shorter than to equalling the flower, linear, 3-8 $\times 0.6-1.0$ $\mathrm{mm}$, glabrous; pedicels straight, reddish brown, $0.5-1.5 \mathrm{~mm}$, tomentose. Sepals green to rose-coloured, ovate-lanceolate to ovate, $(3.0-) 3.5-4.0 \times(1.3-) 1.5-1.8$, shorter than to equalling the corolla tube, striate, surfaces glabrous; margins ciliate; apices acute. Corolla white to dark pink; corolla tube cylindrical, narrowed at mouth, (2.5-)4.0-6.0 $\times 2.3-2.5$ $\mathrm{mm}$, exterior pubescent in upper part; corolla lobes spreading to horizontal, oblong to ovate-triangular, shorter than corolla tube, 1.5-1.7 $\times 1.0-1.1 \mathrm{~mm}$, apices obtuse with an erose margin, inflexed at apices; adaxial surface papillate, abaxial surface glabrous to pubescent. Stamens inserted in upper third of corolla tube, filaments $1.5-1.7 \mathrm{~mm}$ long; anthers included, oblong, light yellow and 0.5-0.7(-1.0) mm long. Ovary subglobose to globose, 0.8-1.0 × 1.1-1.3 mm, glabrous, apex round; nectary scales rectangular, 0.9-1.0 × 0.4-0.5 mm, apex irregularly toothed; style included, $0.7-0.8 \mathrm{~mm}$ long, glabrous; stigma five-lobed. Fruit reddish brown, 1.4-1.5 × 1.5-3.0 mm, obovoid to round, apex round, glabrous. Seeds light brown, filiform, $0.48-0.5 \mathrm{~mm}$ long, testa slightly reticulate. Flowering September-February. (Figure 7.44). 


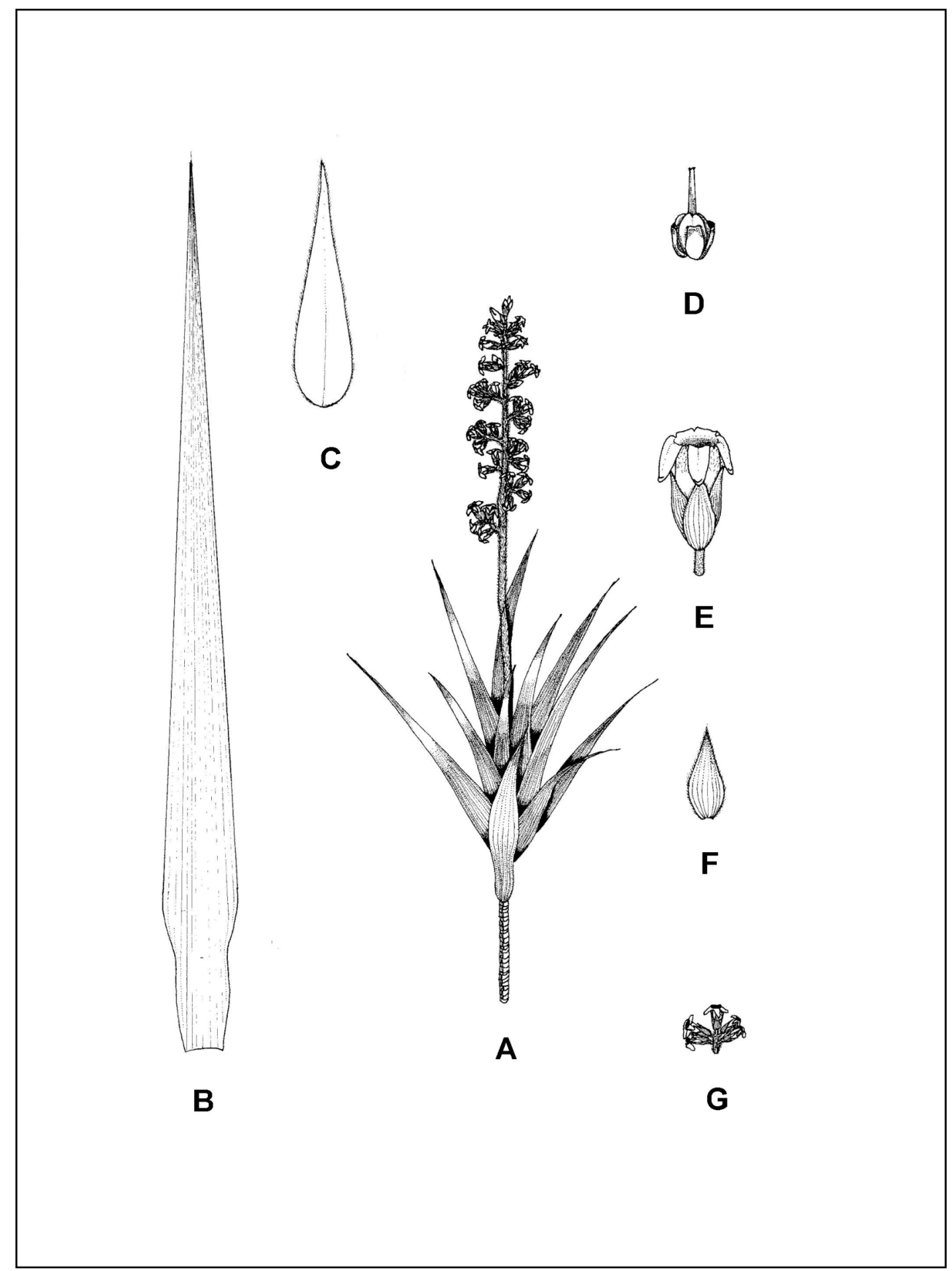

Figure 7.44. Dracopbyllum ramosum. A, flowering branch $(\times 1)$; B, leaf $(\times 1)$; C, inflorescence bract $(\times 1)$; $\mathbf{D}$, ovary $(\times 10)$; $\mathbf{E}$, flower $(\times 5) ; \mathbf{F}$, sepal $(\times 5)$; $\mathbf{G}$, bottom branch of inflorescence $(\times 1)$. Drawn from MacKee 22571. 


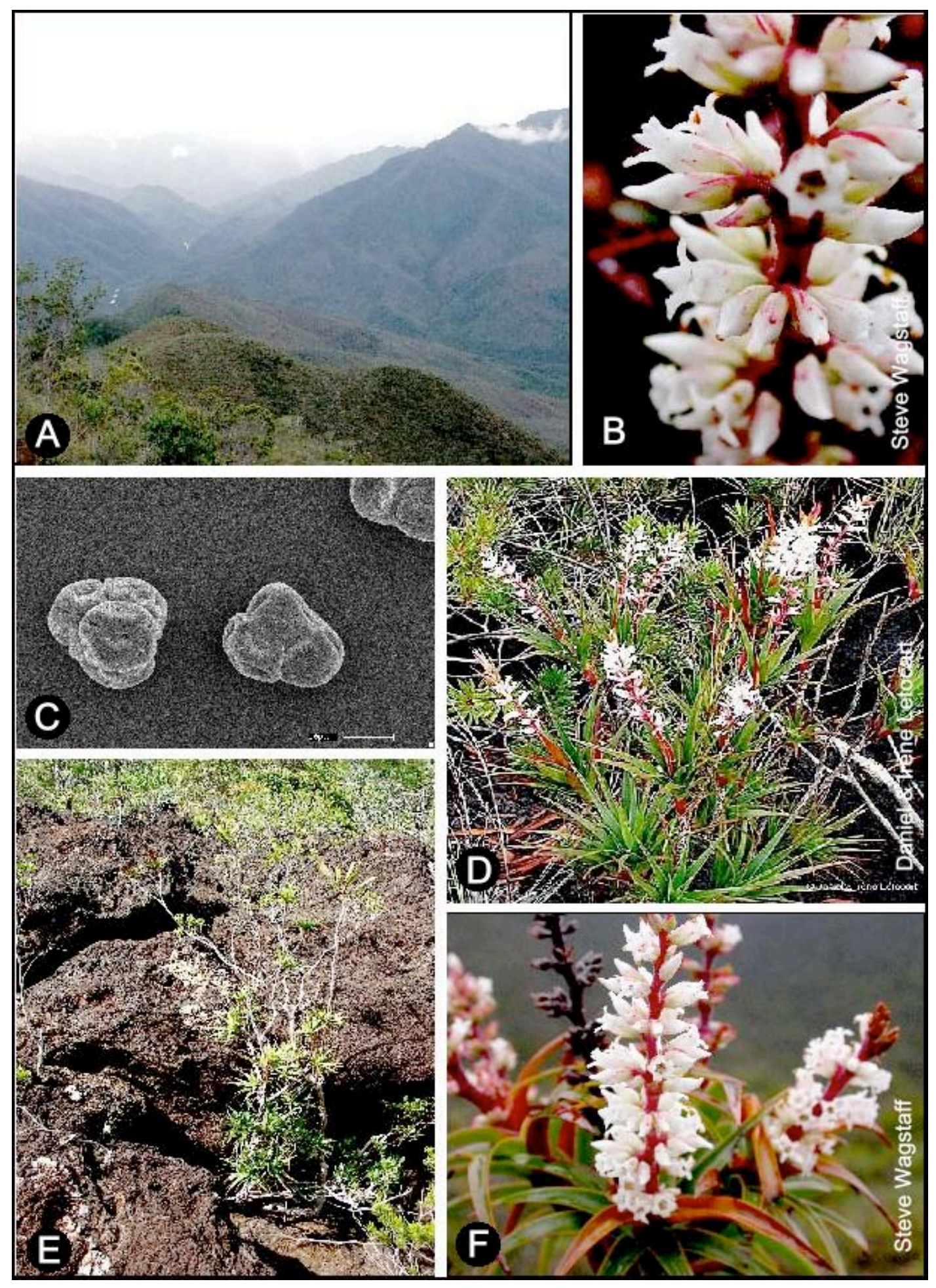

Figure 7.45. Dracopbyllum ramosum. A, habitat at the Tontouta Valley; B, close-up of flowers showing the flower grouping; C, pollen (Scale Bar $=10 \mu \mathrm{m}$ ); $\mathbf{D}$, flowering branches showing the short leaves below the inflorescence and the inflorescence bracts; E, mature plant (Venter 13851); F, flowering branch of Venter 13851. 


\section{Diagnostic features and discussion}

Dracophyllum ramosum is characterized by the side branches that arise from the same point, leaves that decrease in size below the inflorescence, inflorescence being longer than the leaves, flowers arranged in groups of $5-10$ on the basal inflorescence branches, pubescent outer surface of the corolla and the inflexed apices of the corolla lobes.

When Brongniard \& Gris (1864) published the Pancher manuscript name D. ramosum they mentioned two specimens, Vieillard 830 collected at M'bée and Pancher s.n. collected at Kanala. Oliver (1928) gave M'bee as the type locality but he did not designate a specimen, and in a later publication (1952) he selected the Vieillard 830 (L) specimen as lectotype. Virot (1975) however rejected the Vieillard 830 specimen as lectotype, and correctly chose the Pancher specimen from Kanala as the name 'Dracophyllum ramosum' occurs on the label in Pancher's writing. Dracophyllum ramosum is similar to D. fitageraldii but differs in leaf, inflorescence and flower characters (Table 7.8).

\section{Distribution}

New Caledonia endemic, growing on the main island Grande Terre, and on Ile des Pins in the south. D. ramosum is the most common Dracophyllum species in New Caledonia (Fig. 7.46).

\section{Habitat}

Dracophyllum ramosum grows on mountain summits and slopes, in river valleys, on plateaus and commonly along streams from 100-1,200 m. altitude. The vegetation varies from forest, maquis to shrub mosaic (Table 7.18). Soils are rocky loam or clay-loam, mostly ferruginous and derived from peridotite or serpentinite. 


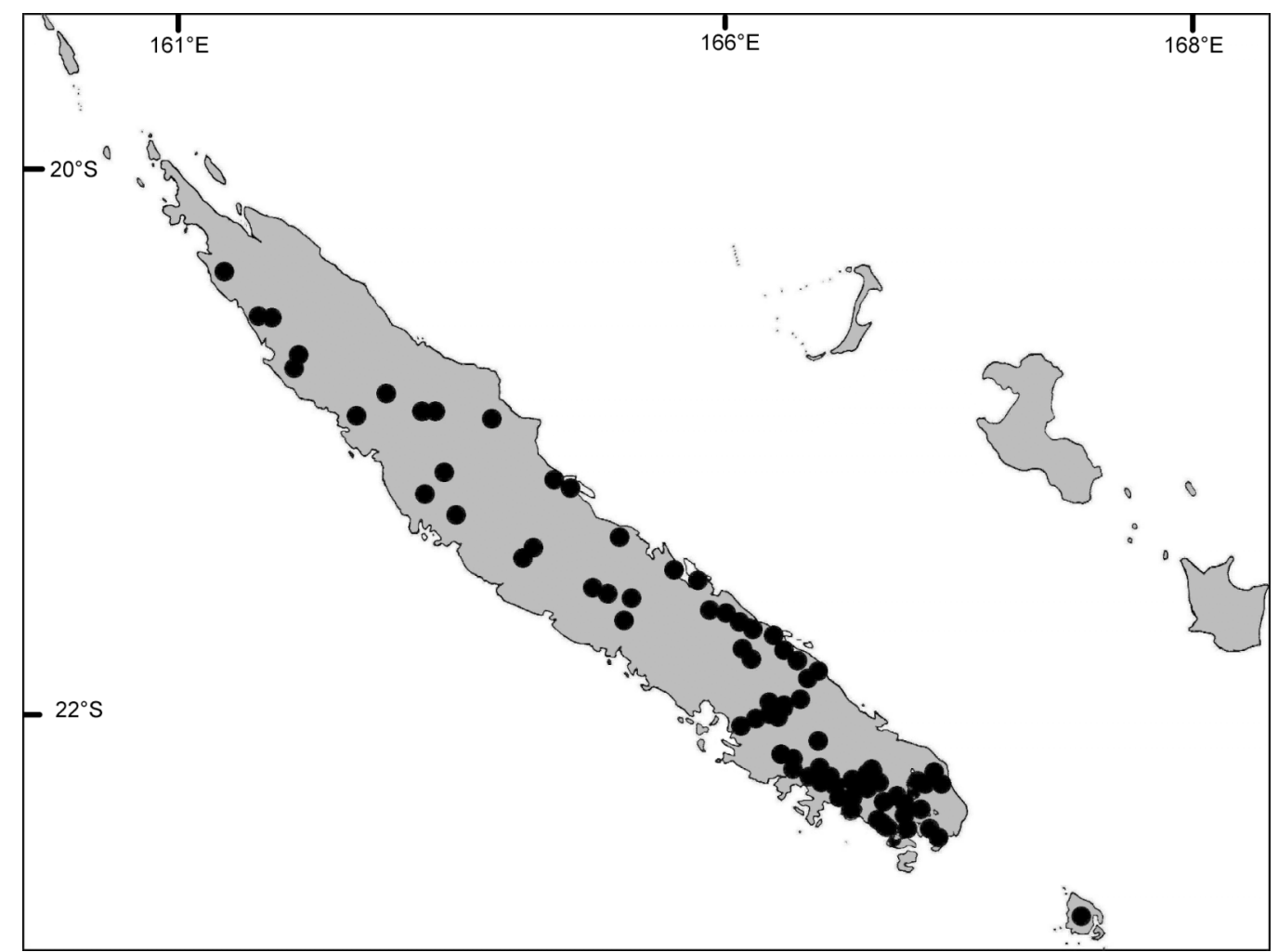

Figure 7.46. Known distribution of Dracophyllum ramosum.

Table 7.18. Plant communities commonly associated with Dracophyllum ramosum.

\section{FOREST}

Low closed evergreen Casuarina deplancheanum - Dacrydium araucarioides - Dracophyllum forest

Tall closed evergreen Nothofagus baumanniae forest

\section{MAQUIS}

Tall open semi-deciduous Gymnostoma intermedium - Dracophyllum verticillatum - Pteridium esculentum maquis

Tall open evergreen Melaleuca brongniartii - Styphelia albicans - Xyris pancheri maquis

Low closed evergreen Boronella pancheri - Babingtonia leratii - Melaleuca brongniartii maquis

Low open evergreen Xanthostemon aurantiacus - Melaleuca brongniartii - Styphelia albicans maquis

Low open evergreen Pancheria vieillardii - Styphelia albicans - Scaevola beckii maquis

Low closed evergreen Tristaniopsis glauca - Xanthostemon aurantiacus - Pteridium esculentum maquis

\section{Variation}

Dracophyllum ramosum is a polymorphic species, with a great deal of variation in the leaves and inflorescence (Virot 1975). It grows as a small shrub scarcely one metre tall at Mt.

Tchingou to a forest element of five metres at Mt. Dore. Branches are spreading and 
mostly sparsely branched or might be many branched, or it may have many branches all from one point. These variations appear to be the result of environmental conditions. Leaves vary in size from 65-125 × 6-11 mm, sometimes having obtuse lamina apices. Inflorescences vary from 40-200 $\mathrm{mm}$ long with the inflorescence bracts narrowly ovate to ovate-triangular at the base and $22-70 \times 10-15 \mathrm{~mm}$. The sepals vary from ovatelanceolate to ovate, with the corolla white to dark pink, the corolla lobes oblong to ovate-triangular that is sometimes glabrous on the abaxial surface in certain populations, but these are not geographically separated. Because most of the above mentioned variation could occur in a small area, it is not practical to depict this on a pictorial map.

\section{Specimens examined}

\section{NEW CALEDONIA}

20-164: Mt. Tiebaghi (-AC), 21.x.1959. Thorne 28058 (L, Z); Pouembout Valley (-BB), 03.vii.1967. MacKee 17024 (L, NOU, Z); Taom, Mt. Homédéboa (-BC), 16.x.1969. MacKee 20999 (K, L, NOU); Mt. Kaala, southern slopes (-CB), 20.x.1956. MacKee 5546 (K, L); Sentier du Dzumac, 12.xi.1975. Whitmore 3115 (K); Dzumac, Le Rat 160 (K); Mt. Tchingou (-DD), 21.viii.1965. Bernardi 10426 (L, S, Z); 21-165: Kopéto, E of Mt. Vert (AA), 08.viii.1970. MacKee 22213 (L, NOU); Plate Forest, Paéoua 13.viii.1965. Bernardi 10121 (L; Z); Moneo (-AB), 8.x.1973. MacKee 27565 (K, L); Mt. Mou, 18.x.1951. Baumann-Bodenheim 15583 (Z); ibid., 23.viii.1950. Baumann-Bodenheim 5639 (Z); ibid., 25.xii.1907. Franc 608 (L); ibid., Le Rat 478 (K); Mé Maoyo, Mine Emma (-AD), 11.vii.1965. Bernardi 9557 (L, Z); Haute Houailou and Haute Baraoua, Spur of Mé Maoya (-BC), 28.xii.1962. MacKee 9894 (K, L, NOU, NSW); Mé Adéo 15 km NE of Bourail, 09.x.1963. Green 1278 (K, L, MEL, Z); 5 km S of Poro, 01.v.1966. MacKee 14869 (L); Bogota (-BD), Sarasin 283 (Z); Dothio (-CA), 21.x.1965. MacKee 13670 (L, NOU); Mé Ori (-DA), 26.v.1965. MacKee 12695 (L, NOU); Summit area of Table Unio, 17.i.1968. 
Schodde 5270 (AD, CANB, L, P); Canala, Mondi (-DB), 24.xi.1970. MacKee 22571 (K, L, NOU, Z); Canala, Deplanche 59 (L, W); 21-166: Baie des Pirogues (-BC), 04.ii.1926. Däniker 3073 (Z); Pirogue River, 03.x.1924. Däniker 182 A (Z); Prony (-BD), 15.x.1914. Franc 1868 (Z); Thio (-CA), i.1872. Balansa 3671 (K); Thio, Pauline Mine, 18.iii.1968. Veillon 1651 (NOU, P); 5 m NW of Thio on road to Canala, 25.vii.1952. MacMillan 5159 (L); Thio, Mt. Nékandi, 7.xi.1967. Valley of Dothio River, c. $12 \mathrm{~km} \mathrm{NW}$ of Thio, 17.xii.1973. Webster 19349 (NSW); MacKee 17905 (K); Ngoye, 25.iii.1908. Schlechter 15257 (K); Upper Tontouta Valley, Mt. Humboldt, 16.xi.1924. Däniker 598 (Z); Baie d’Uié, base du Pic Ia (-DB), 17.ix.1868. Balansa 277 (Z); Ngoye (-DC), 26.xi.1902. Schlechter 15093 (BM, W, Z); 22-166: North Dumbea Valley (-AB), 5.ii.1956. MacKee 3974 (K, L); Dumbea, Vieillard 2831 (K, P, Z); Mont Mou, 30.vii.1965. Bernardi 9889 (L); Montagne des Sources (-BA), 29.ix.1979. McPherson 1921 (NOU, NSW); Riviére Bleue Forest Reserve, 14 km from junction with Nouméa - Yaté road, viii.1980. Schmid 3295 (K); Above junction of Rivière des Lacs with Ruisseau Pernod, 24.ix.1963. Green 1194 (MEL, Z); Near Coulée River, 17 km E of Nouméa, 29.xi.1963. Green 1705 (L, MEL, Z); Pic Casse Cou, 28.xi.1950. Hürlimann 215 (Z); Col de Ouirange, 14.v.2005. Venter 13851 (NOU); De Touaourou ad Mamié (-BB), 26.vii.1965. Bernardi 9812 (K, L); Between N'Go Bay and Touaourou, xii.1903. Robrdorf 93 (Z); Ruisseau Pernoud, $45 \mathrm{~km} \mathrm{E} \mathrm{of}$ Nouméa, 24.ix.1963. Green 1194 (MEL, Z); Yaté, 26.ix.1950. Baumann-Bodenheim 6226 (Z); Yaté Barrage, 09.xi.1970. MacKee 22856 (L); Rivière des Lacs (Yaté), 06.x.1950. Baumann-Bodenheim 6667 (Z); Vallee N’Go, Baie du Sud (-BC), i.1903. Cribs 1267 (K); Plateau Est. Baie du Sud, 1903. Cribs 1569 (NSW); Col de Plum, 22.viii.1950. BaumannBodenheim 5588 (Z); Mt. Dore, 08.xi.1950. Baumann-Bodenheim 7866 (Z); ibid., Guillaumin \& Baumann-Bodenheim 11343 (Z); Val Boise, Creek on east side of Mt. Dore, 1.ii.1991. Weston, Wilson \& Briggs 1624 (NSW); Mt. Dore area, along the Lembi River, 12.v.2005. Venter 13843 (NOU); $12 \mathrm{~km} \mathrm{~S} \mathrm{of} \mathrm{Rivière} \mathrm{des} \mathrm{Pirogues,} \mathrm{ridge} \mathrm{overlooking} \mathrm{Prony,}$ 
15.x.1955. McKee 3236 (L); Vallée de la Rivière des Lacs, Pont (-BD), 20.xi.1969.

Guillamin \& Baumann 6619 (K); 22-167: Ile des Pins (-CB), Germain s.n. (Z).

16. Dracopbyllum sayeri F. Muell.

Dracophyllum sayeri F. Muell., Austr. Journ. of Pharmacy 2: 85 (1887a); Mueller, Bot. Centralbl. 30: 356 (1887); Bailey, Queensland Fl. 3: 942 (1900); Bailey, Compr. Cat. Queensl. Plants.: 296 (1913); Domin, Bibliotheca Botanica. 89 (4): 503 (1928); Oliver, Trans. Proc. N.Z. Inst. 59: 710 (1928); Oliver, Trans. Roy. Soc. N.Z. 80 (1): 15 (1952); Nicholson \& Nicholson, Austr. Rainforest Plants. 3: 24 (1991). Type: Australia, N. Queensland, On Mt. Bellenden-Ker, at elevations between 4500 and 5200 feet; W. Sayer s.n. (MEL 2064424, holo.!).

= Dracophyllum sayeri F. Muell. var. normale F.M. Bailey, Compr. Cat. Queensl. Plants.: 296 (1913). nom. illeg. Type: Australia, on Bellenden-Ker. Name invalid (nom. inval.) as it is presumably meant to be the type variety.

= Dracophyllum sayeri F. Muell. var. reflexum F.M. Bailey, Compr. Cat. Queensl. Plants.: 296 (1913). nom. illeg. Type: Australia, on Bellenden-Ker.

= Dracophyllum sayeri F. Muell. var. sayeri F.M. Bailey, Compr. Cat. Queensl. Plants.: 296 (1913). Autonym.

Icones: Bailey, Compr. Cat. Queensl. Plants.: t. 269 (1913); Domin, Bibliotheca Botanica. 89 (4): t. 173 (1928); Oliver, Trans. Proc. N.Z. Inst. 59: t. 19 (1928). 


\section{Description}

A shrub or tree $2-8 \mathrm{~m}$ tall. Branches sparsely to many branched, sometimes forming a tangled mass. Bark on old branches light brown, flaky, young stems yellowish brown. Leaves recurved in a bromelioid manner; lamina sheath light brown to pinkish-red, 20-27 $\times$ 14-16 mm, coriaceous, striate, tapering and margin ciliate; lamina coriaceous, adaxial surface lighter green; linear-triangular, (240-) $310-440 \times 9.0-11.5(-20) \mathrm{mm}$, surfaces glabrous, prominently striated; margins entire; apex acute. Inflorescence shorter than leaves, erect, dense, 160-210 mm long, linear-oblong and densely branched; rachis and pedicels glabrous to minutely hirsute; inflorescence axis light to mid green, $2.8-6.8 \mathrm{~mm}$ in diameter; basal inflorescence branch 15-28 mm long, widely spreading; inflorescence bracts caducous, overtopping flowers, whitish at base to pink-tipped or wholly pink, ovate-lanceolate at base, $85-110 \times 15-25 \mathrm{~mm}$, surfaces glabrous, margins entire. Flowers 300-500+, in groups of up to 20 at base of inflorescence, pedicellate; bracteoles caducous, recaulescent, with one bracteole situated just below the perianth and the other in the middle of the pedicel, equalling the flower, $4-5 \times 0.5-1.0 \mathrm{~mm}$, glabrous; pedicels straight, 1.5-2.5 mm long, glabrous to pubescent. Sepals green to rose-coloured, lanceolate to ovate-lanceolate, $2.3-3.2 \times 1.0-1.5 \mathrm{~mm}$, shorter than the corolla tube, striate, surfaces glabrous; margins ciliate. Corolla white turning cream-coloured with age to light pink turning deeper pink with age or white with pink lobes; corolla tube narrowly campanulate, widened at mouth, 3-5 $\times 2-3 \mathrm{~mm}$; corolla lobes reflexed, oblong to ovate, shorter than corolla tube, $2.5-3.8 \times 1.5-2.0 \mathrm{~mm}$, apices obtuse; adaxial surface papillate, abaxial surface glabrous. Stamens inserted at top of corolla tube, filaments $1.0-1.3 \mathrm{~mm}$ long; anthers exserted, rectangular, light yellow and 1.0-1.5 mm long. Ovary subglobose, 0.7-1.0 × 1.0-1.2 mm, glabrous, apex round; nectary scales connate at base, rectangular, 0.4-0.5 mm long and wide, apices retuse to irregularly lobed; style included, 1.0-2.2 mm long; stigma five-lobed. Fruit pedicellate, included in persistent calyx, reddish brown, 
1.7-2.0 $\times$ 2.5-3.0 mm, depressed-obovoid; apex round, glabrous. Seeds light brown, ovoid, 0.95-1.0 mm long, testa slightly reticulate. Flowering (April-) June-August. (Figure 7.47).

\section{Diagnostic features and discussion}

Dracophyllum sayeri is characterized by the panicles that are shorter than the leaves and having up to 20 flowers per basal inflorescence branch, inflorescence bracts tapered at both ends and 85-110 mm long, sepals much shorter than the corolla, corolla lobes 2.5$3.8 \mathrm{~mm}$ long with obtuse apices, exserted anthers and club-shaped stigmas.

The Sayer specimen (MEL 2064424) is the only specimen mentioned in the protologue and Oliver (1952) incorrectly stated that the Johnson s.n. (MEL) specimen collected on Mt. Bartle Frere is the type. Dracophyllum sayeri is similar to D. fitageraldii and D. verticillatum but differs in leaf, inflorescence and flower characters (Table 7.8).

The only record of birds feeding on $D$. sayeri nectar is that recorded by Van Balgooy (CANB 330631) on Mt. Bellenden Ker. 


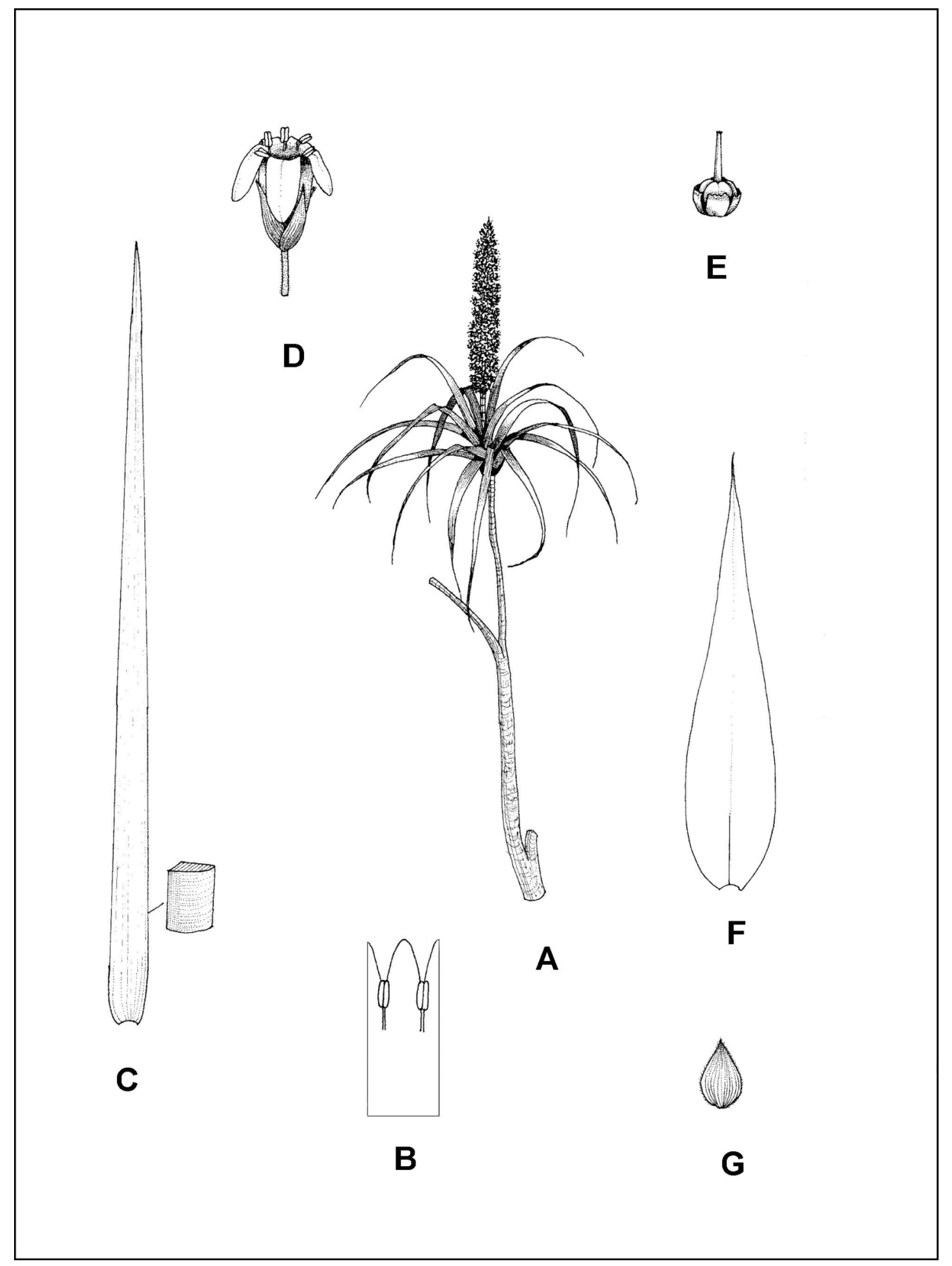

Figure 7.47. Dracopbyllum sayeri. A, flowering branch $(\times 1)$; B, laid out flower $(\times 5)$; $\mathbf{C}$, leaf $(\times 0.5)$ with enlargement of lamina margin $(\times 5)$; $\mathbf{D}$, flower $(\times 5)$; $\mathbf{E}$, ovary $(\times$ $10)$; F, inflorescence bract $(\times 1) ; \mathbf{G}$, sepal $(\times 5)$. Drawn from Powell 817 . 

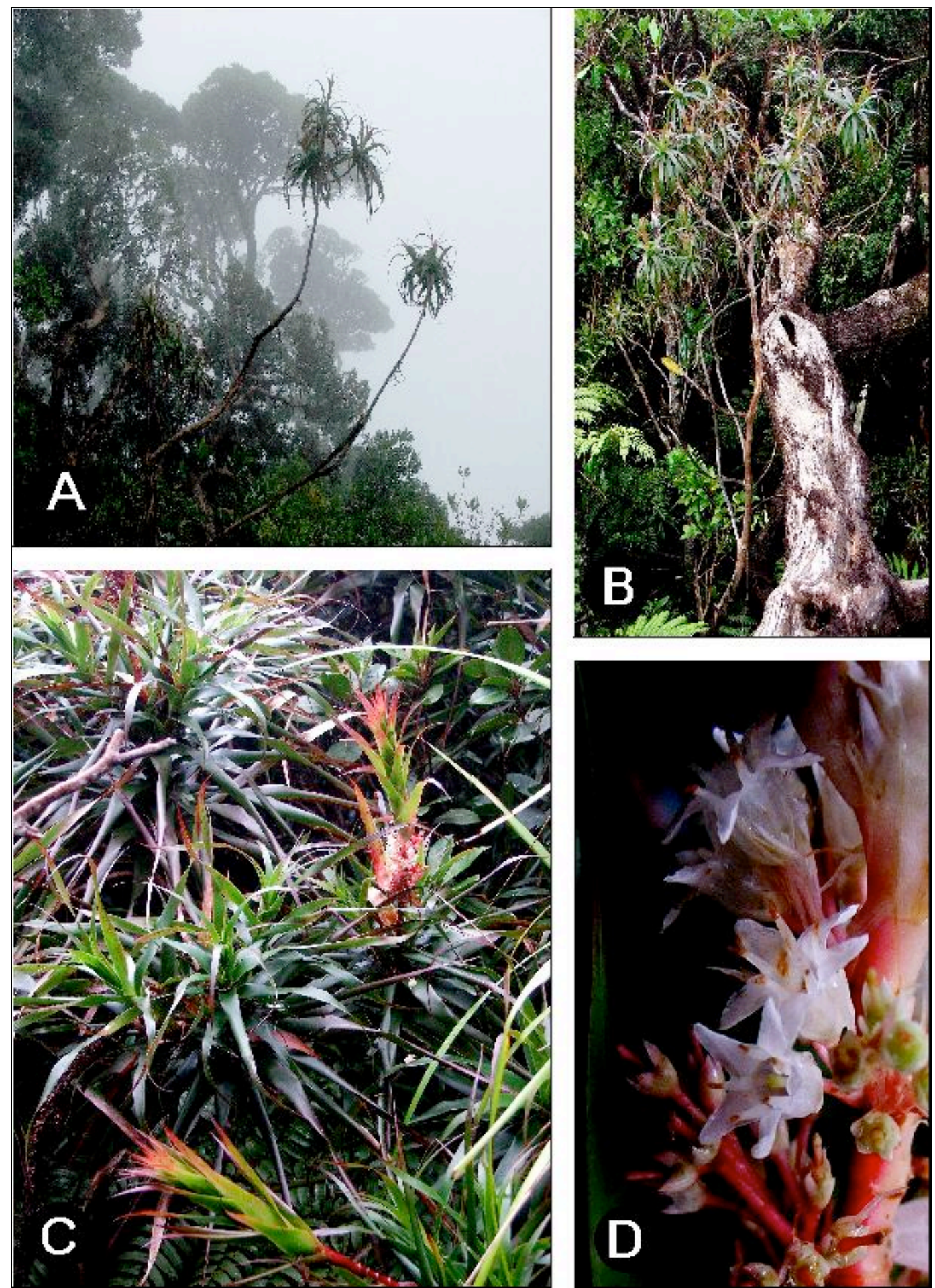

Figure 7.48. Dracophyllum sayeri. A, plant in habitat; B, mature plant; C, flowering branch showing the inflorescence bracts; $\mathbf{D}$, flowers showing the exserted anthers. B-D from Venter 13860. 


\section{Distribution}

Australian endemic, restricted to the Bellenden-Ker and Bartle Frere Mountain Ranges in the Wooroonooran National Park with an isolated record from the eastern slopes of Mt. Spurgeon near Mossman, north-east Queensland (Fig. 7.49).

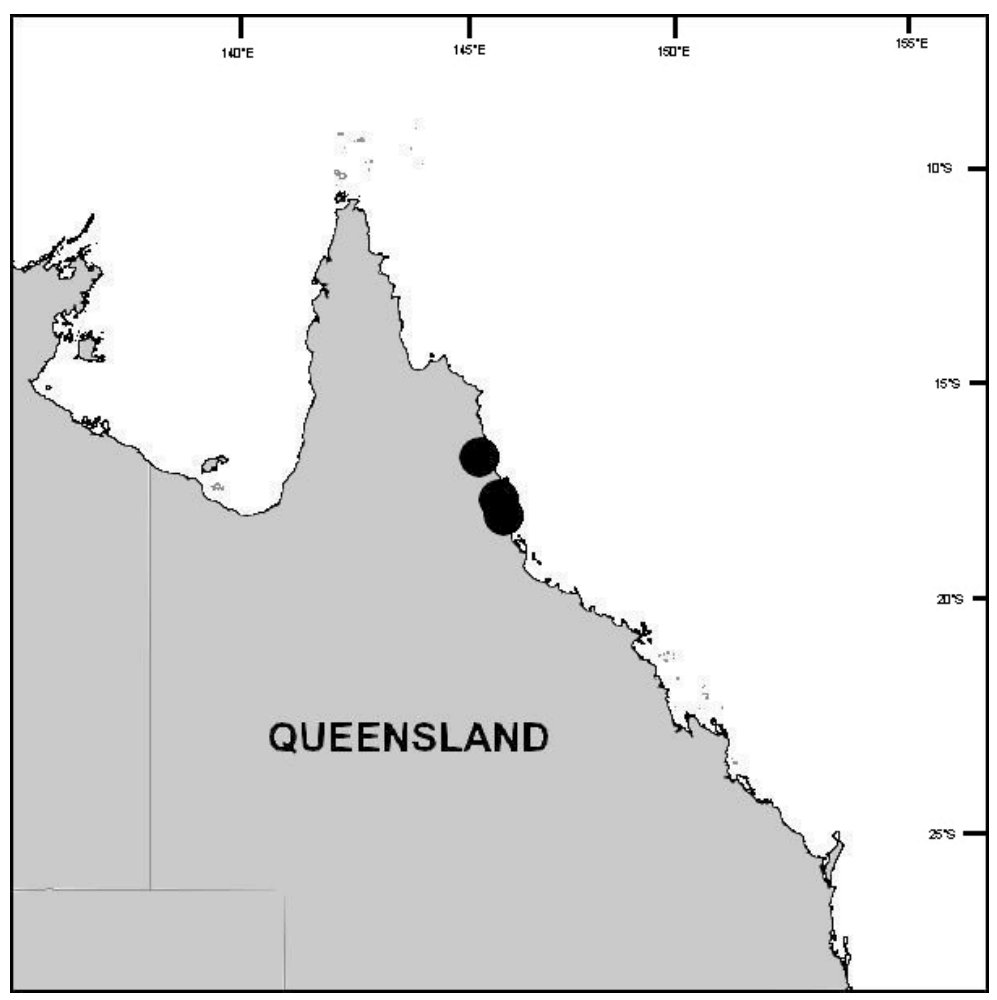

Figure 7.49. Known distribution of Dracophyllum sayeri.

\section{Habitat}

Dracophyllum sayeri is common in the under storey of well-developed low microphyll vine-fern rainforest and less so in stunted rain forest (Table 7.19) on high ridges and slopes at altitudes of $1,371-1,730 \mathrm{~m}$. The soil is skeletal and derived from granite. Plants of $D$. sayeri grow mainly in light shade but there are populations in which all the plants are in full sun having shorter and thicker textured leaves. 
Table 7.19. Plant communities commonly associated with Dracophyllum sayeri.

\begin{tabular}{|l|}
\hline FOREST \\
\hline Low closed evergreen Leptospermum wooroonooran - Trochocarpa laurina forest \\
Low open evergreen Leptospermum wooroonooran - Linospadix palmeriana forest \\
\hline
\end{tabular}

\section{Variation}

Bailey's (1913) two varieties cannot be upheld, as the erect-stemmed plants with white corolla tubes and those with pink corolla lobes $(=D$. sayeri var. normale $)$ grade into plants with more scandent stems, all-white flowers and strongly reflexed corolla lobes $(=D$. sayeri var. reflexum). Some variation occurs in the size of the lamina $(310-440 \times 9.0-11.5$ $\mathrm{mm})$ and in inflorescence length $(160-210 \mathrm{~mm})$. The inflorescence axis varies from 2.8$6.8 \mathrm{~mm}$ in diameter at the base and the inflorescence bracts can vary from subulate to ovate-lanceolate and measure $85-110 \times 15-25 \mathrm{~mm}$ in a single population (Clarkson 6560). Pedicels are either glabrous or pubescent and the corolla lobes are oblong to ovate measuring $2.5-3.8 \times 1.5-2.0 \mathrm{~mm}$. The nectary scale apices vary from retuse to irregularly toothed with the latter being most common and the style $1.0-2.2 \mathrm{~mm}$ long. These variations are present in all the known populations.

\section{Specimens examined}

AUSTRALIA - 17-145: Cairns, summit of Mt. Bellenden Ker (-BD), 16.ix.1977. Powell 817 (BRI, CBG, HO, NE, Z); ibid. 27.vii.1990. Baylis \& Wardle s.n. (CHR); Mt. Bellenden Ker, South Peak, 2.viii.1971. Van Balgooy 1455 (L); ibid., summit, 6.iv.1984. Brass 18313 (L); ibid., 1892. Podanza s.n. (BM); Mt. Bellenden Ker, Centre Peak, 7.vi.1972. Wrigley \& Telford 837 (L); ibid., SW of Centre Peak, 7.vi.1969. Smith 14615 (L); ibid., Centre Peak, near TV-Tower, 9.xi.1972. Webb \& Tracey 10805 (L); Mt. Bellenden Ker, on ridge between cableway and North Peak, 3.ix.1986. Clarkson 6566 (MBA, L, NSW); ibid., 
8.iv.2006. Venter 13860 (CHR, BRI); Queensland, Mt. Bartle Frere, 1892. Johnson s.n. (MEL); ibid., 11.vi.1949. Smith 4212 (L).

17. Dracophyllum secundum R. Br. ex Roemer \& Schultes.

Dracopbyllum secundum R. Br. ex Roemer \& Schult., Syst. Veg. 4: 385 (1819); Brown, Prodr. Fl. Nov. Holl: 566 (1810); Poiret, In: Lamarck (Ed.) Encycl. Méth. Bot. Suppl. 2: 556 (1811); Sprengel, Syst. Veg. 1: 631 (1825); Hooker, Curtis's Bot Mag. 7: t. 3264 (1833); De Candolle, Prod. Syst. Nat. 7: 769 (1838); Hooker, Fl. Antarct. : 46 (1844a); Mueller, Frag. Phytogr. Austr. 6: 65 (1864); Bentham \& Mueller, Fl. Austr. 4: 262 (1869); Engler \& Prantl, Nat. Pflantzenf. 4(1): t.38 (1891); Domin, Bibliotheca Botanica. 89 (4): 501 (1928); Oliver, Trans. Proc. N.Z. Inst. 59: 707 (1928); Oliver, Trans. Roy. Soc. N.Z. 80 (1): 14 (1952); Powell, Flora of NSW. 3: 403 (1992); Brown \& Streiber, Telopea. 8 (3): 399 (1999). Type: Australia, Eastern New South Wales, Port Jackson. 18.vii.1802. R. Brown s.n. [Bennett 2,805] (MEL 2064414, lecto.!; BM 577, 617!; BM 577,619!), designated by Hooker (1844b).

三 Epacris secunda Poiret, nom. illeg. In: Lamarck, Encycl. Méth. Bot. Suppl. 2: 556 (1811).

Prionotes secunda (R. Br.) Sprengel, Syst. Veg. 1: 631 (1825).

$=$ Dracophyllum secundum R. Br. forma secundum Domin, Bibliotheca Botanica. 89: 501 (1928). Autonym. 
= Dracophyllum secundum $\mathrm{R}$. Br. forma rubreo-rosea Domin, Bibliotheca Botanica.

89: 501 (1928). Type: Australia, New South Wales, Sandsteinfelsen der Blue Mts. iv.197. Domin IV (PR?, holo. n.v.).

Icones: Hooker, Curtis's Bot Mag. 7: t. 3264 (1833); Engler \& Prantl, Die Naturlichen Pflanzenfamilien 4(1): t.. 38.

\section{Description}

A sub-shrub to shrub, (0.1-)0.2-1.0(-2.0) $\mathrm{m}$ tall. Branches spreading. Bark on old branches grey to brown, deep and broadly fissured, young stems reddish brown. Leaves crowded at tips of branches on mature stems, spirally arranged on young branches; spreading to recurved, decreasing in size below inflorescence; lamina sheath light green to light brown, 5-17 × 5-18 mm, subcoriaceous, striate, membranous, tapering to rounded and the top half ciliate; lamina coriaceous, glaucous to dark green and glossy, abaxial surface lighter coloured, linear-triangular, (30-)50-160(-180) $\times(1.3-) 4-6(-18) \mathrm{mm}$, glabrous, prominently striated; margins serrulate with 18-27(-40) teeth per $10 \mathrm{~mm}$; apex acute. Inflorescence overtopping the leaves, erect, dense, $80-140 \mathrm{~mm}$ long, linear-oblong and sparsely branched; rachis and pedicels glabrous; inflorescence axis light green to reddish, $1.2-1.8 \mathrm{~mm}$ in diameter; basal inflorescence branch $0.5-1.0 \mathrm{~mm}$ long, widely spreading; inflorescence bracts caducous, overtopping flowers, light green, pink-tipped to wholly pink, ovate to broadly ovate at base, 35-105 × 10-20 mm, surfaces glabrous, margins ciliate. Flowers 24-67, in groups of 5-10 at base of inflorescence, pedicellate; bracteoles persistent, shorter than the perianth, both bracteoles situated at a basal position on the pedicel, $2.0-4.7 \times 0.4-1.1 \mathrm{~mm}$, glabrous, a few teeth at apices; pedicels straight, (0.5-)2.0-3.5 mm long, glabrous. Sepals green to rose-coloured, broadly ovate to triangular, (3-)4-6(-7) $\times(0.9-) 1.1-1.8(-2.2) \mathrm{mm}$, shorter than the corolla tube, striate, 
surfaces glabrous; margins ciliate in upper half. Corolla white to deep pink becoming light red with age; corolla tube cylindrical to narrowly campanulate, narrowed at mouth, 4 $8(-10) \times(1.5-) 2-3(-3.5) \mathrm{mm}$; corolla lobes reflexed, ovate-triangular, shorter than corolla tube, 1-2(-3) mm long and wide, apices obtuse; adaxial surface papillate; abaxial surface glabrous. Stamens hypogynous, filaments $4-8 \mathrm{~mm}$ long with the filaments sometimes adhering to the corolla tube wall with the free part 1-2 mm long; anthers included, rectangular, purple turning light yellow with age and (0.5-)1.2-2.0 $\mathrm{mm}$ long. Ovary pale pink, obovate, $1.5-3.0 \times 1-2 \mathrm{~mm}$, glabrous, apex round; nectary scales rectangular, 0.8-1.0 $\times 0.3-0.5 \mathrm{~mm}$, apex obtuse to irregularly toothed; style pale pink, included, 3-4 mm long and papillose distally; stigma five-lobed. Fruit light brown, 3.5-5.0 $\times 1.3-1.6 \mathrm{~mm}$, round to oblong, apex round, glabrous. Seeds light brown, ovoid, $0.7-0.75 \mathrm{~mm}$ long, testa prominently reticulate. Flowering June-December. (Figure 7.50).

\section{Diagnostic features and discussion}

Dracophyllum secundum is characterized by having prominently striated leaves, flowers moderately large and on long pedicels, frequently arranged to one side of the inflorescence (hence the specific epithet), flowers arranged in groups of 5-10 on the lower inflorescence branches, sepals much shorter than the corolla tube which is narrowed at the mouth, spreading long corolla lobes and the distally papillose styles. 


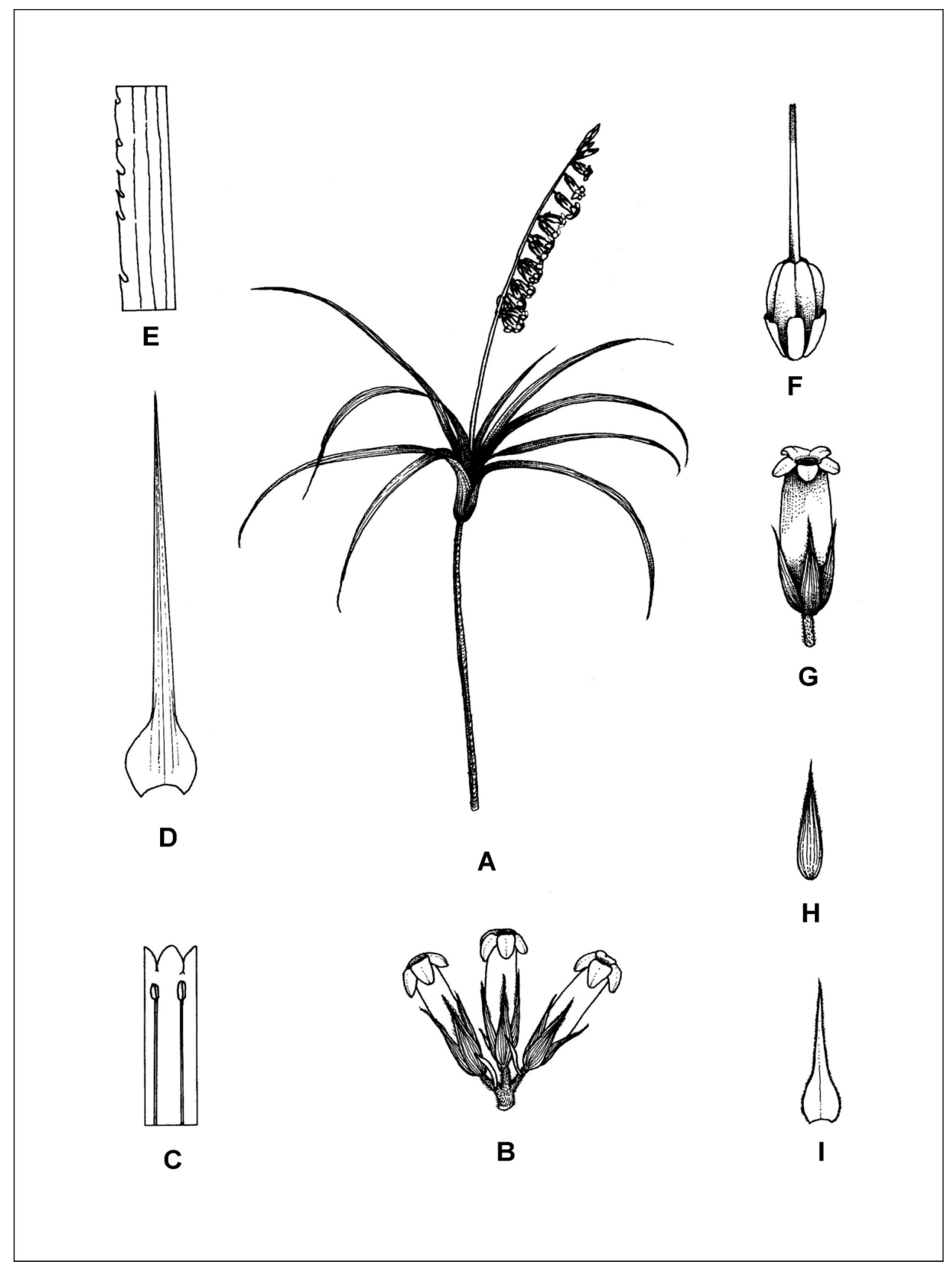

Figure 7.50. Dracopbyllum secundum. A, flowering branch $(\times 0.5)$; B, lower inflorescence branch with only three of the five flowers shown $(\times 2)$; $\mathbf{C}$, laid out corolla $(\times 2)$; D, leaf $(\times 1) ; \mathbf{E}$, lamina margin $(\times 40) ; \mathbf{F}$, ovary $(\times 10) ; \mathbf{G}$, flower $(\times 2) ; \mathbf{H}$, sepal $(\times 2)$; I, inflorescence bract $(\times 1)$. Drawn from Powell 341 . 


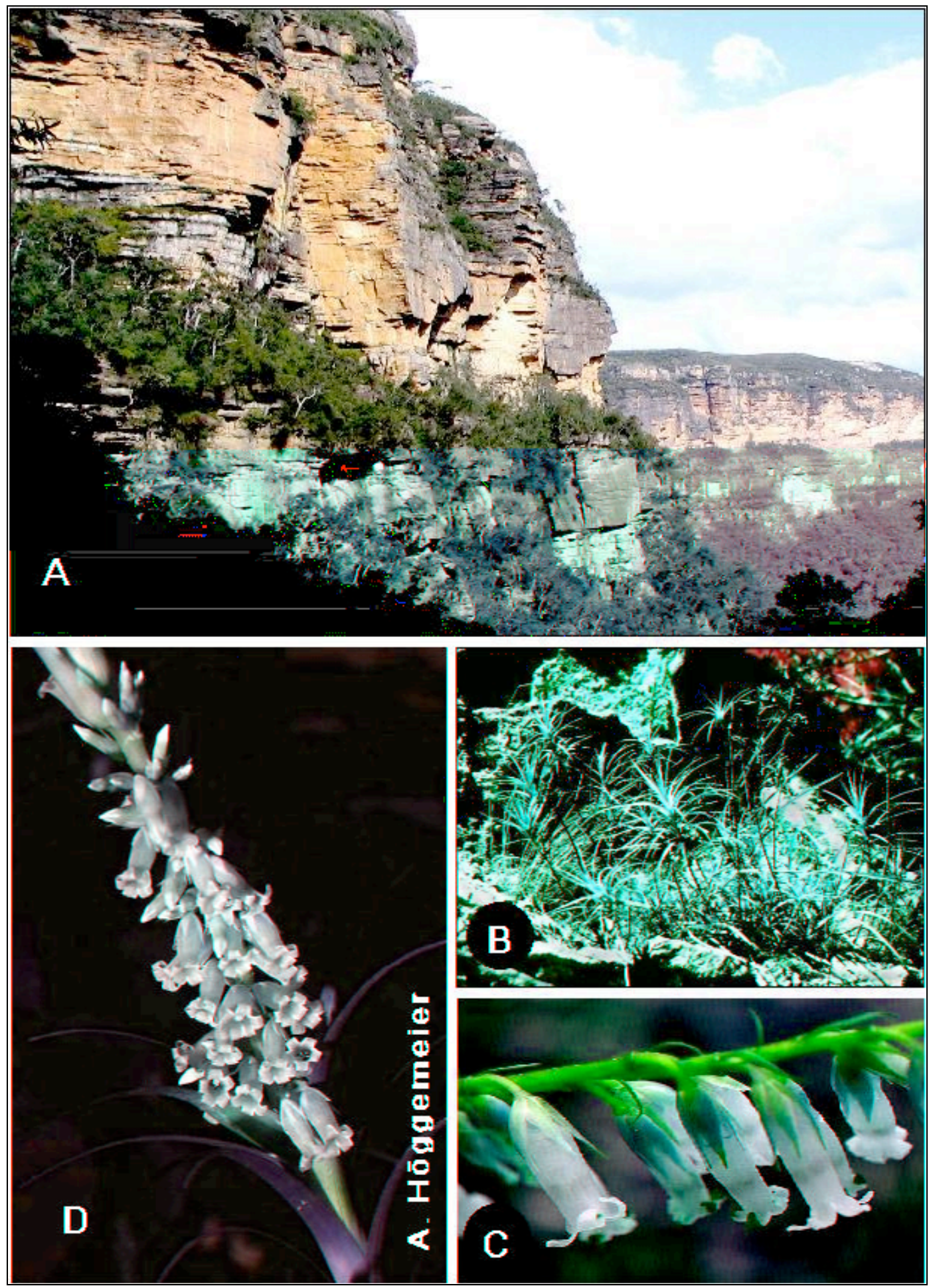

Figure 7.51. Dracophyllum secundum. A, cliff habitat, Blue Mountains; B, mature plant from the Blue Mountains; $\mathbf{C}$, detail of flowers; $\mathbf{D}$, inflorescence of the white colour form. 
Roemer and Schultes (1819), Hooker (1844) and Mueller (1864) gave the type locality as the Port Jackson area but without any collector details. Oliver (1952) was the first to designate a type with collector data and he chose the R. Brown [Bennett 2,805] (MELB 2064414) specimen.

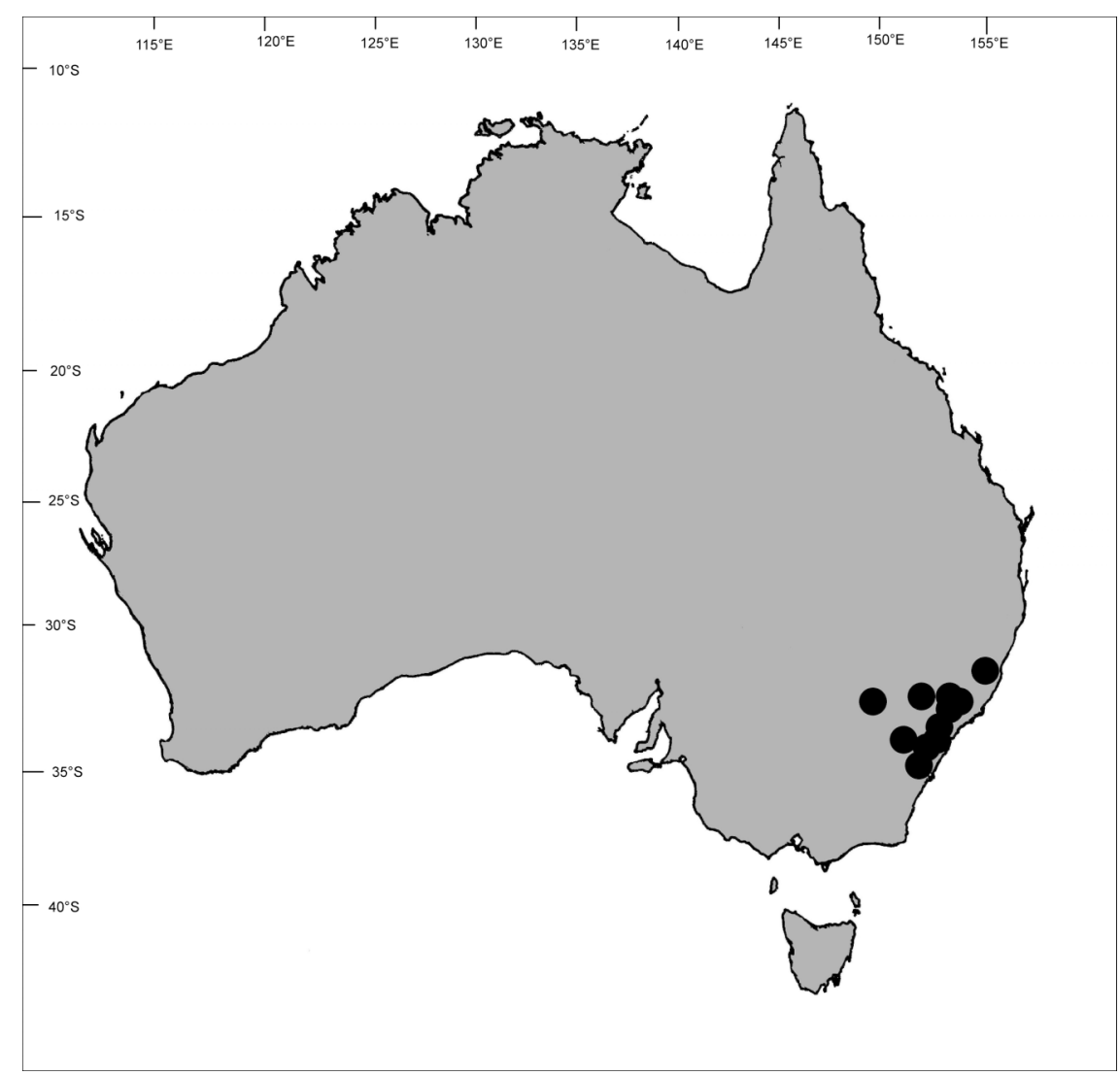

Figure 7.52. Known distribution of Dracophyllum secundum.

\section{Distribution}

Australian endemic restricted to the Central and Southern Tablelands in eastern New South Wales (Fig. 7.52). 


\section{Habitat}

Dracophyllum secundum occurs at altitudes of 165-960 m on cliffs, in gorges, valleys, and occasionally along riverbeds. The vegetation consists of open forest, dry woodland or heathland (Table 7.20). The soils are sandy to loamy lithosols derived from conglomerate, sandstone or occasionally shale. D. secundum grows mostly in full sun but some plants grow in light shade and have larger and darker green leaves.

Table 7.20. Plant associations commonly associated with Dracophyllum secundum.

\begin{tabular}{|c|}
\hline FOREST \\
\hline $\begin{array}{l}\text { Tall open semi-deciduous Eucalyptus cypellocarpa - Acacia spp. - Leucopogon lanceolatus forest } \\
\text { Tall open tall semi-deciduous Eucalyptus oreades - Eucalyptus piperita forest } \\
\text { Tall open semi-deciduous Epacris reclinata - Polyscias sambucifolius - Pimelea forest }\end{array}$ \\
\hline WOODLAND \\
\hline $\begin{array}{l}\text { Short open semi-deciduous Sprengelia monticola - Blechnum gregsonii - Sticherus tenera woodland } \\
\text { Low closed evergreen Eucalyptus sieberi - Kunzea ambigua woodland } \\
\text { Low closed evergreen Eucalyptus piperita - Persoonia pinifolia woodland }\end{array}$ \\
\hline HEATHLAND \\
\hline $\begin{array}{l}\text { Tall closed evergreen Sprengelia monticola - Blechnum gregsonii - Sticherus tenera heathland } \\
\text { Low open evergreen Leucopogon lanceolatus - Epacris longiflora - Bauera rubioides heathland } \\
\text { Low open evergreen Epacris hamiltoni - Gahnia - Gleichenia microphylla heathland }\end{array}$ \\
\hline
\end{tabular}

\section{Variation}

A polymorphic species having no main stem and variously branched from the base. The main variation is in the lamina size $(50-160 \times 4-6 \mathrm{~mm})$, inflorescence length $(80-140$ $\mathrm{mm})$ and inflorescence bract size (34-105 × 10-20 mm). Inflorescences can have from 24 to 67 flowers. Flower colour varies from near white to deep pink, with the corolla tube cylindrical to narrowly campanulate. Mueller (1864), Bentham \& Mueller (1869) and Brown \& Streiber (1999) describe the stamens as adnate to the corolla tube and also mention that most of the flowers studied had the filaments adnate to the corolla tube, whilst the illustration in Curtis's Botanical Magazine (1833) shows the stamens as hypogynous. Filaments appear to be connate to the inside of the corolla but they are actually covered with a single cell thick membrane. This membrane readily breaks up so that the filaments easily come away from the corolla tube in the dry state and also when 
there is excess movement of the flowers in the fresh state. Nectary scale apices vary from obtuse to irregularly toothed. The ovary also varies in size $(1.5-3.0 \times 1-2 \mathrm{~mm})$.

\section{Specimens examined}

AUSTRALIA. New South Wales - 30-153: Escarpment below Waihou Trig., 25 km NW of Coffs Harbour (-AA), 12.x.1978. Streimaw 8135 (A, L, BISH). 32-150: Rylstone, Currant Mountain E. of Gap (-BB), 7.viii.1975. Coveny \& Hind 6608 (NSW, W); 2 km from Dunns Swamp turnoff, towards Rylstone (-CC), 2.xii.1987. Rimes 51 (NSW); Rylstone District, 5 km E of Olinda, 29.ix.1979. Chapman 1429 (CANB, NSW); Central Tablelands, Khyber Pass, $20 \mathrm{~km}$ E of Rylstone to Mt. Coricudgy, 4.x.1975. Crisp 1285 (BISH, L); Central Tablelands, Kelgoola 40 km E of Rylestone (-CD), Baker s.n. (NSW); 33-150: 3m E of Nerriga (-AA), 16.ix.1965. Pullen 4114 (AD, B, BISH, BRI, E, FI, G, K, L, LE, MEL, MO, P, WELT, Z); Central Tablelands, Near Lithgow water supply, Clarence (-AC), 21.x.1939. Blakely s.n. (NSW); Milton, Pointer Gap (-AD), 9.viii.1978. Barnsley 214 (A, HO, L, US); Central Tablelands, Blackheath (-CB), 6.ix.1936. Vickery s.n. (NSW); Blue Mountain National Park, Track from Evans Lookout Road to Neates Glen, short distance up first stream crossed after descent below Evans Lookout Road, 20.viii.1997. Brown 97/72, Streiber \& Taafe (CANB, MEL, NSW, NY); Sydney, Mt. Wilson, ix.1897. Walter s.n. (Z); Sydney, Wentworth Falls, x.1908. Maiden s.n. (W); Central Tablelands, Mt. Tomah, xi.1898. Maiden s.n. (NSW); Central Tablelands, Mt. Victoria, xii.1966. Debenham s.n. (CANB, NSW); Medlow Bath below Lake Medlow (-CB), 18.v.1977. Coveny 9448 \& Telford (K, L); Springwood (-DA), ix.1981. Mayrhofer s.n. (GZU); Blue Mountains, Kurrajong Heights, 14.x.1987. Hind 5382, Ball \& Copp (HO);

Central Tablelands, $1 \mathrm{~km}$ along Chapman Road from junction with Grose Road, 3.viii.1986. Curry 8677 (NSW); 33-151: Woy Woy Creek (-AD), 24.viii.1969. McBarron 17515 (NSW); Central Coast, The Quarry, Hornsby District (-CA), ix.1971. Lassak s.n. 
(NSW); Central Coast, Patonga (-CB), ix.1938. Lilier s.n. (NSW); Central Coast, Warah, 23.iv.1949. Oxenford s.n. (NSW); Central Coast, Oatley (-CC), viii.1904. Boorman s.n. (NSW); Sydney, Port Jackson (-CD), ix.1897. Forsyth s.n. (GZU); 34-150: Central Tablelands, Northern spur of Mt. Colong, 5 miles [8 km] west-southwest of Yerranderie (-AA), 1.x.1951. Johnson s.n. (NSW); (-AC), Near Bullio, 21.xii.1975. Thompson 2372 (NSW); 2 km north of Mittagong, Gibbergunyah Creek (-AD), 16.xi.1982. Cooper \& Powrie s.n. (NSW); Kellys Falls (-BB), 31.vii.1997. Brown 97/21b, Streiber, Jobson \& Taafe (HO); Central Coast, Little River, Buxton (-BC), 30.ix.1951. Whaite 1072 (NSW); Central Coast, $1.25 \mathrm{~km} \mathrm{NE}$ of Nemma Trig, Avon Catchment area, 1.xii.1994. Thomas s.n. (NSW); Wollongong (-BD), Telniek 137 (W); Central Coast, Bulli Tops, 18.viii.1992. Kennedy 398 (NSW); Central Tablelands, Gow Gully, Penrose (-CA), x.1938. Blakely s.n. (NSW); Central Tablelands, Fitzroy Falls (-CB), x.1918. Rodway s.n. (NSW); Central Coast, Kangaroo Valley, also Cambewarra Mountain (-DA), 28.ix.1928. Morris 22442 (NSW); Central Tablelands, Carrington Falls, 8.x.1998. Wiecek \& Simpson 636 (NSW); Central Tablelands, summit of Macquarie Pass, x.1918. Rodway s.n. (NSW); $\mathrm{N}$ of Minnamurra Falls (-DB), 23.x.1993. Gilmour 7505 (CBG, MEL, NSW). 34-151: Central Coast, Sydney, Port Hacking (-AA), x.1907. Boorman s.n. (L, Z); Central Coast, Loftus, x.1893. Cornfield s.n. (NSW); 35-150: Southern Tablelands, 2 miles [3.2 km] NE of Endrick River, Nerriga-Sassafras Road (-AA), 3.x.1959. Williams 126 (NSW); Wandean Road (-AB), 11.ix.1997. Brown 97/97 \& Streiber (CHR, HO, NSW, NY); E slopes of Pigeon House Range above Enrick River along road from Nerriga to Nowra (-AB), 13.x.1965. Hoogland 10040 (L); near Mt Corang (-AC), 6.xi.1975. Powell 341 (BRI, MEL, NSW); Budawang Range, Corang Arch, 18.x.1990. Craven, Jones, Briggs, Quin \& Faunt 8613 (HO); South Coast, Pointer Gap, 9 km NW of Milton (-AD), 9.viii.1978. Barnsley $214(\mathrm{HO}, \mathrm{L})$. 


\section{Dracophyllum strictum Hook. f.}

Dracophyllum strictum Hook. f., Fl. Antarct. 1: 48 (1844); Hooker, Fl. Nov. Zel. 2: 168 (1853);

Hooker, Handb. N.Z. Fl: 181 (1864); Colenso, Trans. Proc. N.Z. Inst. 22: 477 (1890);

Colenso, Trans. Proc. N.Z. Inst. 25: 331 (1893); Cheeseman, Man. N.Z. Fl: 421 (1906);

Cheeseman, Man. N.Z. Fl. $2^{\text {nd }}$ Ed.: 703 (1925); Oliver, Trans. Proc. N.Z. Inst. 59: 707 (1928); Oliver, Trans. Roy. Soc. N.Z. 80 (1): 14 (1952); Allan, Fl. N.Z. 1: 536 (1961); Eagle, Trees and Shrubs of N.Z. : 282 (1975); Poole \& Adams, Trees and Shrubs of N.Z.: 158 (1994). Type: New Zealand, Mt. Tongariro. J.C. Bidwill s.n. (K, holo.!).

= Dracophyllum affine Hook. f., Fl. Antarct. 1: 48 (1844). Type: New Zealand, Northern Island, mountains of the interior. Dr. E. Dieffenbach s.n. (K, holo.!).

= Dracophyllum featonianum Colenso, Trans. Proc. N.Z. Inst. 22: 477 (1890).

Type: New Zealand, Cape Runaway (Whangaparoa) a little north of East Cape. 1889. E.H. Featon s.n. (K, holo. n.v.).

= Dracophyllum imbricatum Colenso, Trans. Proc. N.Z. Inst. 25: 331 (1893).

Type: New Zealand, open lands near Cape Runaway. 1892. H.T. Hill s.n. (WELT 23623, holo.!; K!).

Icones: Oliver, Trans. Proc. N.Z. Inst. 59: t. 16 (1928); Oliver, Trans. Proc. N.Z. Inst. 59: t. 16 (1928); Eagle, Trees and Shrubs of N.Z.: t. 169 (1975). Eagle shows the stamens as being adnate to the corolla tube in the lower third instead of in the upper third and the nectary scales are depicted as overtopping the ovary, which is wrong.; Smith-Dodsworth, N.Z. Native Shrubs \& Climbers.: tt. 58 \& 59, Pl. 24A \& 24B (1991). 


\section{Description}

A shrub to small tree, 50-300 cm tall. Branches. Bark on old branches dark brown, finely fissured, young stems yellowish brown. Leaves adult and juvenile; juvenile leaves spirally arranged along branches, spreading, lamina sheath light green, glaucous to light brown, 14 $20 \times 9-16 \mathrm{~mm}$, tapering and margin minutely ciliate in upper half; lamina coriaceous, glaucous to light green, broadly linear-triangular, 100-140 × 7-10 mm; surfaces glabrous, margins serrulate with 40-50 teeth per $10 \mathrm{~mm}$; apex acute; adult leaves crowded at tips of branches, spreading; lamina sheath glaucous to light brown, 7-15 $\times 6-14 \mathrm{~mm}$, coriaceous, striate, tapering to rounded; margin membranous and minutely ciliate; adult lamina coriaceous, glaucous to light green, lighter coloured below, linear-triangular to lanceolate, $47-75 \times 5-8 \mathrm{~mm}$, surfaces glabrous, slightly striated; margins serrulate with 40-50 teeth per $10 \mathrm{~mm}$; apex thickened, acute. Inflorescence overtopping the leaves, erect, dense, 50-100 mm long, pyramidal and sparingly branched; rachis and pedicels hirsute; inflorescence axis light green, $1.5-1.7 \mathrm{~mm}$ in diameter; basal inflorescence branch 0.5-1.0 mm long, widely spreading; inflorescence bracts caducous, overtopping flowers, whitish at base, pink-tipped to wholly pink, broadly ovate at base, 7.5-18.0 × 6.0-8.5 mm; adaxial surfaces with minute scabrid hairs; abaxial surfaces glabrous, margins ciliate. Flowers 15-60, in groups of 5-10 at base of inflorescence; bracteoles persistent, recaulescent with one bracteole situated just below the perianth and the other in the middle of the pedicel, shorter than flower, linear, 3-4 $\times 0.3-0.6 \mathrm{~mm}$, glabrous; pedicels green to reddish brown, straight, $0.6-2.0 \mathrm{~mm}$ long, pubescent. Sepals green to rosecoloured, ovate to broadly ovate, $(1.7-) 2.0-3.0 \times 1.3-1.5$, shorter than the corolla tube, striate, surfaces glabrous; margins ciliate. Corolla white to light pink; corolla tube narrowly campanulate, widened at mouth, (3.5-)4.0-6.0 × 1.5-2.0 mm; corolla lobes reflexed, ovatetriangular to triangular, shorter than corolla tube, $(1.5-) 2.0-2.5 \times 1.5-2.2 \mathrm{~mm}$, inflexed for the entire length, apices subacute; adaxial surface papillate. Stamens inserted on 
corolla tube in upper third, filaments $0.5-1.3 \mathrm{~mm}$ long; anthers included, oblong, deep yellow and 0.7-0.8 mm long. Ovary obovate, 1-2 mm long and wide, glabrous, apex round; nectary scales rectangular, $0.8-1.0 \times 0.4-0.5 \mathrm{~mm}$, apices subacute; style included, 1.5-2.0 mm long, glabrous; stigma capitate. Fruit light brown to reddish brown, 1.8-2.0 $\times$ 1.7-2.0 mm, depressed-globose, apex round, glabrous. Seeds yellowish brown, ovoid, 0.6-0.7 mm long, testa slightly reticulate. Flowering October-May. (Figure 7.53).

\section{Diagnostic features and discussion}

Dracophyllum strictum is characterized by the juvenile leaves, dense panicles with scabrous short secondary branches, short bracteoles $(3-4 \mathrm{~mm})$, small flowers $(4-6 \mathrm{~mm})$, short sepals $(2-3 \mathrm{~mm})$ and 4-6 $\mathrm{mm}$ long corolla. This is the only species in Dracophyllum with juvenile leaves, separating it morphologically from all the other species.

Dracophyllum strictum is similar to D. secundum but differs in the juvenile leaves, more teeth (40-50 compared to $18-27)$ per $10 \mathrm{~mm}$ on the lamina margin, hirsute not glabrous inflorescence rachis, shorter $(7.5-18.0 \mathrm{~mm}$ compared to $35-105 \mathrm{~mm})$ inflorescence bracts, pubescent pedicels not glabrous, shorter sepals (2-3 $\mathrm{mm}$ compared to 4-6 $\mathrm{mm}$ ), corolla tube widened at the mouth not narrowed, longer corolla lobes $(2.0-2.5 \mathrm{~mm}$ compared to 1-2 $\mathrm{mm}$ ) having subacute not obtuse apices, nectary scale apices subacute not obtuse to irregularly toothed, shorter style (1.5-2.0 $\mathrm{mm}$ compared to 3-4 mm) and slightly reticulated testa. 


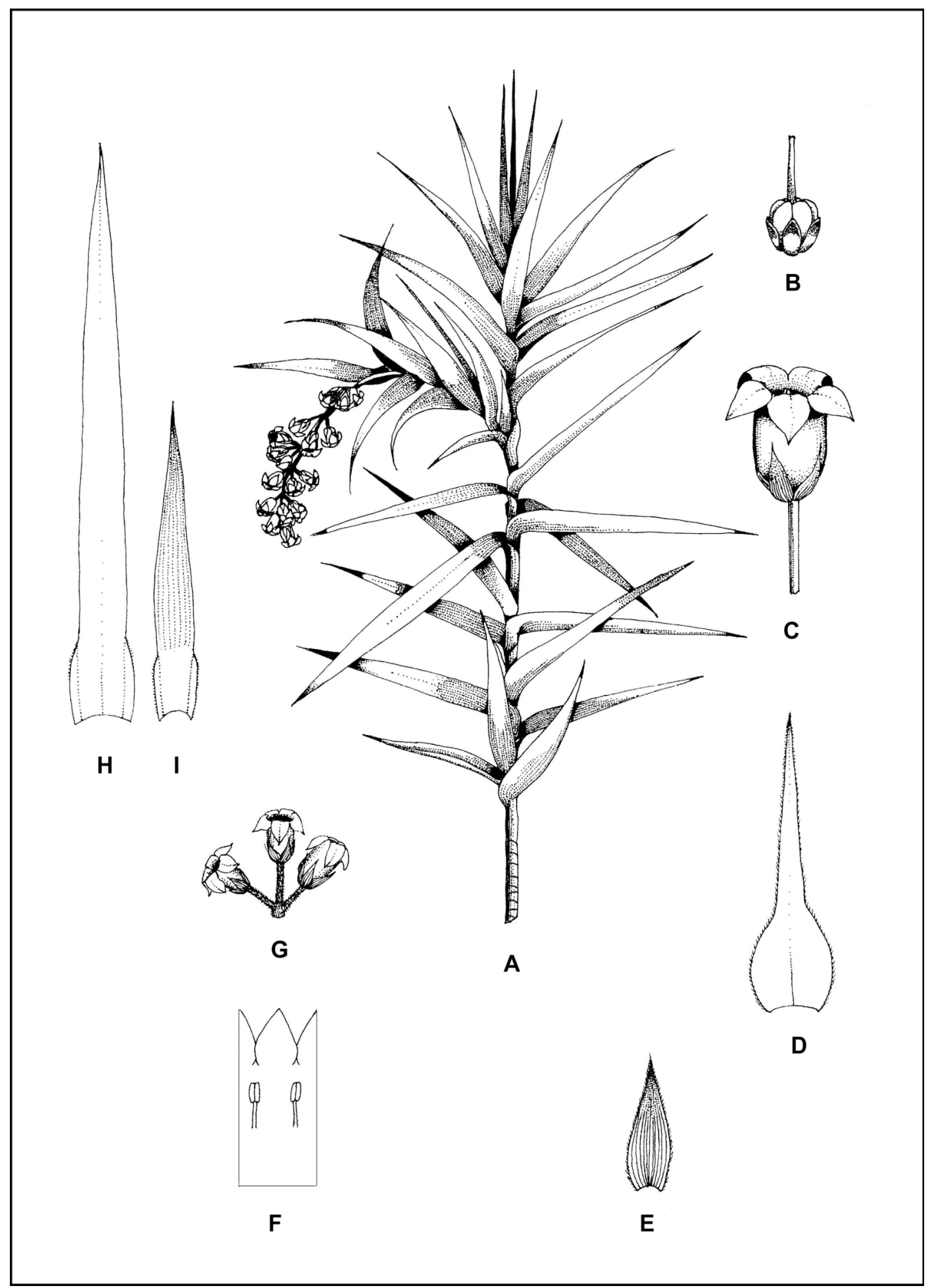

Figure 7.53. Dracophyllum strictum. A, flowering branch $(\times 0.5)$; B, ovary $(\times 10)$; C, flower $(\times 5) ; \mathbf{D}$, inflorescence bract adaxial surface $(\times 2)$; $\mathbf{E}$, sepal adaxial surface $(\times 10)$; $\mathbf{F}$, laid out corolla $(\times 5)$; $\mathbf{G}$, lower inflorescence branch $(\times 2) ; \mathbf{H}$, juvenile leaf $(\times 1)$; $\mathbf{I}$, adult leaf $(\times 1)$. Drawn from Gardner 4185. 


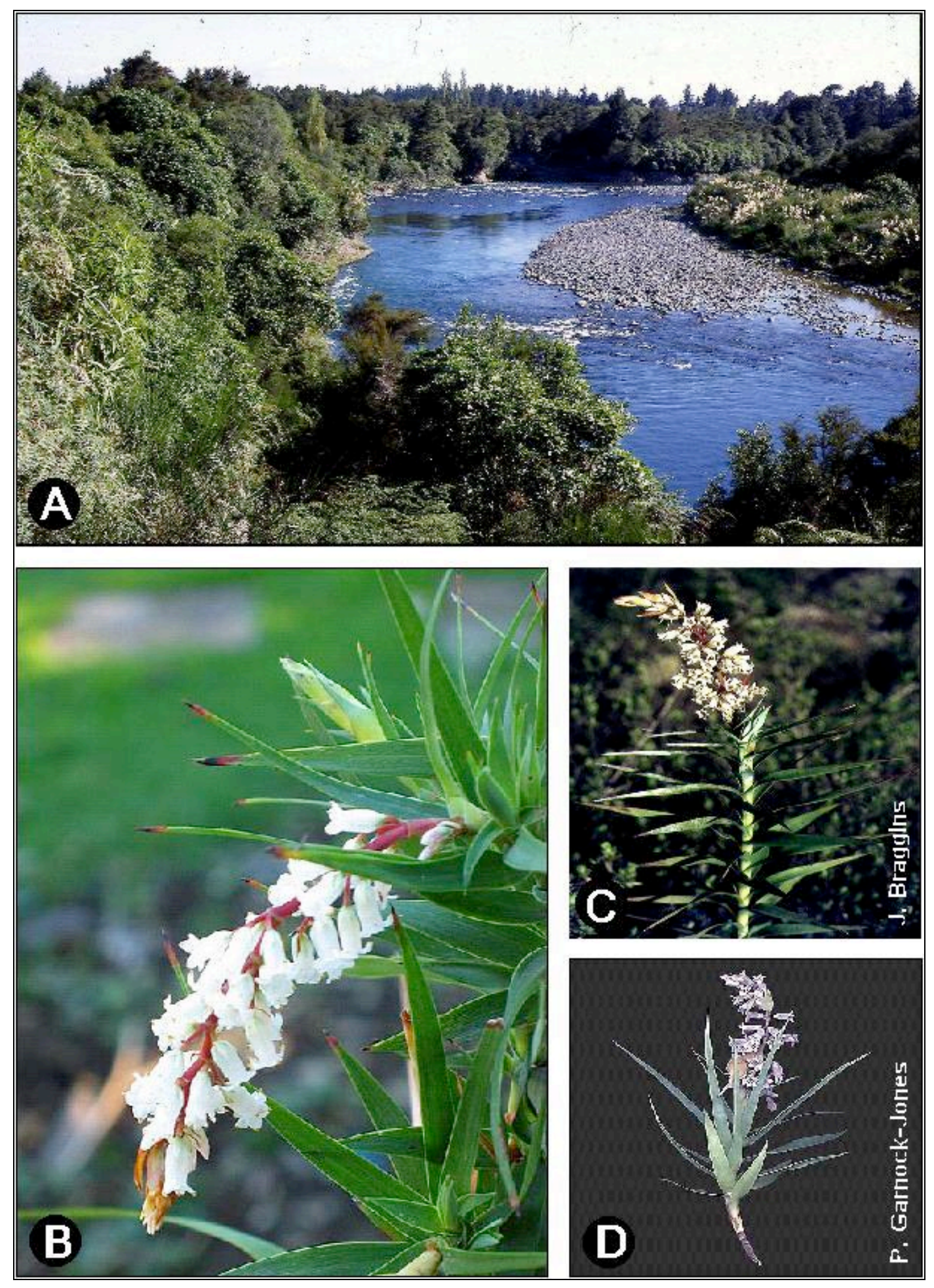

Figure 7.54. Dracopbyllum strictum. A, habitat (Tongariro River, Turangi); B, flowering branch (ex Hort. Venter); C, flowering branch from Mayor Island (Braggins s.n.); $\mathbf{D}$, flowering branch of a plant with mauve flowers. 


\section{Distribution}

Endemic to the North Island of New Zealand from Auckland southwards (Fig. 7.55).

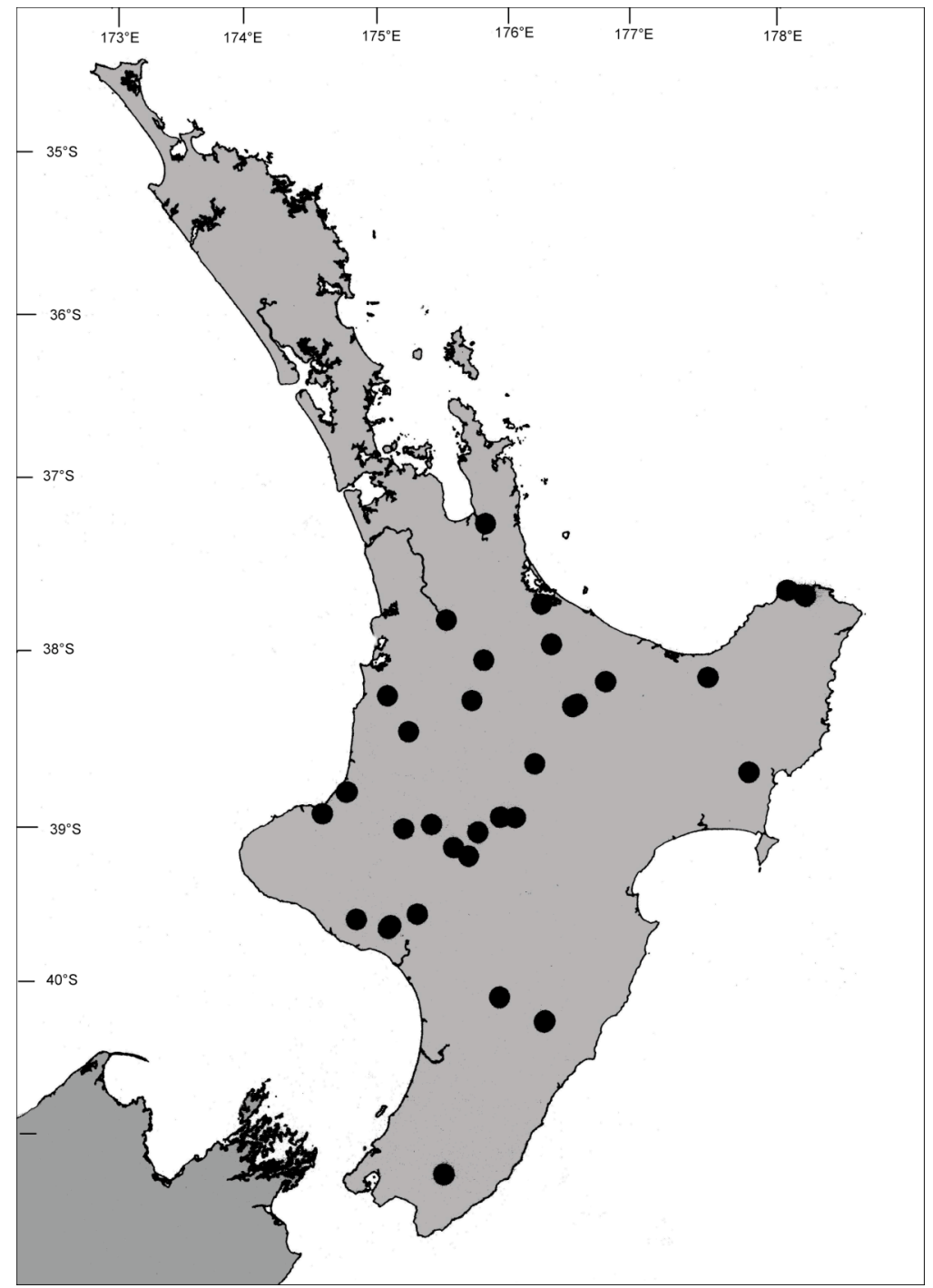

Figure 7.55. Known distribution of Dracophyllum strictum.

\section{Habitat}

Dracophyllum strictum occurs from near sea level to $1,097 \mathrm{~m}$ altitude on cliffs along river banks and on bluffs. The vegetation varies from lowland to montane forest and 
woodland to shrubland (Table 7.21). Soils are usually grey sandy loam derived from sandstone, alluvial material or pumice, or clay derived from ignimbrite, andesite, mudstone or calcareous mudstone. Most plants have been recorded as growing in light shade.

Table 7.21. Plant communities commonly associated with Dracophyllum strictum.

\begin{tabular}{|c|}
\hline FOREST \\
\hline Tall closed evergreen Nothofagus truncata forest \\
\hline WOODLAND \\
\hline Low closed semi-deciduous Leptospermum scoparium - Gaultheria oppositifolia woodland \\
\hline SHRUBLAND \\
\hline Tall closed evergreen Olearia townsonii - Phormium cookianum - Gaultheria oppositifolia shrubland \\
Tall closed evergreen Leptospermum scoparium - Leucopogon fasciculatus - Morelotia affinis shrubland \\
Tall closed evergreen Leptospermum scoparium - Anaphalioides subrigida shrubland. \\
Low closed semi-deciduous Coriaria arborea - Blechnum novae-zeelandiae shrubland \\
\hline
\end{tabular}

\section{Variation}

There is considerable variation in the size and colour of the juvenile $(100-140 \times 7-10$ $\mathrm{mm})$ and adult $(47-75 \times 5-8 \mathrm{~mm})$ leaves. Plants growing in exposed conditions on cliffs have very short and light grey leaves with unbranched short stems and are similar in appearance to $D$. secundum. The inflorescence is short $(50-68 \mathrm{~mm})$ in plants growing in full sun compared to the longer $(70-100 \mathrm{~mm})$ inflorescences of the shade plants. Inflorescence bracts show a wide range in size $(7.5-18.0 \times 6.0-8.5 \mathrm{~mm})$ and the flower number varies from 15-60 per inflorescence with the corolla lobes ovate-triangular to triangular.

\section{Specimens examined}

NEW ZEALAND, North Island - 35-174: Whangarei, Maungakaramea (-CC), 21.x.1938. Skottsberg s.n. (O); 37-175: Thames, Puriri (-BA), ix.1881. Cheeseman s.n. (Z); Tamahere Rapids (-CD), Kirk s.n. (AK); Okoroire (-DD), x.1896. Cheeseman s.n. (AK). 37-176: Mayor Island, Opo Bay, E side (-AC), 29.xi.1992. Sykes 281/92 (CHR); Mayor 
Island, cliffs on $\mathrm{N}$ rim of crater (-AD), xi.1955. Chambers s.n. (AK). 37-178: East Cape, near Potaka, Manga-purua Stream (-CA), 11.ix.1984. Courtney s.n. (CHR); 38-174: Tawarau State Forest, W of Waitomo Mairoa (-BD), 03.i.1984. Ogle 1052 \& Haydock (CHR); Urenui, Mt. Messinger (-DC), 11.ii.1999. Venter 13763 (CHR); ibid., x.1977. Given 10807 \& Purdie (CHR); 38-175: South Auckland, Atapuni Dam (-BA), 08.ix.1990. De Lange 582 (AK, CHR); South Auckland, Ngaroma, 25 m SE of Te Awamutu (-BC), 17.vi.1982. Bartlett NGA161 (CHR); Waipapa Scenic Reserve, 26.xi.1977. Gardner 1611 (L, NSW); Lake Whakameru, $7 \mathrm{~km}$ NE of Whakameru village, Highway 30 (-BD), 13.iii.1985. Hind 3978 (NSW); Near Pureora, Waimiha River (-CB), 7.iii.1978. Gardner 1843 (AK); Rotoroa, Maunga Kakaramea (-DC), 21.x.1938. Skottsberg s.n. (O); Lake Taupo, Western Bay, Waihaha Scenic Reserve (-DD), 8.i.1985. De lange s.n. (AK). 38176: Mangatapu Stream headwaters, Mamaku Plateau (-AA), 5.v.1978. Gardner 1960 (AK, L, NSW); Lake Okataina (-AB), 18.ix.1943. McKenz̧ie s.n. (AK); Rainbow Mountain, near top (-AD), 30.xii.1993. Ford 12/94 (CHR); Mt. Tarawera (-BA), 26.xii.1968. Wood s.n. (AK). 39-174: Wanganui, Waverley, Lake Moumahaki (-DA), 04.ii.1990. Ogle 1917 (CHR); 39-175: Raurimu (-AB), 12.xi.1964. Healy \& Brown s.n. (HO); Taumarunui, Oio Stream $2 \mathrm{~km} \mathrm{~N}$ of Kaitieke, 23.xi.1984. Gardner 4185 (AK, CHR, L); Tongariro (-BA), Bidwill s.n. (K); Turangi, Red Hut (-BB), 09.ii.1999. Venter 13760 (CHR); Kiwitea County, Rangiwahia (-DD), 14.v.1961. Esler s.n. (MPN).

19. Dracopbyllum townsonii Cheeseman

Dracophyllum townsonii Cheeseman, Man. N.Z. Fl: 420 (1906); Cheeseman, Ill. N.Z. Fl.: t. 130 (1914); Cheeseman, Man. N.Z. Fl. $2^{\text {nd }}$ Ed.: 702 (1925); Oliver, Trans. Proc. N.Z. Inst. 59: 705 (1928); Oliver, Trans. Roy. Soc. N.Z. 80 (1): 14 (1952); Allan, Fl. N.Z. 1: 536 
(1961); Moore \& Irwin, Oxford Book N.Z. Plants.: 292 (1978); Eagle, Trees \& Shrubs of N.Z. $2^{\text {nd }}$ series.: 292 (1982); Poole \& Adams, Trees \& Shrubs of N.Z.: 164 (1994). Type: New Zealand, Paparoa Range, near base of Mt. Buckland. W. Townson s.n. (AK 6924, lecto.!; AK 6923 !; AK 6925!; AK 6926!; AK 211642!; AK 211643!), designated by Oliver (1952). The Townson specimen mentioned by Cheeseman (1906) in the protologue lack details on the locality and because of this, Oliver (1952) selected the AK 6924 specimen as the type with a note on the type in Oliver's hand “TYPE SELECTED December 1941”.

Icon: Cheeseman, Ill. N.Z. Fl.: t. 130 (1914); Eagle, Trees \& Shrubs of N.Z. $2^{\text {nd }}$ series.: t. 131(1982).

\section{Description}

A shrub or small tree, 3-6 $\mathrm{m}$ tall. Branches form an open candelabrum-shaped crown. Bark on old branches greyish brown to light brown, flaky, young stems reddish brown. Leaves crowded at tips of branches in a bromelioid manner, spirally arranged on young stems, young leaves distinctly pink coloured; lamina sheath light green, (15-)20-25 × 8-22, coriaceous, striate, tapering, margins membranous with the top half ciliate; lamina lineartriangular, $130-300 \times 4.5-12.0 \mathrm{~mm}$, surfaces glabrous, prominently striated; margins cartilaginous, serrate with $28-50$ teeth per $10 \mathrm{~mm}$. Inflorescence an axillary panicle situated below the leaves; shorter than the leaves, curved and drooping, dense, $40-130$ mm long, pyramidal and sparingly branched; rachis and pedicels hirsute, light green; inflorescence axis, 2.2-4.2 $\mathrm{mm}$ in diameter; basal inflorescence branch (10-)16-24 mm long, suberect; inflorescence bracts caducous, overtopping flowers, whitish in lower half, ovate at base, $40-50 \times 10-12 \mathrm{~mm}$, glabrous, margins ciliate. Flowers hidden by leaves, 30-90, in groups of 5-10 at base of inflorescence, pedicellate; bracteoles persistent, both bracteoles longer than the perianth and situated in the middle of the pedicel, 2.5-7.0 $\times$ 
0.3-1.0 mm, glabrous; pedicels $0.2-0.5 \mathrm{~mm}$ long, pubescent. Sepals green, broadly ovate, 2.5-4.0 $\times 1.7-2.5 \mathrm{~mm}$, shorter than corolla tube, striate, surfaces glabrous; margins ciliate in upper half. Corolla red; corolla tube campanulate, widened at mouth, 2.0-2.5 $\times 2.3-2.5$ $\mathrm{mm}$; corolla lobes reflexed, oblong, shorter than or equalling corolla tube, 1.9-2.0 × 1.0-1.2 $\mathrm{mm}$; glabrous; apices obtuse; surfaces glabrous. Stamens inserted in upper third of corolla tube, filaments 1-2 mm long; anthers exserted, rectangular, light yellow and 1.3-1.5 mm long. Ovary subglobose, $1.3-1.5 \times 2.0-2.5 \mathrm{~mm}$; glabrous, apex round; nectary scales rectangular, $0.4-0.5 \times 0.8-1.0 \mathrm{~mm}$, apex retuse to irregularly toothed; style exserted, 1.5$2.0 \mathrm{~mm}$ long, glabrous; stigma capitate. Fruit light to reddish brown, 2-3 $\mathrm{mm}$ long and wide, depressed-globose, apex round and glabrous. Seeds light brown, ovoid, 1.1-1.3 mm long, testa slightly reticulate. Flowering December-March. (Figure 7.56).

\section{Diagnostic features and discussion}

Dracophyllum townsonii is characterized by the open candelabra-shaped crown, crowded leaves at the end of branches growing in a bromelioid manner, distinctly pink coloured young leaves, small panicle (40-130 mm long) always situated below the leaves, flowers arranged in groups of 5-10 on the basal inflorescence branches, inflorescence bracts broad and contracted into subulate apices, campanulate corolla, sepals being shorter than the corolla tube, sharply reflexed corolla lobes and the exserted anthers. 


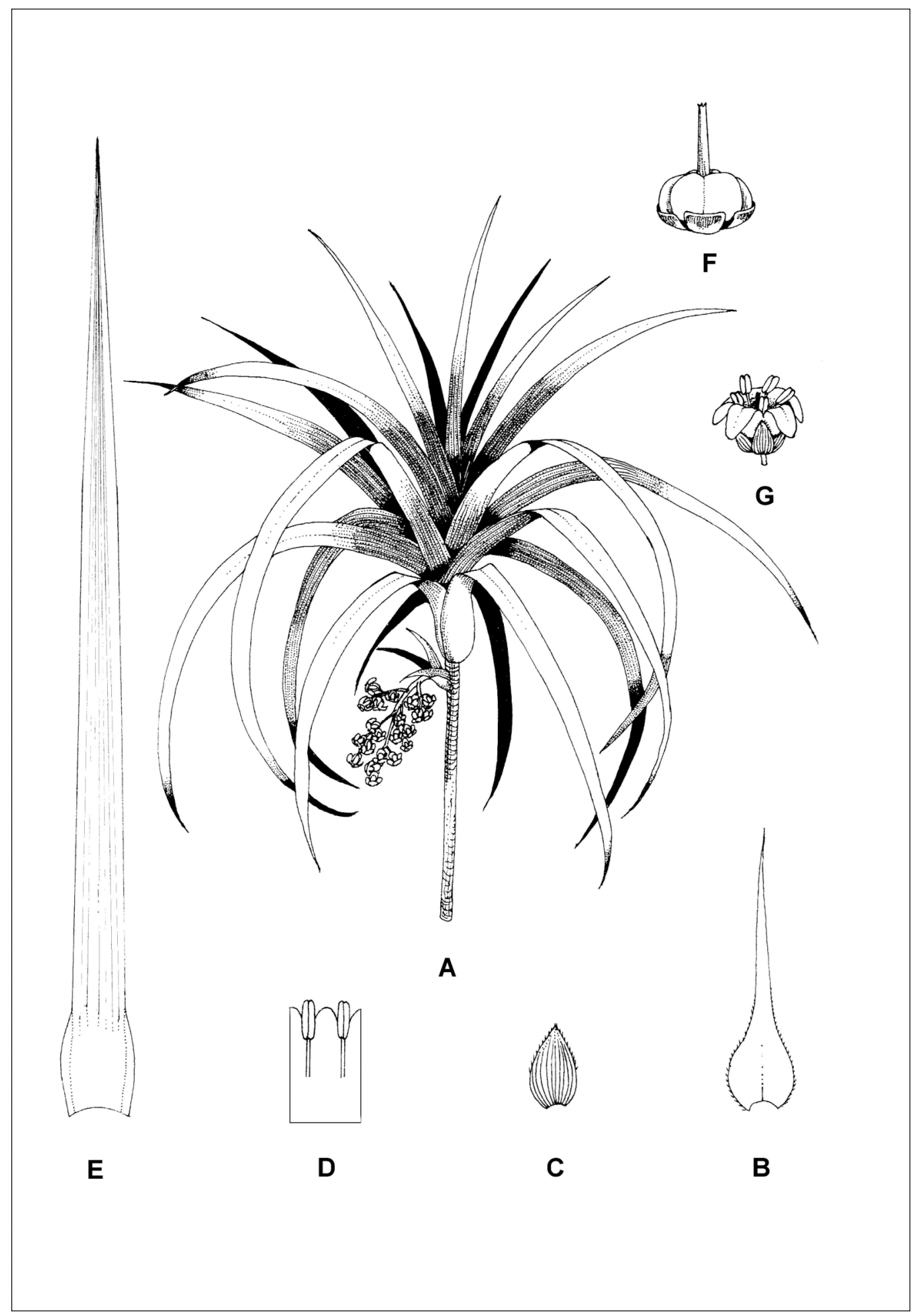

Figure 7.56. Dracopbyllum townsonii. A, flowering branch $(\times 0.5) ; \mathbf{B}$, inflorescence bract $(\times 5)$; C, sepal abaxial surface $(\times 5)$; $\mathbf{D}$, laid open corolla $(\times 5)$; $\mathbf{E}$, leaf $(\times 1) ; \mathbf{F}$, ovary $(\times 10)$; G, flower $(\times 5)$. Drawn from Venter13777. 

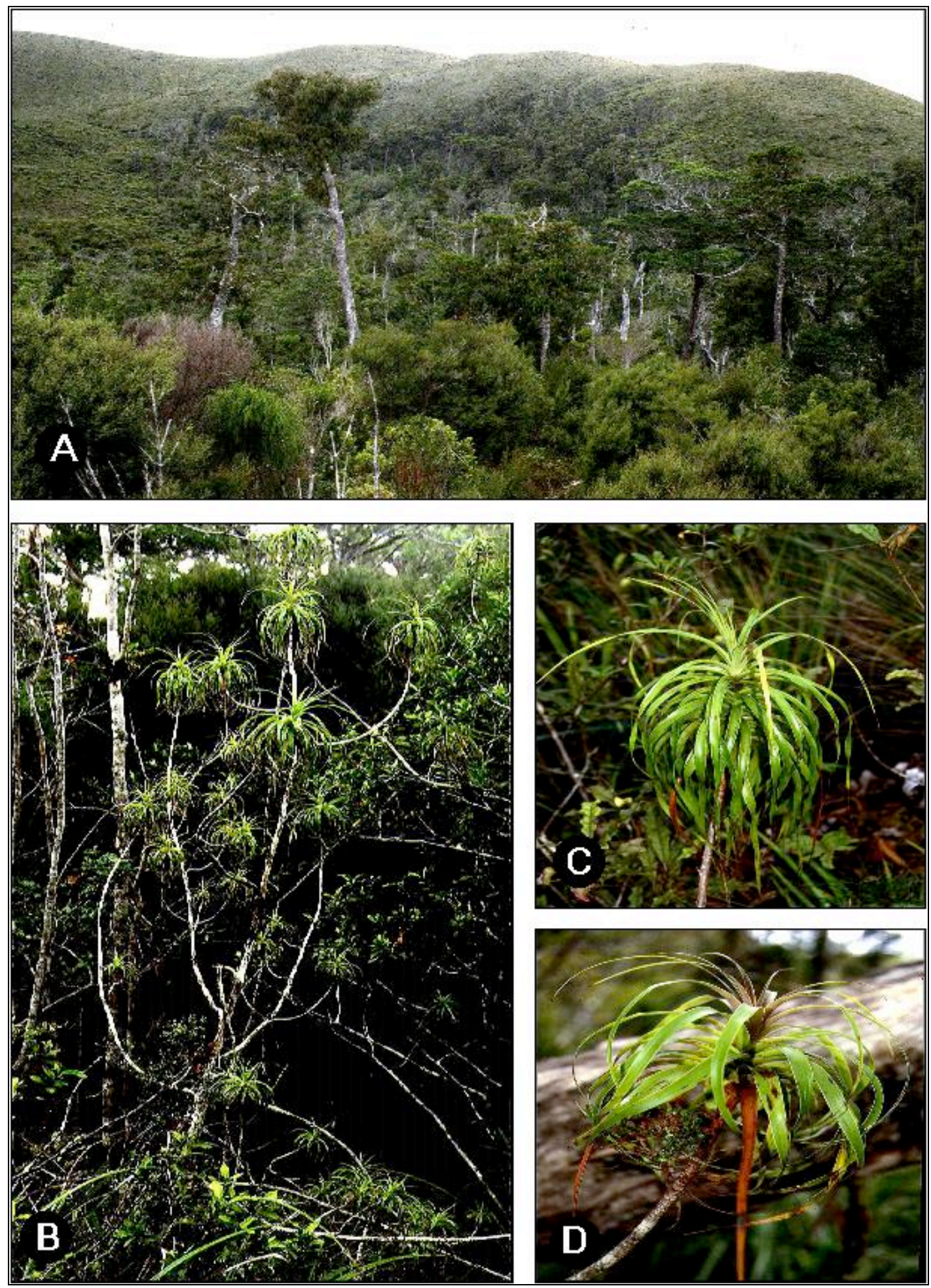

Figure 7.57. Dracopbyllum townsonii. A, forested habitat on the slopes of Knuckle Hill, Kahurangi National Park; $\mathbf{B}$, mature plant showing the open candelabrum growth habit; C, young branch; D, fruiting branch. B-D, Venter 13752. 
Dracophyllum townsonii is related to $D$. fiordense and D. menziesii in the short inflorescence situated below the bromelioid crown of leaves and the campanulate flowers with exserted stamens and style. Dracophyllum townsonii is similar to D. menziesii but differs in being a small tree with an open candelabra-shaped crown, bark on mature stems flaky not smooth, much longer inflorescence (40-50 $\mathrm{mm}$ compared to $50-150 \mathrm{~mm}$ ) and the flowers are arranged in groups of 5-10 not three on the basal inflorescence branches, the bracteole is persistent and equals the flower in length not being shorter, the corolla tube is shorter (2.0-2.5 $\mathrm{mm}$ compared to $6-7 \mathrm{~mm})$ with the anthers exserted not included, the ovary subglobose not obovate, shorter style (1.5-2.0 mm compared to 2.5$3.5 \mathrm{~mm})$ and longer seed $(1.1-1.3 \mathrm{~mm}$ compared to $0.55-0.6 \mathrm{~mm})$. The flowers are reported as having a foetid smell by Cheeseman (1914) but all the flowers I smelled at the localities visited had a sweet scent. Seedlings commonly grow on decaying, mosscovered logs and on tree fern stems in the forest. Basal branches of mature plants develop roots where they touch the ground and later form individual plants.

\section{Distribution}

New Zealand endemic restricted to the north-west Nelson area of the South Island (Figure 7.58). It is regarded as a West Coast element growing from Whanganui Inlet in the north to Hokitika in the south.

\section{Habitat}

Dracophyllum townsonii occurs on gentle $\left(5^{\circ}-15^{\circ}\right)$ southern, south-eastern and southwestern mountain slopes and along drainage lines, at elevations ranging from 152-900 m. D. townsonii is a montane forest element (Table 7.22) rarely growing in full sun except where the shading trees have 


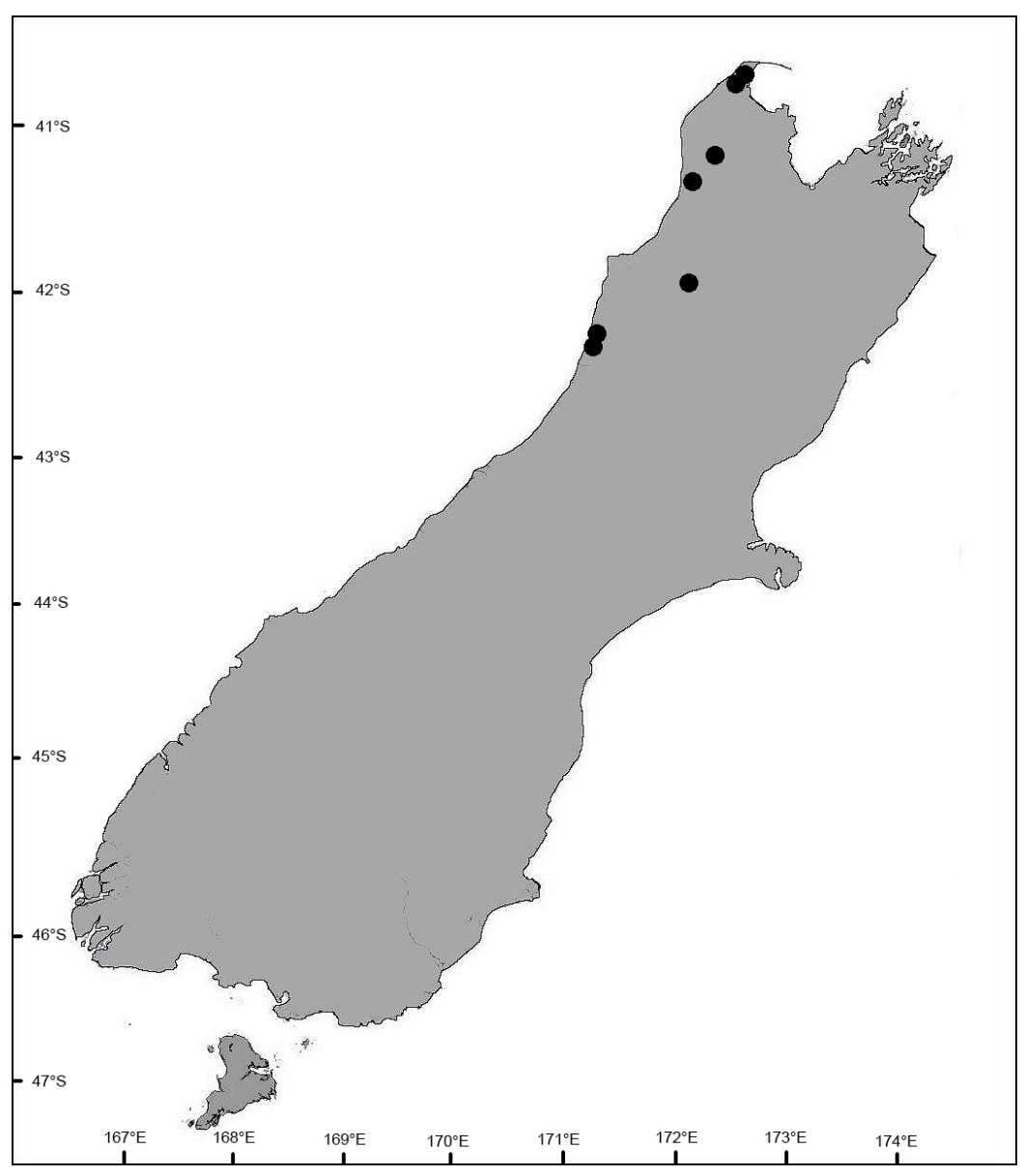

Figure 7.59. Known distribution of Dracophyllum townsonii.

fallen down. Soils are brown clay loam, brown sandy loam or rocky sandy soils derived from sandstone or conglomerate. Plants of $D$. townsonii commonly occur in permanently moist habitats.

Table 7.22. Plant communities commonly associated with Dracophyllum townsonii.

\section{FOREST}

Tall closed evergreen Nothofagus solandri - Lepidothamnus intermedius forest

Tall closed evergreen Nothofagus menziesii - Metrosideros umbellata - Quintinia serrata forest

Tall open evergreen Dacrydium cupressinum - Phyllocladus trichomanoides - Gahnia procera forest

Low closed evergreen Dacrydium cupressinum - Quintinia acutifolia forest 


\section{Variation}

In $D$. townsonii, leaves of plants in deep shade are nearly twice as long, with a thinner texture than those from plants growing in full sun. The number of teeth per $10 \mathrm{~mm}$ on the lamina margin varies from $28-50$ and bracteole size varies from 2.5-7.0 $\times 0.3-1.0$ $\mathrm{mm}$, even on the same inflorescence. The nectary scale apices are either retuse or irregularly toothed.

\section{Specimens examined}

NEW ZEALAND. South Island: 40-172: Collingwood, Knuckle Hill (-DA), 15.i.1999. Venter 13752 (CHR); ibid. Venter 13777 (CHR); Mt. Burnett, 30.iv.1945. Cone s.n. (CHR). 41-171: Charlston (-CD), 15.i.1967. Moore s.n. (CHR); Four Mile Creek, 12.i.1971. Wardle s.n. (CHR); Buckland Peaks (-DC), 24.iii.1996. Glenny 6459 (CHR). 41-172: Karamea, Mossy Burn Catchment (-AA), 03.xii.1984. McLennan s.n. (CHR); Mt. Stormy (-AC), i.1987. Druce s.n. (CHR). 42-171: Greymouth, Ten-mile Creek (-AD), ix.1964. Robins s.n. (O); Sewell Peak, 22.xi.1968. Drury 68W/75 (CHR); Mt. Mantell (-CD), Allan s.n. (CHR); Near Greymouth, Liverpool State Goldmine. 27.iii.1915. Morgan s.n. (AK).

\section{Dracophyllum traversii Hook. f.}

Dracophyllum traversii Hook. f., Hand. N.Z. Fl.: 736 (1864); Cheeseman, Man. N.Z. Fl.: 417 (1906); Cheeseman, Man. N.Z. Fl. $2^{\text {nd }}$ Ed.: 702 (1925); Oliver, Trans. Proc. N.Z. Inst. 59: 712 (1928); Oliver, Trans. Roy. Soc. N.Z. 80 (1): 16 (1952); Allan, Fl. N.Z. 1: 538 (1961); Moore \& Irwin, Oxford Book of N.Z. Plants.: 290 (1978); Eagle, Trees \& Shrubs of N.Z. $2^{\text {nd }}$ series.: 290 (1982); Salmon, Native Trees N.Z.: 272 - 273 (1989); Poole \& Adams, Trees \& Shrubs of N.Z.: 162 (1994). Type: New Zealand, Middle Island, Nelson Province, Arthur's 
top, subalpine, 3,000', x.1865. W.T.L. Travers \& J. Haast 337 (K, holo.!; CHR 236852!; $\mathrm{K} !)$.

= Dracophyllum pyramidale W.R.B. Oliv., Trans. Roy. Soc. N.Z. 80 (1): 16 (1952).

Type: New Zealand, summit of Little Barrier Island, 8.x.1928. W.R.B. Oliver s.n. (WELT 48615, holo.!).

Icones: Oliver, Trans. Proc. N.Z. Inst. 59: tt. 22 \& 23 (1928); Moore \& Irwin, Oxford Book of N.Z. Plants.: 290 (1978); Eagle, Trees \& Shrubs of N.Z. $2^{\text {nd }}$ series.: t. 128 (1982); Salmon, Native Trees N.Z.: 269 \& 270 (1989).

\section{Description}

A shrub or a tree $0.2-13.0 \mathrm{~m}$ tall. Branches form an open candelabrum-shaped crown. Bark on old branches light brown, flaky, young stems reddish brown. Leaves crowded at tips of branches in a bromelioid manner, lamina sheath light green to light brown, 30-65(70) $\times$ 30-50 mm, coriaceous, striate, tapering, margins membranous, smooth; lamina coriaceous, sometimes with a glaucous bloom, linear-triangular to lanceolate, 90-300(860) $\times(17-) 40-50 \mathrm{~mm}$, surfaces glabrous, prominently striated; margins cartilaginous, serrulate with 18-20 teeth per $10 \mathrm{~mm}$. Inflorescence shorter than the leaves, dense, 180350(-400) mm long, pyramidal and densely branched; rachis and pedicels pubescent to hirsute, light green to reddish; inflorescence axis $13.0-16.5 \mathrm{~mm}$ in diameter; basal inflorescence branch 30-60 $\mathrm{mm}$ long, suberect to at right angles with inflorescence axis; inflorescence bracts caducous, overtopping flowers, light green, whitish at base and pinktipped to entirely pink, broadly ovate at base, $130-240 \times 25-50 \mathrm{~mm}$, surfaces glabrous, margins minutely ciliate. Flowers 500-3000+, in groups of more than 10 at base of inflorescence, pedicellate; bracteoles caducous, recaulescent, deciduous, with one bracteole 
situated just below the perianth and the other in the middle of the pedicel, shorter than flower, $4.0-4.8 \times 0.5-0.7 \mathrm{~mm}$, glabrous; pedicels straight, $0.5-2.0 \mathrm{~mm}$ long, pubescent to tomentose. Sepals red to occasionally green, ovate to broadly ovate, $(1.2-) 2-3 \times(1.1-$ )2.0-2.5 mm, equaling corolla tube, striate, surfaces glabrous; margins ciliate; apices subacute to obtuse. Corolla red, tube sometimes white; corolla tube broadly campanulate, widened at mouth, 2.7-3.0 $\times 4-5 \mathrm{~mm}$; corolla lobes reflexed, oblong, longer than corolla tube, $2.5-2.8 \times 2.0-2.5 \mathrm{~mm}$; apices obtuse; surfaces glabrous. Stamens inserted at top of corolla tube, filaments 1.0-1.5 mm long; anthers exserted, oblong, pink turning light yellow with age and 1.8-2.0 mm long. Ovary subglobose, 1.4-1.5 × 1.8-2.0 mm, glabrous, apex round; nectary scales oblong, 1.0-1.5 long and wide, apices retuse; style exserted, 2-3 mm long, glabrous, lengthening in fruit; stigma five-lobed. Fruit not included in persistent calyx, reddish to purplish brown, 1.9-2.0 × 2.8-3.0 mm, depressed-globose; apex round, glabrous. Seeds yellowish brown, ovoid, 0.95-1.0 mm long, testa slightly reticulate. Flowering October-February. (Figure 7.59).

\section{Diagnostic features and discussion}

Dracophyllum traversii is characterized by the candelabra-shaped growth habit, bark flaking in large pieces, broad strongly curved leaves, young leaves with a grey bloom, stout panicle with red flowers having the corolla lobes longer than the corolla tube and capsules $2.8-3.0 \mathrm{~mm}$ in diameter.

Dracophyllum traversii is closely allied and also similar to D. latifolium (Oliver 1928) but differs in lamina and flower characters (Table 7.23). 


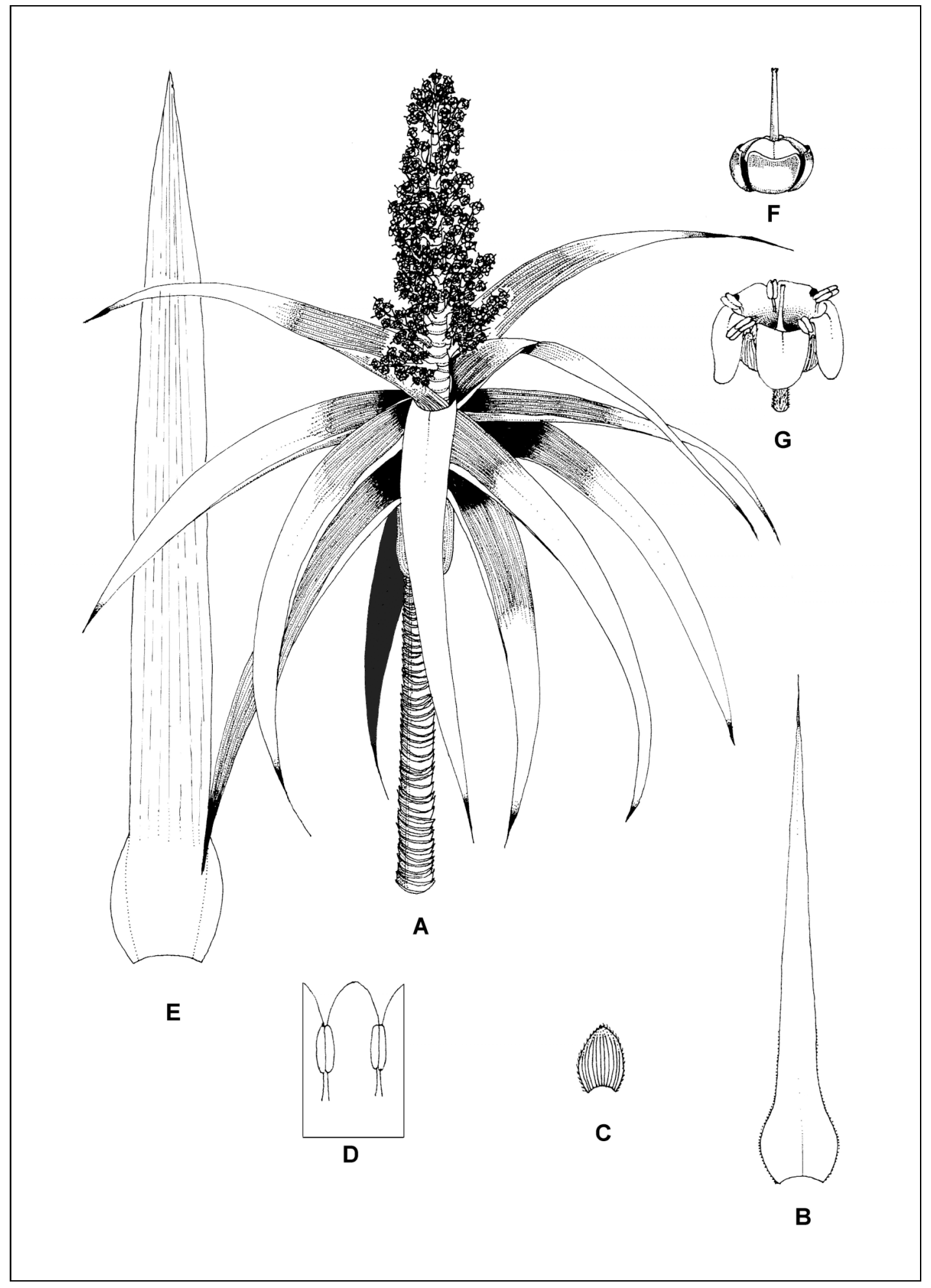

Figure 7.59. Dracopbyllum traversii. A, flowering branch $(\times 0.5)$; $\mathbf{B}$, inflorescence bract $(\times 0.5) ; \mathbf{C}$, sepal $(\times 5) ; \mathbf{D}$, laid out corolla $(\times 5) ; \mathbf{E}$, leaf $(\times 1) ; \mathbf{F}$, ovary $(\times 10) ; \mathbf{G}$, flower $(\times 5)$. Drawn from Venter 13734 . 

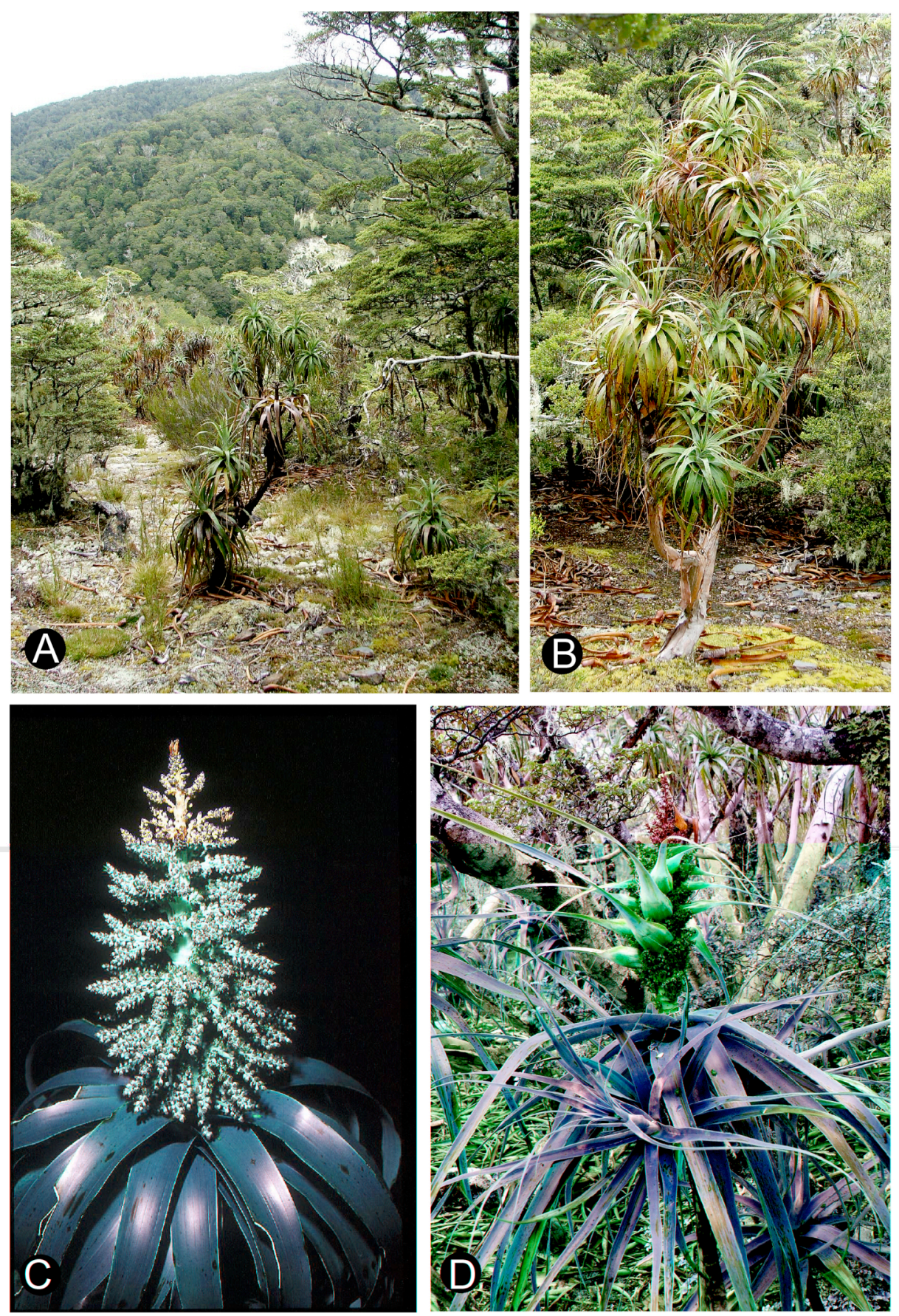

Figure 7.60. Dracophyllum traversii. A, habitat on slopes of Mt. Arthur; B, mature plant on Flora Saddle, Mt. Arthur; C, flowering branch, Coromandel Peninsula; D, plant showing the large coloured inflorescence bracts just before they drop. B, Venter 13741 and $\mathbf{D}$, Venter13778. 
Table 7.23. Differences between Dracophyllum traversii and D. latifolium.

\begin{tabular}{|l|l|l|}
\hline \multicolumn{1}{|c|}{ Character } & \multicolumn{1}{|c|}{ D. traversii } & \multicolumn{1}{c|}{ D. latifolium } \\
\hline Lamina margin & serrulate & serrate to denticulate \\
Lamina width $(\mathrm{mm})$ & $40-50$ & $12-30$ \\
Teeth per $10 \mathrm{~mm}$ on lamina margin & $18-20$ & $2-4$ \\
Flower grouping on inflorescence branch & $>10$ & $5-10$ \\
Sepal size $(\mathrm{mm})$ & $2-3 \times 2.0-2.5$ & $0.7-1.5 \times 1.0-1.7$ \\
Sepal : corolla tube length $(\mathrm{mm})$ & equaling & shorter \\
Sepal adaxial surface & glabrous & pubescent \\
Sepal margins & ciliate & toothed in upper third \\
Corolla tube size $(\mathrm{mm})$ & $2.7-3.0 \times 4-5$ & $1.5-2.0 \times 1.5-2.5$ \\
Corolla lobe size $(\mathrm{mm})$ & $2.5-2.8 \times 2.0-2.5$ & $1.5-2.0 \times 1.5-2.0$ \\
Ovary shape & subglobose & ovate \\
Ovary size $(\mathrm{mm})$ & $1.4-1.5 \times 1.8-2.0$ & $0.8-1.0 \times 1.0-1.5$ \\
Style length $(\mathrm{mm})$ & $2-3$ & $1.0-1.7$ \\
Seed length $(\mathrm{mm})$ & $0.95-1.0$ & $1.2-1.3$ \\
\hline
\end{tabular}

A grey to glaucous waxy bloom covers the young leaves, but this is lost at maturity. Haase (1986) found during a survey on the ecology of $D$. traversii that the forest floor below $D$. traversii trees is covered in a layer (up to $100 \mathrm{~mm}$ thick) of dead leaves that effectively prevent seedling establishment of arborescent and herbaceous species. Seeds of $D$. traversii were released from a height of five metres at a wind speed of approximately two $\mathrm{m} /$ second and the seeds travelled for distances of up to $10 \mathrm{~m}$ (Haase 1986).

During this survey, birds were conspicuously absent from the flowers of both Dracophyllum and Oreothamnus except for a single record of a bellbird (Anthornis melanura (Sparrman)) collecting nectar from the flowers of $D$. traversii on the slopes of Mt. Arthurand photographed by myself, the first record of a bird actively collecting nectar on

\section{Dracophyllum.}




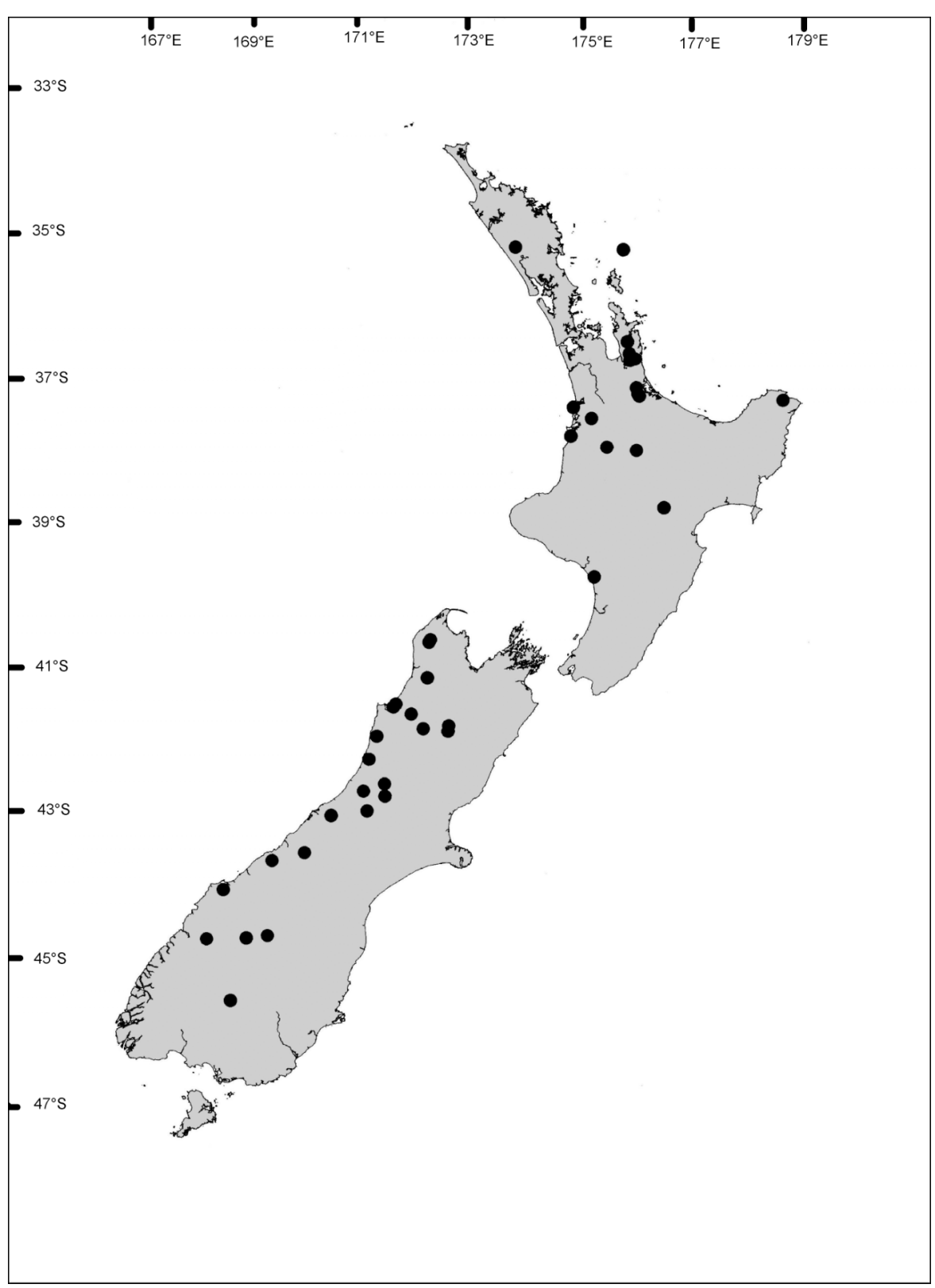

Figure 7.61. Known distribution of Dracophyllum traversii.

\section{Distribution}

New Zealand endemic widely distributed, occurring from the Coromandel Peninsula, Great Barrier Island and Little Barrier Island on the North Island and throughout the South Island (Figure 7.61). 


\section{Habitat}

Dracophyllum traversii occurs on gentle to steep $\left(3^{\circ}-75^{\circ}\right)$ slopes from almost sea level to $1,768 \mathrm{~m}$ altitude. It grows in full sun to light shade on cliffs, in moist gorges, on saddles and mountain slopes. The vegetation consists of lowland forest and shrubland or subalpine forest and shrubland (Table 7.24). It is common in the small tree tier of high altitude conifer/broad-leaved forest and in montane to subalpine Nothofagus forest in the western half of the South Island (Wardle 1984; Poole 1987). Plants of D. traversii experience snow conditions during the winter, and occasionally during the summer months. The small tree and shrub tiers in these forests are underdeveloped with $D$. traversii a common element sometimes forming dense stands. Soils are brown clay to dark brown clay loam derived from sandstone, limestone, graywacke or shale.

Table 7.24. Plant communities commonly associated with Dracophyllum traversii.

\begin{tabular}{|l|}
\hline \multicolumn{1}{|c|}{ FOREST } \\
\hline Tall closed evergreen Nothofagus menziesii- Lepidothamnus intermedius - Weinmannia racemosa forest \\
Tall closed evergreen Nothofagus menziesii - Phyllocladus glaucus - Weinmannia racemosa forest \\
Tall open evergreen Libocedrus plumosa - Knightia excelsa - Astelia fragrans forest \\
Low closed evergreen Nothofagus menziesii - Gahnia rigida forest \\
Low open evergreen Phyllocladus alpinus - Libocedrus bidwillii forest \\
\hline \multicolumn{1}{c}{ SHRUBLAND } \\
\hline Tall closed evergreen Olearia lacunosa shrubland \\
Low closed evergreen Olearia colensoi - Dracophyllum longifolium - Coprosma subalpine shrubland \\
Low closed semi-deciduous Nothofagus menziesii shrubland \\
\hline
\end{tabular}

\section{Variation}

Dracophyllum traversii plants in exposed areas in the subalpine zone rarely reach one metre in height. The form of D. traversii that was described as D. pyramidale on the North Island is more robust in all parts and occurs in lowland forests. Plants growing in the upper edge of the tree line (subalpine forests) display leaves with a distinct grey to glaucous waxy bloom and also show a prominent change in leaf colour during the winter from green to reddish purple (presence of anthocyanins). Lamina sheaths vary in size (30-65 $\times$ 
$30-50 \mathrm{~mm})$ and so to the lamina $(90-300 \times 40-50 \mathrm{~mm})$. Plants in full sun have shorter (180-221 mm) inflorescences than those in forest habitats $(230-350 \mathrm{~mm}$ long). Inflorescence bracts also vary in size from $130-240 \times 25-50 \mathrm{~mm}$.

\section{Specimens examined.}

NEW ZEALAND, North Island - 35-172: North Tangihua Forest (-DD), 29.viii.1991. Cameron 6582 (AK). 35-173: Houto State Forest, summit of Mangatipa No. 2. (-DD), 6.ix.1985. Bellingham 0041 (AK). 36-175: Little Barrier Island, Summit Track (-AA), 9.iii.1962. Melville \& Hamilton 6676 (K); Coromandel, east pinnicle of Moehau (-CB), 22.viii.1974. Wright 710 (AK, L); 37-175: Thames, Mt. Kaitarakihi (-BA), 12.ii.1999. Venter 13765 (CHR); ibid., 12.x.1977. Gardner 1579 (AK); Pirongia, Bald Spur (-CC), 17.viii.1971. May s.n. (AK). 37-178: Mt. Hikurangi (-CC), 15.xi.1926. Oliver s.n. (WELT 48619); South Island - 40-172: Collingwood, Knuckle Hill (-DA), 28.iii.1999. Venter 13778 (CHR); 41-171: Westport, Mt. Rochfort (-DC), 25.xi.1998. Venter 13732 (CHR); 41-172: Motueka, Mt. Arthur, Flora Saddle (-BA), 7.xii.1998. Venter 13734 (CHR); ibid. Venter 13741 (CHR); ibid. Venter 13798a (CHR); Cobb saddle, 22.ii.1965. MacFarlane 452 (LINC). 42-170: Mt. Wilberg (-CD), 28.iv.1993. Wardle \& Buxton s.n. (AK, CHR). 42171: Otira Gorge (-DC), Phillips Turner s.n. (AK). 43-170: Franz Josef, Alex Knob (-AC), 13.i.1966. Wardle s.n. (CHR); 44-167: Fiordland, Esperance Valley (-DB), iii.1974. Atkinson s.n. (CHR); 45-166: Fiordland, Doubtful Sound, Hall Arm (-DB), 31.xii.1939. Cranwell \& Moore s.n. (CHR); Fiordland, Dusky Sound, Pickersgill Harbour to Lake Forester (-DC), 03.i.1969. Dorizac s.n. (CHR). 
Dracophyllum verticillatum Labill., Rel. voy. rech. La Pérouse 2: 211 (1800); Candolle, Prodr. Syst. Nat. Reg. Veg. 7: 770 (1838); Brongniart \& Gris, Ann. Sci. Nat. Bot. 2: 157 \& 238 (1864a); Schlechter, Engl. Bot. Jahrb. 39: 220 (1906); Oliver, Trans. Proc. N.Z. Inst. 59: 710 \& 713 (1928); Däniker, Vier. Nat. Ges. Zürich 78 (19): 341 (1933); Oliver, Trans. Roy. Soc. N.Z. 80 (1): 17 (1952); Virot, Fl. Nov. Caléd. et Depend. 6: 129 (1975). Types: New Caledonia, s. loc. 26.iv.1793. M. Labillardière s.n. (FI, lecto.!, L!, NSW!, P- photo!; Herb. Jussieu.), designated by Virot (1975); New Caledonia, s. loc. M. Labillardière s.n. (Herb. Jussieu, para.!).

= Dracophyllum dracaenoides Schltr., Engl. Bot. Jahrb. 39: 220 (1906). Type: New Caledonia, auf den Bergen bei Ou-Hinna, 900 m, 2.i.1903. R. Schlechter 15599 (P, holo.!; L!, NSW!, P!, S!, W!, Z!).

Icones: Labilladiere., Rel. voy. rech. La Pérouse: t. 40 (1800); Candolle, Prodr. Syst. Nat. Reg. Veg. 7: t.7 (1838); Schlechter, Engl. Bot. Jahrb. 39: t. 21 (1907); Oliver, Trans. Proc. N.Z. Inst. 59: t. 24 (1928); Virot, Fl. Nov. Caléd. et Depend. 6: tt. 19 - 22 (1975).

\section{Description}

A shrub to tree, $0.2-7.0 \mathrm{~m}$ tall. Branches. Bark on old branches grey to brown, finely fissured, young branches reddish brown. Leaves crowded at tips of branches in a bromelioid manner, spreading to recurved; lamina sheath light brown, 17.3-25.2 × 13-17 $\mathrm{mm}$, coriaceous, striate, margins membranous, tapering and margin minutely ciliate; lamina coriaceous, base red, lower surface lighter coloured, linear-triangular, 60-700 ×6$40 \mathrm{~mm}$, surfaces glabrous, prominently striated; margins serrate to serrulate with 20-32 
teeth per $10 \mathrm{~mm}$; apex obtuse to acute. Inflorescence overtopping the leaves, erect, dense, (120-)190-400(-700) mm long, linear-oblong and sparingly branched; rachis and pedicels glabrous to pubescent, light to mid green; inflorescence axis (2.5-)4-15 $\mathrm{mm}$ in diameter; basal inflorescence branch $0.5-2.0 \mathrm{~mm}$ long, widely spreading; inflorescence bracts caducous, overtopping flowers, light green tipped pink, ovate to broadly ovate at base, 42-43 × 17.0-18.3 mm, surfaces glabrous with scattered hairs on abaxial surface, margins ciliate. Flowers $100-500+$, in groups of 5-10 at base of inflorescence, pedicellate; bracteoles caducous, recaulescent, deciduous, with one bracteole situated just below the perianth and the other in the middle of the pedicel, shorter than flower, 1.0 2.5-4.0 $\times(-0.1) 0.2-0.3 \mathrm{~mm}$, glabrous; pedicels straight, $1-5 \mathrm{~mm}$ long, glabrous to pubescent. Sepals green to rose-coloured, ovate to broadly-ovate, $1.7-3.0 \times 1.7-2.0$ $\mathrm{mm}$, shorter than corolla tube, striate, surfaces glabrous; margins ciliate in upper half to completely ciliate; apices subacute to obtuse. Corolla white to light pink; corolla tube narrowly campanulate, widened at mouth, (1.5-)2.0-3.0(-5.0) $\times 2.0-2.5 \mathrm{~mm}$, exterior glabrous; corolla lobes reflexed, oblong to ovate-triangular, shorter to equaling corolla tube, (1.2-)2.0-2.5 × 1.0-2.5 mm, apices obtuse; adaxial surface papillate. Stamens inserted either in middle or in upper third of corolla tube, filaments $1.0-1.5 \mathrm{~mm}$ long; anthers exserted, oblong, pink to purple and 1-2 mm long. Ovary globose, 0.8-1.0 mm long and wide, glabrous, apex round; nectary scales connate at base, rectangular, $0.3-0.5 \times$ 0.4-0.5 mm, apices retuse to irregularly toothed; style included, $1.5-2.0 \mathrm{~mm}$ long, glabrous, lengthening in fruit; stigma clavate. Fruit included in persistent calyx, reddish brown, 1.0-1.2 × (1.0-)1.5-4.0 mm, depressed-globose; apex round, glabrous. Seeds yellowish-brown, ovoid, 0.95-1.0 $\mathrm{mm}$ long, testa slightly reticulate. Flowering September-March. (Figure 7.62). 


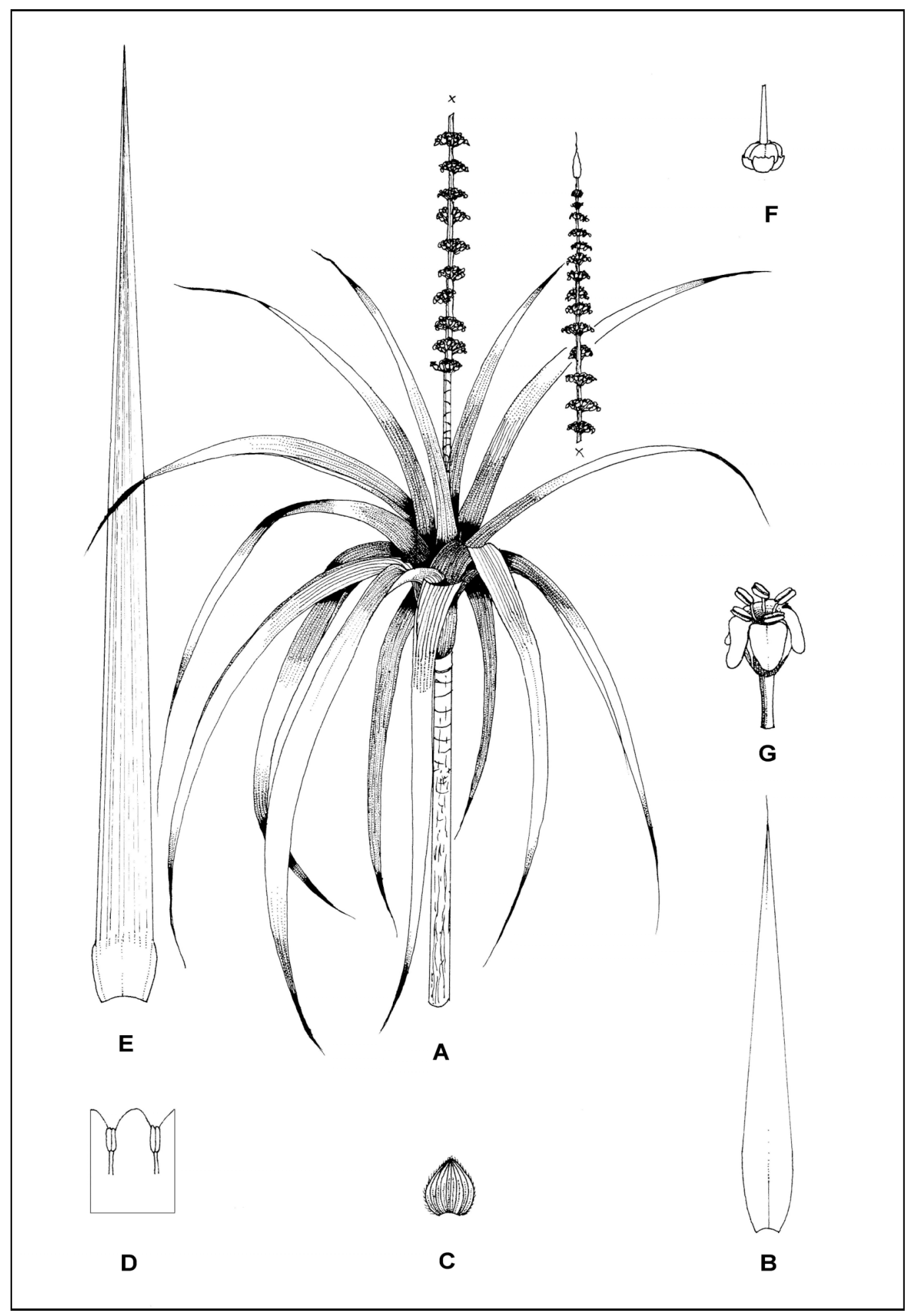

Figure 7.62. Dracopbyllum verticillatum. A, flowering branch $(\times 0.25) ; \mathbf{B}$, inflorescence bract $(\times 0.5)$; $\mathbf{C}$, sepal abaxial surface $(\times 5) ; \mathbf{D}$, laid out corolla $(\times 5) ; \mathbf{E}$, leaf $(\times 0.5) ; \mathbf{F}$, ovary $(\times 10) ; \mathbf{G}$, flower $(\times 5)$. Drawn from MacKee 18864 . 


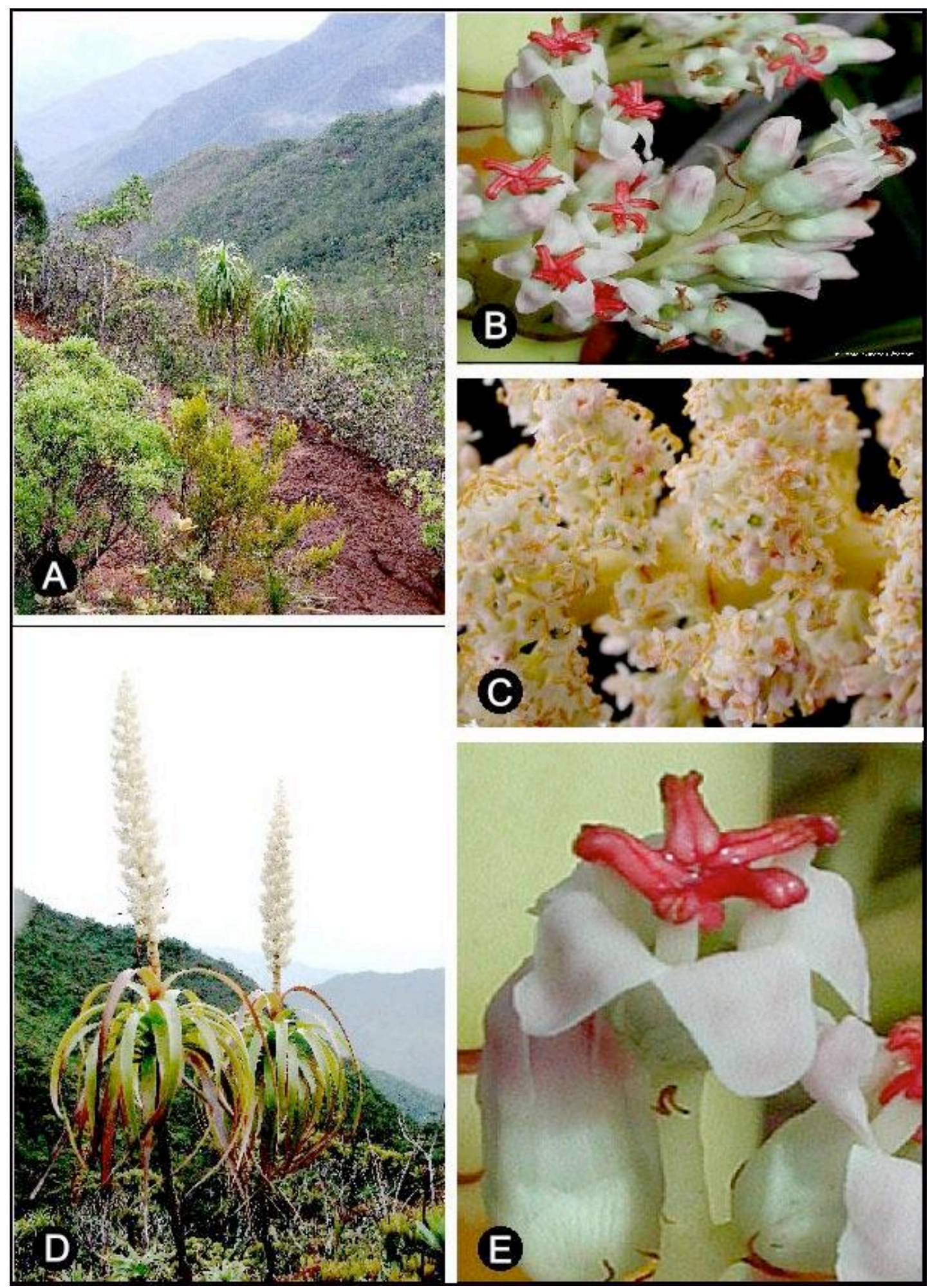

Figure 7.63. Dracophyllum verticillatum. A, plant in habitat near Nomac; B, flowering plant on the slopes of Mt.Mou; C, inflorescence showing the flowers arranged in verticils; $\mathbf{D}$, inflorescence branch with flowers; $\mathbf{E}$, diagnostic red anthers. 


\section{Diagnostic features and discussion}

Dracophyllum verticillatum is characterized by slightly serrated lamina margins, broad lamina sheath, a very long spike-like panicle bearing the flowers in clusters (verticils) at close intervals, broad and obtuse sepals, broad and short corolla tube with recurved corolla lobes and exserted anthers.

Labillardière (1800) gave no specific locality and cited no specimen for the plant he collected but stated that he was the collector. Virot (1975) chose the lectotype at Firenze (FI) but gave no further reference. D. verticillatum is similar to $D$. sayeri but differs in leaf, inflorescence and flower characters (Table 7.8).

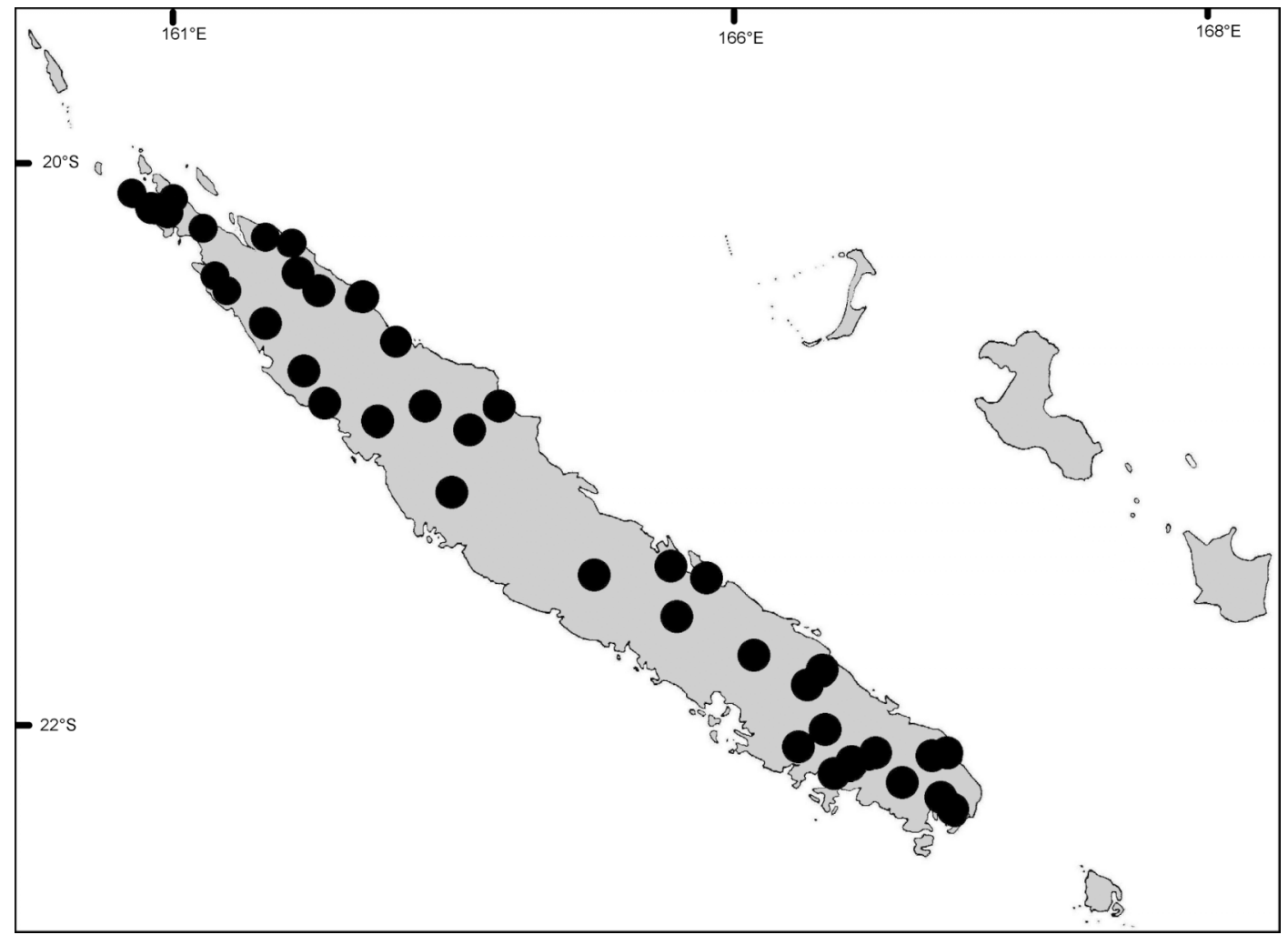

Figure 7.64. Known distribution of Dracophyllum verticillatum. 


\section{Distribution}

Endemic to New Caledonia, widely distributed throughout (Figure 7.64).

\section{Habitat}

Dracophyllum verticillatum occurs in exposed areas on gentle to moderate $\left(5^{\circ}-25^{\circ}\right)$ mountain slopes, in ravines and on plateaus from 40-1,200 $\mathrm{m}$ altitudes. The vegetation consists of forest, maquis or shrubland (Table 7.25). Soils are mostly loam to clay loam and derived from various rock types (peridotite, gneiss, schist, phtanite, quartzite and chalk).

Table 7.25. Plant communities commonly associated with Dracophyllum verticillatum..

\begin{tabular}{|c|} 
MAQUIS \\
\hline Tall closed evergreen Dacrydium araucarioides - Gymnostoma deplancheana - Lomandra insularis maquis \\
Low open evergreen Pancheria vieillardii - Styphelia albicans - Scaevola beckii maquis \\
Low open evergreen Oxanthera neocaledonica - Dracophyllum ramosum - Costularia pubescens maquis \\
Low closed evergreen Boronella pancheri - Babingtonia leratii - Melaleuca brongniartii maquis \\
Low closed evergreen Tristaniopsis glauca - Xanthostemon aurantiacus - Pteridium esculentum maquis \\
Short open evergreen Xeronema moorei - Metrosideros tetrasticha - Drosera neocaledonica maquis
\end{tabular}

\section{Variation}

There is marked variation in leaf size $(60-700 \times 6-40 \mathrm{~mm})$ and inflorescence length $(190-700 \mathrm{~mm})$. The inflorescence axis also varies from $4-15 \mathrm{~mm}$ in diameter at the base. Pedicels are 1-5 $\mathrm{mm}$ long and can either be glabrous or pubescent. Sepal shape (ovate to broadly ovate) and size $(1.7-3.0 \times 1.7-2.0 \mathrm{~mm})$ vary with the margins either ciliate in the upper half or ciliate for the whole length and having subacute to obtuse apices. Flower colour varies from white to deep pink, sometimes in a single population. Corolla lobes vary in shape (oblong to ovate-triangular) and size $(2.0-2.5 \times 1.0-2.5 \mathrm{~mm})$ and on the rare occasion are shorter than the corolla tube. Nectary scale apices are either retuse or irregularly toothed. The above-mentioned variations occur throughout the distribution range. 


\section{Specimens examined}

NEW CALEDONIA - 20-163: Ila Néba (-BB), 08.x.1970. MacKee 22736 (NOU, Z).

20-164: Summit of Arama (-AA), 08.ix.1969. MacKee 20710 (L, NOU, Z); ibid. 16.iv.1925. Däniker 1562a (Z); ibid., Thiébaut 339 (P); Poum, Col de Pointe (-AC), 08.ix.1969. MacKee 20723 (K, L, NOU, P); Tiébaghi and Néhoué, Baumann-Bodenheim 13360 (Z); Diahot (-AD), 30.viii.1951. Hürlimann 1869 (Z); Height above Col d'Amos, 22.x.1959. Thorne 28175 (L); Balade, iv.1871. Balansa 3238a(K); Koniambo Plateau, Koné (-BB), 16.i.1925. Däniker 3072 (P, Z); Chagrin Mine NW of Koumac (-CB), 15.vii.1952. MacMillan 5094 (L); Roche Ouaiéme, massif de Ton-Non (-DB), 18.iv.1968. MacKee 18689 (L); Taom, Mt. Homédéboa (-DC), 16.v.1968. MacKee 18835 (K, L); Tchingou (DD), 17.iv.1951. Hürlimann 1208 (Z). 20-165: Mt. Grandié (-CC), 14.v.1968. MacKee 18864 (Z); Col d'Amos (-CD), 18.viii.1965. Bernardi 10318 (L, Z); ibid. 22.x.1959. Thorne 28175 (L); Canala (-DB), Vieillard 832 (Z); ibid., 13.iii.1951. Guilauminn \& Baumann-Boden 11268 (Z). 21-165: Mt. Mou (-AB), 31.i.1951. Guilauminn \& Baumann-Bodenheim 9994 (Z); ibid., 21.i.1956. MacKee 3815 (L); ibid., Schmid 961 (NOU, Z); ibid., Summit Ridge, 21.i.1956. MacKee 3815 (K, L). 21-166: Thio, Ouégoa (-CA), Brousmiche s.n. (K); Thio, Perpinsin Mountain, ix.1884. Grunow s.n. (W); Ouenghi, Tontouta Valley (-CC), 06.xi.1967. MacKee 17853 (L); Maquis overlooking valley of Tontouta (-CD), 27.ix.1979. McPherson 1902 (NOU, NSW); Ngoye, 02.i.1903. Schlecbter 15206 (L, S, W, Z); Plateau de Dogny (-DB), 12.iv.1969. MacKee 20550 (K, L). 22-166: N side of Mt. Couvelle, Dzumac (-AB), 30.i.1991. Briggs 8716 (NSW); Summit of Chapeau (-BA), 7.i.1869. Balansa 1153 (Z); Col de Ouenarou, 12.ii.1991. Buchanan 11975 (HO); Upper Pirogue River (-BC), 03.x.1924. Däniker 164 (Z); Plaine des Lacs (-BD), MacKee 18572 (L); Bridge over Creek Pernod, 12.v.2005. Venter 13846 (NOU); Mt. Humboldt (-CD), 12.x.1896. Balansa 2192 (P). 
7.3. Oreothamnus (F. Muell.) S. Venter, comb. et stat. nov.

Basionym: Dracophyllum Labill. Sect. Oreothamnus F. Muell., Fragm. Phytograph. Austr. 1: 39 (1858).

Type species: Oreothamnus minimus (F. Muell.) S. Venter (= Dracophyllum minimum F. Muell.).

De Candolle, Prodr. Syst. Nat: 769 (1839); Endlicher, Gen. Plant: 750 (1839); Hooker, Fl. Ant. 1: 45 (1844a); Hooker, Fl. Nov. Zel. 2: 169 (1853); Hooker, Fl. Tasm. 3: 367 (1860); Hooker, Handb. N.Z. Fl. 1: 180 (1864); Bentham, Fl. Austr. 4: 261 (1869); Rodway, Tasm. Fl.: 126 (1903); Cheeseman, Man. N.Z. Fl.: 418 (1906); Cheeseman, Man. N.Z. Fl:: 700 (1925); Oliver, Trans. \& Proc. N.Z. Inst. 59: 678-714 (1928); Oliver, Trans. Royal Soc. N.Z. 80 (1): 1 (1952); Allan, Fl. N.Z. 1: 521 (1961); Eagle, Eagle's Trees \& Shrubs of N.Z.: 282 (1975); Eagle, Eagle's Trees \& Shrubs of N.Z. $2^{\text {nd }}$ Series: 290 (1982); Brown et al., Telopea 8 (3): 381 (1999); Venter, N.Z. Journ. Bot. 40 (1): 39 (2002).

三 Subgenus Oreothamnus (F. Muell.) W.R.B. Oliv., Trans. Proc. Roy. Soc. N.Z. 59: 684 (1928); Brown et al., Telopea 8 (3): 381 (1999); Venter, N.Z. Journ. Bot. 40 (1): 39 (2002).

三Section Oreothamnus F. Muell., Fragm. Phytogr. Austr. 1: 39 (1858). Type species: Dracophyllum minimum $\mathrm{F}$. Muell.

Epacris Forster, non Cav., Charac. Gen. Plant. : 20 (1776). 
Perennial cushion plants, subshrubs, shrubs or trees, 0.15-12 m tall. Leaves sheathing, leaving ringed scars on the branches when falling away, with dry old leaves present in some species; juvenile leaves present in some species; spirally arranged along branches or crowded at ends of branches; lamina sheath tapering to auricled and margin smooth to ciliate; lamina longer and wider than adult lamina, coriaceous, linear-triangular, glabrous, rugose, scabrid or pubescent, sometimes with a patch of scabrid hairs at base of lamina on the adaxial surface, striated in some species; adult leaves crowded at the ends of branches, spirally arranged along branches or imbricate; lamina sheath tapering, rounded, truncate or auricled and margins smooth to ciliate; lamina coriaceous, linear to lineartriangular, $1-232 \times 0.3-6.0 \mathrm{~mm}$; surfaces glabrous, rugose, scabrid, pubescent to tomentose with sometimes a tuft of scabrid hairs at the base on the adaxial surface; sometimes striated; margins serrulate or thickly covered in hairs, sometimes cartilaginous; apex obtuse, acicular, or acuminate, sometimes triquetrous. Inflorescence a terminal or lateral raceme, spike or flowers solitary; shorter than the leaves, erect to drooping, lax to dense, 5-70 mm long, linear-oblong to oblong; inflorescence bracts persistent, shorter than or overtopping flowers, light green to reddish-green, subulate to ovate-triangular at base, $1.5-37 \times 0.5-4 \mathrm{~mm}$, surfaces glabrous to sericeous, margins entire, serrulate to ciliate, apices obtuse to mucronate. Flowers 1-20, sessile or pedicellate; flower bracts persistent or caducous, shorter than or overtopping the flower, membranous to rigid and hard, linear to triangular, 2-20 $\times 0.4-8.0 \mathrm{~mm}$, surfaces glabrous to sericeous, sometimes striate, sometimes with a tuft of scabrid hairs either at the apex or at the base, margins entire or ciliate, apices obtuse to subulate; pedicels straight to curved, $0.3-3.0 \mathrm{~mm}$ long, glabrous to pubescent. Sepals green to purplish-green, lanceolate to triangular; $0.7-13 \times$ 0.6-5.5 mm, shorter to longer than the corolla tube, sometimes striate, surfaces glabrous to pubescent, sometimes with the top half pubescent or with scabrid hairs at base; margins entire, denticulate to ciliate; apices obtuse to acuminate. Corolla white, yellowish 
to light pink; corolla tube cylindrical, slightly urceolate to narrowly campanulate, narrowed to widened at mouth, 1.8-10 $\times 1-4 \mathrm{~mm}$, exterior glabrous; corolla lobes five, imbricate in bud, spreading to strongly recurved, broadly lanceolate to triangular, shorter than corolla tube, $0.8-3 \times 0.8-3.5 \mathrm{~mm}$, apical ridge sometimes present, apices sometimes inflexed, acute to obtuse; surfaces glabrous, adaxial surfaces sometimes papillate. Stamens 5, adnate to corolla tube, filaments $0.1-1.2 \mathrm{~mm}$ long; anthers included, dorsifixed, oblong to rectangular, purple to light yellow, $0.3-1.3 \mathrm{~mm}$ long. Ovary 5-loculed with pendulous placentae; cylindrical to oblong, $0.5-4.5 \times 0.5-2.5 \mathrm{~mm}$, glabrous to pubescent, apex tapering to truncate; nectary scales 5, separate, rectangular to round, $0.2-1.6 \times 0.3-1 \mathrm{~mm}$, apices acute to obtuse, bidentate to variously toothed; style inserted in a depression at the apex of the ovary, included, $0.5-4.0 \mathrm{~mm}$ long, glabrous, sometimes lengthening in fruit; stigma obscurely to prominently 5-lobed. Fruit a loculicidely 5-valved, dry, dehiscent capsule, mostly included in persistent calyx, sessile or pedicellate, light brown to purplish brown, $1.0-4.5 \times 0.8-4.0 \mathrm{~mm}$, depressed-globose to oblong, apex pointed to truncate, glabrous or pubescent. Seeds numerous, filiform to ovoid, $0.2-1.3 \mathrm{~mm}$ long, testa variously reticulate. Chromosome number $n=13$.

Species 29; restricted to the New Zealand Archipelago, its off-shore islands and in Tasmania (Figure 3.2). 


\subsubsection{Key to the genus Oreothamnus}

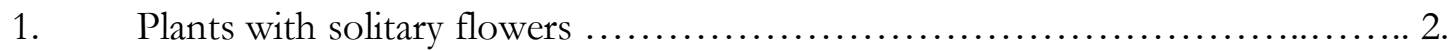

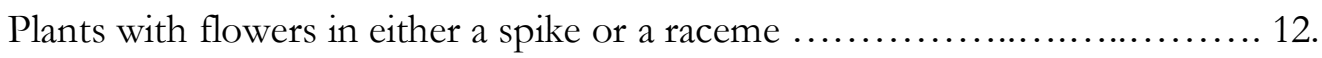

2. Juvenile leaves present, much longer and wider than the adult leaves .....O.

\section{kirkii}

Juvenile leaves absent

3.

3. Flower bract with a broad white margin; plants sparingly leafy

O. palustris

Flower bract without a white margin; plants densely leafy

4.

4. Adaxial surface of the flower bract with a tuft of scabrid hairs at the apex;

margin of flower bract ciliate; apical ridge on corolla lobe absent

O. acerosus

Adaxial surface without scabrid hairs at the apex; margin of flower bract

serrulate; apical ridge on corolla lobe present

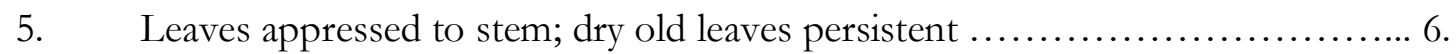

Leaves spreading; dry old leaves falling early leaving a bare stem 10.

6. Sepal shorter than the corolla tube; flower longer than the leaves ...O. prostratus

Sepal equalling or longer than the corolla tube; flower shorter than the leaves ... 7 .

7. Lamina apex prominently triquetrous and acute

O. minimus

Lamina apex acute to obtuse 8. 
8. Sepal margin toothed; apex of corolla lobe acute; apex of fruit truncate

O. densus

Sepal margin ciliate; apex of corolla lobe obtuse; apex of fruit round .... 9.

9. Corolla tube narrowly campanulate; lamina 1-3 $\mathrm{mm}$ long; leaves dull

O. muscoides

Corolla tube cylindrical; lamina 3.5-12(-17.2) mm long; leaves glossy .. O. politus

10. Sepal margin toothed; ovary truncate; ovary 2.5-4.5 mm long;

flower bract longer than flower

O. frondosus

Sepal margin ciliate; ovary round; ovary $0.45-2.1 \mathrm{~mm}$ long; flower

bract shorter or equalling the flower 11.

11. Flower bract 3.5-4.0 × 0.6-0.8 mm; ovary 0.5-1.0 mm long;

stems decumbent

O. pronus

Flower bract 5.0-9.5(-13.0) × 1.0-2.0 mm; ovary 1.7-2.0 mm

long; stems erect

O. rosmarinifolius

12. Inflorescence a spike, flowers sessile

13.

Inflorescence a raceme, flowers pedicellate

24.

13. Juvenile leaves present, much larger and wider than the adult leaves 14.

Juvenile leaves absent 20. 
14. Lamina margin densely pubescent

O. arboreus

Lamina margin serrulate or ciliate

15.

15. Lamina surfaces pubescent to tomentose; margin of inflorescence bract and lamina margin ciliate; sepal shorter than corolla tube

O. pubescens

Lamina surfaces glabrous to shortly scabrid; margin of inflorescence bract either entire or serrulate; lamina margin serrulate; sepal $\geq$ corolla tube 16.

16. Apex of ovary covered with short scabrid hairs; abaxial surface of adult lamina scabrous; abaxial surface of sepal pubescent O. trimorphus Apex of ovary glabrous; abaxial surface of lamina glabrous; abaxial surface of sepal glabrous 17.

17. Margin of flower bract ciliate; adaxial surface of inflorescence bract pubescent to sericeous; stamens inserted close to top of corolla tube O. patens

Margin of flower bract serrulate; adaxial surface of inflorescence bract glabrous or glabrous with a scabrid base; stamens inserted in the upper third of the corolla tube 18. 
18. Sepal apex dark coloured, rigid and hard; flower bract narrow 0.5-0.7 $\mathrm{mm}$; margin of inflorescence bract entire O. lessonianus

Sepal apices green, not hard; flower bract wide 1.6-4.1 mm; margin

of inflorescence bract serrulate 19.

19. Flower bract with broad white margins; apex of ovary truncate; adult lamina $0.5-1.2 \mathrm{~mm}$ wide; corolla tube $1.8-2.0 \mathrm{~mm}$ long .... O. subulatus Flower bract with green margins; apex of ovary round; adult lamina 2-3 mm wide; corolla tube $4.0-4.5 \mathrm{~mm}$ long $O$. sinclairii

20. Lamina margin pubescent to densely pubescent; adaxial surface of lamina pubescent; abaxial surface of sepal pubescent in the upper half O. scoparius Lamina margin serrulate; adaxial surface of lamina glabrous, rugose verrucose or scabrid; abaxial surface of sepal glabrous 21.

21. Inflorescence longer than leaves; lamina rugose 22.

Inflorescence shorter than leaves; lamina smooth 23.

22. Corolla lobe with an apical ridge; flower bract shorter than flower; lamina apex not recurved O. marmoricola

Corolla lobe without an apical ridge; flower bract longer than flower; lamina apex recurved O. recurvus 
23. Corolla lobe with an apical ridge; dry old leaves persistent; lamina apex with a prominent keel

O. pearsonii

Corolla lobe without an apical ridge; dry old leaves deciduous; lamina apex without a prominent keel $O$.

filifolius

24. Juvenile leaves absent; O. opbioliticus

Juvenile leaves present 25.

25. Adaxial surface of adult lamina tomentose; adaxial surface of juvenile lamina scabrid to pubescent; sepal shorter than corolla tube; adult lamina margin densely pubescent O. cockayneanus

Adaxial surface of adult lamina glabrous, rugose to rarely scabrid; adaxial surface of juvenile lamina glabrous; sepal equalling or longer than corolla tube; adult lamina margin serrulate 26.

26. Flower bracts persistent 27.

Flower bracts deciduous 28.

27. Adult lamina apex triquetrous; corolla tube cylindrical; flower bract

3.0-5.5 mm long; inflorescence bract smooth O. oliveri

Adult lamina apex acuminate; corolla tube narrowly-campanulate;

11.3-15.6 mm long; inflorescence bract rugose O. urvilleanus 
28. Lamina not prominently striated; adult lamina adaxial surface rugose; inflorescence near apex of branch; sepal not striate; stamens inserted near top of corolla tube O. septentrionalis Lamina prominently striated; adaxial lamina surface of adult leaf smooth; inflorescence terminal on lateral branchlets; sepal striate; stamens inserted in upper third of corolla tube ..... O. longifolius 
1. Oreothamnus acerosus (Bergg.) S. Venter

Oreotbamnus acerosus (Bergg.) S. Venter. comb. nov. Cheeseman, Man. N.Z. Fl:: 427 (1906); Oliver, Trans. Proc. N.Z. Inst. 59: 690 (1928); Oliver, Trans. Roy. Soc. N.Z. 80 (1): 6 (1952); Allan, Fl. N.Z. 1: 527 (1961); Eagle, Trees and Shrubs N.Z. $2^{\text {nd }}$ series : 295 (1982); Mark \& Adams, N.Z. Alpine Plants : 114 (1986); Poole \& Adams, Trees \& Shrubs of N.Z.: 158 (1994). Type: New Zealand, Mount Torlesse, ii.1874. S. Berggren s.n. (O, holo.!; BM 577613!; CHR!; K!; S!; WELT 32864!, 32867!, 34027!).

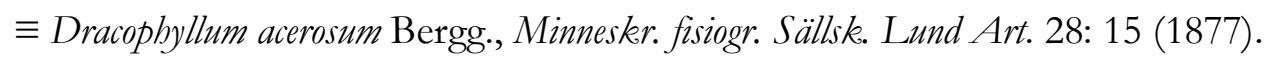

= D. uniflorum Hook. f. var. acicularifolium Cheeseman, Man. N.Z. Fl:: 427 (1906).

Type: New Zealand, Castle Hill, Broken River Basin, T.F. Cheeseman s.n. (AK 7027, lecto.!; WELT 81525!), designated by Oliver (1952).

D. acicularifolium Cockayne, Rep. Scen. Preserv. Soc: 4 (1915). nom. illeg. There is no description or specimen attached to this name.

= D. peninsulare W.R.B. Oliv., Trans. Proc. N.Z. Inst. 59: 690 (1928). Type: New Zealand, Banks Peninsula, Mt.Berard, 2,000', R.M. Laing s.n. (CHR 11093, lecto.!), designated by Oliver (1952). 
Icones: Berggren, Minneskr. fisiogr. Sällsk. Lund Art. 28: t. 4 (1877); Oliver, Trans. Roy. Soc. N.Z. 80 (1): t. 3 (1952); Eagle, Trees and Shrubs N.Z. $2^{\text {nd }}$ series : t.144 (1982); SmithDodsworth, N.Z. Native Shrubs \& Climbers.: tt. 55, Pl. 23A \& 23B (1991).

\section{Description}

Erect multi-stemmed shrub or small tree, 1-2 m tall. Branches: bark on old branches grey to dark grey, smooth to finely fissured, young stems reddish brown. Leaves erect to spreading; lamina sheath $(5-) 7-20 \times 3.5-5.0(-6.5) \mathrm{mm}$, coriaceous, striate, truncate to auricled and margin membranous, smooth or with the top half ciliate; lamina linear to linear- triangular, 30-190 × 0.7-1.5 mm, adaxial surface rugose, abaxial surface glabrous, slightly striated; margins serrulate with 14-21 teeth per $10 \mathrm{~mm}$; apex triquetrous. Inflorescence a solitary terminal flower on lateral branchlets, sessile, shorter than leaves; flower bracts persistent, overtopping flowers, leaf like, ovate-lanceolate, 8.5-17.0 × 2.5-5.0 $\mathrm{mm}$, surfaces glabrous with a tuft of scabrid hairs at apices, margins ciliate. Sepals lanceolate to narrowly ovate, $8-13 \times 2.0-2.5 \mathrm{~mm}$, shorter to equaling the corolla tube, adaxial surfaces with the top half pubescent; abaxial surfaces glabrous; margins ciliate; apices hard. Corolla white to light green turning yellowish; corolla tube cylindrical, 7-8 $\times$ 1.8-2.2 $\mathrm{mm}$; corolla lobes reflexed, ovate-triangular to triangular, shorter than corolla tube, 1-3 × 1-2 mm; apices inflexed, subacute; surfaces glabrous. Stamens inserted on corolla tube in upper third, filaments $0.5-1.0 \mathrm{~mm}$ long; anthers included, rectangular, light yellow, $0.8-1.0 \mathrm{~mm}$ long. Ovary cylindrical, $2.2-3.0 \times 1.3-1.7 \mathrm{~mm}$; glabrous; nectary scales rectangular, $1.5-1.6 \times 0.7-0.8 \mathrm{~mm}$, apices retuse; style included, $1.3-1.5 \mathrm{~mm}$ long, glabrous; stigma capitate. Fruit sessile, light brown, 4.0-4.5 $\times 4.0-4.2 \mathrm{~mm}$, oblong, apex round, glabrous. Seeds yellowish brown, ovoid, 1.45-1.5 mm long, testa slightly reticulate. Flowering November-May (Figure 7.5). 


\section{Diagnostic features and notes}

Oreothamnus acerosus is characterized by the erect branches, erect long acicular leaves with truncate to auricled shoulders to the leaf sheath, solitary erect flowers clustered below the

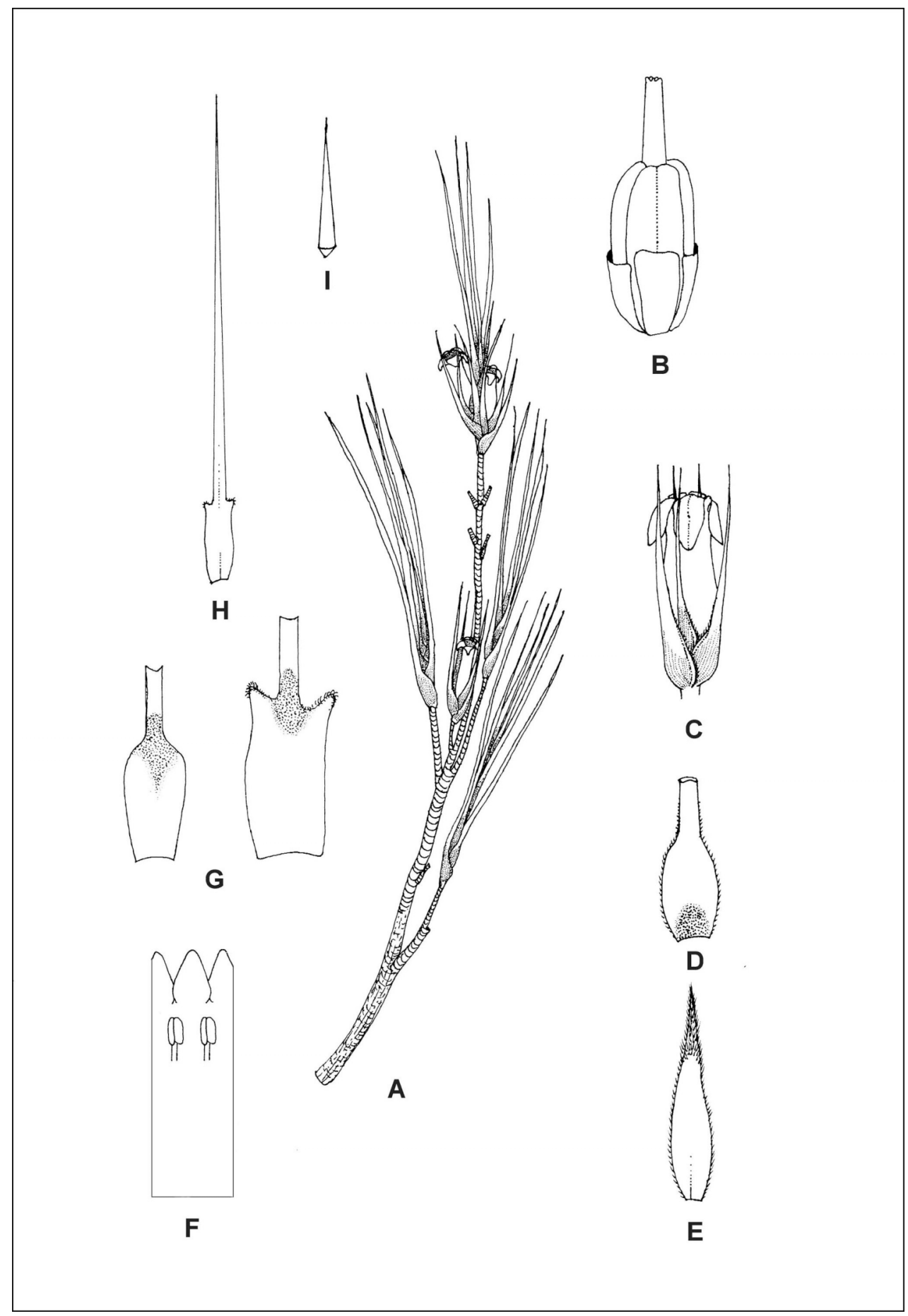


Figure 7.65. Oreothamnus acerosus. A, habit $(\times 1)$; B, ovary $(\times 10)$; C, flower $(\times 5) ; \mathbf{D}$, inflorescence bract base $(\times 5)$; $\mathbf{E}$, sepal adaxial surface $(\times 5) ; \mathbf{F}$, laid out corolla $(\times 5)$; $\mathbf{G}$, lamina sheath $(\times 3) ; \mathbf{H}$, lamina $(\times 1)$; I, lamina apex $(\times 4)$. Drawn from Venter 13754 .
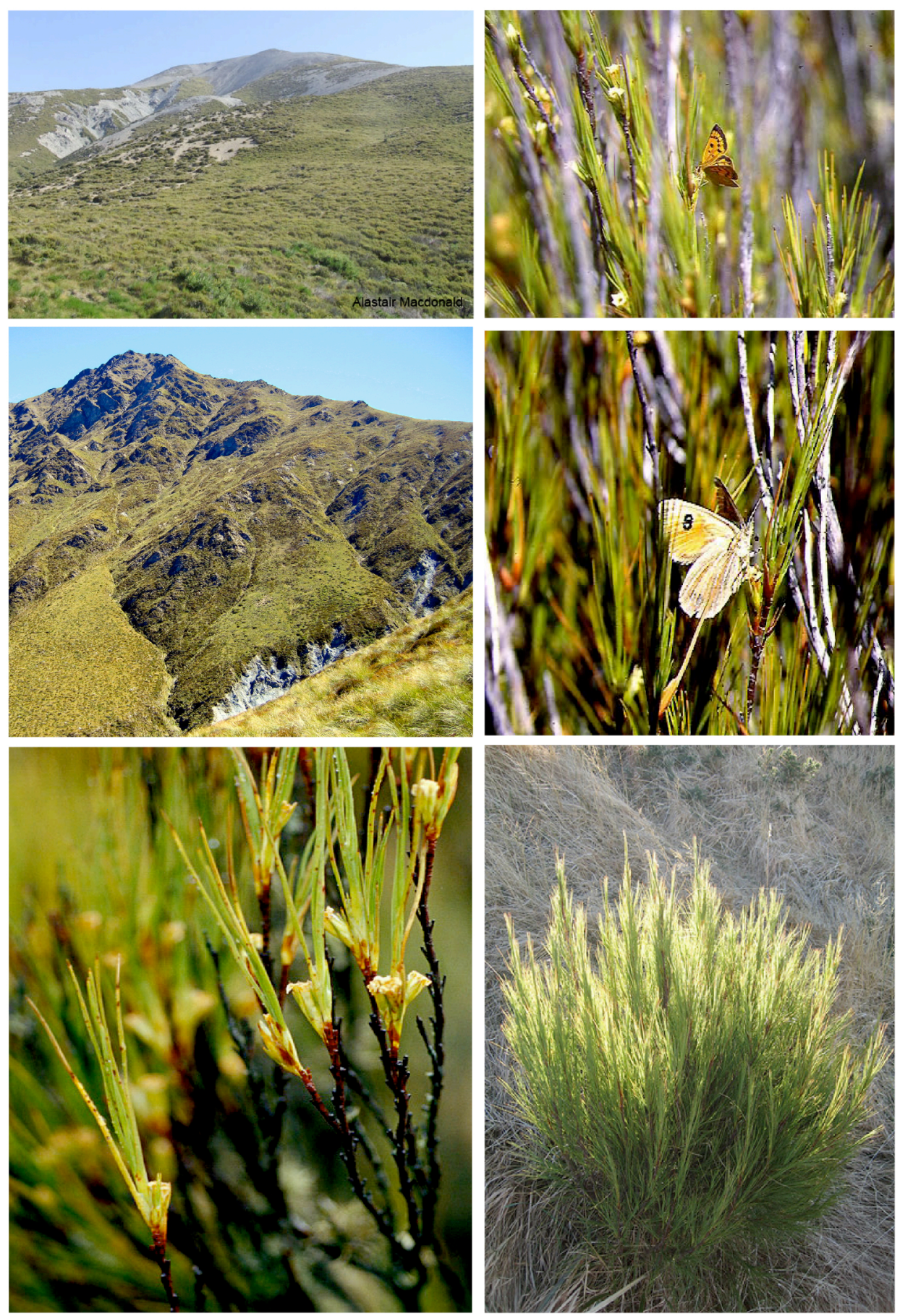

Figure 7.66. Oreothamnus acerosus. A, habitat near Foggy Peak; B, mature plant; C, Lycaena salustius pollinating the flowers; $\mathbf{D}$, characteristic stiff and erect-spreading leaves. B-D, Venter 13754. 
topmost leaves, flower bracts longer than the flowers with the sepals equaling or shorter than the corolla tube with hard apices, 2.2-3.0 mm long cylindrical ovary.

In many aspects, the flowers in Oreothamnus acerosus and all other Oreothamnus species seem to correspond with the general characteristics for settling moth flowers (phalaenophilous) being pale in colour and with a sweet to sickly sweet odour. Moth pollination is fairly important in New Zealand, probably due to the paucity of bee species (Arroyo et al. 1982; Primack 1983). Oliver (1928) did not see the Berggren specimen in Oslo, only the WELT 32864 specimen (isotype). He regarded the Cheeseman type as a hybrid and so described it as Dracophyllum peninsulare based on the Laing specimen at AK. Later Oliver (1952) rectified this by sinking it under Dracophyllum acerosum.

Oreothamnus acerosus is similar to O. kirkii but differs in being erect-stemmed and many branched, with adult leaves that are narrower $(0.7-1.5 \mathrm{~mm})$ with the adaxial lamina surface rugose with fewer teeth per $10 \mathrm{~mm}(14-21)$ on the lamina margin and having a triquetrous lamina apex. The adaxial surface of the flower bract differs in having a tuft of scabrid hairs at the apex. The sepals are longer $(8-13 \mathrm{~mm})$ with the top adaxial half pubescent. The corolla tube is longer $(7-8 \mathrm{~mm})$ with no apical ridge on the corolla lobes that is also glabrous on the adaxial surface. The ovary differs in being cylindrical. Oreothamnus acerosus is also similar to O. frondosus but differs in lacking the prominent apical ridge on the petal and having a subacute corolla lobe apex. The margins of the flower bracts are ciliate not serrulate, the nectary scales are longer (1.5-1.6 mm compared to $1.2-1.5 \mathrm{~mm}$ ), the apex of the ovary is round not truncate and the style is much shorter (1.3-1.5 mm compared to $3-4 \mathrm{~mm})$. 


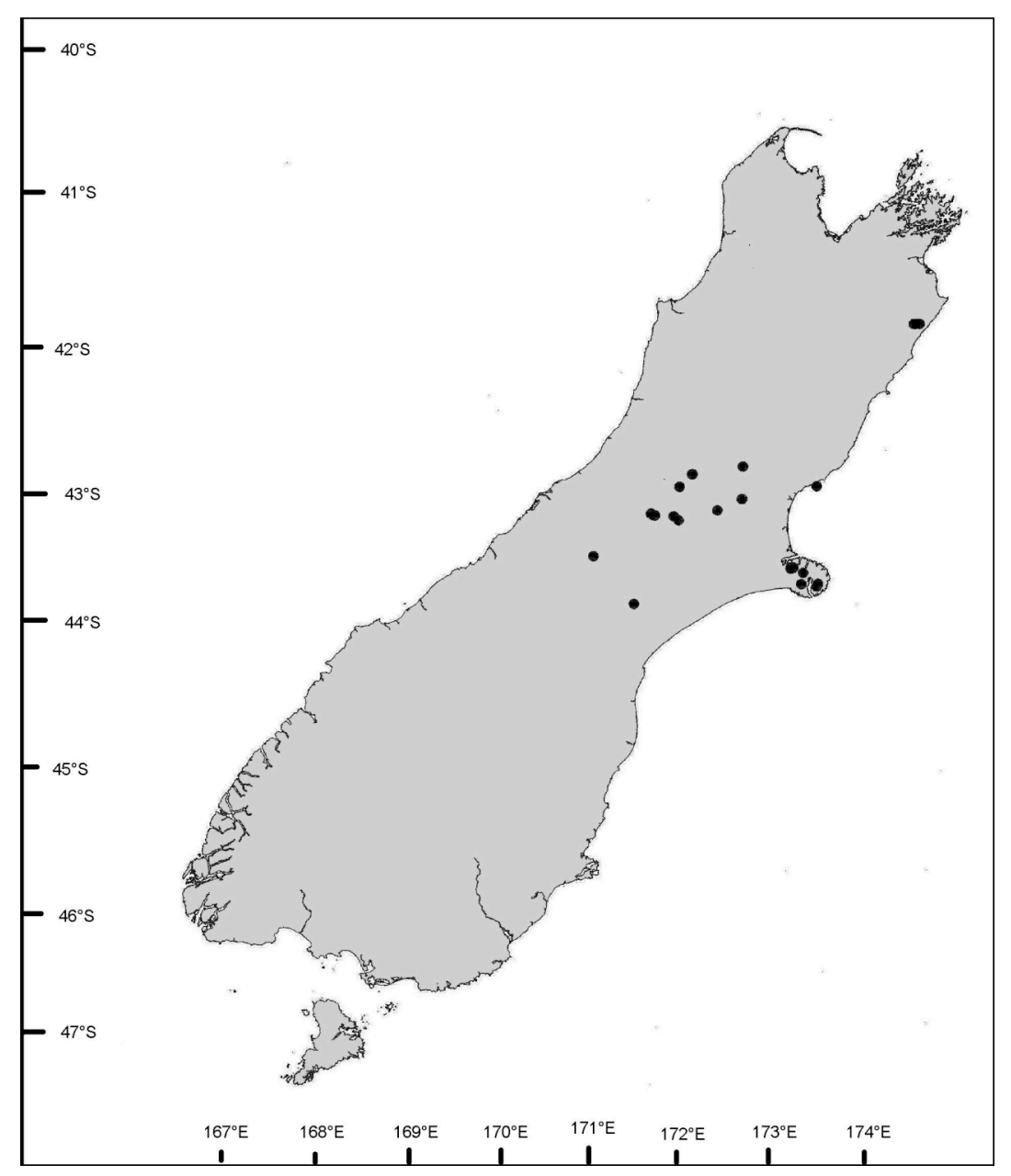

Figure 7.67. Known distribution of Oreothamnus acerosus in New Zealand.

\section{Distribution}

Endemic to the South Island of New Zealand, a species of the eastern mountain ranges of the Southern Alps. It is concentrated in Canterbury with an isolated occurrence near Ben More in Marlborough (Figure 7.67).

\section{Habitat}

Oreothamnus acerosus occurs on gentle to moderate $\left(2^{\circ}-45^{\circ}\right)$ mountain slopes, hillsides, next to rivers or streams and on moraine terraces at altitudes from $300-1250 \mathrm{~m}$. The vegetation consists of subalpine shrubland, tussock grassland, grassland or herbfield 
(Table 7.26). The soil is brown or yellow to grey clay loam derived from greywacke or loess. Plants normally grow fully exposed.

Table 7.26. Plant communities commonly associated with Oreothamnus acerosus.

\begin{tabular}{|l|}
\hline \multicolumn{1}{|c|}{ SHRUBLAND } \\
\hline Low closed Oreothamnus acerosus - Aciphylla monroi shrubland \\
Low open evergreen Olearia ilicifolia - Veronica spp. - Chionochloa conspicua shrubland \\
Low open evergreen Phyllocladus alpinus - Brachyglottis cassinioides - Veronica pauciramosa shrubland \\
Low open Discaria toumatou - Festuca novae-zelandiae - Agrostis capillaris shrubland \\
\hline \multicolumn{2}{|c|}{ TUSSOCKLAND } \\
\hline $\begin{array}{l}\text { Low open Chionochloa rubra tussockland } \\
\text { Low open Chionochloa rigida tussockland }\end{array}$ \\
\hline \\
\hline
\end{tabular}

Oreothamnus acerosus is an important member of the subalpine shrubland and mixed snow tussock shrub communities especially where the plant cover is depleted. At Porters Pass there are areas where it constitutes $\pm 80 \%$ of the vegetation (Venter 13754).

\section{Variation}

The leaf sheath varies in size $(7-20 \times 3.5-5.0 \mathrm{~mm})$ with the shoulders auricled to various degrees with the odd specimen having sloped shoulders but the long cilia on them are always present. Lamina length varies $(30-190 \mathrm{~mm})$ with less variation in lamina width $(1.0-1.3 \mathrm{~mm})$. Flower colour is normally white but near Lake Coleridge there are some populations with lime green flowers. Sepal length varies from 8-13 $\mathrm{mm}$ and usually equal the corolla tube in length but might be slightly shorter in some flowers.

\section{Material studied}

NEW ZEALAND. South Island. 41-173: Marlborough, Whernside Ridge, head of Brian Boru stream (-DD), iii.1975. Druce s.n. (CHR); Peak S of Isolated Hill, iv.1981. Druce s.n. 
(CHR). 41-174: Ben More, Marlborough (-CC), xii.1979. Druce s.n. (CHR). 42-172: Puketeraki Range, Mt. Whatno (-CD), 20.iii.1973. Macmillan 73/309 (CHR). 42-173: Kaikoura, Kowhai Saddle (-BC), 27.i.1989. Buchanan (HO); 43-170: Two Thumb Range, Black Birch Creek (-DB), 11.iii.1985. Mason s.n. (CHR). 43-171: Castle Hill (-BA), 1885. Enys s.n. (AK); Lake Lyndon (-BC), 05.iii.1968. Bernardi 12274 (Z); Porters Pass, 26.x.1976. Moar s.n. (CHR); Boundary Hill, 14.i.1973. Thompson 632 (CHR, L, MO); Fogg Peak, Mt. Torlesse (-BD), i.1969. Adams s.n. (WELT); Kowai Valley, foot of Porters Pass, 13.xii.1947. Oliver s.n. (WELT 56157); Foggy Peak, Mt. Torlesse, 28.i.1999. Venter 13754 (CHR); ibid. ii.1874. Berggren s.n. (O); ibid., i.1969. Adams s.n. (WELT 54837); Lower reaches of Coach Stream, 28.iv.1995. Bellingham 723 (CHR); Cass, hill near Sugar Loaf (CA), 18.i.1922. Foy s.n. (CHR); Andrew River (-CC), Simpson s.n. (CHR); South Canterbury, Orari Valley, ii.1984. Druce s.n. (CHR). 43-172: Mt. Thomas (-AB), 23.xii.1972. Thompson 342 (CHR); (-AC), Mt. Oxford, 09.ii.1955. Mason 3175 (CHR); Banks Peninsula, Kaituna, Mt. Herbert (-DA), Laing s.n. (CHR); ibid., 7.vi.1953. Esler s.n. (AK); Banks Peninsula, Mt. Sinclair (-DB), 23.ix.1967. Lambrechtsen s.n. (CHR); Banks Peninsula, Mt. Berard (-DD), Laing s.n. (CHR); Akaroa, Purple Peak, Oliver s.n. (CHR); Akaroa, Brasenose, viii.1917. Oliver s.n. (CHR); Banks Peninsula, Stoney Bay Peak, 11.i.1972. Simpson \& Chapman s.n. (CHR). 43-173: Banks Peninsula, Cab Stand (-CC), 13.ix.1958. Moar 2634 (CHR).

2. Oreothamnus arboreus (Cockayne) S. Venter, comb. nov.

Oreothamnus arboreus (Cockayne) S. Venter, comb. nov. Mueller, Veg. Chath. Is.: 42 (1864); Hooker, Handb. N.Z. Fl.: 736 (1864); Buchanan, Trans. Proc. N.Z. Inst. 7: 337 (1875); Cheeseman, Man. N.Z. Fl.: 425 (1906); Cheeseman, Man. N.Z. Fl. $2^{\text {nd }}$ Ed.: 707 
(1925); Oliver, Trans. Proc. N.Z. Inst. 59: 694 (1928); Oliver, Trans. Roy. Soc. N.Z. 80 (1): 13 (1952); Allan, Fl. N.Z. 1: 534 (1961); Eagle, Trees \& Shrubs of N.Z. $2^{\text {nd }}$ series: 294 (1982); Salmon, Native Trees of N.Z.: 276 (1989); Poole \& Adams, Trees \& Shrubs of N.Z.: 162 (1994). Type: New Zealand, Chatham Island, 1901. L. Cockayne s.n. (WELT 33086, lecto.!; WELT 81570!; WELT 33094!). Here chosen.

Oliver (1952) mentioned a specimen in WELT for Dracophyllum arboretum as the type and Allan (1961) agreed with this but unfortunately Oliver did not indicate which sheet represented the type. The specimen WELT 33086 (ex Petrie Herbarium) agrees with the protologue and was published by Oliver as 'Plate 82' (right hand specimen) in his revision of Dracophyllum (1928) and is chosen here as lectotype.

三Dracophyllum arboreum Cockayne, Trans. Proc. N.Z. Inst. 34: 318 (1902).

Dracophyllum scoparium F. Muell., Veg. Chath. Is.: 42 (1864). (non Hook. f.) nom. illegit.

Dracophyllum latifolium var. ciliolatum Hook. f., Handb. N.Z. Fl. 2: 736 (1864). In nota., nom. illegit.

= Dracophyllum scoparium var. major Cheeseman, Man. N.Z. Fl:: 425 (1906). Type: New Zealand. Chatham Island. F.A.D. Cox s.n. (WELT 33097, lecto.!; K!; NY; WELT 33095!). Here designated.

Cheeseman (1906) mentioned some specimens for his var. major and var. paludosum but did not indicate which specimens belong to what variety. However it is possible to assign the F.A.D. Cox specimens to var. major according to the protologue (Cheeseman 1906). 
Icones: Oliver, Trans. Proc. N.Z. Inst. 59: t. 82 (1928); Eagle, Trees \& Shrubs of N.Z. $2^{\text {nd }}$ series.: t. 141 (1982).

\section{Description}

Tree 4-6(-12) m tall. Branches. Bark on old branches greyish-brown to brown, finely fissured, young stems yellowish to reddish brown. Leaves juvenile and adult; juvenile leaves crowded at tips of branches, spreading; lamina sheath yellowish to light green, (9-)15-17 $\times$ 7.4-16.6 mm, coriaceous, tapering and margin ciliate or ciliate in upper half only; lamina subcoriaceous to coriaceous, linear-triangular, 100-220 ×10-18 mm, surfaces glabrous, margins densely pubescent; adult leaves spreading; lamina sheath light green, 6-12 × 4-12 $\mathrm{mm}$, membranous, tapering with a ciliate margin; lamina linear to linear-triangular, (25-) $40-86(-90) \times 1-2 \mathrm{~mm}$, surfaces glabrous with a tuft of scabrid hairs at base of adaxial surface; margins densely pubescent. Inflorescence a terminal spike on lateral branchlets, shorter than leaves, erect to drooping, dense, 15-38 mm long, linear-oblong; inflorescence bract overtopping the flower, subulate, $18-20 \times 3-5 \mathrm{~mm}$, surfaces glabrous, adaxial surface pubescent at base, margins ciliate. Flowers (4-)6-9, sessile; flower bract persistent, overtopping flowers, leaf like, ovate to broadly ovate; 5.5-9.0 $\times 2.5-3.0 \mathrm{~mm}$, surfaces glabrous, adaxial surface with a tuft of scabrid hair at apex; margins ciliate. Sepals ovate lanceolate, $(4-)$-7 $\times 2.5-3.0 \mathrm{~mm}$, longer than corolla tube, surfaces glabrous with the top half pubescent; margins ciliate. Corolla white; corolla tube cylindrical, $4-5 \times 2.5-3.0$ $\mathrm{mm}$; corolla lobes reflexed, triangular, shorter than corolla tube, (2.0-)2.3-2.4 × 1-2 mm; apices acute; adaxial surface papillate. Stamens inserted on corolla tube in upper third, filaments 0.3-1.0 mm long; anthers included, oblong, light yellow, 0.3-0.4 mm long. Ovary obovate, $1.7-2.0 \times 1.0-2.0 \mathrm{~mm}$; glabrous, apex round; nectary scales, oblong, 1.0-1.2 $\times$ 0.5-0.8 mm, apices irregularly toothed; style included, 2.0-2.5 mm long, glabrous; stigma capitate. Fruit sessile, dark brown, 1.2-1.5 × 1.0-1.5 mm, oblong, apex round, glabrous. 
Seed yellowish brown, ovoid, 0.6-0.65 mm long, testa slightly reticulate. Flowering November-February. (Figure 7.68).

\section{Diagnostic features and notes}

Oreothamnus arboreus is characterized by trees growing up to $6 \mathrm{~m}$ tall, long and broad juvenile leaves with adult leaves densely ciliated on the margins and pubescent at the base, persistent hard and sharp-tipped bracts that are broad with long white hairs on the adaxial surface, corolla tube $4-5 \mathrm{~mm}$ long and shorter than the sepals that have long cilia and hairs on the abaxial surface.

Hooker (1864) first mentioned this species under the name Dracophyllum latifolium var. ciliolatum but failed to give any description or mention any specimens associated with it, thus the name is illegitimate according to Article 32 of the I.C.B.N (Greuter et al. 2000).

Oreothamnus arboreus is similar to O. cockayneanus and O. scoparius but can immediately be separated from O. scoparius, which lacks juvenile leaves. It differs from O. cockayneanus in the glabrous surfaces of the juvenile lamina that is also wider $(10-18 \mathrm{~mm})$ and the flower bracts are persistent. It also 


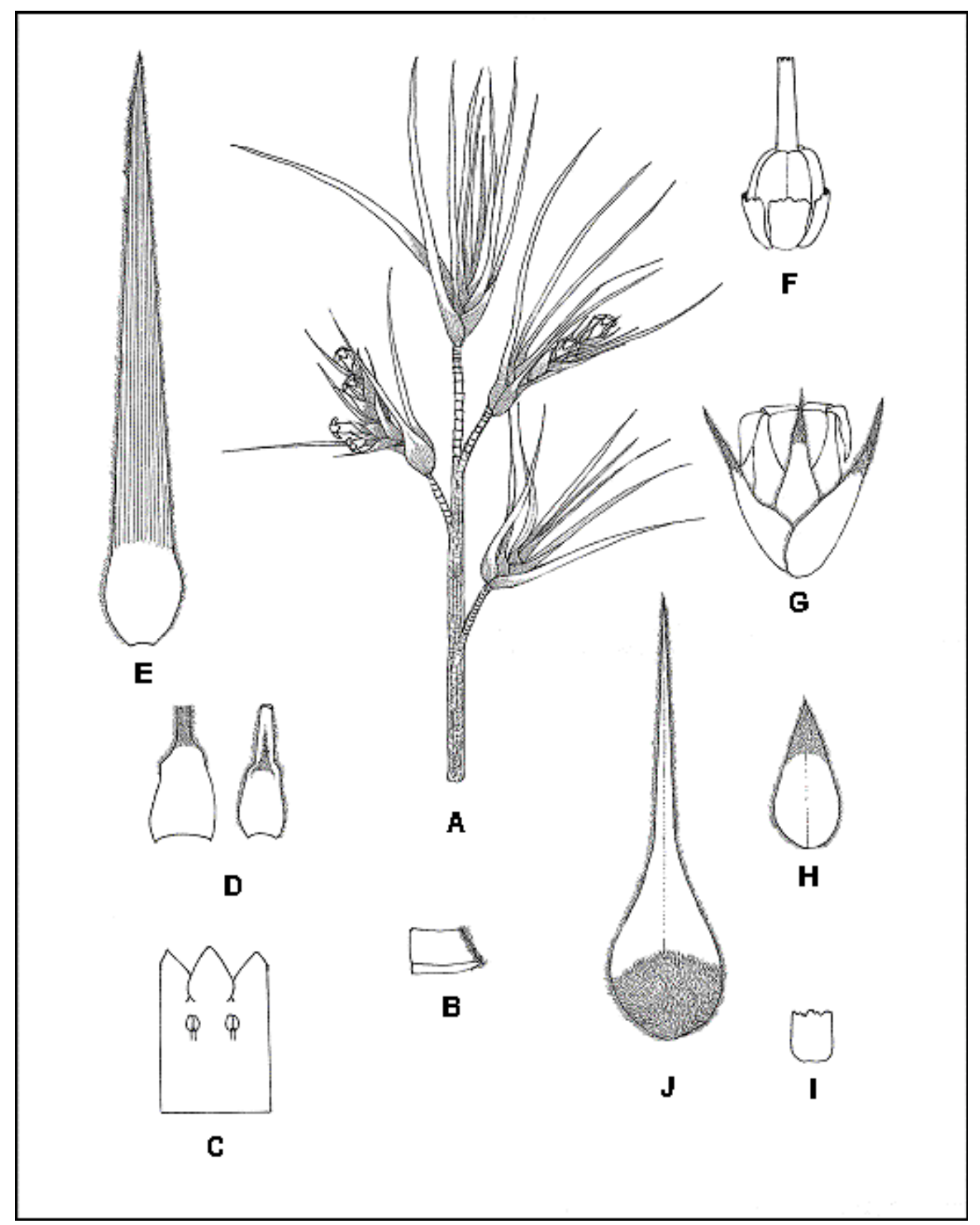

Figure 7.68. Oreothamnus arboreus. A, habit $(\times 1)$; B, lamina margin $(\times 40)$; C, laid out corolla $(\times 5)$; $\mathbf{D}$, lamina sheath $(\times 2)$; $\mathbf{E}$, lamina $(\times 1) ; \mathbf{F}$, ovary $(\times 10)$; $\mathbf{G}$, flower $(\times$ $7)$; $\mathbf{H}$, sepal abaxial surface $(\times 5)$; $\mathbf{I}$, nectary scale $(\times 10)$ and $\mathbf{J}$, inflorescence bract adaxial surface $(\times 5)$. Drawn from Cockayne s.n. (WELT 33086). 

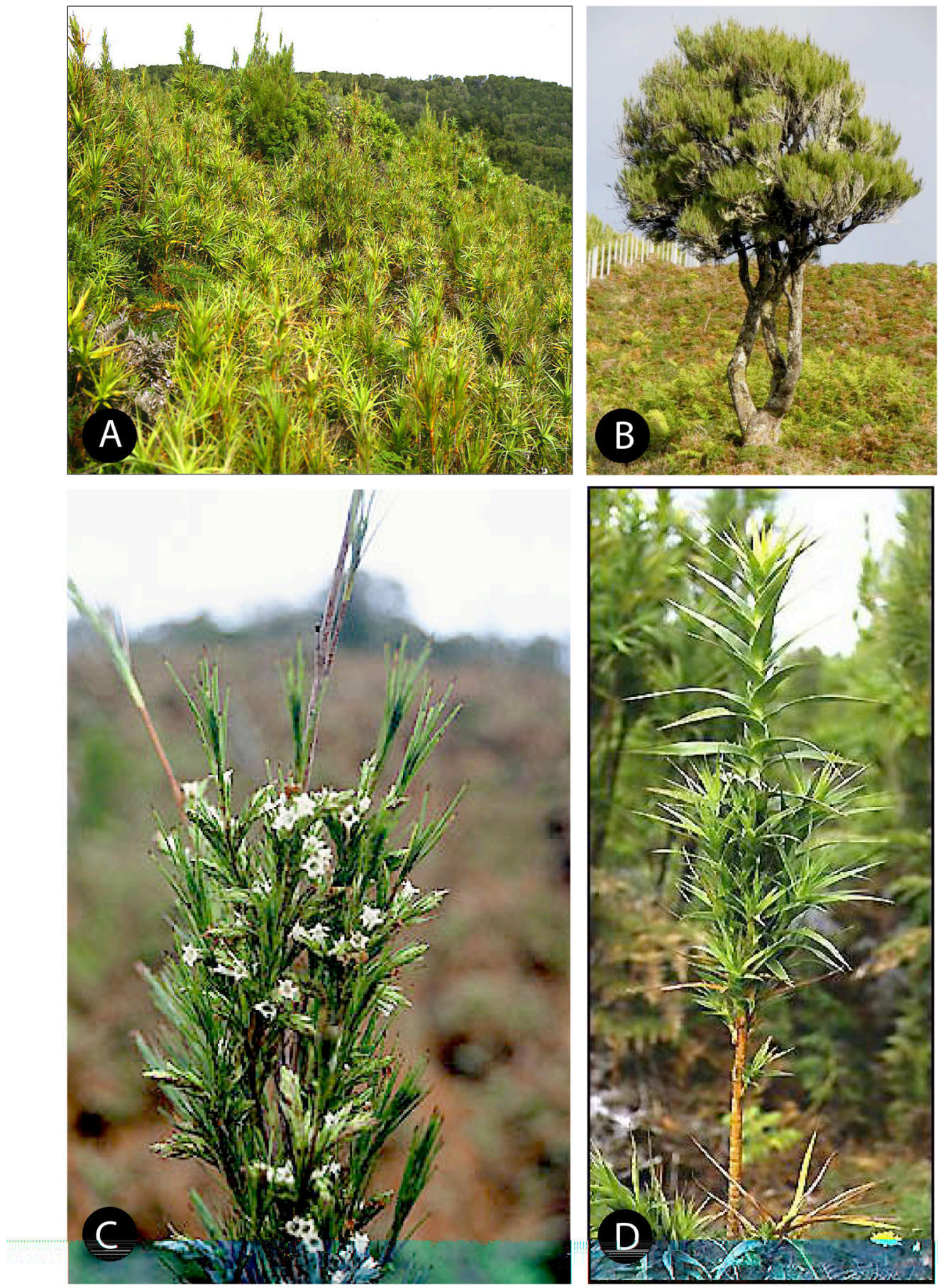

Figure 7.69. Oreothamnus arboreus. A, a dense stand of young plants with a few older plants emerging; B, a mature tree with the undergrowth removed by livestock; C, flowering branch; $\mathbf{D}$, juvenile leaves. 
differs in the tapering shoulder of the adult lamina sheath and glabrous lamina with a tuft of scabrid hairs at the base. The inflorescence in $O$. arboreus is a spike with a persistent glabrous flower bract having a tuft of scabrid hairs at the apex on the adaxial surface. The sepals are longer than the corolla tube with the upper half of the sepal pubescent on the abaxial surface and the cylindrical corolla has lobes with papillate adaxial surfaces. The apices of the nectary scales in $O$. arboreus are irregularly toothed but subacute to obtuse in O. cockayneanus.

Seeds commonly germinate on tree ferns, growing for a period as an epiphyte. Plants stay in the juvenile form with large leaves for many years before taking on the adult leaf shape and size. Leaves of the juvenile form commonly appear high up in the branches of adult O. cockayneanus plants and are here called reversion shoots.

\section{Distribution}

New Zealand endemic restricted to the Chatham- and Pitt Islands (Fig. 7.70).

\section{Habitat}

Oreothamnus arboreus occurs from near sea level up to $270 \mathrm{~m}$ altitude in gullies, gully floors, along streams, hillsides and on coastal cliffs. The vegetation consists of forest, shrubland, lowland bogs and grassland (Table 7.27). Soils are typically boggy and peaty. Most $O$. arboreus plants grow in full sun but occasionally occur in light shade inside forest communities. 


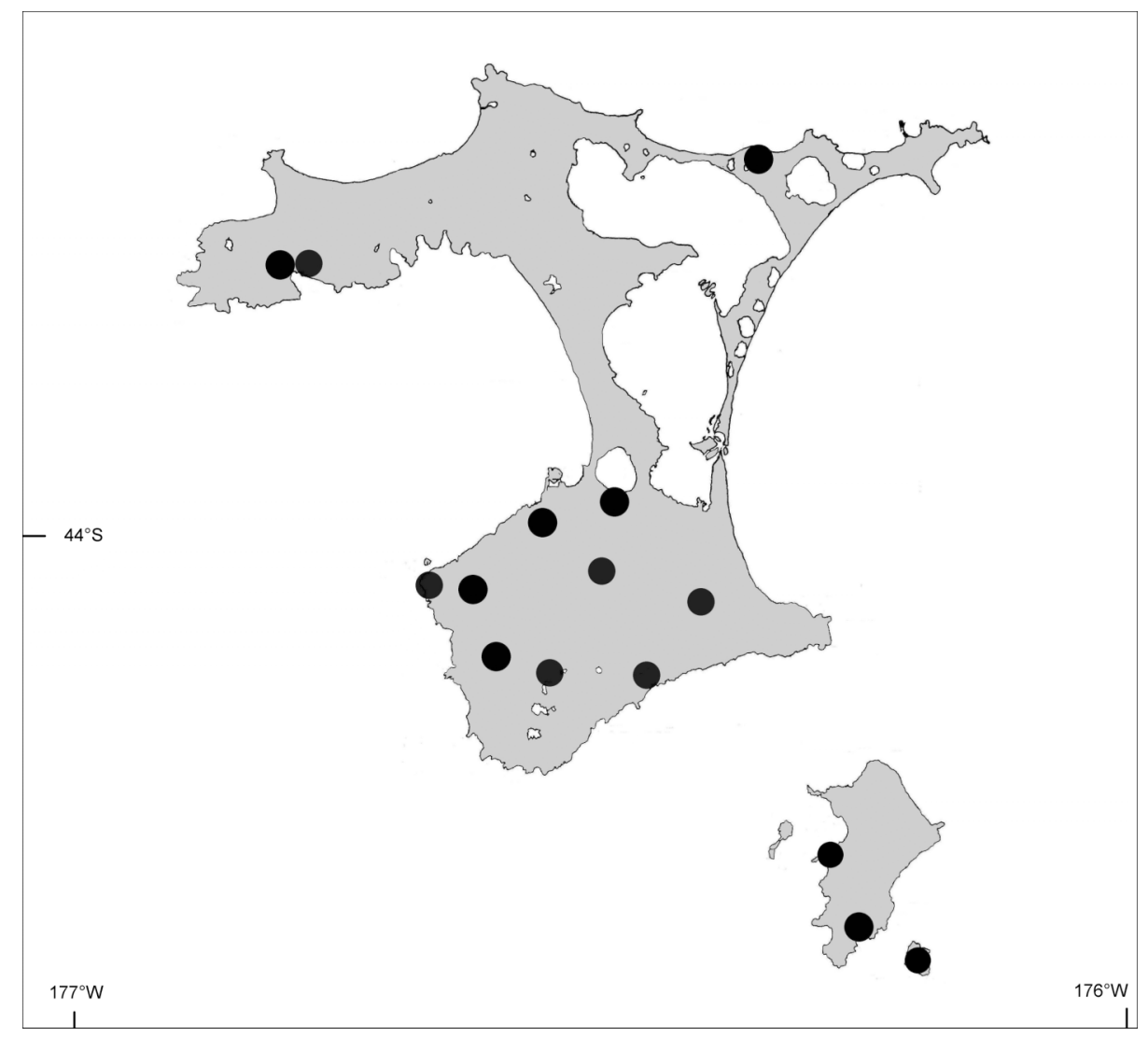

Figure 7.70. Known distribution of Oreothamnus arboreus. The large island is Chatham Island and the smaller island is Pitt Island.

Table 7.27. Plant communities commonly associated with Oreothamnus arboreus.

\begin{tabular}{|l|}
\hline \multicolumn{1}{|c|}{ FOREST } \\
\hline Low closed evergreen Plagianthus chathamicus forest \\
\hline \multicolumn{1}{c|}{ SHRUBLAND } \\
\hline Tall open evergreen Muehlenbeckia australis shrubland \\
Low closed evergreen Coprosma - Olearia semidentata shrubland \\
Low open evergreen Olearia chathamica shrubland \\
\hline
\end{tabular}

\section{Variation}

Juvenile and adult leaves are quite variable in shape and size. The abaxial surface of the sepal can be either completely glabrous or only pubescent in the upper half. Filament length $(0.3-1.0 \mathrm{~mm})$ varies from population to population. 


\section{Material studied}

NEW ZEALAND. Chatham Islands. 43-176: Ocean Mail Scenic Reserve (-CB), 24.ii.1996. De Lange CH97 (AK, HO); Te Awatea, swamp forest on southern shore of Lake Huro (-DC), 20.ii.1982. Given \& Williams 13018 (AK, WELT); South of Lake Huro, 28.i.1974. Hamel s.n. (CHR); Te Moko Creek, Ocean Bay (-DD), 6.iii.1985. Given 14050 (CHR). 44-176: Head of Mangahou Creek (-AB), 14.ii.1985. Wardle 85/2 (CHR); Rangatira Island, Rangatira Trig. (-AC), 27.ii.1986. Courtney s.n. (CHR); Woolshed Bush. 7.iii.1986. Courtney s.n. (CHR); Top of large slump, SE Coast, 14.ii.1985. Wardle 85/1 (CHR); Pitt Island, between Glory Bay and Canister Cove (-AD), 17.ii.1985. Wardle 85/7 (CHR); ibid., 05.i.1970. Hamlin 1816 (WELT); Near Point Durham (-BA), 7.ix.1959. Moar 2591 (CHR); Lake Rakeinui, 18.ii.1982. Given s.n. (CHR); Tukutamatea Valley, 15.i.1978. Olsen s.n. (AK, HO).

3. Oreothamnus cockayneanus (Du Rietz) S. Venter

Oreothamnus cockayneanus (Du Rietz) S. Venter, comb. nov. Buchanan, Trans. Proc. N.Z. Inst. 7: 337 (1875); Oliver, Trans. Proc. N.Z. Inst. 59: 702 (1928); Allan, Fl. N.Z. 1: 532 (1961). Type: New Zealand, Campbell Island, Perseverance Harbour, 1.iv.1927. W.R.B. Oliver s.n. (WELT 280, holo.!).

=Dracophyllum longifolium (J.R. Forst. \& G. Forst.) R. Br. ex Roem. \& Schult. var. cockayneanum (Du Rietz) W.R.B. Oliv., Trans. Roy. Soc. N.Z. 80 (1): 11 (1952).

三Dracophyllum cockayneanum Du Rietz, Svensk Botanisk Tidskrift 24(3): 375 (1930). 


\section{Description}

Tree 3-12 m tall. Branches: bark on old branches brown, rough to occasionally finely fissured, young stems reddish brown. Leaves juvenile and adult. Juvenile leaves spirally arranged along branches, spreading; lamina sheath 15-20 × 12-14 mm; shoulders tapering to rounded, margin ciliate; lamina linear-triangular; 100-140 × 4-6 mm; adaxial surface scabrid to pubescent, abaxial surface glabrous to scabrid, margins densely pubescent; adult leaves erect to spreading; lamina sheath light green, $12.0-18.3 \times 9-13 \mathrm{~mm}$, coriaceous, shoulders rounded to truncate and margin ciliate in the top half; lamina linear to lineartriangular, $(40-) 60-120(-140) \times 1.5-3.0(-4.0) \mathrm{mm}$, adaxial surface tomentose; abaxial surface with upper half covered in scabrid hairs, slightly striated; margins serrulate and densely pubescent with 60-70 teeth per $10 \mathrm{~mm}$. Inflorescence a terminal raceme on lateral branchlets; shorter than leaves, erect to drooping, dense, 30-70 mm long, linearoblong; inflorescence bract persistent, overtopping flowers, subulate, 15-30 × 1.5-2.0 mm, adaxial surface scabrid, abaxial surface glabrous, margins ciliate. Flowers 6-12(-20), pedicellate; flower bracts caducous, overtopping flowers, ovate-lanceolate to ovate; 8.0$14.0 \times 3-6 \mathrm{~mm}$, adaxial surfaces pubescent or pubescent in upper third only; abaxial surfaces glabrous, margins ciliate; pedicels straight, $1-3 \mathrm{~mm}$ long, glabrous to pubescent. Sepals ovate-lanceolate, $4-5 \times 2.0-2.5 \mathrm{~mm}$, shorter than the corolla tube, surfaces glabrous but occasionally pubescent in the top half of adaxial surface; margins ciliate. Corolla white to occasionally light pink; corolla tube narrowly campanulate, widened at mouth, 4-6 $\times 3.0-3.5 \mathrm{~mm}$; corolla lobes reflexed, ovate-triangular, shorter than corolla tube, 1.5-2.0 mm long and wide; surfaces glabrous. Stamens inserted on corolla tube in upper third, filaments $0.5-1.0 \mathrm{~mm}$ long; anthers included, oblong, pink, 0.7-0.8 mm long. Ovary obovate, $1.5-2.0 \times 1.2-2.0 \mathrm{~mm}$, apex truncate; nectary scales rectangular, $1.2-1.5 \times$ 0.6-1.0 mm, apices subacute to obtuse; style included, $1.5-2.0 \mathrm{~mm}$ long, glabrous, lengthening in fruit; stigma five-lobed. Fruit pedicellate, light brown, 2.5-3.5 × 3-4 mm, 
obovoid, apex truncate, glabrous. Seeds light brown, filiform, $0.65-0.7 \mathrm{~mm}$ long, testa slightly reticulate. Flowering October-March. (Figure 7.71).

\section{Diagnostic features and notes}

Oreothamnus cockayneanus is characterized by the erect stiff that are mostly white tomentose in the bottom half and the margin ciliated with broad sheaths having rounded to truncate shoulders with dense white cilia. The pedicel is $1-3 \mathrm{~mm}$ long and the flower bracts are caducous having the upper third of the adaxial surface covered in dense long white hairs.

Du Rietz (1930) argued that as far as his experience goes Oliver's (1928) D. longifolium form 3 is quite as good a species as many of the species recognized by Oliver and therefore raised it to the rank of species namely D. cockayneanum. Later Oliver (1952) described it as a variety of O. longifolius on the basis of the broad, stiff, spear-like leaves with broad sheaths, erect racemes and the deciduous flower bracts (Oliver 1952). Morphologically it is similar to O. longifolius, but it differs in various leaf and flower characters (Table 7.28). The combination of the following characters prompted me to raise D. longifolium var. cockayneanum to species level: the erect stiff adult leaves that are white tomentose in the bottom half, rounded to truncate shoulders of the lamina sheath, ciliate margin of the inflorescence bract, sepals shorter than the corolla tube and the truncate apex of the ovary. 


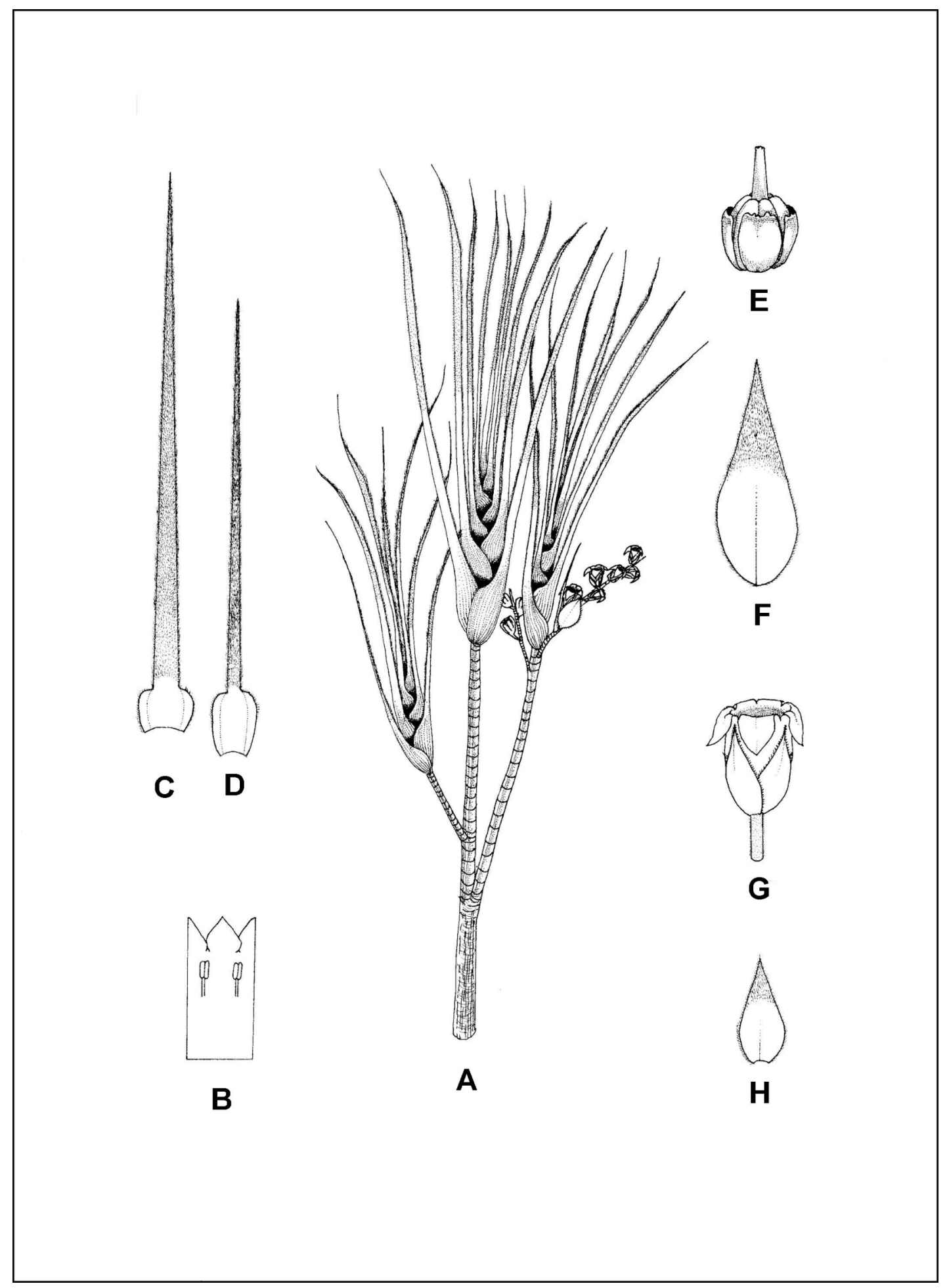

Figure 7.71. Oreothamnus cockayneanus. A, flowering branch $(\times 1)$; $\mathbf{B}$, laid out corolla $(\times 5)$; $\mathbf{C}$, juvenile leaf $(\times 1) ; \mathbf{D}$, adult leaf $(\times 1)$; $\mathbf{E}$, ovary $(\times 10) ; \mathbf{F}$, flower bract adaxial surface $(\times 5)$; $\mathbf{G}$, flower $(\times 5)$; $\mathbf{H}$, sepal adaxial surface $(\times 5)$. Drawn from Hooker s.n. (HO). 


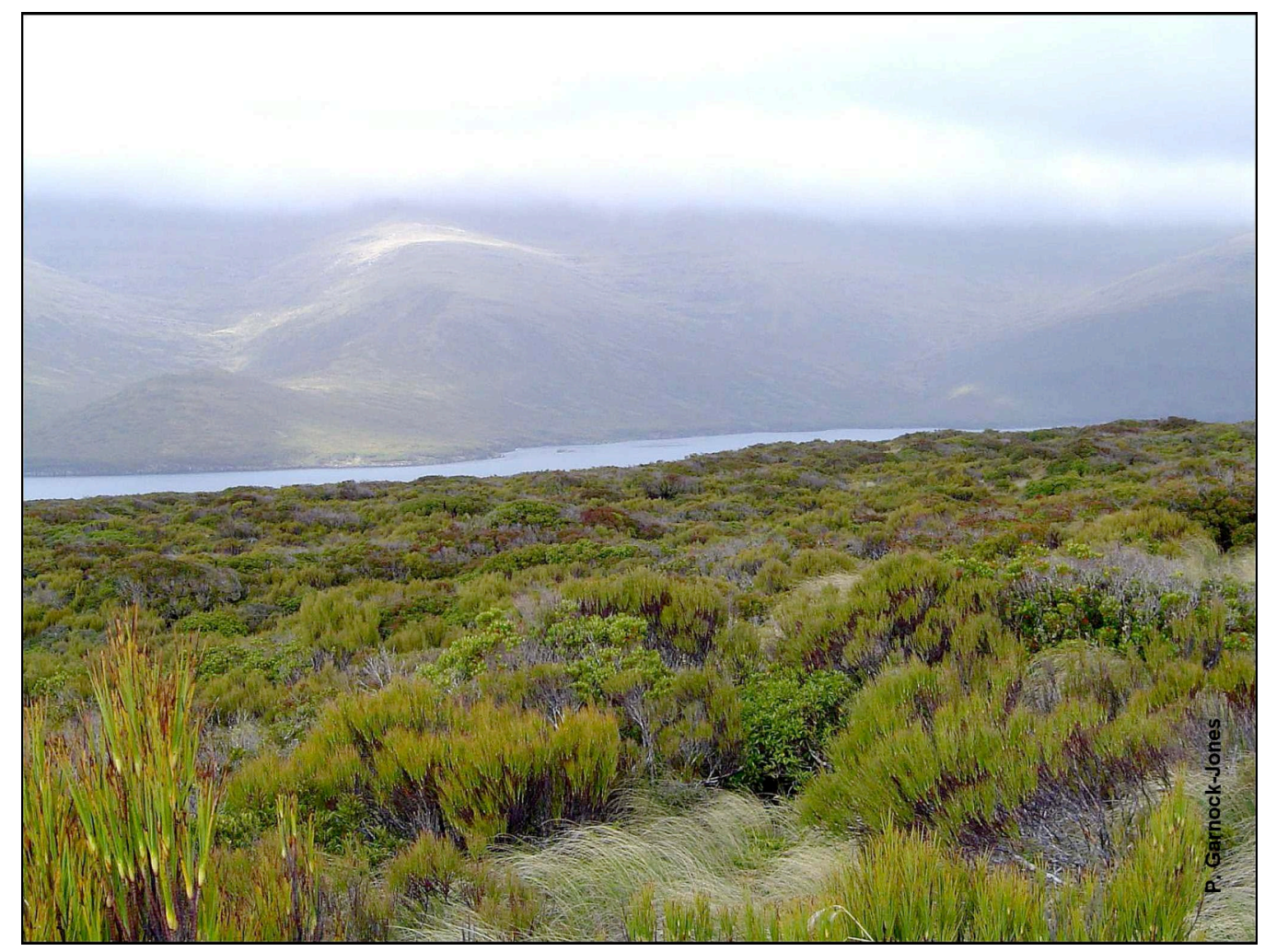

Figure 7.72. Oreothamnus cockayneanus. Habitat on Enderby Island.

Table 7.28. Differences between Oreothamnus longifolius and O. cockayneanus.

\begin{tabular}{|c|c|c|}
\hline Character & O. longifolius & O. cockayneanus \\
\hline Juvenile lamina surface & glabrous & scabrid to pubescent \\
\hline Adult lamina sheath size (mm) & $5.0-15 \times 4.0-7.0$ & $12.0-18.3 \times 9.0-13.0$ \\
\hline Adult lamina adaxial surface & glabrous & tomentose \\
\hline Lamina margin & serrulate & densely pubescent \\
\hline Inflorescence bract margin & serrulate & ciliate \\
\hline Sepal length compared to corolla tube & equalling to longer & shorter \\
\hline Sepal surface texture & glabrous, top half rarely pubescent & striate \\
\hline Corolla lobe adaxial surface & papillate & glabrous \\
\hline Nectary scale apex & irregularly toothed & subacute to obtuse \\
\hline Ovary apex shape & round & truncate \\
\hline Seed shape & ovoid & filiform \\
\hline
\end{tabular}




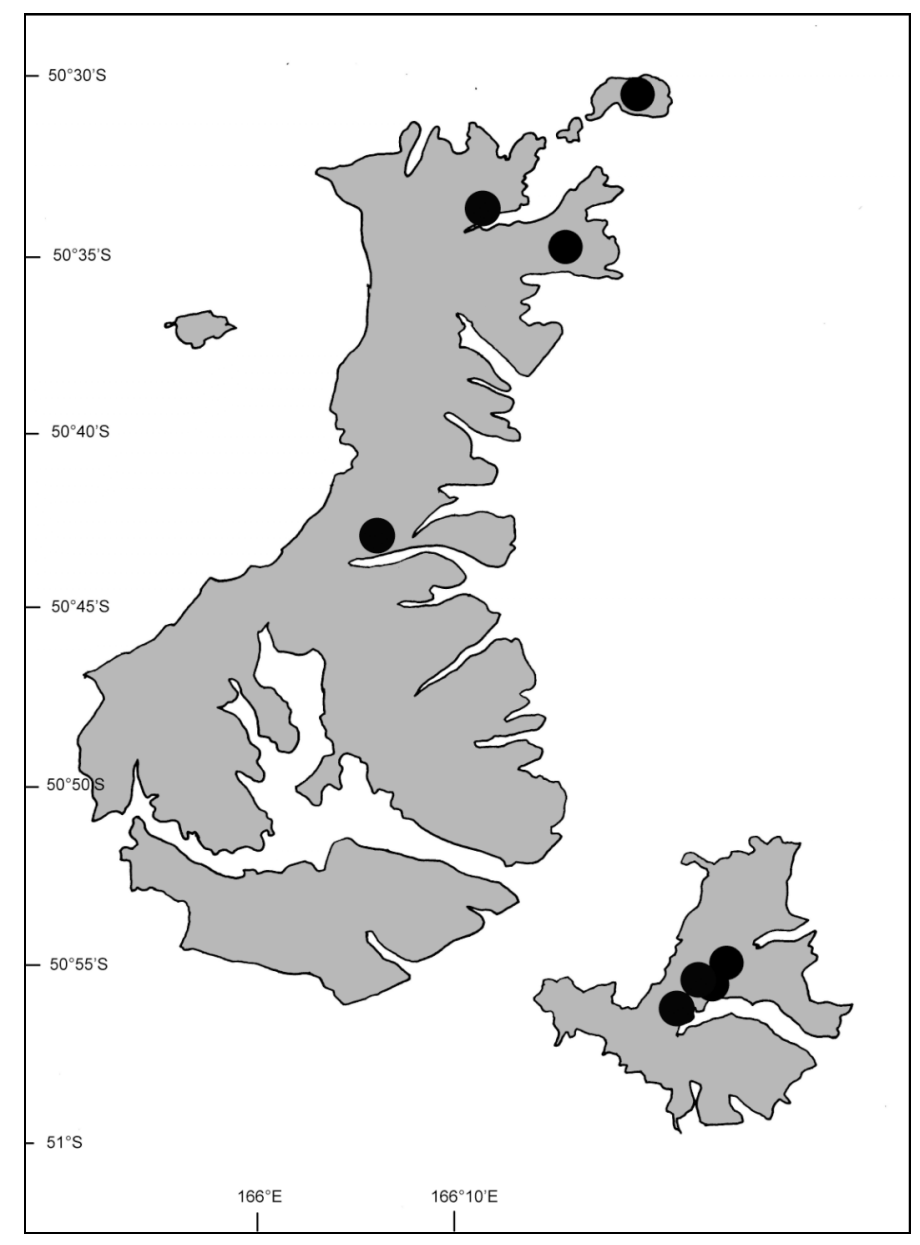

Figure 7.73. Known distribution of Oreothamnus cockayneanus. The larger island is Auckland Island and the small island to the south-east, Campbell Island.

\section{Distribution}

Endemic to the subantarctic Campbell-, Auckland and Enderby Islands of New Zealand (Fig. 7.73). Widespread, from the coast to the main summit ridges.

\section{Habitat}

Oreothamnus cockayneanus grows from sea level to $450 \mathrm{~m}$ altitude on ridge crests, in gullies and to a lesser degree in open flat areas. The vegetation consists of low forest, open shrubland and to a lesser degree grassland also in permanently moist peaty soils (Table 7.29). 
Table 7.29. Plant associations commonly associated with Oreothamnus cockayneanus.

\begin{tabular}{|c|}
\hline FOREST \\
\hline Low closed evergreen Metrosideros umbellata forest \\
\hline SHRUBLAND \\
\hline Low closed evergreen Metrosideros umbellata - Myrsine divaricata - Raukaua simplex var. simplex shrubland \\
\hline GRASSLAND \\
\hline Closed tall Chionochloa antarctica tussock shrub grassland \\
\hline
\end{tabular}

\section{Variation}

There is some variation in size of the adult lamina sheath $(13.0-18.3 \times 10-13 \mathrm{~mm})$, adult lamina $(70-120 \times 1.5-2.5 \mathrm{~mm})$ and the ovary (1.5-2.0 $\mathrm{mm}$ long and wide).

\section{Hybrids}

On Campbell Island O. cockayneanus hybridises freely with O. scoparius to form abundant fertile hybrids. These are polymorphic, connecting the parent species by a wide spectrum of transitional forms. These hybrids are discussed in detail by Cockayne (1904), Du Rietz (1930) and Wardle (1987).

\section{Material studied}

NEW ZEALAND. 50-166: Enderby Island (-AD), vii. 1903. Cockayne 3370 (AK, WELT); Moorland near centre of island. 3.xii.1972. Cambell s.n. (WELTU); Auckland Island, Erebus Cove (-CA), 6.xii.1972. Burke s.n. (WELTU); Port Ross.8.xi.1954. Moar 730 (CHR). 52-169: Campbell Island, Beeman Hill (-DB), 23.xi.1966. Roberts s.n. (WELTU); Tucker Cove. 13.xi.1944. Oliver s.n. (WELT). 
4. Oreothamnus densus (W.R.B. Oliv.) S. Venter

Oreothamnus densus (W.R.B. Oliv.) S. Venter, comb. nov. Allan, Fl. N.Z. 1: 525 (1961);

Poole \& Adams, Trees \& Shrubs of N.Z.: 156 (1994). Type: New Zealand, Westport, Mt. Rochfort, 2,000', 2.iii.1949. W.R.B. Oliver s.n. (WELT 314, holo.!).

三Dracophyllum densum W.R.B. Oliv., Trans. Roy. Soc. N.Z. 80 (1): 3 (1952).

Icon: Oliver, Trans. Roy. Soc. N.Z. 80 (1): t. 1 (1952).

\section{Description}

Scrambling sub-shrub or low shrub, 3-50 cm tall. Branches spreading, decumbent or prostrate. Bark on old branches dark grey to brown, deeply fissured, young stems grey to reddish brown. Leaves spirally along branches, imbricate, erect and appressed to stem, old leaves present; lamina sheath olive green, $2-5 \times 2-4 \mathrm{~mm}$, membranous, tapering and margin ciliate; lamina olive green, linear, $6-22 \times 0.7-1.0 \mathrm{~mm}$, adaxial surface flat, abaxial surface rounded with a keeled apex, surfaces glabrous with a tuft of scabrid hairs at the base on adaxial surface, slightly striated; margins serrulate with $25-30$ teeth per $10 \mathrm{~mm}$; apex obtuse to acute. Inflorescence a solitary terminal flower on lateral branchlets, sessile, shorter than leaves, erect, mostly hidden by leaves; flower bract shorter than to equaling flower, leaf-like, coriaceous to rigid and hard, broadly ovate at base, 3.5-7.0 $\times 2-3 \mathrm{~mm}$, surfaces glabrous with a tuft of scabrid hairs at base of adaxial surface, margins serrulate, apex obtuse to acute. Sepals lanceolate, 3.5-5.7 $\times 1.5-2.0 \mathrm{~mm}$, equaling corolla tube, top half pubescent on adaxial surface; margins toothed; apex subacute to obtuse. Corolla white; corolla tube cylindrical, $3.5-5.0 \times 1.0-1.5 \mathrm{~mm}$; corolla lobes spreading horizontally to reflexed, ovate-triangular to triangular, shorter than corolla tube, 1.5-2.0 × 1.0-1.3 mm; 
apical ridge present, apices acute; adaxial surface papillate. Stamens inserted on corolla tube in upper third, filaments $0.5-0.55 \mathrm{~mm}$ long; anthers included, rectangular, light yellow, $1 \mathrm{~mm}$ long. Ovary obovate, $1-2 \times 1.0-1.4 \mathrm{~mm}$; apex truncate; nectary scales rectangular, $0.9-1.0 \times 0.6-0.8 \mathrm{~mm}$, apices retuse to irregularly toothed; style included, $1.5-1.55 \mathrm{~mm}$ long, glabrous, lengthening in fruit; stigma five-lobed. Fruit sessile, light brown, 1.3-2.0 $\times$ 1-2 mm, depressed-obovoid to obovoid, apex truncate, glabrous. Seeds light brown, ovoid, $0.45-0.5 \mathrm{~mm}$ long, testa slightly reticulate. Flowering January-April. (Figure 7.74).

\section{Diagnostic features and notes}

Oreothamnus densus is characterized by the prostrate habit, dark grey deeply fissured bark, old leaves being persistent for a very long time, erect leaves clasping the stem and with obtusely acute apices, solitary flowers, sepals with subacute to obtuse apices and equalling the corolla tube and the short capsule that is widest at the top.

Oliver (1952) placed O. densus nearest to O. pronus but it differs in being a shrublet, is more compact with denser foliage and having larger leaves with more acute apices. The branches are clothed with dead leaves (or their bases), a character shared with O. politus, O. muscoides and O. prostratus. Oreothamnus densus is similar to O. politus but differs in leaf and flower characters (Table 7.30). 


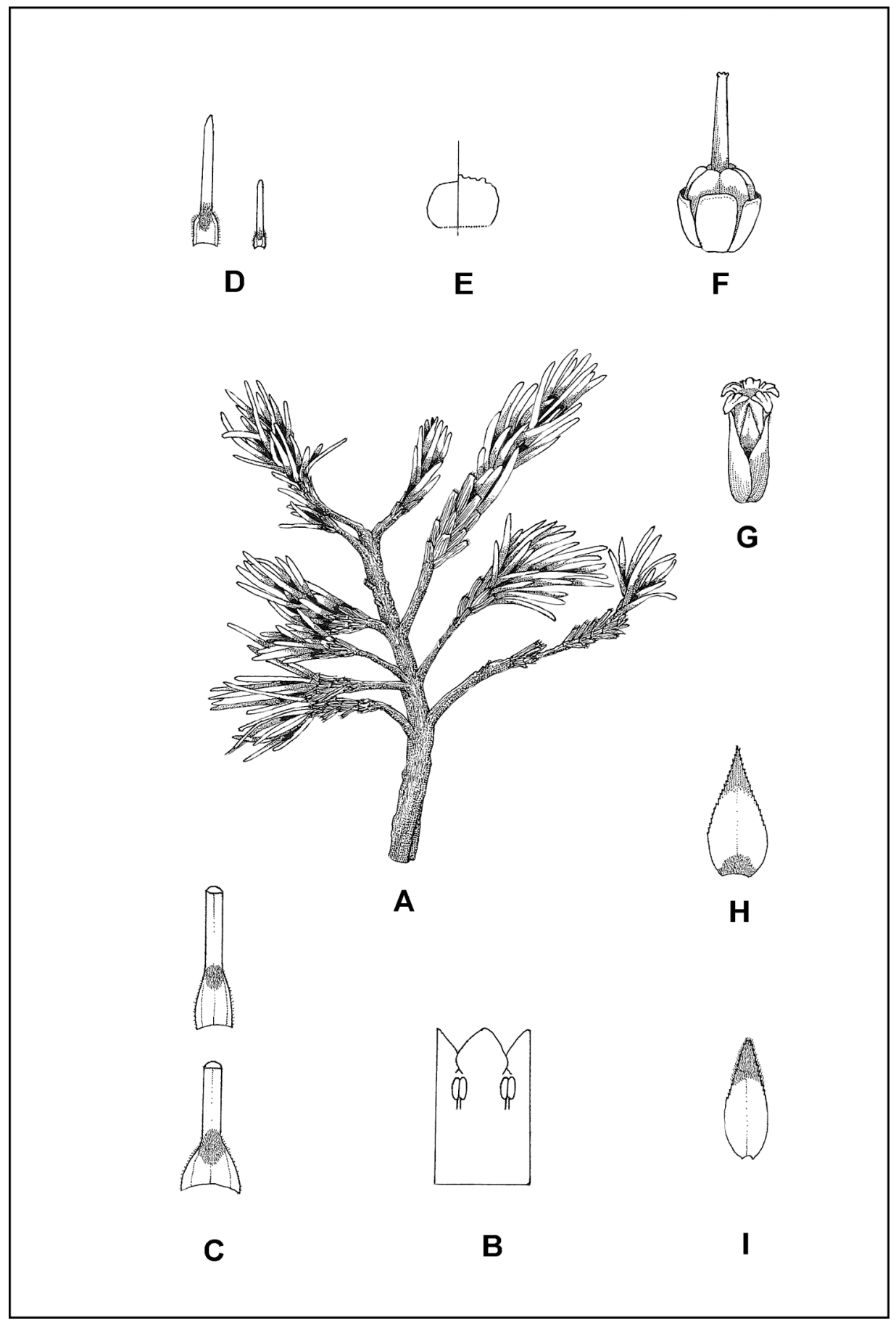

Figure 7.74. Oreothamnus densus. A, habit $(\times 1)$; B, laid out corolla $(\times 1)$; C, lamina sheath $(\times 5)$; $\mathbf{D}$, leaves $(\times 1)$; $\mathbf{E}$, nectary scale $(\times 10) ; \mathbf{F}$, ovary $(\times 10)$; $\mathbf{G}$, flower $(\times 5) ; \mathbf{H}$, inflorescence bract adaxial surface $(\times 5)$ and $\mathbf{I}$, sepal adaxial surface $(\times 5)$. Drawn from Venter 13746 . 


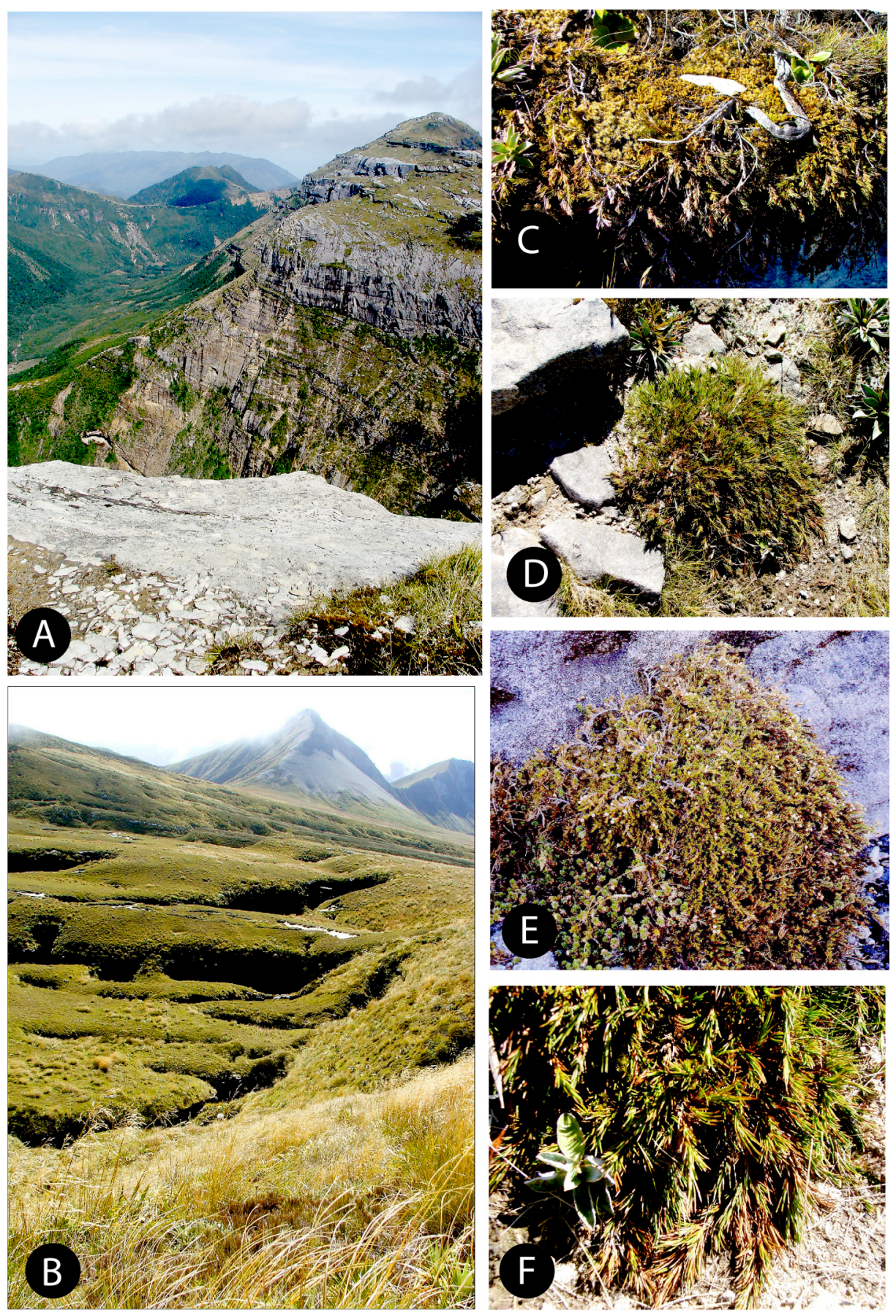

Figure 7.75. Oreothamnus densus. A, habitat on Mt. Garibaldi; B, grass-covered karst topography on the Garibaldi Range.C; mature plant showing the typical gnarled main stem; D, mature plant, Denniston Plateau; E, flowering plant Mt. Garibaldi; F, stems showing the dense foliage (=densum);C and $\mathbf{E}$, Venter 13859, $\mathbf{D}$ and $\mathbf{F}$, Venter 14730. 
Table 7.30. Morphological differences between Oreothamnus densus and O. politus.

\begin{tabular}{|l|l|l|}
\hline \multicolumn{1}{|c|}{ Character } & \multicolumn{1}{|c|}{ O. densus } & \multicolumn{1}{|c|}{ O. politus } \\
\hline Tuft of scabrid hairs on lamina & present & absent \\
Number of teeth on lamina margin $($ per $10 \mathrm{~mm})$ & $25-30$ & $90-100$ \\
Flower bract size $(\mathrm{mm})$ & $3.5-7.0 \times 2-3$ & $2-3 \times 0.7-0.8$ \\
Flower bract margin & ciliate & serrulate \\
Sepal length & equals corolla tube & Longer than \\
Apex of corolla lobe & acute & obtuse \\
Ovary apex shape & truncate & round \\
Seed surface of testa & rlightly reticulated & \\
& & \\
\hline
\end{tabular}

In $O$. densus and $O$. politus, two similar species, epicuticular wax platelets are absent in $O$. politus but prominent in $O$. densus. I have found that the presence of platelets is a valuable tool to distinguish between two or more similar species.

\section{Distribution}

New Zealand endemic restricted to the northwest Nelson area on the South Island. Most localities are in the Westport-Karamea areas and not further than $20 \mathrm{~km}$ from the sea (Fig. 7.76).

\section{Habitat}

Oreothamnus densus occurs on gentle to moderate $\left(3^{\circ}-10^{\circ}\right)$ slopes on mountain summits, terraces and plateaus at altitudes ranging from $610-1218 \mathrm{~m}$. The vegetation consists of montane shrubland, subalpine shrubland, herbland, tussockland and grassland (Table 7.31). The soil is a greybrown sandy lithosol derived from sandstone, conglomerate or a gritty sandy loam derived from granite. 


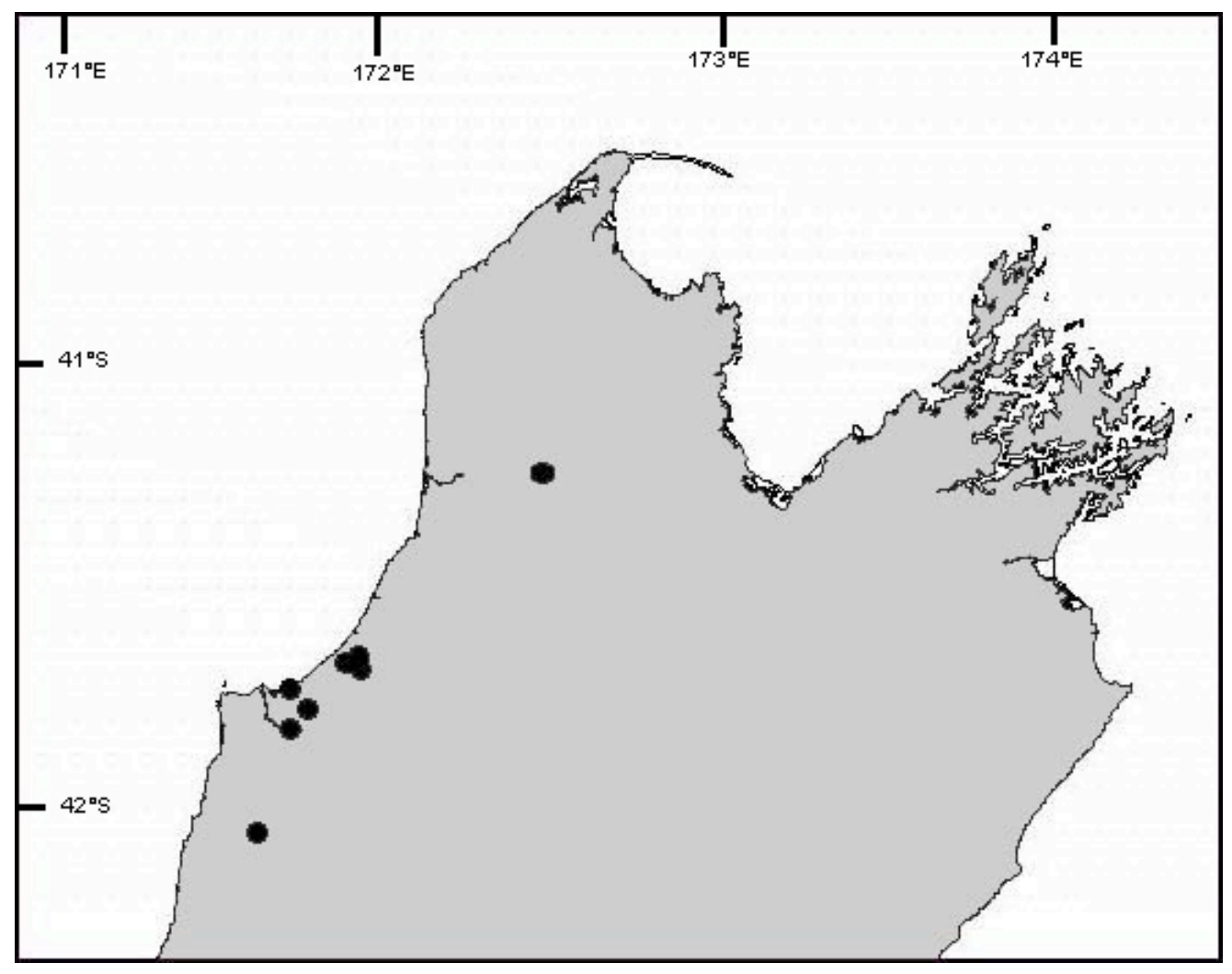

Figure 7.76. Known distribution of Oreothamnus densus. South Island, New Zealand.

Table 7.31. Plant associations commonly associated with Oreothamnus densus.

\begin{tabular}{|c|}
\hline SHRUBLAND \\
\hline Low open evergreen Brachyglottis rotundifolia - Phormium cookianum - Chionochloa australis shrubland \\
\hline GRASSLAND \\
\hline Low open Chionochloa australis - Phormium cookianum - Drosera grassland \\
Low open Chionochloa australis - Leptospermum scoparium grassland \\
\hline
\end{tabular}

\section{Variation}

Growth habit varies from a flat compact shrublet to small shrubs up to $50 \mathrm{~cm}$ tall with trailing branches. The leaf sheath varies mostly in length $(2.5-5.2 \mathrm{~mm})$ and so to the sepals (4.5-9.0 mm long). Lamina apices are either obtuse or acute on the same plant. In spite of Oliver (1952) describing the lamina apex as obtuse I found that most plants have acute apices. The flower bracts vary in size $(3.5-7.0 \times 2-3 \mathrm{~mm})$ and the corolla lobes in shape from ovate-triangular to triangular. 


\section{Material studied}

NEW ZEALAND. South Island. 41-171: Near Denniston (-DA), 6.i.1968. Brownlie 664 (CHR); Denniston (-DB), 14.xi.1966. Davidson s.n. (CHR); Burma Road, 28.i.1953. Mason \& Moar 1962 (CHR); Westport, Mt. Rochfort, Denniston Plateau (-DC), 07.i.1999. S. Venter 3746 (CHR). 41-172: Below Garibaldi Ridge (-AB), iii.1980. Druce s.n. (CHR). 42-

171: Greymouth, Paparoa Range, Mt. Davy (-AD), 26.ii.1949. Oliver s.n. (WELT); E of Mt. Priestly (-BA), 12.iv.1983. Wardle s.n. (CHR).

5. Oreothamnus filifolius (Hook. f.) S. Venter

Oreothamnus filifolius (Hook. f.) S. Venter, comb. nov. Richard, Voy. Astrol. Bot.: 221 (1832); Hooker, Fl. Nov. Zel. 2 (1): 170 (1853); Hooker, Handb. N.Z. Fl.: 182 (1864); Cheeseman, Man. N.Z. Fl: 424 (1906); Oliver, Trans. Proc. N.Z. Inst. 59 : 695 (1928); Oliver, Trans. Roy. Soc. N.Z. 80 (1): 10 (1952); Allan, Fl. N.Z. 1: 530 (1961); Eagle, Trees \& Shrubs of N.Z. $2^{\text {nd }}$ series.: 294 (1982); Mark \& Adams, N.Z. Alpine Plants.: 116 (1986); Salmon, Native Trees of N.Z.: 276 (1989); Poole \& Adams, Trees \& Shrubs of N.Z.: 158 (1994). Type: New Zealand, Ruahine Range. 1849. W. Colenso s.n. (K, lecto.!; K!), designated by Oliver (1952).

三 Dracophyllum filifolium Hook. f., Fl. Nov. Zel. 2 (1): 169 (1853).

= Dracophyllum setifolium Stchegl., Bull. Soc. Nat. Mosc. 32 (1): 23 (1859). Type: New Zealand, Auckland, 1843. W. Stephenson 77 (K, holo.!). 
= Dracophyllum pungens Colenso, Trans. Proc. N.Z. Inst. 28: 602 (1896). Type: New Zealand, east side of Ruahine Mountain range, 1895. H. Hill s.n. (K, holo.!; WELT 42851!).

= Dracophyllum virgatum Colenso, Trans. Proc. N.Z. Inst. 28: 605 (1896). Type: New Zealand, east side of Ruahine Mountain Range, 1895. A. Olsen s.n. (WELT 23628, holo.!; K!).

= Dracophyllum heterophyllum Colenso, Trans. Proc. N.Z. Inst. 28: 605 (1896). Type: New Zealand, east side of Ruahine Mountain range, 1895. E.W.Andrews s.n. (K, holo.!; WELT 42835!).

= Dracophyllum $\times$ vulcanicum W.R.B. Oliv., Trans. Proc. N.Z. Inst. 59: 697 (1928). Type: New Zealand, Waimarino Plains, 2,600 feet, 22.xii.1923. H. Carse s.n. (CHR 332586, holo.!; K!).

= Dracophyllum urvillianum A. Rich. var. filifolium Cheeseman, Man. N.Z. Fl.: 424 (1906).

= Dracophyllum collinum W.R.B. Oliv., Trans. Proc. N.Z. Inst. 59: 696 (1928). Type: New Zealand, mountains of the Tinline Valley, xi.1924. J.H.MacMahon s.n. (WELT 55185, holo.!).

= Dracophyllum filifolium var. centrale W.R.B. Oliv., Trans. Roy. Soc. N.Z. 80 (1): 10 (1952). Type: New Zealand, Mt. Ruapehu, 3,800 feet, 7.ii.1949. W.R.B. Oliver s.n. (WELT 318, holo.!).

= Dracophyllum filifolium var. collinum W.R.B. Oliv., Trans. Roy. Soc. N.Z. 80 (1): 10 (1952). 
Icones: Oliver, Trans. Proc. N.Z. Inst. 59: 696, t. 7a (1928); Eagle, Trees \& Shrubs of N.Z. $2^{\text {nd }}$ series.: t.138 (1982); Mark \& Adams, N.Z. Alpine Plants.: t. 45 (1986).

\section{Description}

Erect multi-stemmed shrub or tree, 1-4 m tall. Branches: bark on old branches grey to brown, finely fissured, young stems reddish brown. Leaves erect to spreading; lamina sheath 6-16 $\times 3.0-5.5 \mathrm{~mm}$, membranous, shoulders tapering to auricled and the margin ciliate in the upper half; lamina linear to linear-triangular, $(40-) 60-130(-200) \times 0.7-1.5$ $\mathrm{mm}$, surfaces glabrous with a tuft of scabrid hairs at base of adaxial surface, slightly striated; margins serrulate with 18-25 teeth per $10 \mathrm{~mm}$; apex acute to weakly triquetrous. Inflorescence a terminal spike on lateral branchlets, shorter than leaves, erect to drooping, dense, 20-30 mm long, linear-oblong; inflorescence bract overtopping flowers, ovate-lanceolate, 8.5-17 × 2-4 mm, surfaces glabrous; margins ciliate. Flowers 5-9(-10), sessile; flower bracts overtopping flowers, broadly-ovate; 5.6-9.3(-13.0) $\times 3-4 \mathrm{~mm}$, surfaces glabrous with a tuft of scabrid hair at base of adaxial surface, margins ciliate. Sepals ovate-lanceolate, occasionally ovate, 4-6 $\times 1.5-1.7 \mathrm{~mm}$, equaling corolla tube, surfaces glabrous; margins ciliate. Corolla white; corolla tube cylindrical, 3.5-5.5(-6.0) $\times$ 1.8-2.5 mm; corolla lobes reflexed, ovate, shorter than corolla tube, 1.5-2.0 × 1.5-1.6 mm; apices subacute to acute; surfaces glabrous. Stamens inserted on corolla tube in upper third, filaments $0.2-0.3 \mathrm{~mm}$ long; anthers included, oblong, light yellow and $1 \mathrm{~mm}$ long. Ovary subglobose, $1.5-2.0 \times 1.0-1.5 \mathrm{~mm}$, glabrous, apex round; nectary scales oblong, 0.7-1.0 × 0.5-0.7; apices obtuse to retuse; style included, 1-2 mm long, glabrous; stigma five-lobed. Fruit sessile, light brown, 2.0-2.5 $\times 2.0-2.2 \mathrm{~mm}$, obovoid, apex round, glabrous. Seeds yellowish brown, filiform, (0.8-)1.0-1.1(-1.2) $\mathrm{mm}$ long, testa slightly reticulate. Flowering November-April (-June). (Figure 7.77). 


\section{Diagnostic features and notes}

Oreothamnus filifolius is characterized by the inflorescence being a spike $17-24 \mathrm{~mm}$ long with the inflorescence bracts and flower bracts longer than the flower, sepals equal the corolla tube which is $3.0-4.5 \mathrm{~mm}$ long with the corolla lobes $1.5-2.0 \mathrm{~mm}$ wide, nectary scales 1.0-1.3 mm long with obtuse apices.

Hooker (1853) mentioned two syntypes in the protologue and said that there are more known localities. However, Oliver (1952) selected a specimen at Kew, collected by William Colenso in 1849, as type. Allan (1961) stated that he did not find the Colenso specimen mentioned by Oliver and therefore did not cite any material. The Colenso specimen mentioned by Oliver (1952) was nevertheless found by me under the Kew material. Oreothamnus filifolius is a much-misunderstood taxon with earlier authors placing O. lessonianus and O. urvilleanus into it, resulting in a rather confused nomenclature and literature. Oliver (1928) wrote that Cheeseman (1906) misunderstood the species, giving the distribution from Bay of Islands to Stewart Island and he placed O. lessonianus within O. filifolius. Oliver (1952) also did not understand the species and described three varieties, Dracophyllum filifolium var. filifolium, D. filifolium var. centrale and D. filifolium var. collinum. Oreothamnus filifolius is similar to O. urvilleanus and O. lessonianus but differs in leaf, inflorescence and flower characters (Table 4.1). 


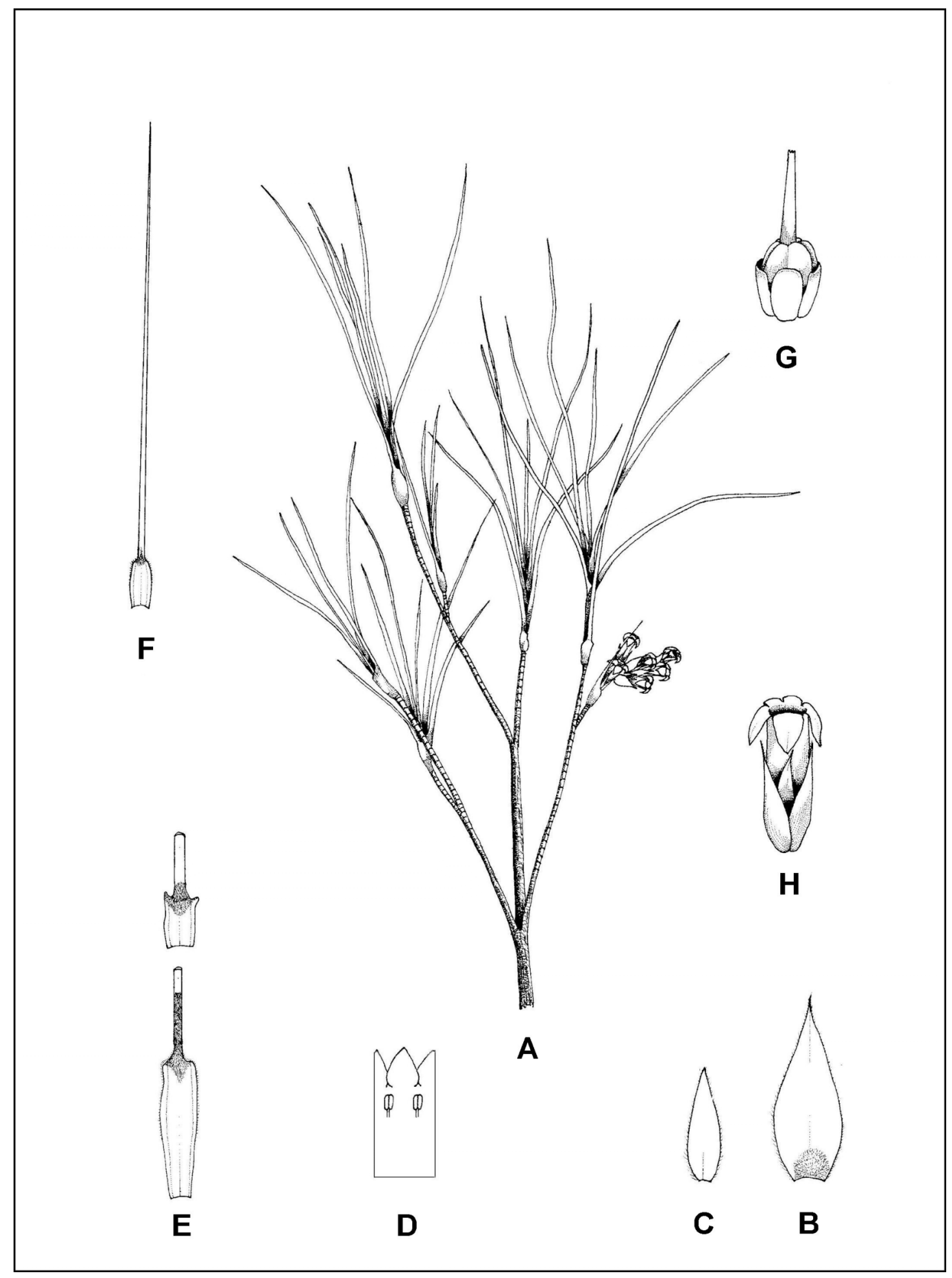

Figure 7.77. Oreothamnus filifolius. A, flowering branch $(\times 1) ; \mathbf{B}$, inflorescence bract adaxial surface $(\times 5)$; $\mathbf{C}$, sepal adaxial surface $(\times 5)$; $\mathbf{D}$, laid out corolla $(\times 5)$; $\mathbf{E}$, lamina sheaths to show variation $(\times 5)$; $\mathbf{F}$, leaf $(\times 1)$; $\mathbf{G}$, ovary $(\times 10)$; $\mathbf{H}$, flower $(\times 5)$. Drawn from Venter 13762. 

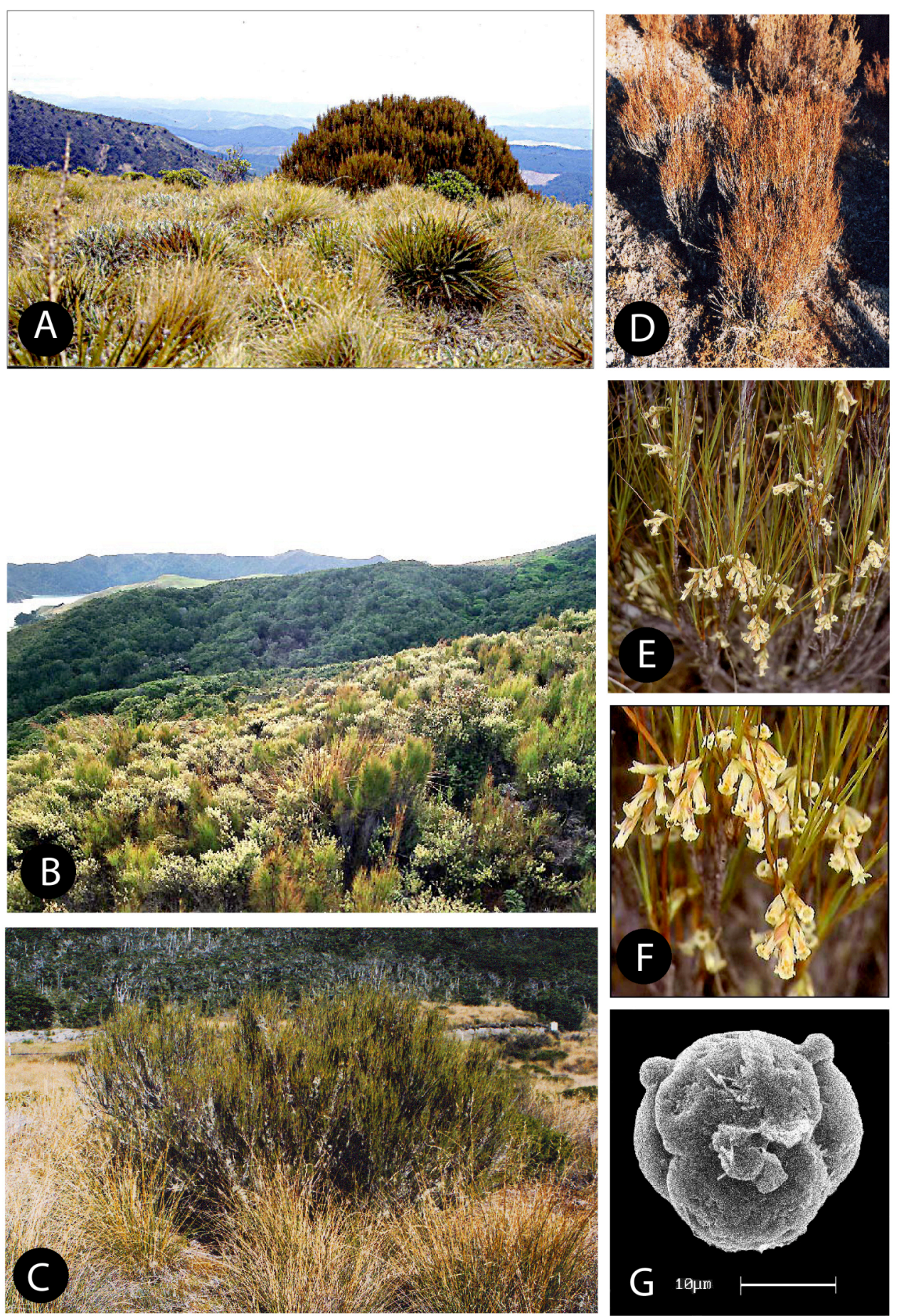

Figure 7.78. Oreothamnus filifolius. A, mature plant from a subalpine habitat on Gordons Knob; B, O. filifolius plants growing on serpentinite, D' Urville Island; C, mature plant at Maruia Springs; D, mature plant on serpentinite, Cobb Reservoir; E, flowering plant from the Dun Mountain, Nelson; F, close-up of inflorescences; G, SEM micrograph of a pollen tetrad (Scale Bar $=10 \mu)$. C, Venter 13762; D, Venter 13737 and F, Venter 13785 . 
I have found that in Oreothamnus filifolius nectar is secreted during the afternoon and early evening reaching maximum volume available to pollinators (moths) around 20:00 $\mathrm{h}$ with a second period of nectar secretion commencing from 10:00 h on a sunny day and ceasing at about 15:00 $\mathrm{h}$ (Figure 7.79). It is this second secretion period that is utilized by butterflies of the genera Argyrophenga and Lycaena (pers. obs.).

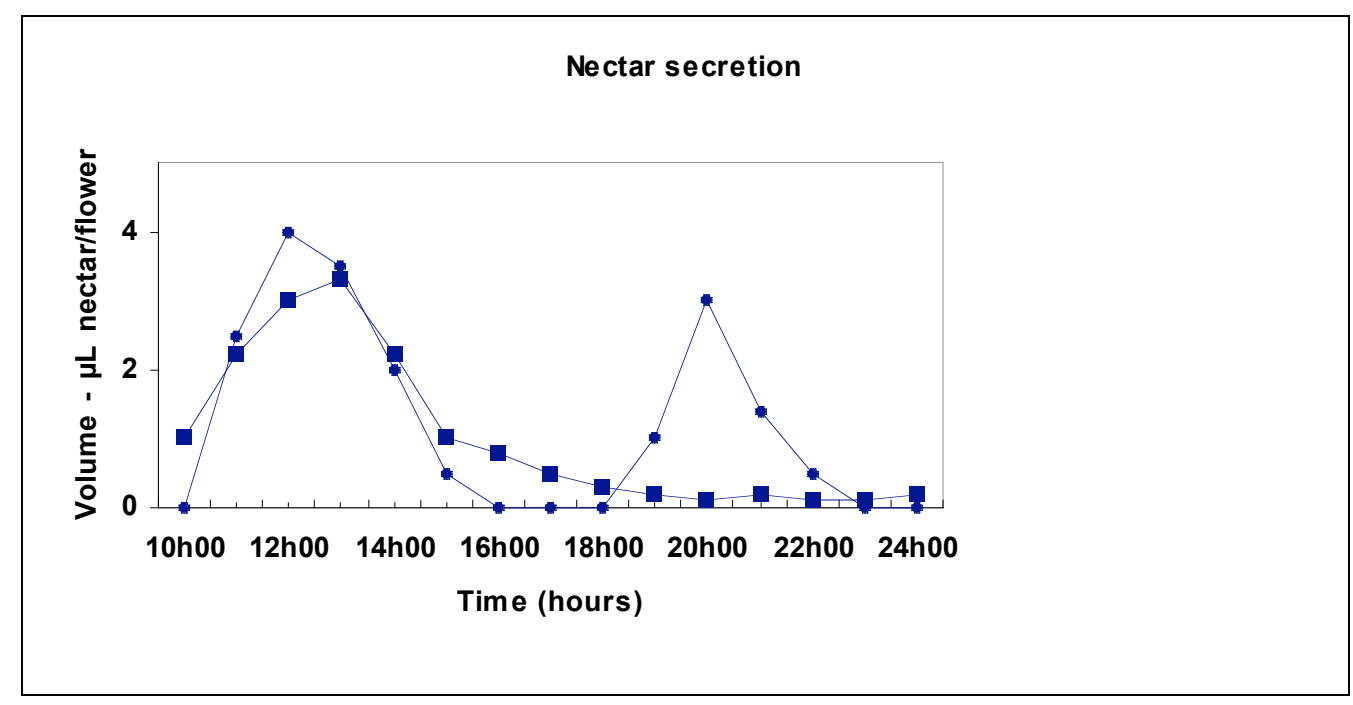

Figure 7.79. Peak nectar flow periods in Dracophyllum traversii ( ) and Oreothamnus filifolius ( ).

\section{Distribution}

New Zealand endemic, restricted to the North Island, South Island and Stewart Island (Fig. 7.80).

\section{Habitat}

Oreothamnus filifolius occurs on gentle $\left(0^{\circ}-30^{\circ}\right)$ mountain slopes on saddles and mountain ridges from near sea level up to $1500 \mathrm{~m}$ altitude. The vegetation consists of lowland to 


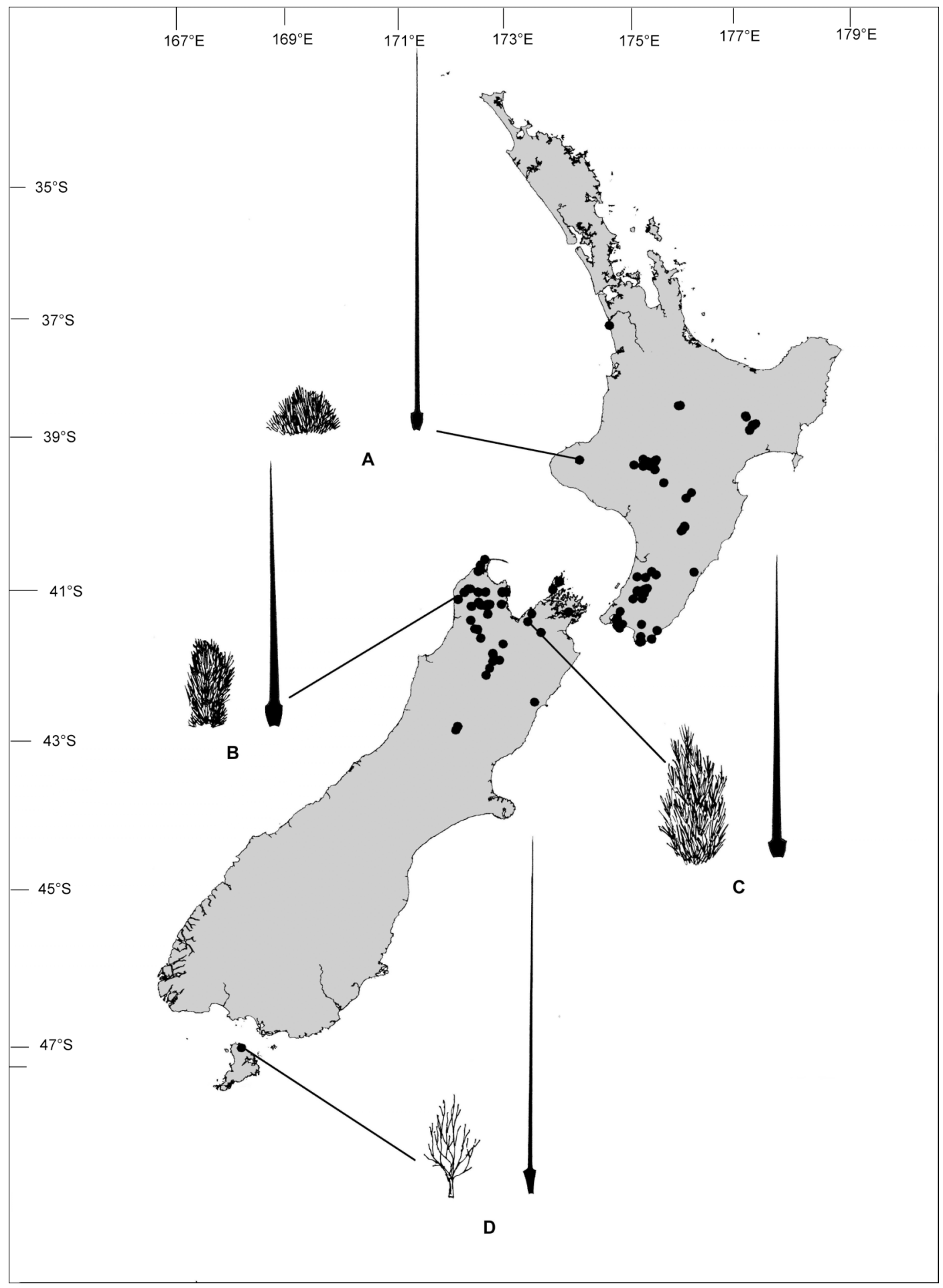

Figure 7.80. Known distribution, growth habit and leaf variation in Oreothamnus filifolius. A, Egmont National Park (Venter 13762); Mt. Perry (Druce s.n.); C, Dun Mountain, Nelson (Venter 13785); D, Mt. Anglem, Stewart Island (Venter 13792). All leaves drawn $\times$ 0.5 . 
montane forest, shrubland and grassland (Table 7.32). In montane areas O. filifolius forms extensive populations within Leptospermum scoparium shrubland and very much occupies the same ecological niche. Soils are gritty dark brown sandy loam or brown clay loam derived from greywacke and roll stone conglomerate, or on grey clay loam lithosol or grey clay loam derived from basalt, shale, serpentinite and granidiorite.

Table 7.32. Plant communities commonly associated with Oreothamnus filifolius

\begin{tabular}{|l|}
\hline \multicolumn{1}{|c|}{ FOREST } \\
\hline $\begin{array}{c}\text { Low closed evergreen Dracophyllum traversii - Nothofagus solandri-Gahnia procera forest } \\
\text { Low closed evergreen Nothofagus solandri - Libocedrus bidwillii - Cordyline australis forest }\end{array}$ \\
\hline \multicolumn{1}{|c|}{ SHRUBLAND } \\
\hline Tall closed evergreen Podocarpus nivalis - Halocarpus bidwillii - Ozothamnus leptophyllus shrubland \\
Tall closed evergreen Olearia colensoi shrubland \\
Tall closed semi-deciduous Oreothamnus filifolius - Leptospermum scoparium shrubland \\
Low closed semi-deciduous Olearia colensoi - Chionochloa rubra - Oreothamnus filifolius shrubland \\
Low closed semi-deciduous Leptospermum scoparium - Phormium tenax - Oreothamnus filifolius shrubland \\
Low closed evergreen Olearia colensoi - Chionochloa shrubland \\
Low open semi-deciduous Leptospermum scoparium - Juncus sp. - Pimelea longifolia shrubland \\
\hline \multicolumn{1}{c|}{ GRASSLAND } \\
\hline Tall open Chionochloa flavescens - Celmisia spectabilis - Aciphylla aurea grassland \\
Tall open Chionochloa flavescens grassland \\
\hline
\end{tabular}

\section{Variation}

Oreothamnus filifolius is a polymorphic species (Figure 7.80). Populations at the Cobb Reservoir near Takaka, on the Dun Mountain near Nelson and on D'Urville Island in the Marlborough Sounds grow as a low roundish shrub with erect branches and thickly textured, stiff and short leaves. This is the typical growth habit on serpentinite (Fig. 7.78E). Populations at West Whanganui Inlet at the northern tip of the South Island, grow as a columnar small tree with erect spreading branches and thinly textured, erect, long leaves. In some populations on Stewart Island (Venter 13791) the flower bract is lightly attached and sometimes drops whilst the plant is still in full flower. 


\section{Hybrids}

Dracophyllum filifolium hybridises with D. recurvum and described by Oliver (1928) as Dracophyllum $\times$ arcuatum. D. filifolium also hybridises with O. rosmarinifolius on Mt. Arthur and with O. subulatus named Dracophyllum ×vulcanicum by Oliver (1928).

\section{Material studied}

NEW ZEALAND. 38-175: Mt. Kakaramea (-DC), i.1905. Cheeseman s.n. (AK). 38-176: Rainbow Mountain (-AD), v.1947. Sibson s.n. (AK). 38-177: Urewera Nat. Park, W of Waikareiti, Puna Hokoi Clearing (-CA), ii.1968. Druce s.n. (CHR); Urewera, Maungapohatu. 19.iii.1930. Moore s.n. (CHR); Waikaremoana, Panekiri Bluff (-CC), i.1954. Druce s.n. (CHR); Panekirikiri Bluff [Panekiri Bluff], 20.i.1953. Druce s.n. (CHR). 39-174: Egmont National Park, Pouakai Range, near tarns on Kaiauai Track (-AA), 7.ii.1999. Venter 13762 (CHR); Mt. Egmont, near Wilkie's Pools. 19.i.1934. Cranwell s.n. (AK). 39-175: Taumaranui, E of National Park Township (-AB), 2.i.1970. Donovan s.n. (CHR); Tongariro Nat. Park, Mt. Hauhungatahi (-AD), 14.ix.1924. Oliver s.n. (CHR); Waimarino Stream, i.1965. Druce s.n. (CHR); Chateau Tongariro (-BA), i.1960. Puffy s.n. (CHR); Kaimanawa Mountains, E foot of Stowman Range (-BD), i.1973. Druce s.n. (CHR). 39-176: NW Ruahine Range, Waiokotore Stream (-CA), xii.1973. Druce s.n. (CHR); Rangiwahia (-CC), Esler s.n. (AK). 40-172: Mouth of Green Hills Stream (-BC), vii.1979. Druce s.n. (CHR); Cape Farewell, Ngurua Bay Road (-DA), 30.x.1998. Venter 13725 (CHR); Collingwood, Knuckle Hill, 15.i.1999. Venter 13,753 (CHR); Northern end of Whanganui Inlet, 20.ii.1957. Mason \& Moar 4865 (O); Mt. Perry (-CD), i.1973. Druce s.n. (CHR); Takaka, Haupiri Range, Walker Ridge, 26.xii.1951. Hay s.n. (CHR); Abel Tasman Nat. Park, Moa Park (-DD), i.1969. Druce s.n. (CHR). 40-173: Takaka, Awaroa (-CC), 23.x.1961. Scott s.n. (CHR); Gouland Downs (-CD), xii.1951. Talbot s.n. (CHR); Near head of Whanganui Inlet (-DA), 13.ii.1969. Sykes 44/69 (CHR); Lead Hills (-DC), 
Gibbs s.n. (CHR). 40-175: South Ruahine Range (-BB), ii.1971. Druce s.n. (CHR); Tiritea Catchment (-BC), 4.x.1958. Esler s.n. (AK); Waiopehu Track (-CA), 18.ii.1934. Zotov s.n. (CHR); Tararua Ranges, Ngapuketurua (-CB), 1.iii.1931. Zotov s.n. (CHR); Mt. Holdsworth (-CD), 28.i.1906. Cockayne s.n. (CHR). 40-176: Southern Ruahine Range, Takapari (-AA), i.1966. Druce s.n. (CHR); SW of Akitio, $\mathrm{N}$ of Mt. Kupukore (-CA), xii.1973. Druce s.n. (CHR). 41-172: Gunner Downs (-AA), xi.1979. Druce s.n. (CHR); Peak at head of Cobb River (-AB), 1.i.1943. Mason s.n. (CHR); Mt. Luna (-AD), i.1971. Druce s.n. (CHR); Motueka, Cobb Valley, ridge above Cobb Information building (-BA), 11.xii.1998. Venter 13737 (CHR); Motueka, Mt. Arthur, Flora Saddle, 02.i.1999. Venter13740 (CHR); Mt. Patriarch (-BC), i.1974. Druce s.n. (CHR); Mt. Arthur (-CA), Gibbs s.n. (CHR); Tararua Ranges, Mt. Dennan (-CD), 5ii.1931. Zotov s.n. (CHR); Saint Arnaud, Big Bush (-DA), 27.v.1964. Fryer s.n. (CHR); Gordons Knob (-DB), 16.ii.1975. Simpson 7598 (CHR); Lake Rotoiti Peninsula (-DD), 16.ii.1961. Simpson 2809 (CHR); D’Urville Island, Mt. Ears, vi.1975. Kelly \& Kelly s.n. (CHR). 41-173: Nelson, Dun Mountain, before Dun Saddle (-AD), 28.ix.1999. Venter 13785 (CHR); Tennyson Inlet (BB), 16.ii.1969. Hynes s.n. (AK); Okaramio, Kaituna Valley (-BC), 24.xii.1935. Healy s.n. (WELTU); Wairau Valley, Red Hills (-CA), i.1898. Cheeseman s.n. (AK); Gordon's Knob (-DC), 24.i.1922. Allan s.n. (AK). 41-174: Endevour Inlet (-AA), xii.1945. Healy s.n. (CHR); Wellington, top of Days Bay Hills (-BD), 27.vii.1921. Atkinson s.n. (CHR); Wainuiomata Valley, west slopes, 26.vii.1937. Healy s.n. (CHR). 40-175: Eastern Tararuas, track to Mt. Holdsworth (-CC), 23.i.1967. Hynes s.n. (AK). 41-175: Tararua Range, Mayhorn (-AA), i.1968. Druce s.n. (CHR); Tararua Mountains, Smiths Creek (-AB), 26.xii.1932. Zotov s.n. (CHR); Mt. Matthews (-AC), iv.1931. Oliver s.n. (CHR); Aorangi Range, Mt. Whawanui (-AD), ix.1969. Druce s.n. (CHR); Wairarapa, Oterei Taipos, Heights (-BC), xii.1978. Druce s.n. (CHR); ENE of Cape Palliser (-CB), 2.xi.1966. Druce s.n. (CHR); E Wairarapa, taipos above the Oterei River (-DA), xii.1957. Druce s.n. (CHR). 
42-171: Mawheraiti (-BA), 19.iv.1948. Oliver s.n. (CHR). 42-172: Upper Hurunui River, 
1.2); adaxial surface scabrid, abaxial surface glabrous, margin serrulate. Sepals lanceolate, 4.5-9.0 $\times 1.5-2.0 \mathrm{~mm}$, equaling corolla tube, surfaces glabrous with the top half pubescent on adaxial surface; margins serrulate. Corolla white; corolla tube cylindrical, widened at mouth, (5.5-)7.0-7.0 × (1.5-)2.0-3.0(-4.0) mm, exterior glabrous; corolla lobes reflexed, ovate-triangular to triangular, shorter than corolla tube, 1.4-1.5 $\times 1.0-1.2 \mathrm{~mm}$, apices inflexed, acute; apical ridge prominent, adaxial surface papillate. Stamens inserted on corolla tube in upper third, filaments (0.3-)1.0-1.2 mm long; anthers included, oblong, light yellow, 1.0-1.2 mm long. Ovary cylindrical, $2.5-4.5 \times 1.2-2.5 \mathrm{~mm}$, apex truncate; nectary scales rectangular, $1.2-1.5 \times 0.5-0.7 \mathrm{~mm}$, apices subacute to retuse; style included, (2-)3-4 mm long, glabrous; stigma five-lobed. Fruit sessile, light brown, 4.0-4.2 × 2-3 $\mathrm{mm}$, broadly obovoid, apex truncate, glabrous. Seed brown, ovoid, 0.6-0.7 mm long, testa slightly reticulate. Flowering December-February. (Figure 7.81).

\section{Diagnostic features and notes}

Oreothamnus frondosus is characterized by the lax growth habit, erect-spreading leaves that are $25-50 \mathrm{~mm}$ long with ciliate lamina sheaths and a prominent tuft of scabrid hairs at the base on the adaxial surface of the lamina, the solitary flowers, flower bracts longer than the flowers; 7-10 mm long corolla tube that equals the sepals, densely papillate corolla lobes and the cylindrical ovary with truncate apex.

According to Simpson (1952), his var. frondosum was closely allied to Dracophyllum uniflorum (=O. rosmarinifolius). In the protologue of $O$. frondosus he states that the style is exserted for up to $3 \mathrm{~mm}$ but this could not be verified in either the type material or in plants at the localities visited in the wild. 


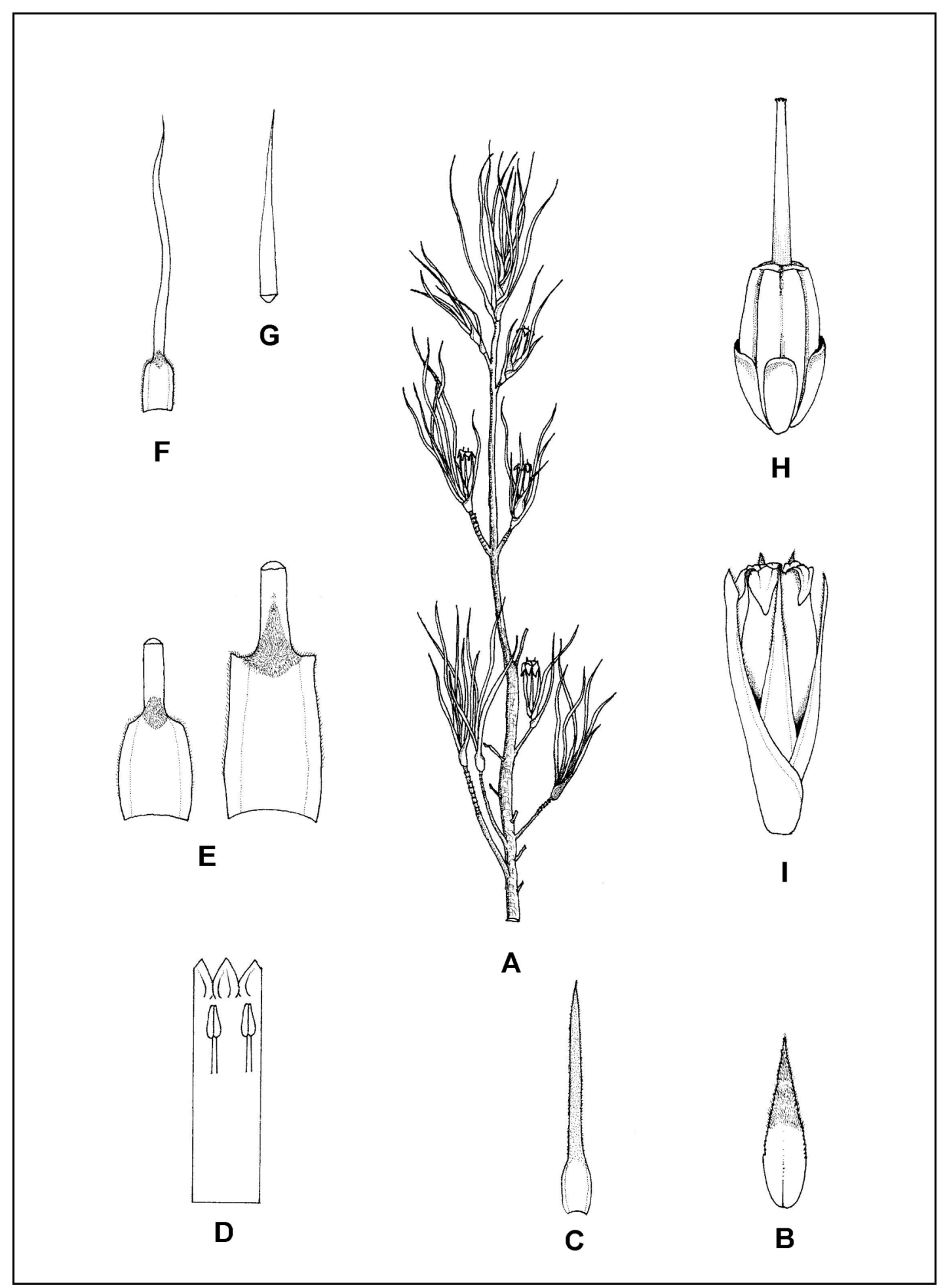

Figure 7.81. Oreothamnus frondosus. A, flowering branch $(\times 1)$; B, sepal adaxial surface $(\times 5)$; $\mathbf{C}$, inflorescence bract adaxial surface $(\times 5)$; $\mathbf{D}$, laid out corolla $(\times 5)$; $\mathbf{E}$, leaf sheaths adaxial surface to show variation $(\times 5) ; \mathbf{F}$, leaf $(\times 2)$; $\mathbf{G}$, lamina apex $(\times 5) ; \mathbf{H}$, ovary (× 10); I, flower (× 1). Drawn from Venter 13817 . 

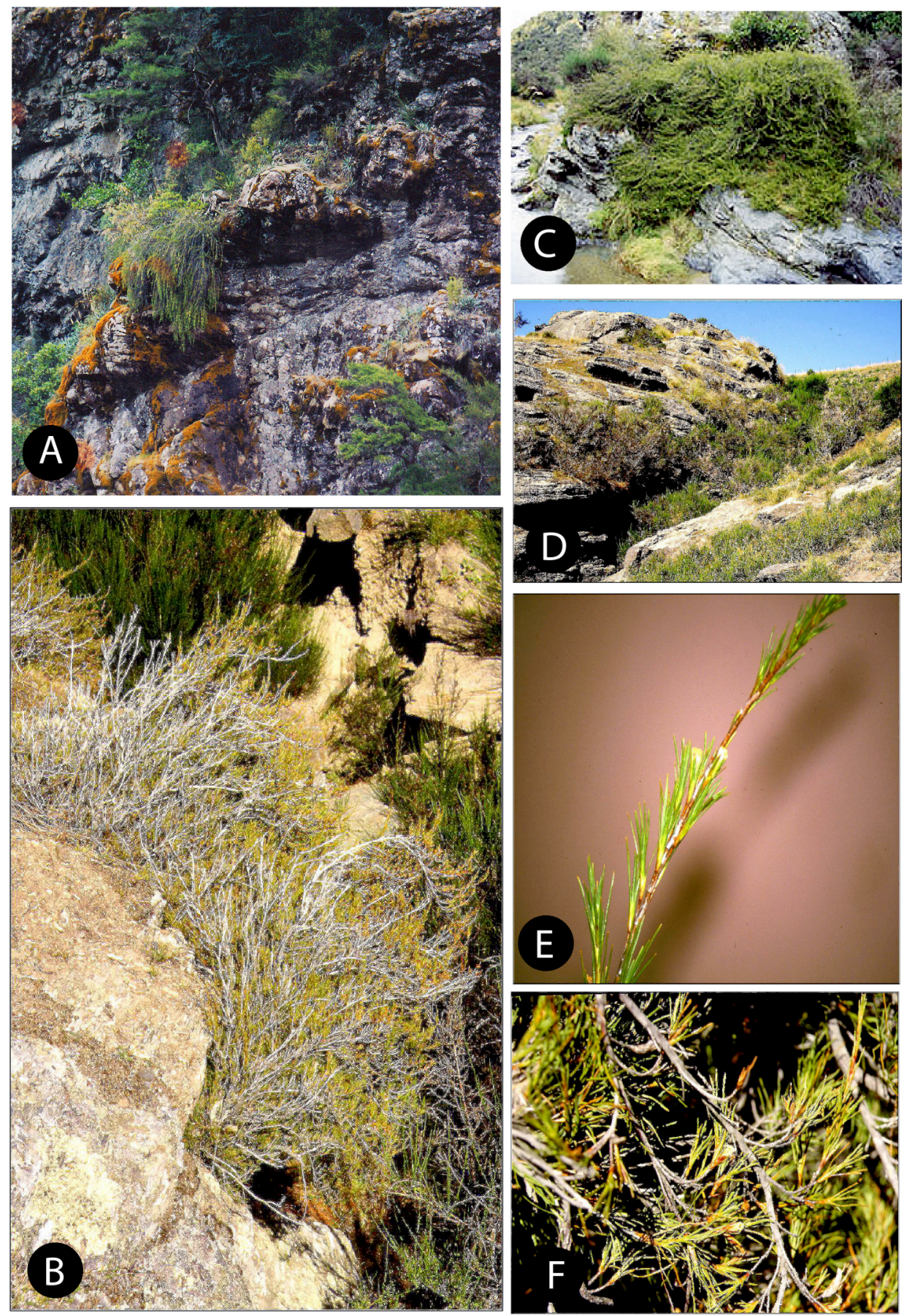

Figure 7.82. Oreothamnus frondosus. A, mature plant growing on cliff, Leatham Valley; B, plant growing on a low cliff at the type locality at Deep Stream; C, typical sprawling growth habit; D, mature plant showing the pendant branches; $\mathbf{E}$, flowering branch showing the erect solitary flowers; F, flowering branches. B, E-F, Venter13817. 
Oliver (1952) divided Dracophyllum uniflorum into two unnamed forms but accepted Simpson's var. frondosus on the basis of the trailing stems and the narrow, 'needlepointed' leaves. It was decided to raise this taxon to species level on the basis of the spreading to decumbent growth habit and a combination of flower characters. I place far more value on the flower characters than Oliver, thus recognizing the flower bracts that are longer than the corolla, sepals equaling the corolla in length, adaxial surface of sepals being pubescent in the top half, longer filaments and ovary and the truncate ovary apex.

Oreothamnus frondosus is similar to O. rosmarinifolius (Table 7.33.) but differs in the lax habit and scrambling stems. The flower bract is also longer than the flower and narrower (0.5$1.0 \mathrm{~mm}$ compared to $1-2 \mathrm{~mm}$ ) with the adaxial surface scabrid. The sepal in $O$. frondosus equals the corolla tube and the adaxial surface texture of the sepal is pubescent in the top half and it is also longer $(7-10 \mathrm{~mm})$ and wider (2-3 $\mathrm{mm}$ compared to $1.2-2.5 \mathrm{~mm})$ than the corolla tube; the corolla lobes are shorter (1.4-1.5 mm compared to2.0-2.5 mm), with longer (1.0-1.2 mm compared to 0.3-0.5 mm) filaments, longer $(2.5-4.5 \mathrm{~mm})$ cylindrical ovary with truncate apex and a longer (3-4 $\mathrm{mm})$ style.

Table 7.33. Differences between Oreothamnus rosmarinifolius and O. frondosus.

\begin{tabular}{|l|l|l|}
\hline \multicolumn{1}{|c|}{ Character } & \multicolumn{1}{|c|}{ O. rosmarinifolius } & \multicolumn{1}{c|}{ O. frondosus } \\
\hline Branching & upright & spreading to decumbent \\
Flower bract & $5.0-9.5(-13) \times 1-2$ & $(5.5-) 7-10(-11) \times(0.4-) 0.5-1.0(-1.2)$ \\
Flower bract : corolla length & shorter to equalling & longer \\
Flower bract adaxial surface & scabrid at base only & scabrid \\
Sepal length to corolla tube length & equalling to longer & same length \\
Sepal adaxial surface & glabrous & pubescent in top half \\
Sepal size $(\mathrm{mm})$ & $(4.5-) 5.0-9.0(-12.0) \times 1.2-2.5$ & $4.5-9.0 \times 1.5-2.0$ \\
Corolla lobe size $(\mathrm{mm})$ & $1.4-1.5 \times 1.0-1.2$ \\
Filament length $(\mathrm{mm})$ & $2.0-2.5 \times 1.2-1.5(-2.0)$ & $(0.3-) 1.0-1.2$ \\
Ovary length $(\mathrm{mm})$ & $0.3-0.5$ & $2.5-4.5$ \\
Ovary apex shape & $1.7-2.0$ & truncate \\
Style length $(\mathrm{mm})$ & round & $(2-) 3-4$ \\
\hline
\end{tabular}




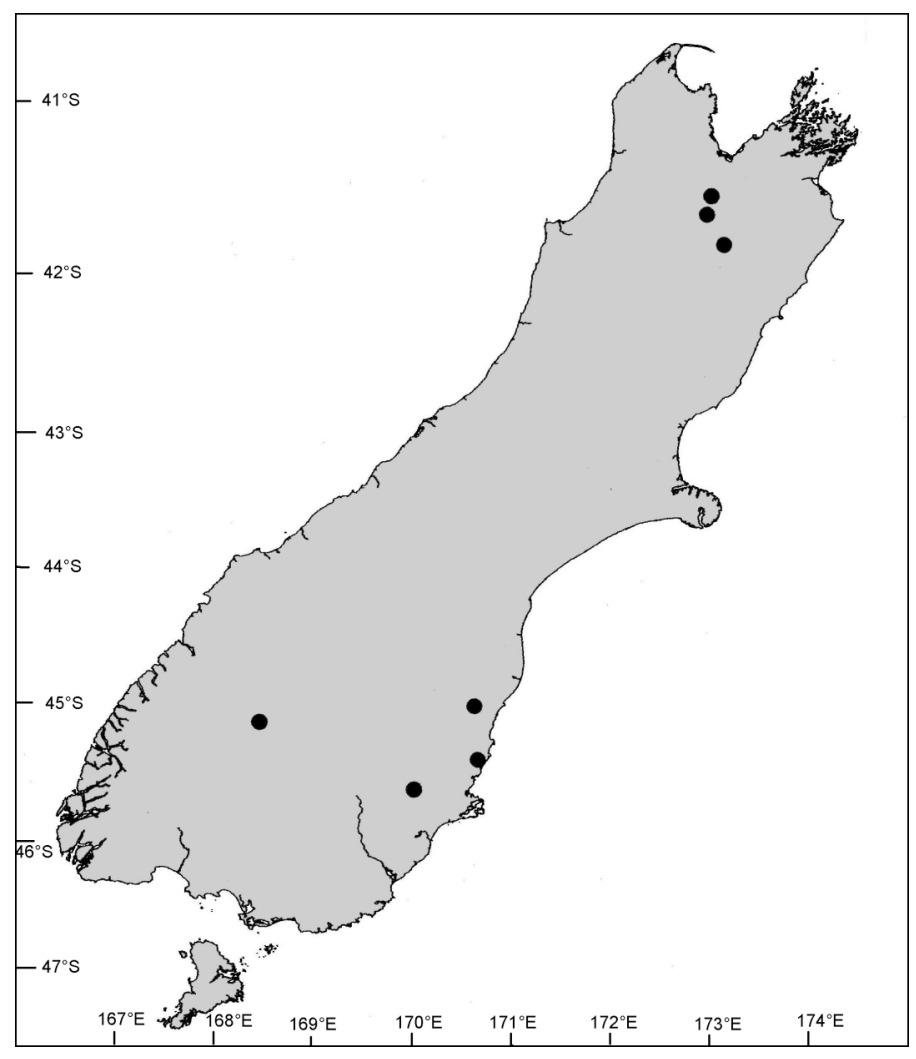

Figure 7.83. Known distribution of Oreothamnus frondosus.

\section{Distribution}

New Zealand endemic and restricted to the South Island. The main distribution is in the Otago area with a smaller distribution area in the mountains around the Nelson Lakes area $\pm 600 \mathrm{~km}$ distant (Fig. 7.83).

\section{Habitat}

Oreothamnus frondosus occurs on steep $\left(25^{\circ}-90^{\circ}\right)$ riverbanks and on cliffs at altitudes ranging from $300-900 \mathrm{~m}$. The vegetation consists of open montane forest, shrub or grassland (Table 7.34). The soils are brown loam or brown clay loam derived from calcareous sandstone, greywacke or schist. 
Table 7.34. Plant communities commonly associated with Oreothamnus frondosus.

\begin{tabular}{|c|}
\hline FOREST \\
\hline Tall open evergreen Nothofagus solandri - Leptospermum scoparium - Veronica forest \\
\hline SHRUBLAND \\
\hline Tall closed semi-deciduous Leptospermum scoparium shrubland \\
\hline GRASSLAND \\
\hline Low open Chionochloa grassland on cliffs \\
\hline
\end{tabular}

\section{Variation}

Oreothamnus frondosus is a species with little variation between populations. Some variation exists in the size of the leaf $(18-34 \times 0.5-1.5 \mathrm{~mm})$ and the corolla tube $(7-10 \times 2-4$ $\mathrm{mm})$. In populations where the slope of the habitat is gentle to flat, plants tend to have decumbent branches but plants from populations growing in rock cracks in cliffs have hanging branches up to three metres long (Venter 13823).

\section{Material examined}

NEW ZEALAND. South Island. 41-173: St. Arnaud, upper reaches of the Leatham Valley (-CC), 06.v.2000. Venter 13823 (CHR); Red Hills, Motueka River, xii.1980. Druce s.n. (CHR). 45-170: Kauro River headwaters (-BA), 9.x.2003. Barkla s.n. (CHR); Palmerston, road over Horse Range, top of limestone cliffs (-BC), 4.xii.1942. Simpson s.n. (CHR), 19.ii.1949. Simpson s.n. (CHR); Dunedin-Middlemarch Road at bridge over Deep Stream (-CA), Thomson s.n. (CHR); ibid., 5.ii.1949. Simpson s.n. (CHR), ibid., 18.ii.1957. Allison s.n. (CHR); ibid., 23.iii.2000. Venter 13817 (CHR). 
7. Oreothamnus kirkii (Bergg.) S. Venter

Oreotbamnus kirkii (Bergg.) S. Venter, comb. nov. Cheeseman, Man. N.Z. Fl.: 708 (1925); Oliver, Trans. Proc. N.Z. Inst. 59: 692 (1928); Oliver, Trans. Roy. Soc. N.Z. 80 (1): 7 (1952); Allan, Fl. N.Z. 1: 528 (1961); Moore \& Irwin, The Oxford Book of N.Z. Plants.: 295 (1978); Eagle, Trees \& Shrubs of N.Z. $2^{\text {nd }}$ series: 295 (1982); Poole \& Adams, Trees \& Shrubs in N.Z.: 158 (1994). Type: New Zealand, Mt. Torlesse, 1877. S. Berggren s.n. (O, lecto.!). Designated by Oliver (1952).

= Dracophyllum kirkii Bergg., Journ. Bot. Lond. 17: 104 (1880).

Dracophyllum uniflorum Bergg., Minn. Fisiogr. Sall. Lund. 28: 15 (1877). (non Hook. f.) nom. illigit.

Icones: Berggren, Minn. Fisiogr. Sall. Lund. : t. 4 (1877); Eagle, Trees \& Shrubs of N.Z. $2^{\text {nd }}$ series: t. 147 (1982).

\section{Description}

Decumbent to spreading multi-stemmed shrub, 20-140 cm tall. Branches: bark on old branches grey to dark grey, smooth or finely fissured, young stems reddish brown. Leaves juvenile and adult; juvenile leaves spirally arranged along branches, spreading, glaucous; lamina sheath $9.3-7.5 \times 5.4-8.0 \mathrm{~mm}$, coriaceous, tapering and margin ciliate in upper half; lamina coriaceous, linear-triangular, 42-60 $\times 4.0-4.7 \mathrm{~mm}$, surfaces glabrous; margins serrulate with $80-90$ teeth per $10 \mathrm{~mm}$; adult leaves spreading, glaucous to occasionally light green; lamina sheath 4-10 × 3.5-7.0(-9.0) $\mathrm{mm}$, subcoriaceous, striate, shoulders tapering to auricled and margin membranous, smooth to ciliate in the top half; 
adult lamina linear-triangular, (16-)20-40(-70) $\times(1.5-) 2.0-4.0 \mathrm{~mm}$, prominently striated; margins serrulate with 90-110 teeth per $10 \mathrm{~mm}$. Inflorescence a solitary sessile and erect flower near apices of branches; shorter than leaves; inflorescence bract overtopping flower, glaucous, ovate, $8-20 \times 2.0-2.6 \mathrm{~mm}$, surfaces glabrous, margins ciliate. Sepals ovate, 6.5-7.0 $\times 2-3 \mathrm{~mm}$, shorter than to equaling corolla tube; margins ciliate. Corolla white; corolla tube cylindrical, $5-6 \times 2.0-2.5 \mathrm{~mm}$; corolla lobes reflexed, ovate-triangular to triangular, shorter than corolla tube, $1.8-2.0 \times 1.0-1.5 \mathrm{~mm}$, apices acute to subacute; apical ridge present, adaxial surface papillate. Stamens inserted on corolla tube in upper third, filaments $0.4-0.6 \mathrm{~mm}$ long; anthers included, oblong, light yellow and 0.8-1.2 mm long. Ovary cylindrical to ovate, $1.8-2.0 \times 1.5-2.0 \mathrm{~mm}$, glabrous, apex round; nectary scales rectangular, 1.0-1.5 × 0.7-0.9 mm, apices retuse; style included, 0.7-2.0 mm long, glabrous; stigma capitate. Fruit light brown, $2.7-3.0 \times 2.3-2.5 \mathrm{~mm}$, broadly obovoid, apex round, glabrous. Seeds light brown, ovoid, 0.95-1.0 $\mathrm{mm}$ long, testa slightly reticulate. Flowering October-April. (Figure 7.84).

\section{Diagnostic features and notes}

Oreothamnus kirkii is characterized by its sprawling habit with the branchlets erect at the tips; smooth, dark grey bark with shallow fissures; leaves glaucous, lamina 20-40 × 2-4 $\mathrm{mm}$, lamina sheath not much wider than lamina and the lamina base scabrous; flowers solitary; corolla tube $5 \mathrm{~mm}$ long and shorter to equaling the sepals.

Cheeseman (1906) mentioned its nearest ally as being O. pubescens, which differs in the leaves being pubescent and having 3-5-flowered racemes. Oreothamnus kirkii resembles O. pubescens in general appearance of the glaucous leaves, but they are glabrous not pubescent and the inflorescence is a solitary flower compared to the 3-5-flowered spike 


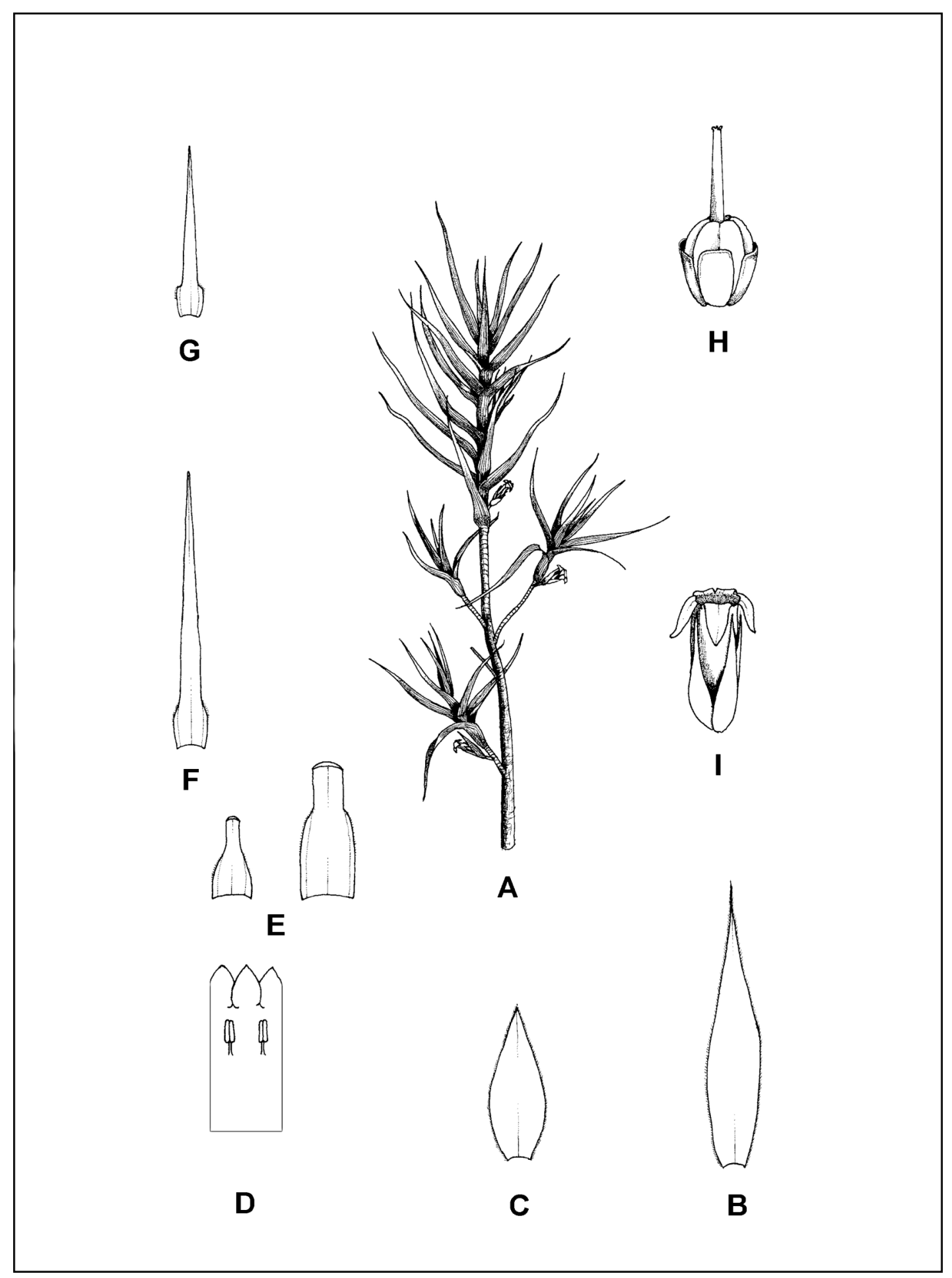

Figure 7.84. Oreothamnus kirkii. A, flowering branch $(\times 1)$; B, inflorescence bract $(\times$ 5); C, sepal $(\times 5)$; $\mathbf{D}$, laid out corolla $(\times 5)$; $\mathbf{E}$, lamina sheaths adaxial surface to show variation $(\times 2) ; \mathbf{F}$, juvenile leaf $(\times 1)$; $\mathbf{G}$, adult leaf $(\times 1)$; $\mathbf{H}$, ovary $(\times 10)$; I, flower $(\times 5)$. Drawn from Sykes 344/72. 

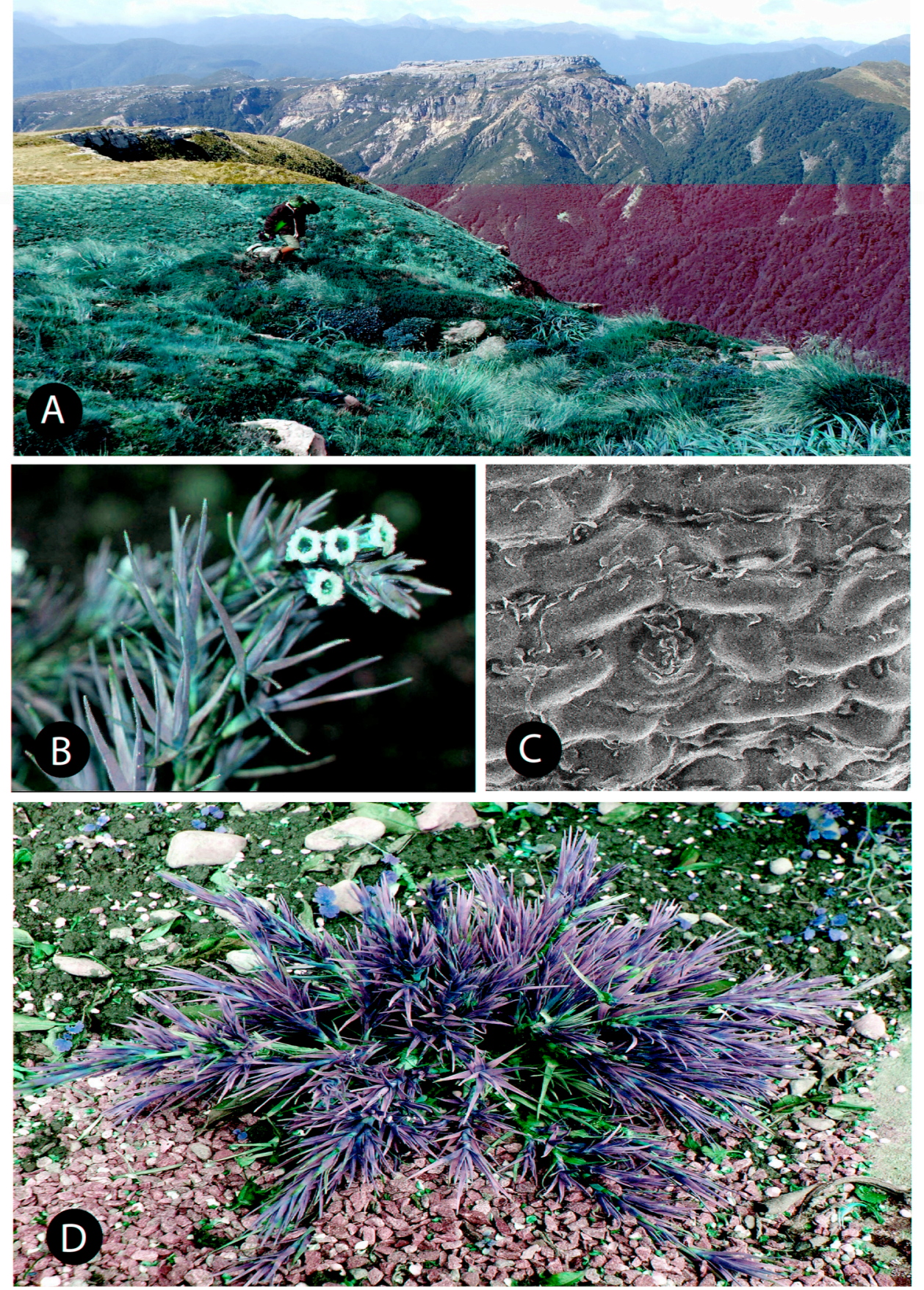

Figure 7.85. Oreothamnus kirkii. A, submontane habitat, Mt. Garibaldi; B, flowering branch showing the solitary flowers; C, SEM micrograph of the epicuticular wax on the adaxial lamina surface; $\mathbf{D}$, cultivated plant showing the short and spreading adult leaves; B-C, Redman s.n. (CHR). 
of $O$. pubescens. In $O$. marmoricola the tubules are arranged in a parallel manner distinguishing it from O. kirkii, that has scattered unordered platelets (Figure 7.85B). These two species were confused in the past.

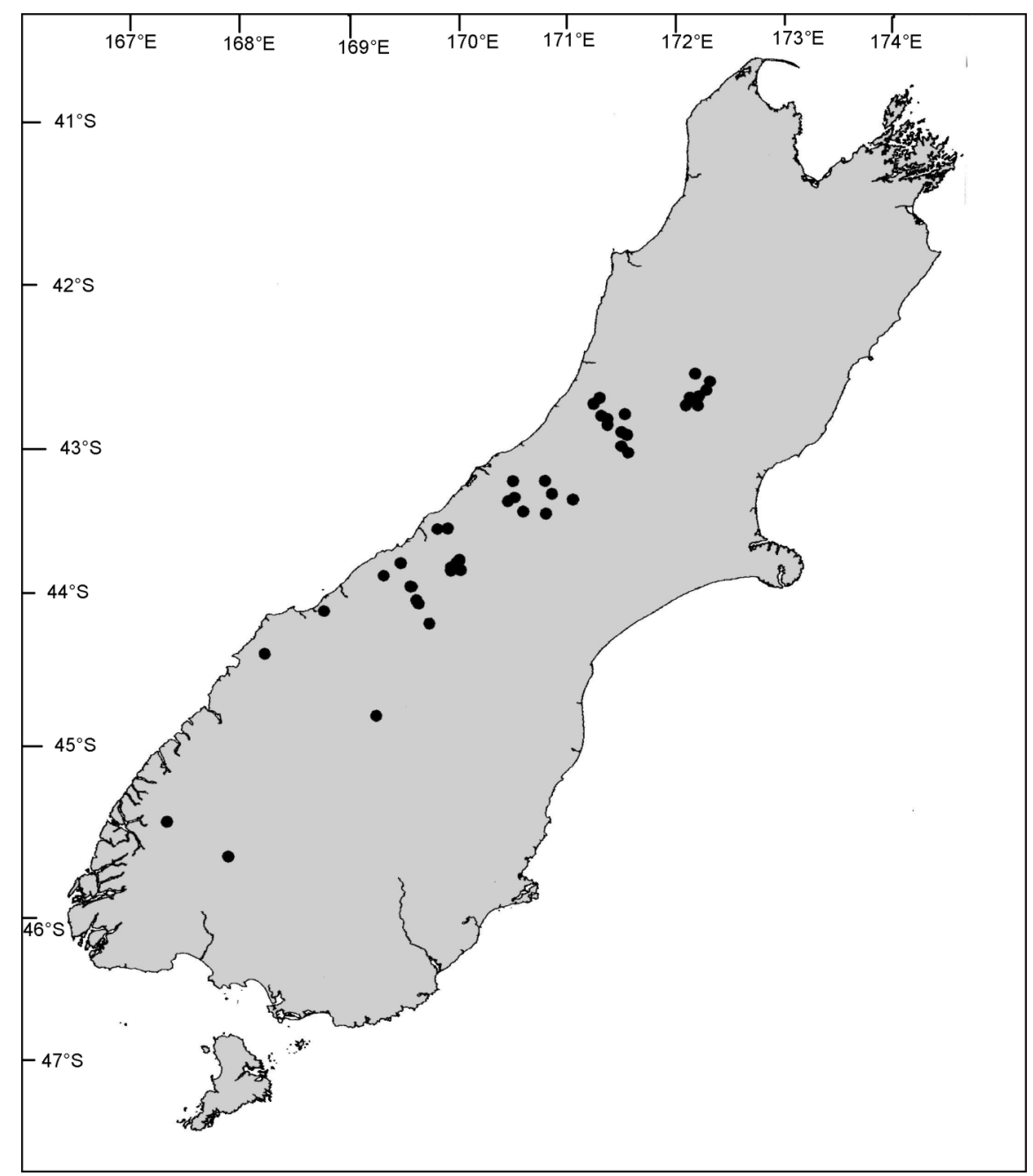

Figure 7.86. Known distribution of Oreothamnus kirkii., South Island, New Zealand.

\section{Distribution}

Endemic to the South Island of New Zealand. It occurs from southern Nelson southwards to West Canterbury and North Westland (Fig. 7.86). 


\section{Habitat}

Oreothamnus kirkii grows on gentle to steep $\left(5^{\circ}-40^{\circ}\right)$ mountain slopes and bluffs at altitudes of $700-2,166 \mathrm{~m}$. The vegetation consists of subalpine shrubland, tussock grassland, fell field and herbfield (Table 7.35). Soils are rocky loam to clay loam derived from granite, greywacke, marble and limestone.

Table 7.35. Plant communities commonly associated with Oreothamnus kirkii.

\begin{tabular}{|l|}
\hline \multicolumn{1}{|c|}{ SHRUBLAND } \\
\hline $\begin{array}{l}\text { Low closed evergreen Leptospermum scoparium shrubland } \\
\text { Low open evergreen Oreothamnus rosmarinifolius - Celmisia spectabilis - Gaultheria depressa shrubland }\end{array}$ \\
\hline \multicolumn{1}{c|}{ GRASSLAND } \\
\hline $\begin{array}{l}\text { Tall open Chionochloa teretifolia - Chionochloa crassiuiscula grassland } \\
\text { Open Chionochloa rigida grassland } \\
\text { Open Chionochloa australis - Chionochloa pallens grassland }\end{array}$ \\
\hline \multicolumn{1}{c|}{ HERBFIELD } \\
\hline Tall open Oreothamnus rosmarinifolius - Celmisia spectabilis herbfield. \\
\hline
\end{tabular}

\section{Variation}

Leaf size is polymorphic in Oreothamnus kirkii. Oliver (1928) mentioned that specimens from southern localities show narrower leaves $(1.2-2.5 \mathrm{~mm})$ compared to those $(4.0-4.5$ $\mathrm{mm}$ ) from northern populations but I have found that this character breaks down possibly as a result of being able to visit many populations in the wild and having more dried specimens available for study.

\section{Hybrids}

Oreothamnus kirkii hybridises with O. pronus at Arthur's Pass and it was described as Dracophyllum $\times$ saxicolum by Oliver (1928). 


\section{Material studied}

NEW ZEALAND, South Island. 42-171: Hokonu Range, S of Lake Brunner, Mt. French (-CB), 19.xi.1936. Mackay s.n. (CHR); Hohonu Range, Mt. French. 18.xi.1995. De Lange s.n. (AK); Above Arthur's Pass, Bealy Ridge (-DC), 14.iii.1972. Sykes 344/72 (CHR). 42-172: Upper Hurunui River, Nigger Head (-CA), 1.ii.1973. Macmillan \& Stemmer s.n. (CHR); West Amuri, Mt. Garfield (-CB), 12.xii.1936. Brockie s.n. (CHR). 43169: Westland Nat. Park, top E of Mt. Fox (-BD), 28.ii.1967. Wardle \& Fryer s.n. (CHR); Mariners Peak (-CD), 9.ii.1978. Wardle \& Campbell s.n. (CHR); Mt. Reynolds (-DA), 16.ii.1978. Wardle s.n. (CHR); Head of Clarke River, Kea Cliffs (-DC), 9.iv.1978. Wardle s.n. (CHR). 43-170: Hooker Valley, Black Birch Stream (-AA), i.1898. Cheeseman s.n. (AK); Mt. Wilberg (-BA), 27.iv.1993. Wardle, Buxton \& Ford s.n. (CHR); Wanganui River, between Smythe River and Whirlwind Spur (-BB), 14.iv.1994. Wardle P 94/166 \& Buxton (CHR); Mt. Barlow (-BC), 15.ii.1978. Campbell s.n. (CHR); Mt. Cook, Sebastapol (-CA), 26.ii.1958. Connor s.n. (CHR); Mount Cook Nat. Park, Malte Brun (-CB), 28.iii.1967. Simpson s.n. (CHR); Hooker Valley, Stocking Creek (-CC), 25.ii.1957. Connor s.n. (CHR); Lake Tekapo, Godley River (-DC), Laing s.n. (CHR). 43-171: Rakaia River, Cascade Hill (-AB), 16.i.1985. McGilvary s.n. (CHR). 44-168: Gorge Plateau (-AB), 30.x.1985. Wardle s.n. (CHR); Bealy Spur (-BA), 8.ii.1991. Douglass P 91/2 (CHR); Woolsack Spur (-BB), 1.iv.1979. Wardle \& Williams s.n. (CHR); Tutoko Valley (-CA), i.1977. Johnson s.n. (CHR). 44-169: Hopkins Valley, Temple Stream (-BB), 9.i.1975. Johnson s.n. (CHR). 45-167: Murchison Mountains, Dana Burn branch of Ettrick Burn (AD), iii.1978. McSweeny s.n. (CHR). 
8. Oreothamnus lessonianus (A. Rich.) S. Venter

Oreotbamnus lessonianus (A. Rich.) S. Venter, comb. nov. Hombron \& Jacquinot, Bot. Voy. Astrol. \& Zel. 2: 85 (1833); De Candolle, Prodr. Syst. Nat.: 770 (1839); Cunningham, Annals of Natural History 2: 49 (1839); Hooker, Ann. Nat. Hist. 2: 49 (1839); Hooker, Flora Antarct. 1: 49 (1844); Hooker, Flora Nov. Zel. 2 (1): 170 (1853); Hooker, Handb. N.Z. Fl.: 182 (1864); Cheeseman, Man. N.Z. Fl.: (1906); Oliver, Trans. Proc. N.Z. Inst. 59: 696 (1928); Oliver, Trans. Roy. Soc. N.Z. 80 (1): 9 (1952); Allan, Fl. N.Z. 1: 530 (1961); Eagle, Trees \& Shrubs of N.Z., $2^{\text {nd }}$ series.: 294 (1982); Salmon, Native Trees of N.Z.: 275 (1989); Poole \& Adams, Trees \& Shrubs of N.Z.: 162 (1994). Type: New Zealand, Crescit in rupibus Novae-Zealandiae (Bay of Islands). 1827. J.S.C. Dumont D'Urville s.n. (P, lecto.!; K!; W!), designated by Oliver (1952).

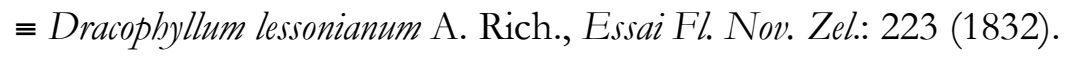

= Dracophyllum robustum Hook. f., Flora Antarct. 1: 49 (1844). Type: New Zealand, Northern Island. J. Edgerley s.n. (K, holo.!).

= Dracophyllum lessonianum A. Rich. var. robustum Hook. f., Fl. Nov. Zel. 2 (1): 170 (1853).

Icones: Hombron \& Jacquinot, Bot. Voy. Astrol. \& Zel. 2: 85, t. 29 (B) (1833); Eagle, Trees \& Shrubs of N.Z., $2^{\text {nd }}$ series.: 294, t. 139 (stamens wrongly illustrated as hypogynous) (1982); Salmon, Native Trees N.Z.: 275 (1989). 


\section{Description}

Erect to spreading single-stemmed shrub or tree $0.5-5 \mathrm{~m}$ tall. Branches: bark on old branches grey to dark brown, finely fissured or occasionally deeply fissured on very old stems, young stems reddish brown. Leaves. juvenile leaves spirally arranged along branches, erect to spreading; lamina sheath yellowish green, 8-17 × 3.7-5.0 mm; shoulders truncate to auricled and margin ciliate or ciliate in upper half; lamina coriaceous, linear to linearsubulate, $60-120 \times 1.6-1.8 \mathrm{~mm}$; surfaces glabrous; margin serrulate with 50-78 teeth per $10 \mathrm{~mm}$; adult leaves spreading; lamina sheath light green, $6.0-14 \times 2-4 \mathrm{~mm}$, membranous, shoulders truncate to auricled and margin with the top half ciliate; lamina light to olive green, linear to linear-subulate, $(20-) 27-108 \times 0.5-1.2 \mathrm{~mm}$, surfaces glabrous with a tuft of scabrid hairs at the base of adaxial surface; margins serrulate with 53-70 teeth per 10 $\mathrm{mm}$; apex triquetrous. Inflorescence a terminal spike on lateral branchlets, shorter than the leaves, erect, lax, 20-40(-50) mm long, linear-oblong; inflorescence bract overtopping flowers, coriaceous to rigid and hard, light to dark green, subulate, $6.0-17.5 \times 0.6-1.0(-$ 3.3) $\mathrm{mm}$; adaxial surface scabrid at base; abaxial surface glabrous to pubescent at the apex; margins entire. Flowers 3-9, sessile; flower bract overtopping flowers, leaf-like, coriaceous to rigid and hard, ovate-lanceolate, $8.0-12.5 \times 0.5-0.7 \mathrm{~mm}$, surfaces glabrous with a tuft of scabrid hair at base of adaxial surface, margins serrulate and white, apices acute and dark coloured. Sepals lanceolate to ovate-lanceolate, $6-8 \times 1.5-2.0 \mathrm{~mm}$, longer than corolla tube; surfaces glabrous with top half of adaxial surface pubescent; margins ciliate; apices acuminate and hard. Corolla white to pinkish; corolla tube cylindrical, widened at mouth, (4-)5-6 × 2.0-2.5 mm; corolla lobes spreading horizontally, reflexed in old flowers, ovate triangular, shorter than corolla tube, 2.5-3.0 × 1.0-1.5 mm, inflexed at apex, apices acute; surfaces glabrous. Stamens inserted on corolla tube in upper third, filaments $0.3-0.5 \mathrm{~mm}$ long; anthers included, 


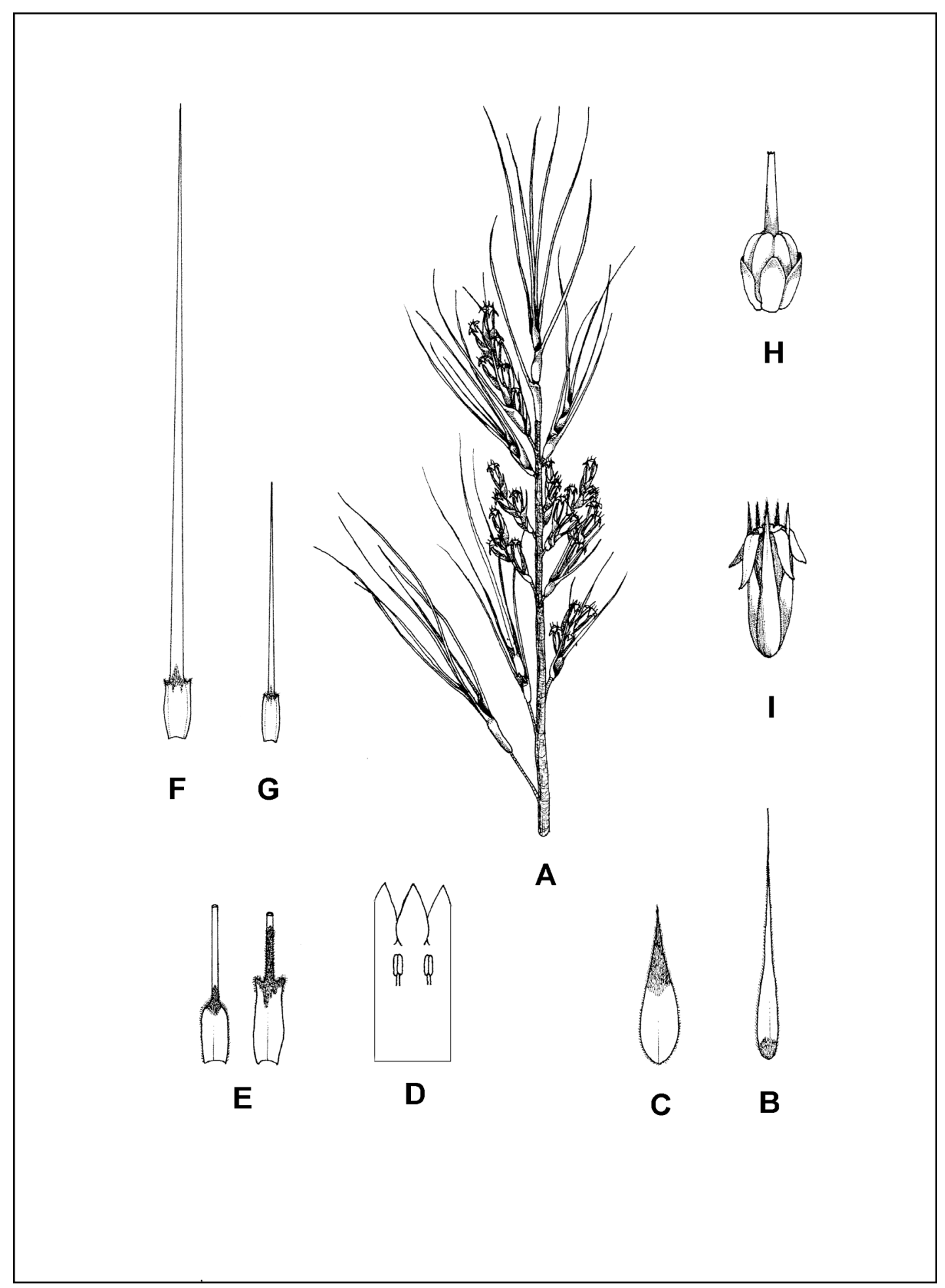

Figure 7.87. Oreothamnus lessonianus. A, flowering branch $(\times 1)$; $\mathbf{B}$, inflorescence bract adaxial surface $(\times 5)$; $\mathbf{C}$, sepal abaxial surface $(\times 5)$; $\mathbf{D}$, laid out corolla $(\times 5)$; $\mathbf{E}$, lamina sheaths to show variation $(\times 2) ; \mathbf{F}$, juvenile leaf $(\times 1)$; $\mathbf{G}$, adult leaf $(\times 1) ; \mathbf{H}$, ovary $(\times 10)$; I, flower $(\times 5)$. Drawn from Venter 13767 . 

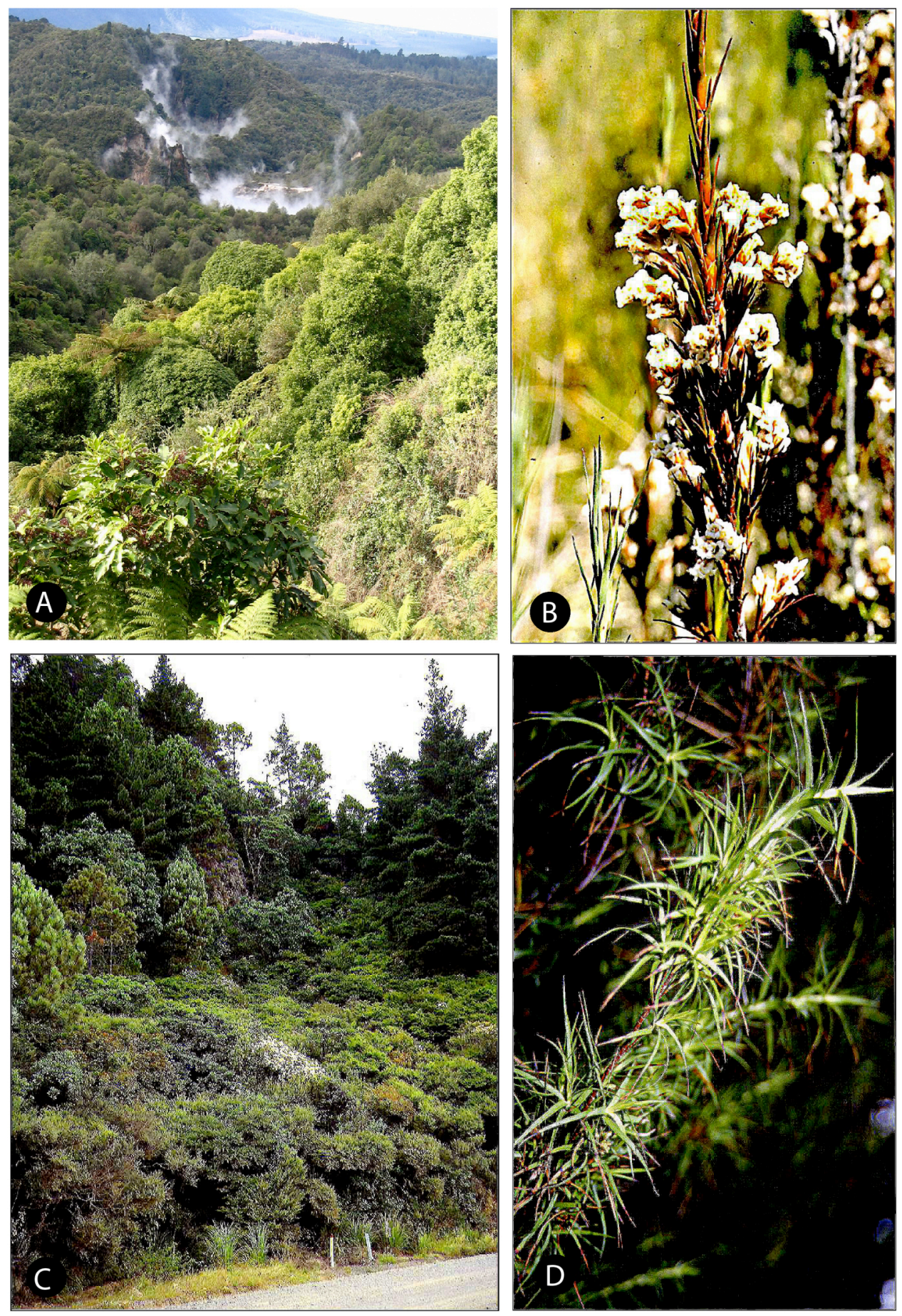

Figure 7.88. Oreothamnus lessonianus. A, habitat near Rotorua; B, flowering branch showing the clumped inflorescences; C, habitat Coromandel Peninsula; D, plant from Lake Rotokawau on the Karikari Peninsula showing adult leaves. D - Venter 13767. 
oblong, light yellow and $0.9-1.0 \mathrm{~mm}$ long. Ovary oblong, $1.3-1.5 \times 1.2-1.3 \mathrm{~mm}$, apex truncate; nectary scales rectangular, $1.0-1.3 \times 0.5-0.6 \mathrm{~mm}$, apices subacute; style included, 1.5-2.0 mm long, glabrous; stigma capitate. Fruit sessile, light brown, 4.0-4.5 × 1.7-2.0 mm, oblong, apex truncate, glabrous. Seeds yellowish brown, ovoid, 1.0-1.2 mm long, testa slightly reticulate. Flowering November-May. (Figure 7.87).

\section{Diagnostic features and notes}

Oreothamnus lessonianus is characterized by the erect-spreading branches with dark grey and smooth bark, juvenile leaves, adult leaves with auricled lamina sheaths having pale margins, base of the lamina covered in short hairs and a triquetrous apex, racemes that terminate the lateral branches, flower bracts persistent with long narrow sheaths, sepals slightly longer $(6-8 \mathrm{~mm})$ than the corolla tube and having hard apices and having the inside covered in white hairs.

I agree with Oliver (1928) that Oreothamnus lessonianus is distinguished from similar species by the long racemes, long acuminate sepals with hard apices and long flowers. Oreothamnus lessonianus is similar to O. filifolius but differs in having juvenile leaves, sepals longer than the corolla tube, the inflorescence bracts and flower bracts having broad white margins and the apex of the ovary is truncate not round.

\section{Distribution}

Endemic to the North Island of New Zealand (Fig. 7.90). The localities are concentrated in the northern part of the North Island with a few scattered localities as far south as Taumarunui. 


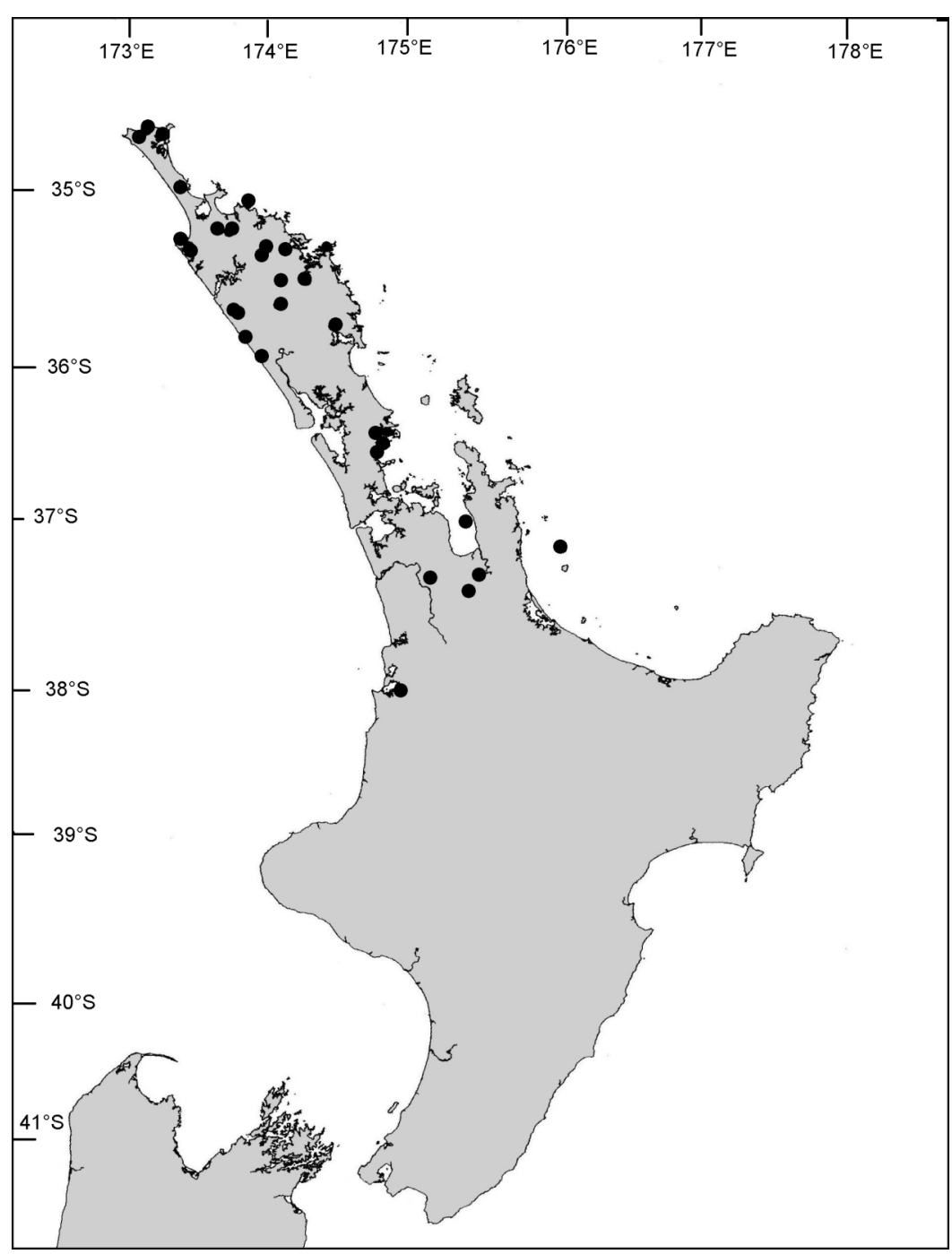

Figure 7.89. Known distribution of Oreothamnus lessonianus, North Island, New Zealand.

\section{Habitat}

Oreothamnus lessonianus occurs on gentle $\left(0^{\circ}-15^{\circ}\right)$ south facing coastal flats and mountain slopes from sea level up to $260 \mathrm{~m}$ altitude. The vegetation consists of lowland shrubland and swampy areas along he coast (Table 7.36). Oreothamnus lessonianus commonly forms extensive populations in Leptospermum scoparium shrubland and, in some areas, it is the only other woody dominant within this vegetation type. Soils are grey sandy to greyish brown clay soils derived from sandstone and quartzite. 
Table 7.36. Plant communities commonly associated with Oreothamnus lessonianus.

\section{SHRUBLAND}

Tall closed Leptospermum scoparium - Leucopogon fasciculatus - Phormium tenax shrubland

Tall closed Kunzea ericoides shrubland

Tall closed Leptospermum scoparium - Epacris pauciflora - Schoenus brevifolius shrubland

Low closed Leptospermum scoparium - Baumea teretifolia - Gleichenia dicarpa shrubland

\section{Variation}

Variation in O. lessonianus is in the size of the juvenile leaf sheath $(8-17 \times 3.7-5.0 \mathrm{~mm})$, juvenile lamina (60-120 mm long), adult leaf sheath $(6.0-12.2 \times 2-4 \mathrm{~mm})$, adult lamina $(27-108 \times 0.5-1.2 \mathrm{~mm})$, inflorescence $(20-40 \mathrm{~mm}$ long) and the inflorescence bract $(6.0-$ $17.5 \times 0.6-1.0 \mathrm{~mm})$.

\section{Hybrids}

Oreothamnus lessonianus hybridises with O. subulatus and was described as Dracophyllum $\times$ marginatum and the hybrid with $O$. sinclairii described as $D . \times$ densiflorum by Oliver (1928).

\section{Material studied}

NEW ZEALAND. North Island. 34-172: Te Paki Bush (-BD), xii.1966. Kelly s.n. (CHR); Cape Reinga (-BC), viii.1962. Woods s.n. (AK); Spirits Bay, Kapowairua (-BD), 30.x.1969. Cooper s.n. (AK); Te Paki Station, Radar Bush (-DB), 31.xii.1954. Moore s.n. (CHR). 34-173: Track $3 \mathrm{~km} \mathrm{SW}$ of Kaimaumau N side of Kaimaumau Road (-CC), 29.iv.1990. Brownsey \& Fox s.n. (WELT); Karikari Peninsula, Lake Rotokawau (-CD), 14.ii.1999. Venter 13767 (CHR); Cooper Beach (-DC), 16.xii.1940. Oliver s.n. (CHR). 35173: Ahipara, Reef Point (-AA), ix.1949. Allan s.n. (O); W of Whangaroa Harbour (-BA), viii.1967. Druce s.n. (CHR); Kerikeri, Rainbow Falls (-BB), 22.xi.1991. De Lange 1283 (AK, CHR, WELT); Kerikeri, Puketi Forest, near Forestry HQ, 15.ii.1999. Venter 13770 
(CHR); Ngawha Springs (-BD), 11.vii.1970. Lambrechtsen s.n. (CHR); Waipoua State Forest, road to Kawerua (-CB), 13.i.1976. Wright 1047 (AK); Waipoua State Forest, near Te Matua Ngahere (-DA), 11.iv.1972. Rawlings, Esler, Smithe Astridge s.n. (CHR); Kaitaia, Pukemiro (-DB), 1.ii.1926. Matthews s.n. (AK, CHR); Near Lake Taharoa (-DC), 15.i.1978. Bartlett s.n. (CHR). 35-174: Ruapekapeka Bay (-AC), 29.viii.1967. Cooper s.n. (CHR); Whangarei (-CB), ix.1928. Allan s.n. (CHR). 36-173: Okahu (-BB), 20.vii.1905. Carse s.n. (CHR). 36-174: Matakana (-BC), Kirk 519 (CHR); Omaha (-BD), 7.x.1940. Moore s.n. (CHR). 37-175: $\mathrm{N}$ of Mangatawhiri (-AA), 5.xii.1981. Ogle 765 (CHR); Whangamarino, Reao Arm (-AC), 9.x.1991. De Lange 1068 (AK, CHR); Hapuakohe Range, Waiti Road (-AD), 6.vii.1991. De Lange \& Crowcroft 854 (WELT); Kopuatai (Piako) peat dome (-BC), x.1981. Ogle s.n. (CHR). 38-174: Kawhia Harbour Road, Upper Tawairoa Stream below Hautapu Hill (-BB), 9.iv.1988. De Lange s.n. (AK, WAIK).

9. Oreothamnus longifolius (J.R. Forst. \& G. Forst.) S. Venter

Oreothamnus longifolius (J.R. Forst. \& G. Forst.) S. Venter, comb. nov. Forster \& Forster, Charact. Gen.: 20 (1776); Forster, Flor. Insul. Austr. Prodr: 13 (1786); Gaertner, Fruct. Sem. Pl. 1: 77 (1791); Brown, Prodr. Fl. Nov. Holl: 556 (1810) in nota; Sprengel, Syst. Vegetab. 1: 629 (1825);Richard, Fl. Nov. Zel. 1: 219 (1832); Hombron \& Jacquinot, Bot. Voy. Astrol. Zel:: 86 (1833); Cunningham, Ann. Nat. Hist. 2: 48 (1839); Hooker, Fl. Antarct. 1: 45 p.p. (1844); Hooker, Fl. Nov. Zel. 2 (1): 169 (1853); Hooker, Handb. N.Z. Fl.: 179 \& 182 p.p. (1864); Kirk, Forest Fl. N.Z.: 251 p.p. (1889); Cheeseman, Man. N.Z. Fl.: 424 p.p. (1906); Cheeseman, Man. N.Z. Fl. $2^{\text {nd }}$ Ed.: 704 p.p. (1925); Oliver, Trans. Proc. N.Z. Inst. 59: 701 (1928); Oliver, Trans. Roy. Soc. N.Z. 80 (1): 10 (1952); Matthews, New Zealand Trees.: 25 (1953); Allan, Fl. N.Z. 1: 531 (1961); Eagle, Trees \& Shrubs of N.Z. $2^{\text {nd }}$ 
series: 293 (1982); Salmon, Native Trees of N.Z.: 276 (1989); Poole \& Adams, Trees \& Shrubs of N.Z.: 164 (1994). Type: New Zealand, Dusky Bay, in woods. 26.iii.1773. G. Forster s.n. (K, lecto.!; BM 77,637!; K!, P 34!.), designated by Hooker (1853).

Brown (1810) did not indicate a specimen whilst mentioning the name Dracophyllum longifolium (in nota) and Hooker (1839) was the first to assign a specimen to the species and only mentioned the collector and collecting year (South Island, in woods, 1773-G. Forster), but in a later publication (Hooker 1853) he again mentioned the Forster specimen, but here with Dusky Bay as the precise locality. The correct date of selection of the type is thus 1853 .

= Dracophyllum longifolium (J.R. Forst. \& G. Forst.) R. Br. ex Roemer \& Schultes var. longifolium, Syst. Veg. 4: 385 (1819).

= Epacris longifolia J.R. Forst \& G. Forst., Charact. Gen. Plant:: 20, t. 10 (1776).

= E. frondosa Gaertn., Fruct. Sem.1: 77, t. 94 (1791).

= Dracophyllum longifolium (J.R. Forst. \& G. Forst.) R. Br., Prodr. Flor. Nov. Holl.: 556 (1810). in nota.

$=$ Dracophyllum longifolium (J.R. Forst. \& G. Forst.) R. Br. ex Roem. \& Schult. var. retortum Hombr. \& Jacq., Voy. Pole Sud.: 86, t. 27 (1833). Type: New Zealand. 1839. M. Hombron s.n. (K, holo!).

Dracophyllum longifolium Sweet, Sweet's Hortus Britannicus: 488 (1826). nom. illeg. 
= Dracophyllum lyallii Hook. f., Fl. Nov. Zel. 1: 169 (1854). Type (Here chosen): New Zealand, Port Preservation and Thompson's Sound, D. Lyall s.n. (K, lecto.!).

Hooker (1853) mentioned two syntypes with the protologue of D. byallii, a Menzies specimen from Dusky Bay and a Lyall specimen from Port Preservation and Thompson's Sound. The Lyall specimen agrees with the protologue of D. Lyallii and is therefore selected here as lectotype.

= Dracophyllum longifolium var. pluviale W.R.B. Oliv., Trans. Roy. Soc. N.Z. 80 (1): 11 (1952).

Type: New Zealand, Caswell Sound, Leslie Valley, 2,000', 29.iii.1949. W.R.B.

Oliver s.n. (WELT 313, holo.!).

Icones: Forster \& Forster, Charact. Gen.: t. 10 (1776); Gaertner, Fruct. Sem. Pl. 1: t. 94 (1791); Hooker, Fl. Antarct. 1: tt. 31 \& 32 (1844); Hombron \& Jacquinot, Bot. Voy. Astrol. Zel.: t. 27 p.p. (1853); Kirk, Forest Fl. N.Z.: t. 109 (1889); Salmon, Field Guide Alpine Pl. N.Z.: t. 32 (1968); Eagle, Trees \& Shrubs of N.Z. $2^{\text {nd }}$ series: t. 137 (1982); Salmon, Native Trees N.Z.: 276 (1989).

\section{Description}

Erect to spreading single-stemmed shrub or tree 1-12 $\mathrm{m}$ tall. Brancbes: bark on old branches grey to blackish brown, finely to deeply fissured, young stems reddish brown. Leaves juvenile and adult. Juvenile leaves spirally arranged or crowded at tips of branches, erect to spreading; lamina sheath light green, (9-)15-20 × 5-11 mm, shoulders tapering to truncate and margin ciliate in upper half; lamina linear-triangular to lanceolate, 100-250 $\times 2.5-8.0(-7.0) \mathrm{mm}$; margins serrulate with $50-80$ teeth per $10 \mathrm{~mm}$. Adult leaves erect to 
spreading; lamina sheath light green, 5-15 × 4-7 mm, striate, shoulders rounded to auricled and margin membranous with the top half ciliate; lamina linear to lineartriangular, 40-140(-232) $\times 1-4(-6) \mathrm{mm}$, prominently striated; margins serrulate with 120-170 teeth per $10 \mathrm{~mm}$; apex triquetrous. Inflorescence a terminal raceme on lateral branchlets, shorter than leaves, initially erect but drooping later, dense, $24-55 \mathrm{~mm}$ long, linear-oblong. Inflorescence bract overtopping flowers, subulate, (17-)30-35 × 1.2-1.5 mm, scabrous at base of adaxial surface, margins serrulate. Flowers 5-12(-18), pedicellate; flower bract caducous, equaling to longer than flower, broadly ovate, $10-15 \times 5-6(-8) \mathrm{mm}$, adaxial surface pubescent in upper third, margins ciliate; pedicel straight, (0.7)1.0-2.0 mm. Sepals ovate-lanceolate, $(2.5-) 3.0-7.0 \times(1.5-) 2.0-3.0 \mathrm{~mm}$, equaling to longer than corolla tube, striate, surfaces glabrous with the top half sometimes pubescent on adaxial surface; margins ciliate. Corolla white; corolla tube cylindrical, widened at mouth, 4.0-5.0 $\times(2.5-) 3.0-3.5 \mathrm{~mm}$; corolla lobes reflexed, ovate to ovate-triangular, shorter than corolla tube, $1.5-2.0 \times(1.5-) 2.0-2.5 \mathrm{~mm}$, inflexed at apex; apices subacute; adaxial surface papillate. Stamens inserted on corolla tube in the upper third, filaments $0.3-0.5 \mathrm{~mm}$ long; anthers included, oblong, light yellow and 0.8-1.0 mm long. Ovary obovate, $1.3-2.0 \mathrm{~mm}$ long and wide, apex round; nectary scales rectangular, $1.2-1.5 \times 0.8-1.0 \mathrm{~mm}$, apices irregularly toothed; style included, $0.7-1.3 \mathrm{~mm}$ long, glabrous; stigma capitate. Fruit pedicellate, light brown, 3.5-3.6 $\times 3.8-4.0 \mathrm{~mm}$, obovoid, apex round, glabrous. Seeds light brown, ovoid, 0.8-1.2 mm long, testa slightly reticulate. Flowering October-March. (Figure 7.90). 


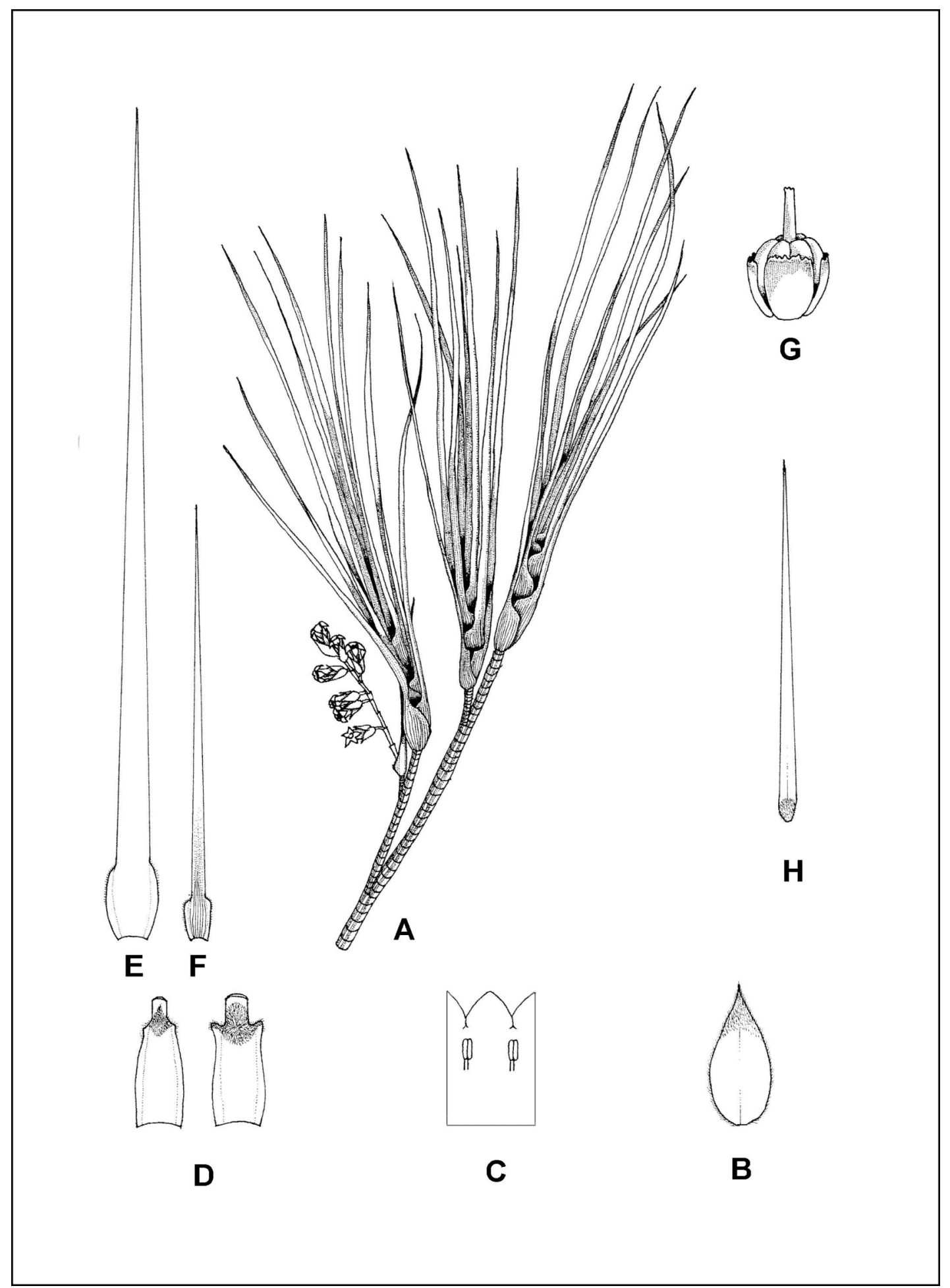

Figure 7.90. Oreothamnus longifolius. A, flowering branch $(\times 1) ; \mathbf{B}$, inflorescence bract adaxial surface $(\times 2.5)$; $\mathbf{C}$, laid out corolla $(\times 5)$; $\mathbf{D}$, lamina sheaths to show variation $(\times$ $2)$; E, juvenile leaf $(\times 1) ; \mathbf{F}$, adult leaf $(\times 1)$; $\mathbf{G}$, ovary $(\times 10) ; \mathbf{H}$, inflorescence bract adaxial surface $(\times 2.5)$. Drawn from Venter13750. 


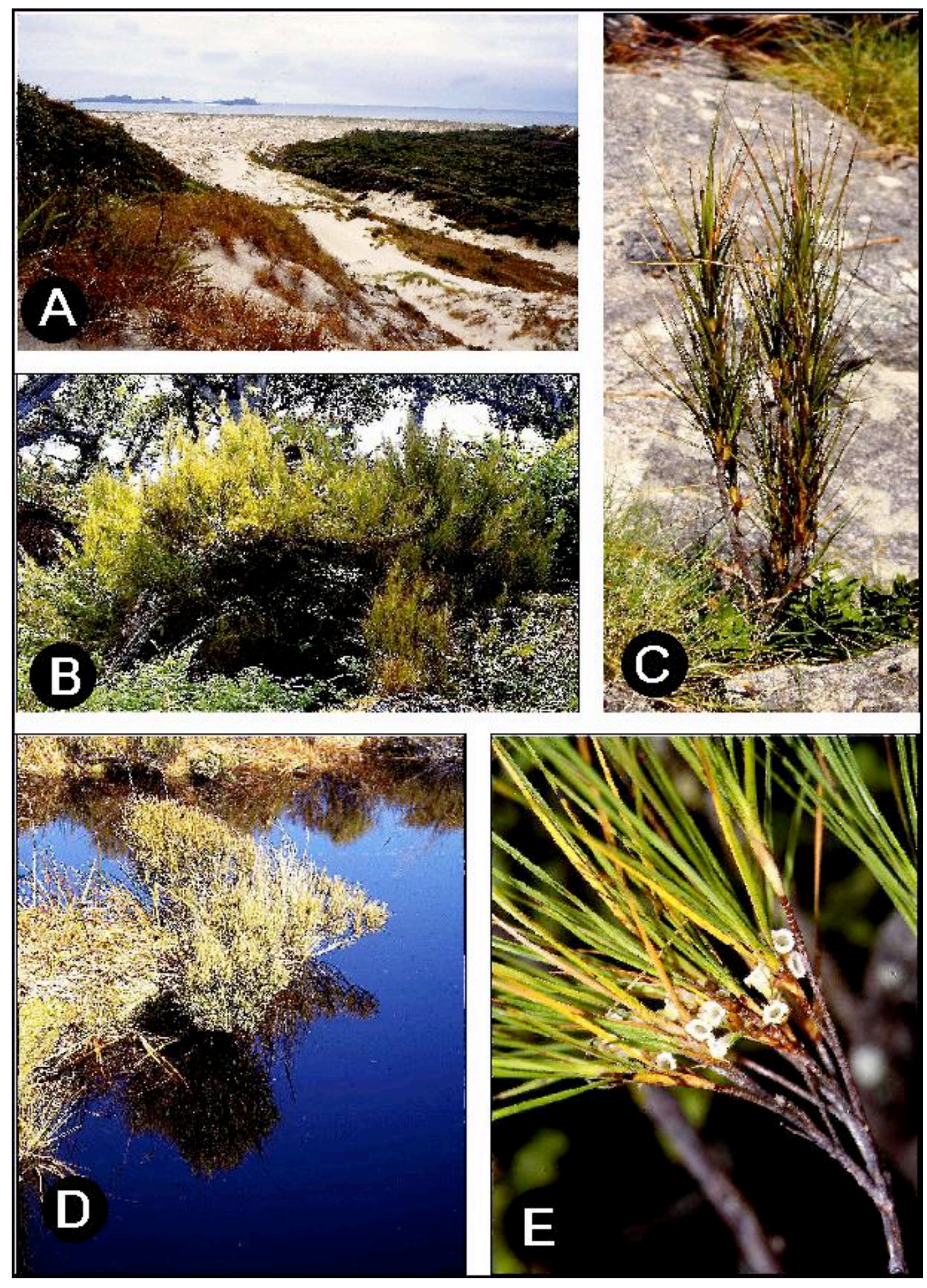

Figure 7.91. Oreothamnus longifolius. A, dune habitat at Masons Bay, Stewart Island; B, mature plant along beach at Christmas Village, Stewart Island; C, young plant with large juvenile leaves; $\mathbf{D}$, mature plant growing next to a tarn in a subalpine habitat on Mt. Maungatua; E, flowering branch. B, Venter 13787 and D, Venter 13812. 


\section{Diagnostic features and notes}

Oreothamnus longifolius is characterized by the very broad, long and flat juvenile leaves, stiff, narrow and erect adult leaves with wide, shouldered sheaths, flower bracts that fall early; sepals short and broad with long white cilia and the mouth of the corolla tube that is slightly widened.

Oreothamnus longifolius is similar to O. cockayneanus, but is immediately separated from it by the glabrous juvenile and adult leaves. Further differences are discussed under $O$. cockayneanus. Matthews (1953) and Cockayne and Phillips Turner (1967) confused O. longifolius with O. filifolius in stating that it occurs on North Island from the East Cape mountains to the Tararua Mountains. Oreothamnus longifolius has up to this point not been recorded for the North Island.

\section{Distribution}

Endemic to New Zealand and its subantarctic islands, Stewart Island, Auckland Island and Campbell Island (Fig. 7.92).

\section{Habitat}

Oreothamnus longifolius occurs on mountain and hill slopes, commonly on coastal cliffs and on bluffs from sea level to 1,200 $\mathrm{m}$ altitude. The vegetation consists of forest, woodland, shrubland and bogs stretching from sea level to the subalpine zone (Table 7.37). Soils are grey sandy loam, various types of lithosol, brown clay loam and peaty dark brown loam, derived from calcareous sandstone, greywacke, schist, diorite gneiss or granidiorite. 


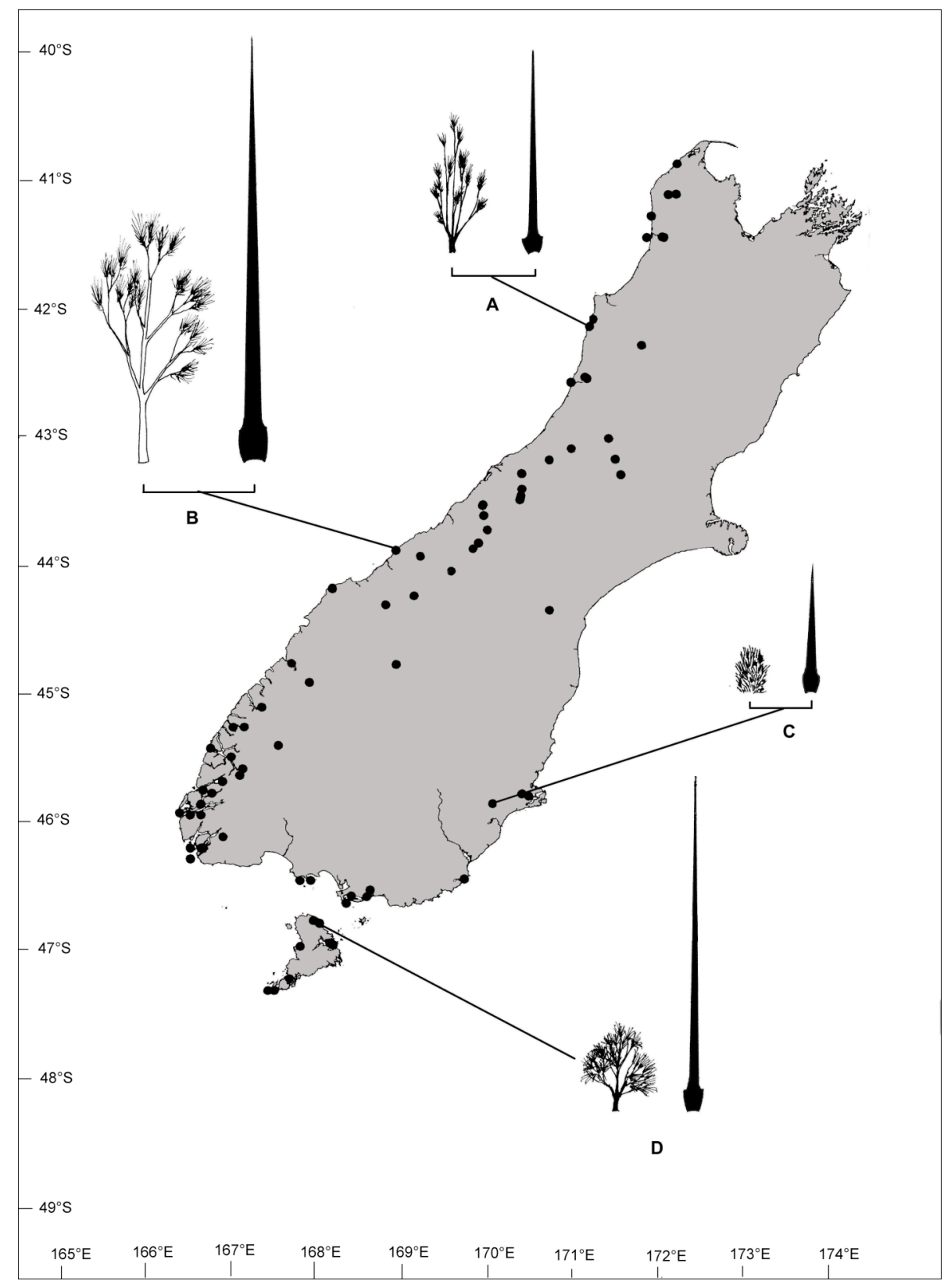

Figure 7.92. Known distribution(also occurs on Auckland and Campbell Islands), variation in growth habit and adult leaf in Oreothammus longifolius. A, Charleston, Needle Point area (Venter 13750 ); B, Between Knights Point and Haast, Ship Creek (Lambrechtsen s.n.); C, Dunedin, Mt. Maungatua (Venter 13812 ); D, Christmas Village (Venter 13787). Illustrations of leaves made at $\times 0.25$. 
Table 7.37. Plant communities commonly associated with Oreothamnus longifolius

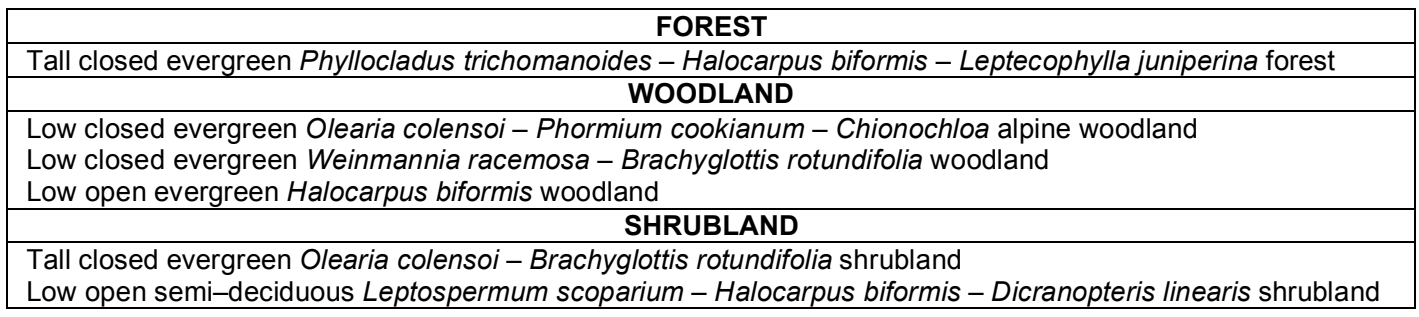

\section{Variation}

Plants from populations near sea level are up to $12 \mathrm{~m}$ tall and have branches with a drooping habit whereas plants from populations in drier and rockier habitats are short, 1-3 $\mathrm{m}$ tall and have an erect growth habit (Charleston, Needle Point area -Venter 13750). Shoulders of the leaf sheaths vary from tapering to auricled on the same plant and are clearly illustrated (Plate 109, 1 \& 2) by Kirk (1889). The juvenile lamina varies in size from $100-250 \times 2.5-8.0 \mathrm{~mm}$ and the adult lamina $40-140(-232) \times 1-4 \mathrm{~mm}$. Plants from populations with short and narrow leaves (Mt. Maungatua - Venter 13812) can easily be confused with forms of $O$. filifolius, but it is readily distinguished on the basis of the broader leaf sheath and the presence of juvenile leaves (Fig. 7.91E). Sepal length varies from $3-7 \mathrm{~mm}$.

\section{Hybrids}

Oreothamnus longifolius hybridises with O. scoparius (Dracophyllum $\times$ insulare) and with $O$. rosmarinifolius (Dracophyllum $\times$ acicularifolium) both described by Oliver (1928).

\section{Material studied}

NEW ZEALAND. South Island. 40-172: $1 \mathrm{~m} \mathrm{~N}$ of Sandhill Creek (-CB), viii.1978. Cowin s.n. (CHR); Gouland Downs, Mt. Goul (-CD), xii.1962. Talbot s.n. (CHR). 41-171: 
Charleston, Needle Point area (-CD), 07.i.1999. Venter 13750 (CHR). 41-172: N of Karamea (-AC), iv.1977. Simpson s.n. (CHR). 42-171: Greymouth, above Roa Coal Mine (-AD), 18.xii.1965. Moore, Clarke \& Robins s.n. (CHR); Hokitika, Crawford River (-CD), 17.xii.1957. Rockell s.n. (CHR); Arthur's Pass, Dobson Way (-DC), 31.i.1996. Hörandl \& Hadacek 7890 (W). 43-169: Between Knights Point and Haast, Ship Creek (-CC), 22.viii.1967. Lambrechtsen s.n. (CHR); Ranganui, true left of Moeraki River (-CD), 18.iv.1978. Campbell s.n. (CHR). 43-170: Franz Josef Glacier, Alex Knob (-AC), 19.iii.2000. Venter 13802 (CHR); Mt. Wilberg (-BA), 27.iv.1993. Wardle, Buxton \& Ford s.n. (CHR); Perth River, Scone Creek (-BC), 17.ii.1978. Campbell s.n. (CHR); Mt. Cook, Hooker Valley, Stocking Creek (-CA), 25.ii.1958. Conner s.n. (CHR); Cropp River (-CC), 4.ii.1983. Basher s.n. (CHR). 43-171: Mt. Peel, Lynn Stream (-BB), 15.i.1985. Mayrhofer \& Molloy 4821 (GZU). 44-167: Fiordland, north of Homer Tunnel, Esperance Valley (DB), iii.1974. Atkinson s.n. (CHR). 44-168: Ailsa Mountains, Ocean Peak (-CC), 4.i.1936. Zotov s.n. (CHR). 45-166: Dusky Sound, Cooper Island, Sportmans Cove (-DB), 7.ii.1946. Allan s.n. (CHR); Dusky Sound, Pickersgill Harbour to Lake Forester (-DC), 3.i.1969. Dorizac s.n. (CHR). 45-167: Caswell Sound, Leslie Clearing (-AA), 30.iii.1949. Zotov s.n. (CHR); Caswell Sound, Large Burn (-AB), 02.iv.1949. Zotov s.n. (O); Doubtful Sound, Hall's Arm [Hall Arm] (-AC), 31.xii.1939. Cranwell \& Moore s.n. (CHR). 45-168: Eyre Mountains, upper part of Matuara River (-BC), 23.xi.1972. Given 72999 (CHR). 45170: Dunedin, Mt. Maungatua (-CC), 23.iii.2000. Venter 13812 (CHR); Dunedin, Swampy Hill (-CD), 25.i.1948. Allan. s.n. (CHR); Dunedin (-DC), iv.1874. Berggren s.n. (W). 46166: Puysegur Point (-BA), 26.i.1946. Allan s.n. (CHR). 46-167: The Hump (-AB), Richardson s.n. (AK). 46-168: Invercargill, Awarua Plains (-DA), 7.i.1974. Johnson s.n. (CHR). 46-169: Near Mokoreta, Slopedown Range, Catlins State Forest Park (-AC), 7.i.1994. Sykes 37/94 (AK, CHR). STEWART ISLAND: 46-167: East coast of Codfish Island (-DC), 8.xii.1966. Ritchie s.n. (CHR); Mason Bay (-DD), i.1940. Attwood s.n. (AK). 
46-168: NW of Oban (-CC), 20.ii.1935. Doore \& Earle 330 (S); Off Ulva Island, Tamahau [Tamihau] Island, 7.ii.1957. Gillham s.n. (CHR). Christmas Village (-DD), 11.i.2000. Venter 13787 (CHR). 47-167: Big South Cape Island [Long Island] (-AB), 9.iv.1961. Bell s.n. (CHR); Open country head of Basin Creek (-BA), 21.ii.1966. Wardle s.n. (CHR). CAMPBELL ISLAND: 52-169: Camp Cove (-DB), 6.i.1961. Godley s.n. (CHR); Tucker Cove, 14.i.1961. Zotov s.n. (CHR). AUCKLAND ISLAND: 50-166: Mount Eden, (-CA), 28.xii.1962. Godley s.n. (CHR); Above Terror Cove, ii.1976. Given 9459 (CHR); Crest of scarp above Lake Hinemoa, 20.ii.1985. Meurk s.n. (CHR); Ranui Cove (-CB), 11.viii.1944. Turbott s.n. (AK).

7. Oreothamnus marmoricola (S. Venter) S. Venter

Oreothamnus marmoricola (S. Venter) S. Venter comb. nov. Venter, N.Z. Journ. of Bot. 40(1): 39 (2002); Eagle, Trees \& Shrubs N.Z. $2^{\text {nd }}$ ed. : 296 (1982). Type: New Zealand, Kahurangi National Park, Mt. Arthur, Horseshoe Basin. 02.i.1999. Venter 13739 (CHR, holo.!; AK, K, NSW, P, WELT).

= Dracophyllum marmoricola S. Venter, N.Z. Journ. of Bot. 40 (1): 39-43. (2002).

Icones: Eagle, Trees \& Shrubs N.Z. $2^{\text {nd }}$ ed. : t.152 (1982); Smith-Dodsworth, N.Z. Native Shrubs and Climbers. : 34; Venter, N.Z. Journ. of Bot. 40 (1): t. 1 \& 2 (2002).

\section{Description}

Decumbent to prostrate multi-stemmed shrublet $2-15 \mathrm{~cm}$ tall, plants sometimes form compact cushions. Branches: bark on old branches grey, smooth to finely fissured, 
young branches reddish brown. Leaves crowded at the tips of branches, spreading, glaucous; lamina sheath $2.2-6.5 \times 3-4 \mathrm{~mm}$, shoulders rounded to truncate, margin membranous, ciliate or with upper half ciliate; lamina linear-triangular to broadly lineartriangular, $5.6-32.0 \times 0.75-2.00 \mathrm{~mm}$, slightly concave, surfaces minutely verrucose, margins serrulate with 12-13 teeth per $10 \mathrm{~mm}$; apex triquetrous. Inflorescence a terminal spike; overtopping the leaves, erect, dense, 9-24 mm long, oblong. inflorescence bracts overtopping flowers, subulate, 1.5-2.0 $\times(0.6-) 1.2-1.4 \mathrm{~mm}$, surfaces verrucose, margins serrulate. Flowers 3-8, sessile; flower bracts shorter than flowers, broadly ovate, $5-6 \times 3.0$ $3.5 \mathrm{~mm}$, surfaces glabrous, margins ciliate, apices subacute to acute. Sepals green to reddish brown, ovate-lanceolate, $4.5-5.0 \times 1.5-2.0 \mathrm{~mm}$, equal to shorter than corolla tube, surfaces glabrous; margins ciliate; apices subacute to acute. Corolla white; corolla tube cylindrical, widened at mouth, $4.0-6.5 \times 2.0-2.5 \mathrm{~mm}$; corolla lobes spreading to reflexed, ovate-triangular to broadly triangular, shorter than corolla tube, 1.5-2.2 $\times 1.5-$ $1.8 \mathrm{~mm}$, apices acute to subacute; adaxial surface papillate, abaxial surface glabrous. Stamens inserted in corolla tube in the upper third, filaments $0.4-0.5 \mathrm{~mm}$ long; anthers included, oblong, light yellow and 0.6-0.8 mm long. Ovary obovate, 1.4-1.5 × 1.3-1.5 $\mathrm{mm}$, apex truncate; nectary scales rectangular, $0.7-0.8 \times 0.4-0.8 \mathrm{~mm}$, apices truncate and emarginate to variously toothed; style included, 1.3-1.5 mm long, glabrous; stigma 5lobed. Fruit sessile, light brown, 2.5-3.5 × 1.8-2.0 mm, obovoid, apex truncate, glabrous. Seeds light brown, ovoid, 0.7-1.0 mm long, testa slightly reticulate. Flowering December-March. (Figure 7.93).

\section{Diagnostic features and notes}

Oreothamnus marmoricola is characterized by the decumbent to prostrate branches forming cushions; lamina sheath $2.2-6.5 \times 3-4 \mathrm{~mm}$ with rounded to truncate shoulders; leaves glaucous, surfaces rugose, $5.6-32 \times 0.75-2.00 \mathrm{~mm}$; $12-13$ teeth per $10 \mathrm{~mm}$; inflorescence 


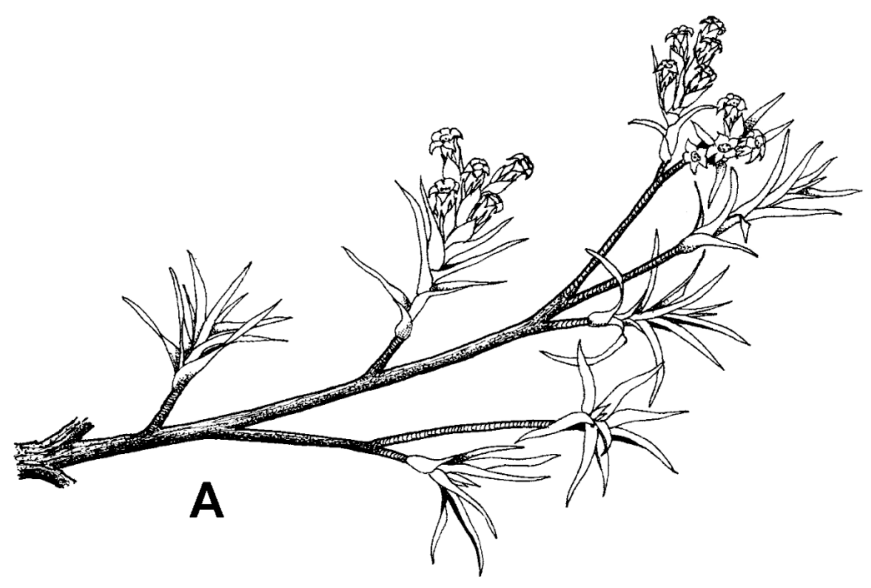

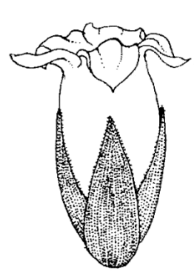

$\mathbf{B}$

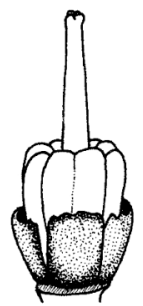

E

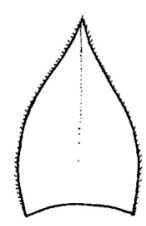

C

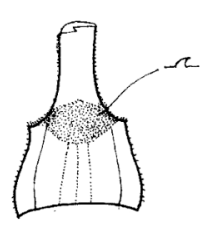

$\mathbf{F}$

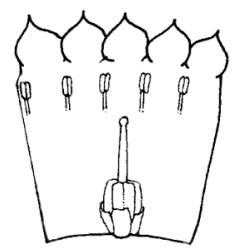

D

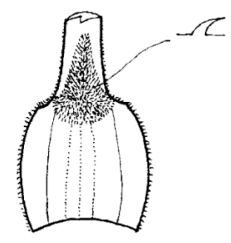

F

Figure 7.93. Oreothamnus marmoricola. A, flowering branch $(\times 1)$; B, flower $(\times 5)$; C, flower bract $(\times 5)$; $\mathbf{D}$, laid out flower $(\times 5)$; $\mathbf{E}$, ovary $(\times 10) ; \mathbf{F}$, lamina sheaths to show variation $(\times 5)$. Drawn from Venter 13739 . 



Figure 7.94. Oreothamnus marmoricola. A, alpine habitat at the type locality on Mt. Arthur; B, plants forming dense cushions on the slopes of Mt. Arthur; C, flowering plant from the type collection; $\mathbf{D}$, plant showing the dense carpet growth habit. $\mathbf{E}$, fruiting branch; F, SEM micrograph of a pollen tetrad; G, SEM micrograph of the epicuticular wax on the adaxial lamina surface. B-G. Venter 13739. 
terminal on branches, dense and oblong, 9-24 mm long; inflorescence bracts verrucose; corolla tube shorter than sepals, $4.0-6.5 \times 2.0-2.5 \mathrm{~mm}$; corolla lobes spreading to reflexed; ovary apex truncate.

Oreothamnus marmoricola is similar to O. recurvus in the dense oblong apical racemes and broad flower bracts but differs in the leaves having far less teeth (12-13) per $10 \mathrm{~mm}$ on the lamina margin and the leaf apices not recurved. The flower bracts are also shorter than the flowers, flower bracts glabrous and the ovary with a truncate apex. Oreothamnus marmoricola superficially resembles $O$. kirkii.

\section{Distribution}

Endemic to the north-west Nelson area of the South Island, New Zealand (Fig. 7.95). All known localities are in the Kahurangi National Park.

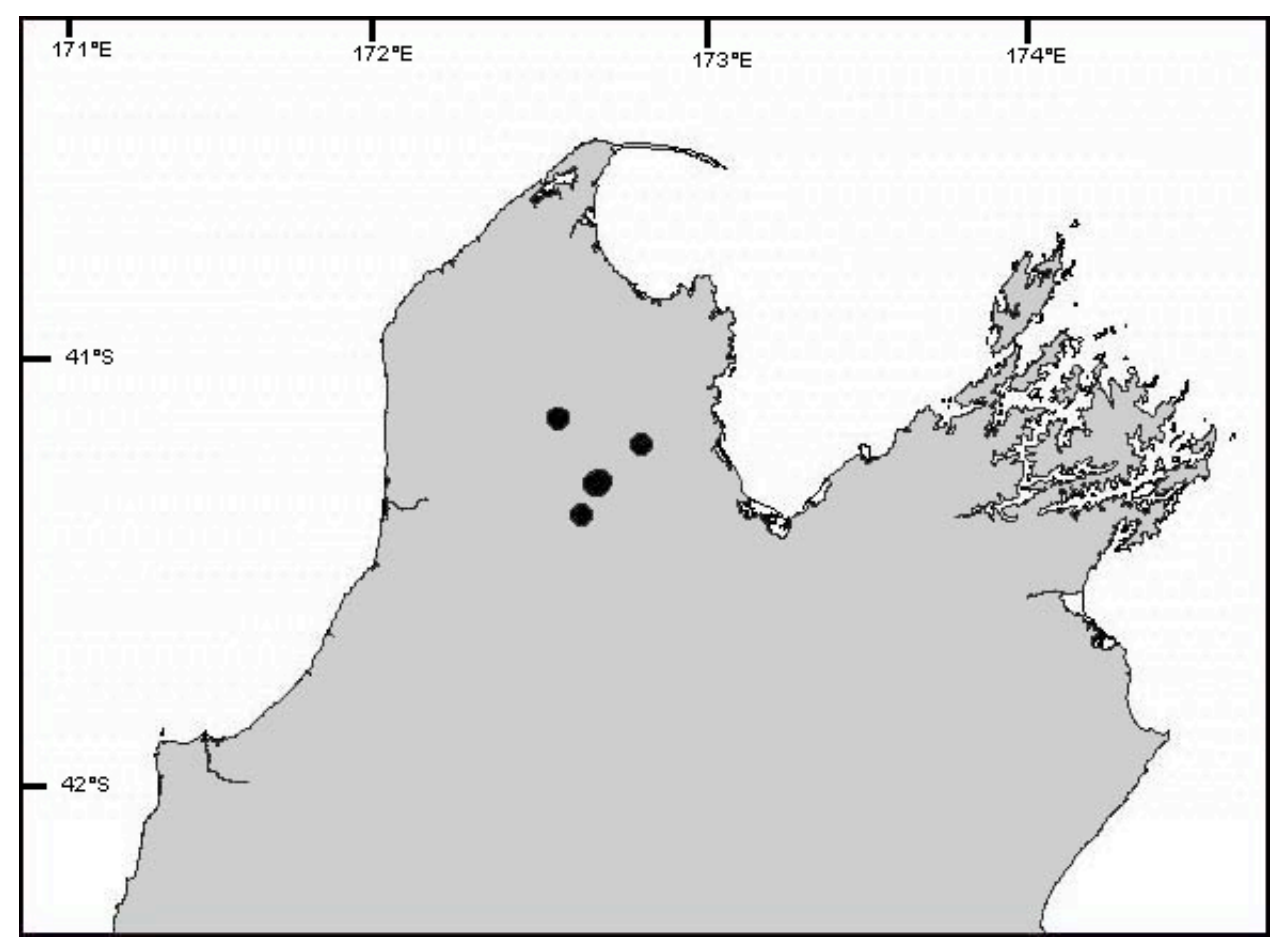

Figure 7.95. Known distribution of Oreothamnus marmoricola, South Island, New Zealand. 


\section{Habitat}

Oreothamnus marmoricola occurs on high mountain slopes and peaks at $1310-1790 \mathrm{~m}$ above sea level. It grows on dark sandy loam soil in open exposed sites or in rock crevices in low cliffs in alpine tussock-herbfield and grassland (Table 7.38). Marble plays an important role in the distribution of calcicoles in New Zealand and Druce et al. (1987) mentioned Oreothamnus marmoricola (as Dracophyllum sp. (a)) as a weak calcicole but according to the results of my survey it acts as a strong calcicole, restricted in distribution to shallow soils on marble of the Mount Arthur Group (Druce et al 1987, Venter 2002). The substrate specificity of $O$. marmoricola is as striking as that of $=$ Hebe calcicola (Bayly et al. 2001). All O. marmoricola populations are covered by snow during winter, yet none of the plants show the typical red coloration of the leaves during winter that is so common for most Dracophyllum and Oreothamnus species in New Zealand.

Table 7.38. Plant associations commonly associated with Oreothamnus marmoricola.

\begin{tabular}{|c|}
\hline HERBLAND \\
\hline Low open evergreen Veronica albicans - Pimelea traversii - Coprosma depressa herbland \\
\hline GRASSLAND \\
\hline Tall open Chionochloa - Aciphylla aurea - Veronica albicans grassland \\
Low open Chionochloa - Aciphylla aurea - Ranunculus insignis grassland \\
\hline
\end{tabular}

O. marmoricola is associated with Veronica albicans, Aciphylla aurea, Luzula picta var. picta, Oreothamnus rosmarinifolius, Ranunculus insignis, Coprosma depressa, Leucopogon fraseri, Wablenbergia pygmaea and Pimelea traversii.

\section{Variation}

On rock sheets with little soil, plants of O. marmoricola grow as compact cushions whereas plants hanging down from cliffs can have branches up to $35 \mathrm{~cm}$ long. Plants on moderately flat areas in rock rubble grow as extensive mats sometimes covering areas up 
to $100 \mathrm{~cm}$ in diameter. The length and width of the leaf sheath is very variable even on a single branch. Most plants have leaves 5.6-15.0 $\mathrm{mm}$ long but those in sheltered areas are usually 18-32 $\mathrm{mm}$ long and greener. Plants in protected areas receiving more shade tend to have erect-spreading stems up to $200 \mathrm{~mm}$ long with somewhat larger and greener leaves.

\section{Material studied}

NEW ZEALAND. South Island. 41-172: Mt. Benson, near Ruby Lake (-BA), Druce s.n. (CHR); Lockett Range, rocks above Ruby Lake, Druce s.n. (CHR); Mt. Arthur, i. 1982. Druce s.n. (CHR); ibid., i.1975. Druce s.n. (CHR); Mt. Arthur, ridge to summit (-BC), 16.i.1975. Simpson 7507 (CHR). 41-172: Mt. Hoary Head (-BB), xii.1980. Druce s.n. (CHR).

11. Oreothamnus minimus (F. Muell.) S. Venter

Oreothamnus minimus (F. Muell.) S. Venter, comb. nov. Hooker, Fl. Tas. 2: 367 (1860); Mueller, Frag. Phytogr. Austr. 6: 65 (1864); Bentham, Fl. Austr. 4: 265 (1869); Oliver, Trans. Proc. N.Z. Inst. 59: 685 (1928); Oliver, Trans. Roy. Soc. N.Z. 80 (1): 3 (1952); Curtis, Student's Fl. of Tasmania 2: 461 (1963); Gray, Austr. Plants 5: 208 (1969). Type: Australia, Tasmania, In tergo alpino montis Lapéyrouse pulvinis Pterygoppi Lawrencii innatum. $A$. Oldfield s.n. (MELB 2064413, holo.!).

$\equiv$ Dracophyllum minimum F. Muell., Frag. Phytogr. Austr. 1: 39 (1858).

Icon: Oliver, Trans. Proc. N.Z. Inst. 59: 685, t. 1 (1928). 


\section{Description}

Forming a compact cushion, 3-16 cm tall and 30-90 cm in diameter. Branches erect stemmed, many-branched and closely packed. Bark on old branches reddish brown, smooth, young stems yellowish brown. Leaves spirally arranged along branches, imbricate, appressed to stem, olive green, dry old leaves present; lamina sheath 2.0-3.5 $\times$ 2-3 mm, tapering and margin membranous and ciliate; lamina coriaceous to rigid and hard, linear to linear-triangular, $2-3 \times 0.7-2.0 \mathrm{~mm}$, adaxial surface flat, abaxial surface with a prominent keel, surfaces glabrous; margins serrulate with 40-60 (-80) teeth per 10 $\mathrm{mm}$; apex triquetrous, acute. Inflorescence a terminal solitary, erect, sessile flower, shorter than the leaves; inflorescence bract equaling flower, rigid and hard, dark green, ovatelanceolate, $4.0-4.5 \times 1.3-1.5 \mathrm{~mm}$, margins serrulate. Sepals lanceolate, 4-6 × 2.7-3.0 $\mathrm{mm}$, equaling corolla tube; margins ciliate in upper half. Corolla white; corolla tube cylindrical, (3-)4-6 × 1.4-1.5 mm; corolla lobes spreading horizontally to sometimes reflexed, ovate-triangular, shorter than corolla tube, $1.5-3.0 \times 1.5-3.5 \mathrm{~mm}$, apices obtuse; margin erose; apical ridge present; adaxial surface papillate. Stamens inserted in corolla in middle of the tube, filaments $0.8-1.0 \mathrm{~mm}$ long; anthers included, oblong, deep yellow and 0.6-1.0 mm long. Ovary ovate, $0.9-1.0 \times 1.0-1.2 \mathrm{~mm}$; apex round; nectary scales rectangular, $0.8-1.0 \times 0.4-0.5 \mathrm{~mm}$, apices bidentate to irregularly toothed; style included, 1.0-1.5 mm long, glabrous, not lengthening in fruit; stigma five-lobed. Fruit light brown to reddish brown, 1.5-2.0 $\times 2-3 \mathrm{~mm}$, obovoid; apex round, glabrous. Seeds dark brown, ovoid, 0.55-0.6 mm long, testa slightly reticulate. Flowering JanuaryFebruary. (Figure 7.96). 

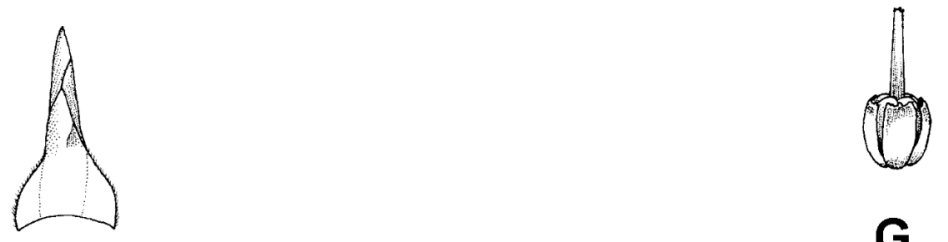

$\mathbf{F}$

G

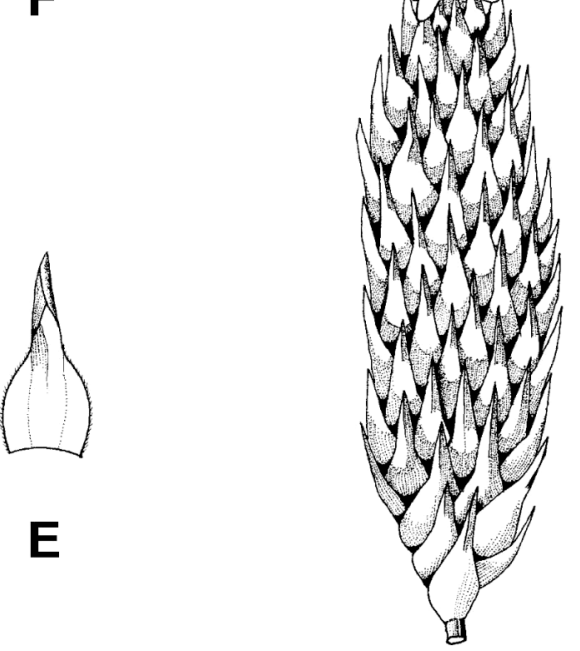

A

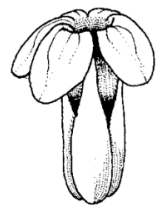

H
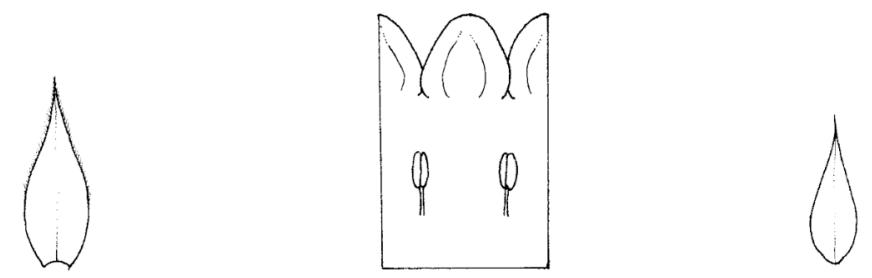

D

C

$\mathbf{B}$

Figure 7.96. Oreothamnus minimus. A, flowering branch $(\times 4)$; $\mathbf{B}$, inflorescence bract $(\times 5)$; $\mathbf{C}$, laid out corolla $(\times 5) ; \mathbf{D}$, sepal $(\times 5) ; \mathbf{E}$ and $\mathbf{F}$, leaves to show variation in leaf sheaths $(\times 5)$; G, ovary $(\times 10) ; \mathbf{H}$, flower $(\times 5)$. Drawn from Jarman 134. 

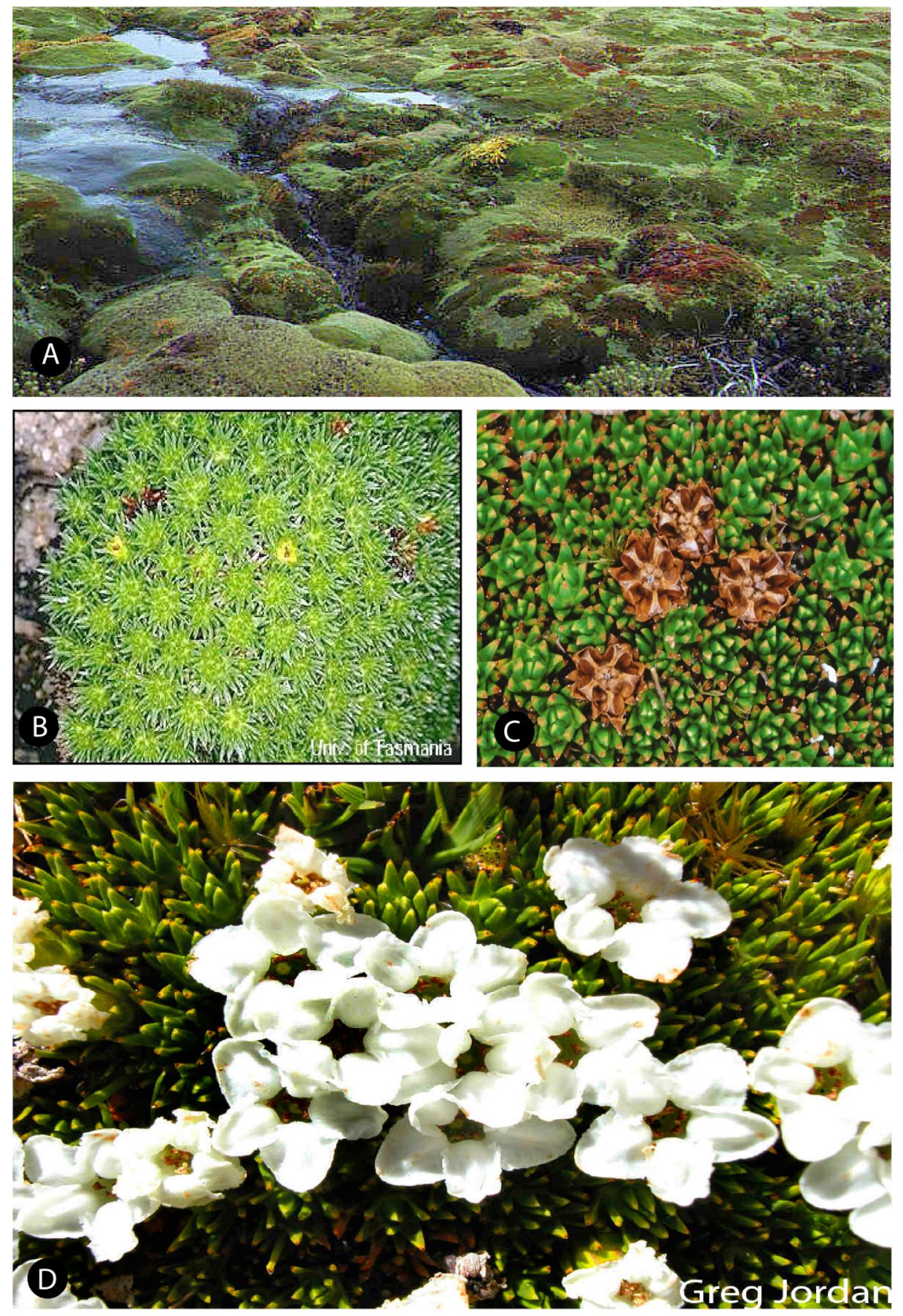

Figure 7.97. Oreotbamnus minimus. A, habitat in Mt. Field National Park; B, Mature plant showing the dense growth of the leaves; $\mathbf{C}$, dehisced capsules; $\mathbf{D}$, flowers showing the horizontal petals with the broad apical ridge. 


\section{Diagnostic features and notes}

Oreothamnus minimus is characterized by its cushion growth habit; branches tightly packed; leaves closely appressed to the stems and 5.0-6.5 $\times 0.7-2.0 \mathrm{~mm}$; flowers solitary on the apices of branches with 4-6 mm long corolla tubes and the nectary scales as long as the ovary.

Oreothamnus minimus is similar to O. muscoides in the growth habit and solitary erect flowers that do not exceed the leaves in length but differs in leaf and flower characters (Table 7.39).

Table 7. 39. Morphological differences between O. minimus and O. muscoides.

\begin{tabular}{|l|l|l|}
\hline \multicolumn{1}{|c|}{ Character } & \multicolumn{1}{|c|}{ O. minimus } & \multicolumn{1}{c|}{ O. muscoides } \\
\hline Lamina width & $0.7-2.0$ & $0.6-0.8$ \\
Lamina apex shape & acute to triquetrous & $\begin{array}{l}\text { obtuse } \\
5-10\end{array}$ \\
Teeth per 10 mm on lamina margin & $40-60$ & $5-10$ \\
Flower grouping on inflorescence branch & $>10$ & $1.5-2.0$ \\
Sepal width (mm) & $2.7-3.0$ & narrowly campanulate \\
Corolla tube shape & cylindrical & smooth \\
Corolla lobe adaxial surface & papillate & $0.2-0.5$ \\
Filament length (mm) & $0.8-1.0$ & $0.2-0.5$ \\
Ovary length (mm) & $0.9-1.0$ & $0.8-1.0$ \\
Style length (mm) & $1.0-1.5$ & \\
\hline
\end{tabular}

Because of the densely packed leaves, the branches inside are protected from wind and snow and the core of the plant retains a fairly constant temperature. This form of growth is useful in coping with harsh conditions experienced at higher altitudes (Corbett 1995). 


\section{Distribution}

Endemic to the subalpine and alpine areas in the central plateau and western mountains of Tasmania with a single distant locality in the north-eastern areas (Fig. 7.98).

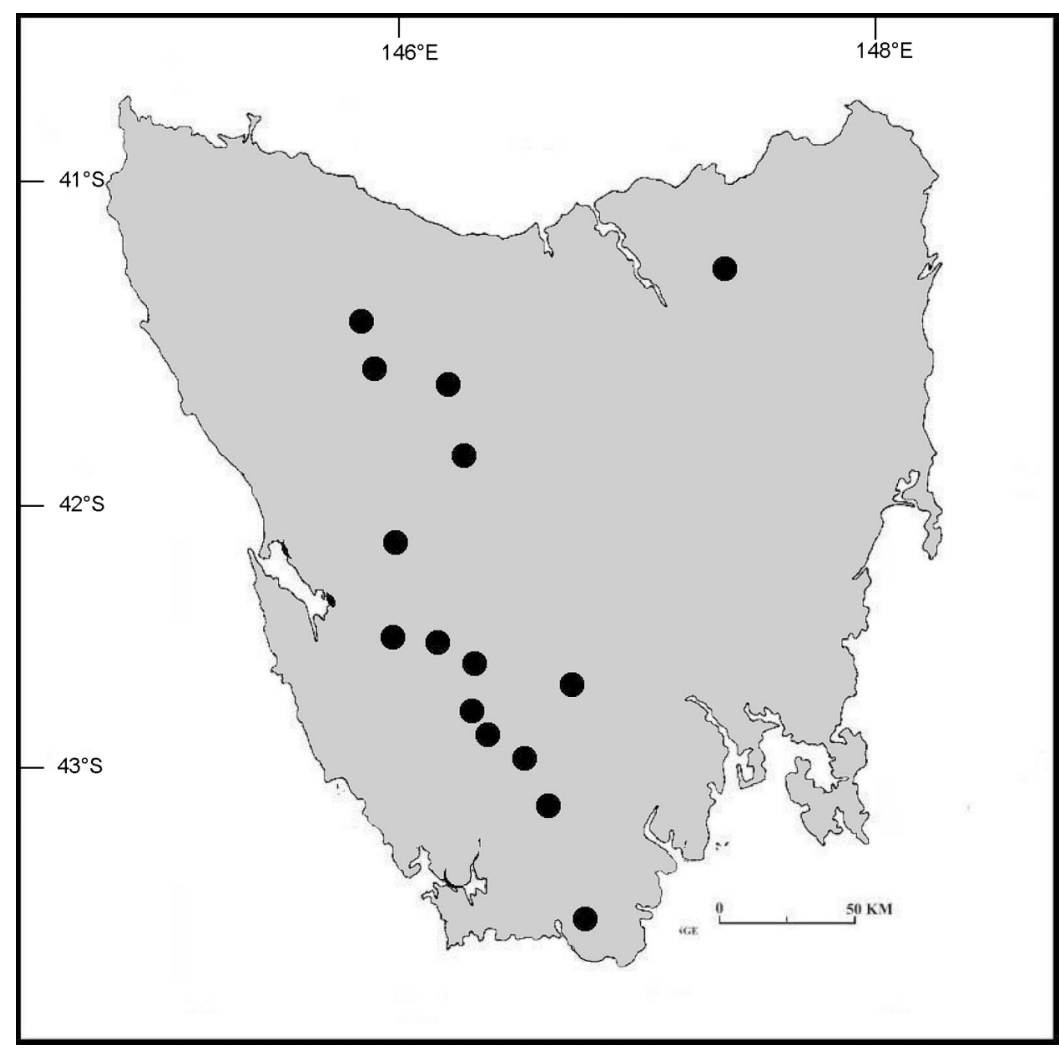

Figure 7.98. Known distribution of Oreothamnus minimus.

\section{Habitat}

Oreothamnus minimus occurs above the tree line on gentle $\left(0^{\circ}-15^{\circ}\right)$ mountain slopes and on mountain plateaus from $300-1,615 \mathrm{~m}$ altitude, especially in areas covered in snow during the winter months. Oreothamnus minimus experiences snow conditions and long periods of low temperatures with many populations in the bolster heath vegetation under snow for extended periods. It is restricted to subalpine and alpine grassland, heathland and cushion-herbfield (bolster heathland) (Table 7.40). It grows on poorly drained soil, 
mostly in shallow peat or peat over olive brown clay which is derived from dolerite. Plants are fully exposed with the habitat receiving up to 2,600 $\mathrm{mm}$ of rain per annum with added moisture from mist and melting snow.

Table 7.40. Plant associations commonly associated with Oreothamnus minimus.

\section{Variation}

Oreothamnus minimus is a very distinct species that shows little variation. There is some variation in the width of the leaf sheath $(2-3 \mathrm{~mm})$, in the corolla tube (4-6 mm long) and the corolla lobes $(1.5-3.0 \times 1.5-3.5 \mathrm{~mm})$.

\section{Material studied}

AUSTRALIA, Tasmania. 41-145: Cradle Mountain (-DB), 28.i.1949., Vickery s.n. (HO); Eldon Bluff, summit plateau (-DD), 1987., Buchanan 10010 (HO); 41-146: Top of Mt. Ossa (-CC), Davies 72 (HO). 42-145: Mt. Rufus, near Lake St. Clair (-AA), 15.xii.1917., Rodway s.n. (HO); Near summit of Mt. Rufus, 1983., Buchanan 1157 (HO); Frenchmans Cap (-BD), 20.xii.1978., Jarman s.n. (HO). 42-146: Between Reeds Peak and Great Dome, Denison Range (-CB), 1993. Buchanan 12992 (HO); Mt. Cullen, summit area (CC), 1986., Moscal s.n. (HO); Double Peak, 1978., Jarman s.n. (HO); Mt. Eliza (-CD), 1985., Moscal 9543 (HO); Mt. Field National Park, Tarn Shelf above Lake Seal (-DA), 1928. Comber s.n. (HO); Snowdrift Tarns, Snowy Range (-DC), 1983., Moscal 2167 (HO); 43-145: Mt. Maconochie (-AA), 1978., Jarman s.n. (HO); Southeast base of Mt. Sarah Jane (-AB), 1978., Brubl 633 (HO); Abrotanella Rise (-BA), 1998., Buchanan 15170 (HO);

Between Mt. La Perouse and Maxwell Ridge (-BC), 1984., Buchanan s.n. (HO); Moonlight 
Ridge (-BD), 1984., Buchanan 3060 (HO); Mt. La Perouse (-DA), 15.xii.1895., Rodway s.n. (HO, NSW).

12. Oreothamnus muscoides (Hook. f.) S. Venter

Oreothamnus muscoides (Hook. f.) S. Venter, comb. nov. Armstrong, Trans. Proc. N.Z. Inst. 13: 342 (1881); Buchanan, Trans. Proc. N.Z. Inst. 14: 346 (1882); Cheeseman, Man. N.Z. Fl: 428 (1906); Cheeseman, Man. N.Z. Fl. $2^{\text {nd }}$ Ed:: 710 (1925); Oliver, Trans. Proc. N.Z. Inst. 59: 685 (1928); Oliver, Trans. Roy. Soc. N.Z. 80 (1): 2 (1952); Allan, Fl. N.Z. 1: 524 (1961); Eagle, Trees \& Shrubs of N.Z. $2^{\text {nd }}$ series.: 296 (1982); Mark \& Adams, N.Z. Alpine Plants.: 118 (1986). Type: New Zealand, Alps of Otago, Mt. Alta and Hector's Col, 7,000 - 8,000', 1864. J. Hector \&J. Buchanan s.n. (K, holo.!).

The type sheet comprises three different collections made by different people and at different localities. The specimens in the top left hand corner of the sheet are the Hector and Buchanan material and I determined it as such. Plants of this species are small and all eight pieces form the type material (ICBN-Article 8.1).

=Dracophyllum muscoides Hook. f., Handb. N.Z. Fl.: 183 (1864).

Icones: Buchanan, Trans. Proc. N.Z. Inst. 14: t. 26 (1882); Eagle, Trees \& Shrubs of N.Z. $2^{\text {nd }}$ series.: t. 150B (1982); Smith-Dodsworth, N.Z. Native Shrubs \& Climbers.: tt. 51 \& 52, Pl. 22A \& 22B (1991). 


\section{Description}

Compact cushions, 15-50 mm tall. Branches erect stemmed and much-branched, closely packed together. Bark on old branches greyish brown, deeply fissured, young stems reddish brown. Leaves spiralling along branches, imbricate, appressed to stem, dry old leaves present; lamina sheath light green, 1.5-3.0 mm long and wide, tapering and margin membranous, ciliate. lamina coriaceous to rigid and hard, mid to olive green, linear to linear-triangular, $1-3 \times(0.3-) 0.6-0.8 \mathrm{~mm}$; margins serrulate with $5-10$ teeth per $10 \mathrm{~mm}$ (only the front third of leaf with teeth); apex thickened, obtuse and keeled. Inflorescence a terminal, erect, sessile, solitary flower; shorter than the leaves. inflorescence bract shorter than flower, ovate-lanceolate, 3.3-3.5 × 1.5-2.0 mm; margins serrulate; apex obtuse. Sepals ovate-lanceolate, $(1.5-) 3.5-4.5 \times 1.5-2.0 \mathrm{~mm}$, equaling corolla tube; margins ciliate; apices subacute to obtuse. Corolla white; corolla tube narrowly-campanulate, 2.0$4.5 \times 1.5-3.5 \mathrm{~mm}$; corolla lobes spreading horizontally, ovate-triangular, shorter than corolla tube, 1,0-1.5 mm long and wide, apices obtuse; apical ridge present; inflexed for the entire length; surfaces glabrous. Stamens inserted on corolla tube in the upper third, filaments $0.2-0.5 \mathrm{~mm}$ long; anthers included, oblong, initially pink turning light yellow and 0.8-1.0 mm long. Ovary ovate, $1.4-1.5 \times 1.3-1.4 \mathrm{~mm}$, apex round; nectary scales rectangular, $0.5-0.9 \times 0.5-0.7 \mathrm{~mm}$; apices retuse to irregularly toothed; style included, 0.8-1.0 mm long, glabrous, not lengthening in fruit; stigma five-lobed. Fruit light brown, 1.0-1.1 $\times$ 0.8-1.0 mm, depressed-globose; apex truncate, glabrous. Seeds yellowish brown, ovoid, 0.5-0.6 mm long, testa slightly reticulate. Flowering December-May. (Figure 7.99). 


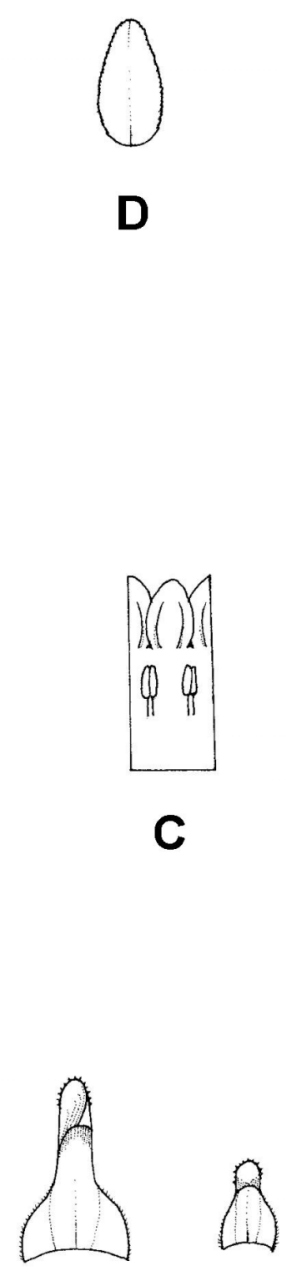

B

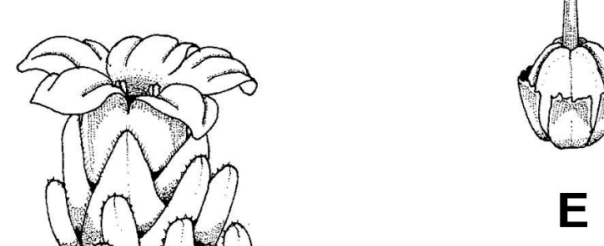

$\mathbf{E}$

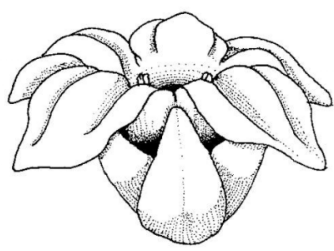

$\mathbf{F}$

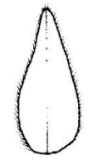

G

Figure 7.99. Oreothamnus muscoides. A, flowering branch $(\times 5)$; $\mathbf{B}$, leaves to show the variation in the lamina sheath $(\times 5)$; $\mathbf{C}$, laid out corolla $(\times 5)$; $\mathbf{D}$, inflorescence bract $(\times 5)$; E, ovary $(\times 10)$; F, flower $(\times 10)$; G, sepal (× 5). Drawn from Garnock-Jones 2366. 


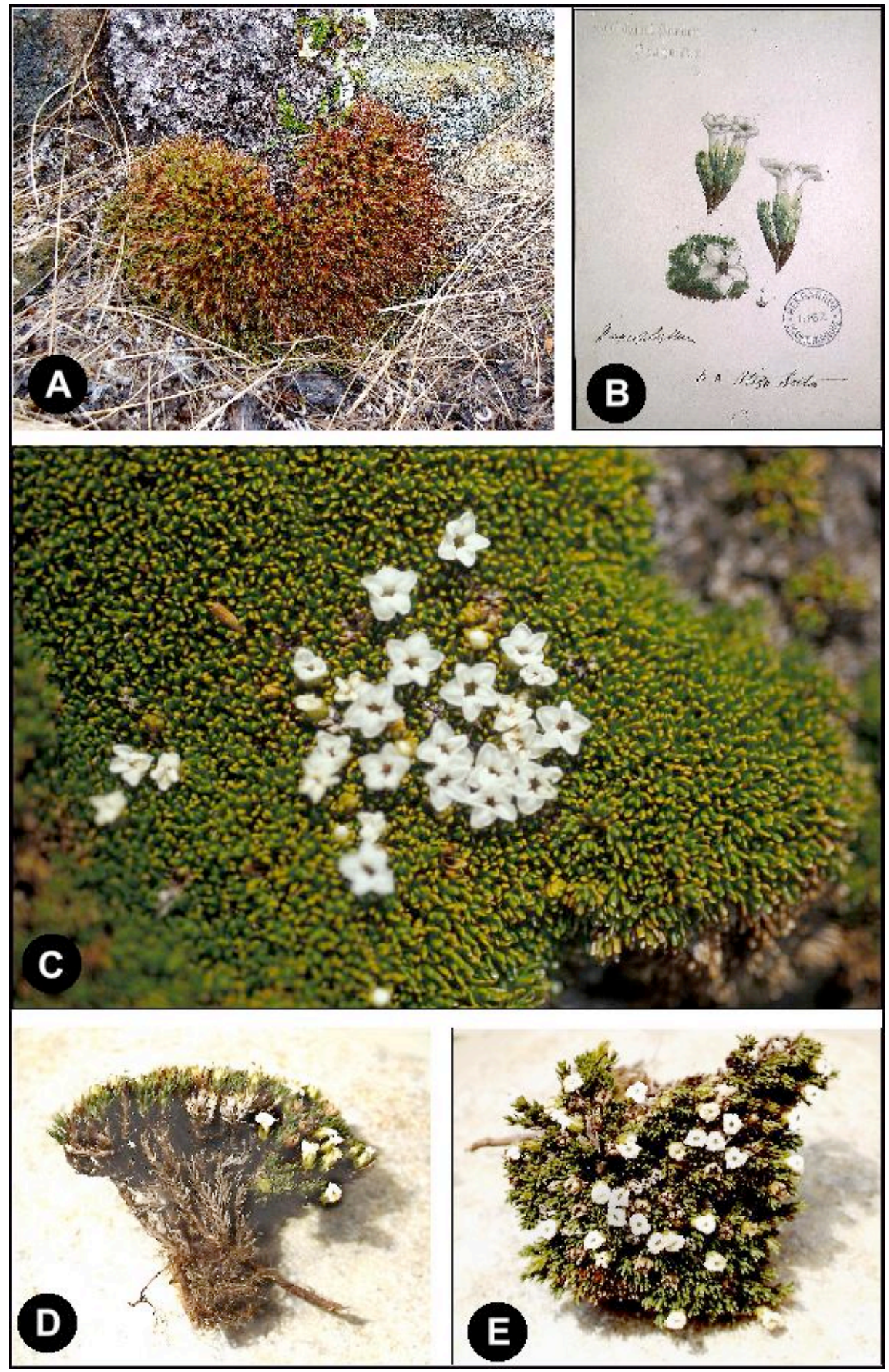

Figure 7.100. Oreothamnus muscoides. A, mature plant from Mt. Dobson near Lake Tekapo; B, watercolour of a plant from the type locality housed at CHR; C, flowering specimen showing apical ridges on petal lobes; $\mathbf{D}$ and $\mathbf{E}$, flowering plant from the Garvie Mountain. D-E, Garnock-Jones 2366. 


\section{Diagnostic features and notes}

Oreothamnus muscoides is characterized by the cushion growth habit; leaves closely imbricating and $1-3 \times(0.3-) 0.6-0.8 \mathrm{~mm}$, widening suddenly into a broad sheath (1.5-3.0 $\mathrm{mm}$ ); flowers solitary and situated at the apices of the stems, sepals (2.5-)3.5-4.5 mm long and the corolla tube $2.0-2.5 \mathrm{~mm}$ long.

According to Oliver (1928) its nearest ally is O. prostratus, but it is denser and the leaves much smaller. There is a note by Cheeseman (1906) that O. muscoides and O. minimus are placed together in the Index Kewensis. However, he noted the difference between the two species after receiving a piece of material from Baron von Mueller from Australia. The type sheet comprises of three different collections made by different people and at different localities. The specimens in the top left-hand corner of the sheet are the Hector and Buchanan material. This is a small species and all eight pieces form the type material according to Article 8.1 of the ICBN (Greuter et al. 1994).

Armstrong (1881) mentioned that the corolla is pubescent with the lobes scarcely spreading but no material of Oreothamnus with a pubescent corolla is known from New Zealand or Tasmania.

O. muscoides is similar to Oreothamnus prostratus but differs in the many erect-stemmed branches, deeply fissured bark and fewer (5-10 compared to 10-40) teeth per $10 \mathrm{~mm}$ on lamina margin. The flowers are also shorter than the leaves, sepals equaling the corolla tube and the corolla tube shorter $(2.0-2.5 \mathrm{~mm}$ compared to $3.0-4.5 \mathrm{~mm})$ and narrowly campanulate. The corolla lobes are mostly horizontal and the ovary ovate and wider (1.3$1.4 \mathrm{~mm}$ compared to $1.0-1.5 \mathrm{~mm})$. 


\section{Distribution}

Endemic to the South Island of New Zealand (Fig. 7.101). From Mount Hercules in the north southwards to the Princess Mountains.

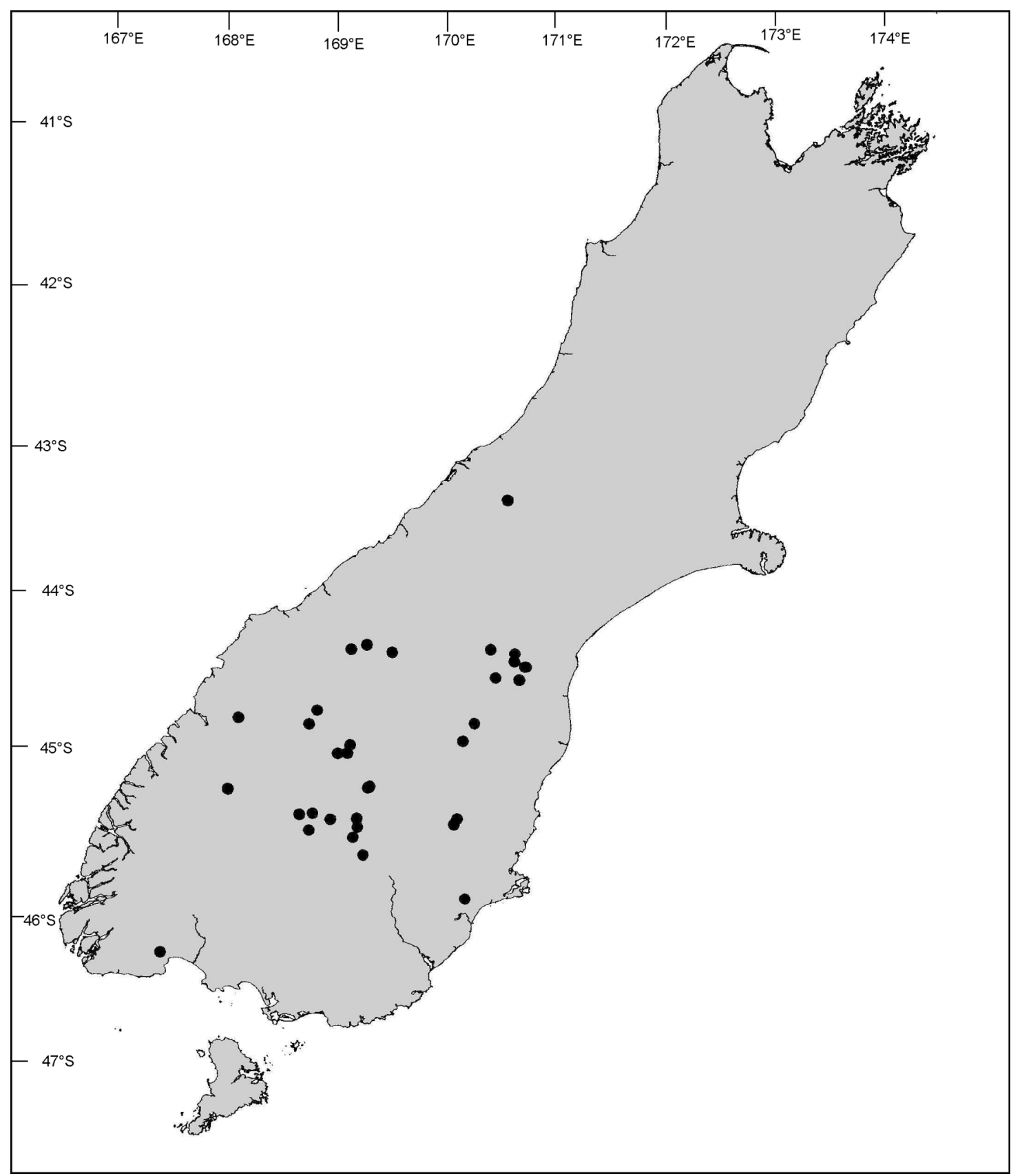

Figure 7.101. Known distribution of Oreothamnus muscoides. 


\section{Habitat}

Oreothamnus muscoides grows on gentle $\left(2^{\circ}-10^{\circ}\right)$ mountain slopes and mountain tops at altitudes of $914-2,600 \mathrm{~m}$. The vegetation consists of subalpine cushion herbfield, grassland to alpine bog, fellfield and boulderfield (Table 7.41). Soils are commonly boggy otherwise loam or clay loam derived from greywacke and shale. Plants are fully exposed to severe climatic conditions receiving moisture from rain, mist and melting snow.

Table 7.41. Plant associations commonly associated with Oreothamnus muscoides.

\begin{tabular}{|l|}
\hline \multicolumn{1}{c|}{ GRASSLAND } \\
\hline Low closed Chionochloa rigida grassland \\
Low open Chionochloa macra - Oreothamnus pronus grassland \\
\hline
\end{tabular}

\section{Variation}

Variation in O. muscoides is mostly in the size of the lamina sheath (1.5-3.0 mm long), the lamina (1-3 mm long) and the corolla tube $(2.0-4.5 \times 1.5-3.5 \mathrm{~mm})$.

\section{Material studied}

NEW ZEALAND. South Island. 44-168: Harris Mountains, End Peak (-DB), 17.i.1950. McNeur s.n. (CHR); Lake Wanaka, Cattle Flat Station (-DD), 17.i.1950. Zotov s.n. (CHR); Mt. Cardrona. 29.iii.1921. Cockayne s.n. (AK). 44-169: Mt. St. Mary (-BC), 21.i.1940. Simpson s.n. (CHR); Pisa Range, Gordon's Rock [Gordon Rock] (-CC), 19.i,1947. Langbein 9/28 (CHR). 44-170: Ridge on east of Grampians from Hakataramea Pass (BC), 12.i.1961. Connor s.n. (CHR); Hunter Hills, Mount Nessing, 21.iii.1980. Given 12384 (CHR); The Hunter Hills, Mt. Nimrod summit (-BD), 19.iv.1979. Given 11687 (CHR); Awakino River, West Branch (-CD), 29.xi.1994. Wardle 96/78 (CHR). 45-168: Remarkables, Nevis side (-BB), 12.xii.1964. Sneddon s.n. (WELTU); Mt. Dick (-BC), 
29.i.xi.1995. Wardle 96/86 (CHR). 45-169: Alexandra - Old Man Range (-AC), 27.iii.1919. Cockayne s.n. (CHR); ibid., $1-2 \mathrm{~km}$ east of Obelisk. 26.xi.1988. SmithDodsworth s.n. (AK); Knobby Range near Pinelheugh (- AD), 25.v.1995. Patrick s.n. (CHR); Old Man Range, near Roxburgh (-CB), 17.i.1968. Elder \& Elder s.n. (CHR). 45170: Middlemarch - Rock and Pillar Range (-AC), 28.i.1985. Mayrhofer, Hertel \& Mark 4859 (GZU); ibid., 1.xii.1969. Macmillan 69/298 (CHR).

13. Oreothamnus oliveri (Du Rietz) S. Venter

Oreothamnus oliveri (Du Rietz) S. Venter, comb. nov. Oliver, Trans. Proc. N.Z. Inst. 59: 702 (1928); Simpson, Trans. Roy. Soc. N.Z. 75 (2): 191 (1945); Oliver, Trans. Proc. N.Z. Inst. 59: 702 (1928); Oliver, Trans. Roy. Soc. N.Z. 80 (1): 11 (1952); Allan, Fl. N.Z. 1: 533 (1961). Type: New Zealand, Mt. Rochfort, 1,800', 5.ii.1913. D. Petrie s.n. (WELT 33022, holo.!; WELT 33021!, WELT 33025!).

三Dracophyllum oliveri Du Rietz, Svensk. Bot. Tidskr. 24: 374 (1920).

Icones: Du Rietz, Svensk. Bot. Tidskr. 24: t. 24 (1920); Oliver, Trans. Proc. N.Z. Inst. 59: t. 7b. (1928); Oliver, Trans. Proc. N.Z. Inst. 59: t. 7b (1928).

\section{Description}

Erect to spreading single-stemmed small tree, 1-4 m tall. Branches: bark on old branches dark grey to dark brown, finely fissured, young stems reddish brown. Leaves juvenile and adult. Juvenile leaves spirally arranged, spreading to recurved; lamina sheath yellowish to light green, $6-9 \times 3.0-3.5 \mathrm{~mm}$; shoulders rounded to truncate and margin ciliate in upper half; 
lamina linear-triangular, $75-85 \times 1.3-1.5 \mathrm{~mm}$; surfaces glabrous, margins serrulate with 60-80 teeth per $10 \mathrm{~mm}$. Adult leaves crowded at tips of branches, spreading; lamina sheath 3.5-9.0 $\times 3-5 \mathrm{~mm}$, membranous; shoulders rounded to auricled, margin ciliate or only the top half ciliate; lamina linear to linear-triangular, $(30-) 50-75 \times(0.6-) 1.5-2.0 \mathrm{~mm}$; margins serrulate with (50-)80-100 teeth per $10 \mathrm{~mm}$; apex triquetrous and acute. Inflorescence a terminal raceme on lateral branchlets, shorter than leaves, erect, drooping later, dense, 17-24 mm long, oblong; inflorescence bract overtopping flowers, ovatelanceolate, $(0.6-) 13-20 \times 0.8-1.2 \mathrm{~mm}$; margins serrulate. Flowers 5-10, pedicellate; flower bract overtopping flowers, broadly ovate, $3.0-5.5 \times 2.0-3.5 \mathrm{~mm}$, with a tuft of scabrid hairs at base of adaxial surface; margins ciliate; pedicels straight, $0.3-0.5 \mathrm{~mm}$. Sepals ovate to triangular, (3-)5-6 $\times(1.3-) 4.5-5.5 \mathrm{~mm}$, equaling corolla tube, adaxial surface with the top half pubescent; margins ciliate. Corolla white turning light yellow with age; corolla tube cylindrical, widened at mouth, 3.0-4.5(-6.0) $\times 2.0-2.5 \mathrm{~mm}$; corolla lobes spreading horizontally to reflexed, broadly triangular, shorter than corolla tube, 1.5$2.0 \mathrm{~mm}$ long and wide; apex inflexed, acute; adaxial surface papillate. Stamens inserted on corolla tube in upper third; filaments $0.5-0.7 \mathrm{~mm}$ long; anthers included, oblong, light yellow, 0.6-0.8 mm long. Ovary ovate, $1.4-1.5 \times 1.3-1.5 \mathrm{~mm}$, apex round; nectary scales rectangular, 1.0-1.3(-1.5) × 0.6-0.8 mm; apices retuse; style included, 1.3-1.7 mm long, glabrous; stigma five-lobed. Fruit light to dark brown, 1.0-1.5 $\times 1.0-1.3 \mathrm{~mm}$, obovoid; apex round and glabrous. Seed yellowish brown, filiform, 0.95-1.2 $\mathrm{mm}$ long with a slightly reticulated testa. Flowering November-March (Figure 7.102). 


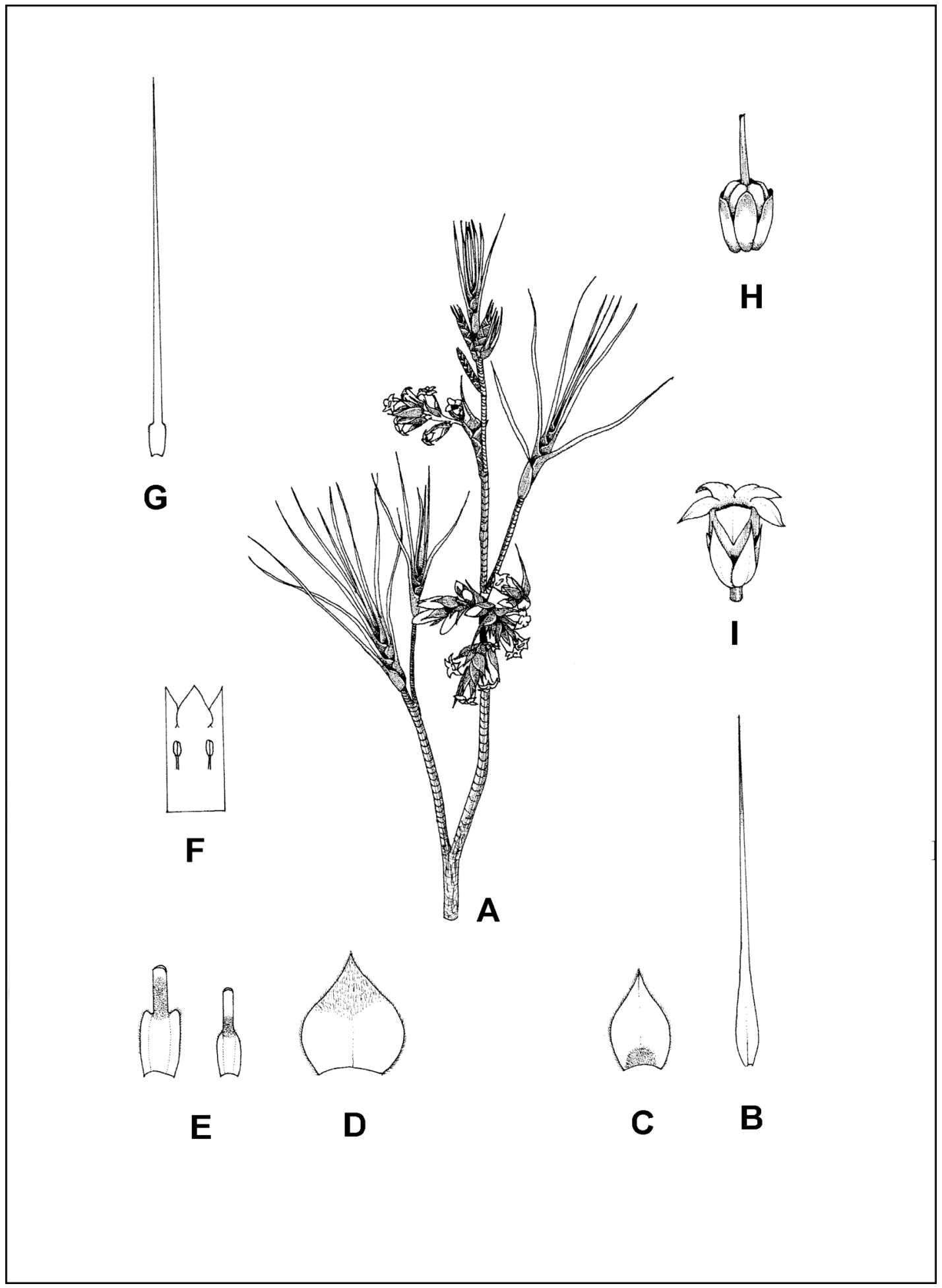

Figure 7.102. Oreothamnus oliveri. A, flowering branch $(\times 1)$; $\mathbf{B}$, inflorescence bract $(\times$ 5); C, flower bract adaxial surface $(\times 5)$; $\mathbf{D}$, sepal adaxial surface $(\times 5)$; E, lamina sheaths to show variation $(\times 2) ; \mathbf{F}$, laid out corolla $(\times 5)$; $\mathbf{G}$, leaf $(\times 1)$; $\mathbf{H}$, ovary $(\times 10)$; $\mathbf{I}$, flower $(\times 5)$. Drawn from Venter13728. 

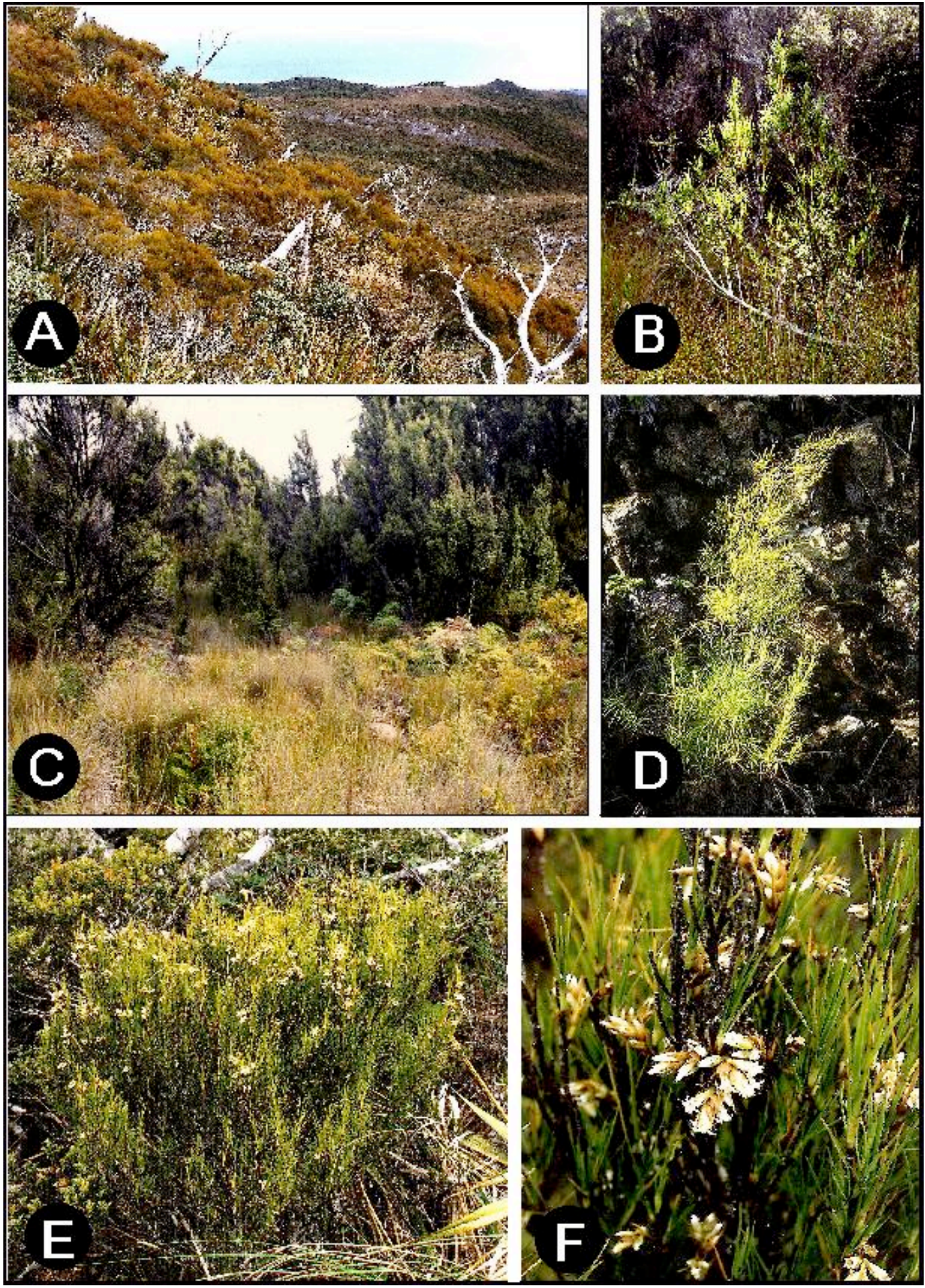

Figure 7.103. Oreothamnus oliveri. A, habitat at the type locality on Mt. Rochfort; B, plant from Lake Te Anau; C, habitat at Lake Te Anau; D, young plant from Mt. Rochfort; $\mathbf{E}$, mature flowering plant from the type locality; F, flowering branch showing the typical drooping inflorescences. B, Venter 13805 and $\mathbf{E}-\mathbf{F}$, Venter13744. 


\section{Diagnostic features and notes}

Oreothamnus oliveri is characterized by $8-10$ teeth per $10 \mathrm{~mm}$ on the lamina margin, clustered 5-10-flowered racemes on short lateral branches, sepals 5-6 $\mathrm{mm}$ long that are longer than the corolla tube and with light coloured margins.

Oreothamnus oliveri is similar to O. filifolius but differs in leaf, inflorescence and flower characters (Table 4.1). Oliver (1952) separated O. oliveri from O. longifolius on the basis of the narrower juvenile leaves and Allan (1961) saw O. oliveri as a polymorphic species with caducous flower bracts but according to Simpson (1945) and my own observations, they are persistent. On this basis I separate $O$. oliveri from the O. longifolius group in which Oliver (1928; 1952) placed it.

\section{Distribution}

Endemic to the South Island of New Zealand (Fig. 7.104). Localities are scattered along the western part of the South Island.

\section{Habitat}

Oreothamnus oliveri occurs on gentle $\left(0^{\circ}-30^{\circ}\right)$ north to northwest facing mountain slopes, gullies, plateaus and depressions at 157-1,160 m altitudes. The vegetation consists of open montane forest, woodland, shrubland or tussock grassland (Table 7.42). Soils are greyish brown sand to brown sandy loam derived from sandstone, conglomerate and alluvium, or clay loam along drainage lines. Most of the populations in Southland occur in permanently moist bogs whereas the northern populations (Hokitika northwards to Karamea) tend to grow under dry conditions. 


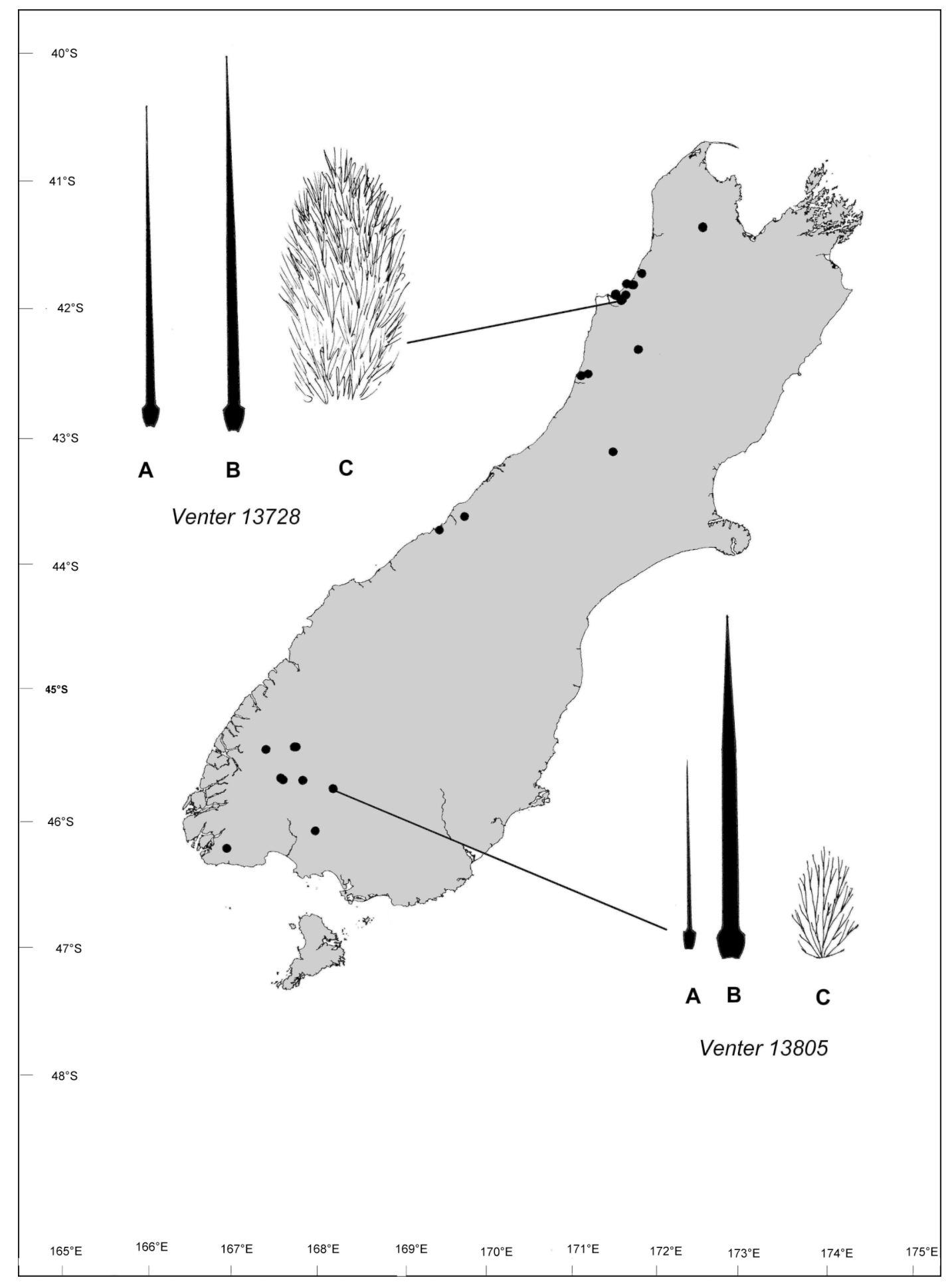

Figure 7.104. Known distribution, habit and leaf variation in Oreothamnus oliveri. Venter 13728 - Westport, Mt. Rochfort; Venter 13805 - Lake Te Anau, Boundary Creek. A, adult leaf $(\times 1)$; $\mathbf{B}$, juvenile leaf $(\times 1)$; $\mathbf{C}$, growth habit. 
Table 7.42. Plant associations commonly associated with Oreothamnus oliveri.

\begin{tabular}{|c|}
\hline FOREST \\
\hline Low open evergreen Nothofagus solandri var. solandri - Lepidothamnus intermedius forest \\
\hline WOODLAND \\
\hline Tall closed semi-deciduous Leptospermum scoparium woodland \\
Low closed semi-deciduous Leptospermum scoparium - Leptecophylla juniperina - Lycopodium woodland \\
\hline
\end{tabular}

\section{Variation}

The lamina sheath in O. oliveri varies in size $(5-9 \times 3-5 \mathrm{~mm})$ and the shoulders of the lamina sheath can either be round or truncate on the same branch. Plants from the Southland populations, especially at Lake Te Anau, are lower (up to $2 \mathrm{~m}$ maximum) with shorter (30-50 mm) more glaucous leaves (Fig. 104). The inflorescence bracts vary considerably in size $(13-20 \times 0.8-1.2 \mathrm{~mm})$ on the same plant. Flower bracts tend to be small $(3 \times 2 \mathrm{~mm})$ in Southland populations compared with material $(5.5 \times 3.5 \mathrm{~mm})$ from populations at Mt. Rochfort in the north.

\section{Hybrids}

Du Rietz (1930) described hybrids between O. oliveri and O. prostratus from west of Lake Wakatipu but no specimen could be found to verify this and searches in the named area produced no hybrid plants.

\section{Material studied}

NEW ZEALAND. South Island. 41-171: Denniston (-DA), 4.vii.1965. Wardle s.n. (CHR); Westport - Mt. Rochfort, near summit (-DC), 25.xi.1998. Venter 13728 (CHR); ibid. Venter 13744 (CHR); ibid., Venter 13820 (CHR); ibid.,ii.1913. Petrie s.n. (AK). 41-172: Salisbury Open (-BA), 31.i.1964. Talbot s.n. (CHR). 43-169: Bruce Bay, near Lake Kiri (DA), 18.ii.1958. Mason \& Moar 5365 (CHR). 45-167: Te Anau, Lake Luxmore (-BD), 
9.i.1995. De Lange s.n. (AK, HO); Between Lake Te Anau and the Key (-DB), 11.i.1937. Simpson s.n. (CHR); Lake Henry, 29.xii.1963. Buchanan s.n. (HO).

\section{Oreotbamnus opbioliticus (S. Venter) S. Venter}

\section{Oreothamnus opbioliticus (S. Venter) S. Venter, comb. nov.}

Type: New Zealand, NW Nelson, Takaka Valley, Kahurangi National Park, Asbestos Creek opposite Chaffey's Hut, 820 m, 22.iv.2000. S. Venter 13822 (CHR, holo.!; AK!, BM!, K!, WELT! ).

= Dracophyllum opbioliticum S. Venter, N.Z. Journ. Bot. 40 (1): 43 - 47 (2002).

Icones: Venter, N.Z. Journ. Bot. 40 (1): tt. 5 \& 6 (2002).

\section{Description}

A multi-stemmed shrub, 0.3-1.0 $\mathrm{m}$ tall but reaches $2 \mathrm{~m}$ in the shade. Branches decumbent. Bark on old branches grey, finely fissured, young stems yellowish brown to reddish brown. Leaves spreading, glaucous to olive green; lamina sheath 4-9 $\times 4-8 \mathrm{~mm}$, striate, shoulders rounded to truncate and margin ciliate; lamina linear-triangular, 21-50 $\times(1.0-) 1.3-2.5 \mathrm{~mm}$, slightly concave, surfaces minutely verrucose and covered in short, white scabrid hairs; margins serrulate with 10-13 teeth per $10 \mathrm{~mm}$; apex triquetrous. Inflorescence a terminal raceme on lateral branchlets; shorter than the leaves, erect, dense, (13 -)19-23(-28) mm long, oblong; inflorescence bract overtopping flowers, ovate lanceolate, 13.9-22.2 × 0.7-0.9 mm, surfaces rugose, margins serrulate. Flowers (3-)69, pedicellate; flower bracts shorter than flower, keeled, broadly ovate, $(4.5-) 6.5-8.0 \times(2.5$ -)3-4 mm, adaxial surfaces scabrid in upper third, abaxial surfaces scabrid; margins 
white, ciliate; pedicel straight, 1.5-2.0 mm long, tomentose. Sepals ovate-lanceolate, (4 )5-6 $\times(1.5-) 2.0-3.0 \mathrm{~mm}$, shorter than corolla tube, adaxial surfaces glabrous with scabrid hairs at apex; abaxial surfaces with scattered scabrid hairs; margins white, ciliate. Corolla white; corolla tube cylindrical, narrowed at mouth, 5.5-6.5 $\times 2.0-2.5 \mathrm{~mm}$; corolla lobes reflexed, triangular, shorter than corolla tube, $1.8-2.0 \times 1.5-2.0 \mathrm{~mm}$, apices inflexed, subacute; adaxial surface papillate, abaxial surface glabrous. Stamens inserted on corolla tube in the upper third, filaments $0.5-0.7 \mathrm{~mm}$ long; anthers included, oblong, light yellow and $1 \mathrm{~mm}$ long. Ovary obovate, $1.3-1.5 \times 1.2-1.5 \mathrm{~mm}$, apex round; nectary scales rectangular, $0.8-1.0 \times 0.6-0.7 \mathrm{~mm}$, apices truncate and emarginate to variously toothed; style included, 1.5-2.0 mm long, glabrous; stigma 5-lobed. Fruit pedicellate, light brown, (2.7-)3.5-4.0 × 2.5-2.7 mm, obovoid, and apex round, glabrous. Seeds yellowish brown, ovoid, 0.8-1.0 mm long, testa prominently reticulate. Flowering January-March. (Figure 7.105).

\section{Diagnostic features and notes}

Oreothamnus ophioliticus is a multi-stemmed shrub up to $1 \mathrm{~m}$ tall with decumbent stems, glaucous leaves that are minutely verrucose and covered with scabrid hairs when young, pedicellate flowers, flower bracts shorter than the flower and keeled with the abaxial surface scabrid, sepals shorter than corolla tube, mouth of the corolla tube narrowed and the ovary obovate.

Oreothamnus ophioliticus is similar to O. filifolius in the spreading linear-triangular to filiform leaves and persistent flower bracts. It differs in being a many-stemmed shrub with decumbent to prostrate stems, the verrucose surfaces of the leaves with scabrid hairs, sepals shorter than the corolla tube and the mouth of the corolla tube narrowed. In the 


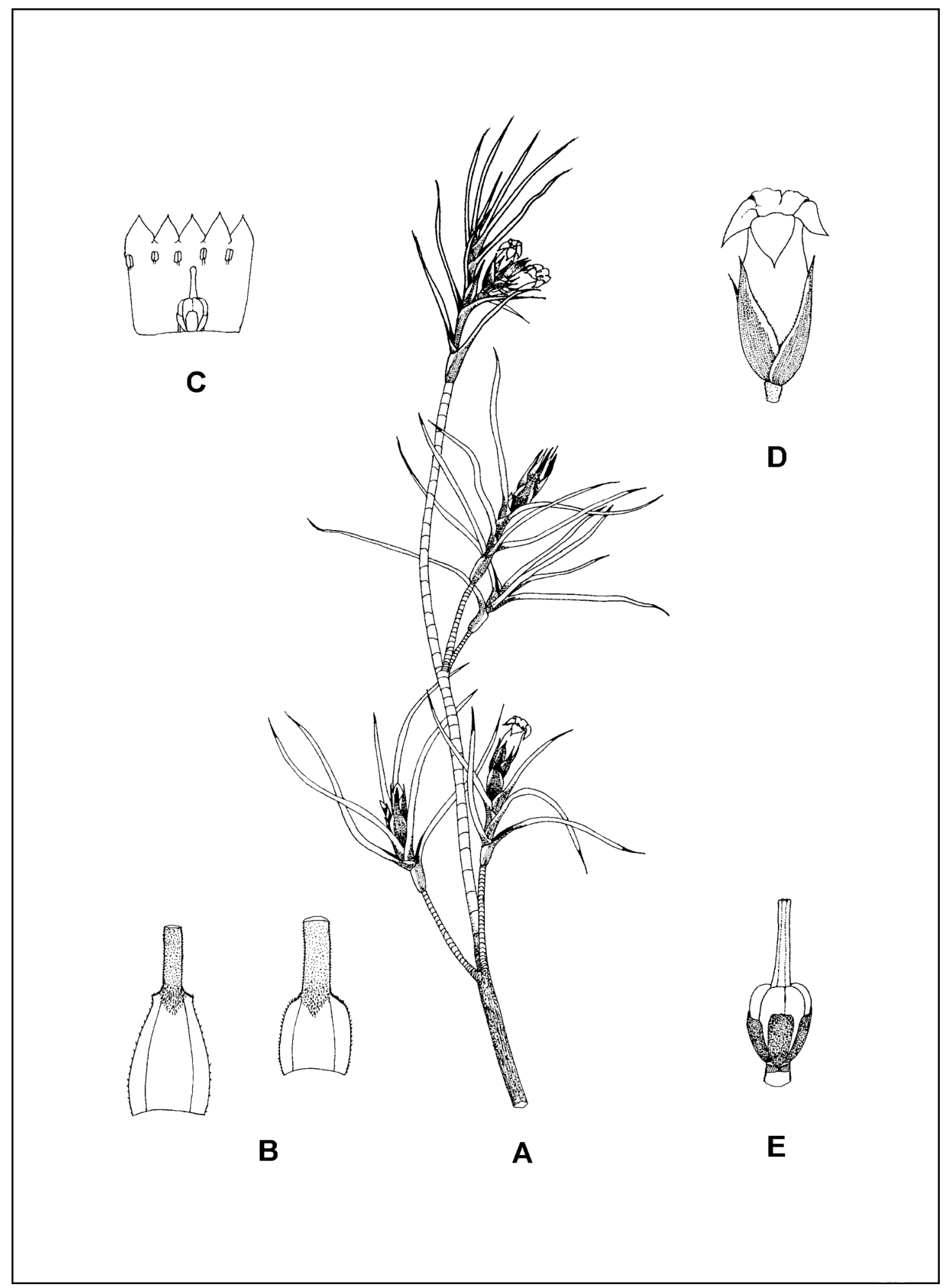

Figure 7.105. Oreothamnus ophioliticus. A, flowering branch $(\times 1)$; $\mathbf{B}$, adaxial surface of the lamina sheaths to show variation $(\times 5)$; $\mathbf{C}$, laid out flower $(\times 3)$; $\mathbf{D}$, flower $(\times 5)$; E, ovary (× 10). Drawn from Venter 13800 . 

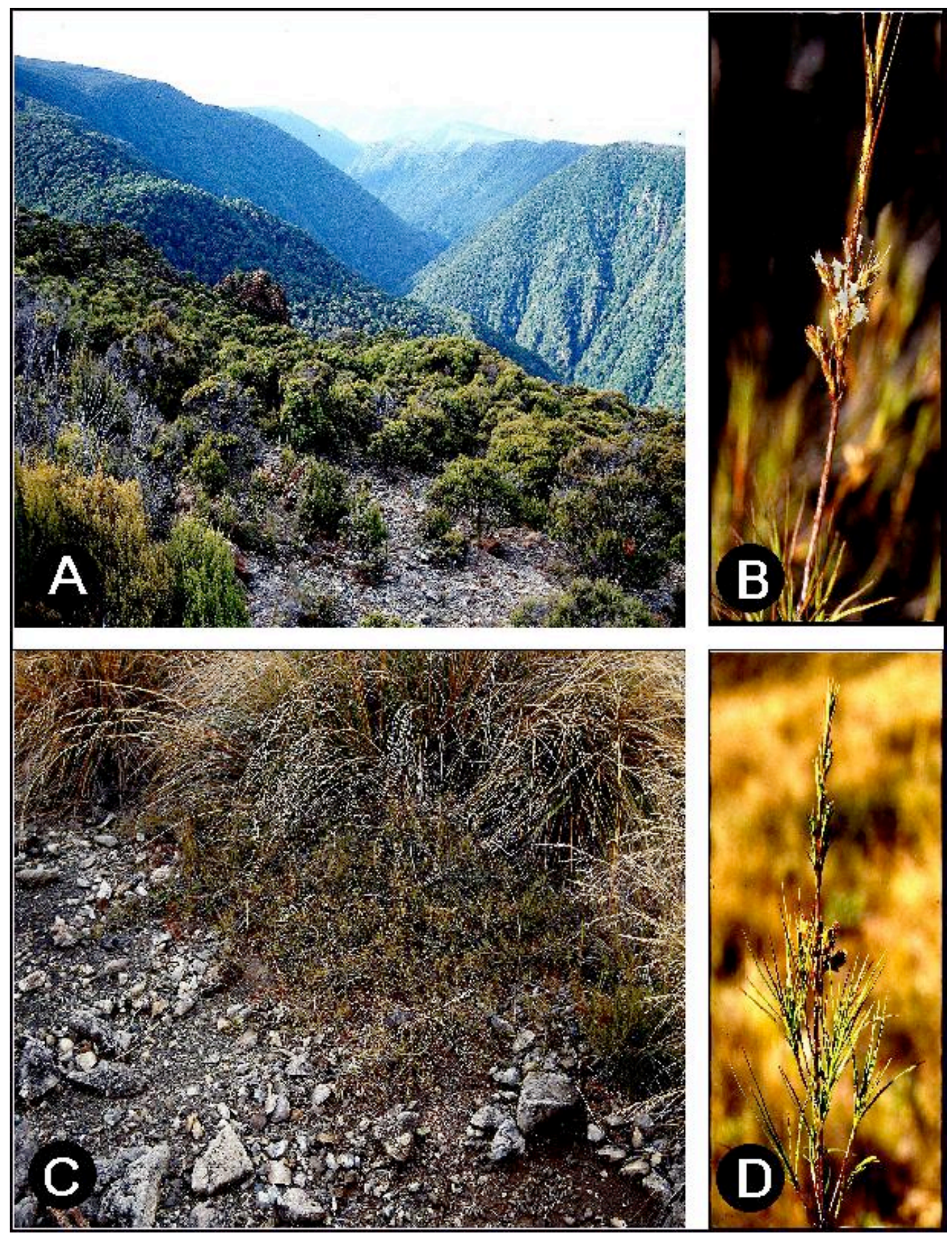

Figure 7.106. Oreothamnus opbioliticus. A, habitat at the type locality near Chaffey's Hut in the upper reaches of the Takaka River; $\mathbf{B}$, flowering branch; $\mathbf{C}$, plant showing the characteristic prostrate stems; D, fruiting branch. B-D, Venter 13822. 
past, it was thought that O. ophioliticus was merely a form of O. longifolius but it is easily distinguished by the absence of large juvenile leaves and caducous flower bracts, characters that Oliver $(1928 ; 1952)$ regard as diagnostic for O. longifolius. An endemic of ultramafic soils. The scarcity of endemics on the ultramafics in the South Island has been attributed to the relatively short time in which these habitats have been available to plant life since the most recent glaciation (Lee 1992; Wardle 2002).

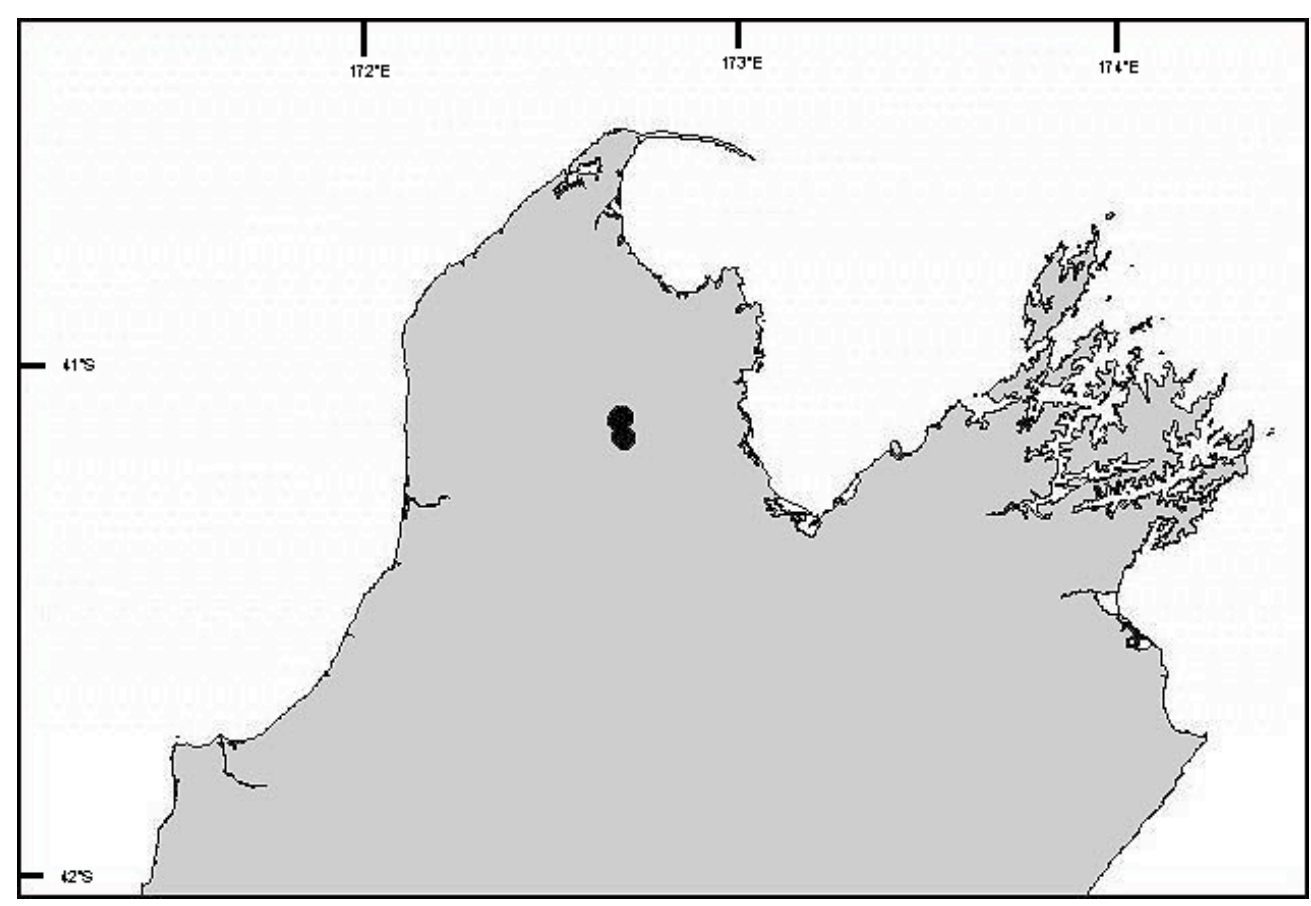

Figure 7.107. Known distribution of Oreothamnus ophioliticus, South Island, New Zealand.

\section{Distribution}

New Zealand endemic restricted to the upper reaches of the Takaka River in the Kahurangi National Park, South Island (Fig. 7.107). 


\section{Habitat}

Oreothamnus ophioliticus grows in greyish- to reddish brown clay loam on steep $\left(10^{\circ}-30^{\circ}\right)$ mountain slopes at 457-1000 m altitude in mainly open sites or in rock crevices in montane woodland restricted to serpentinite rocks with asbestos veins. Common associated species include Leptospermum scoparium, Veronica albicans, Phormium cookianum subsp. cookianum, Griselinia littoralis, Astelia fragrans, Leptecophylla juniperina, Phyllocladus trichomanoides, Exocarpus bidwillii, Pseudopanax crassifolius, Melicytus alpinus, Gaultheria antipoda, Coprosma microcarpa, C. perpusilla subsp. perpusilla, Veronica masoniae and Dianella nigra (Table 7.43).

Table 7.43. Plant associations commonly associated with Oreothamnus ophioliticus.

\section{WOODLAND}

Low closed semi-deciduous Leptospermum scoparium - Veronica albicans - Coprosma microcarpa woodland Low closed semi-deciduous Kunzea ericoides - Veronica albicans - Dianella nigra woodland

\section{Variation}

Most $O$. opbioliticus plants growing on the unstable and easily weathered serpentinite form prostrate stems of up to four metres long. These stems commonly root at the nodes anchoring the stems; this appears to be an adaptation to survival in the unstable soil conditions. Plants grown under garden and glasshouse conditions maintain this growth habit. The leaves of O. ophioliticus are glaucous and short (21-29 mm long) in exposed areas but greener and longer (30-50 $\mathrm{mm}$ long) in protected areas. The leaf sheath varies considerably in length and width $(4-9 \times 4-8 \mathrm{~mm})$ with the shoulder ranging in shape from rounded to truncate. 


\section{Material examined}

NEW ZEALAND. South Island. 41-172: (-BA), Cobb Valley, below dam, xi.1979. Druce s.n. (CHR); ibid., i.1987. Hayward s.n. (CHR); Takaka Valley, Asbestos Creek, xi.1979. Druce s.n. (CHR); Summit of Asbestos Hill, 25.xii.1950. Hay s.n. (CHR); Asbestos Creek opposite Chaffey's Hut, 22.iv.2000. Venter 13822 (CHR).

15. Oreothamnus palustris (Cockayne ex W.R.B. Oliv.) S. Venter

Oreothamnus palustris (Cockayne ex W.R.B. Oliv.) S. Venter, comb. nov. Cheeseman, Man. N.Z. Fl. $2^{\text {nd }}$ Ed.: 709 (1925); Oliver, Trans. Proc. N.Z. Inst. 59: 690 (1928); Oliver, Trans. Roy. Soc. N.Z. 80 (1): 7 (1952); Allan, Fl. N.Z. 1: 528 (1961); Moore \& Irwin, Oxford Book of N.Z. Plants.: 294 (1978); Eagle, Trees \& Shrubs of N.Z. $2^{\text {nd }}$ Series.: 294 (1982); Poole \& Adams, Trees \& Shrubs of N.Z.: 162 (1994). Type: New Zealand, near Kumara, ii.1877. T. Kirk s.n. (AK 7028, lecto.!; WELT 44737!; WELTU 4275!), designated by Oliver (1952).

Oliver (1928) did not mention a type in the protologue when he gave the new name $D$. palustre to Cheeseman's (1906) Dracophyllum uniflorum var. virgatum, but in a later publication, Oliver (1952) designated the specimen AK 7028 as type from the two mentioned syntypes.

= Dracophyllum palustre Cockayne ex W.R.B. Oliv., Trans. Proc. N.Z. Inst. 59: 690 (1928). nom. nov.

= Dracophyllum virgatum (Cheeseman) Cockayne, Trans. Proc. N.Z. Inst. 44: 53 (1912). non Colenso (= D. filifolium). 
三Dracophyllum uniflorum var. virgatum Cheeseman, Man. N.Z. Fl: 427 (1906). Type: New Zealand, Westland, swamp near Lake Brunner. L. C[ockayne] s.n. (WELT 33156, holo.!).

Icon: Eagle, Trees \& Shrubs of N.Z. $2^{\text {nd }}$ Series.: t.142 (1982).

\section{Description}

Multi-stemmed scrambler or sub-shrub, 20-100 $\mathrm{cm}$ tall. Branches spreading to decumbent. Bark on old branches dark grey, smooth, young stems reddish brown to purplish brown. Leaves erect to spreading, olive green; lamina sheath 2.5-6.0 × 2.2-4.0 $\mathrm{mm}$, tapering to truncate and margin membranous, ciliate; lamina linear, 14-27 $\times 0.5-1.0$ $\mathrm{mm}$, adaxial surface flat, occasionally minutely scabrous with a tuft of scabrid hairs at the base; margins serrulate with 70-110 teeth per $10 \mathrm{~mm}$; apex keeled, triquetrous. Inflorescence a solitary terminal, sessile flower on shortened lateral branchlets; shorter than leaves; inflorescence bract equaling flower, light to dark green, ovate-lanceolate, 4.0-4.5 $\times 1.5-2.0 \mathrm{~mm}$, adaxial surface pubescent at apex; margin ciliate; apex obtuse to acute; flower bracts overtopping flowers, ovate-lanceolate to ovate, $5.0-5.5 \times 2.0-2.5 \mathrm{~mm}$, surfaces glabrous with a tuft of scabrid hairs at base of adaxial surface; margins prominently white and ciliate; apices acute to slightly obtuse. Sepals ovate to triangular, $4.0-5.5 \times 1-2 \mathrm{~mm}$, equaling corolla tube, glabrous with the top half of the abaxial surface pubescent; margins ciliate; apices acute. Corolla white to light pink; corolla tube cylindrical, $3.5-5.0 \times 2.0-2.2 \mathrm{~mm}$; corolla lobes reflexed, ovate-triangular, shorter than corolla tube, $1.6-3.0 \times 1.3-2.2 \mathrm{~mm}$, apices inflexed, acute; adaxial surface papillate. Stamens inserted on corolla tube in the upper third, filaments $0.5-0.7 \mathrm{~mm}$ long; anthers included, oblong, light yellow and $0.7-0.9 \mathrm{~mm}$ long. Ovary obovate, $0.7-1.0(-1.2) \times 0.6-$ $1.0 \mathrm{~mm}$, apex truncate; nectary scales rectangular, $0.8-1.5 \times 0.6-0.7 \mathrm{~mm}$, apices retuse; style 
included, 1.0-1.2 mm long, glabrous; stigma five-lobed. Fruit light brown, 3.5-4.0 × 2.8$3.0 \mathrm{~mm}$, obovoid, apex round to slightly truncate, glabrous. Seeds yellowish brown, ovoid, 0.95-1.0 mm long, testa slightly reticulate. Flowering (October-) December-May (-July). (Figure 7.108).

\section{Diagnostic features and notes}

Oreothamnus palustris is characterized by the long and slender stems that are sparingly leafy; leaves $14-27 \times 0.5-1.0 \mathrm{~mm}$, lamina apices bluntly pointed and the shoulders of the lamina sheaths rounded and ciliate; flowers solitary on the lateral branches; flower bracts broad with a very broad pale margin and corolla tube $3.5-5.0 \mathrm{~mm}$ long with acute lobes.

Oreothamnus palustris is similar to O. rosmarinifolius in the solitary flowers and narrow short leaves, but differs in the slender strict habit, small leaves and the small flowers that are arranged on short peduncles. However it is similar to O. subulatus but differs in the absence of juvenile leaves, flowers solitary not in spikes with the inflorescence bract equaling the flower and having a ciliate not serrulate margin. The sepal is longer (4.0-5.5 mm compared to $2.6-3.2 \mathrm{~mm}$ ) with the top half of the abaxial surface pubescent. The corolla tube is also much larger $(3.5-5.0 \times 2.0-2.2 \mathrm{~mm}$ compared to $1.8-2.0 \times 1.0-1.2$ $\mathrm{mm})$ with larger nectary scales $(0.8-1.5 \times 0.6-0.7 \mathrm{~mm}$ not $0.4-0.5 \times 0.3-0.5 \mathrm{~mm})$ and fruit $(3.5-4.0 \times 2.8-3.0 \mathrm{~mm}$ compared to $2.9-3.0 \times 1.7-1.8 \mathrm{~mm})$. The diagnostic broad and pale to white flower bract margin is similar to that of $O$. subulatus. 


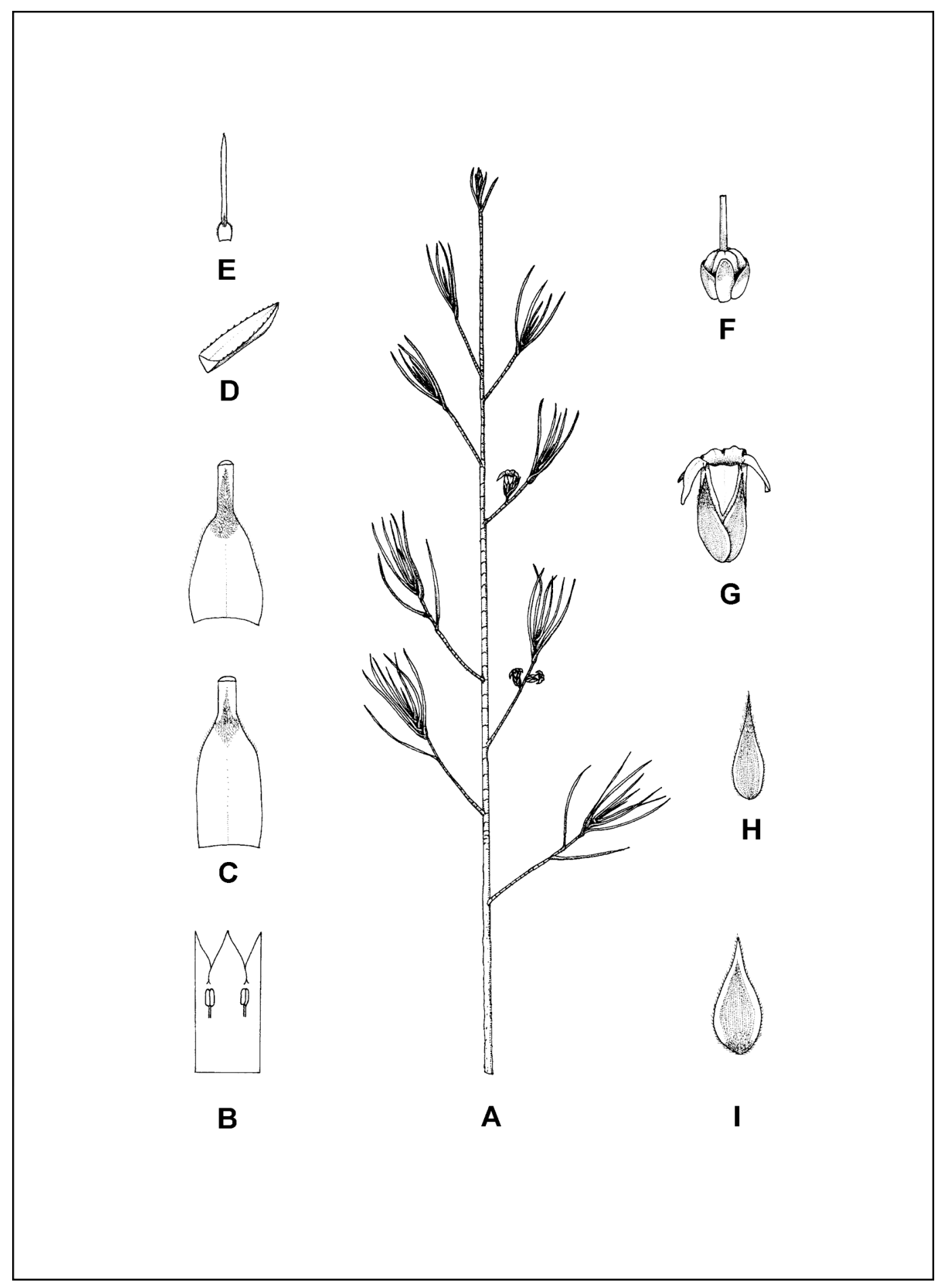

Figure 7.108. Oreothamnus palustris. A, flowering branch $(\times 1)$; B, laid out corolla $(\times$ $5)$; $\mathbf{C}$, lamina sheaths to show variation $(\times 5) ; \mathbf{D}$, lamina apex $(\times 5)$; $\mathbf{E}$, leaf $(\times 1) ; \mathbf{F}$, ovary $(\times 10)$; $\mathbf{G}$, flower $(\times 5)$; $\mathbf{H}$, sepal abaxial surface $(\times 5)$; I, flower bract adaxial surface ( $\times 5)$. Drawn from Mason \& Moar 5539 . 


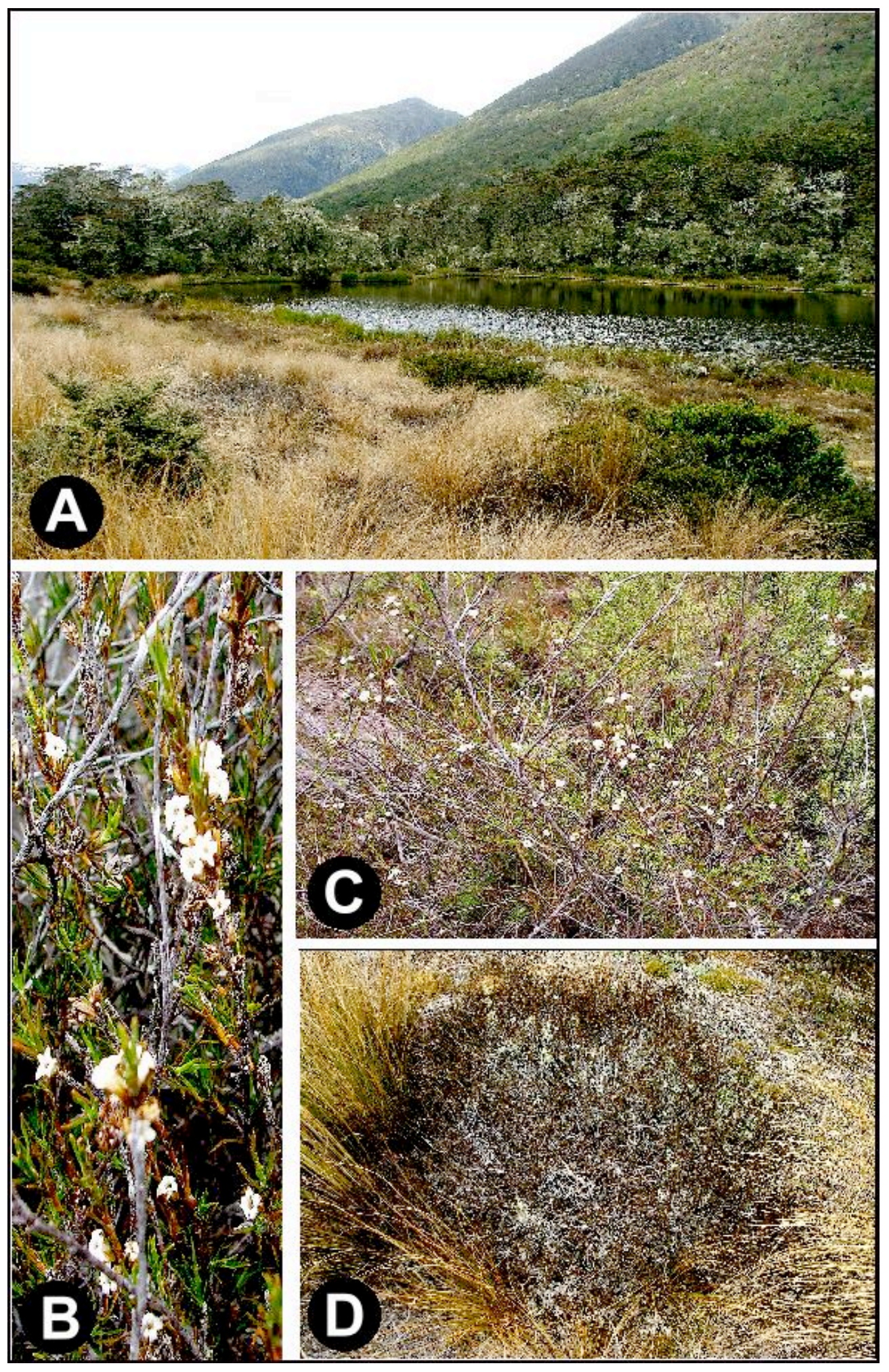

Figure 7.109. Oreothamnus palustris. A, habitat in Lewis Pass; B, flowering branch; C, mature plant in flower; $\mathbf{D}$, mature plant. 


\section{Distribution}

New Zealand endemic, common in the northern half of the South Island (Fig. 7.110).

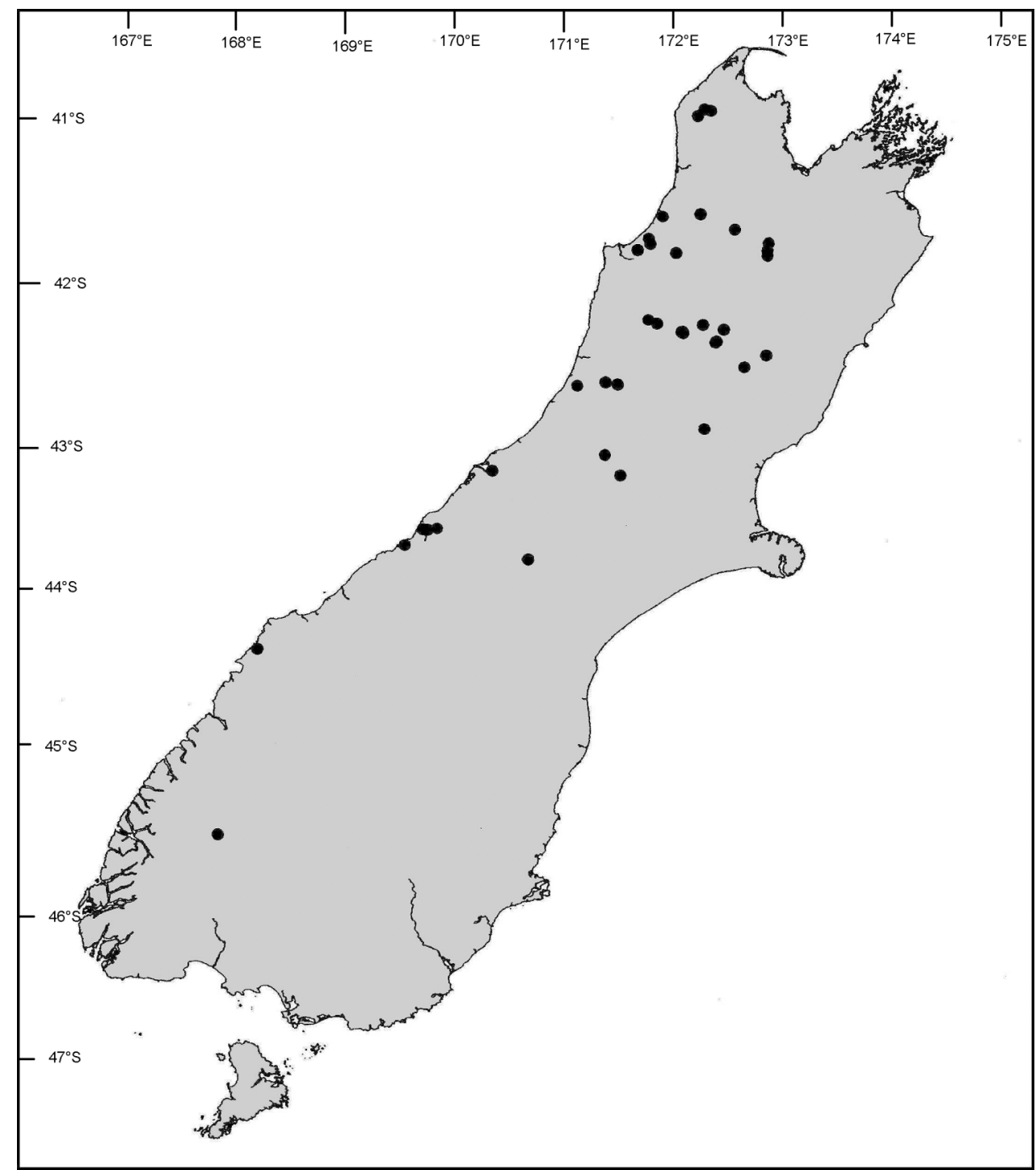

Figure 7.110. Known distribution of Oreothamnus palustris.

\section{Habitat}

Oreothamnus palustris occurs from sea level to altitudes of 1,280 m. It grows exposed in boggy, swampy or permanently moist habitats. The surrounding vegetation is lowland to 
montane shrubland, tussock grassland (Table 7.44) or peat bog. Soils are mostly boggy or humus rich loam derived from greywacke.

Table 7.44. Plant associations commonly associated with Oreothamnus palustris.

\begin{tabular}{|c|}
\hline SHRUBLAND \\
\hline Low open evergreen Phyllocladus alpinus shrubland \\
\hline GRASSLAND \\
\hline Low open Chionochloa rubra tussock grassland \\
\hline
\end{tabular}

\section{Variation}

The lamina sheath $(2.5-6.0 \times 2.2-4.0 \mathrm{~mm})$ and lamina $(14-27 \times 0.5-1.0 \mathrm{~mm})$ show some variation in size. The adaxial surface of the lamina is mostly glabrous but some plants have a prominent patch of scabrid hair at the base of the lamina. The flower bract can vary from ovate-lanceolate to ovate and the sepals from ovate to triangular on the same plant. Populations found in areas from a high-elevation have small $(1.6 \times 1.3 \mathrm{~mm})$ corolla lobes becoming gradually larger $(3.0 \times 2.2 \mathrm{~mm})$ in plants growing near sea level.

\section{Material examined}

NEW ZEALAND. South Island. 40-172: Perry's Saddle (-CD), i.1969. Druce s.n. (CHR);

Gouland Downs Scenic Reserve, i.1975. Kelly \& Kelly s.n. (CHR); Peak north of Mt. Goul, vi.1981. Druce s.n. (CHR). 41-171: Denniston Plateau (-DB), i.1981. Druce s.n. (CHR); Westport, upper Waimangaroa River, 28.ix.1976. Given 9577 \& Molloy (CHR); Mt. Augustus, 7.i.1976. Moore s.n. (CHR); Westport, Mt. Rochfort (-DC), 30.x.1998. Venter 13727 (CHR); Westport, German Terrace, 19.xi.1985. Courtney P33 (CHR); Mt. William (-DD), Townson s.n. (CHR). 41-172: Matiri Range, Mt. Misery (-CB), iii.1981. Druce s.n. (CHR); Buller River, Lyall, Dublin Terrace (-CC), 22.xi.1985. Courtney P34 (CHR). 42-171: South of Reefton, Fossicker Creek basin (-BB), Gardner 6908 (AK, 
WAIK); 4 m NW of Lake Brunner, Kangaroo Lake (-DA), 30.iii.1950. Potter s.n. (CHR). 42-172: Rahu Saddle (-AC), 17.ii.1983. Van Balgooy 4469 (CHR, L). Westport, 31.xii.1897. Townson s.n. (WELT); Spencer Mountains, Ada Pass Saddle (-AD), 8.i.1945. Brockie s.n. (CHR); Maruia Valley, Thompsons Flat, 19.xi.1990. Johnson \& Buxton s.n. (CHR). 43-169: Westland National Park, Skiffington Swamp (-BD), 12.x.1965. Wardle s.n. (CHR). 43-171: Mt. Greenlaw (-AB), i.1924. Wall s.n. (CHR). 44-168: Gorge River north of Jerry Gorge junction (-AA), 3.xi.1985. Johnson 465 \& Wardle (CHR); Forbes Mountains, Mt. Earnslaw (-CB), ii.1992. Druce 1720 (CHR).

16. Oreothamnus patens (W.R.B. Oliv.) S. Venter

Oreothamnus patens (W.R.B. Oliv.) S. Venter, comb. nov. Oliver, Trans. Roy. Soc. N.Z. 80 (1): 13 (1952); Allan, Fl. N.Z. 1: 534 (1961); Moore \& Irwin, Oxford Book of N.Z. Plants.: 293 (1978); Eagle, Trees and Shrubs of N.Z. $2^{\text {nd }}$ series. : 293 (1982); Poole \& Adams, Trees \& Shrubs of N.Z.: 162 (1994). Type: New Zealand, Great Barrier Island, summit of Mt. Hobson, 8.xii. 1916. W.R.B. Oliver s.n. (WELT 33296, holo.!).

三Dracophyllum patens W.R.B. Oliv., Trans. Proc. N.Z. Inst. 59: 698 (1928).

Icones: Oliv., Trans. Proc. N.Z. Inst. 59: t. 9 (1928); Eagle, Trees and Shrubs of N.Z. $2^{\text {nd }}$ series. : t. 136 (1982).

\section{Description}

Multi-stemmed shrub 0.5-3 m tall. Branches erect. Bark on old stems dark grey to greyish brown, smooth, young stems yellowish to reddish brown. Leaves juvenile and 
adult. Juvenile leaves spirally along branches, erect to spreading; lamina sheath 10-12 × 8-14 $\mathrm{mm}$, rounded to truncate and margin ciliate in upper half; lamina linear-triangular; 80.0_ $126.4 \times 5.0-7.1 \mathrm{~mm}$, adaxial surface sparsely scabrid; abaxial surface glabrous; margin serrulate with 30-40 teeth per $10 \mathrm{~mm}$. Adult leaves erect to spreading; lamina sheath light green to light brown, $4.5-12.0 \times 4-10 \mathrm{~mm}$, striate, tapering to truncate and margin membranous, top half ciliate; lamina broadly linear-triangular, 30-75 $\times 2-6 \mathrm{~mm}$, adaxial surface covered in minute scabrid hairs becoming denser towards the apex, slightly striated; margin serrulate with 45-70 teeth per $10 \mathrm{~mm}$. Inflorescence a terminal spike on lateral branchlets, shorter than leaves, drooping, dense, (16.5-)35-40 mm long; inflorescence bract overtopping flowers, coriaceous, ovate-lanceolate, 4.5-6.0(-7.0) $\times 1.2$ $1.5 \mathrm{~mm}$, adaxial surface pubescent to sericeous; margin serrulate. Flowers $5-8$, sessile; flower bract longer than flower, broadly ovate; apex subulate; 5-8 $\times 2.8-3.0 \mathrm{~mm}$; adaxial surface with a tuft of scabrid hairs at the base; margins ciliate. Sepals ovate-lanceolate, 4-8 $\times 1.5-2.7 \mathrm{~mm}$, longer than the corolla tube, adaxial surface pubescent in the top half; margins ciliate. Corolla white; corolla tube narrowly campanulate, widened at mouth, $4-5 \times 2.3-2.5 \mathrm{~mm}$; corolla lobes spreading horizontally to reflexed, broadly triangular, shorter than corolla tube, $2.5-3.0 \times 2.3-2.5 \mathrm{~mm}$, apices subacute; surfaces glabrous. Stamens inserted at top of corolla tube, filaments $(0.25-) 0.5-1.0 \mathrm{~mm}$ long; anthers included, oblong, light yellow and 1.0-1.2 mm long. Ovary subglobose, 1.0-1.1 mm long and wide; apex round; nectary scales rectangular, 1.2-1.5 $\times 0.5-0.7 \mathrm{~mm}$, apices subacute; style included, 1.0-1.4 mm long, glabrous, lengthening in fruit; stigma five- lobed. Fruit light brown, 2.5-3.5 $\times$ 2.5-3.0 mm, obovoid, apex round, glabrous. Seeds yellowish brown, ovoid, 1.1-1.2 mm long, testa slightly reticulate. Flowering April-June (November) (Figure 7.111). 


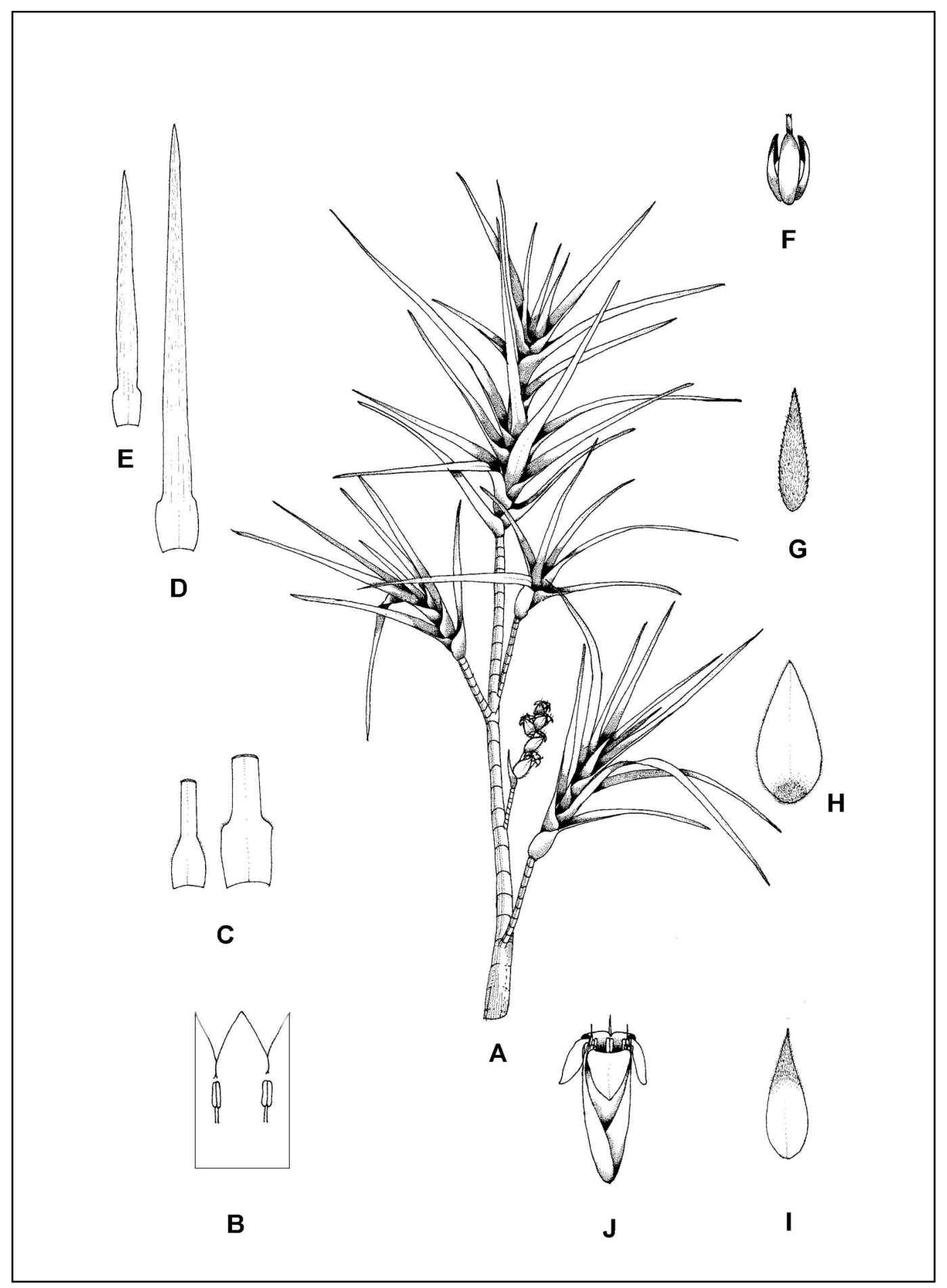

Figure 7.111. Oreothamnus patens. A, flowering branch $(\times 1) ; \mathbf{B}$, laid out corolla $(\times 5)$; $\mathbf{C}$, lamina sheaths to show variation $(\times 1) ; \mathbf{D}$, juvenile leaf $(\times 1) ; \mathbf{E}$, adult leaf $(\times 1) ; \mathbf{F}$, ovary with nectary scales $(\times 10)$; $\mathbf{G}$, inflorescence bract adaxial surface $(\times 5)$; $\mathbf{H}$, flower bract adaxial surface $(\times 5)$; I, sepal adaxial surface $(\times 5)$; J, flower $(\times 5)$. Drawn from Venter 13771. 


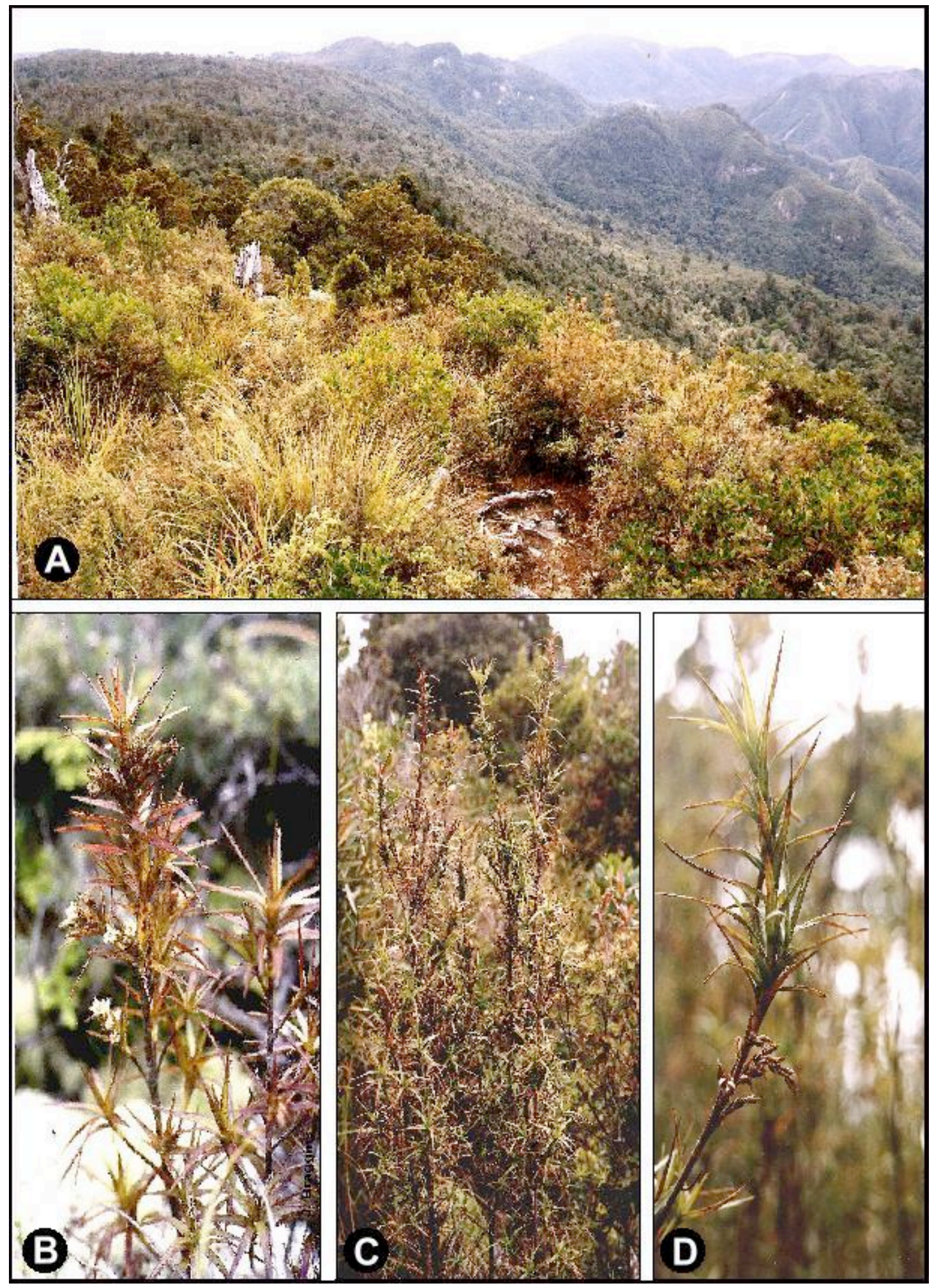

Figure 7.112. Oreothamnus patens. A, habitat on top of Mt. Rowe on the Coromandel Peninsula; B, flowering branch from a plant at the type locality on Great Barrier Island. C, adult plant showing the erect branches; D, fruiting branch. A, C and $\mathbf{D}$ Venter 13771. 


\section{Diagnostic features and notes}

Oreothamnus patens is characterized by the erect stems with short $(38-75 \mathrm{~mm})$ leaves that are broad $(2-6 \mathrm{~mm})$ at the base, broad lamina sheaths $(5.5-12.0 \times 4-10 \mathrm{~mm})$ with scarious margins and with some short hairs on shoulders, juvenile leaves much larger than the adult leaves $(80-110 \times 5-7 \mathrm{~mm}), 5-6$-flowered inflorescences, broad flower bracts, corolla tube $4-5 \times 2.3-2.5 \mathrm{~mm}$ and nectary scales overtopping the ovary.

A diagnostic species and easily distinguishable from other Oreothamnus species in the long erect stems, narrow long juvenile leaves and much broader and shorter, strongly spreading adult leaves.

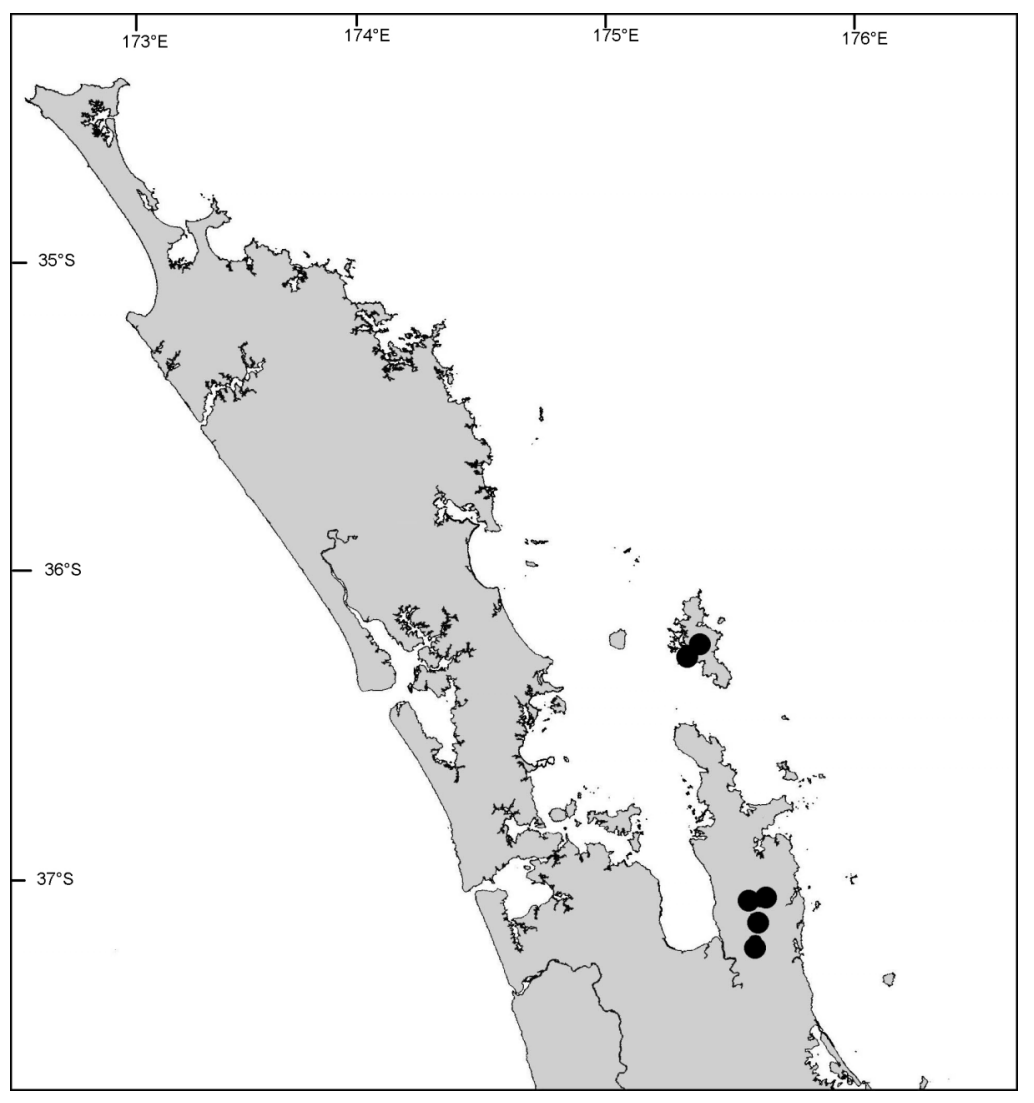

Figure 7.113. Known distribution of Oreothamnus patens, northern part of the North Island, New Zealand. 


\section{Distribution}

Endemic to the Coromandel area and Great Barrier Island off the North Island of New Zealand (Fig. 7.113).

\section{Habitat}

Oreothamnus patens grows exposed in permanent moist to seasonally moist areas on mountain peaks, plateau areas and cliffs at altitudes from $300-795 \mathrm{~m}$. The vegetation consists of open lowland to montane forest, woodland or shrubland (Table 7.45). The soils are dark brown loam to clay loam. Most populations occur in full sun, sometimes with a number of plants growing in light shade of the forest (Mt. Rowe, Coromandel).

Table 7.45. Plant associations commonly associated with Oreothamnus patens.

\begin{tabular}{|c|}
\hline FOREST \\
\hline Tall open evergreen Weinmannia silvicola - Dacrydium cupressinum - Gahnia setifolia forest \\
\hline WOODLAND \\
\hline Tall closed semi-deciduous Leptospermum scoparium woodland \\
\hline SHRUBLAND \\
\hline Low open evergreen Ixerba brexioides - Pseudowintera axillaris - Gahnia setifolia shrubland \\
\hline
\end{tabular}

\section{Variation}

Size variation occurs in the juvenile lamina $(80-126 \times 5-7 \mathrm{~mm})$, the adult lamina sheath $(4.5-12.0 \times 4-10 \mathrm{~mm}$ with the shoulders tapering to truncate), adult lamina $(30-75 \times 2-$ $6 \mathrm{~mm})$ and the sepals $(4-8 \times 1.5-2.7 \mathrm{~mm})$.

\section{Material examined}

NEW ZEALAND. North Island. 36-175: Great Barrier Island, upper slopes of Mt. Hobson (-AB), 25.x.1976. Bartlett s.n. (AD, AK, L, NZRFI); Ahumata (White cliffs). 15.xii.1938. Molesworth s.n. (AK); Coromandel Range, Papakai Plateau (-DC), 8.iv.1983. 
Gardner 3465 (AK). 37-175: Coromandel, Kauaranga National Park, Table Mountain (BA), iv.1971, Druce s.n. (CHR); ibid, i.1977. Bartlett s.n. (CHR); Coromandel, Kauaranga National Park, The Pinnacles, iv.1971, Druce s.n. (CHR); ibid., 31.viii.1982. Clarkson s.n. (CHR); Thames, Upper Kauaeranga River, vi.1977. Bartlett s.n. (CHR); Coromandel, Kauaranga National Park, top of Mt. Rowe, next to Trig. Beacon, 16.02.1999. Venter 13771 (CHR); Coromandel Range, Pakirarahi, 7.vi.1977. Bartlett s.n. (AK, CHR); ibid. v.1977. Bartlett s.n. (CHR).

17. Oreothamnus pearsonii (Kirk) S. Venter

Oreothamnus pearsonii (Kirk) S. Venter, comb. nov. Cheeseman, Man. N.Z. Fl.: 424 (1906); Cheeseman, Man. N.Z. Fl. $2^{\text {nd }}$ Ed.: 706 (1925); Oliver, Trans. Proc. N.Z. Inst. 59: 687 (1928); Oliver, Trans. Roy. Soc. N.Z. 80 (1): 4 (1952); Allan, Fl. N.Z. 1: 525 (1961); Moore \& Irwin, Oxford Book of N.Z. Plants.: 295 (1978); Eagle, Trees and Shrubs of N.Z. $2^{\text {nd }}$ series.: 295 (1982). Type: New Zealand, Stewart Island, exact locality doubtful. W.L. Pearson s.n. (WELT 33309, holo.!).

= Dracophyllum pearsonii Kirk, Trans. Proc. N.Z. Inst. 17: 223 (1885).

Icon: Eagle, Trees and Shrubs of N.Z. $2^{\text {nd }}$ series.: t. 148 (1982).

\section{Description}

Multi-stemmed shrub 30-50 cm tall. Branches: bark on old branches dark grey, deeply fissured, young stems reddish brown. Leaves spirally arranged along branches, imbricate, appressed to stem, dry old leaves present; lamina sheath olive green to light brown, 4-7 $\times$ 
3-5 mm, coriaceous, striate, shoulders rounded to truncate with margins membranous, ciliate or with only the top half ciliate; lamina rigid and hard, mid to olive green, linear to linear-subulate, 19-32 ×0.8-1.5 mm, adaxial surface flat, abaxial surface keeled, margins serrulate with 90-100 teeth per $10 \mathrm{~mm}$, apex triquetrous. Inflorescence a few flowered spike near apices of branches; shorter than leaves, erect, lax, 12-20 mm long, oblong. Inflorescence bract overtopping flowers, leaf-like, coriaceous, linear, ovate-lanceolate at base, $6.0-6.5 \times 4-5 \mathrm{~mm}$, surfaces glabrous with a tuft of scabrid hairs at base of adaxial surface, margins ciliate. Flowers 3-6, sessile; flower bracts overtopping flowers, leaf like, linear, $6.0-6.5 \times 4-5 \mathrm{~mm}$, with a tuft of scabrid hairs at base of adaxial surface, margins ciliate. Sepals lanceolate to ovate-lanceolate, $4.2-4.5 \times 1.5-2.0 \mathrm{~mm}$, shorter to equaling corolla tube; margins ciliate. Corolla white; corolla tube cylindrical, $4.2-4.5 \times 1.8-2.0 \mathrm{~mm}$; corolla lobes reflexed, ovate-triangular to broadly triangular, shorter than corolla tube, 1.9$2.0 \times 1.4-1.5 \mathrm{~mm}$, apical ridge present, apices inflexed at tip, subacute; adaxial surface papillate. Stamens inserted on corolla tube near the top, filaments $0.2-0.5 \mathrm{~mm}$ long; anthers included, oblong, light yellow and $0.8 \mathrm{~mm}$ long. Ovary globose, 1.9-2.0 × 1.8-2.0 mm, apex round; nectary scales oblong, 1.0-1.2 × 0.8-1.0 mm, apices obtuse; style included, 0.8$1.0 \mathrm{~mm}$ long, glabrous; stigma five-lobed. Fruit light brown, $1.0-1.5 \times 1.0-1.2 \mathrm{~mm}$, obovoid, apex truncate, glabrous. Seeds yellowish brown, ovoid, 0.55-0.6 mm long, testa slightly reticulate. Flowering December-February. (Figure 7.114).

\section{Diagnostic features and notes}

Oreothamnus pearsonii is characterized by the imbricate leaves that densely cover the branches and the dead leaves that remain on the branches for a long period, flowers in few-flowered racemes near the ends of branches and a prominent apical ridge on the upper surface of the petal. Oreothamnus pearsonii is a very distinct species and easily 


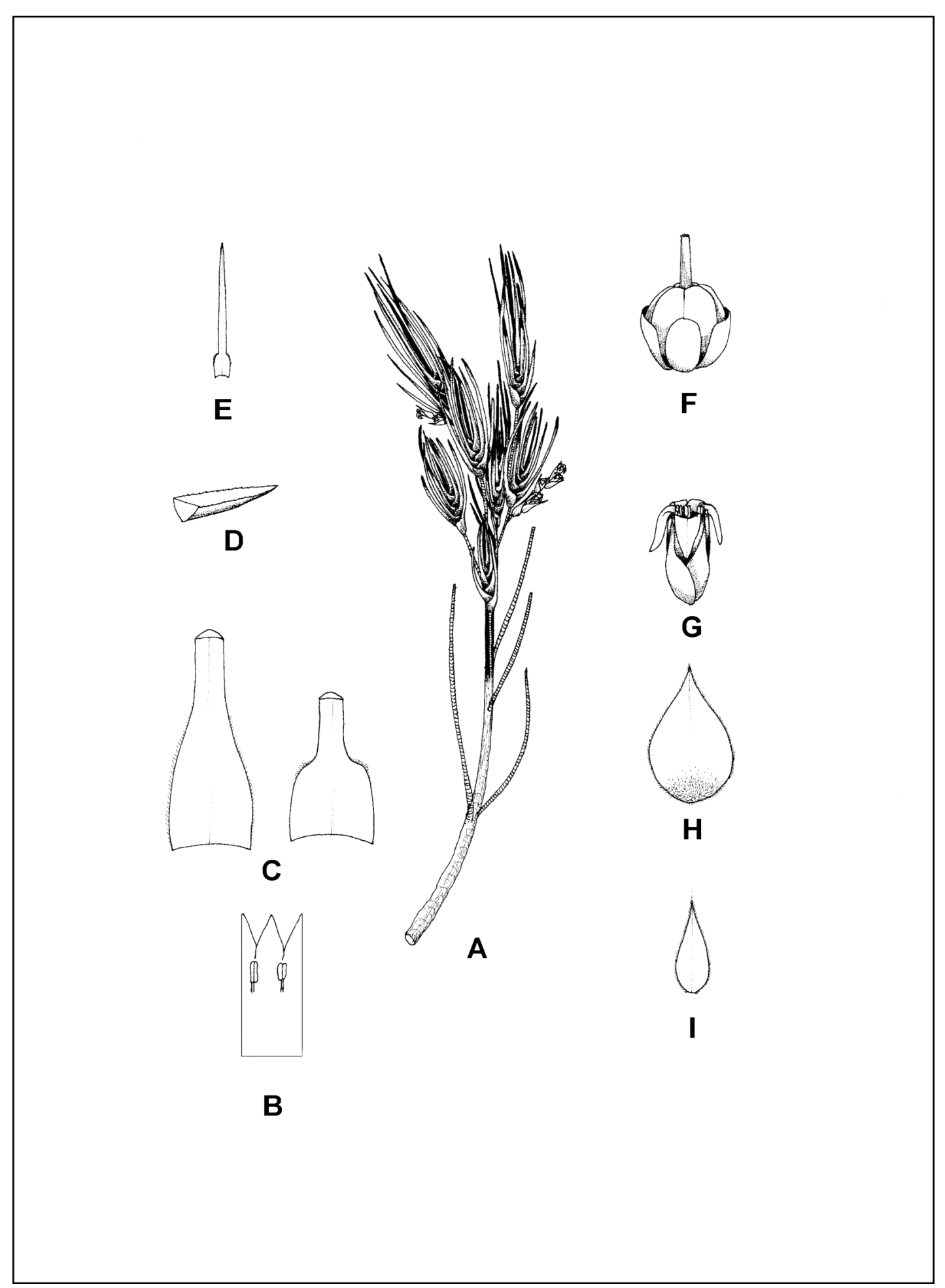

Figure 7.114. Oreothamnus pearsonii. A, flowering branch $(\times 1)$; B, laid out corolla $(\times$ 5); C, lamina sheaths to show variation $(\times 5)$; $\mathbf{D}$, lamina apex $(\times 5)$; $\mathbf{E}$, leaf $(\times 1) ; \mathbf{F}$, ovary $(\times 10)$; $\mathbf{G}$, flower $(\times 5)$; $\mathbf{H}$, inflorescence bract adaxial surface $(\times 5)$; I, sepal $(\times 5)$. Drawn from Venter13790. 


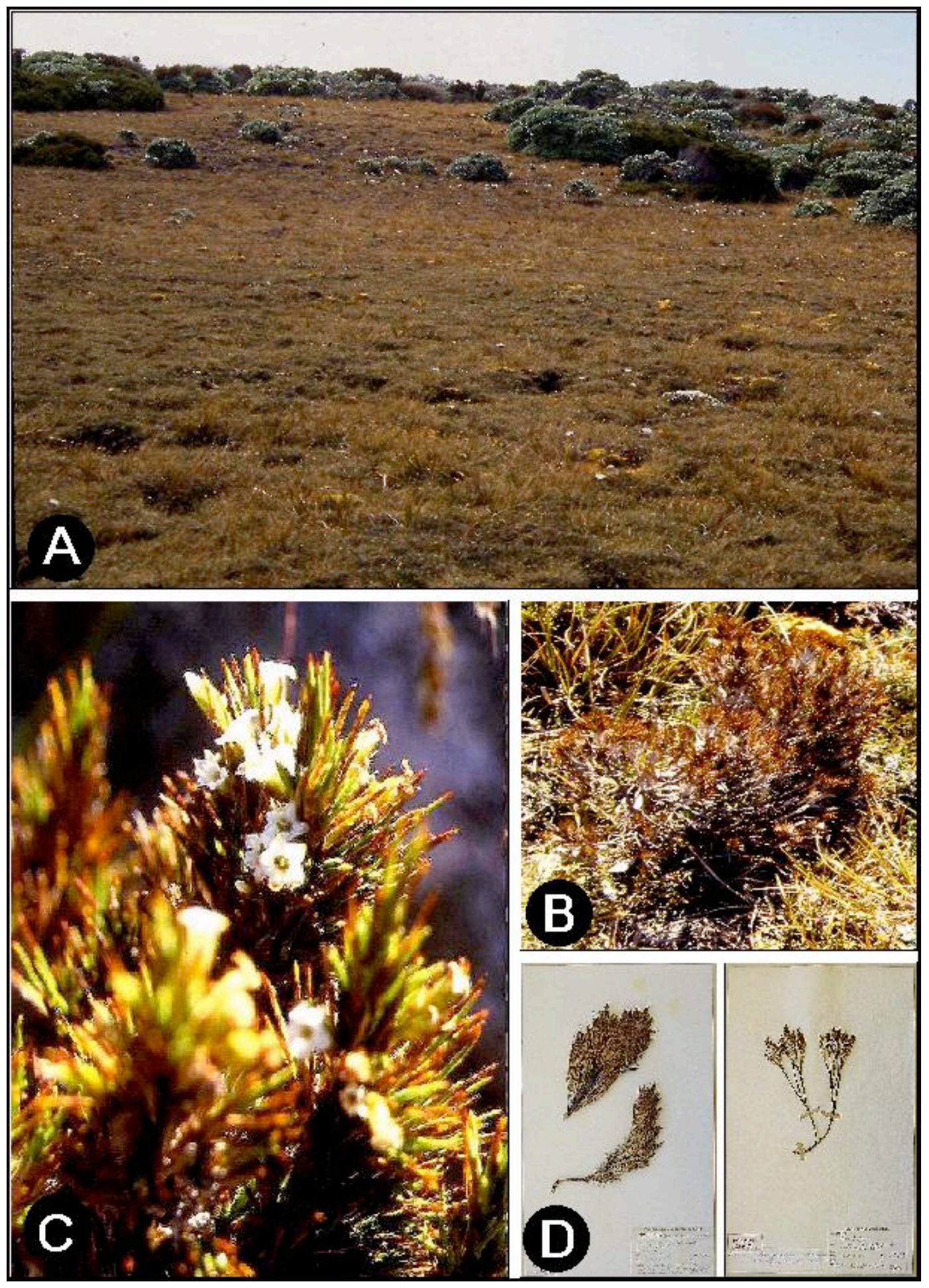

Figure 7.115. Oreothamnus pearsonii. A, plateau habitat, Mt. Anglem; B, adult plant showing the persistent old leaves; $\mathbf{C}$, flowering branch; $\mathbf{D}$, herbarium specimens showing variation. B-C, Venter 13790. 
distinguished from other species by the imbricate and strongly keeled leaves with triquetrous apices, dry old leaves that remain on the plant for a long period and the few-flowered (3-6 flowers) inflorescence.

\section{Distribution}

New Zealand endemic. Restricted in distribution to a small area in the Fiordland

National Park, South Island b ut widely distributed on Stewart Island (Fig. 7.116).

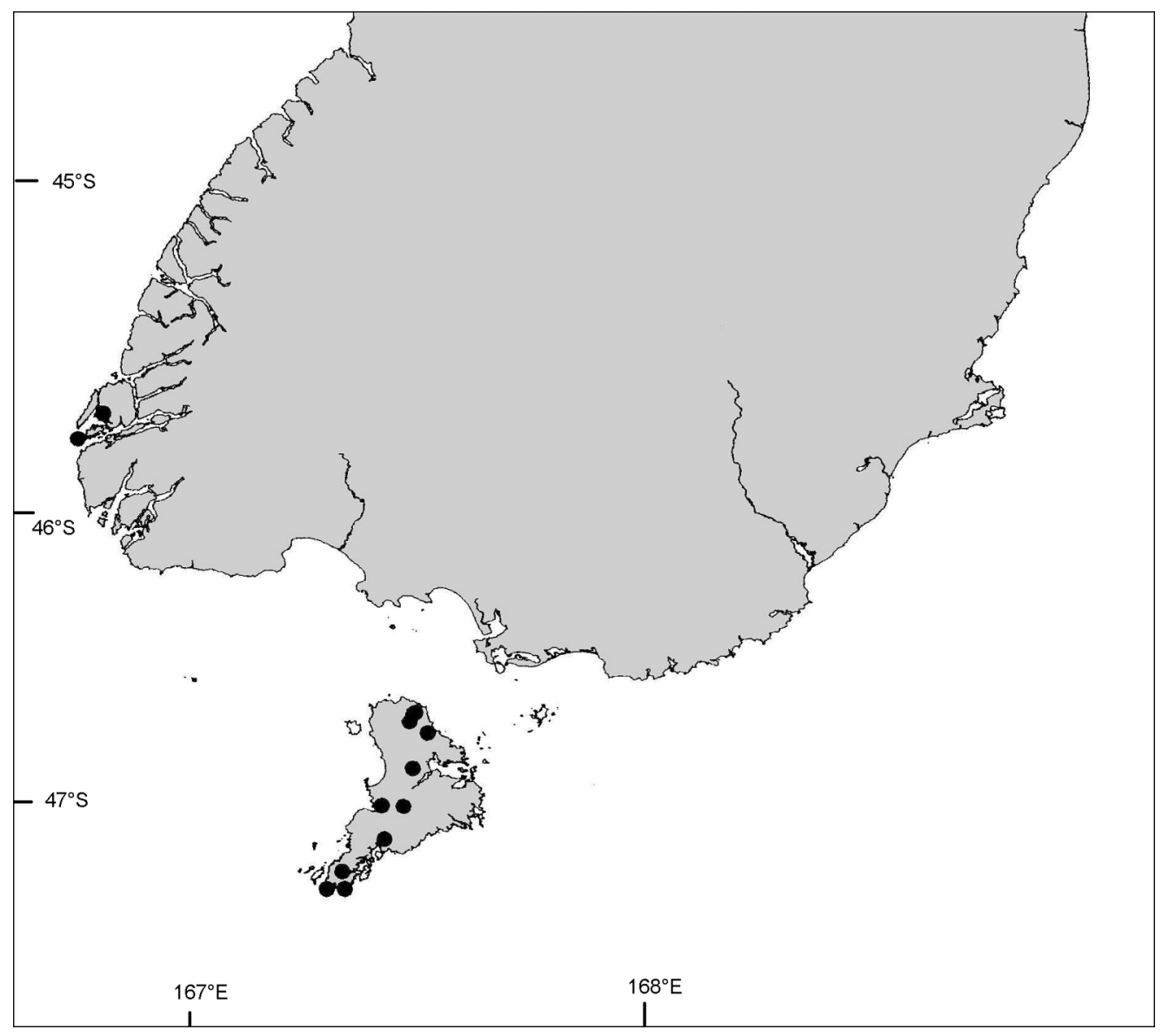

Figure 7.116. Known distribution of Oreothamnus pearsonii - southern part of the South Island with Stewart Island. 


\section{Habitat}

Oreothamnus pearsonii occurs on gentle $\left(0^{\circ}-15^{\circ}\right)$ north and east facing mountain slopes, ridges and plateaus from 300-1,000 $\mathrm{m}$ altitude. The vegetation of these areas consists of montane to subalpine shrubland, herbfield or grassland (Table 7.46). The soil is a brown gritty sandy loam derived from granite and granidiorite.

Table 7.46. Plant associations commonly associated with Oreothamnus pearsonii.

\section{SHRUBLAND}

Low closed evergreen Olearia colensoi - Leptospermum scoparium shrubland

Low open evergreen Oreothamnus filifolius - Olearia colensoi - Halocarpus biformis shrubland

\section{Variation}

The leaves can be very dense or somewhat openly arranged on the branches (Fig. 7.115D). The leaf sheath varies in size $(4.0-7.0 \times 3-5 \mathrm{~mm})$ and can sometimes have an area of dense scabrid hairs at the base of the lamina. Lamina length varies from $19-32$ $\mathrm{mm}$, even on the same plant.

\section{Material examined}

NEW ZEALAND. South Island. 45-166: Secretary Island (-BB), 7.ii.1964. Wardle s.n. (CHR); Dusky Sound, Facile Harbour (-CB), 9.ii.1946. Allan s.n. (CHR); Fiordland National Park, near West Cape, east of Lake Fraser (-DC), 9.ii.1972. Mark s.n. (CHR). Stewart Island - 46-167: Hill N of Smiths Lookout (-AD), i.1952. Findlay s.n. (CHR); Table Hill Track (-BA), 12.i.1940. Cranwell \& Moore s.n. (CHR); Mt. Anglem, high ridge below summit (-DB), 11.i.2000. Venter 13790 (CHR); Mt. Rakeahua (-DD), 12.i.1940. Cranwell s.n. (CHR). 47-167: Hill north of Smiths Lookout (-AD), i.1952. Findley s.n. (CHR); Pegasus Bay (-BA), Aston s.n. (AK, CHR). 
18. Oreothamnus politus (Cheeseman) S. Venter

Oreotbamnus politus (Cheeseman) S. Venter, comb nov. Cheeseman, Man. N.Z. Fl:: 427 (1906); Cheeseman, Man. N.Z. Fl. $2^{\text {nd }}$ Ed.: 525 (1925); Oliver, Trans. Proc. N.Z. Inst. 59: 687 (1928); Oliver, Trans. Roy. Soc. N.Z. 80 (1): 4 (1952); Allan, Fl. N.Z. 1: 525 (1961); Moore \& Irwin, Oxford Book of N.Z. Plants.: 296 (1978); Eagle, Trees and Shrubs of N.Z. $2^{\text {nd }}$ series.: 296 (1982); Mark \& Adams, N.Z. Alpine Plants.: 118 (1986); Poole \& Adams, Trees and Shrubs of N.Z.: 156 (1994). Type: New Zealand, Mt. Maungatua near Dunedin, 3,000'. D. Petrie s.n. (AK 7033, lecto.!; WELT 33366!), designated by Oliver (1952).

三 Dracophyllum politum (Cheeseman) Cockayne, Rep. Bot. Surv. Stewart Is.: 43 (1909). comb. nov.

=Dracophyllum rosmarinifolium var. politum Cheeseman in Man. N.Z. Fl.: 427 (1906).

Icones: Oliver, Trans. Proc. N.Z. Inst. 59: 687, t. 3 (1928); Eagle, Trees and Shrubs of N.Z. $2^{\text {nd }}$ series.: 296, t. 151 (1982).

\section{Description}

Cushion-forming, up to $50 \mathrm{~cm}$ tall and $100 \mathrm{~cm}$ in diameter, to a scrambler 2-25(-50) cm tall. Branches spreading to prostrate, much-branched. Bark on old stems grey to brown, broadly fissured, young stems reddish brown. Leaves imbricate, appressed to stem, erect, olive to dark green, dry old leaves present. Leaf sheath $2.5-4.0 \times 3-4 \mathrm{~mm}$, shoulders tapering to round and margin membranous, ciliate. Lamina rigid and hard, linear, 3.5$12.0(-17.2) \times 0.7-1.5 \mathrm{~mm}$, adaxial surface flat; surfaces glossy, margins serrulate with 90 100 teeth per $10 \mathrm{~mm}$; apex obtuse or occasionally subacute. Inflorescence a sessile, 
solitary terminal flower; shorter than leaves, erect. Flower bract shorter than flower, leaf like, broadly ovate to triangular, $2-3 \times 0.7-0.8 \mathrm{~mm}$, margins serrulate, apices obtuse. Sepals ovate-lanceolate, $4.8-5.0 \times 1.8-2.0 \mathrm{~mm}$, longer than corolla tube, adaxial surface with top half pubescent; abaxial surface glabrous; margins ciliate. Corolla white; corolla tube cylindrical, widened at mouth, 3.5-4.5 × 1.4-1.5 mm; corolla lobes spreading horizontally to reflexed, ovate-triangular, shorter than corolla tube, 1.5-2.2 × 1.0-1.8 mm, apical ridge present, inflexed at apex, obtuse; adaxial surface papillate. Stamens inserted on corolla tube in upper third, filaments $0.5-1.0 \mathrm{~mm}$ long; anthers included, oblong, light yellow and $0.9-1.0 \mathrm{~mm}$ long. Ovary ovate, $1.2-1.8 \times 1.2-1.3 \mathrm{~mm}$, apex round; nectary scales rectangular, $0.8-1.2 \times 0.5-0.7 \mathrm{~mm}$, apices irregularly toothed; style included, 1.0-1.1 mm long, glabrous, not lengthening in fruit; stigma five-lobed. Fruit dark brown, $2.5-3.0 \times 1.5-2.5 \mathrm{~mm}$, oblong and ridged at the ribs; apex round, glabrous. Seeds dark brown, ovoid, 0.68-0.7 mm long, testa prominently reticulate. Flowering December-March. (Figure 7.117).

\section{Diagnostic features and notes}

Oreothamnus politus is a dense cushion plant or a prostrate shrublet with densely imbricated leaves appressed to the branch. The lamina is very glossy (hence the specific epithet) and convex, slightly curved inwards and with obtuse apices. Flowers are solitary and the flower bracts have blunt apices. The corolla lobes that are inflexed have prominent apical ridges.

Oreothamnus politus is similar to O. densus but differs in leaf and flower characters (Table 7.30). 


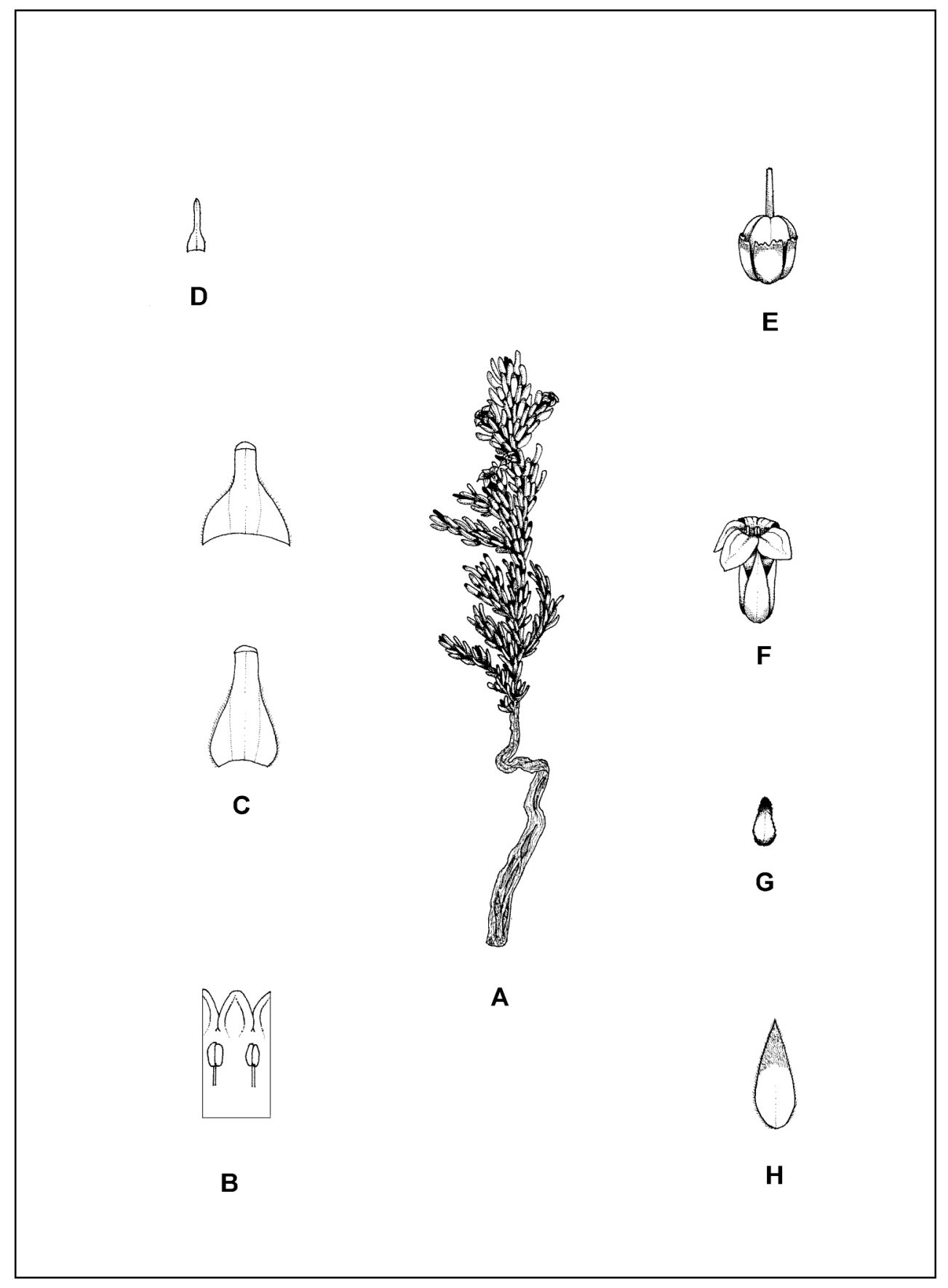

Figure 7.117. Oreothamnus politus. A, flowering branch $(\times 1)$; B, laid out corolla $(\times 5)$; $\mathbf{C}$, leaf sheaths to show variation $(\times 5) ; \mathbf{D}$, leaf $(\times 1)$; E, ovary $(\times 10) ; \mathbf{F}$, flower $(\times 5) ; \mathbf{G}$, inflorescence bract $(\times 3)$; $\mathbf{H}$, sepal adaxial surface $(\times 6)$. Drawn from Venter 13789 . 

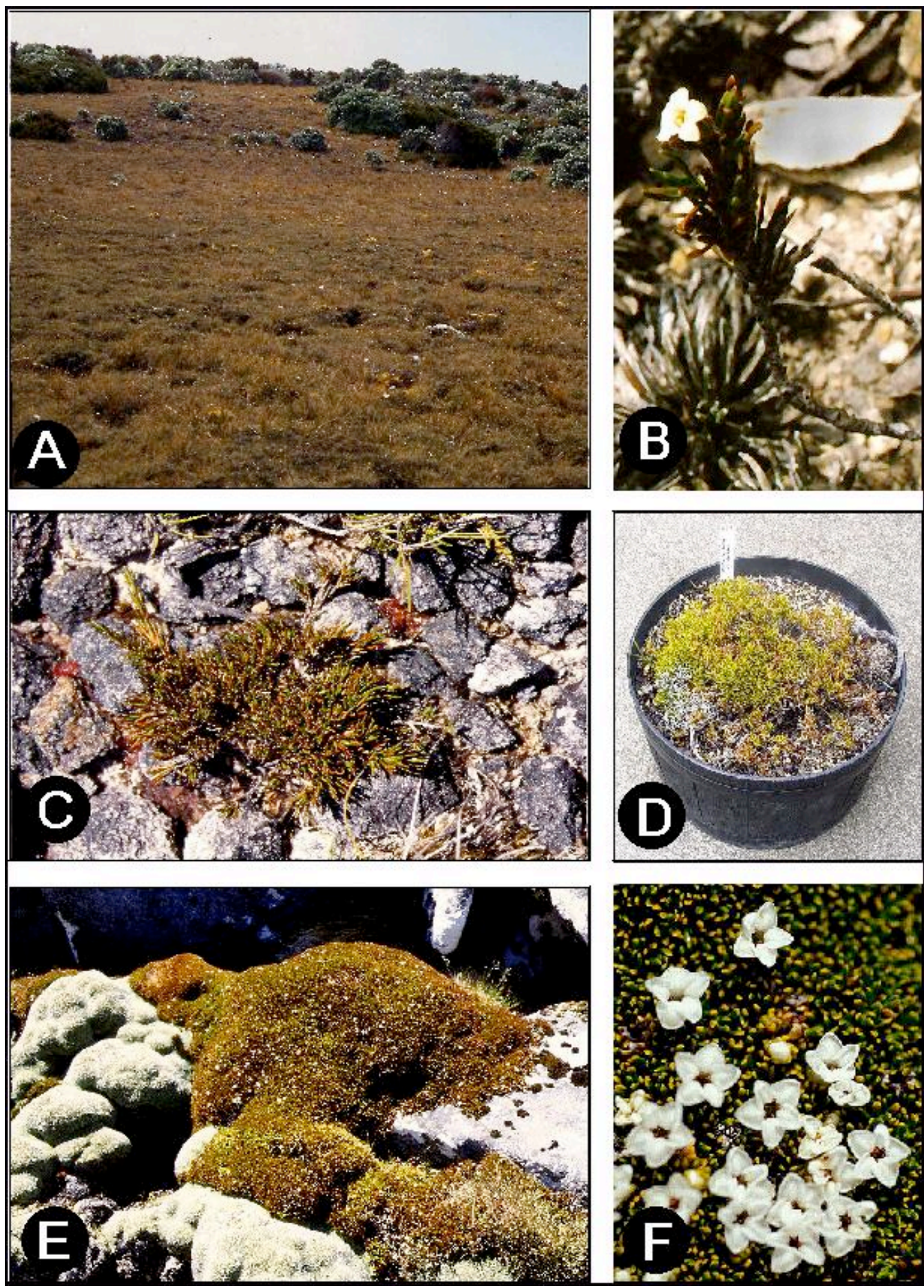

Figure 7.118. Oreothamnus politus. A, habitat on Mt. Anglem, Stewart Island; B, flowering branch, Mt. Rochfort; C, trailing form from Mt. Rochfort; D, plant in cultivation keeps cushion habit; E, mature plant from Mt. Anglem showing the cushion growth habit; F, flowers are carried above the leaves. E-F, Venter 13789. 


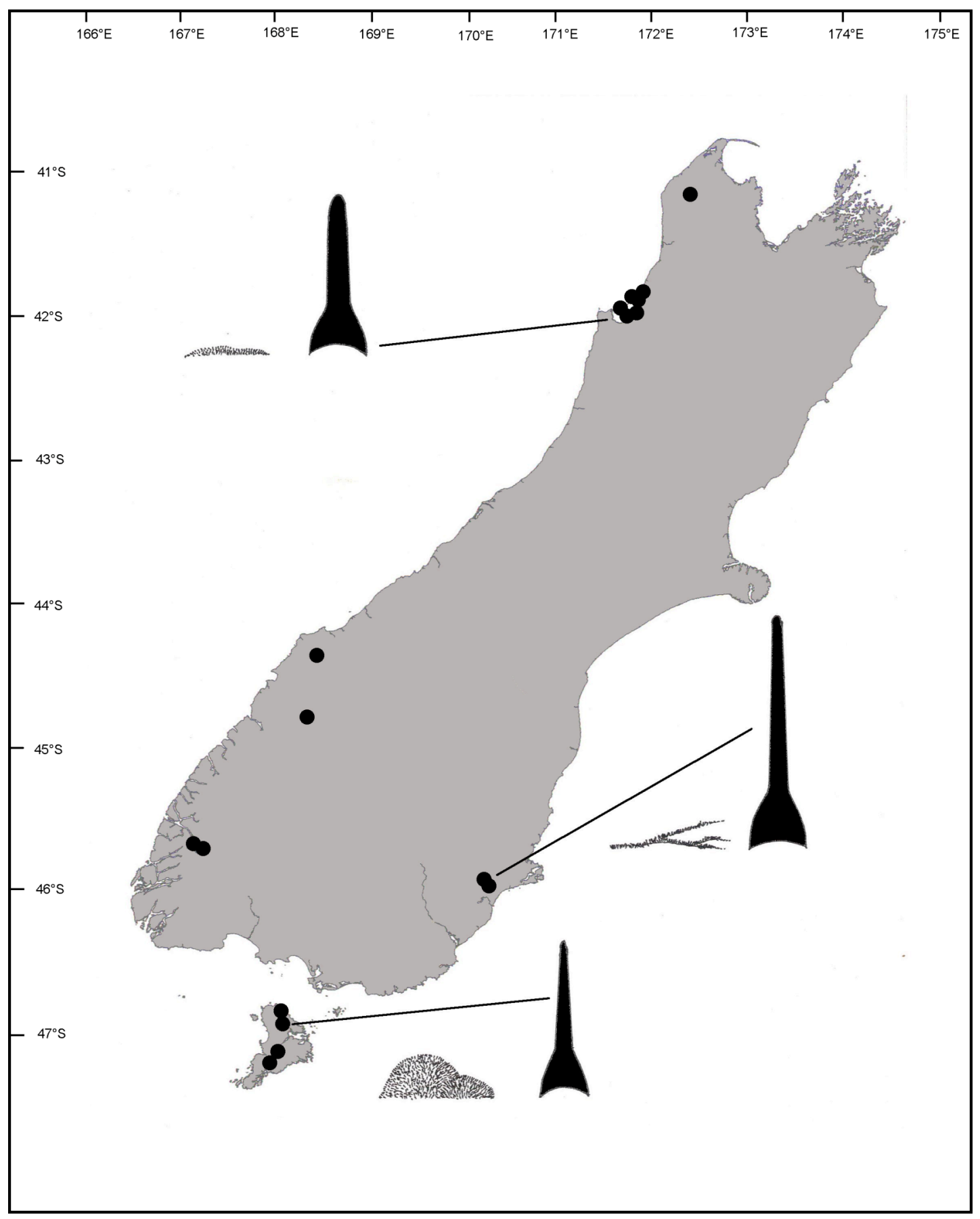

Figure 7.119. Known distribution, growth habit and leaf variation in Oreothamnus politus. A, Westport, Mt. Rochfort (Venter 13730); B, Mt. Maungatua (Venter 13810); C, Stewart Island, top of Mt. Anglem (Venter 13789). All leaves drawn $\times 4$.

\section{Distribution}

New Zealand endemic. Known from Mount Goul and the Denniston area in the north,

Fiordland National Park, Mount Maungatua and Stewart Island in the south (Fig. 7.119). 


\section{Habitat}

Oreothamnus politus grows fully exposed on gentle $\left(0^{\circ}-15^{\circ}\right)$ mountain slopes, especially on mountain peaks and plateaus at altitudes of $500-1,524 \mathrm{~m}$. These areas are covered in subalpine to alpine shrubland, herbfield, fell field, grassland or bog (Table 7.47). Soils are dark brown peaty soil, gritty sandy loam or light brown clay derived from granidiorite, greywacke, granite, sandstone or conglomerate. Oreothamnus politus sometimes grows in permanently wet areas on Mt. Maungatua and in bogs on the Table Hill Range (Stewart Island) where they grow into other cushion plants (Donatia novae-zelandiae and Oreobolus pectinatus).

Table 7.47. Plant associations commonly associated with Oreothamnus politus.

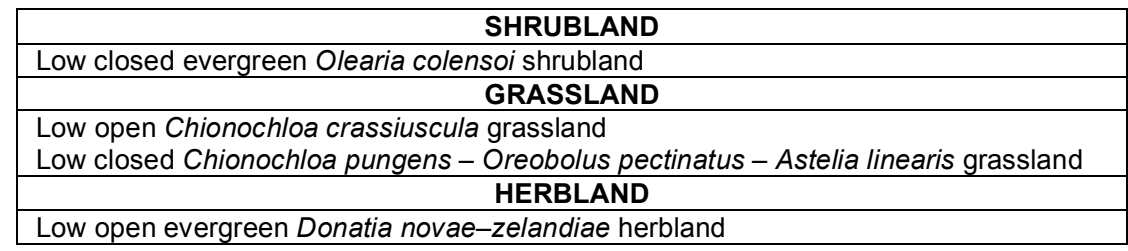

\section{Variation}

The plant habit is polymorphic (Figure 7.119) from dense round cushions $30 \mathrm{~cm}$ tall to plants with sprawling stems and carpet-like. The leaves vary in size $(3.5-12.0 \times 0.7-1.5$ $\mathrm{mm}$ ) with minimal variation in shape.

\section{Material examined}

NEW ZEALAND. South Island. 40-172: Peak N of Mt. Goul (-CD), i.1973. Druce s.n. (CHR). 41-171: Denniston, (-DA), 6.i.1968. Brownlie 665 (CHR); Stockton Plateau (DB), 16.vii.1979. Given 11834 (CHR); Mt. Augustus, 7.i.1976. Moore s.n. (CHR); Summit 
of Mt. Rochford (-DC), 14.xi.1966. Kelly \& Kelly s.n. (CHR); Westport - Mount Rochfort, Denniston Plateau (-DD), 25.xi.1998. Venter 13730 (CHR), ibid., Venter 13819 (CHR); ibid., Venter 13826 (CHR); Burnetts Face. Ii.1913. Petrie s.n. (AK). 41-172: Below Garibaldi Ridge (-AB), iv.1980. Druce s.n. (CHR). 44-168: Mt. Earnslaw (-CB), ii.1992. Druce 1720 (CHR). 45-167: Wilmott Pass, Pahiri Peak (-CA), 25.xii.1944. Simpson s.n. (CHR, WELT). Stewart Island. 46-167: Top of Mt. Anglem (-DB), 11.i.2000. Venter 13789 (CHR); Thompson Ridge (-DD), 19.ii.1962. Wardle s.n. (CHR). 47-167: Unnamed hill north of Smith's Lookout (-BA), 1.i.1952. Findley s.n. (CHR); Port Pegasus. xi.1907. Aston s.n. (AK).

19. Oreothamnus pronus (W.R.B. Oliv.) S. Venter

Oreothamnus pronus (W.R.B. Oliv.) S. Venter, comb. nov. Hooker, Fl. Antart. 1: 48 (1844a); Hooker, Fl. Nov. Zel. 1: 171 (1853); Oliver, Trans. Proc. N.Z. Inst. 59: 686 (1928); Oliver, Trans. Roy. Soc. N.Z. 80 (1): 2 (1952); Allan, Fl. N.Z. 1: 524 (1961); Moore \& Irwin, Oxford Book of N.Z. Plants.: 296 (1978); Eagle, Trees and Shrubs N.Z. $2^{\text {nd }}$ series.: 296 (1982); Mark \& Adams, N.Z. Alpine Plants.: 118 (1986); Poole \& Adams, Trees and Shrubs of N.Z.: 156 (1994). Type: New Zealand, Blimit Mountain, above Arthur's Pass, above 6,000', 29.i.1928. W.R.B. Oliver s.n. (WELT 33206, holo.!; WELT 33349!; WELT 33354!; WELT 33354 dupl.!; WELT 33359!).

= Dracophyllum pronum W.R.B. Oliv., Trans. Proc. N.Z. Inst. 59: 686 (1928), nom. nov.

Dracophyllum rosmarinifolium Hook. f., Fl. Antarct. 1: 48 (1844a). Non R. Br. 
Dracophyllum rosmarinifolium Cheeseman, Man. N.Z. Fl: 427 (1906). Non R. Br.

Dracophyllum muscoides Armstrong, Trans. Proc. N.Z. Inst. 13: 342 (1881). Non

Hook. f.

Dracophyllum rosmarinifolium Betts, Trans. Proc. N.Z. Inst. 51: 155 (1919). Non

R. Br.

Icones: Oliver, Trans. Proc. N.Z. Inst. 59: t. 2 (1928); Oliver, Trans. Roy. Soc. N.Z. 80 (1): t. 2 (1952); Eagle, Trees and Shrubs N.Z. $2^{\text {nd }}$ series.: t. 149 (1982); Smith-Dodsworth, N.Z. Native Shrubs \& Climbers.: t. 53, Pl. 22C \& 22D (1991); Salmon, Native N.Z. Flowering Plants. : 216, t. 899 (1991).

\section{Description}

Scrambler or subshrub (1-)10-25 cm tall. Branches decumbent to prostrate. Bark on old branches grey and smooth, sometimes with deep fissures in very old specimens, young stems reddish brown. Leaves spreading; lamina sheath $0.7-4.0 \times 1-3 \mathrm{~mm}$, shoulders tapering to rounded and margin membranous, ciliate. Lamina linear, 2.5-11 × 0.5-1.0 $\mathrm{mm}$, adaxial surface flat, with a tuft of scabrid hairs at base; margins serrulate with 100 140 teeth per $10 \mathrm{~mm}$; apex obtuse to acute. Inflorescence a sessile, terminal, solitary flower on lateral branchlets; shorter than leaves; inflorescence bract shorter than flower, coriaceous, ovate at base, $3.2-4.1 \times 0.6-0.8 \mathrm{~mm}$, margins serrulate; flower bract shorter than flower, leaf like, ovate, $3.5-4.0 \times 0.6-0.8 \mathrm{~mm}$; margins serrulate. Sepals ovatelanceolate, (1.7-) 4.0-4.5 × 1.4-1.6 mm, equaling to longer than corolla tube; margins ciliate. Corolla white to light pink; corolla tube cylindrical, $2.5-4.0 \times 1.5-1.8 \mathrm{~mm}$; corolla lobes reflexed, ovate-triangular, shorter than corolla tube, $(1.0-) 1.5-2.0 \times(1.0-) 1.5-2.0$ 
$\mathrm{mm}$, apex inflexed, subacute; apical ridge present, adaxial surface papillate. Stamens inserted on corolla tube in the middle, filaments $0.5-1.0 \mathrm{~mm}$ long; anthers included, oblong, light yellow and $0.8-1.0 \mathrm{~mm}$ long. Ovary ovate, $0.5-1.0 \times 0.5-1.2 \mathrm{~mm}$, apex round; nectary scales rectangular, $0.5-0.8 \times 0.5-0.7 \mathrm{~mm}$; apices retuse; style included, $1.0-1.5 \mathrm{~mm}$ long, glabrous; stigma capitate. Fruit light brown, 1.2-2.5 $\times 1.5-2.0 \mathrm{~mm}$, oblong, glabrous, apex truncate. Seeds yellowish brown, ovoid, 0.46-0.5 mm long, testa slightly reticulate. Flowering December-February (-April). (Figure 7.120).

\section{Diagnostic features and notes}

Oreothamnus pronus is characterized by the decumbent to prostrate stems, flat adaxial lamina surface, flower bract shorter than the corolla tube and with a serrulate margin, sepals equal to longer than the corolla tube, a prominent apical ridge on the corolla lobe and the retuse nectary scales apices.

Hooker (1844a) included Oreothamnus pronus under Forster's Dracophyllum rosmarinifolium and Cheeseman (1906) suspected that his D. rosmarinifolium was different to that of the Forsters but not being able to get hold of the Forster type, he made no alteration. Oreothamnus pronus is also quite distinct from O. politus and for this reason Oliver (1928) gave it the new name Dracophyllum pronum. Oreothamnus pronus is similar to O. palustris but differs in the leaves being shorter $(2.5-11 \mathrm{~mm}$ compared to $14-27 \mathrm{~mm})$ and the lamina apex acute not triquetrous. The inflorescence bract is shorter than the flower (not equaling) and far narrower (0.6-0.8 $\mathrm{mm}$ compared to $1.5-2.0 \mathrm{~mm})$ with serrulate green not white margins. The corolla tube is also narrower (1.5-1.8 mm compared to 2.0-2.2 $\mathrm{mm}$ ) and the apical ridge on the corolla lobe is absent in O. palustris. 
D

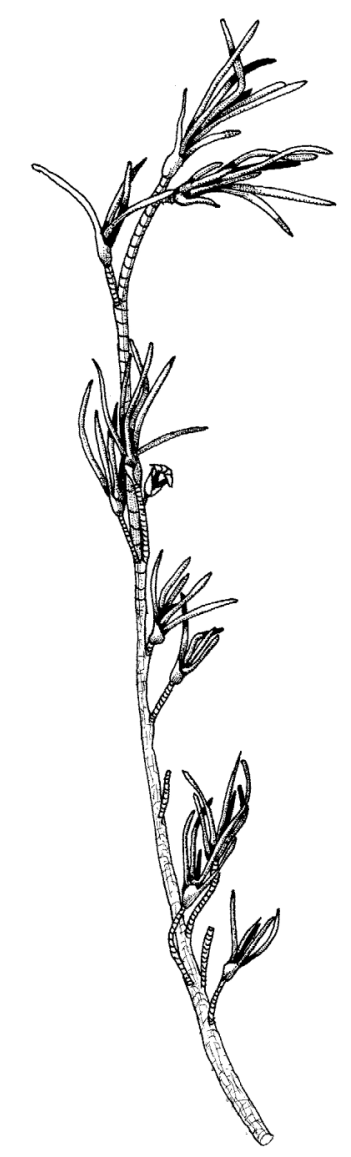

E
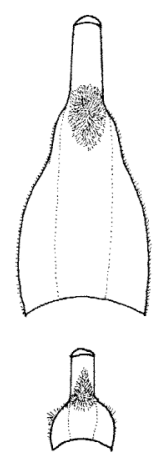

C

A

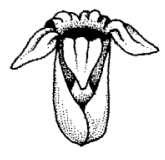

$\mathbf{F}$

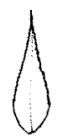

G

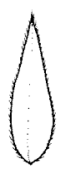

H

Figure 7.120. Oreothamnus pronus. A, flowering branch $(\times 1)$; B, laid out corolla $(\times 5)$; $\mathbf{C}$, lamina sheaths to show variation $(\times 5)$; $\mathbf{D}$, leaf $(\times 1)$; E, ovary $(\times 10) ; \mathbf{F}$, flower $(\times 5)$; G, inflorescence bract $(\times 5)$; H, sepal $(\times 5)$. Drawn from Venter 13786 . 


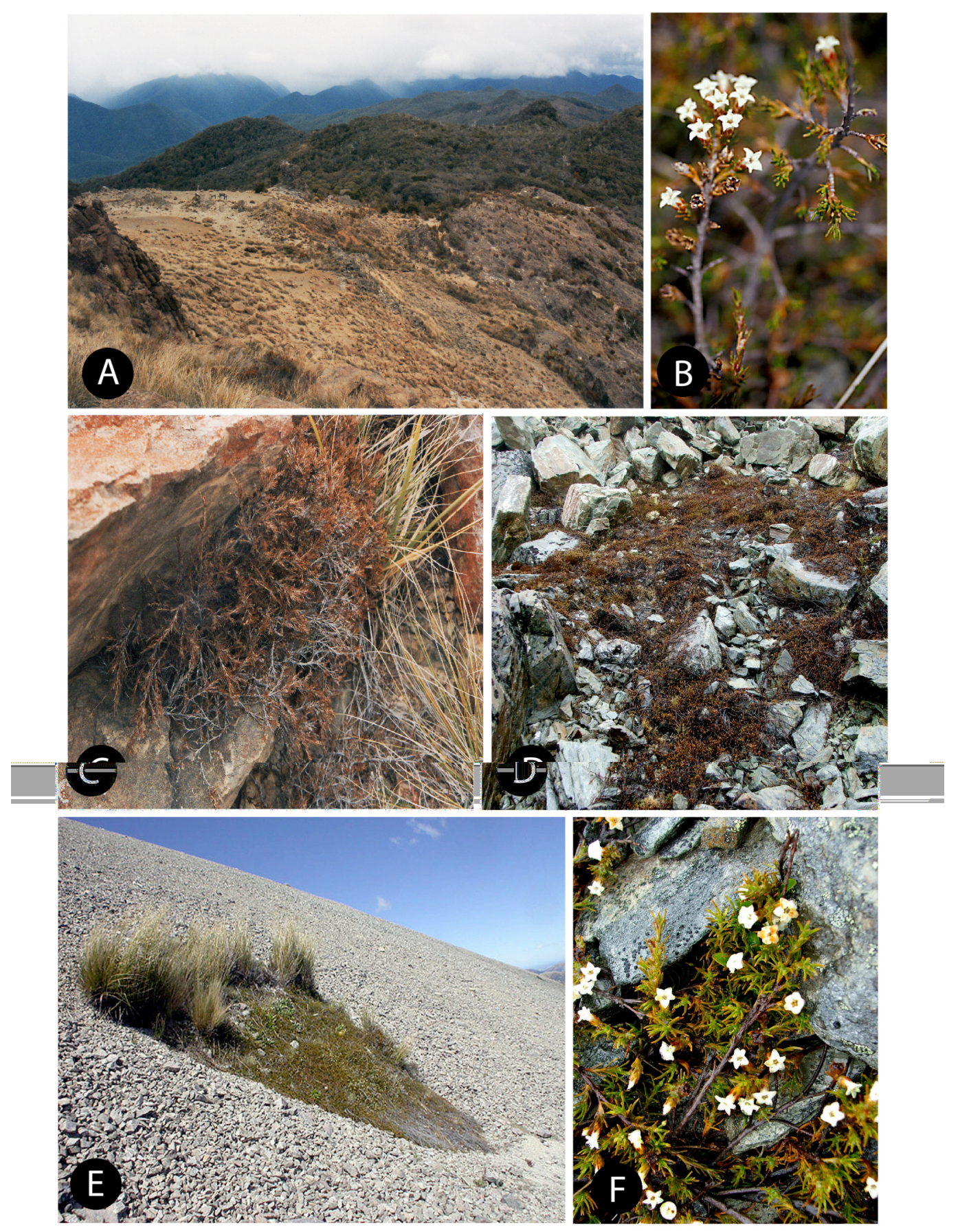

Figure 7.121. Oreothamnus pronus. A, serpentinite habitat on Dun Mountain; B, flowering branch - Porters Pass; C, shrubby growth habit of the Dun Mountain plants; D, prostrate growth habit of plants from alpine habitats - Mt. Dobson; E, prostrate alpine form - Porters Pass; F, flowering branch - Mt. Dobson. A-C Venter 13786. 


\section{Distribution}

New Zealand endemic restricted to the South Island (Fig. 7.122).

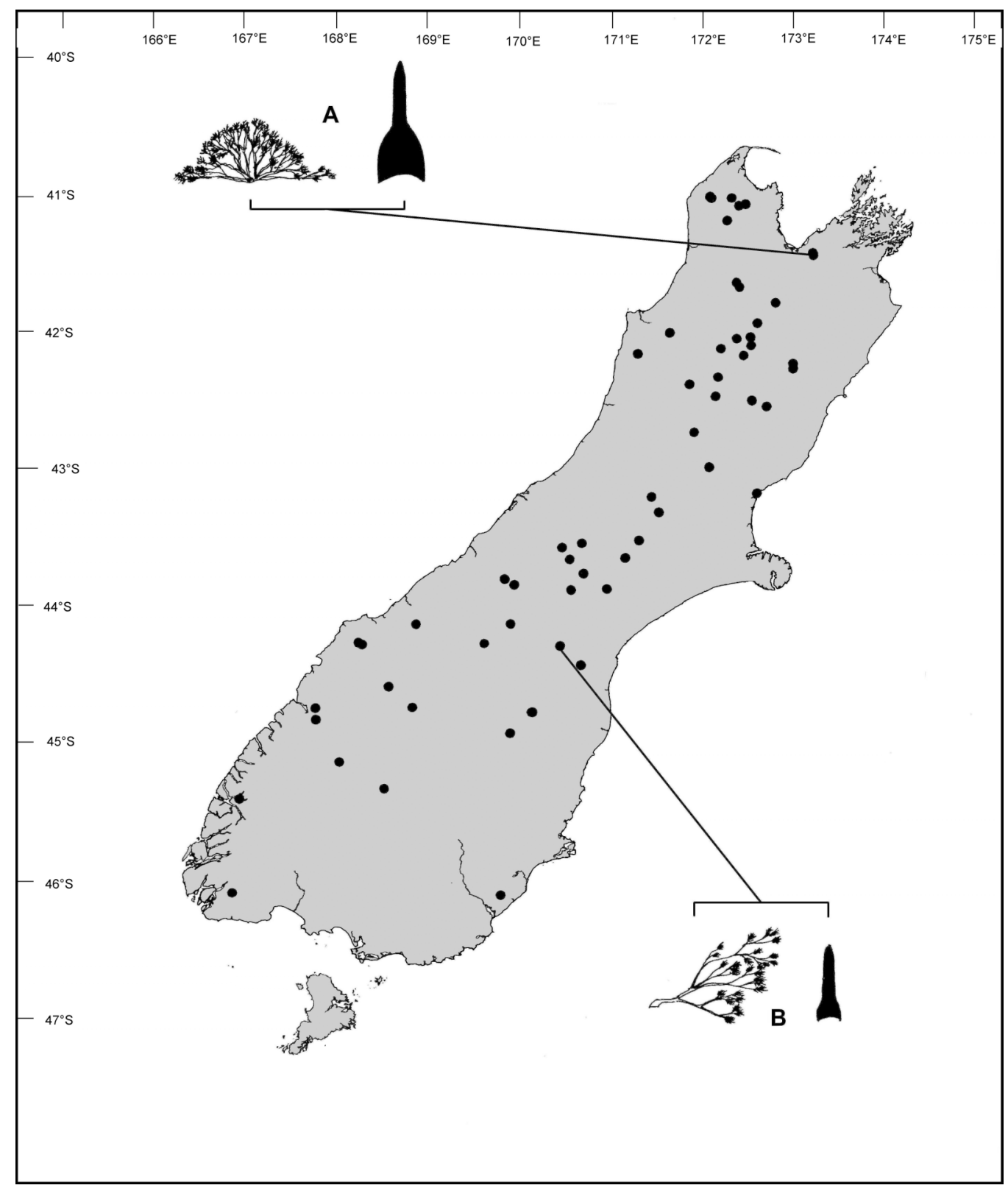

Figure 7.122. Known distribution, variation in growth habit and leaves of Oreothamnus pronus. A, Nelson, Dun Mountain (Venter 13786); B, Mt. Peel (Mayrhofer \& Molloy 4793). All leaves drawn $\times 7$. 


\section{Habitat}

Oreothmnus pronus occurs on gentle to steep $\left(5^{\circ}-40^{\circ}\right)$ mountain slopes, mountain saddles and exposed rocky ridges at altitudes of $600-2,000 \mathrm{~m}$. These areas are covered in montane to subalpine shrubland, shrub-tussockland, herbfield to alpine herbfield, fellfield, bogland or tussock grassland (Table 7.48). Soils are brown to reddish brown gritty to rocky clay loam derived from greywacke, serpentinite, granite or gneiss. O. pronus is one of the few plant species to survive on mountain peaks where the snow lies in shaded areas for up to five months of the year.

Table 7.48. Plant associations commonly associated with Oreothamnus pronus.

\begin{tabular}{|l|}
\hline \multicolumn{1}{|c|}{ SHRUBLAND } \\
\hline $\begin{array}{l}\text { Low open evergreen Podocarpus nivalis - Acrothamnus colensoi shrubland } \\
\text { Low open semi-deciduous Oreothamnus acerosus - Aciphylla monroi shrubland }\end{array}$ \\
\hline \multicolumn{1}{c|}{ FELLFIELD } \\
\hline Low open Haastia pulvinaris fellfield \\
\hline \multicolumn{1}{c|}{ GRASSLAND } \\
\hline $\begin{array}{l}\text { Tall open Chionochloa crassiuscula tussock grassland } \\
\text { Low open Chionochloa rigida tussock grassland }\end{array}$ \\
\hline Bonochloa rubra- Leptospermum scoparium subalpine grassland \\
\hline Closed evergreen Sphagnum bogland \\
\hline
\end{tabular}

\section{Variation}

Oreothamnus pronus is a polymorphic species, influenced by its habitat (Figure 7.121A). Populations in exposed alpine areas (Mt.Torlesse) grow as a prostrate plant closely hugging the ground with leaves $2.5-3.2 \times 0.5-0.6 \mathrm{~mm}$ and the lamina sheath $0.7-2.0 \times$ 1-2 mm (Venter 13755). Populations in more protected areas at lower altitude (Dun Mountain), grow as a roundish shrublet of $30 \mathrm{~cm}$ tall (Fig. 7.121C) with leaves $3-4 \times$ 0.7-1.0 mm and the lamina sheath 2.5-4.0 × 2.5-3.0 $\mathrm{mm}$ (Venter 13786). The sepals can equal the length of the corolla tube or can be longer, with the corolla tube varying from 
2.5-4.0 $\mathrm{mm}$ long on the same plant. Light pink flowers sometimes occur scattered throughout populations.

\section{Hybrids}

Oreothamnus pronus hybridises with O. kirkii and this was described by Oliver (1928) as Dracophyllum $\times$ saxicolum. On Dun Mountain near Nelson, O. pronus hybridises freely with O. filifolius and at Lake Te Anau, it hybridises with O. oliveri.

\section{Material examined}

NEW ZEALAND. South Island. 40-172: Gouland Downs (-CD), i.1969. Druce s.n. (CHR); Lead Hills (-DC), 29.xii.1949. Moore s.n. (CHR). 41-172: Lake Sylvester (-BA), 15.i.1962. Melville 6036, Melville \& Talbot (AK, CHR); Beeby's Knob (-DB), i.1952. Talbot s.n. (CHR); Mole Tops (-DC), 13.ii.1964. Simpson 4053 (CHR). 41-173: Nelson, Dun Mountain, Dun Saddle (-AD), 28.ix.1999. Venter 13786 (CHR); Mt. Baldy (-BC), iii.1984. Druce s.n. (CHR); Red Hills, Motueka River (-CA), xii.1980. Druce s.n. (CHR). 42-171: Paparoa Range, E of Mt. Priestly (-BA), 30.v.1983. Wardle s.n. (CHR). 42-172: West Glenroy Range, Glenroy Valley (-AB), 15.i.1985. Burke 274 (CHR); Mt. Haast (AC), 21.i.1994. Wardle 96/48 (CHR); Mt. Technical (-AD), ii.1937. Simpson s.n. (CHR); Spencer Range, Waiau Pass (-BA), 12.i.1970. Simpson 5701 (CHR); Mt. Sebastepol (-BB), 26.ii.1958. Connor s.n. (CHR); Mt. Saint Patrick (-BC), 14.i.1972. Canterbury Botanical Society Camp s.n. (CHR); Jollies Pass (-BD), 7.ii.1938. Zotov s.n. (CHR); Mac's Knob (-CA), 30.i.1973. Macmillan 73/77 \& Stemmer (CHR); Ant Creek (-CC), i.1934. Wall s.n. (CHR). 43-170: Summit of Mt. Burnette (-CC), 3.v.1964. Dawson s.n. (CHR); Two Thumb Range, The Growler (-DA), ii.1991. Druce APD222 (CHR); Mt. Potts (-DB), xii.1918. Cockayne s.n. (CHR); Mt. Sinclair, iii.1986. Druce s.n. (CHR); Fox Peak (-DD), iii.1985. Druce s.n. (CHR). 43-171: Mt. Cockayne, Craigieburn Basin (-BA), 30.v.1973. Chapman 
s.n. (AD, BREM, CANB, E, K, L, MO, NBG, PRC, RSA, TI, WISCON); Mt. Ida, 7.i.1911. Petrie s.n. (CHR); Christchurch - Porters Pass, Foggy Peak (-BC), 28.i.1999. Venter 13755 (CHR); Mt. Torlesse (-BD), iv.1909. Travers s.n. (L, W, Z); Mt. Peel (-CC), 16.i.1985. Mayrhofer \& Molloy 4793 (GZU); Mt. Hutt (-DA), 6.iv.1972. Molloy s.n. (CHR). 44-168: Cascade River, east of Woodhen Creek (-AB), 12.iii.1978. Wardle, Lee \& Johnson s.n. (CHR); Torlesse Range, Fog Peak (-DB), 14.ii.1948. Oliver s.n. (WELT); Crown Range, $7 \mathrm{~m}$ SE of Arrowtown (-DD), 26.ii.1962. Melville 6551 (AK, L). 44-169: Pisa Range, Gordon's Rock (-CC), 19.i.1947. Langbein 9/14 (CHR). 44-170: St. Marys Range, Awakino Skifield (-CD), 19.xii.1987. Rance s.n. (CHR). 45-168: Mt. Dick (-BC), 25.xi.1995. Wardle 96/85 (CHR).

20. Oreothamnus prostratus (Kirk) S. Venter

Oreothamnus prostratus (Kirk) S. Venter, comb.nov. Cheeseman, Man. N.Z. Fl: 428 (1906); Cheeseman, Man. N.Z. Fl. $2^{\text {nd }}$ Ed.: 710 (1925); Oliver, Trans. Proc. N.Z. Inst. 59: 686 (1928); Oliver, Trans. Roy. Soc. N.Z. 80 (1): 2 (1952); Allan, Fl. N.Z. 1: 524 (1961); Eagle, Trees and Shrubs of N.Z. $2^{\text {nd }}$ series.: 296 (1982); Mark \& Adams, N.Z. Alpine Plants.: 118 (1986). Type: New Zealand, Otago, mountains above Lake Harris, Longwood Range, 4,000', among Sphagnum, 11.i.1877, W.T. Kirk s.n. (WELT 32884, lecto.; BM 577656!; CHR 332686!; K!; WELT 32882!; WELT 32883!; WELT 32891!). Designated by Oliver (1952).

= Dracophyllum prostratum Kirk, Trans. Proc. N.Z. Inst. 13: 384 (1881). 
Icones: Eagle, Trees and Shrubs of N.Z. $2^{\text {nd }}$ series.: t.150A (1982); Mark \& Adams, N.Z. Alpine Plants.: t. 47 (1986).

\section{Description}

A scrambler, sometimes forming cushions 1-10 cm tall. Branches prostrate. Bark on old branches dark grey to blackish brown, smooth, young stems reddish brown. Leaves spirally arranged along branches, erect to appressed to the stem, glaucous to light green, old leaves present; lamina sheath $1.5-3.0 \times 2-3 \mathrm{~mm}$, shoulders tapering to rounded and margin membranous, ciliate; lamina linear to linear-triangular, $2.5-5.0(-7.3) \times 0.5-0.9(-$ 1.0) $\mathrm{mm}$, adaxial surface flat to slightly concave, abaxial surface keeled; margins serrulate with 10-40 teeth per $10 \mathrm{~mm}$ (only at the apex,); apex obtuse to acute. Inflorescence a sessile, solitary terminal flower; longer than leaves, erect. Inflorescence bract shorter than flower, ovate-lanceolate, 3.6-3.8 × 1.8-2.0 mm; margin serrulate; apex obtuse. Sepals lanceolate, (3.5-) 4.0-4.5 × 1.5-2.0 mm, shorter than corolla tube; margin ciliate. Corolla white; corolla tube cylindrical, $3.0-4.5 \times 2.0-2.5 \mathrm{~mm}$; corolla lobes reflexed, ovate-triangular, shorter than corolla tube, $1.5-2.0 \mathrm{~mm}$ long and wide; apex obtuse; inflexed for entire length, apical ridge present, adaxial surface papillate. Stamens inserted on corolla tube in the upper third, filament $0.2-0.3 \mathrm{~mm}$ long; anthers included, oblong, light yellow and 1.0$1.2 \mathrm{~mm}$ long. Ovary obovate, $1.0-1.5 \times 0.8-1.0 \mathrm{~mm}$, apex round; nectary scales rectangular, $(0.5-) 0.7-0.8 \times 0.4-0.5 \mathrm{~mm}$; apices retuse to irregularly toothed; style included, 0.9-1.0 mm long, glabrous; stigma capitate. Fruit reddish brown, 1.5-2.0 × 1.4 $1.5 \mathrm{~mm}$; obovoid, apex truncate, glabrous. Seeds light brown, ovoid, 0.45-0.7 mm long, testa slightly reticulate. Flowering December-February. (Figure 7.123). 


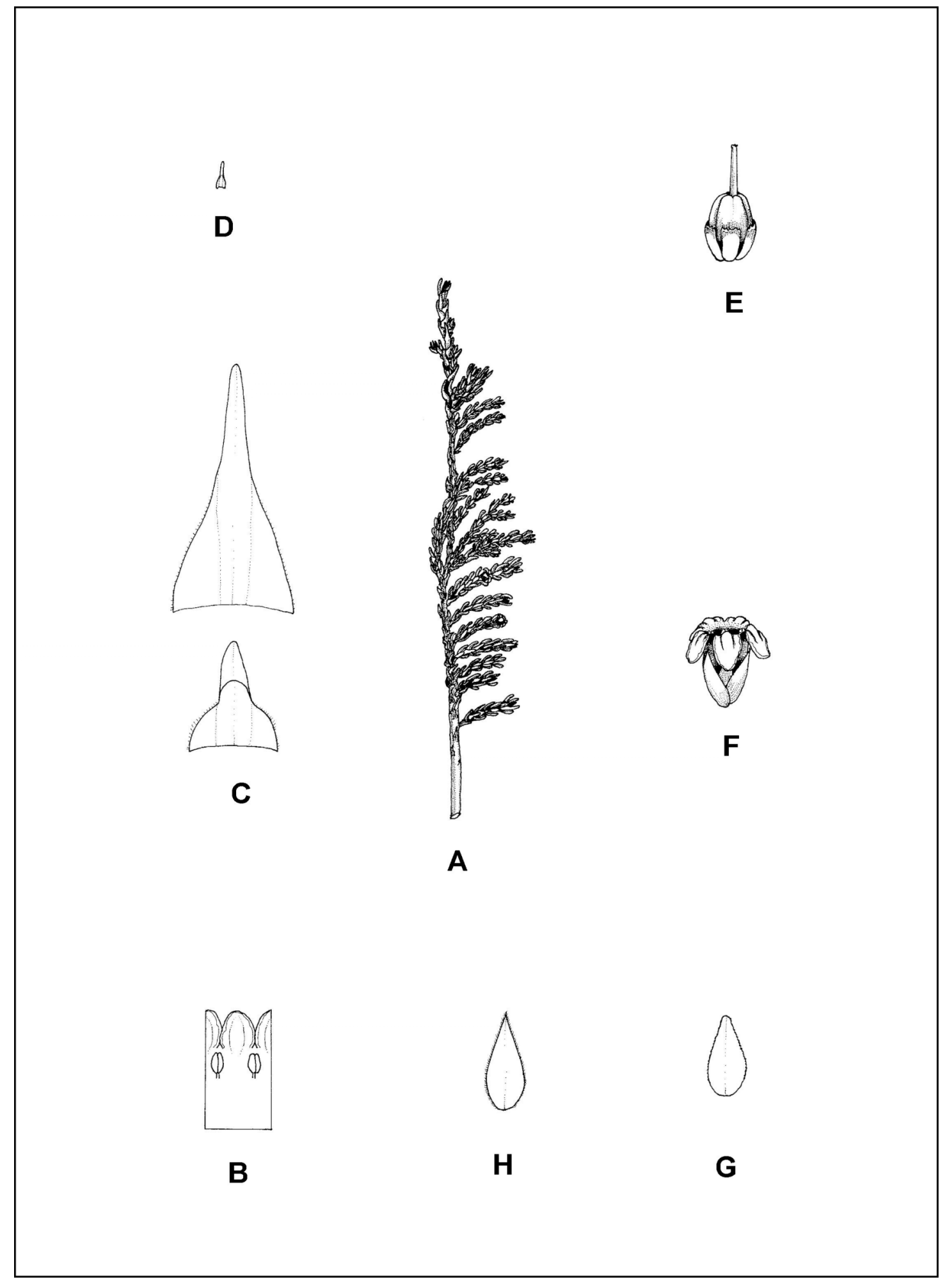

Figure 7.123. Oreothamnus prostratus. A, flowering branch $(\times 1)$; B, laid out corolla $(\times$ 5); C, lamina sheaths with lamina showing variation $(\times 10)$; $\mathbf{D}$, leaf $(\times 1)$; $\mathbf{E}$, ovary $(\times$ $10)$; F, flower $(\times 5)$; $\mathbf{G}$, inflorescence bract $(\times 5)$; $\mathbf{H}$, sepal $(\times 5)$. Drawn from GarnockJones 2367. 

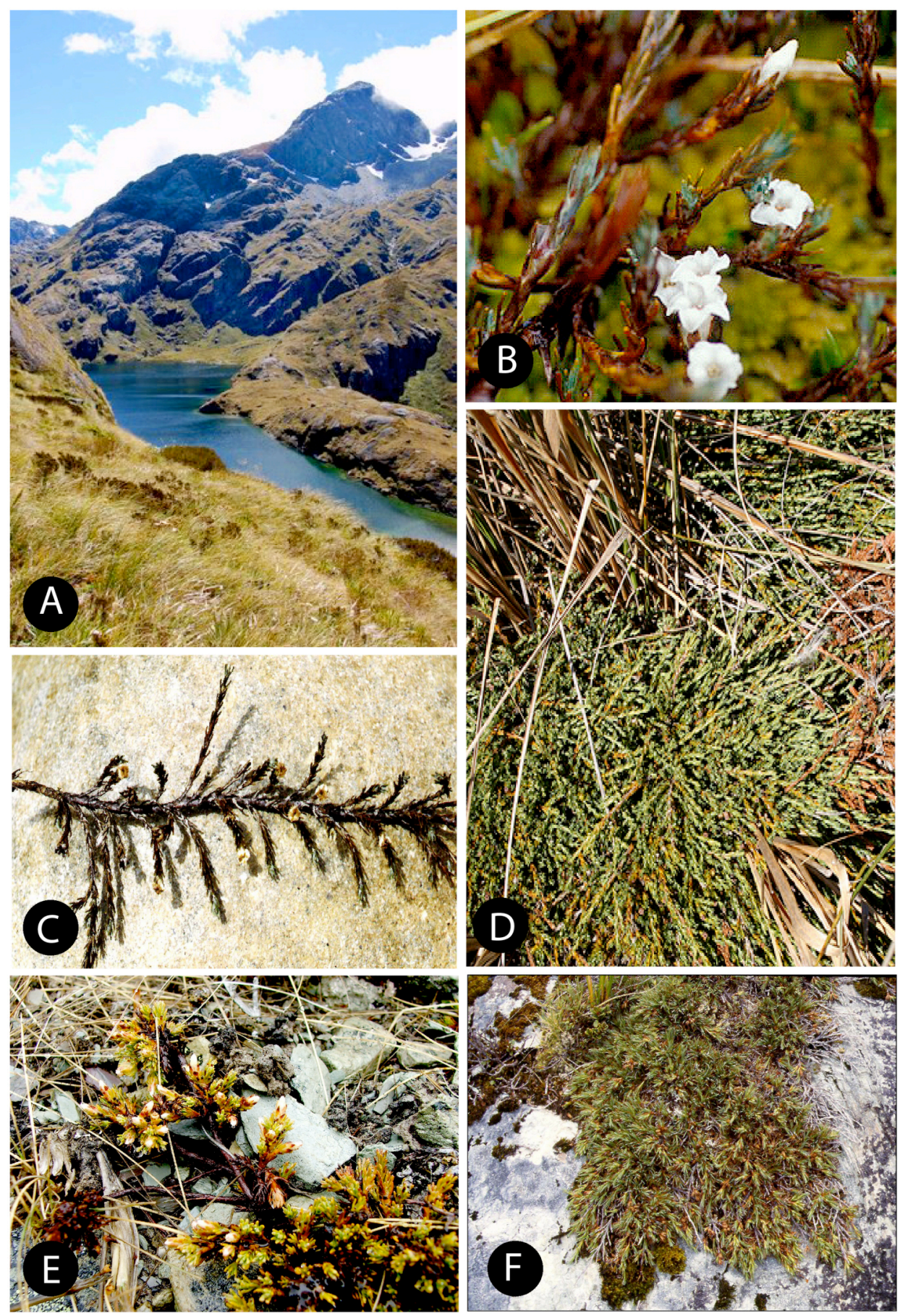

Figure 7.124. Oreothamnus prostratus. A, habitat at the type locality near Lake Harris; B, flowering branch from a plant collected at the type locality, Lake Harris; C, flowering branch from the Garvie Mountains; $\mathbf{D}$, prostrate form from Mt. Maungatua; $\mathbf{E}$, compact form from Mt. Dobson; F. robust form from Fiordland. C-Garnock-Jones 2367, DVenter 13810, F-Venter 13807. 


\section{Diagnostic features and notes}

Oreothamnus prostratus is characterized by its prostrate habit, dark brown and smooth bark, erect and clasping leaves being 3-5 $\mathrm{mm}$ long, short and broad $(1.5-3.0 \times 2-3 \mathrm{~mm})$ lamina sheaths with short cilia, solitary flowers with the sepals equaling or longer than the corolla tube.

Kirk (1881) is correct in saying that it is a variable species in habit, but the floral characters are quite stable. He mentioned in the protologue that the apices of the sepals are obtuse, but those on the type are acute. Oreothamnus prostratus is similar to O. muscoides but differs in the more prostrate branches with smooth bark, leaves with more $(10-40$ compared to 5-10) teeth per $10 \mathrm{~mm}$ on the lamina margin and the flowers are longer than the leaves. The sepals are shorter than the corolla tube not equaling and the apex is acute not subacute to obtuse. The corolla lobes are longer (1.5-2.0 mm compared to 1.0$1.5 \mathrm{~mm}$ ) and with papillate adaxial surfaces not glabrous. The ovary is obovate not ovate and narrower (0.8-1.0 mm compared to 1.4-1.5) with the fruit longer and wider.

\section{Distribution}

New Zealand endemic. Restricted in distribution to the South Island with all known localities situated south of a line from Arthur's Pass to Christchurch (Fig. 7.125).

\section{Habitat}

Oreothamnus prostratus occurs on gentle to steep $\left(5^{\circ}-80^{\circ}\right)$ mountain slopes and on plateaus at altitudes ranging from $350-1,828 \mathrm{~m}$. The vegetation consists of subalpine shrubland to alpine herbfield, fellfield, tussockland, bogland and cushion field or short grassland (Table 7.49). The soil is gritty greybrown sandy loam derived from schist, diorite gneiss or greywacke, with a thin $(1-5 \mathrm{~mm})$ humus layer that can be as thick as $15 \mathrm{~mm}$ in moist 
habitats. Plants are fully exposed to the harsh weather conditions and are permanently moist in seepages or seasonally moist after melting snow, rain or mist.

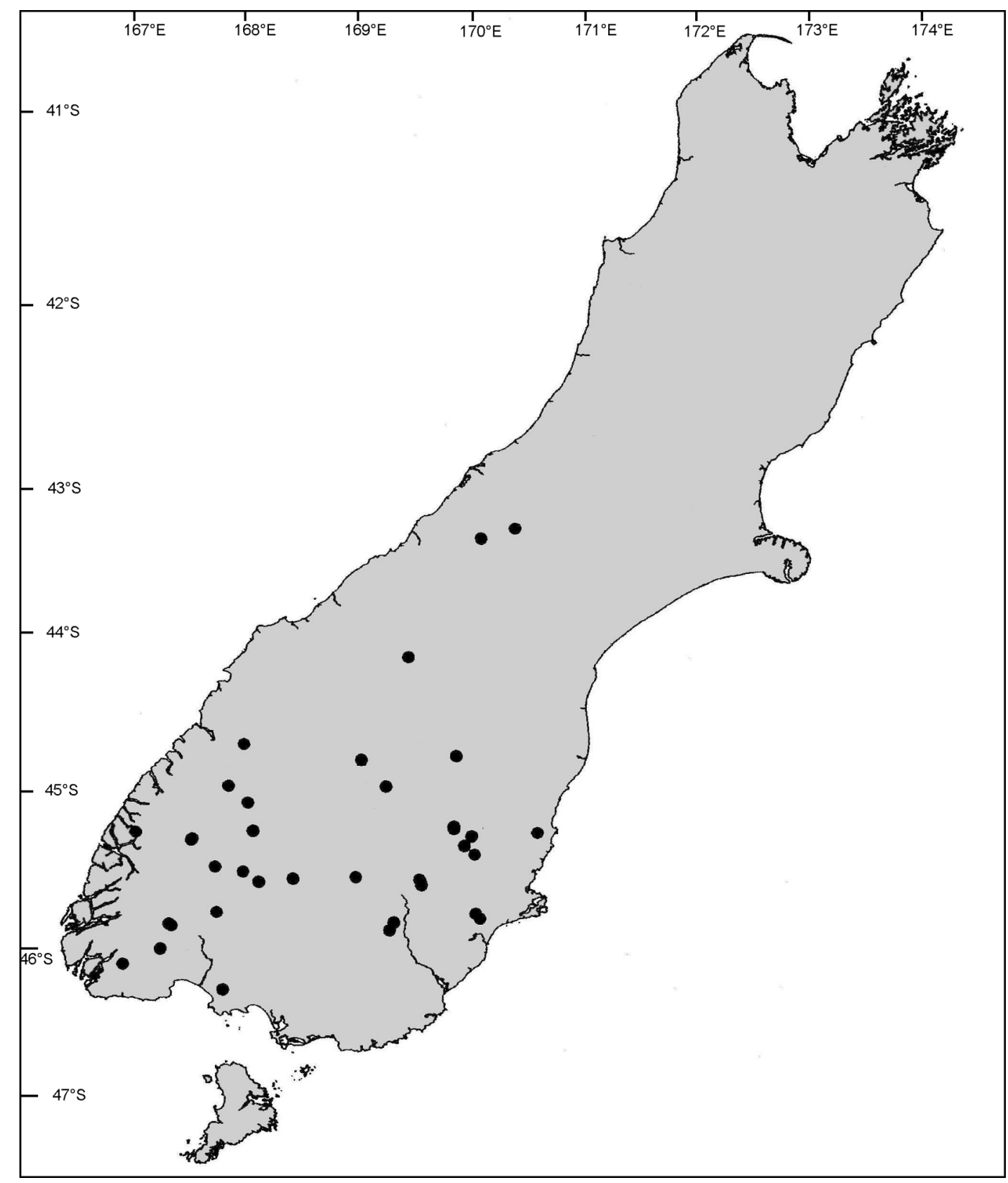

Figure 7.125. Known distribution of Oreothamnus prostratus. 
Table 7.49. Plant associations commonly associated with Oreothamnus prostratus.

\begin{tabular}{|c|}
\hline $\begin{array}{c}\text { SHRUBLAND } \\
\end{array}$ \\
\hline Low open Oreothamnus longifolius - Chionochloa subalpine shrubland \\
\hline FELLFIELD \\
\hline Low closed Chionochloa macra - Oreothamnus muscoides - O. pronus fellfield \\
\hline GRASSLAND \\
\hline Tall open Chionochloa australis - Celmisia discolor tussock grassland \\
\hline Low closed Chionochloa rubra - Empodisma minus grassland \\
\hline Low closed Chionochloa rigida grassland \\
\hline Low open Dracophyllum menziesii - Aciphylla congesta - Chionochloa alpine grassland \\
\hline BOGLAND \\
\hline $\begin{array}{l}\text { Closed low Sphagnum bogs } \\
\text { Closed low Oreobolus pectinatus bogland }\end{array}$ \\
\hline CUSHIONFIELD \\
\hline Closed low Oreobolus pectinatus cushionfield \\
\hline
\end{tabular}

\section{Variation}

Most specimens have glaucous leaves but there are a few scattered populations with green leaves that are also wider and longer. The adult lamina varies from $2.5-5.0 \times 0.5-$ $0.9 \mathrm{~mm}$ being small in alpine localities (Lake Harris) and larger in populations at lower altitudes (Mt. Maungatua).

\section{Hybrids}

Oreothamnus prostratus hybridises with O. rosmarinifolius and these specimens were described as Dracophyllum $\times$ erectum by Oliver (1952). On Mt. Maungatua there is a hybrid series covering the whole spectrum between $O$. prostratus and O. rosmarinifolius (pers. obs.).

\section{Material examined}

NEW ZEALAND. South Island. 43-170: Takitimu Mountains, Mt. Hamilton (-CB), 16.i.1938. Barker s.n. (CHR); Two Thumb Range, head of Bush Stream (-DA), iii.1986. Druce s.n. (CHR). 44-168: Fiordland National Park, Lake Harris (-CA), 27.ii.1911. Petrie s.n. (CHR, WELT); ibid., Kirk s.n. (AK); Fiordland National Park, 2 km S of Key Summit (-CC), 15.i.1997. Hörandl \& Hadacek 8113 (W); Livingstone Range, Key Summit. 24.xii.1944. Oliver s.n. (AK, WELT); Livingstone Range, above Knobs Flat, 3.i.1962. 
Wardle s.n. (CHR). 44-169: Mt. Pisa (-CC), 15.i.1950. Zotov s.n. (CHR). 44-170: Danseys Pass (-CD), 27.iv.1969. Moore s.n. (CHR). 45-167: Murchison Mountains, Ettrick Burn (BC), iii.1978. McSweeney s.n. (CHR); Lake Hauroko, South Caroline Burn (-CC), xii.1975. Sutcliffe, Craighead \& Williams s.n. (CHR); Mt. Cuthbert (-CD), Laing s.n. (CHR); Above Green Lake. 7.i.1967. Given s.n. (CHR). 45-168: Ben Lomond (-BA), 2.i.1936. Zotov s.n. (CHR); Windley Branch of Wyre Creek (-CA), 1970. Given 70463 (CHR); Mid Dome (DA), 9.ii.1961. Connor s.n. (CHR). 45-170: Dunedin, Mt. Maungatua (-CC), 23.iii.2000. Venter 13810 (CHR); ibid. Venter 13815 (CHR); ibid. Petrie s.n. (AK, Z).

21. Oreotbamnus pubescens (Cheeseman) S. Venter

Oreotbamnus pubescens (Cheeseman) S. Venter, comb. nov. Cheeseman, Man. N.Z. Fl. $2^{\text {nd }}$ Ed.: 708, (1925); Oliver, Trans. Proc. N.Z. Inst. 59: 692 (1928); Oliver, Trans. Roy. Soc. N.Z. 80 (1): 8 (1952); Allan, Fl. N.Z. 1: 528 (1961); Moore \& Irwin, Oxford Book of N.Z. Plants.: 295 (1978); Eagle, Trees and Shrubs of N.Z. $2^{\text {nd }}$ series.: 295 (1982); Mark \& Adams, N.Z. Alpine Plants.: 116 (1986); Poole \& Adams, Trees \& Shrubs of N.Z.: 162 (1994). Type: New Zealand, mountains near Westport, 1,500 - 2,000', W. Townson s.n. (AK 211641, lecto.!; AK 7004!). here designated.

= Dracophyllum pubescens Cheeseman, Man. N.Z. Fl.: 426 (1906).

Icones: Eagle, Trees and Shrubs of N.Z. $2^{\text {nd }}$ series.: t. 146 (1982); Mark \& Adams, N.Z. Alpine Plants.: t. 46 (1986). 


\section{Description}

Multi-stemmed shrub $50-80 \mathrm{~cm}$ tall. Branches decumbent to prostrate. Bark on old branches grey to dark grey, deeply fissured, young stems reddish brown. Leaves juvenile and adult, glaucous. Juvenile leaves spirally arranged along branches, spreading; lamina sheath 10-13 × 6-8 mm; shoulders rounded with margin ciliate in upper half; lamina lineartriangular to lanceolate, $60-80 \times 5-7 \mathrm{~mm}$, surfaces pubescent; margins serrulate with 60 70 obscured teeth per $10 \mathrm{~mm}$. Adult leaves crowded at tips of branches, spreading, glaucous; lamina sheath $(3.3-) 4.5-7.0 \times(3.5-) 4.5-6.0 \mathrm{~mm}$, striate, shoulders rounded to truncate and margins membranous, ciliate; lamina linear-triangular to lanceolate, 14-54(65) $\times$ 2-6 mm, adaxial surface densely pubescent to tomentose; abaxial surface sparsely pubescent; prominently striated; margins ciliate with $80-100$ obscure teeth per $10 \mathrm{~mm}$. Inflorescence a terminal spike on lateral branchlets; shorter than leaves, erect, lax, 15-17 $\mathrm{mm}$ long, oblong; inflorescence bract overtopping flowers, glaucous, ovate-lanceolate at base, (7.4-)14.9-21.8 × 1.6-2.5 mm, pubescent; margin ciliate. Flowers 3-5, sessile; flower bract shorter to equaling flower, ovate-lanceolate, $9.5-13.0 \times 1.0-2.5 \mathrm{~mm}$, adaxial surface pubescent; abaxial surface with sparse scabrid hairs; margin ciliate. Sepals ovatelanceolate to ovate, $5.0-5.5 \times 1.3-2.0 \mathrm{~mm}$, shorter than corolla tube, surfaces glabrous on the top half, pubescent on adaxial surface; margin ciliate. Corolla white; corolla tube cylindrical, 5-6 × 1.6-2.0 mm; corolla lobes spreading horizontally to reflexed, triangular, shorter than corolla tube, $1.5-2.0 \mathrm{~mm}$ long and wide; apices inflexed, acute; adaxial surface papillate. Stamens inserted on corolla tube in the upper third, filament $0.5-0.8 \mathrm{~mm}$ long; anthers included, rectangular, light yellow and 0.8-1.0 mm long. Ovary oblong, 1.4 $1.5 \mathrm{~mm}$ long and wide, glabrous, apex truncate; nectary scales separate, rectangular, 0.8-1.0 $\times$ 0.7-1.0 mm, apices irregularly toothed; style included, glabrous, 1.5-2.0 mm long; stigma capitate. Fruit light brown, 1.5-2.0 mm long and wide, obovoid; apex 


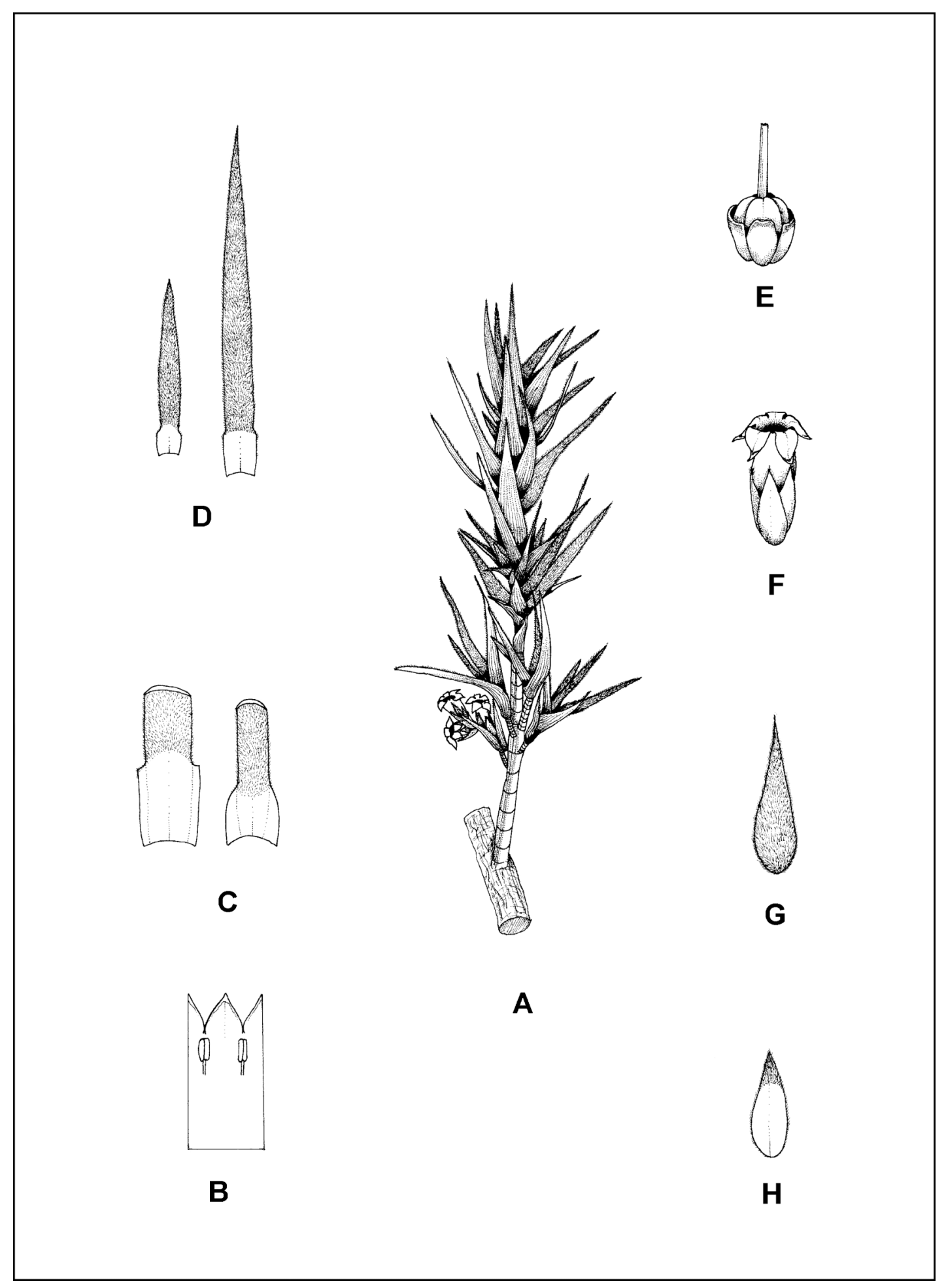

Figure 7.126. Oreothamnus pubescens. A, flowering branch $(\times 1)$; B, laid out corolla $(\times$ $5)$; $\mathbf{C}$, lamina sheaths to show variation $(\times 2)$; $\mathbf{D}$, adult and juvenile leaves $(\times 1)$; $\mathbf{E}$, ovary $(\times 10) ; \mathbf{F}$, flower $(\times 5) ; \mathbf{G}$, inflorescence bract abaxial surface $(\times 5) ; \mathbf{H}$, sepal adaxial surface $(\times 5)$. Drawn from Venter13774. 


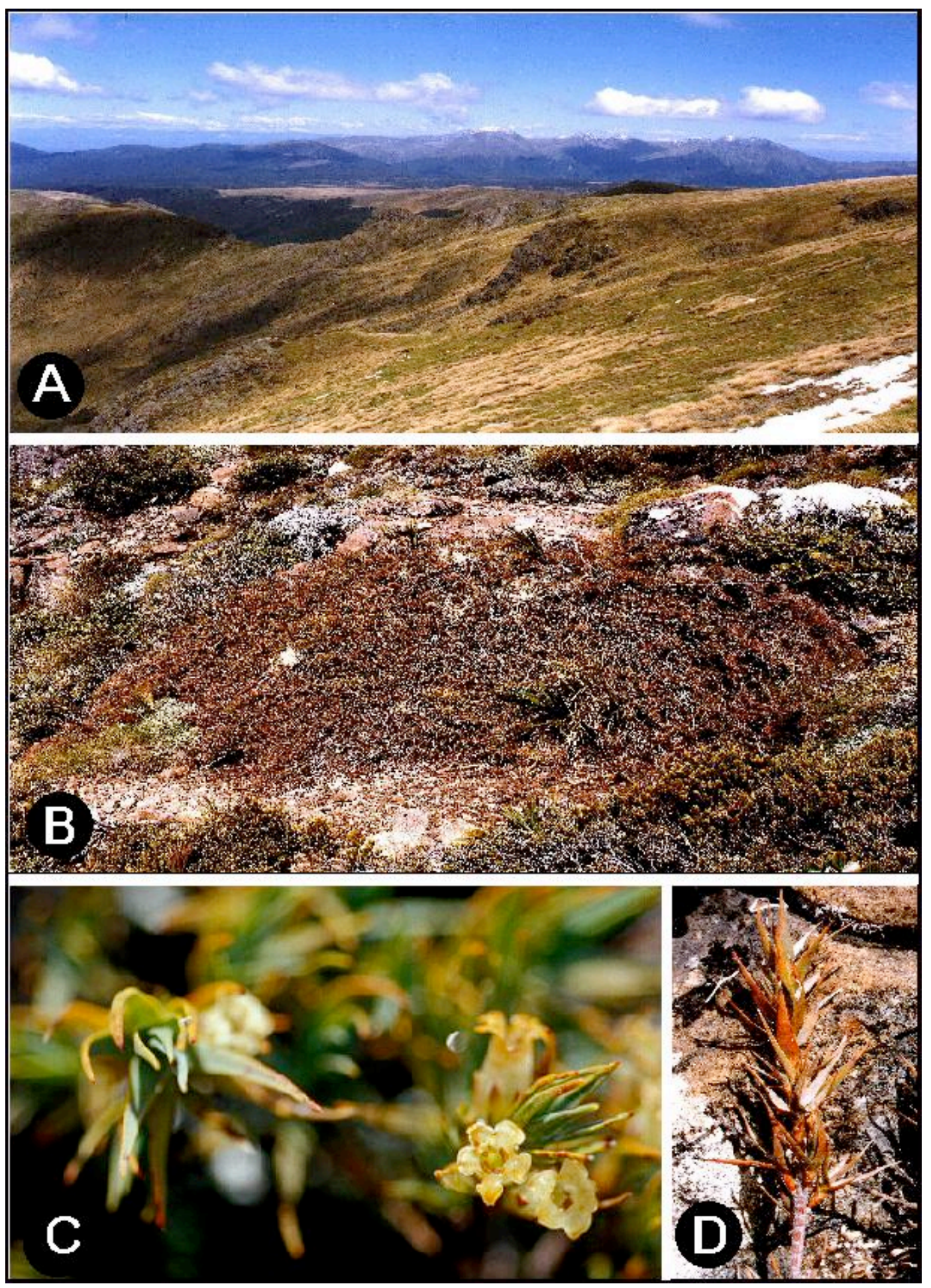

Figure 7.127. Oreothamnus pubescens. A, habitat on Mt. Mytton; B, mature plant on top of Mt. Mytton; C, flowering branch; D, branch showing the spreading short leaves. B and $\mathbf{D}$, Venter 13736. 
truncate, glabrous. Seeds brown, filiform, $0.7-1.0 \mathrm{~mm}$ long, testa slightly reticulate. Flowering December-March. (Figure 7.126).

\section{Diagnostic features and notes}

Oreothamnus pubescens is easily recognized by the grey bark with broad fissures, presence of juvenile leaves, the glaucous, broad and pubescent leaves, few-flowered (1-)3-4 racemes, sepals 5.0-5.5 $\mathrm{mm}$ long and pubescent on the outside and the 5-6 $\mathrm{mm}$ long corolla tube.

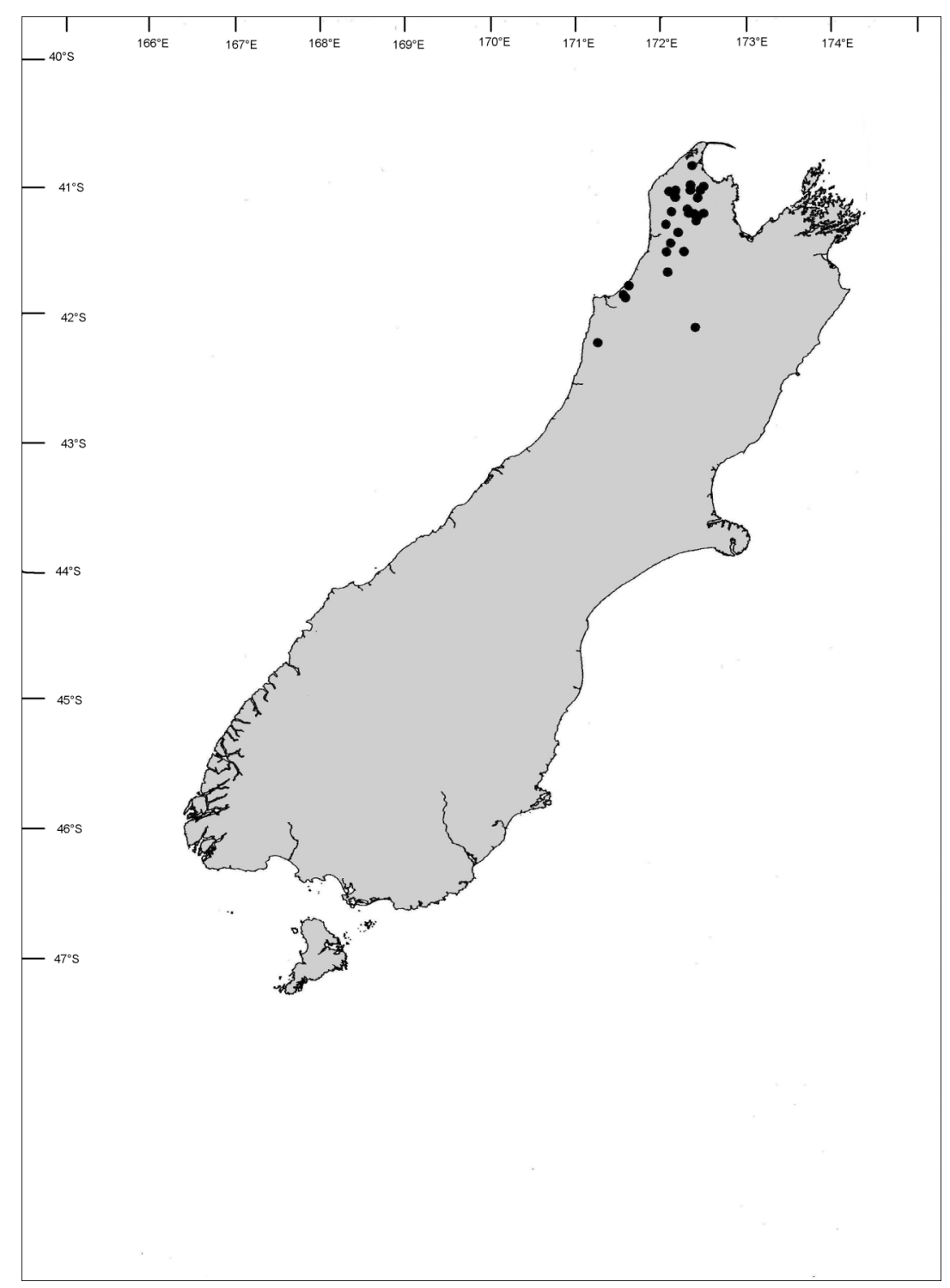

Figure 7.128. Known distribution of Oreothamnus pubescens. 
Oreothamnus pubescens is similar to O. kirkii but differs in the prominent pubescence of the lamina. The racemes are 3-5-flowered whereas it is a solitary flower in O. kirkii.

\section{Distribution}

New Zealand endemic restricted to the north-west Nelson area of the South Island with most of the known localities in the Kahurangi National Park (Fig. 7.128).

\section{Habitat}

Oreothamnus pubescens grows fully exposed on cliffs, gentle $\left(5^{\circ}-35^{\circ}\right)$ slopes and bluffs at altitudes of $500-2,500 \mathrm{~m}$. These areas are covered in montane to sub-alpine shrubland, herbfield, fellfield or grassland (Table 7.50). Soils are mostly brown clay lithosols or clay loam lithosols derived from serpentinite, greywacke, granite, sandstone or conglomerate. These areas receive condensation in the form of rain and often in the form of mist and melting snow.

Table 7.50. Plant associations commonly associated with Oreothamnus pubescens.

\section{SHRUBLAND}

Low open semi-deciduous Leptospermum scoparium - Oreothamnus oliveri - Phormium tenax shrubland HERBFIELD

Low closed evergreen Veronica - Celmisia - Haastia sinclairii herbfield

\section{Variation}

Variation in O. pubescens is mostly in the size of the adult lamina sheath $(4.5-7.0 \times 4.5-6.0$ $\mathrm{mm})$, the adult lamina $(14-54 \times 2-6 \mathrm{~mm})$, inflorescence bract $(15-22 \times 1.6-2.5 \mathrm{~mm})$ and the flower bract $(9.5-13.0 \times 1.0-2.5 \mathrm{~mm})$. 


\section{Material examined}

NEW ZEALAND. South Island: 40-172: Above Mt. Perry Saddle (-BD), 31.i.1964. Hynes s.n. (AK); Gouland Downs (-CD), xii.1962. Talbot s.n. (CHR); Saxon River. 25.iii.1949. Richardson s.n. (AK); Mt. Haidinger (-DA), 4.i.1969. Soper s.n. (CHR); Lead Hills (-DC), ii.1935. Simpson s.n. (CHR); Edge of Boulder Lake. 6.i.1962. Hynes s.n. (AK). 41-171: Mt. Bovis (-AB), i.1951. Talbot s.n. (CHR); Mt. Frederick (-DB), 04.iii.1912. Morgan s.n. (AK, WELT); ibid., Townson 208 (AK); Burnetts Face (-DD), 7.i.1976. Simpson 7754 (CHR). 41-172: Twenty Four Tarn Basin, Herbert Range (-AA), ii.1987. Druce s.n. (CHR); Karamea, Bald Hill (-AB), 17.ii.1985. McLennan s.n. (CHR); Herbert Range, Twenty Four Tarn Basin (-AD), ii.1987. Druce s.n. (CHR); Cobb Valley, Mt. Mytton (BA), 11.xii.1998. Venter 13736 (CHR). 41-173: Cobb, Lake Sylvester (-BA), 23.iii.1999. Venter 13774 (CHR). 42-171: Mt. Williams (-DC), 30.iv.1912. Morgan s.n. (CHR).

22. Oreothamnus recurvus (Hook. f.) S. Venter

Oreothamnus recurvus (Hook. f.) S. Venter, comb. nov. Hooker, Fl. Nov. Zel. 1: 171 (1853); Hooker, Handb. N.Z. Fl: 181 (1864); Cheeseman, Man. N.Z. Fl: 422 (1906); Cheeseman, Illustr. N.Z. Fl.: t. 131 (1914); Cheeseman, Man. N.Z. Fl. $2^{\text {nd }}$ Ed.: 704 (1925); Oliver, Trans. Proc. N.Z. Inst. 59: 700 (1928); Oliver, Trans. Roy. Soc. N.Z. 80 (12): 13 (1952); Allan, Fl. N.Z. 1: 534 (1961); Moore \& Irwin, Oxford Book of N.Z. Plants.: 293 (1978); Eagle, Trees and Shrubs of N.Z., $2^{\text {nd }}$ series.: 292 (1982). Type: New Zealand, Mt. Tongariro, 1839. J.C. Bidwill 65 (K, holo.!).

$\equiv$ Dracophyllum recurvum Hook. f., Fl. Antarct. 1: 50 (1844a). 
= Dracophyllum rubrum Colenso, Trans. Proc. N.Z. Inst. 20: 200 (1888). Type: New Zealand, base of Mt. Ruapehu, 1879. Colenso s.n. (WELT 23615, holo.!).

= Dracophyllum tenuicaulis Colenso, Trans. Proc. N.Z. Inst. 22: 476 (1890). Type: New Zealand, high up on Mt. Ruapehu, 1889. H. Hill s.n. (WELT 23614, holo.!).

= Dracophyllum brachyphyllum Colenso, Trans. Proc. N.Z. Inst. 28: 604 (1896). Type: New Zealand, Ruahine Mountains, 1895. H. Hill s.n. (WELT 23617, holo.!).

= Dracophyllum brachycladum Colenso, Trans. Proc. N.Z. Inst. 31: 275 (1899). Type: New Zealand, east side of Ruahine Mountains, 1898. H. Hill s.n. (WELT 23618, holo.!).

Icones: Cheeseman, Illustr. N.Z. Fl.: t. 131 (1914); Eagle, Trees and Sbrubs of N.Z., $2^{\text {nd }}$ series.:

t. 133 (stamens wrongly illustrated as hypogynous) (1982); Smith-Dodsworth, N.Z. Native Shrubs \& Climbers.: t. 56, Pl. 23C \& 23D (1991).

\section{Description}

Many-stemmed shrublet $10-90 \mathrm{~cm}$ tall. Branches spreading, decumbent to prostrate and much-branched. Bark on old branches grey to dark grey, smooth, young stems reddish brown. Leaves spreading to mostly recurved, glaucous to light green. Lamina sheath 4-6 $\times$ 3.0-6.5 mm, striate, tapering to truncate and margin membranous, ciliate or only the top half ciliate; lamina linear to linear-triangular, $15-30(-40) \times 1-2 \mathrm{~mm}$, adaxial surface rugose to scabrid, abaxial surface glabrous, slightly striated; margin serrulate with 90-120 teeth per $10 \mathrm{~mm}$; apex thickened, obtuse and triquetrous. Inflorescence a terminal spike on lateral branchlets; overtopping leaves, erect, dense, 12-25 mm long, oblong. Flowers 
5-8, sessile; inflorescence bracts overtopping flowers, light green to glaucous, ovatelanceolate at base, $10-17 \times 1.2-1.7 \mathrm{~mm}$, surfaces rugose; margins serrulate; flower bract overtopping flowers, ovate, $6.5-9.0 \times 4.0-4.5 \mathrm{~mm}$, surfaces glabrous with a tuft of scabrid hairs at apex on adaxial surface; margins ciliate. Sepals lanceolate to ovatelanceolate, $4.8-6.0 \times 1.5-2.0 \mathrm{~mm}$, equaling corolla tube, with the top half pubescent on adaxial surface; margins ciliate. Corolla white to occasionally light pink; corolla tube narrowly-campanulate, widened at mouth, 4.0-4.5 × 1.7-2.0 $\mathrm{mm}$; corolla lobes reflexed, ovate-triangular to triangular, shorter than corolla tube, $1.3-1.7 \times 1.4-1.5 \mathrm{~mm}$; apex acute; adaxial surface papillate. Stamens inserted in middle of the corolla tube, filaments 0.19-0.2 mm long; anthers included, oblong, initially pink turning light yellow and 0.8-1.2 mm long. Ovary obovate, $1.5-2.0 \times 1.9-2.0 \mathrm{~mm}$; apex round; nectary scales rectangular, 0.6-0.7 $\times 0.5-0.6 \mathrm{~mm}$, apices irregularly toothed; style included, $1.5-2.0 \mathrm{~mm}$ long, glabrous; stigma capitate. Fruit light brown, 3-4 × 2.8-3.0 mm, broadly obovoid, apex round, glabrous. Seeds yellowish brown, ovoid, $0.8-0.9 \mathrm{~mm}$ with testa slightly reticulate. Flowering December-April. (Figure 7.129).

\section{Diagnostic features and notes}

Oreothamnus recurvus is characterized by the rugose to scabrid adaxial lamina surface, triquetrous and keeled recurved leaf apices, flowers in short stout terminal racemes, very broad flower bracts, sepals equaling the corolla tube and the narrowly campanulate corolla tube.

A most distinctive species (Cheeseman 1914) related and similar to Oreothamnus marmoricola but differs mainly in having smooth bark, recurved leaves with more (90-120) teeth per $10 \mathrm{~mm}$ on the lamina margin. The flower bracts are also longer than the flowers and the corolla tube is narrowly campanulate not cylindrical. 


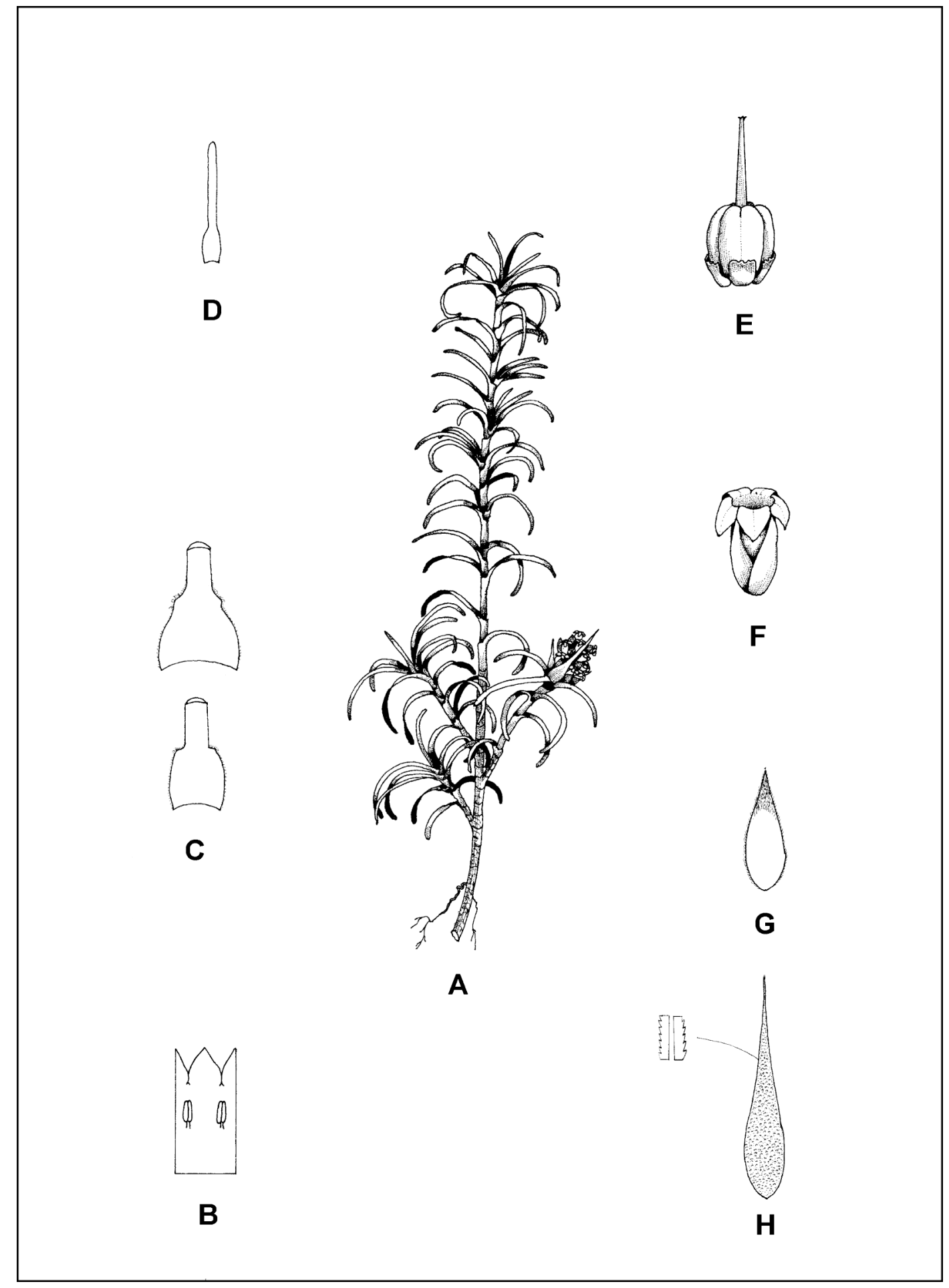

Figure 7.129. Oreothamnus recurvus. A, flowering branch $(\times 1)$; B, laid out corolla $(\times$ $5)$; $\mathbf{C}$, lamina sheaths to show variation $(\times 5)$; $\mathbf{D}$, leaf $(\times 1)$; $\mathbf{E}$, ovary $(\times 10) ; \mathbf{F}$, flower $(\times$ 5); $\mathbf{G}$, sepal adaxial surface $(\times 5) ; \mathbf{H}$, inflorescence bract abaxial surface $(\times 5)$. Drawn from Venter 13757. 

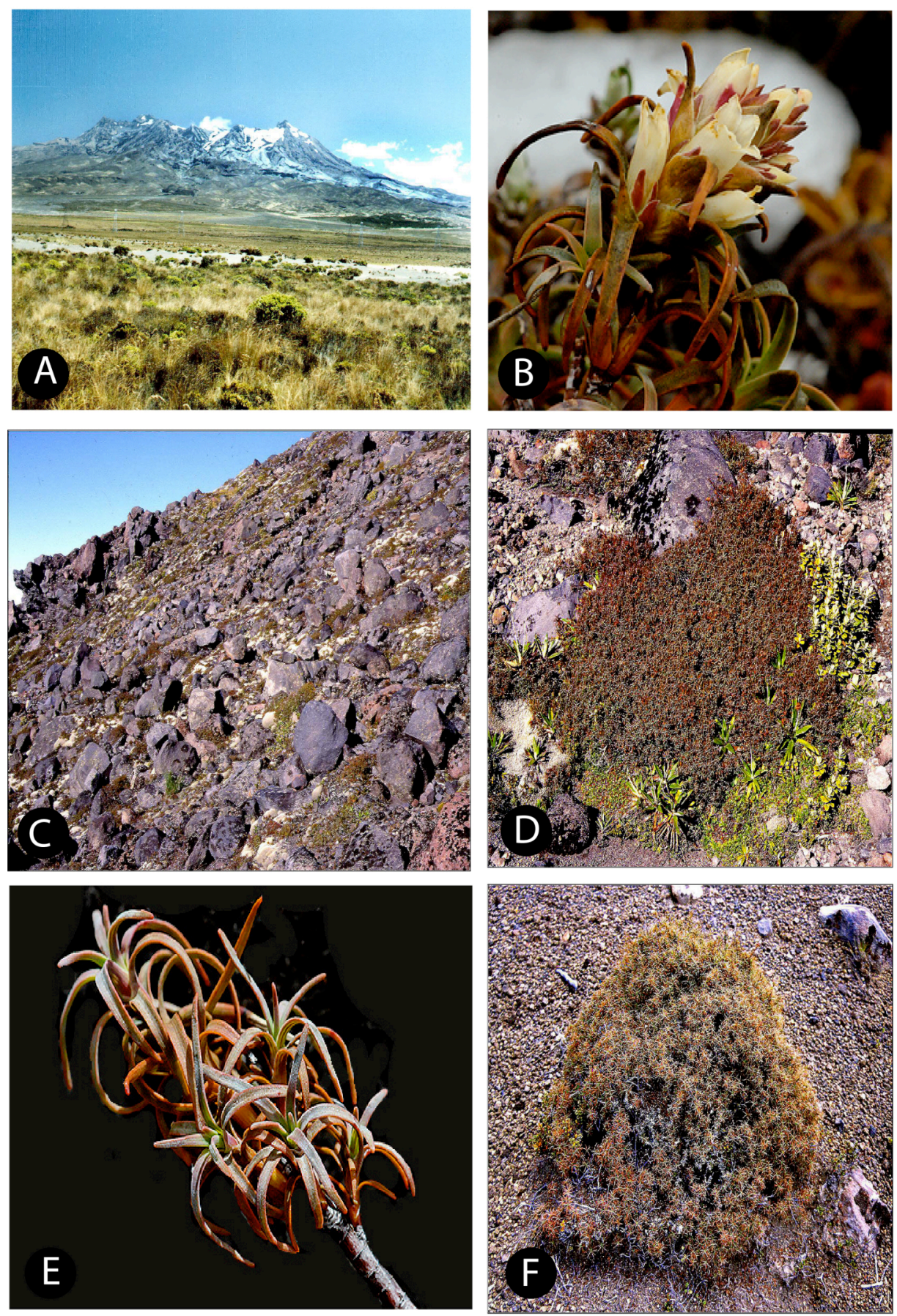

Figure 7.130. Oreothamnus recurvus. A, 'desert' habitat near Mt. Ruapehu; B, flowering branch; C, alpine habitat at Mt. Ruapehu; D, prostrate growth habit in subalpine habitats; $\mathbf{E}$, branch showing the recurved leaves; E, cushion growth habit in montane areas, specimen $400 \mathrm{~mm}$ tall. F-Venter 13757. 


\section{Distribution}

Endemic to the North Island of New Zealand centred on the volcanic plateau area with a few scattered localities in the Bay of Plenty area (Fig. 7.131).

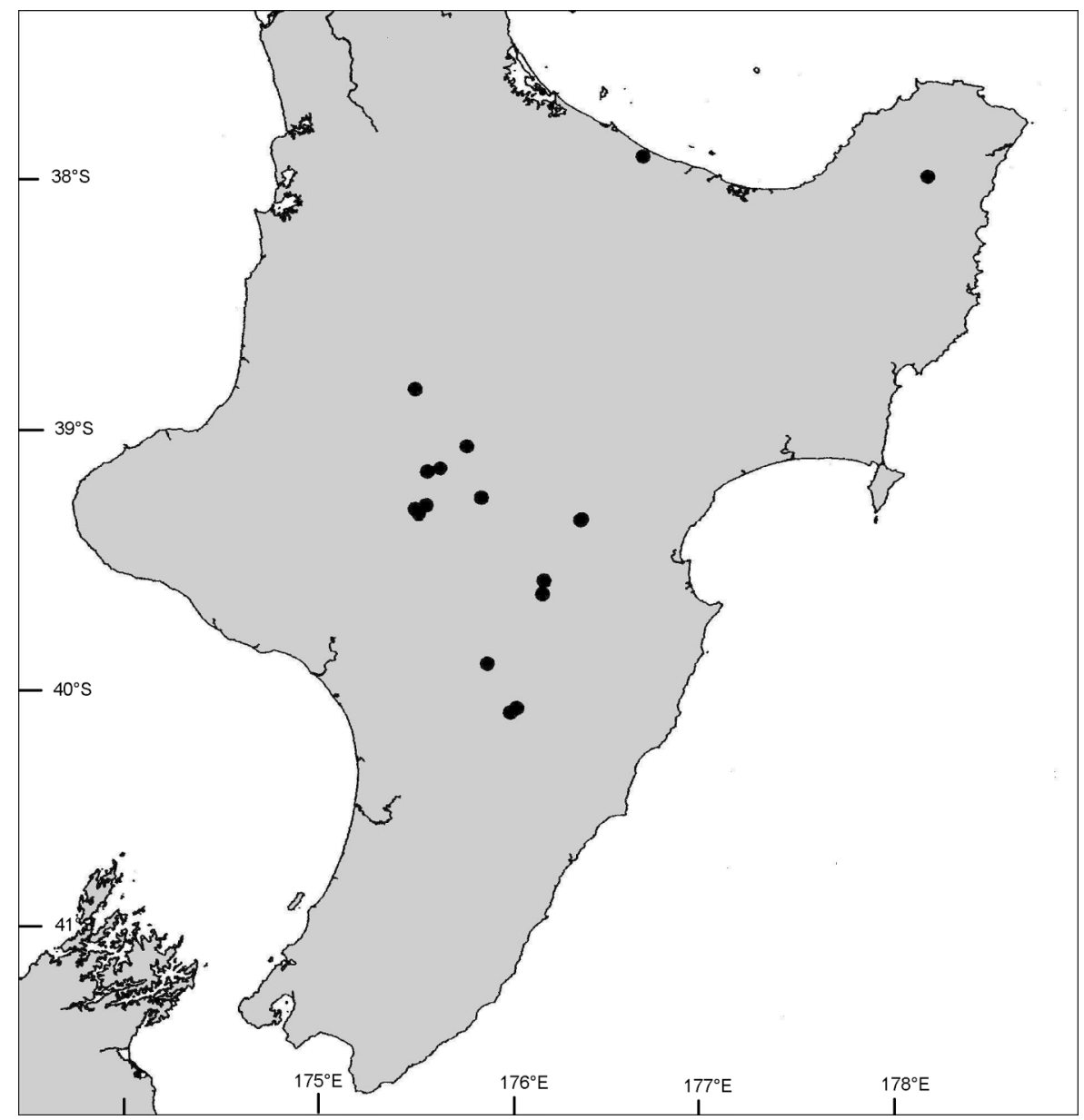

Figure 7.131. Known distribution of Oreothamnus recurvus, North Island, New Zealand.

\section{Habitat}

Oreothamnus recurvus grows on gentle to steep $\left(3^{\circ}-60^{\circ}\right)$ mountain slopes or on plateaus at altitudes of $900-2,000 \mathrm{~m}$. The surrounding vegetation is montane to subalpine shrubland, fellfield, grassland, herbfield or tussockland (Table 7.51). Soils are brown gritty sandy 
loam, brown loam or brown clay loam derived from andesite, basalt, pumice, rhyolite, scoria or volcanic sand.

Table 7.51. Plant associations commonly associated with Oreothamnus recurvus.

\begin{tabular}{|c|}
\hline FELLFIELD \\
\hline Low open Oreothamnus recurvus - Celmisia spectabilis - Veronica fellfield \\
\hline HERBFIELD \\
\hline $\begin{array}{l}\text { Low open Gaultheria colensoi - Pentachondra pumila herbfield } \\
\text { Low open Oreothamnus recurvus - Poa spp. herbfield }\end{array}$ \\
\hline
\end{tabular}

\section{Variation}

Oreothamnus recurvus is a remarkably distinct species. There is limited variation in growth habit due to habitat preferences. The prostrate form is associated with sub-alpine areas whereas plants forming cushions occur in drier and warmer areas in the Rangipo Desert. The shoulders of the lamina sheath are variable, from tapering to truncate. The inflorescences of plants growing in alpine or sub-alpine conditions are usually short (12$15 \mathrm{~mm}$ ) compared to those growing in the Rangipo Desert (18-25 mm).

\section{Hybrids}

Oreothamnus recurvus hybridises with O. filifolius (Dracophyllum $\times$ arcuatum of Oliver 1928) and this was described by Colenso (1896) as Dracophyllum $\times$ varium. According to Oliver (1928) this is a putative hybrid between O. longifolius and O. recurvus. Only O. filifolius occurs naturally with $O$. recurvus and it is therefore suggested that the parents of this putative hybrid are O. filifolius and O. recurvus (Venter 13759). On the western slopes of Mt. Ruapehu hybrids between O. filifolius and O. recurvus are common, grading from the one parent to the other (pers. obs.). 


\section{Material examined}

NEW ZEALAND. North Island. 37-178: W side of Mt. Hikurangi (-CC), 7.x.1964. Fryer s.n. (CHR); Mt. Hikurangi. 30.iii.1932. Moore \& Cranwell s.n. (AK). 38-175: Summit of Mt. Kakaramea (-DC), i.1905. Cheeseman. S.n. (AK). 38-177: Raukumara Range, Maungawaru Plateau (-BA), i.1953. Druce s.n. (CHR). 39-175: Hauhangatahi (-AB), 9.i.1933. Allan s.n. (CHR); Mt. Tongariro (-BA), xi.1924. Sladden s.n. (CHR); Taupo, Mt. Pihanga (-BB), 1.iv.1961. Parsons s.n. (CHR); Tongariro National Park, Turoa Skifield (BC), 08.ii.1999. Venter 13757 (CHR); Mt. Ruapehu, ii.1875. Berggren s.n. (O); ibid., 13.i.1921. Matthews \& Carse s.n. (AK). 39-176: Kaweka range, The Tits (-AB), xii.1974. Druce s.n. (CHR); Kaweka Range, Makahu Stream, N side of Makahu Spur (-AD), 3.xi.1966. Given 65331 (CHR); Ruahine Range, Makirikiri (-CC), xii.1976. Druce s.n. (CHR). 40-176: Ruahine Range, $2 \mathrm{~m} \mathrm{SW}$ of Takapari (-AA), i.1966. Druce s.n. (CHR).

23. Oreothamnus rosmarinifolius (Forst. f.) S. Venter

Oreothamnus rosmarinifolius (Forst. f.) S. Venter, comb. nov. Forster, Fl. Insul. Austr. Prodr: 13 (1786); Brown, Prodr. Fl. Nov. Holl: 556 (1810) in nota; Sprengel, Syst. Vegetab. 1: 629 (1825); Richard, Fl. Nov. Zel.: 220 (1832); Cunningham, Ann. Nat. Hist.: 48 (1839); Hooker, Fl. Antarct. 1: 50 (1844); Hooker, Fl. Nov. Zel. 2 (1): 171 (1853) p.p.; Hooker, Handb. N.Z. Fl:: 181 - 182 (1864) p.p.; Hooker, Handb. N.Z. Fl.: 182 (1864); Cheeseman, Man. N.Z. Fl., $2^{\text {nd }}$ Ed,.: 709 (1925) p.p.; Oliver, Trans. Proc. N.Z. Inst. 59: 690 (1928); De Candolle, Prodr. Syst. Nat. Veg. 7: 770 (1938); Allan, Trans. Roy. Soc. N.Z. 69: 272 (1939); Simpson, Trans. Roy. Soc. N.Z. 75: 191 (1945); Oliver, Trans. Roy. Soc. N.Z. 80 (1): 4 \& 9 (1952); Allan, Fl. N.Z. 1: 525 (1961); Moore \& Irwin, Oxford Book of N.Z. Plants.: 294 (1978); Eagle, Trees \& Shrubs of N.Z., $2^{\text {nd }}$ Series.: 294 (1982); Mark \& Adams, N.Z. Alpine 
Plants.: 114 (1986); Poole \& Adams, Trees \& Shrubs of N.Z.: 156 (1994). Type: New Zealand, Dusky Bay, on summits of the highest mountains. 26.iii.1773. G. Forster s.n. (BM 577640, lecto.!), designated by Hooker (1839).

三Dracophyllum rosmarinifolium (Forst. f.) R. Br. ex Roem. \& Schult., Syst. Vegetab. 4: 385 (1819).

三Dracophyllum rosmarinifolium (Forst.f.) R. Br., Prodr. Fl. Nov. Holl: 556 (1810). in nota.

= Epacris rosmarinifolia Forst. f., Flor. Ins. Austr. Prodr: 13 (1786).

= Dracophyllum uniflorum Hook. f., Handb. N.Z. Fl: 182 (1864). Type: New Zealand, Wairau Mountains, Marlborough, W.T.L. Travers s.n. (K, lecto.!; CHR 45864!), designated by Oliver (1952). Left hand specimen.

Icones: Oliver, Trans. Proc. N.Z. Inst. 59: t. 4 (1928); Oliver, Trans. Roy. Soc. N.Z. 80 (1): t. 2 (1952); Moore \& Irwin, Oxford Book of N.Z. Plants.: t. 143 (1978); Eagle, Trees \& Shrubs of N.Z., $2^{\text {nd }}$ Series.: t. 143 (1982); Smith-Dodsworth, N.Z. Native Shrubs \& Climbers.: t. 54, Pl. 22E \& 22F (1991).

\section{Description}

Multi-stemmed shrub 30-100 cm tall. Branches erect to spreading and much-branched. Bark on old branches grey to dark grey, finely to deeply fissured, young stems reddish brown. Leaves erect to spreading, light to olive green; lamina sheath $(2.0-) 3.0-8.5 \times 2.5-$ $4.0 \mathrm{~mm}$; shoulders rounded to truncate and margins membranous, ciliate; lamina linear to linear-subulate, $(8-) 8.5-40.0(-55) \times 0.59-1.5 \mathrm{~mm}$; adaxial surface glabrous, occasionally 
rugose, with a tuft of short scabrid hairs at base; margins serrulate with $70-80$ teeth per $10 \mathrm{~mm}$; apex obtuse to acute and triquetrous. Inflorescence a terminal solitary erect flower; shorter than leaves; inflorescence bract shorter to equaling flower, narrowly ovatelanceolate at base, 5.0-9.5(-13.0) $\times 1-2 \mathrm{~mm}$, with adaxial surface scabrid at base; margins serrulate. Flowers sessile. Sepals lanceolate to ovate-lanceolate, $(4.5-) 5.0-9.0(-12.0) \times$ 1.2-2.5 $\mathrm{mm}$, equaling to longer than corolla tube, top half rarely shortly pubescent; margins ciliate. Corolla white turning pale yellow with age, occasionally light pink; corolla tube cylindrical, (4-)5-7 $\times 1.5-2.0 \mathrm{~mm}$; corolla lobes reflexed, triangular, shorter than corolla tube, $2.0-2.5 \times 1.2-1.5(-2.0) \mathrm{mm}$; apex inflexed, subacute to acute; apical ridge present, adaxial surface papillate. Stamens inserted on corolla tube in the upper third, filaments $0.3-0.5 \mathrm{~mm}$ long; anthers included, oblong, initially pink turning light yellow and 0.7-1.0 mm long. Ovary obovate, $1.7-2.0 \times 1.0-1.3(-2.0) \mathrm{mm}$, apex round; nectary scales rectangular, (0.7-)1.0-1.5 $\times 0.4-0.7 \mathrm{~mm}$; apices retuse to irregularly toothed; style included, 1.5-2.5 mm long, glabrous, not lengthening in fruit; stigma capitate. Fruit light brown, 3.7-4.0 × 3.8-4.0 mm, obovoid; apex round, glabrous. Seeds yellowish brown, ovoid, $0.8-1.0 \mathrm{~mm}$ long with the testa slightly reticulate. Flowering October-April (May). (Figure 7.132).

\section{Diagnostic features and notes}

Oreothamnus rosmarinifolius is characterized by the linear spreading leaves, solitary flowers that terminate short branchlets, sepals equaling or longer than the corolla tube, prominent apical ridge on the corolla lobes, inflexed corolla lobe apex and an obovoid ovary. 


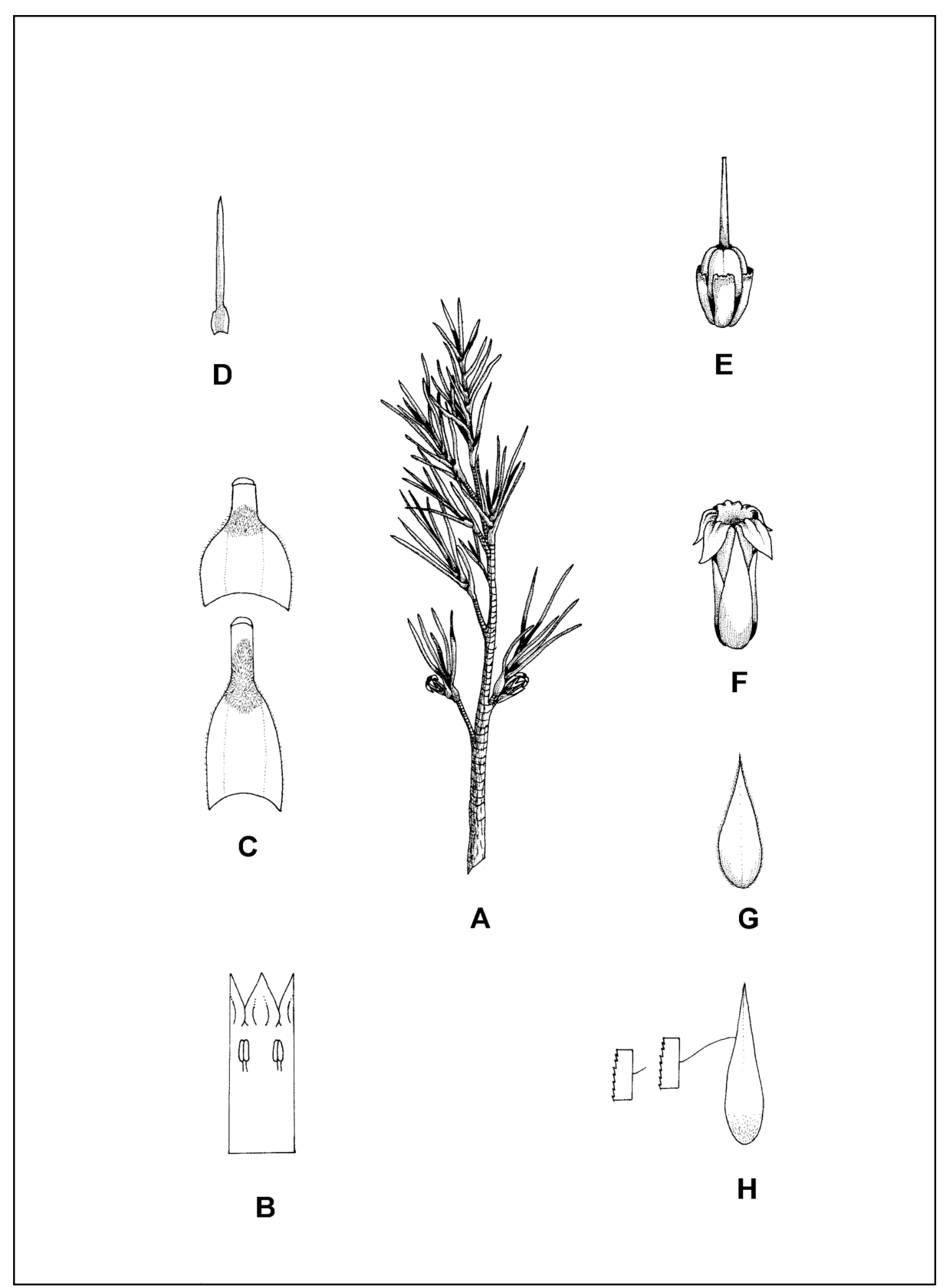

Figure 7.132. Oreothamnus rosmarinifolius. A, flowering branch $(\times 1)$; B, laid out corolla $(\times 5)$; C, lamina sheaths to show variation $(\times 5)$; $\mathbf{D}$, leaf $(\times 1)$; $\mathbf{E}$, ovary $(\times 10)$; $\mathbf{F}$, flower $(\times 5)$; $\mathbf{G}$, sepal $(\times 5) ; \mathbf{H}$, inflorescence bract adaxial surface $(\times 5)$. Drawn from Venter13747. 

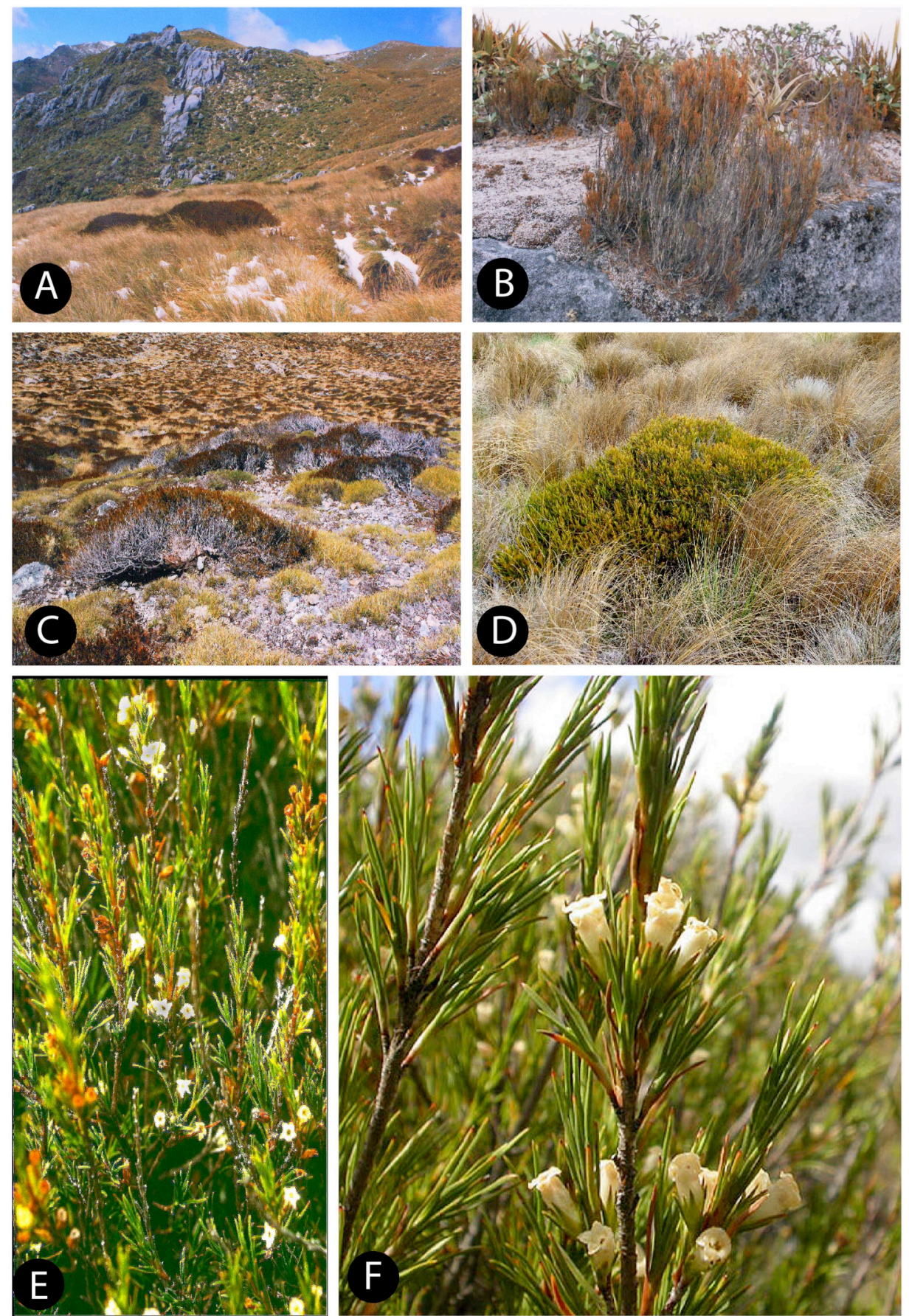

Figure 7.133. Oreothamnus rosmarinifolius. A, mature plant near Mt. Mytton; B, erectstemmed form from Mt. Rochfort; C, O. rosmarinifolius the dominant shrub in the subalpine zone on Mt. Arthur; D, mature plant near Lake Te Kapo; E, flowering branches, Lake Tekapo; F, flowering branch showing the solitary flowers on short branches. B, Venter 13729, C, Venter 13742, E, Venter 794. 
Brown (1810) moved the species in genus Epacris to Dracophyllum without mentioning any specimens or giving any discussion as to why he was doing so (in nota) and Index Kewensis gives R. Brown (1810) as the author, but the combination is not validly made therein (no discussion, specimen, reference or illustration). Hooker (1839) was the first person to designate a specimen for O. rosmarinifolius and he chose a G. Forster specimen collected in 1773. Richard (1832) used Forster's manuscripts to publish a full description to amplify Forster's brief diagnosis. Cheeseman (1925) mentioned that his plant and that of other botanists differed from Forster's (1786) Epacris rosmarinifolia. Oliver (1952) supplied a further amplified description of Forster's Dracophyllum rosmarinifolium [=Epacris rosmarinifolia]. All this confusion came about because Forster's species was not recollected for more than a 100 years after his visit to Dusky Sound, and not recognised for another 40 years (Oliver 1952).

Oreothamnus rosmarinifolius is similar to O. frondosus but differs in having erect to spreading not spreading to decumbent branches, inflorescence bracts equaling the flowers not overtopping them, sepals longer than the corolla tube not equaling them and the corolla tube is shorter (5-7 mm compared to $7-10 \mathrm{~mm}$ ). Further differences between the species are discussed under $O$. frondosus. During this study I recorded butterflies pollinating the flowers of Oreothamnus rosmarinifolius and O. acerosus, species with solitary, erect flowers having reasonably large spreading to recurved corolla lobes that provide effective settling platforms.

\section{Distribution}

New Zealand endemic. Widely distributed on the South Island with a few scattered localities on the Tararua Mountains in the south of the North Island (Fig. 7.134). 


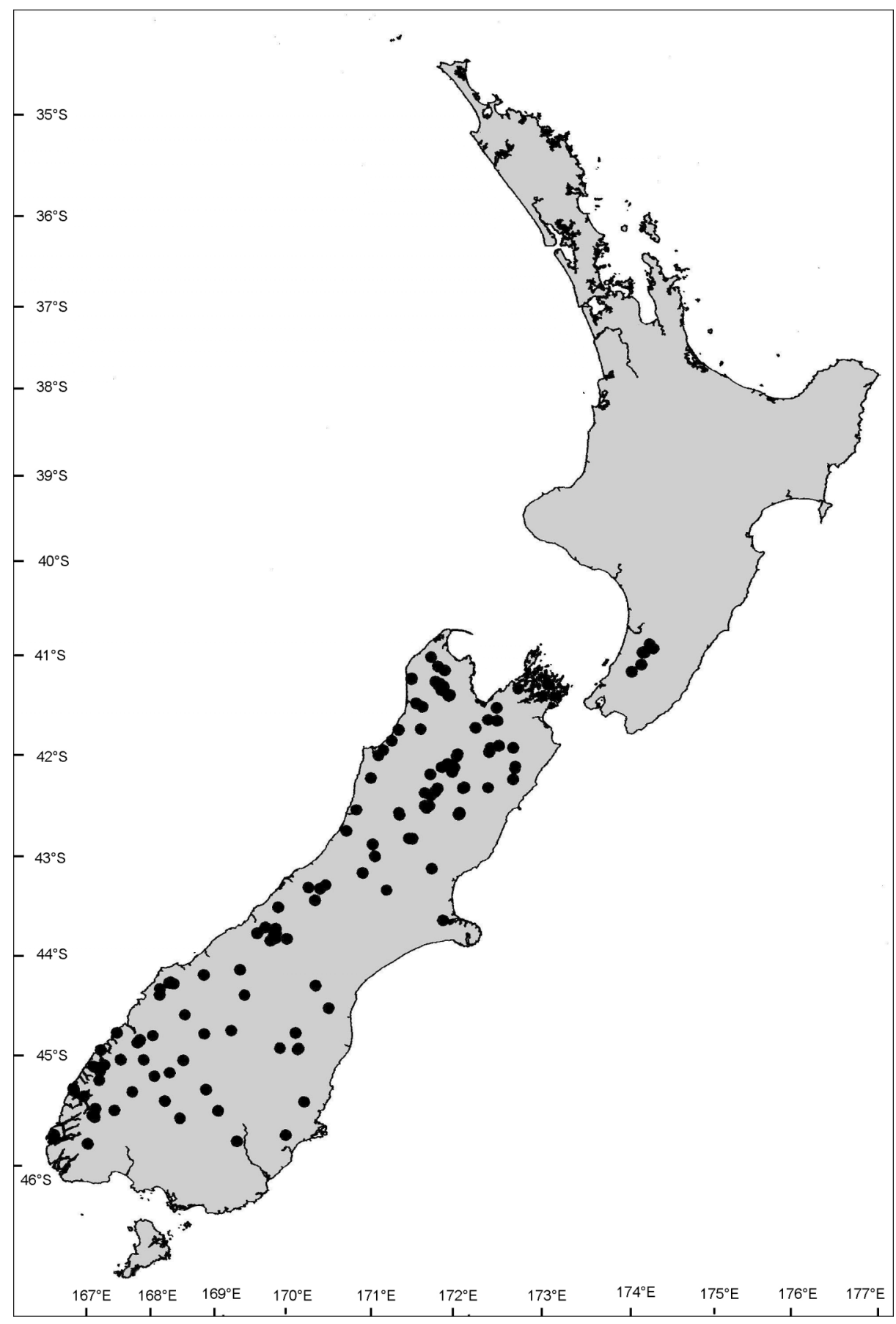

Figure 7.134. Known distribution of Oreothamnus rosmarinifolius.

\section{Habitat}

Oreothamnus rosmarinifolius occurs in mountain gullies, on mountain slopes ranging from $0^{\circ}-80^{\circ}$, ridges, bluffs, plateaus and on valley floors from $152-2,100 \mathrm{~m}$ altitude. The 
vegetation consists of montane woodland and shrubland to subalpine or alpine grassland, herbfield, fellfield or bogland (Table 7.52). Soils are greybrown lithosols derived from alluvium, grey to greyish brown gritty sandy loam derived from sandstone, conglomerate and granite or brown gritty clay loam to brown

Table 7.52. Plant associations commonly associated with Oreothamnus rosmarinifolius.

\begin{tabular}{|l|}
\hline WOODLAND \\
\hline Low closed evergreen Olearia colensoi - Phormium cookianum - Chionochloa alpine woodland \\
\hline \multicolumn{1}{|c|}{ SHRUBLAND } \\
\hline Tall closed semi-deciduous Leptospermum scoparium - Pteridium esculentum shrubland \\
Low closed evergreen Olearia lacunosa - O. colensoi - Pseudopanax colensoi shrubland \\
Low closed semi-deciduous Leptospermum scoparium - Ozothamnus leptophyllus - Oreothamnus shrubland \\
Low open evergreen Dracophyllum menziesii - Aciphylla congesta - Chionochloa alpine shrubland \\
\hline \multicolumn{1}{c|}{ GRASSLAND } \\
\hline High open Kunzea ericoides - Chionochloa rubra tussock grassland \\
Tall closed Chionochloa flavescens alpine grassland \\
Tall closed Dracophyllum menziesii - Chionochloa - Aciphylla congesta grassland \\
Tall closed Chionochloa rigida tussock grassland \\
Tall open Chionochloa australis - C. pallens tussock grassland \\
Low open Chionochloa rubra tussock grassland \\
\hline \multicolumn{1}{c|}{ BOGLAND } \\
\hline Low closed evergreen Halocarpus bidwillii - Oreothamnus rosmarinifolius - Sphagnum bogland \\
\hline
\end{tabular}

humusrich clay loam derived from greywacke, marble, peridotite, serpentinite or schist. Plants occasionally grow in permanently moist areas (bogland) and in drainage lines, but normally receive most of their moisture from rain, melting snow and mist. In certain places O. rosmarinifolius is very abundant and can form dominant stands especially above the tree line.

\section{Variation}

The main distinguishing character, according to Simpson (1945) and Oliver (1928), is the shape of the lamina apex, which is obtuse in Dracophyllum rosmarinifolium and subacute to acute in D. uniflorum (Fig. 4.3.). This character was seen to break down completely whilst visiting the various populations in the wild (pers. obs.). My field observations have shown that $O$. rosmarinifolius is an extremely polymorphic species and the present 
circumscription incorporates several ecological races scattered throughout the distribution range (Chapter 4.3.1.1.). Populations from the northern part of its distribution (Lake Sylvester - Venter 13775) tend to be low growing, less erect with shorter subacute leaves and with much smaller flowers. There is considerable variation in the size of the lamina $(10-40 \times 0.7-1.5 \mathrm{~mm})$, the inflorescence bracts $(5.0-9.5 \times 1-2$ $\mathrm{mm})$, sepals $(5-9 \times 1.2-2.5 \mathrm{~mm})$ and corolla tube $(5-7 \times 1.5-2.0 \mathrm{~mm})$. The nectary scales can vary from 1.7-2.0 $\times 0.4-0.7 \mathrm{~mm}$ on a single plant. Branching habit and height depends largely on the habitat.

\section{Material examined}

NEW ZEALAND. North Island. 40-175: Tararua Range, Mt. Bannister (-CB), 5.vi.1938. Healy 908 (CHR); Mt. Hector (-CD), 29.i.1907. Petrie s.n. (CHR); Mt. Holdsworth. 26.i.1990. Druce 482 (CHR); Mt. Kaipororo (-DA), iv.1979. Druce s.n. (CHR). South Island. 40-172: Mt. Stevens (-CD), ii.1976. Druce s.n. (CHR); Lead Hills (DC), ii.1935. Simpson s.n. (CHR). 41-171: Burma Road, gully north-west of open cast coal mine office (-DB), 26.i.1953. Mason \& Moar 1762 (CHR); Westport, Mt. Rochfort, near top (-DC), 25.xi.1998. Venter 13729 (CHR); ibid., 07.i.1999. Venter 13747 (CHR). 41172:Gunner Downs, near Mt. Barr (-AA), xi.1979. Druce s.n. (CHR); Matiri Range, Mt. Misery (-AD), iii.1980. Druce s.n. (CHR); Motueka, Mt. Arthur, above Arthur's Hut (BA), 02.i.1999. Venter 13742 (CHR); Takaka, Cobb Reservoir, Lake Sylvester, 23.iii.1999. Venter 13775 (CHR); ibid. Venter 13776 (CHR); Motueka, Mt. Arthur, Horseshoe Basin, 01.iii.2000. Venter 13796 (CHR); Nelson Lakes National Park, Travers Range, $2^{\text {nd }}$ Basin (DD), 21.iii.1961. Simpson 3018 (CHR). 41-173: Nelson, Mt. Starveall (-AC), Gibbs s.n. (CHR); Mt. Richmond (-AD), ii.1980. Druce s.n. (CHR); Marlborough Sounds, Moncrieff Scienic Reserve, Editor Hill (-BA), ii.1975. Kelly \& Kelly s.n. (CHR); Head of Hodder River, near Hodder Hut (-DC), 20.iv.1981. Wardle s.n. (CHR). 42-171: Basin east of Mt. 
Priestly (-BA), 11.vi.1983. Wardle s.n. (CHR); Otira (-DC), x.1908. Travers s.n. (Z); Arthur's Pass, Mt. Blimit, 21.ii.1943. Zotov s.n. (CHR). 42-172: Lewis Pass \pm 7 km from Maruia Springs to Christchurch (-AD), 13.xi.1998. Venter 13726 (CHR);Tarndale, Cat Creek (-BB), 2.iv.1946. Allan s.n. (CHR); Sout-west of Mt. Baldy (-BC), iii.1984. Druce s.n. (CHR); Hanmer Springs, Jacks Pass, Jollies Scenic Reserve (-BD), 27.ii.2000. Venter 13794 (CHR); ibid. Venter 13795 (CHR); Crawford Range, Upper Hurunui River (-CA), 31.i.1973. Macmillan 73/115 \& Stemmer (CHR); Organ Range, ridge to The Organ, Island Hills Station (-DA), 12.iii.1991. Macmillan 91/38 \& Woods (CHR; AK). 42-173: Upper Awatere, Yeo Creek (-AB), 3.iv.1949. Allan s.n. (CHR). 43-169: Karangarua River, between Cassel and Lame Duck Flats (-DB), 31.iii.1969. Wardle \& Fryer s.n. (CHR); Ranganui, true left of Moeraki River (-CD), 18.iv.1978. Campbell s.n. (CHR). 43-170: Franz Josef Glacier, Alex Knob (-AC), 19.iii.2000. Venter 13803 (CHR); Mount Cook National Park, Sealy Lakes track, near lakes (-CA), 13.xii.1966. Wilson 447 (CHR); Liebig Range, Mount Cook Station, north side Jollie River Valley (-CB), 3.iii.1966. Macmillan 66/75 (CHR; HO); Mount Cook, Sebastepol (-CC), 26.ii.1958. Connor s.n. (CHR). 43171: Waimakariri Valley, Anti Crow River (-BA), 24.iii.1963. Fryer s.n. (CHR); Mt. Somers, Woolshed Creek (-CB), iii.1987. Druce s.n. (CHR); Arundel, Mt. Peel (-CC), 15.i.1985. Mayrhofer \& Molloy 4771 (GZU). 44-167: Fiordland, Catseye Bay (-CD), 5.i.1978. Lee s.n. (CHR); Poison Bay (-DA), 7.ii.1974. Wardle \& Mark s.n. (CHR); North of Homer Tunnel, Esperance Valley (-DB), iii.1974. Atkinson s.n. (CHR); Franklin Mountains, Nitz Creek (-DC), 31.xii.1968. Given 69033 (CHR). 44-168: Cascade Valley, Woodhen Creek (-AB), 9.iii.1978. Wardle, Lee \& Johnson s.n. (CHR); Cascade River, top of Martyr Hill (-BA), 11.iii.1978. Wardle, Lee \& Johnson s.n. (CHR); Fiordland National Park, Lake Harris (-CA), 21.iii.2000. Venter 13806 (CHR). 44-169: Hunter Valley, Ferguson Creek (-BA), 4.i.1961. Mason 8131 (CHR); Ahuriri River, slopes of Puke Makariri (-BC), 22.i.1960. Connor s.n. (CHR). 44-170: Hunter Hills, headwater of south 
Pareora River, Weaner Run (-DB), 4.iv.1973. Macmillan 73/401 \& Woodhouse (CHR). 45-

166: Fiordland, Secretary Island, Central Hill (-BB), 3.ii.1967. Wardle s.n. (CHR); Fiordland, Secretary Island, southern peaks, (-BD), 31.i.1967. Wardle s.n. (CHR). 45-167:

Mt. George, rocky basin immediately north of peak (-AC), 21.iii.1977. Garnock-Jones, Lee, Anderson \& Given 10343 (CHR); Lake Manapouri, near entrance to Keplar Track (-BC), 7.i.1997. Sykes 28/97 (CHR); Lake Hauroko, Hay Burn (-CC), Thomson s.n. (CHR). 45168: Thompson Range, North Von River, $3 \mathrm{~m}$ south of North Von Hut $(-\mathbf{A B})$, 11.ii.1961. Connor s.n. (CHR); Queenstown, Ben Lamond (-BA), 2.i.1936. Zotov s.n. (CHR). 45-169: Umbrella Mountains, near Gem Lake (-CA), iii.1986. Druce s.n. (CHR). 45-170: Palmerston, Sanatorium (-BC), 26.iv.1925. Millin s.n. (CHR); Dunedin, Mt. Maungatua (-CC), 23.iii.2000. Venter 13811 (CHR); Dunedin, Swampy Hill (-CD), Simpson \& Thompson s.n. (CHR).

24. Oreothamnus scoparius (Hook. f.) S. Venter

Oreothamnus scoparius (Hook. f.) S. Venter, comb. nov. Lindley, Vegetable Kingdom. 3: 448 (1848); Hooker, Fl. Nov. Zel. 2 (1): 170 (1853); Buchanan, Trans. Proc. N.Z. Inst. 7: 337 (1875) p.p.; Cheeseman, Man. N.Z. Fl.: 425 (1906); Cockayne, Veg. N.Z.: 308 (1921); Cheeseman, Man. N.Z. Fl., $2^{\text {nd }}$ Ed.: 706 (1925); Oliver, Trans. Proc. N.Z. Inst. 59: 693 (1928); Oliver, Trans. Roy. Soc. N.Z. 80 (1): 9 (1952); Allan, Fl. N.Z. 1: 529 (1961); Eagle, Trees \& Shrubs of N.Z. $2^{\text {nd }}$ series.: 295 (1982); Wardle, N.Z. Jnl Bot. 25: 107 (1987). Type: New Zealand, Campbell Island, small bush near the sea, 7.xii.1840. J.D. Hooker 1611 (K, lecto.!; BM 577654!; BM 577668!; BM 577669!; BM 577670!; WELT 54858!), designated by Oliver (1952). 
= Dracophyllum scoparium Hook. f., Fl. Antarct. 1: 46 (1844a).

$\equiv$ Dracophyllum urvillianum var. scoparium Hook. f., Handb. N.Z. Fl.: 182 (1864).

Dracophyllum rosmarinifolium Buchanan, Trans. Proc. N.Z. Inst. 7: 338 (1875), non R. Br., in nota.

Dracophyllum urvillianum Filhol, Miss. Ile Camp. Bot: 6 (1885), non A. Rich.

$=$ Dracophyllum paludosum Cockayne, Trans. Proc. N.Z. Inst. 34: 318 (1902). Type: New Zealand, Chatham Island, Tableland, ii.1902. L. Cockayne s.n. (WELT 33105, lecto.!), designated by Oliver (1952).

Dracophyllum scoparium Hook. f. var. paludosum (Cockayne) Cheeseman, Man. N.Z. Fl: 425 (1906).

Dracophyllum subantarcticum Cockayne, Veg, N.Z.: 265 (1921), nomen nudum.

= Dracophyllum arboreum Cockayne var. paludosum Cheeseman, Manual N.Z. Fl. $2^{\text {nd }}$ Ed:: 707 (1925).

Icones: Hooker, Fl. Antarct. 1: t. 33 (1844); Eagle, Trees \& Shrubs of N.Z. 2 $2^{\text {nd }}$ series.: t. 145 (stamens wrongly illustrated as hypogynous) (1982). 


\section{Description}

Erect multi-stemmed shrub to small tree, 1-4 m tall. Branches: bark on old branches dark brown to blackish brown, finely fissured, young stems reddish brown. Leaves erect to spreading; lamina sheath $(2-) 3-5 \times 1.5-4.0 \mathrm{~mm}$, shoulders tapering to truncate and margins membranous and ciliate; lamina linear to linear-subulate, (24-)30-50(-80) $\times$ $(0.3-) 0.6-1.0(-1.5) \mathrm{mm}$, adaxial surface pubescent, slightly striated; margins ciliate to densely pubescent with 100-120 teeth per $10 \mathrm{~mm}$; apex triquetrous. Inflorescence a terminal spike on lateral branches; shorter than leaves, erect, dense, 13-20 mm long, oblong; inflorescence bract overtopping flower, ovate-lanceolate at base, 1.8-2.0 × 0.9-1.0 $\mathrm{mm}$, adaxial surface glabrous, pubescent at apex; abaxial surface pubescent at base; margins ciliate. Flowers 3-6, sessile. Flower bracts overtopping flowers, broadly ovate, 5.0$9.5 \times 2.5-4.0 \mathrm{~mm}$, adaxial surfaces pubescent; margins ciliate. Sepals oblong, (2.5-)4.0$5.0 \times(1.5-) 2.0-3.5 \mathrm{~mm}$, equaling to longer than corolla tube, striate, surfaces glabrous with the top half pubescent; margins ciliate; apices acute to acuminate. Corolla white; corolla tube cylindrical, 3.0-3.5 × 1.3-1.5 mm; corolla lobes reflexed, triangular, shorter than corolla tube, (1.7-)2.0-2.5 × 1.2-2.0 mm, apex inflexed and acute; adaxial surface papillate. Stamens inserted on corolla tube in the upper third, filaments $0.3-0.5 \mathrm{~mm}$ long; anthers included, rectangular, light yellow and 0.9-1.0 mm long. Ovary obovate, $0.8-1.0 \times$ 0.9-1.0 mm, apex round; nectary scales rectangular, $0.6-0.7 \times 0.5-0.6 \mathrm{~mm}$, apices subacute to obtuse; style included, $0.95-1.0 \mathrm{~mm}$ long, glabrous, not lengthening in fruit; stigma fivelobed. Fruit light brown, 1.8-2.0 × 2.1-2.5 mm, obovoid; apex round, glabrous. Seeds light brown, ovoid, $0.7-0.8 \mathrm{~mm}$ long, testa slightly reticulate. Flowering NovemberFebruary. (Figure 7.135). 


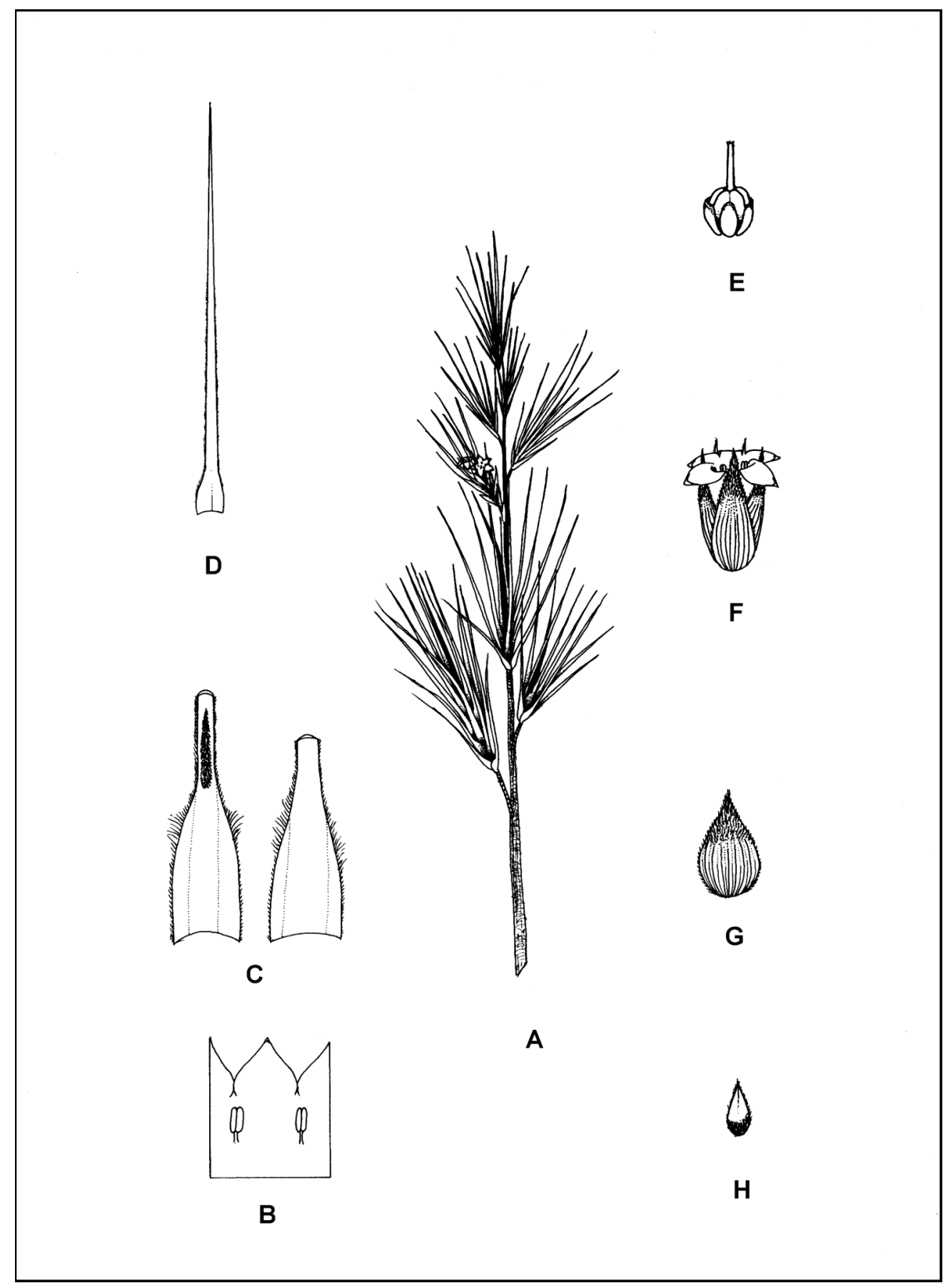

Figure 7.135. Oreothamnus scoparius. A, flowering branch $(\times 1)$; B, laid out corolla $(\times$ $5)$; $\mathbf{C}$, lamina sheaths to show variation $(\times 2)$; $\mathbf{D}$, leaf $(\times 1)$; $\mathbf{E}$, ovary $(\times 10) ; \mathbf{F}$, flower $(\times$ $5)$; $\mathbf{G}$, sepal abaxial surface $(\times 5)$; $\mathbf{H}$, inflorescence bract abaxial surface $(\times 5)$. Drawn from Brockie s.n. (O). 


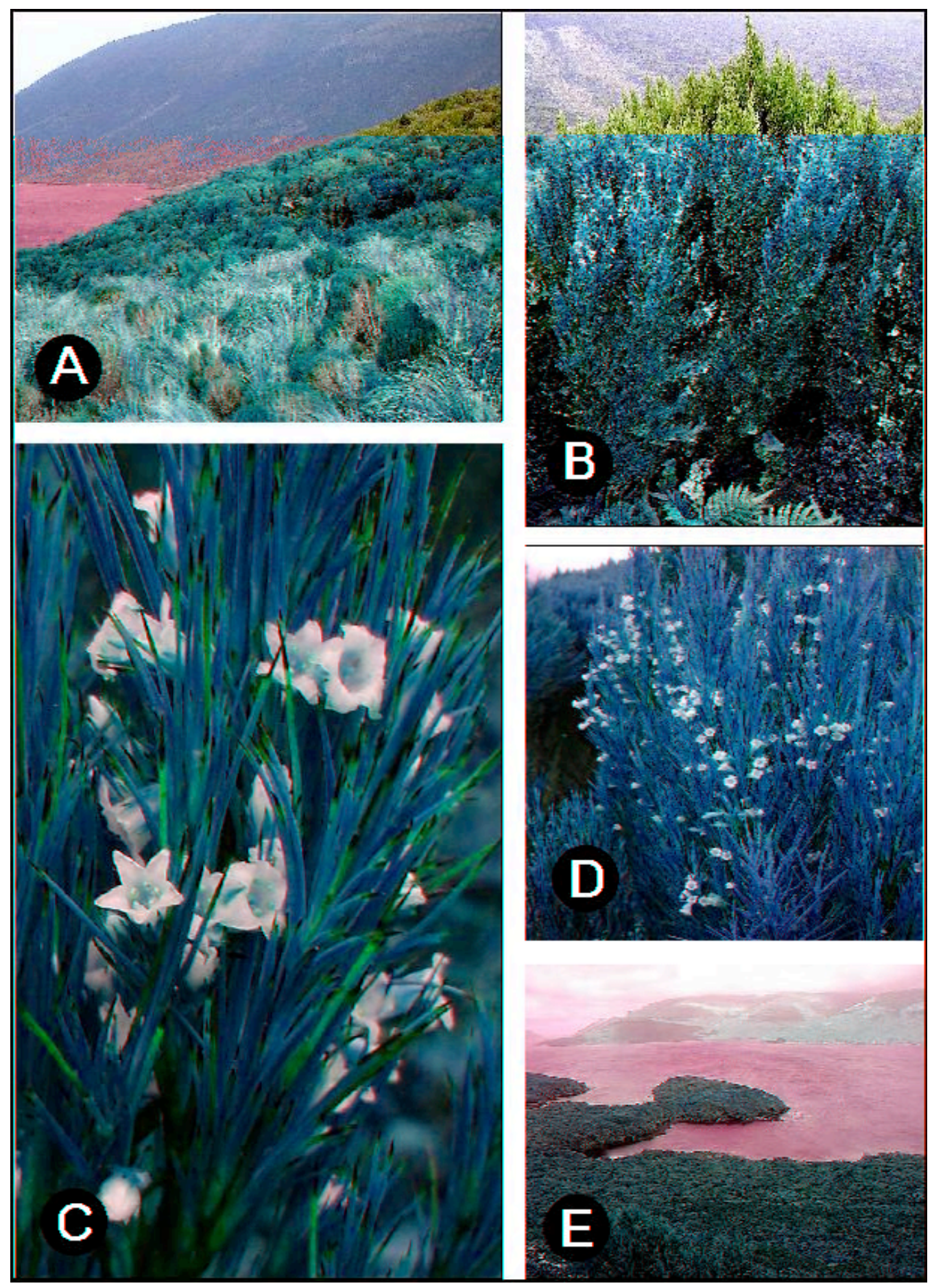

Figure 7.136. Oreothamnus scoparius. A, habitat on Campbell Island showing $O$. scoparius as the dominant woody species; $\mathbf{B}$, flowering plant; $\mathbf{C}$, flowering branch showing the erect-spreading leaves; $\mathbf{D}$, mature plant in flower; $\mathbf{E}$, habitat on Auckland Island. Photographs by P. Garnock-Jones. 
The name Dracophyllum paludosum was merely mentioned in nota by Cockayne (1902), with no indication of locality or specimen and he mentioned a few characters to point out how it differs from $O$ arboreus, he also mentioned that it might prove to be a form of $O$. scoparius. Cheeseman (1906) was the first to publish a description of the species hence the 'ex Cheeseman'. Oliver (1952) was the first to designate a specific specimen to the name and he chose the specimen from the original Cockayne Herbarium (number 3567). This specimen later ended up in the Petrie Herbarium, and is now incorporated in the WELT collection as WELT 33105.

Oreothamnus scoparius is similar to O. filifolius, but differs in having smaller leaves $(30-50 \times$ 0.6-1.0 mm compared to $60-130 \times 1.0-1.5 \mathrm{~mm})$, lamina pubescent on the adaxial surfaces not glabrous with the lamina margin densely pubescent (glabrous in O. filifolius). The inflorescence bract is subulate with pubescent abaxial surfaces and the adaxial surface of the flower bract is pubescent not glabrous. The sepals are striate and longer than the corolla tube (not equaling and smooth) with the top half pubescent not glabrous. The corolla tube is narrower $(1.3-1.5 \mathrm{~mm}$ compared to $1.8-2.5 \mathrm{~mm})$ with longer (2.0-2.5 mm compared to $1.5-2.0 \mathrm{~mm}$ ) triangular corolla lobes having papillate not glabrous adaxial surfaces, smaller nectary scales and an obovate not subglobose ovary.

\section{Distribution}

New Zealand endemic restricted to the subantarctic Campbell-, Chatham- and Pitt Islands (Fig. 7.137). 


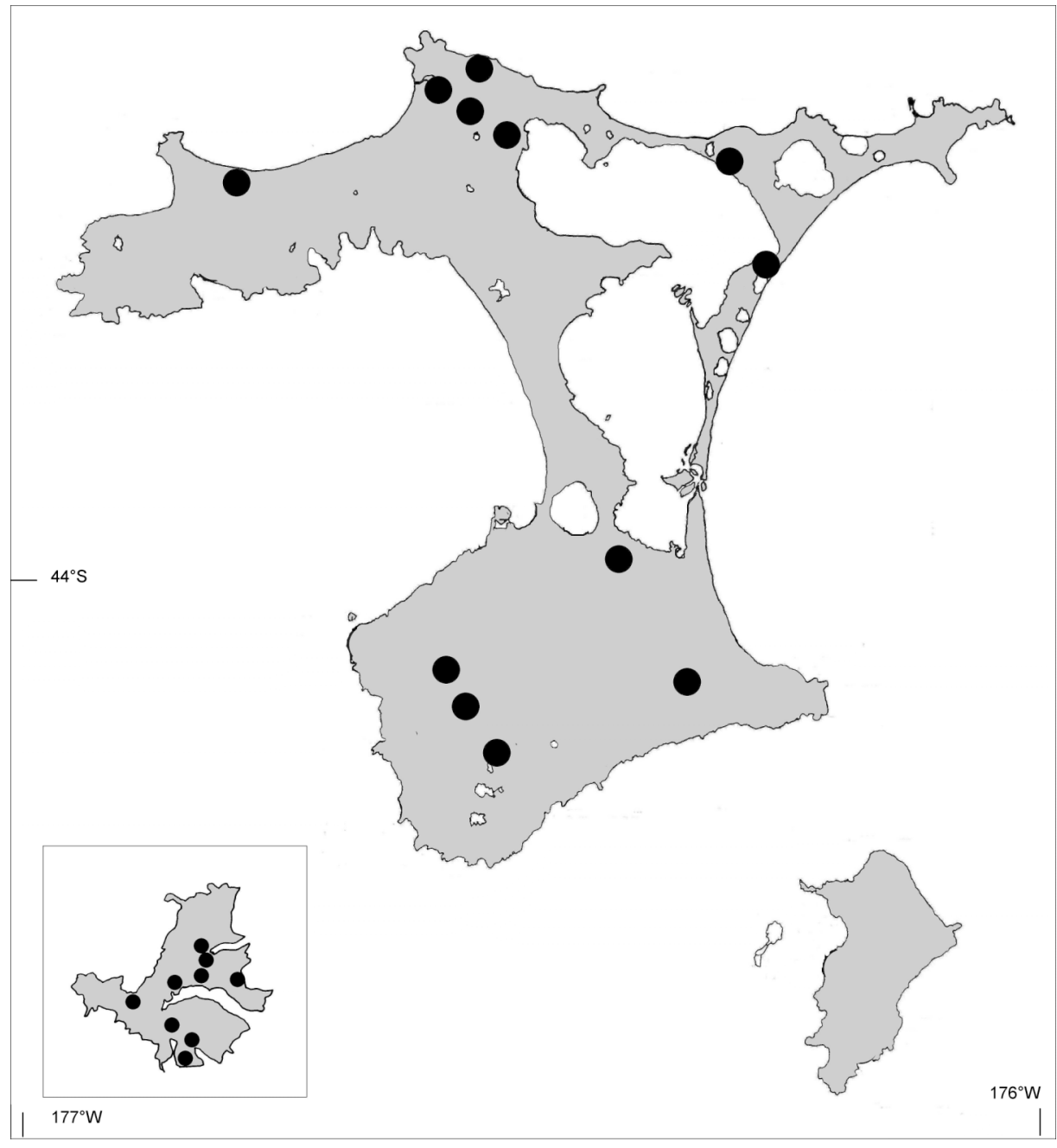

Figure 7.137. Known distribution of Oreothamnus scoparius. The main map is of the Chatham Islands and the insert that of Campbell Island, $\pm 1700 \mathrm{~km}$ further south.

\section{Habitat}

Oreothamnus scoparius grows on flat boggy areas or on gentle $\left(5^{\circ}-30^{\circ}\right)$ hill slopes reaching from sea level up to $260 \mathrm{~m}$ altitude. These areas are covered with shrubland that grows up to five metres tall in sheltered areas and in the open areas, grassland and bogland (Table 7.53). The soil is moist for prolonged periods due to the high rainfall and frequent mists. 
Table 7.53. Plant associations commonly associated with Oreothammus scoparius.

\begin{tabular}{|l|}
\hline \multicolumn{1}{c|}{ SHRUBLAND } \\
\hline $\begin{array}{c}\text { Low closed evergreen Pteridium esculentum - Leptecophylla robusta shrubland } \\
\text { Low closed evergreen Oreothamnus - Myrsine divaricata - Polystichum vestitum shrubland }\end{array}$ \\
\hline \multicolumn{1}{c|}{ GRASSLAND } \\
\hline Low open low Chionochloa antarctica - Poa litorosa tussock grassland \\
\hline \multicolumn{1}{c|}{ BOGLAND } \\
\hline $\begin{array}{l}\text { Low closed Sporadanthus traversii - Olearia semidentata bogland } \\
\text { Low closed Oreothamnus scoparius - Sphagnum bogland } \\
\text { Low open Chionochloa antarctica bogland }\end{array}$ \\
\hline
\end{tabular}

\section{Variation}

Plants of O. scoparius have a dense covering of long whitish hairs at the base of the lamina that can sometimes be short and scabrid in some individuals. The shape of the leaf sheath shoulders is polymorph and varies from tapering to truncate on the same branch. Some variation exists in lamina size $(30-50 \times 0.6-1.0 \mathrm{~mm})$. The flower bract is variable in size even on the same plant $(5.0-9.5 \times 2.5-4.0 \mathrm{~mm})$.

\section{Hybrids}

According to Wardle (1987) vegetation modified by sheep grazing and burning are factors that encourage the development of hybrid populations. On Campbell Island, $O$. scoparius commonly hybridises with O. cockayneanus and was described by Oliver (1928) as Dracophyllum $\times$ insulare.

\section{Material examined}

NEW ZEALAND. Chatham Island - 43-176: Taupeka (-DB), 21.ii.1996. De Lange CH14 \& Crocroft (AK); Te Puke Hill between Waitangi West and Maunganui (-DD), 13.xi.1991. Dugdale \& Marfarlane s.n. (CHR); Te Puke Hill. 6.vi.1996. Dugdale \& Macfarlane s.n. (CHR). 44-176: Southern Plateau, Tuku headwaters (-BA), 4.iii.1985. Wardle s.n. (CHR); Lake Rakenui, The Clears. 24.x.1987. Taylor s.n. (AK). Campbell Island - Tucker 
Cove Valley, 7.ii.1947. Brockie s.n. (CHR; O); Camp Cove. 6.i.1961. Godley s.n. (CHR); South Col ridges. 20.xii.1944. Oliver s.n. (CHR); Valley at head of South East Harbour. 15.xi.1945. Sorenson s.n. (CHR); Beeman Cove, Lookout Bay. ii.1976. Given 9167 (CHR; HO); Smoothwater Bay. 25.i.1976. Given 9276 (CHR); Bull Rock. 6.ii.1976. Given 9423 (CHR); Beeman Point. 7.xii.1995. Meurk s.n. (CHR).

25. Oreothamnus septentrionalis (W.R.B. Oliv.) S. Venter

Oreothamnus septentrionalis (W.R.B. Oliv.) S. Venter, comb. nov. Oliver, Trans. Roy. Soc. N.Z. 80 (1): 11 (1952); Allan, Fl. N.Z. 1: 532 (1961). Type: New Zealand, Ruahine Mountains, Mt. Maharahara, vi.1946. R.M. Greenwood s.n. (CHR 65032, holo.!).

= Dracophyllum longifolium var. septentrionale W.R.B. Oliv., Trans. Roy. Soc. N.Z. 80 (1): 11 (1952).

Icones: Oliver, Trans. Roy. Soc. N.Z. 80 (1): t. 6 (1952).

\section{Description}

A multi-stemmed shrub or small tree, 1-2 $\mathrm{m}$ tall. Branches: bark on old branches dark grey to greyish brown, smooth or finely fissured, young stems reddish brown. Leaves adult and juvenile. Juvenile leaves spirally arranged along branches, spreading; lamina sheath yellowish green, $11-16 \times 6.0-7.6 \mathrm{~mm}$, shoulders truncate and margin ciliate in upper half; lamina linear to linear-triangular, surfaces glabrous, 110-200 $\times 4-6 \mathrm{~mm}$, margins serrulate with 50-60 teeth per $10 \mathrm{~mm}$; adult leaves erect to spreading; lamina sheath 7-12 $\times$ 2.8-5.0 $\mathrm{mm}$, striate, rounded to truncate and margin membranous with the top half 
ciliate; lamina linear to linear-triangular, (46-)80-130 × 1.0-2.5 mm; adaxial surface rugose; margins serrulate with 50-60 teeth per $10 \mathrm{~mm}$. Inflorescence a raceme near the apices of branches; shorter than leaves, erect, dense, 12-24 mm long, oblong; inflorescence bracts overtopping flowers, ovate-lanceolate, $28-37 \times 0.6-0.7 \mathrm{~mm}$, adaxial surfaces scabrid; margins serrulate, apices acuminate. Flowers 3-11, pedicellate; flower bracts caducous, overtopping flowers, coriaceous, broadly ovate, $5.0-7.5 \times 2-3 \mathrm{~mm}$, adaxial surfaces sericeous; margins ciliate; apices acute; pedicels straight, 0.6-1.5 mm long, glabrous. Sepals ovate-lanceolate, 3.5-5.0 × 1.3-2.0 mm, equaling corolla tube, adaxial surface pubescent in the top half; margins ciliate. Corolla white; corolla tube cylindrical, 3.5-4.0 $\times 1.5-2.0 \mathrm{~mm}$; corolla lobes reflexed, ovate-triangular, shorter than corolla tube, 1.5-1.7 × 1.0-1.2 mm, apex subacute; surfaces glabrous. Stamens inserted onto corolla tube near the top, filaments $0.6-1.0 \mathrm{~mm}$ long; anthers included, oblong, light yellow and 0.9-1.0 mm long. Ovary obovate, 2.9-3.0 × 1.8-2.0 mm, apex round; nectary scales rectangular, $1.5-1.6 \times 0.7-0.8 \mathrm{~mm}$, apices retuse; style included, $1.3-1.5 \mathrm{~mm}$ long, glabrous; stigma five-lobed. Fruit pedicellate, light brown, $2-3 \times 2.0-3.5 \mathrm{~mm}$, obovoid, apex round, glabrous. Seeds cream coloured, ovoid, 0.7-1.3 $\mathrm{mm}$ long, testa slightly reticulate. Flowering November-February. (Figure 7.138).

\section{Diagnostic features and notes}

Oreothamnus septentrionalis is characterized by the long and wide juvenile (110-200 × 4-6 $\mathrm{mm})$ and adult leaves $(80-125 \times 1.5-2.5 \mathrm{~mm})$, rugose adaxial surface of the adult lamina, caducous flower bracts overtopping the flower with sericeous adaxial surfaces, short pedicels, sepals equaling the corolla tube and pubescent in the top half of the adaxial surface, stamens inserted onto the corolla tube near the top and the cream coloured ovoid seeds. 


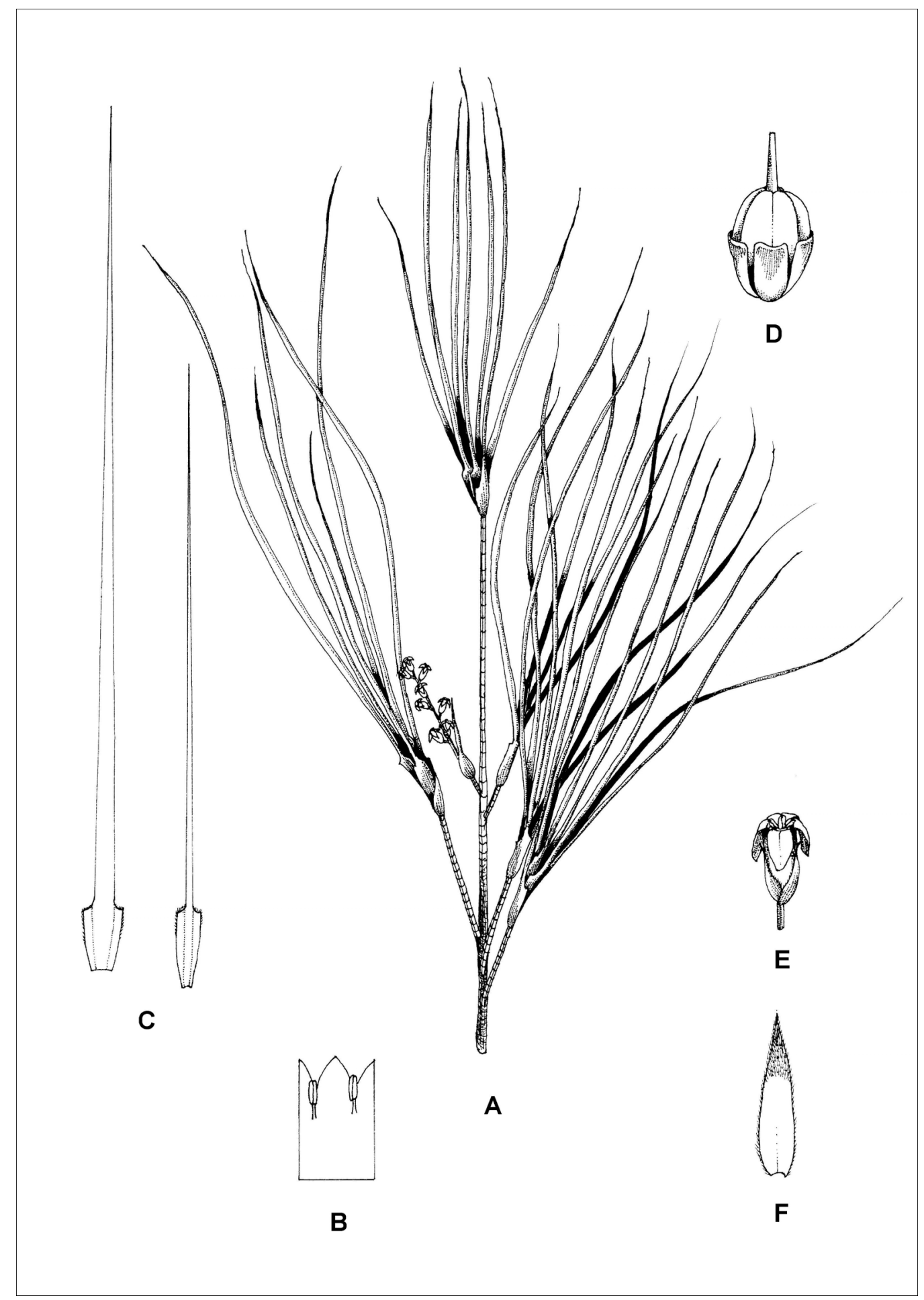

Figure 7.138. Oreothamnus septentrionalis. A, flowering branch $(\times 1)$; $\mathbf{B}$, laid out corolla $(\times 5)$; C, juvenile and adult leaves $(\times 1)$; $\mathbf{D}$, ovary $(\times 10)$; $\mathbf{E}$, flower $(\times 3) ; \mathbf{F}$, sepal adaxial surface $(\times 8)$. Drawn from Venter 13756 . 

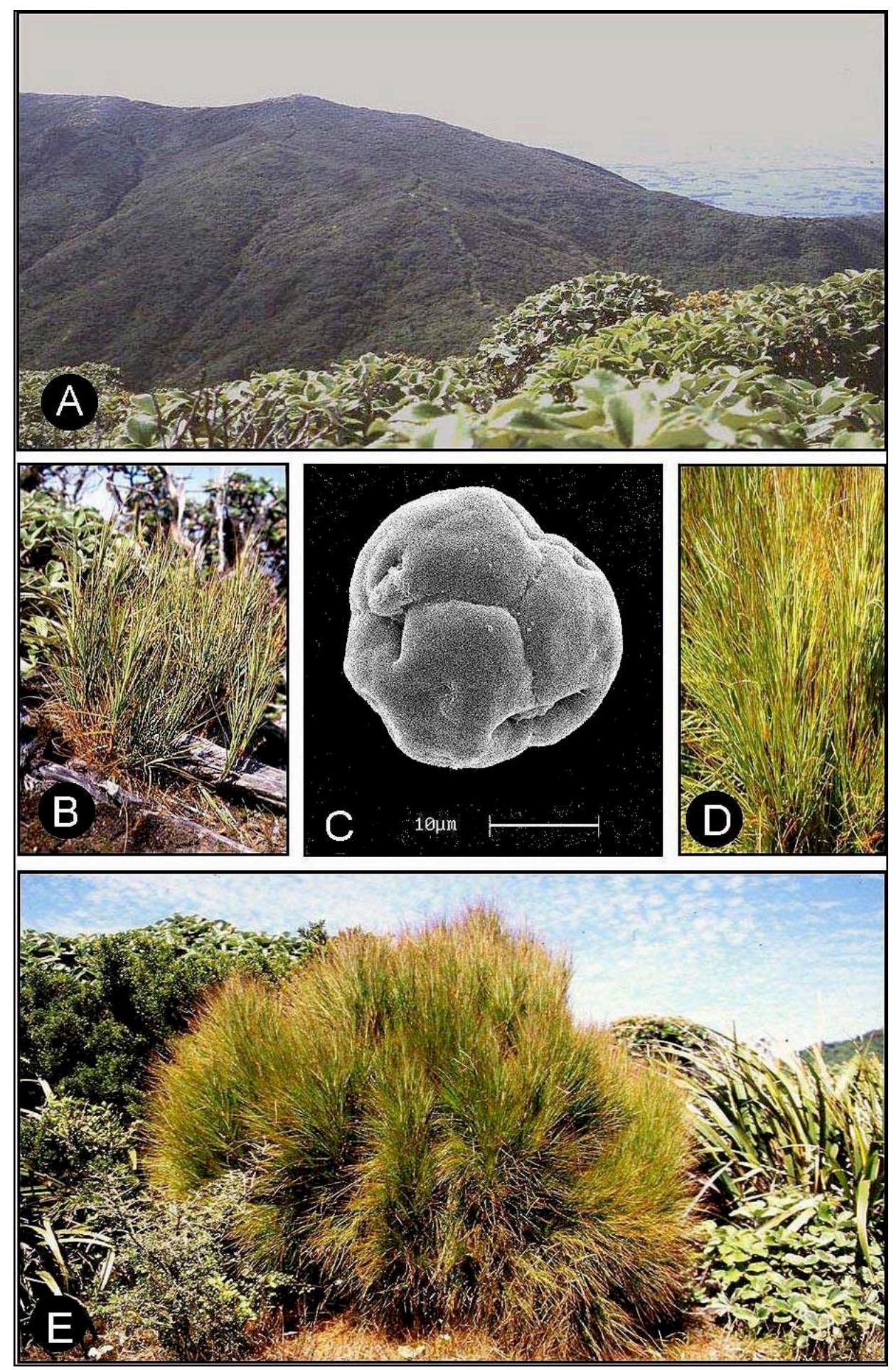

Figure 7.139. Oreothamnus septentrionalis. A, habitat on the Ruahine Mountains; B, juvenile plant showing the large juvenile leaves; C, SEM micrograph of the pollen; D, mature leaves and $\mathbf{E}$, mature plant from the type locality, Mt. Maharahara, Ruahine Mountains. C, Druce s.n. CHR366362 and E, Venter13756. 
It is similar to $O$. oliveri in the racemose inflorescence, serrulate margin of the inflorescence bract and the retuse apices of the nectar scales but it differs in various leaf and flower characters (Table 7.54). Oliver (1952) compared the raceme and leaves of Dracophyllum longifolium var. septentrionale (=O. septentrionalis) with that of $D$. filifolius $(=O$. filifolius) but described it as a variety of $D$. longifolium based on the measurements of the leaves stating that the leaves are much wider than that of $D$. filifolius.

Table 7.54. Morphological differences between O. septentrionalis and O. oliveri.

\begin{tabular}{|l|l|l|}
\hline \multicolumn{1}{|c|}{ Character } & \multicolumn{1}{|c|}{ O. septentrionalis } & \multicolumn{1}{c|}{ oliveri } \\
\hline Juvenile leaf size $(\mathrm{mm})$ & $110-200 \times 4-6$ & $75-85 \times 1.3-1.5$ \\
Adaxial lamina surface texture & rugose & glabrous \\
Number of teeth on lamina margin (per $10 \mathrm{~mm})$ & $50-60$ & $80-100$ \\
Inflorescence bracts & deciduous & persistent \\
Inflorescence bracts adaxial surface & sericeous & tuft of hairs at apex \\
Sepal width (mm) & $1.3-2.0$ & $4.5-5.5$ \\
Adaxial sepal texture & pubescent in top half & glabrous \\
Corolla tube width (mm) & $1.5-2.0$ & $2.0-2.5$ \\
Corolla lobe width (mm) & $1.0-1.2$ & $1.5-2.0$ \\
Adaxial surface of corolla lobe & glabrous & papillate \\
Stamen insertion on corolla tube & near the top & in upper third \\
Ovary length (mm) & $2.9-3.0$ & $1.4-1.5$ \\
Seed shape & ovoid & filiform \\
\hline
\end{tabular}

\section{Distribution}

New Zealand endemic, restricted to the North Island in the Taihape area, on the Ruahine Mountains and on the Flaggstaff Mountains (Fig. 7.140). 


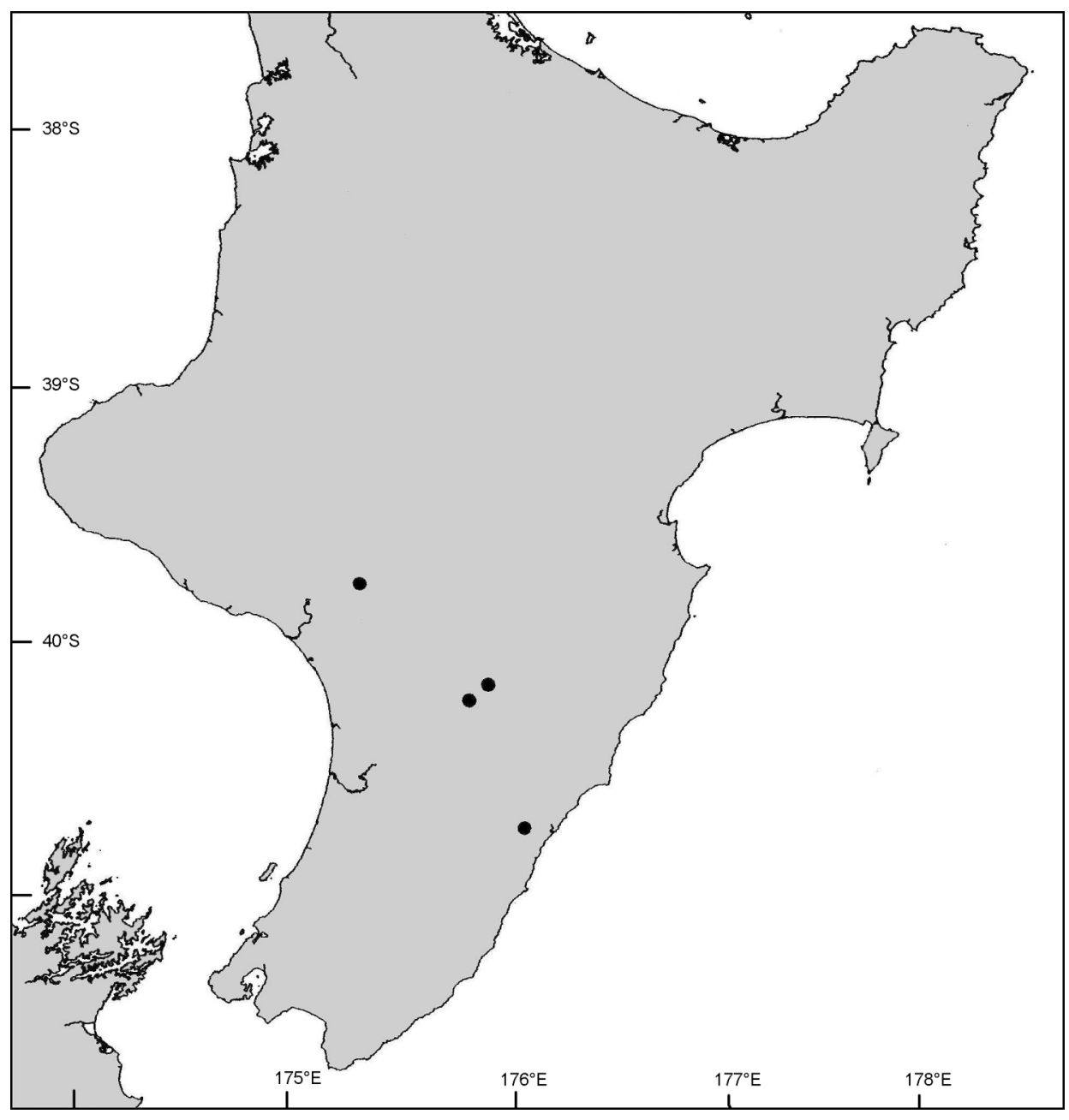

Figure 7.140. Known distribution of Oreothamnus septentrionalis, North Island, New Zealand.

\section{Habitat}

Oreothamnus septentrionalis appears to be restricted to gentle $\left(15^{\circ}-30^{\circ}\right)$ mountain slopes at altitudes of 1,000-1,500 m. These slopes are covered in dense montane shrubland (Table 7.55). Oreothamnus septentrionalis is so far only recorded on dark brown clay loam which is derived from shale. 
Table 7.55. Plant associations commonly associated with Oreothamnus septentrionalis.

\section{SHRUBLAND}

Short closed evergreen Olearia colensoi var. colensoi shrubland

\section{Variation}

A very uniform species. A basal patch of very short scabrid hairs is sometimes present at the base of the lamina.

\section{Material examined}

NEW ZEALAND. North Island. 40-175: (-BB), Ruahine Mountains, Mt. Maharahara, vi.1946. Greenwood s.n. (CHR); ibid., 07.ii.1999. Venter 13756 (CHR). 40-176: SW of Takapari (-AA), xi.1979. Druce s.n. (CHR); Wairarapa, Taipos $1 \mathrm{~m} \mathrm{~W}$ of Kupekore (-CA), v.1965. Druce s.n. (CHR).

26. Oreothamnus sinclairii (Cheeseman) S. Venter

Oreothamnus sinclairii (Cheeseman) S. Venter, comb. nov. Hooker, Fl. Antarct. 1: 48 (1844a); Hooker, Fl. Nov. Zel. 1: 169 (1853); Hooker, Handb. N.Z. Fl.: 181 (1864); Petrie, Trans. Proc. N.Z. Inst. 55: 435 (1924); Cheeseman, Man. N.Z. Fl., $2^{\text {nd }}$ Ed.: 704 (1925); Oliver, Trans. Proc. N.Z. Inst. 59: 698, 699 \& 702 (1928); Oliver, Trans. Roy. Soc. N.Z. 80 (1): 12 - 13 (1952); Allan, Fl. N.Z. 1: 533 - 534 (1961); Moore \& Irwin, Oxford Book of N.Z. Plants.: 293 (1978); Eagle, Trees \& Shrubs of N.Z. $2^{\text {nd }}$ series.: 293 - 294 (1982); Salmon, Native Trees of N.Z.: 274 (1989); Poole \& Adams, Trees \& Shrubs of N.Z.:158, 162 (1994). Type: New Zealand, Manukau Bay (Green Bay, Manukau Bay), W. Colenso s.n. (K, lecto.!), designated by Oliver (1952). 
= Dracophyllum sinclairii Cheeseman, Man. N.Z. Fl:: 421 (1906).

= Dracophyllum squarrosum Hook. f., Fl. Antarct. 1: 48 (1844a). non R. Br. Type: New Zealand, Manukau Bay (Green Bay, Manukau Bay), W. Colenso s.n. (K, lecto.!), designated by Oliver (1952).

$=$ Dracophyllum adamsii Petrie, Trans. Proc. N.Z. Inst. 55: 435 (1924). Type: New Zealand, Waiapu County, roadside near mouth of Awatere River, i.1897. J. Adams \& D. Petrie s.n. (WELT 55082, lecto!; CHR 332735!; WELT 55081!, 55084!; WELTU 4240!.), designated by Oliver (1952).

= Dracophyllum viride W.R.B. Oliv., Trans. Proc. N.Z. Inst. 59: 699 (1928). Type: New Zealand, Mangonui County, Spirit's Bay, Peria, 28.xi.1916. W.R.B. Oliver s.n. (WELT 33297, lecto.!; AK 105638!; WELT 13558!.), designated by Oliver (1952).

Icones: Oliver, Trans. Proc. N.Z. Inst. tt. 8, 10 \& 12 (1928); Oliver, Trans. Roy. Soc. N.Z. 80 (1): t. 10 (1952); Eagle, Trees \& Shrubs of N.Z. $2^{\text {nd }}$ series.: tt. 134, 135 (stamens wrongly illustrated as hypogynous) \& 140 (anthers wrongly illustrated as exserted) (1982); Salmon, Native Trees N.Z.: 274 (1989), Native N.Z. Flowering Plants. : 61, tt. 243 - 245 (1991).

\section{Description}

Single-stemmed small tree (1-)4-7(-7.6) m tall. Branches: bark on old branches dark grey to blackish brown, finely to deeply fissured, young stems reddish brown. Leaves juvenile and adult. Juvenile leaves spirally arranged along branches, spreading to recurved; lamina sheath, 9-30 $\times 5.0-12.7 \mathrm{~mm}$, shoulders tapering to truncate and margin entire, 
occasionally ciliate in upper half; lamina subcoriaceous to coriaceous, linear-triangular, 85-221 × 2.5-9.0 mm, surfaces glabrous with a patch of scabrid hairs at base of adaxial surface; margins serrulate with 50-70 teeth per $10 \mathrm{~mm}$. Adult leaves spreading to recurved, glaucous to light green (occasionally light brown); lamina sheath (3.5-)5.7-7.3 × 3.3-6.6 $\mathrm{mm}$, rounded to truncate and margin membranous with the top half ciliate; lamina lineartriangular, $37-95 \times(1-) 2-3(-5) \mathrm{mm}$, surfaces glabrous with a tuft of scabrid hairs at base on adaxial surface; slightly striated; margins serrulate with $60-80$ teeth per $10 \mathrm{~mm}$. Inflorescence a terminal spike; shorter than leaves, erect, drooping later, dense, 14.5$34.7 \mathrm{~mm}$ long, linear-oblong; inflorescence bract overtopping flowers, ovate to broadly ovate, $7-8 \times 0.7-1.0 \mathrm{~mm}$, adaxial surface glabrous with a patch of scabrid hairs at base; margins serrulate. Flowers 4-9, sessile. Flower bracts overtopping flowers, ovate, 6-20× 3-4 mm, adaxial surfaces sericeous; abaxial surfaces glabrous to scabrid; margins minutely serrulate. Sepals ovate-lanceolate, $(2.5-) 5.0-6.0 \times 1.2-2.0 \mathrm{~mm}$, longer than corolla tube; adaxial surfaces with the top half pubescent; margins ciliate. Corolla white; corolla tube narrowly-campanulate, widened at mouth, $4.0-4.5 \times 2.5-3.0 \mathrm{~mm}$; corolla lobes spreading horizontally to reflexed, triangular, shorter than corolla tube, $2.3-2.5 \times 1.7-$ 2.2; apex inflexed, subacute; adaxial surface papillate. Stamens inserted on corolla tube in the upper third, filaments $0.5-1.0 \mathrm{~mm}$ long; anthers included, rectangular, light yellow and $0.8-1.0 \mathrm{~mm}$ long. Ovary obovate, $1.4-1.5 \mathrm{~mm}$ long and wide, apex round; oblong, 1.3-1.4 $\times 0.6-0.7 \mathrm{~mm}$; apices mostly bidentate, sometimes irregularly toothed; style included, 1.3-1.5 mm long, glabrous; stigma five-lobed. Fruit light brown, 1.5-3.5 × 1.5$2.5 \mathrm{~mm}$, obovoid; apex truncate, glabrous. Seeds yellowish brown, ovoid, 1.0-1.3 mm long, testa slightly reticulate. Flowering January-November. (Figure 7.141). 


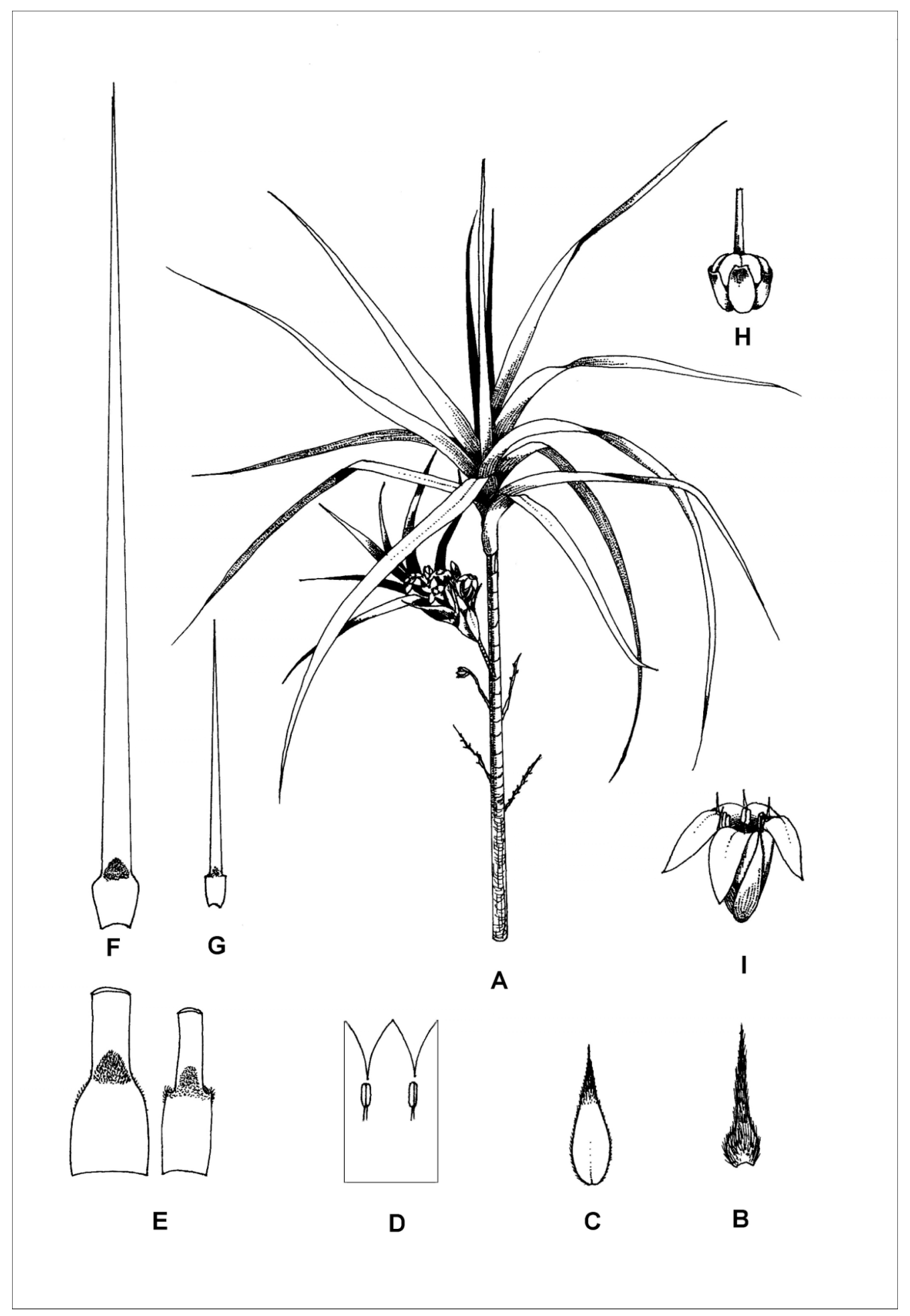

Figure 7.141. Oreothamnus sinclairii. A, flowering branch $(\times 1) ; \mathbf{B}$, flower bract adaxial surface $(\times 2)$; $\mathbf{C}$, sepal adaxial surface $(\times 5) ; \mathbf{D}$, laid out corolla $(\times 5)$; $\mathbf{E}$, lamina sheaths to show variation $(\times 2)$; $\mathbf{F}$, juvenile leaf $(\times 1)$; $\mathbf{G}$, adult leaf $(\times 1)$; $\mathbf{H}$, ovary $(\times$ 10); I, flower $(\times 5)$. Drawn from Venter 13781 . 

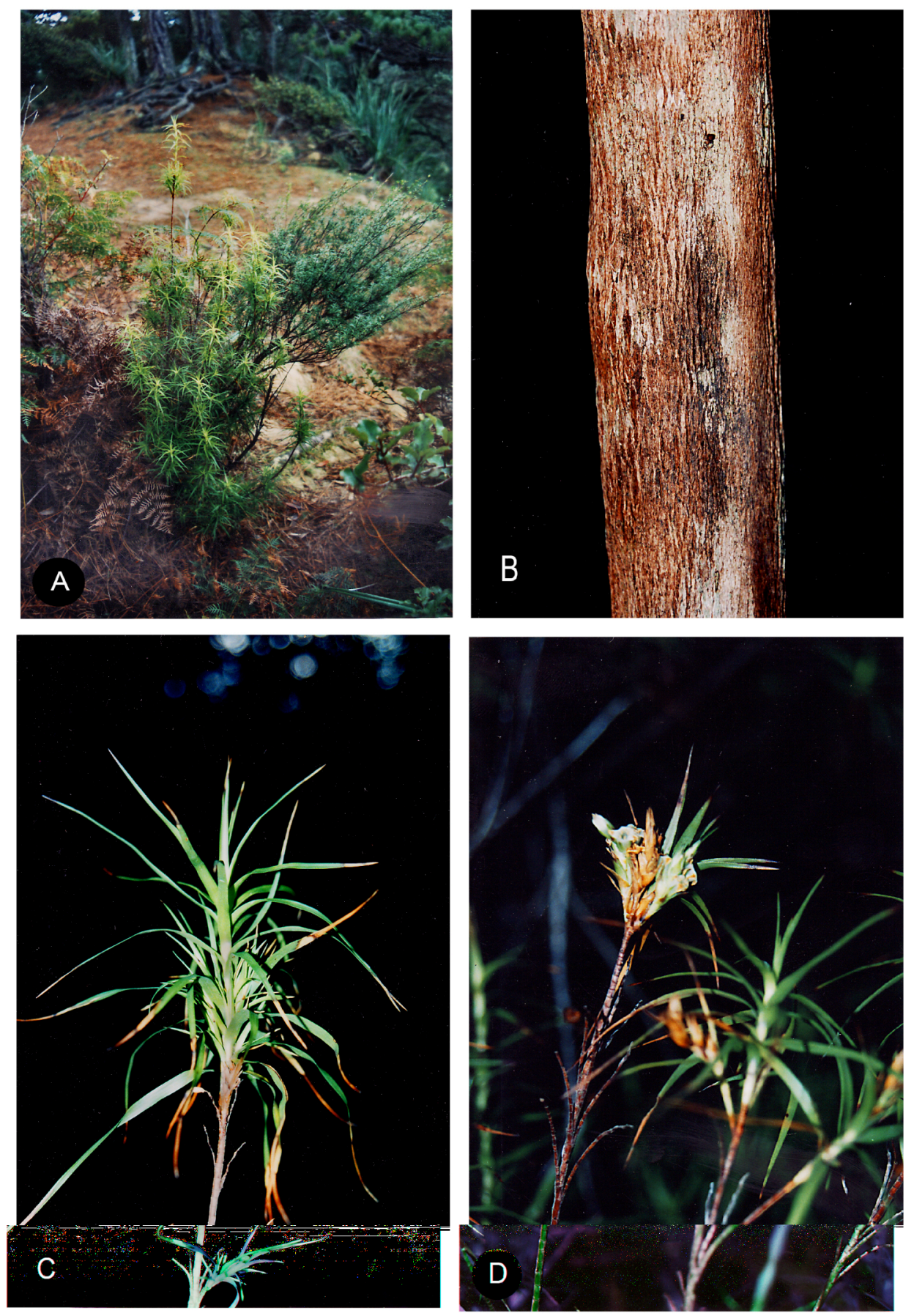

Figure 7.142. Oreothamnus sinclairii. A, habitat along the Black Jack Road, Coromandel Peninsula; B, mature tree (Venter 13760); C, branch with juvenile leaves (Venter 13780); D, fruiting branch (Venter13769). 


\section{Diagnostic features and notes}

Oreothamnus sinclairii is characterized by the large juvenile leaves, slightly striated adult leaves, the inflorescences on the lateral branches grouped together below the leaves of the main branch, flower bracts longer than the flower and covered in dense long hairs (sericeous) on the adaxial surfaces (in some populations only at the top half), sepals longer than the corolla tube and sericeous in the top half on the adaxial surface and the narrow campanulate corolla tube.

Cheeseman (1906) failed to mention a specimen when he described the species, but Hooker (1844a) mentioned the Colenso specimen under Dracophyllum squarrosum, which Oliver (1952) designated to D. sinclairii. Hooker wrongly named it D. squarrosum for Don (1834) had already used that name for the type species of the genus Sphenotoma in Australia. Bentham and Hooker (1876) later placed Sphenotoma back into Dracophyllum unfortunately without giving their reason why.

Oreothamnus sinclairii is similar to O. lessoneanus but differs in having a much wider (2.5-9.0 mm compared to 1.6-1.8 $\mathrm{mm}$ ) juvenile lamina with a patch of scabrid hairs at the base on the adaxial surface. The adult lamina is also wider (2-3 mm compared to $0.5-1.2 \mathrm{~mm})$ with an acute apex not prominently triquetrous. The inflorescence bract has a serrulate not entire margin. The corolla tube in O. sinclairii is narrowly campanulate not cylindrical, shorter (4.0-4.5 mm compared to 5-6 $\mathrm{mm}$ ) and wider (2.5-3.0 $\mathrm{mm}$ compared to $2.0-2.5$ $\mathrm{mm})$. 


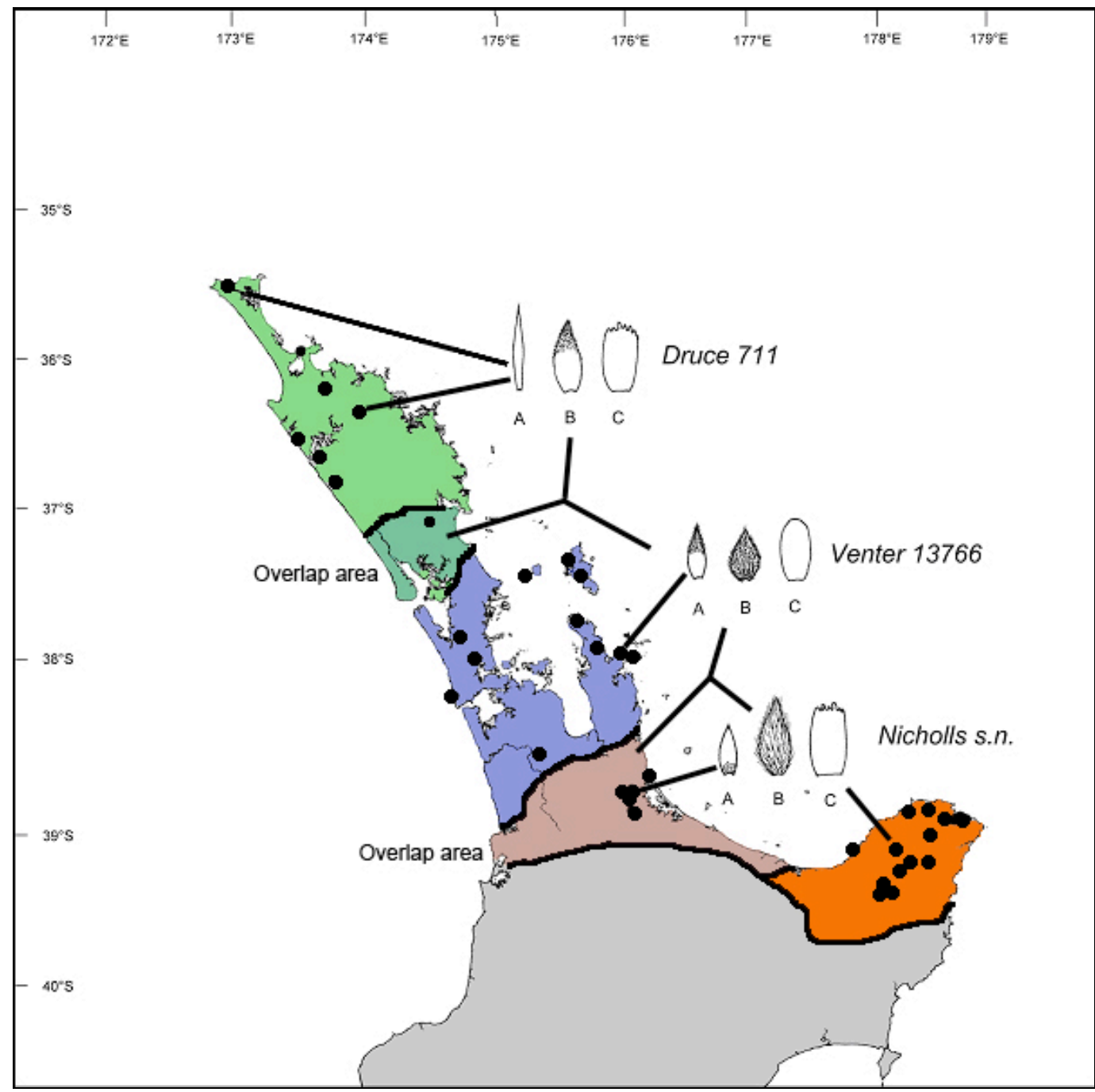

Figure 7.143. Known distribution and variation in Oreothamnus sinclairii. The three most different forms of inflorescence bracts and nectary scales are illustrated. Druce 711, North Auckland, Unuwhao; Venter 13766, Coromandel Peninsula, Black Jack Road; Nicholls s.n., N Kaimai Range, Mt. Ngatamahinerua. A, inflorescence bract adaxial surface $(\times 1)$; $\mathbf{B}$, flower bract adaxial surface $(\times 2)$; C, nectary scale $(\times 10)$.

\section{Distribution}

New Zealand endemic restricted to the North Island from Gisborne north and on Great Barrier Island (Fig. 7.143).

\section{Habitat}

Oreothamnus sinclairii is common on coastal cliffs, along ridges, mountain slopes, along drainage lines, gently sloped $\left(5^{\circ}-30^{\circ}\right)$ scree areas and on mountain summits from 25 
$1432 \mathrm{~m}$ altitudes. The vegetation consists of lowland to montane forest, woodland, shrub or shrub-tussockland (Table 7.56). O. sinclairii is associated with Leptospermum scoparium shrubland and woodland on the dry ridges along the coast. Soils are yellowish brown clay loam to light brown clay derived from mudstone, dacite or andesite, or grey to brown loam derived from sandstone.

Table 7.56. Plant associations commonly associated with Oreothamnus sinclairii.

\begin{tabular}{|l|}
\hline \multicolumn{1}{|c|}{ FOREST } \\
\hline High closed evergreen Nothofagus truncata forest \\
Tall closed evergreen Agathis australis - Ixerba brexioides - Gahnia lacera forest \\
Tall closed evergreen Agathis australis - Libocedrus plumosa - Halocarpus kirkii forest. \\
Tall open evergreen Agathis australis - Toronia toru - Gahnia lacera forest \\
Low closed evergreen Beilschmiedia tawa forest \\
Low closed evergreen Weinmannia silvicola - Knightia excelsa forest \\
Low closed semi deciduous Kunzea ericoides - Weinmannia silvicola - Dianella nigra forest \\
Low open evergreen Halocarpus biformis - Gahnia procera forest \\
\hline \multicolumn{1}{c|}{ WOODLAND } \\
\hline $\begin{array}{c}\text { Tall closed semi-deciduous Kunzea ericoides woodland } \\
\text { Tall closed semi-deciduous Leptospermum scoparium woodland }\end{array}$ \\
\hline \multicolumn{1}{c|}{ SHRUBLAND } \\
\hline $\begin{array}{l}\text { Tall closed semi-deciduous Leptospermum scoparium shrubland } \\
\text { Low closed evergreen Myrsine australis - Pteridium esculentum - Leucopogon fasciculatus shrubland } \\
\text { Low closed semi-deciduous Olearia townsonii - Leptospermum scoparium shrubland }\end{array}$ \\
\hline
\end{tabular}

\section{Variation}

A highly polymorphic species (Figure $7.143 \& 7.144$ ). The shoulders of the leaf sheath of both juvenile and adult leaves are either tapering, rounded or truncate. The size of the leaf sheaths, are likewise variable in the juvenile $(9-30 \times 5.0-12.7 \mathrm{~mm})$ and adult leaves $(5.7-7.3 \times 3.3-6.6 \mathrm{~mm})$. The lamina size varies (juvenile: $85-221 \times 2.5-9.0 \mathrm{~mm}$, adult: 37-95 $\times 2-3 \mathrm{~mm}$ ), with a patch of scabrid hairs sometimes present at the base of the lamina and some populations lacking this character 


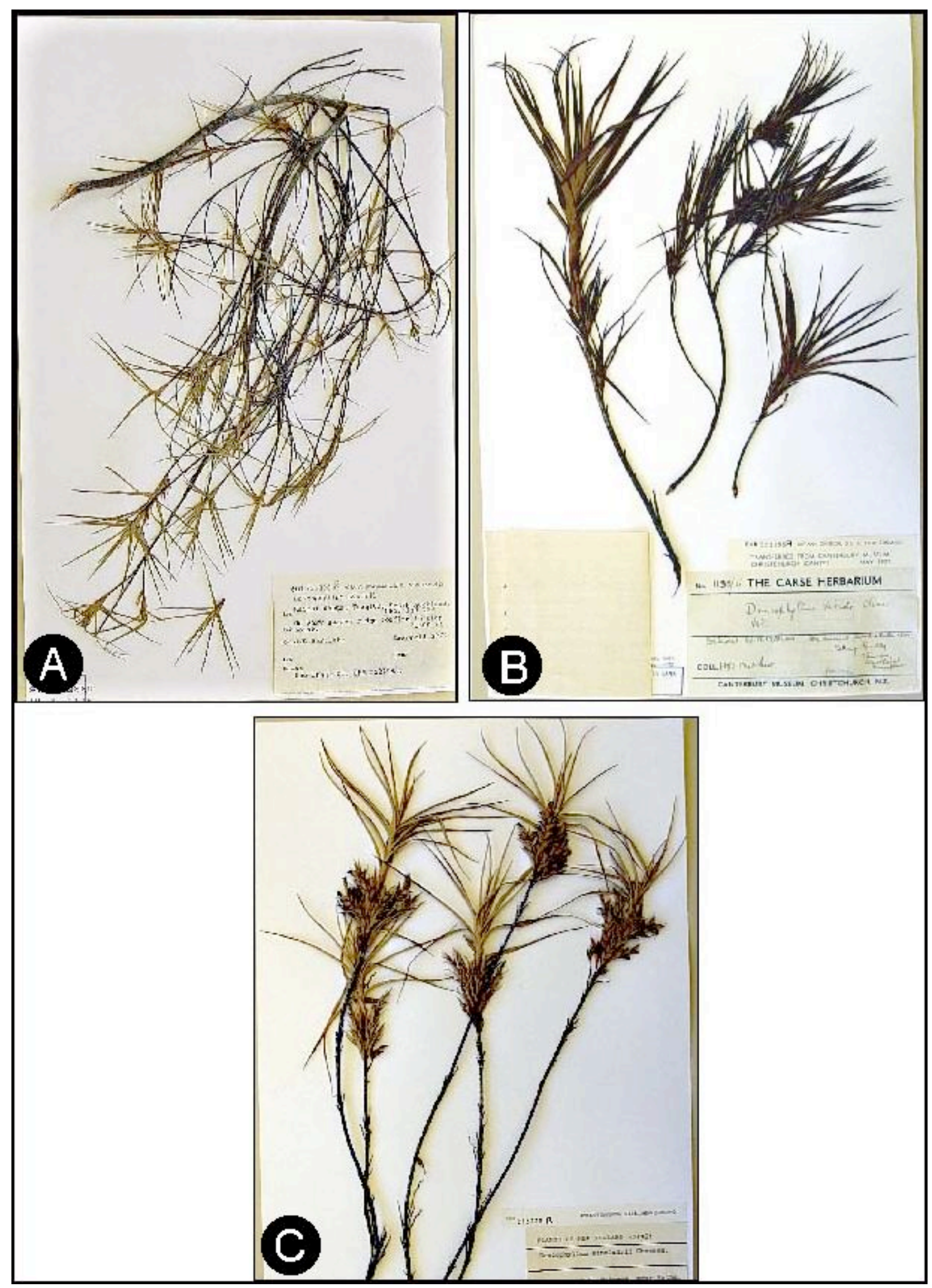

Figure 7.144. Oreothamnus sinclairii variation. $\mathbf{A},=$ Dracophyllum adamsii (CHR 322398); B, = Dracophyllum viride (CHR 332191A); C, = Dracophyllum sinclairii (CHR 213770A). 
entirely. The length of the inflorescence varies from population to population (14.5-34.7 $\mathrm{mm})$ and flower bract length is variable even on the same plant $(6.0-20.0 \mathrm{~mm})$.

The three groups formerly known as Dracophyllum sinclairii, D. adamsii and D. viride (Fig. 7.144), grade into each other to such an extent that it would be futile to attempt in describing it as varieties of $O$. sinclairii. Plants with glabrous, long and narrow inflorescence bracts tend to be more common in the area north of Auckland but it is still present in some populations in the east (Raukumara Range). Specimens with the inflorescence bracts having the top half pubescent, is common in the area around Auckland and the Coromandel Peninsula. Plants with flower bracts having the top half of the adaxial surface covered in scabrid hairs or being tomentose, are common in the area around Auckland and further north whilst plants with pubescent flower bracts more common in the eastern part of the distribution. Specimens with rounded apices to the nectary scales occur mostly in the Coromandel populations and the apices become more toothed in specimens further to the north and east (Fig. 7.143).

In describing Dracophyllum viride Oliver (1952) mentioned that he regarded the specimens from Spirits Bay as D. viride but Petrie placed them in D. adamsii. During a survey of the Spirits Bay area I found the plants to be extremely variable in the size of the juvenile and adult leaves, shape and degree of pubescence of the inflorescence and flower bracts and the apex shape of the nectary scales.

Oliver (1952) stated that O. sinclairii is allied to O. longifolius in the deciduous bracts and the narrow flat leaves. All herbarium specimens and the plants in the wild that I studied showed persistent bracts. He used this character to place D. adamsii in the D. longifolium group (D. longifolium and D. adamsii). Oliver (1952) mentioned that Dracophyllum viride is 
related to $D$. sinclairii and $D$. adamsii but differs in the larger, broader leaves, short flowering branches and much longer flowers with long acuminate sepals. All these variations fall within my concept of $O$. sinclairii (Fig. 7.143).

\section{Material examined}

NEW ZEALAND. North Island. 34-172: North Auckland, Unuwhao (-BD), i.1990. Druce 711 (CHR); Spirits Bay, Pandora Bush. 18.ix.1976. Michie \& Bartlett s.n. (AK); Northland, Te Paki (-DB), xii.1966. Kelly s.n. (CHR). 35-172: North Tangihua Forest, north end of ridge before trig (-DD), 29.viii.1991. Cameron 6569 (AK). 35-173: Northland, Ahipara (-AA), Bartlett s.n. (CHR); Mangonui County, Peria (-AB), 14.ix.1913. Carse s.n. (CHR); Paranui, Taylor's Road. 26.i.1984. McCrae s.n. (AK, MU); Kerikeri, Puketi Forest, near trig 1171 (-BB), 15.ii.1999. Venter 13769 (CHR); Northland, Lake Taharoa (-DC), 15.i.1978. Bartlett s.n. (CHR). 36-174: Little Barrier Island (-BB), Shakespear s.n. (CHR); Auckland, Birkenhead (-DC), 02.vii.1999. Venter 13780 (CHR); Auckland, Manukau Harbour, Green Bay, 30.vi.1999. Venter 13781 (CHR); Coatesville, 06.iv.1982. Clunie 28 (CHR). 36-175: Little Barrier Island (-AA), Shakespear s.n. (CHR); Little Barrier Island, Track 16, 25.i.1980. Beever 80245 (CHR); Great Barrier Island, Te Ahumata, track from Whangaparapara side, near summit (-AB), 14 iii.1991. GarnockJones \& Clarkson (CHR; HO); Coromandel Peninsula, track from Stoney Bay to Mochau trig. (-CB), 14.xi.1981. Cameron 759 (AK, CHR); Coromandel, Black Jack Road (-DA), 28.ix.1992. De Lange 1714 (CHR); ibid. 13.ii.1999. Venter 13766 (CHR); Kennedy Bay, 25.x.1872. Kirk s.n. (WELT 55086); Coromandel Peninsula, Opito Bay (-DB), 24.ii.1981. Bartlett s.n. (CHR); Great Murcury Island, valley behind Peachgrove Bay, 02.ix.1962. Atkinson s.n. (CHR); Mercury Bay (-DC), 5.xi.1769. Banks \& Solander s.n. (AK, BM). 37175: N Kaimai Range, Mt. Ngatamahinerua (-DB), viii.1961. Nicholls s.n. (CHR). 37-177: Eastern Bay of Plenty, Waihau Bay (-DB), 20.x.1984. Courtney s.n. (CHR); Eastern Bay of 
Plenty, Whitianga Bay, Okawhiti Stream (-DC), xii.1983. Courtney s.n. (CHR); Raukumara Range, Mt. Honokawa (-DD), 30.xii.1962. Druce s.n. (CHR). 37-178: East Cape, Mt. Hikurangi (-BB), xii.1949. Druce s.n. (CHR); Pukeamaru (-CA), 25.xi.1949. Oliver s.n. (WELT 13559); 38-174: Waitapu Stream (-BA), 22.i.1985. De Lange s.n. (AK); Te Wharu Bush (-BB), 14.i.1967. Devlin s.n. (AK); 38-177: Raukumara Range, summit of Arowhana (-BB), 16.x.1964. Fryer s.n. (CHR). 39-176: Ruahine Range, Mt. Hikurangi (-CC), i.1897. Petrie s.n. (Z).

27. Oreothamnus subulatus (Hook. f.) S. Venter

Oreotbamnus subulatus (Hook. f.) S. Venter, comb. nov. Hooker, Fl. Nov. Zel. 2 (1): 171 (1853); Hooker, Handb. N.Z. Fl: 182 (1864); Cheeseman, Man. N.Z. Fl.: 425 (1906); Cheeseman, Ill. N.Z. Fl.: t. 132 (1914); Cheeseman, Man. N.Z. Fl. $2^{\text {nd }}$ Ed.: 707 (1925); Oliver, Trans. Proc. N.Z. Inst. 59: 691 (1928); Oliver, Trans. Roy. Soc. N.Z. 80 (1): 7 (1952); Allan, Fl. N.Z. 1: 527 (1961); Eagle, Trees \& Shrubs $1^{\text {st }}$ series.: 282 (1975); Poole \& Adams, Trees \& Shrubs of N.Z.: 162 (1994). Type: New Zealand, near the Rangitaiki River [near nowaday town of Galatea], i.1842. J.C. Bidwill s.n. (K, lecto.!), designated by Oliver (1952).

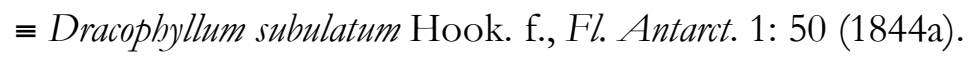

= Dracophyllum angustifolium Colenso, Trans. Proc. N.Z. Inst. 28: 603 (1896). Type: New Zealand, Ruahine Mountain-range. 1895. H. Hill s.n. (n.v.). 
Icones: Cheeseman, Ill. N.Z. Fl: t. 132 (1914); Eagle, Trees \& Shrubs 1"t series.: t.168 (1975). The anthers are depicted as being exserted instead of inserted; SmithDodsworth, N.Z. Native Shrubs \& Climbers.: t. 57, Pl. 23E \& 23F (1991).

\section{Description}

A multi-stemmed shrub 30-200 cm tall. Branches: bark on old branches grey, smooth, young stems reddish to purplish brown. Leaves juvenile and adult. Juvenile leaves spirally arranged along branches, spreading; lamina sheath $4.5-6.5 \times 2.5-3.0 \mathrm{~mm}$, shoulders truncate to auricled and margin membranous with the upper half ciliate; lamina linear to rarely linear-triangular, $18-45 \times 1-2 \mathrm{~mm}$, adaxial surface with a patch of scabrid hairs at base; margins serrulate with $70-80$ teeth per $10 \mathrm{~mm}$. Adult leaves erect to spreading, olive to dark green; lamina sheath $2.5-6.5 \times 2-4 \mathrm{~mm}$, subcoriaceous, shoulders rounded to auricled and margins membranous, ciliate; lamina linear to linear-subulate, $10-48 \times 0.5-$ $1.2 \mathrm{~mm}$, surfaces glabrous with a tuft of scabrid hairs at base on adaxial surface; margins serrulate with 90-120 teeth per $10 \mathrm{~mm}$; apex triquetrous. Inflorescence a terminal spike on lateral branches; shorter than leaves, erect, dense, 5.3-12.3 mm long, linear-oblong; inflorescence bract overtopping flowers, ovate-lanceolate at base, 4-6 $\times 0.5-0.6 \mathrm{~mm}$; margins serrulate. Flowers 2-4 (-6), sessile; flower bracts equaling to longer than flowers, leaf like, broadly ovate, $3.5-4.5(-7.8) \times 1.7-2.0 \mathrm{~mm}$, with a tuft of scabrid hairs at the apex; margins with a prominent broad and white margin, serrulate. Sepals lanceolate to ovate-lanceolate, $2.6-3.2 \times 0.6-1.2 \mathrm{~mm}$, longer than corolla tube; adaxial surface pubescent or only the top half pubescent; margins ciliate. Corolla white to light pink; corolla tube cylindrical, $1.8-2.0 \times 1.0-1.2 \mathrm{~mm}$; corolla lobes spreading horizontally to reflexed, triangular, shorter than corolla tube, 1.0-1.5 $\times 0.8-1.0 \mathrm{~mm}$; apices acute; adaxial surface papillate. Stamens inserted in corolla tube in the upper third, filaments $0.1-0.2$ 


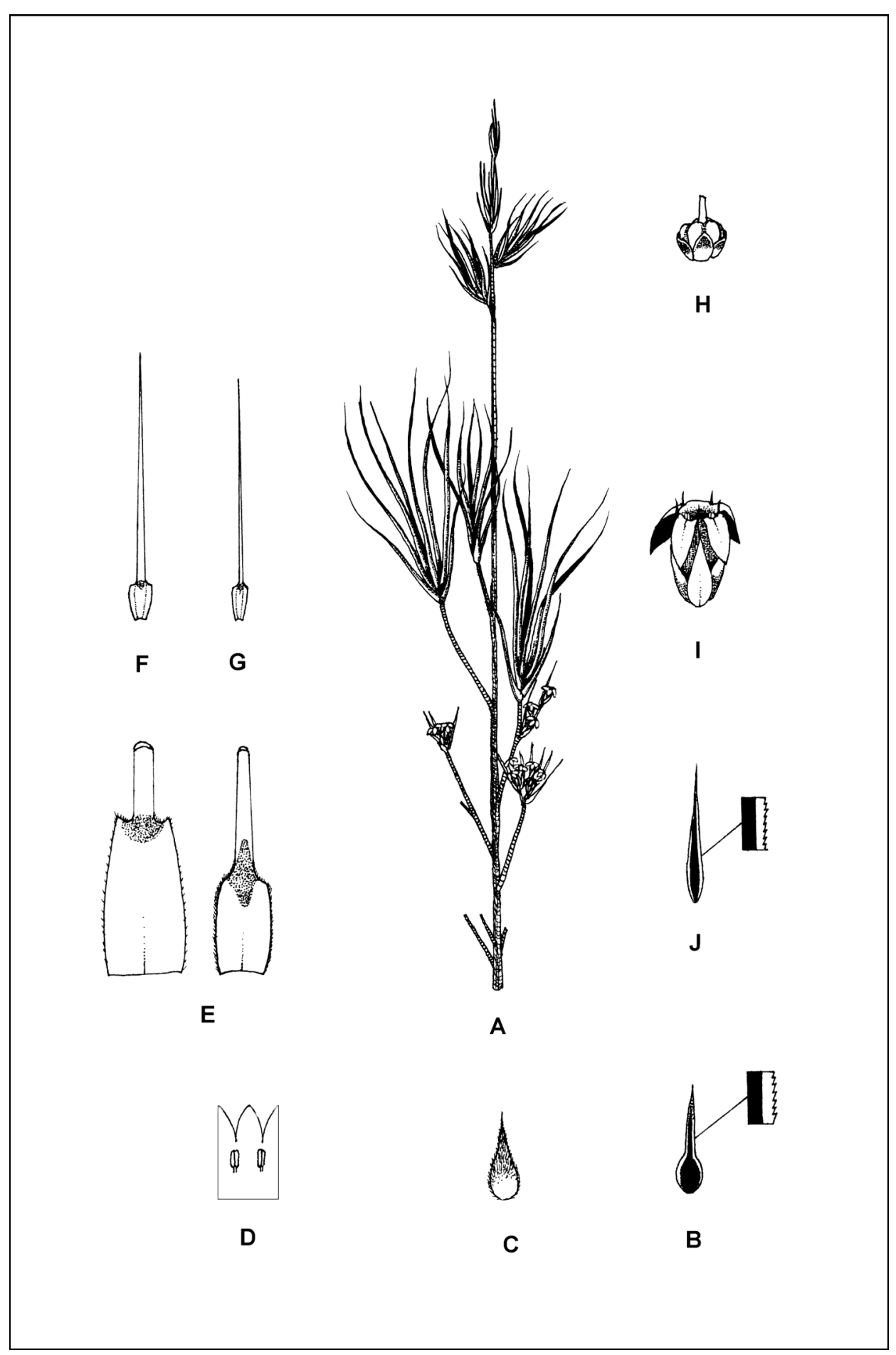

Figure 7.145. Oreothamnus subulatus. A, flowering branch $(\times 1)$; B, flower bract adaxial surface $(\times 5)$; $\mathbf{C}$, sepal $(\times 5)$; $\mathbf{D}$, laid open corolla $(\times 5)$; $\mathbf{E}$, lamina sheaths to show variation $(\times 5) ; \mathbf{F}$, juvenile leaf $(\times 1)$; $\mathbf{G}$, adult leaf $(\times 5)$; $\mathbf{H}$, ovary $(\times 10)$; $\mathbf{I}$, flower $(\times 5)$; J, inflorescence bract $(\times 5)$. Drawn from Venter 13761 . 

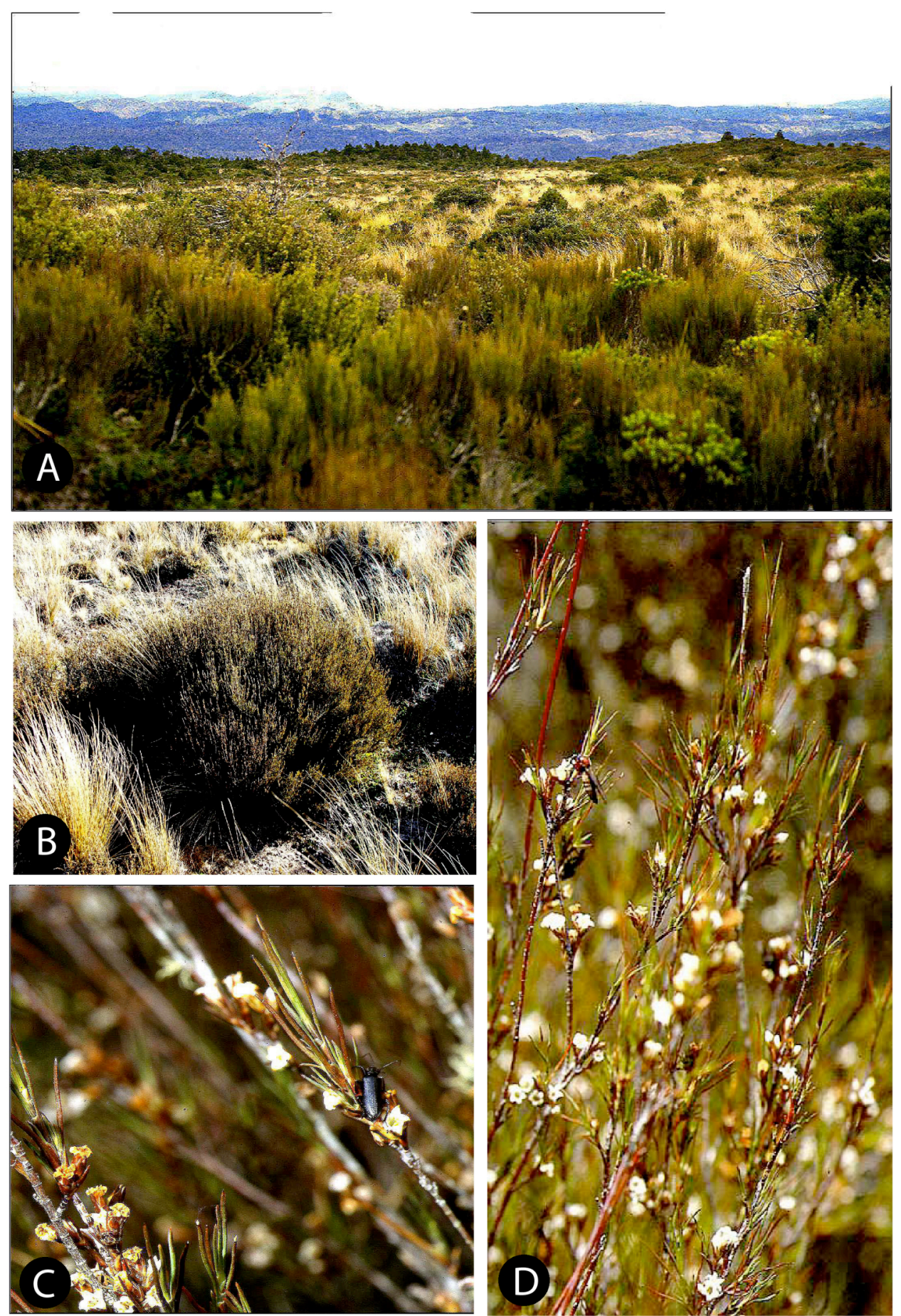

Figure 7.146. Oreotbamnus subulatus. A, frost flats near Mt. Ruapehu; B, habitat near Lake Taupo; C, mature plant in fruit; D, flowering branches showing the short inflorescence and small flowers; E, mature plant in the Rangipo Desert; F, flowering branch with a beetle from the Cerambycidae, collecting pollen. 
mm long; anthers included, rectangular, light yellow and 0.7-0.8 mm long. Ovary obovate, 0.8-1.0 mm long and wide, apex truncate; nectary scales rectangular, $0.4-0.5 \times 0.3-0.4 \mathrm{~mm}$, apices retuse; style included, 0.5-1.0 mm long, glabrous; stigma clavate. Fruit 2.9-3.0 $\times$ 1.7- $1.8 \mathrm{~mm}$, oblong; apex truncate, glabrous. Seeds yellowish brown, filiform, 1.0-1.2 $\mathrm{mm}$ long, testa prominently reticulate. Flowering November-March. (Figure 7.145).

\section{Diagnostic features and notes}

Oreothamnus subulatus is characterized by the slender branches, juvenile leaves, small (5.3$12.3 \mathrm{~mm}$ long) few flowered (2-6) inflorescences, flower bracts with a broad white margin, small corolla tubes $(1.8-2.0 \times 1.0-1.2 \mathrm{~mm})$ and seeds with a prominently reticulate testa.

Oreothamnus subulatus is similar to O. palustris, especially in the flower bracts having prominent white margins. It differs in having juvenile leaves, inflorescence being a spike not a solitary flower, inflorescence bracts longer than the flower not equaling and being much narrower $(0.5-0.6 \mathrm{~mm}$ compared to $1.5-2.0 \mathrm{~mm})$, sepals longer and filiform not ovoid and the seed with a prominently reticulate testa not slightly reticulate.

\section{Distribution}

New Zealand endemic, restricted to the Volcanic Plateau area on the North Island. (Fig. 7.147). 


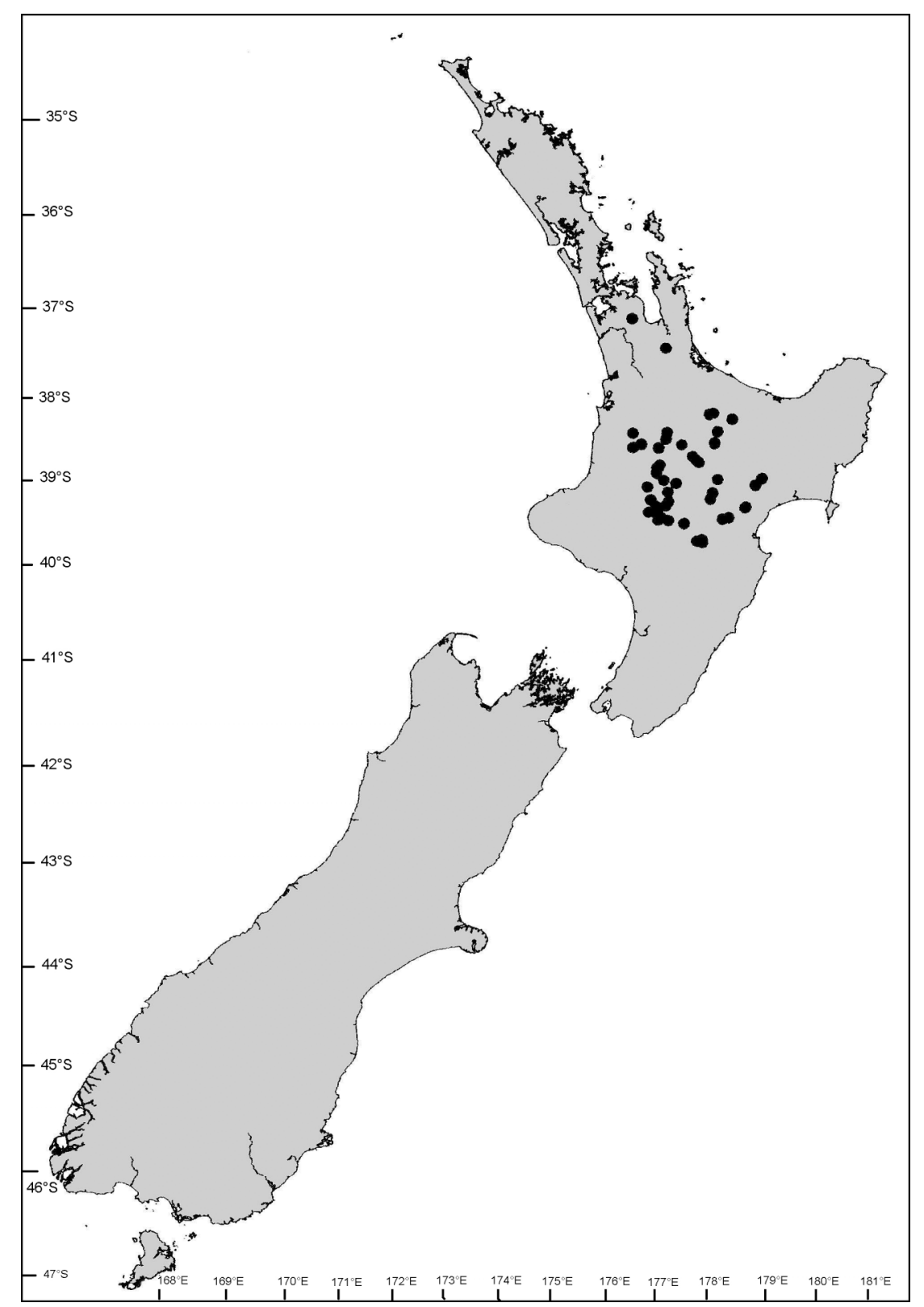

Figure 7.147. Known distribution of Oreothamnus subulatus.

\section{Habitat}

Oreothamnus subulatus grows at altitudes of 100-1,220 m on the Volcanic Plateau and on the associated volcanoes and mountains surrounding the Plateau. It occurs on flat or gently sloped $\left(5^{\circ}-15^{\circ}\right)$ areas that are covered in montane shrubland, shrub-tussockland, grassland, fernland or bogs (Table 7.57). The soil is mostly brown to grey sandy loam 
derived from greywacke, andesite or pumice. Oreothamnus subulatus and O. recurvus are associated with areas where there is a presence of tephra (Bruce Clarkson, pers. comm.).

Table 7.57. Plant associations commonly associated with Oreothamnus subulatus.

\begin{tabular}{|c|}
\hline SHRUBLAND \\
\hline $\begin{array}{l}\text { Low closed semi-deciduous Leptospermum scoparium shrubland } \\
\text { Low closed semi-deciduous Leptospermum scoparium - Gleichenia shrubland }\end{array}$ \\
\hline GRASSLAND \\
\hline Low closed semi-deciduous Kunzea ericoides - Chionochloa rubra tussock grassland \\
\hline
\end{tabular}

\section{Variation}

Lamina size is variable in the juvenile leaves $(18-45 \times 1-2 \mathrm{~mm})$ and the adult leaves $(10$ $48 \times 0.5-1.2 \mathrm{~mm})$. Inflorescence length varies from $5.3-12.3 \mathrm{~mm}$. All this variation can be present in a single population.

\section{Hybrids}

Oreothamnus subulatus hybridises with O. lessonianus on the Volcanic plateau and was described as Dracophyllum $\times$ marginatum by Oliver (1928).

\section{Material examined}

NEW ZEALAND. North Island. 38-175: South of Lake Waipapa (-BC), 18.xi.1978.

Gardner 2135 (CHR, L); Hauhungaroa Range, Maungatukutuku Stream (-CB), iv.1984. Druce APD617 (CHR); Maraeroa (-DA), i.1947. Bannister s.n. (CHR); Wairakei, Craters of the Moon (-DB), vii.1976. Given 9498 (CHR); Moerangi (-DC), 7.ii.1979. Gardner 2298 (CHR); Hauhangaroa Range, Kuratau Clearing (-DD), 24.i.1951. Druce s.n. (CHR). 38176: Rotorua, Whakarewarewa geyser enclosure (-AA), 20.iii.1969. Macmillan 69/183 (CHR); Mt. Tarawera (-AB), 16.iv.1989. Clarkson s.n. (CHR); Mihi (-AD), 24.i.1963. 
Mason 9888 (CHR); Waiotapu, 25.iv.1939. Healy s.n. (CHR); Maungakakaramea [Rainbow Mountain]. i.1905. Cheeseman s.n. (AK); Lake Taupo (-CA), ii.1875. Berggren s.n. (O); Hilltop above Waiora Valley bores, 27.xi.1979. Given 11930 (CHR); Broadlands (-CB), 2.iii.1978. Given 11105 (CHR); $13 \mathrm{~km}$ south of Taupo Township (-CC), 15.iii.1962. Melville \& Melville 6707B (AK); Kaingaroa Plain, Rangitaiki (-CD), x.1978. Druce s.n. (CHR); Huiarau Range, near Maungataniwha Scientific Reserve (-DD), x.1977. Druce s.n. (CHR); Urewera National Park, Mangatoatoa Clearing, 7.xi.1984. Shaw \& Beadel s.n. (CHR). 39-175: National Park Junction (-AB), 16.iv.1966. Lamoureux 3653 (CHR); Turangi, Rangipo Desert (-BB), 09.ii.1999. Venter 13761 (CHR); Tongariro River, Pourini Scenic Reserve. 24.xi.1983. Gardner 3981 (AK). 39-175: Kakaramea (-BA), xii.1912. Aston s.n. (CHR); Mt. Ruapehu, west of Bruce Road, 27.i.1983. Powell 2016 (CHR); Tongariro National Park, Mt. Ngaurahue (-BC), 08.ii.1999. Venter 13758 (CHR). 39-176: North East Kaimanawa Range, Poronui (-AA), 15.ii.1973. Gardner 529 (CHR); Potonui Station (-AB), 7.vii.1949. Poole s.n. (CHR); Rangitikei, upper edge of Tikitiki Bush (-AC), 7.i.1950. Hamlin s.n. (CHR); Puketitiri, Ball's Clearing (-AD), xii.1976. Druce s.n. (CHR); Kaweka Range, east foot of Kuripapango Hill, The Lakes, xii.1974. Druce s.n. (CHR); Maungaharuru Range, 1 mile east of Kopua (-BA), xii.1970. Druce s.n. (CHR).

28. Oreothamnus trimorphus (W.R.B. Oliv.) S. Venter

Oreothamnus trimorphus (W.R.B. Oliv.) S. Venter, comb. nov. Allan, Fl. N.Z. 1: 529 (1961); Poole \& Adams, Trees \& Shrubs of N.Z.: 162 (1994). Type: New Zealand, West Whanganui Inlet, near shore in shrub, 28.xii.1949. W.R.B. Oliver s.n. (WELT 55515a, holo.!; WELT 55515b; WELT 55515c!; WELT 55516a!; WELT 55516b!; WELT 55516c!; WELT 55516d!; WELT 55516e!; WELT 55516f!; WELT 55516g!). 
三Dracophyllum trimorphum W.R.B. Oliv., Trans. Roy. Soc. N.Z. 80 (1): 8 (1952).

Icon: Oliv., Trans. Roy. Soc. N.Z. 80 (1): t. 4 (1952).

\section{Description}

Multi-stemmed shrub to small tree $0.2-3 \mathrm{~m}$ tall. Branches: bark on old branches grey, finely fissured, young stems yellowish to reddish brown. Leaves juvenile and adult. Jwvenile leaves spirally arranged along branches, spreading, light green to glaucous; lamina sheath 6-10 × 9-11 mm, shoulders tapering and margins ciliate in upper half; lamina linear-triangular to lanceolate, $60-125 \times 5.0-8.5(-7.0) \mathrm{mm}$, margin minutely serrulate with 50-70 teeth per $10 \mathrm{~mm}$. Adult leaves spreading, glaucous; lamina sheath 3-7 × 2.2-6.0 $\mathrm{mm}$, striate, shoulders rounded to auricled and margin membranous with the top half ciliate; lamina subulate to linear-triangular, $12-52 \times 1.0-3.5 \mathrm{~mm}$, surfaces scabrid, prominently striated; margin serrulate with 60-100 teeth per $10 \mathrm{~mm}$. Inflorescence a terminal spike on lateral branchlets; shorter than leaves, erect, lax, 5.5-14.0 mm long, oblong; inflorescence bracts overtopping flowers, glaucous, ovate-lanceolate at base, (6-)8$18 \times 0.7-2.0 \mathrm{~mm}$, surfaces widely scabrid; margins serrulate. Flowers hidden by the leaves, 1-4, sessile; flower bracts shorter than flowers, narrowly ovate, 5-7 $\times 0.6-1.5 \mathrm{~mm}$, adaxial surface rugose with a basal tuft of scabrid hairs; abaxial surface scabrid and rugose; margins serrulate. Sepals lanceolate to narrowly ovate, $4.5-6.0 \times 1.5-2.0 \mathrm{~mm}$, longer than corolla tube, striate, adaxial surfaces glabrous with the top half pubescent; abaxial surfaces pubescent; margins ciliate or ciliate in upper half. Corolla white; corolla tube cylindrical, $3.5-5.0 \times 2.4-2.5 \mathrm{~mm}$; corolla lobes spreading to spreading horizontally, triangular, shorter than corolla tube, 1,8-2.0 $\times 1.5-2.0 \mathrm{~mm}$, apices inflexed, subacute; glabrous. Stamens inserted in corolla tube in the upper third, filaments $0.3-0.5 \mathrm{~mm}$ long; anthers included, oblong, light yellow and 1.2-1.3 mm long. Ovary obovate, 1.3-2.0 $\times$ 


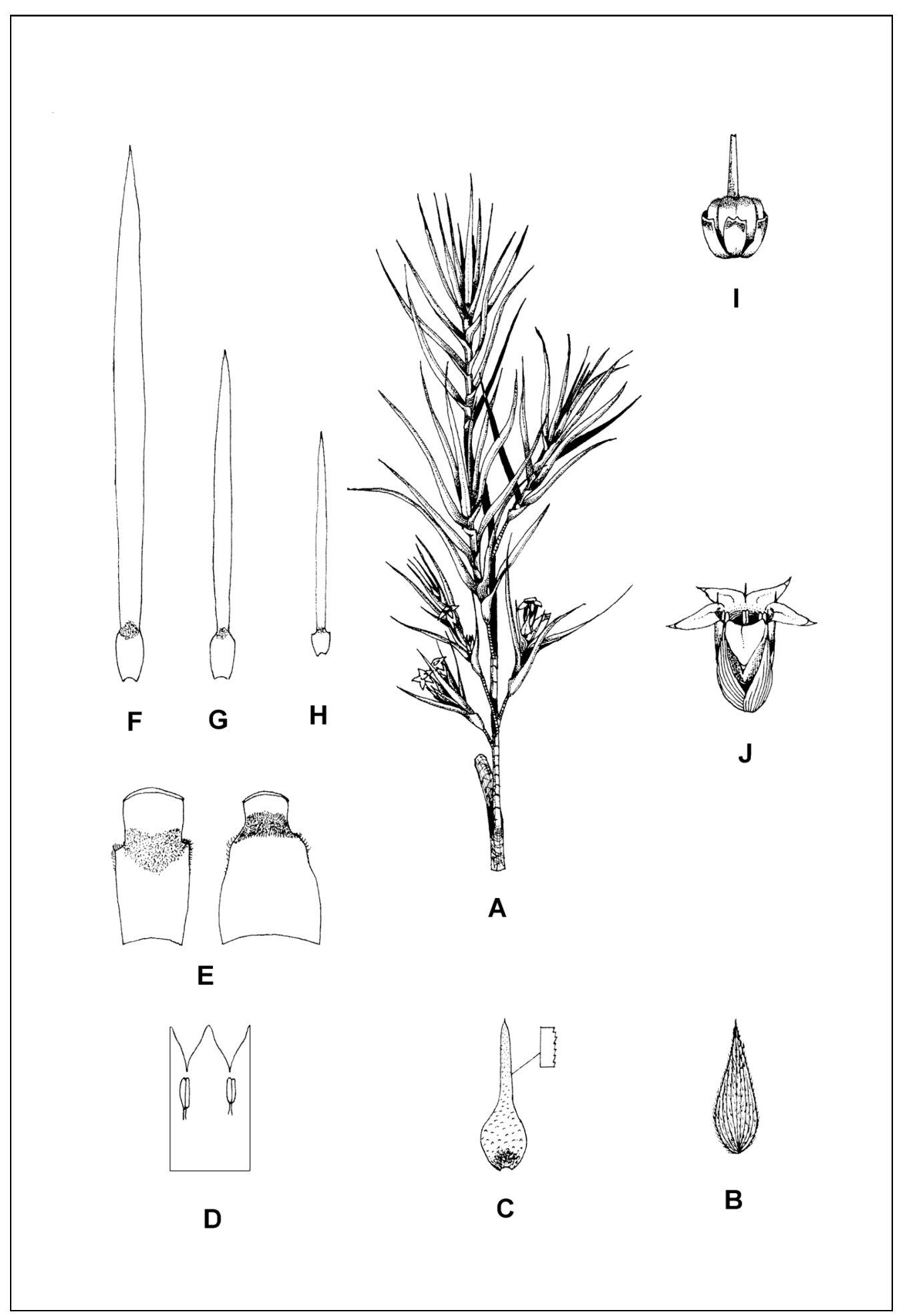

Figure 7.148. Oreothamnus trimorphus. A, flowering branch $(\times 1)$; B, sepal abaxial surface $(\times 5)$; $\mathbf{C}$, flower bract adaxial surface $(\times 5)$; $\mathbf{D}$, laid out corolla $(\times 5)$; $\mathbf{E}$, lamina sheaths to show variation $(\times 5)$; $\mathbf{F}$, stage one juvenile leaf $(\times 1)$; $\mathbf{G}$, stage two juvenile leaf $(\times 1) ; \mathbf{H}$, adult leaf $(\times 1)$; I, ovary $(\times 10)$; J, flower $(\times 5)$. Drawn from Venter 13779 . 


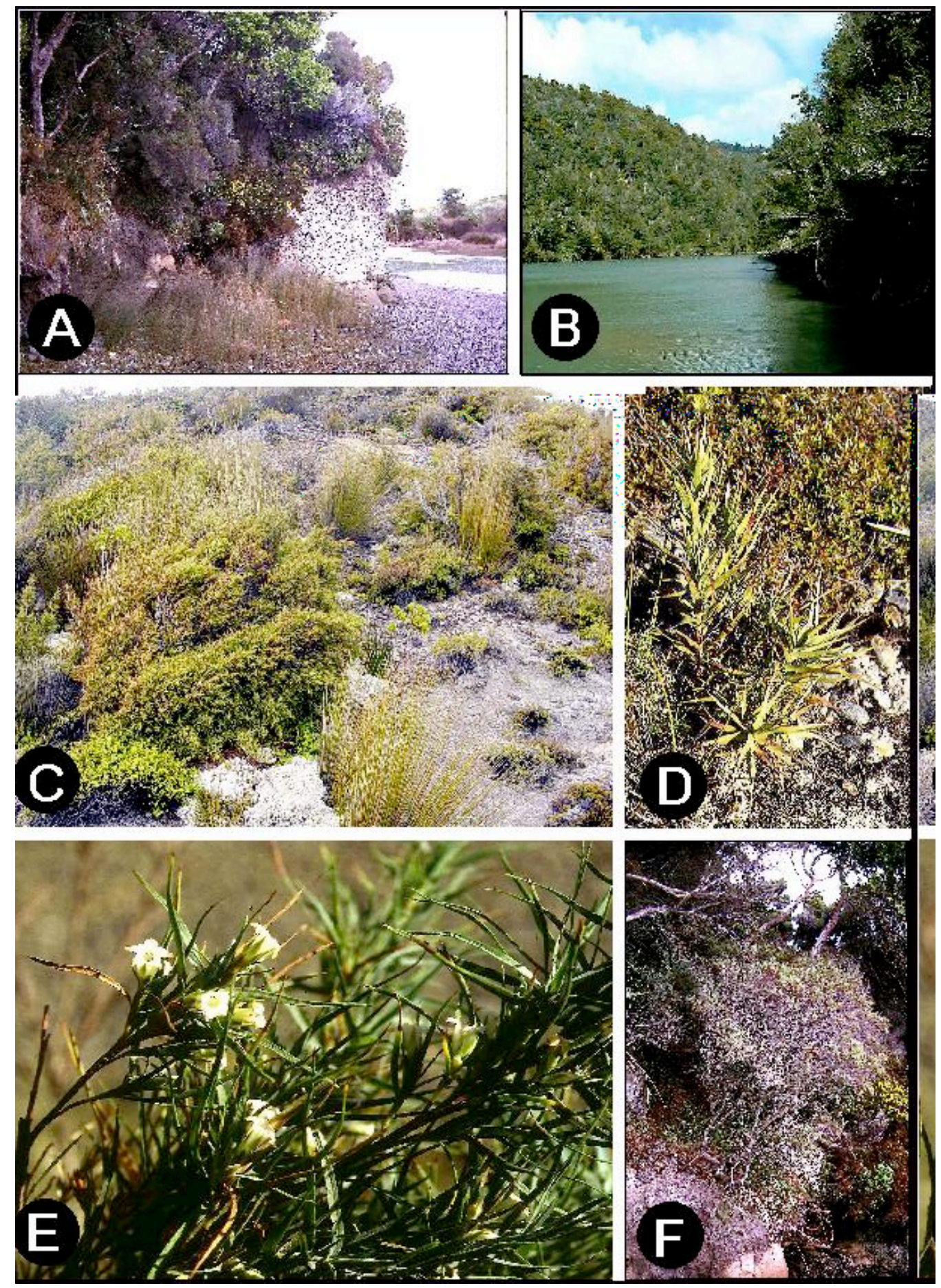

Figure 7.149. Oreothamnus trimorphus. A, habitat on coastal cliffs near Puponga Point, the type locality; B, habitat at Whanganui Inlet; C, wind pruned plants at Puponga Point; $\mathbf{D}$, young plant with large juvenile leaves; $\mathbf{E}$, flowering branch; $\mathbf{F}$, mature plant showing the short narrow leaves. E-F, Venter 13779. 
1.3-1.5 mm, apex pubescent, truncate; nectary scales rectangular, $1.0-1.5 \times 0.5-0.7 \mathrm{~mm}$, apices obtuse to retuse; style included, 1.2-2.0 mm long, glabrous; stigma five-lobed. Fruit dark brown, $1.5-3.0 \times 1.5-2.0 \mathrm{~mm}$, obovoid; apex truncate, shortly pubescent. Seeds cream coloured, ovoid, 1.0-1.3 mm long, testa slightly reticulate. Flowering OctoberMarch. (Figure 7.148).

\section{Diagnostic features and notes}

Oreothamnus trimorphus is characterized by the three distinct growth stages evident in the shape and size of the leaves. Leaves of the first juvenile stage are large becoming smaller in the middle juvenile stage and ultimately small and narrow in the adult stage. It is also characterized by glaucous adult leaves that are prominently striated with the basal part of the lamina covered in dense scabrid hairs, 1-4-flowered and 6-8 $\mathrm{mm}$ long inflorescence, adaxial surface of the flower bracts pubescent in the top half, sepals shorter than the corolla tube and the top of the ovary covered in short hairs that sometimes appear papillate when the scabrid hairs are very short.

A diagnostic species that can be separated from all other Oreothamnus species in the prominent three growth stages of the glaucous leaves and the ovary with a truncate apex covered in scabrid hairs.

\section{Distribution}

New Zealand endemic restricted to the extreme northern part of the north-west Nelson area, South Island (Fig. 7.150). 


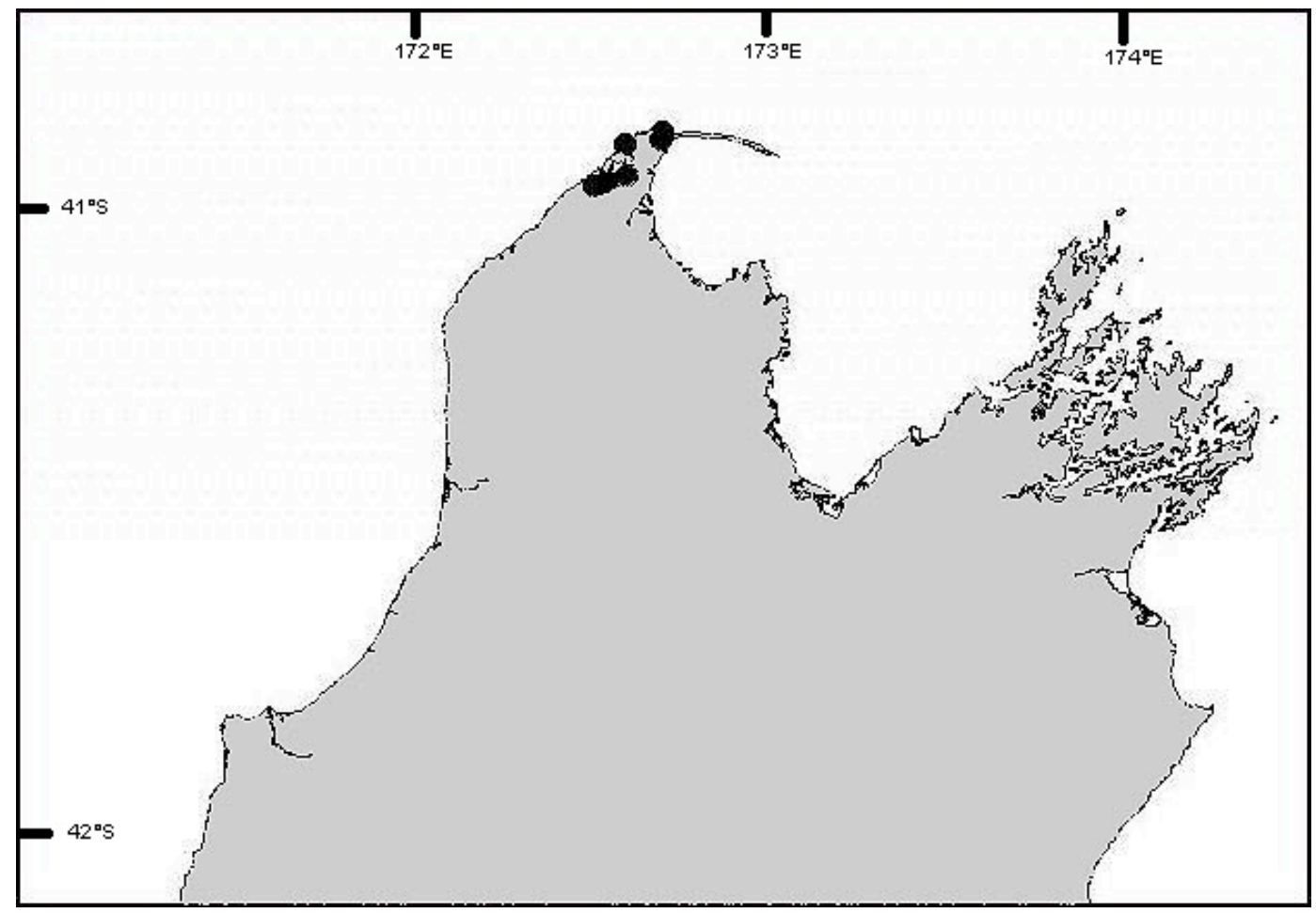

Figure 7.150. Known distribution of Oreothamnus trimorphus, top of the South Island, New Zealand.

\section{Habitat}

Oreothamnus trimorphus has not been recorded further than $1 \mathrm{~km}$ from the sea. It occurs from sea level up to $150 \mathrm{~m}$ altitude on steep $\left(70^{\circ}-90^{\circ}\right)$ sea cliffs, gentle $\left(5^{\circ}-30^{\circ}\right)$ hillslopes and ridges covered in lowland shrubland or heathland (Table 7.58). Soils are lightish brown sandy loam lithosol or greybrown clay loam lithosol derived from pebbly conglomerate and quartzofeldspathic sandstone of the Kapuni Group in the Farewell Formation. Plants normally grow fully exposed with some individuals growing in light shade on the margin of shrubland. Plants that are exposed to salt spray and wind have a deformed growth habit and appear stunted (Fig. 7.149C). 
Table 7.58. Plant associations commonly associated with Oreothamnus trimorphus.

\begin{tabular}{|c|}
\hline SHRUBLAND \\
\hline Tall closed semi-deciduous Leptospermum scoparium - Coprosma lucida - Phormium tenax shrubland \\
Low closed semi-deciduous Leptospermum scoparium - Juncus distegus - Pimelea longifolia shrubland \\
\hline HEATHLAND \\
\hline Short closed semi-deciduous Leptospermum scoparium - Juncus distegus heathland \\
\hline
\end{tabular}

\section{Variation}

The growth habit is variable and depends on the climatic factors like strong wind and salt spray. O. trimorphus grow as shrublets a mere $20 \mathrm{~cm}$ tall on the exposed ridges along the coast near the lighthouse at Pillar Point (Puponga). In more protected areas facing away from the sea (Puponga Point), it grows as a small many branched tree $3 \mathrm{~m}$ tall. The shape of the leaf sheath is polymorph. The adult lamina is very variable, even on the same branch $(25-52 \times 1.0-3.5 \mathrm{~mm})$ and the inflorescence consists of one (rarely) or two to four flowers. The sepals are lanceolate to narrowly ovate and vary in size $(4.5-6.0 \times 1.5-$ $2.0 \mathrm{~mm}$ ) having the margin either ciliate in the upper half or it can be wholly ciliate. The corolla tube varies on the same plant from $3.5-5.0 \mathrm{~mm}$ long. The apex of the ovary is covered in hairs that vary from prominently scabrid to small and papillae-like but always present.

\section{Material examined}

NEW ZEALAND. South Island. 40-172: Puponga, NE of Wharariki Road south of Pillar Point Lighthouse (-DA), 29.x.1998. Venter 13723 (CHR); Cape Farewell, Nguroa Bay Road, hilltop next to homestead, 30.x.1998. Venter 13724 (CHR); Collingwood, West Whanganui Inlet, Echo Point, 12.xii.1998. Venter 13738 (CHR); Puponga, next to Fossil Island, Puponga Farm, 28.iii.1999. Venter 13779 (CHR). 
Oreotbamnus urvilleanus (A. Rich.) S. Venter, comb. nov. Cunningham, Ann. Nat. Hist. 2: 48 (1839) p.p.; Hooker, Fl. Antarct. 1: 49 (1844a) p.p.; Hooker, Fl. Nov. Zel. 2 (1): 170 (1853) p.p.; Hooker, Handb. N.Z. Fl: 182 (1864) p.p.; Cheeseman, Handb. N.Z. Fl:: 423 (1906) p.p.; Oliver, Trans. Proc. N.Z. Inst. 59: 694 (1928); Oliver, Trans. Roy. Soc. N.Z. 80 (1): 9 (1952); Allan, Fl. N.Z. 1: 530 (1961). Type: New Zealand, Tasman Bay, on rocks. i.1827. J.S.C. Dumont D’Urville s.n. (P, holo!; W!).

三Dracophyllum urvillianum A. Rich., Essai Fl. N.Z.: 221 (1832).

Icon: Oliver, Trans. Proc. N.Z. Inst. 59: t. 6 (1928).

\section{Description}

Small single-stemmed tree, 2-8 m tall. Branches: bark on old branches grey to greyish brown, finely fissured, young stems reddish brown. Leaves juvenile and adult. Juvenile leaves spirally arranged along branches, spreading to recurved; lamina sheath yellowish green, 5-6 $\times 1.3-1.5 \mathrm{~mm}$, truncate and margin membranous with the upper half ciliate; lamina linear-triangular, 79-145 × (1.5-)2.3-3.7 mm, margins serrulate with 40-50 teeth per $10 \mathrm{~mm}$. Adult leaves spreading to recurved; lamina sheath 3.6-9.0 $\times 2.5-3.0 \mathrm{~mm}$, thinly coriaceous, shoulders truncate to auricled and margins membranous with the top half ciliate; lamina linear to linear-triangular, (33-)54-128 $\times 0.42-1.68 \mathrm{~mm}$, adaxial surface sometimes shortly scabrid; margins serrulate with 45-60 teeth per $10 \mathrm{~mm}$. Inflorescence a terminal raceme on lateral branchlets; shorter than leaves, erect, lax, 14-23 mm long, oblong. Inflorescence bract overtopping flowers, ovate-lanceolate, (15.4-)31.0-35.0 × 0.5$0.6 \mathrm{~mm}$, surfaces rugose; margins serrulate. Flowers hidden by leaves, 2-4(-5), 
pedicellate; flower bracts overtopping flowers, narrowly ovate, $11.3-15.6 \times 0.4-0.5 \mathrm{~mm}$; margins ciliate; pedicel $0.5-0.7 \mathrm{~mm}$ long. Sepals ovate-lanceolate, $5.5-7.0 \times 1.2-3.0 \mathrm{~mm}$, equaling corolla tube, adaxial surface with the top half pubescent; margins ciliate in the upper half; apices acute. Corolla white; corolla tube narrowly-campanulate, widened at mouth, $3.5-5.0 \times 1.5-2.0 \mathrm{~mm}$; corolla lobes spreading horizontally to reflexed, ovate, shorter than corolla tube, $1.9-2.0 \times 1.3-1.5 \mathrm{~mm}$, apices acute, adaxial surface papillate. Stamens inserted on corolla tube in the upper third, filaments $0.5-0.8 \mathrm{~mm}$ long; anthers included, oblong, light yellow and 0.5-1.0 mm long. Ovary globose, 1.0-1.5 × 1.0-1.3 $\mathrm{mm}$, apex round to truncate; nectary scales rectangular, $0.5-0.6 \times 0.4-0.5 \mathrm{~mm}$; apices subacute to retuse; style included, 1.3-2.0 mm long, glabrous, not lengthening in fruit; stigma capitate. Fruit with the old sepals widely spreading, light brown, $2-3 \times 2.0-2.5$ mm, oblong; apex truncate. Seeds yellowish brown, ovoid, 0.95-1.0 mm, testa slightly reticulate. Flowering November-March. (Figure 7.151).

\section{Diagnostic features and notes}

Oreothamnus urvilleanus is characterized by the thinly textured wide juvenile leaves, truncate to auricled shoulders of the adult lamina sheath, long linear adult leaves, short (14-23 $\mathrm{mm}$ ) few-flowered (2-4) raceme, flower bract overtopping the flower, narrowlycampanulate corolla tube, style longer than the ovary and the fruit enclosed in widely spreading persistent sepals. Oreothamnus urvilleanus is similar to O. oliveri but differs in the narrower thinly textured juvenile leaves, longer and narrower drooping adult leaves, fewer flowered (mostly 2-3 flowers not 5-10) racemes and truncate not round fruit apices. O. urvilleanus is also similar to O. filifolius with the differences discussed in detail under O. filifolius. Oreothammus urvilleanus at Kaiteriteri was recorded to have a second flush of flowers during 


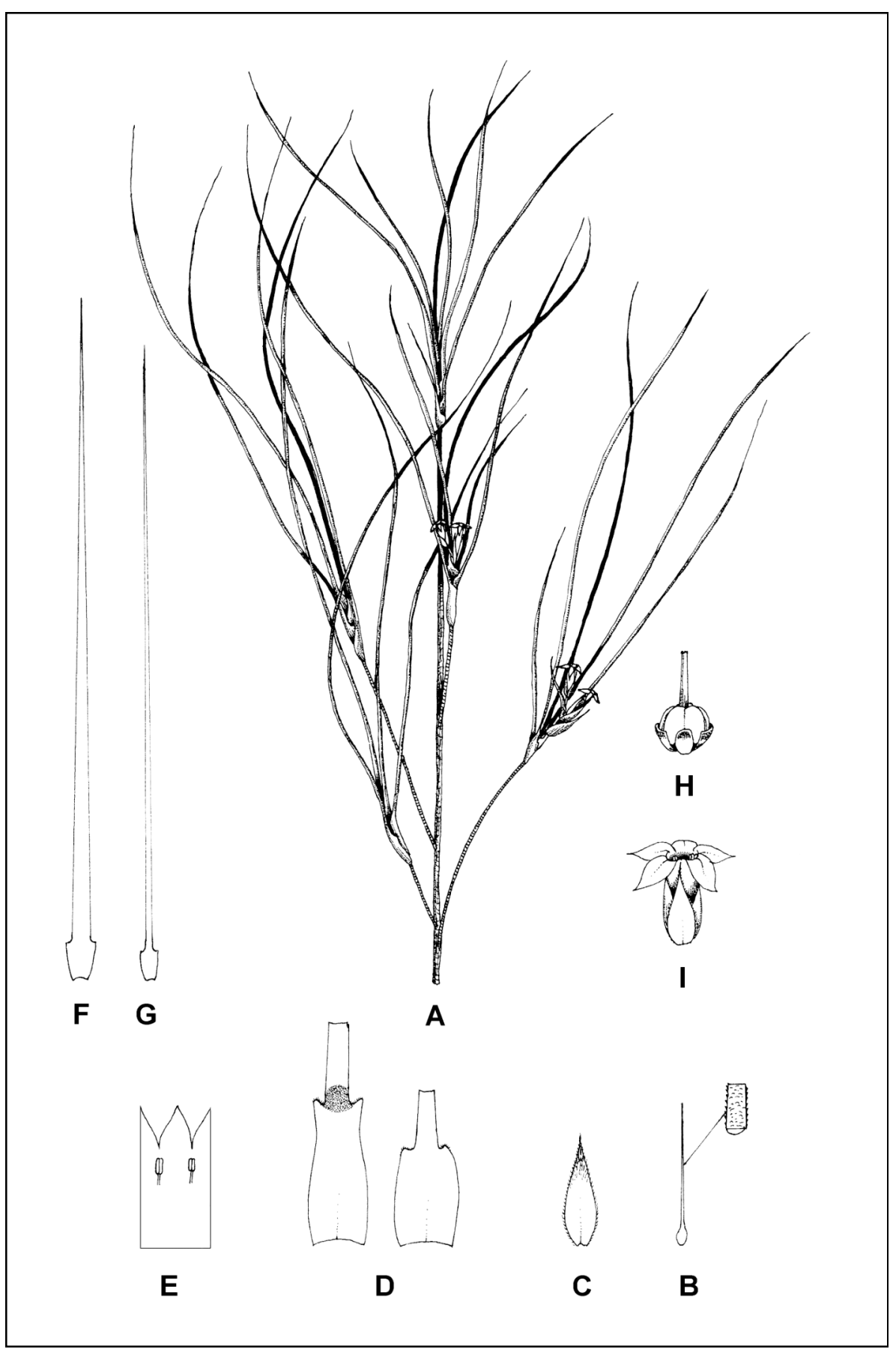

Figure 7.151. Oreothamnus urvilleanus. A, flowering branch $(\times 1)$; $\mathbf{B}$, inflorescence bract $(\times 5)$; C, sepal adaxial surface $(\times 5) ; \mathbf{D}$, lamina sheaths to show variation $(\times 5) ; \mathbf{E}$, laid out corolla $(\times 5)$; F, juvenile leaf $(\times 1)$; $\mathbf{G}$, adult leaf $(\times 1)$; $\mathbf{H}$, ovary $(\times 10)$; I, flower (× 5). Drawn from Venter 13799 . 

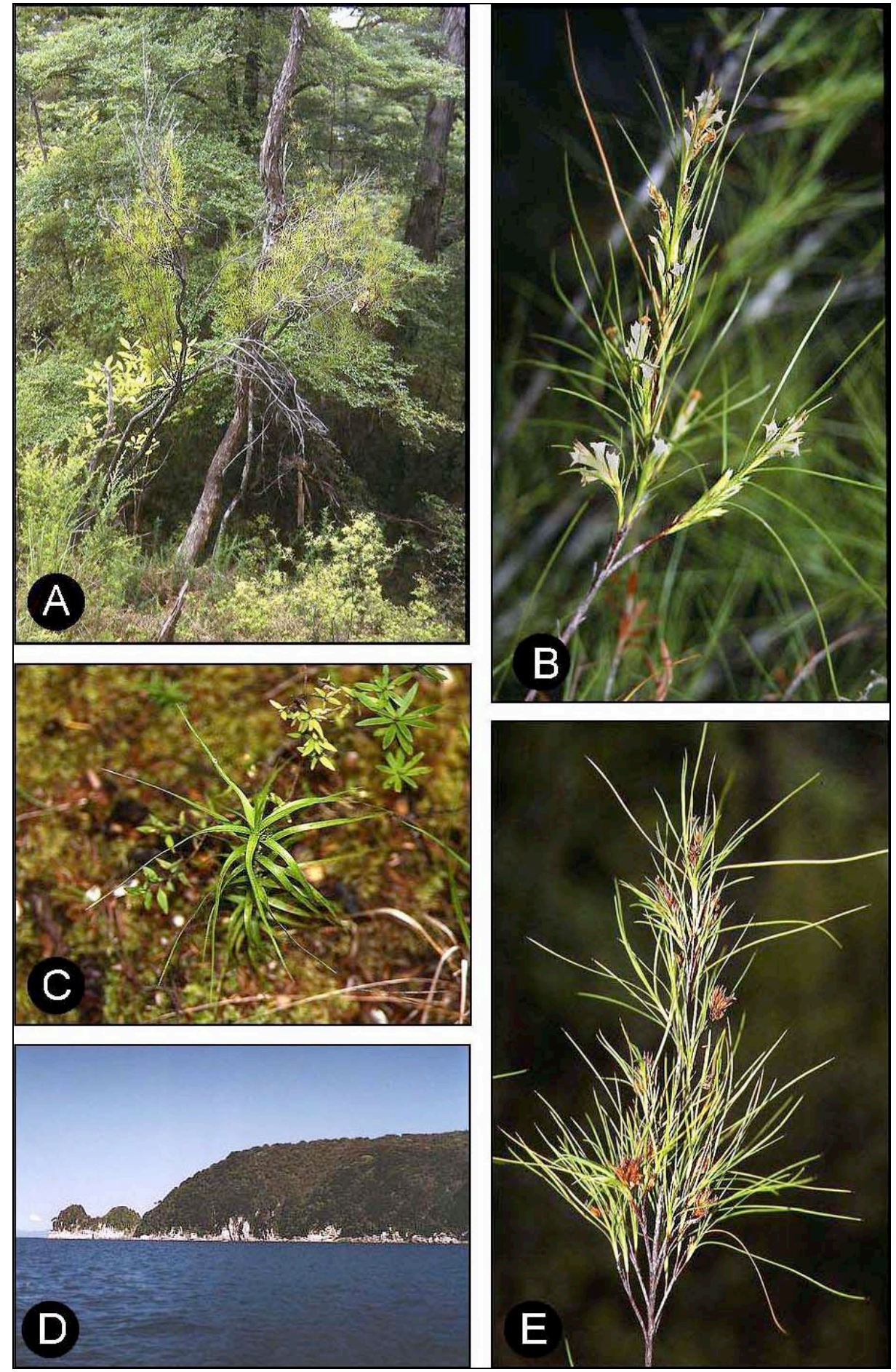

Figure 7.152. Oreothamnus urvilleanus. A, mature plant from the type locality in Abel Tasman National Park; B, flowering branch, Kaiteriteri; C, young plant showing the large juvenile leaves, Kaiteriteri; $\mathbf{D}$, habitat in low forest along the coast; $\mathbf{E}$, fruiting branch. A, Venter 13799, B, Venter 13793 and B-E, Venter 13799. 
April 2003 after a long dry and hot period followed by heavy rain (pers. obs.). Bullock et al. (1983) called this type of flowering 'episodic flowering' and can be regarded as a survival strategy of the plant when under severe weather conditions.

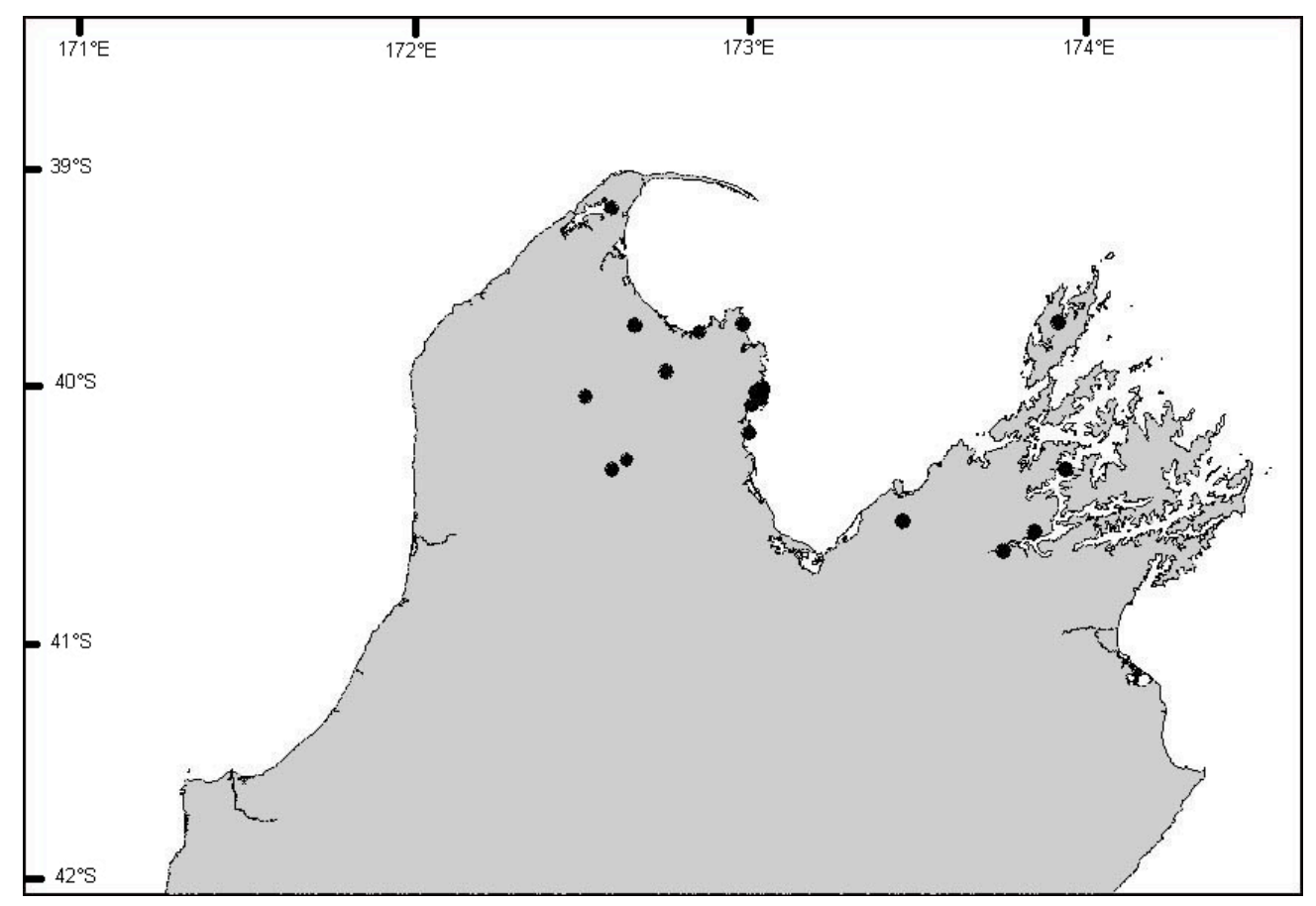

Figure 7.153. Known distribution of Oreothamnus urvilleanus, top of the South Island, New Zealand.

\section{Distribution}

New Zealand endemic. Occurs in the eastern part of northwest Nelson and in the Marlborough Sounds on the South Island (Fig. 7.153).

\section{Habitat}

Oreothamnus urvilleanus occurs from sea level up to $1158 \mathrm{~m}$ altitude on gentle $\left(5^{\circ}-30^{\circ}\right)$ slopes as well as on coastal cliffs. The surrounding vegetation consists of lowland to montane shrubland and forest (Table 7.59). Soils are brown clay or gritty greybrown clay 
loam derived from shale (Whangamoa Saddle, Nelson), schist or serpentinite (Cobb Reservoir) or light brown gritty sandy loam and brown loam derived from granite (Abel Tasman National Park). Plants are usually in light to deep shade in the forest and rarely fully exposed to sunlight (Whangamoa Saddle, Nelson).

Table 7.59. Plant associations commonly associated with Oreothamnus urvilleanus.

\begin{tabular}{|c|}
\hline FOREST \\
\hline Tall closed evergreen Nothofagus menziesii - Phyllocladus trichomanoides - Dianella nigra forest \\
Tall closed evergreen Nothofagus menziesii - Leucopogon fasciculatus - Pseudopanax arboreus forest \\
Tall open semi-deciduous Nothofagus solandri var. cliffortioides - Kunzea ericoides - Dianella nigra forest \\
\hline SHRUBLAND \\
\hline $\begin{array}{c}\text { Low closed semi-deciduous Leptospermum scoparium - Pseudopanax arboreus - Dianella nigra shrubland } \\
\text { Low closed semi-deciduous Leptospermum scoparium - Coprosma lucida shrubland }\end{array}$ \\
\hline
\end{tabular}

\section{Variation}

Some variation occurs in the size of the juvenile $(79-145 \times 2.3-3.7 \mathrm{~mm})$ and adult lamina $(70-128 \times 0.7-1.3 \mathrm{~mm})$. Plants from the population at the serpentine quarry, Cobb Reservoir (Venter 13772) are unique in having very long adult leaves (109-128 $\mathrm{mm})$. The length of the inflorescence varies between populations $(14-23 \mathrm{~mm})$ and the flower bracts vary in length from $11.3-15.6 \mathrm{~mm}$ even within the same population. Corolla tube length is short $(3.5-4.0 \mathrm{~mm})$ in populations growing at high altitudes (1000$1158 \mathrm{~m}$ ) compared to those that grow close to sea level (4-5 mm long).

\section{Material examined}

NEW ZEALAND: South Island. 40-172: Anatoki Scenic Reserve (-DC), x.1974. Kelly \& Kelly s.n. (CHR). 40-173: Abel Tasman National Park, Marahau, Freshwater Cove (CC), 02.iii.2000. Venter 13799 (CHR); Torrent Bay, xi.1974. Druce s.n. (CHR). 41-172: Takaka, Cobb Reservoir, Serpentine Quarry (-BA), 23.iii.1999. Venter 13772 (CHR); Tasman Bay, Otowhero Inlet Scenic Reserve (-BB), v.1974. Kelly \& Kelly s.n. (CHR). 41- 
173: Kaiteriteri, $3 \mathrm{~km}$ on road to Marahau (-AA), 02.xii.1998. Venter 13733 (CHR); ibid., Venter 13793 (CHR); Sandy Bay, 12.xi.1968. Talbot s.n. (CHR); Kaiteriteri, beach N of Riwaka \& Motueka River outlets, 04.vii.1971. Simpson s.n. (CHR); W of Astrolobe Harbour, iii.1921. Gibbs s.n. (CHR, WELT); Nelson, Whangamoa Saddle, $500 \mathrm{~m}$ along Slaters Road (-AB), 05.i.1999. Venter 13743a (CHR); ibid. Venter 13782 (CHR). 41-174: Picton (-AC), xi.1928. McMahon s.n. (CHR). 42-172: Nelson Lakes Nat. Park, D’Urville River in gorge (-BA), 18.ii.1964. Simpson 4246 (CHR). 


\subsection{NOMINA DUBIA AND NOMINA EXCLUSA}

\section{Nomina dubia}

Dracophyllum angustifolium Colenso, Trans. Proc. N.Z. Inst. 28: 603 (1896).

The plant described in the protologue appears to be Oreothamnus subulatus ( $=$ D. subulatum) but the specimen marked as type of $D$. angustifolium (WELT 23627) does not fit the description and is without doubt O. filifolius (= Dracophyllum filifolium). No other specimen could be located to agree as type for $D$. angustifolium and the species is therefore not included in this study.

\section{Nomina exclusa}

Daenikeranthus M.G. Baumann-Bodenheim, Syst. Fl. Neu-Caledonien 5: 76 (1989) nom. illeg., Published without a replaced synonym reference and the author of Dracophyllum is not stated. The generic name is not validly published.

Daenikeranthus alticolus (Däniker) M.G. Baumann-Bodenheim, Syst. Fl. Neu-Caledonien 5: 76 (1989) nom. illeg.. Generic name not validly published.

Dracophyllum capitatum R. Br., Prodromus Florae Novae Hollandiae : 556 (1810).

=Sphenotoma capitata (R. Br.) Lindley (as 'capitatum').

Dracophyllum dracopbylloides (Sonder) Druce, The Botanical Exchange Club and Society of the British Isles Report for 1916, Supplement 2: 620 (1917).

=Sphenotoma dracophylloides Behr \& F. Muell. Ex Sond. 
Dracophyllum drummondii Benth., Flora Australiensis 4: 263 (1868).

=Sphenotoma drummondii (Benth.) F. Muell.

Dracophyllum gracile R. Br., Prodromus Florae Novae Hollandiae. : 556 (1810).

$\equiv$ Epacris gracilis $(\mathrm{R} . \mathrm{Br}$.) Spreng.

Dracophyllum gracile sensu Roemer \& Schultes non R. Br.

=Sphenotoma gracilis Sweet

Dracophyllum parviflorum Benth., Flora Australiensis 4: 265 (1868).

=Sphenotoma parviflora (Benth.) F. Muell. (as 'parviflorum')

Dracophyllum phlogiflorum Benth., Flora Australiensis 4: 263 (1868). (nom. Illeg.)

= Sphenotoma dracophylloides Behr \& F. Muell. Ex Sond.

Dracophyllum squarrosum R. Br., Prodromus Florae Novae Hollandiae. : 556 (1810).

=Sphenotoma squarrosa (R. Br.) G. Don

Oreothamnus M.G. Baumann-Bodenheim, Syst. Fl. Neu-Caledonien 5: 76 (1989) nom.

illeg., generic name not validly published, without a Latin description or type.

Oreothamnus amabilis (Brongn. \& Gris) M.G. Baumann-Bodenheim, Syst. Fl. Neu-

Caledonien 5: 76 (1989) nom. illeg., generic name not validly published.

Oreothamnus cosmelioides (Panch. Ex Oliv.) M.G. Baumann-Bodenheim, Syst. Fl. NeuCaledonien 5: 6 (1989) nom. illeg., generic name not validly published. 
Oreothamnus ramosus (Panch. Ex Brongn. \& Gris) M.G. Baumann-Bodenheim, Syst. Fl.

Neu-Caledonien 4: 102 (1989) and 5: 76, 97 (1989), nom. illeg., without basionym reference, generic name not validly published.

ACKNOWLEDGEMENTS 
I am deeply indebted to my principal supervisor Professor Phil Garnock-Jones, School for Biological Sciences, Victoria University of Wellington for continuous interest, experienced advice and critical reading of the thesis manuscript. My gratitude is also extended to Dr. Ilse Breitwieser, my co-supervisor for her interest in my studies and constructive criticism of the manuscript.

Proof reading of the text and descriptions of new species, were kindly done by Ralph Baines (Nelson), Dr. John Braggins formerly of Auckland University, Dr. Philip Downs (Auckland), Dr. Hugh Glen (Durban), Dr. John Lavranos (Portugal), Bill Sykes (Lincoln), Dr. Ernst van Jaarsveld (Cape Town), Dr. Aaron Wilton (Landcare, Lincoln), Prof. Darren Crayen (Australian Tropical Herbarium) and Tony Whitaker (Motueka).

I am indebted to the curators and their staff of the following Herbaria for material on loan and handling various requests: AK, BM, CHR, FI, K, L, MEL, O, P, S, W, WELT, WELTU, Z. Further I wish to thank the staff of Landcare, New Zealand for fruitful discussions and help in many ways.

The following people assisted in various ways: Neil Andrews for assistance with the electron microscope (SEM) work. Mark Baines for help with fieldwork. Dr. John Braggins formerly of Auckland University for support and helping with specimens and photographs. Dr. Patrick Brownsy from Te Papa for help with the WELT material. Ewen Cameron from the Auckland Museum for help with literature and specimens. John Barkla, Shannel Courtney and Cathy Jones (DoC) for organizing the collecting permit and for collecting specimens in isolated areas. Mike Crawford from Nikau Gardens, Nelson for providing shade house and glasshouse space for the collection and helping to look after the collection of live material. Dr. John Dugdale, Landcare Research, Nelson, 
for identification of insect specimens and valuable discussions on pollination. Aurdrey Eagle for hospitality during fieldwork. Chris Turner for accompanying me on various field trips and growing plants for this study. Mr. Jan A. Venter (my father) for help with fieldwork, proofreading and encouragement. Dr. Steve Wagstaff, Landcare Research, Lincoln for most enjoyable field trips and valuable discussions on cladistic aspects. Dr. Aaron Wilton and his wife Vicky for help with fieldwork and, very valuable discussions also acting as my hosts everytime I visited Christchurch.

Lastly a very special word of thanks to my wife Julye-Ann for continual encouragement, love and doing proof reading, also our two boys Steaphan and Elan for all their encouragement and joining me on field trips making it an unforgettable experience.

\section{REFERENCES}


Allan, H.H. 1939. Notes on New Zealand floristic botany. Transactions of the Royal Society of New Zealand 69: 272-273.

Allan, H.H. 1961. BORAGINACEAE. Flora of New Zealand 1: 806-833. Government Printer, Wellington.

Allan, H.H. 1961. EPACRIDACEAE. Flora of New Zealand 1. Government Printer, Wellington.

Anderberg, A.A. 1993. The circumscription of the Ericales and their cladistic relationships to other families of "Higher" Dicotyledons. Systematic Botany 17 (4): $660-675$.

Anderson, E. 1940. The concept of the genus. II. A survey of modern opinion. Bulletin of the Torrey Botanical Club 67: 363-369.

Andersson, L. 1990. The driving force: species concepts and ecology. Taxon 39 (3): 375382.

Aradhya, M.K., Manshardt, R.M., Zee, F., and Morden, C.W. 1999. A phylogenetic analysis of the genus Carica L. (Caricaceae) based on restriction fragment length variation in a cpDNA intergenic spacer region. Genetic Resources and Crop Evolution 46: 579-586. 
Armstrong, J.B. 1881. Description of new and rare New Zealand plants. Transactions and Proceedings of the New Zealand Institute 13: 342.

Australian Plant Name Index [APNI] - www.anbg.gov.au/cgi-bin/apni

Bailey, F.M. 1900. The Queensland Flora 3. Diddams, Brisbane.

Bailey, F.M. 1913. Comprehensive catalogue of Queensland plants both indigenous and naturalised. Government Printer, Brisbane.

Barlow, B.A. 1994. Australian Vegetation. Cambridge University Press.

Barthlott, W., and Wollenweber, E. 1981. Zur Feinstruktur. Chemie und taxonomischen Signifikanz epicuticularer Wachse und ähnlicher Sekrete. Tropische und subtropische Pflanzenwelt 32: 7-67.

Barthlott, W., Neinhuis, C., Cutler, D., Ditsch, F., Meusel, I., Theisen, I., and Wilhelmi, H. 1998. Classification and terminology of plant epicuticular waxes. Botanical Journal of the Linnean Society 126: 237-260.

Baumann-Bodenheim, M.G. 1989a. Systematik der Flora von Neu-Caledonien MelanesienSudparifike) 4 : 102. A.L. Schenk-Baumann, Merenschwand, Switzerland.

Baumann-Bodenheim, M.G. 1989b. Systematik der Flora von Neu-Caledonien (MelanesienSudparifike) 5 : 76, 97. A.L. Schenk-Baumann, Merenschwand, Switzerland. 
Bayly, M.J., Kellow, A.V., De Lange, P.J., Mitchell, K.A., Markham, K.R., GarnockJones, P.J., and Brownsey, P.J. 2003. Geographic variation in morphology and flavonoid chemistry in Hebe pubescens and H. bollonsii (Scrophulariaceae), including a new infraspecific classification for $H$. pubescens. New Zealand Journal of Botany 41: $23-53$.

Bellamy, D., Springett, B., and Hayden, P. 1990. Moa's Ark: The Voyage of New Zealand. Viking, New Zealand.

Bentham, G. 1869. EPACRIDEAE. Flora Australiensis 4. L. Reeve \& Co., London.

Bentham, G., and Hooker, J.D. 1876. Epacrideae. Genera Plantarum 2. L. Reeve \& Co., London.

Berggren, S. 1877. New Zealand Phanerogams. Minneskrift uitgifuen af Kanyl Fysiografiska Sällskapet $i$ Lund 28: 15, t. 4.

Berggren, S. 1880. New Zealand Phanerogams. Journal of Botany (London) 17: 104.

Betts, M.W. 1919. Notes on the autecology of certain plants of the peridotite belt, Nelson : Part 1-Structure of some of the plants (No. 2). Transactions and Proceedings of the New Zealand Institute 51: 136-156.

Brongniart, A.D., and Gris, A. 1864a. Plantes Peu Connues de la Nouvelle-Calédonie. Annales des sciences naturelles Botanique et biologie Vegetale (Fr.) 2: 156-157, 238. 
Brongniart, A.D., and Gris, A. 1864b. Note sur les Épacridées de la Nouvelle-Calédonie et sur un Genre nouveau de cette Famille. Bulletin Société Botanique de France 11: 68-69.

Brongniart, A.D., and Gris, A. 1865. Observations sur diverses plantes nouvelles ou peu connues de la Nouvelle-Calédonie Annales sciences naturelles Botanique et biologie Vegetale 3: 238.

Brown, R. 1810. Prodromus Florae Novae Hollandiae et Insulae Van-Diemen 1. Taylor, London.

Brown, E.A., and Streiber, N. 2000. Systematic studies in Dracophyllum (Epacridaceae) 2. New species of Dracophyllum in New South Wales. Telopea 8(3): 393-401.

Brummitt, R.K., and Powell C.E. (eds.) 1992. Authors of Plant Names. Royal Botanic Gardens, Kew.

Buchanan, J. 1875. On the botany of the Chatham Islands. Transactions and Proceedings of the New Zealand Institute 7: 337-338.

Buchanan, J. 1882. On the alpine flora of New Zealand. Transactions and Proceedings of the New Zealand Institute 14: 346, t. 26.

Budd, A. F., and Mishler, B. D. 1990. Species and evolution in clonal organisms summary and discussion. Systematic Botany 15: 166-171. 
Burtt, B.L. 1948. Studies in Ericales VIII. The taxonomic position of Wittsteinia. Kew Bulletin 3: 493-495.

Burtt, B.L., Hedge, I.C., and Stevens, P.F. 1970. A taxonomic critique of recent numerical studies in Salvia and Ericales. Notes of the Royal Botanical Garden, Edinburgh 30: 141-158.

Candolle, A.P. de, 1839. Prodromus Systematis Naturalis Regni Vegetabilis 7. Treuttel \& Wurtz, Paris.

Cantino, P. D., Olmstead, R. G., and Wagstaff, S. J. 1997: A comparison of phylogenetic nomenclature with the current system: a botanical case study. Systematic Biology 46: 313-331.

Carlquist, S. 1967. The biota of long-distance dispersal. V. Plant dispersal to Pacific Islands. Bulletin of the Torrey Botanical Club 94: 129-162.

Carse, H. 1916. Additions to the flora of Monganui County. Transactions and Proceedings of the New land Institute 48: 238-239.

Carse, H. 1926. Botanical Notes. Transactions and Proceedings of the New Zealand Institute 56: 86.

Cheeseman, T.F. 1906. EPACRIDEAE. Manual of New Zealand Flora. Government Printer, Wellington. 
Cheeseman, T.F. 1914. Illustrations of the New Zealand Flora. 2. New Zealand Government Printer, Wellington.

Cheeseman, T.F. 1925. BORAGINACEAE. Manual of the New Zealand Flora. 2nd Edn. Government Printer, Wellington.

Cheeseman, T.F. 1925. EPACRIDACEAE. Manual of the New Zealand Flora. $2^{\text {nd }}$ Edn. Government Printer, Wellington.

Cockayne, L. 1902. A Short Account of the Plant-covering of Chatham Island. Transactions and Proceedings of the New Zealand Institute 34: 318.

Cockayne, L. 1904. Some Hitherto-unrecorded Plant-habitats. Transactions and Proceedings of the New Zealand Institute 36: 322.

Cockayne, L. 1912. Some hitherto-unrecorded plant-habitats. Transactions and Proceedings of the New Zealand Institute 44: 53.

Cockayne, L. 1915. Report of the Scenery Preservation Society.

Cockayne, L. 1928. Vegetation of New Zealand. Wilhelm Engelmann, Leipzig.

Cockayne, L., and Phillips Turner, E. 1967. The trees of New Zealand. $5^{\text {th }}$ Ed. Government Printer, Wellington, New Zealand. 
Colenso, W. 1888. On new Phaenogamic plants. Transactions and Proceedings of the New Zealand Institute 20: 200.

Colenso, W. 1889. On new Phaenogamic plants. Transactions and Proceedings of the New Zealand Institute 21: 92-93.

Colenso, W. 1890. On new Phaenogamic plants. Transactions and Proceedings of the New Zealand Institute 22: 476-477.

Colenso, W. 1893. On Phaenogams. Transactions and Proceedings of the New Zealand Institute 25: $331-332$.

Colenso, W. 1896. On New Phaenogams. Transactions and Proceedings of the New Zealand Institute 28: 602-605.

Colenso, W. 1899. On Phaenogams. Transactions and Proceedings of the New Zealand Institute 31: 275 .

Copeland, H.F. 1953. Observations on certain Epacridaceae. American Journal of Botany 41: $215-222$.

Corbett, C. 1995. Pollination ecology in a Tasmanian alpine environment. Unpublished BSc Honours thesis, School of Geography and Environmental Studies, University of Tasmania, Australia. 
Couper, R.A. 1960. New Zealand Mesozoic and Cainozoic plant microfossils. New Zealand Geological Survey Palaeontological Bulletin 32: 1-87.

Cox, C.B., and Moore, P.D. 2000. Biogeography: An Ecological and Evolutionary Approach. Wiley-Blackwell Publishing.

Cracraft, J. 1983. Species concepts and speciation analysis. Current Ornithology 1: 159-187.

Cracraft, J. 1989. Speciation and its ontology : the empirical consequences of alternative species concepts for understanding patterns and processes of differentiation. : 28-55. In D. Otte \& J.A. Endler (Eds.). Speciation and its consequences. Sinauer, Sunderland, Massachusettes.

Crayn, D.M., Kron, K.A., Gadek, P.A., and Quinn, C.J. 1996. Delimitation of Epacridaceae: Preliminary molecular evidence. Annals of Botany 77: 317-321.

Crayn, D.M., Kron, K.A., Gadek, P.A., and Quinn, C.J. 1998. Phylogenetics and evolution of Epacrids: a Molecular analysis using the plastid gene $r b c \mathrm{~L}$ with a reappraisal of the position of Lebetanthus. Australian Journal of Botany 46: 187-200.

Crayn, D.M., and Quinn, C.J. 2000. The evolution of the $a t p B-r b c$ L intergenic spacer in the Epacrids (Ericales) and the systematic and evolutionary implications. Molecular Phylogenetics and Evolution 16: 238-252. 
Crisp, M.D., Laffan, S., Linder, H.P., and Monro, A. (2001). Endemism in the Australian flora. Journal of Biogeography 28: 183-198.

Cronquist, A.J. 1981. An Integrated System of Classification of flowering plants. Columbia University Press, New York.

Cronquist, A.J. 1988. The Evolution and Classification of flowering plants. New York Botanical Garden, New York.

Cunningham, A. 1837. Specimen of the botany of New Zealand. Florae Insularum Novae Zelandiae Precursor. Annals of Natural History 2: 48-49 and 412-416.

Curtis, W.M. 1963. ANGIOSPERMAE: Lythraceae to Epacridaceae. The Student's Flora of Tasmania. 2. Government Printer, Hobart, Tasmania.

Dahlgren, R. 1983. General aspects of angiosperm evolution and macrosystematics. Nordic Journal of Botany 3: 119-149.

Dallwitz, M.J., Paine, T.A., and Zurcher, E.J. 1993. 'User's Guide to the DELTA System: a General System for Processing Taxanomic Descriptions.' $4^{\text {th }}$ Edn. CSIRO Division of Entomology, Canberra.

Däniker, A.U. 1933. Ergebnisse der Reise von Dr. A. U. Daniker nach Neu-Caledonien und den Loyalty-Inseln. Vierteljahrsschrift der Naturforschaden Gesellschaft in Zürich 78 (19): 339-341. 
Davis, P.H., and Haywood, V.H. 1967. Principles of angiosperm taxonomy. Oliver \& Boyd, Edinburgh \& London.

Dawson, J. W. 1961. A revision of the genus Anisotome (Umbelliferae). University of California Publications in Botany 33: 1-98.

Dawson, J.W. 1981. The species rich, highly endemic serpentine flora of New Caledonia. Tuatara 25(1): 1-6.

Dawson, J. W. 1988. Forest vines to snow tussocks. Victoria University Press, Wellington.

De Queiroz, K., and Donoghue, M.J. 1990. Phylogenetic systematics or Nelson's version of cladistics? Cladistics 6: 61-75.

De Queiroz, K., and Gauthier, J. 1990. Phylogeny as a central principle in taxonomy. Phylogenetic definitions of taxon names. Systematic Zoology 39(4): 307-322.

De Queiroz, K., and Gauthier, J. (1994). Toward a phylogenetic system of biological nomenclature. Trends in Ecology and Evolution 9: 27-31.

Domin, K. 1928. Beiträge zur Flora und Pflanzengeographie Australiens. Bibliotheca Botanica 89 (4): 501-503, t. 173. Stuttgart.

Donoghue, M.J. 1985. A critique of the biological species concept and recommendations for a phylogenetic alternative. Bryologist 88: 172-181. 
Douglas, B.J. 1986. Lignite resources of central Otago. New Zealand Energy Research and Development Committee, Publication P 104.

Druce, G.C. 1917. The Epacridaceae. The Botanical Exchange Club and Society of the British Isles Report for 1916. Supplement 2: 620.

Druce, A.P., Williams, P.A., and Heine, J.C. 1987. Vegetation and flora of Tertiary calcareous rocks in the mountains of western Nelson, New Zealand. New Zealand Journal of Botany 25: 41-78.

Drude, O. 1889. Epacridaceae. In: A, Englar, and K, Prantl, eds. Die natürlichen Pflanzenfamilien 4(1). Engelman, Leipzig.

Du Rietz, G.E. 1930. The fundamental units of biological taxonomy. Svensk Botanisk Tidskrift. 24(3): 333-428.

Edwards, D. 1983. A broad-scale structural classification of vegetation for practical purposes. Bothalia 14 (3 \& 4): 705-712.

Eagle, A. 1975. Eagle's Shrubs and Trees of New Zealand. Collins, Auckland.

Eagle, A. 1982. Eagle's Shrubs and Trees of New Zealand. $2^{\text {nd }}$ series. Collins, Auckland.

Eiten, G. 1968. Vegetation forms. Instituto de Botânica, Bol. 4: 1-88.

Eiten, G. 1972. The cerrado vegetation in Brazil. Botanical Review 38: 201-341. 
Elzinga, R. J. 1978. Fundamentals of Entemology. $2^{\text {nd }}$ Edition. Prentice-Hall Inc., New Jersey.

Endlicher, S.L. 1836. Genera Plantarum : 750. Fr. Beck, Vindobonae.

Felsenstein, J. 1985. Confidence limits on phylogenies: an approach using the bootstrap. Evolution 39: 783-791.

Fisher, F.J.F. 1965. The alpine Ranunculi of New Zealand. New Zealand Department of Scientific and Industrial Research Bulletin 165. Government Printer, Wellington.

Fleming, C.A. 1962. New Zealand biogeography. A palaeontologist's approach. Tuatara 10: $53-108$.

Fleming, C.A. 1963. The nomenclature of biogeographic elements in the New Zealand biota. Transactions of the Royal Society of New Zealand 1 (2): 13-22.

Fleming, C.A. 1975. New Zealand as a minor source of terrestrial plants and animals in the Pacific. Tuatara 22 (1): 30-37.

Fleming, C.A. 1976. New Zealand as a minor source of terrestrial plants and animals in the Pacific. Tuatara 22(1): 30-37.

Fosberg, F.R. 1967. A classification of vegetation for general purposes. In: G.F. Peterken, Guide to the check sheet for IBP areas. IBP Handbook No. 4. Blackwells, Oxford. 
Forster, G. 1786. Florulae insularum australium prodromus. J.C. Dietrich, Gottingae.

Forster, J.R., and Forster, G. 1776. Characteres generum plantarum quas in itinere ad insulas maris australis. 1772 - 1775. B. White, T. Cadell and P. Elmsley, Londini.

Frankie, G.W., and Haber, W.A. 1983. Why bees move among mass-flowering Neotropical trees. In: C.E. Jones \& R.J. Little, Handbook of experimental pollination biology. Scientific and Academic Editions. Van Nostrand Reinhold Company Inc., New York.

Gaertner, J. 1791. De fructibus et seminibus plantarum 1. Tubingae.

Garnock-Jones, P.J. and Langer, H.J. 1980. Parahebe catarractae (Scrophulariaceae): infraspecific taxonomy. New Zealand Journal of Botany 18: 285-298.

Garnock-Jones, P.J. 1993. Phylogeny of the Hebe complex (Scrophulariaceae: Veronicae). Australian Systematic Botany 6: 457-459.

Garnock-Jones, P.J., and Lloyd, D.G. 2004. A taxonomic revision of Parabebe (Plantaginaceae) in New Zealand. New Zealand Journal of Botany 42(2): 181-232.

Garnock-Jones, P.J., Albach, D. \& Briggs, B.G. 2007. Botanical names in Southern Hemisphere Veronica (Plantaginaceae): sect. Detæneria, sect. Hebe, and sect. Labiatoides. Taxon 56 (2): 571-582. 
Ghani, M.A. 1978. Late Cenozoic vertical crust movement in the southern North Island, New Zealand. New Zealand Journal of Geology and Geophysics 21: 117-125.

Gibbs, G.W. 1980. New Zealand Butterflies - identification and natural history. Collins, Auckland.

Gibson, N. 1991. The anatomy and morphology of four Tasmanian cushion species. Aspects of Tasmanian Botany. Royal Society, Hobart. Tasmania.

Glenny, D. 2003. A revision of the genus Gentianella in New Zealand. Unpublished PhD thesis. University of Canterbury, New Zealand.

Godley, E.J. 1967. Widely distributed species, land bridges and continental drift. Nature 214: 74-75.

Godley, E.J. 1975. Flora and Vegetation. In: G. Kuschel (Ed.). Biogeography and Ecology in New Zealand. Dr. W. Junk BV, The Hague.

Godley, E.J. 1985. Paths to maturity. New Zealand Journal of Botany 23: 687 - 706.

Godley, E.J. 1979. Flower biology in New Zealand. New Zealand Journal of Botany 17: 441466.

Goloboff, P.A., Farris, J.S., \& Nixon, K. 2004. TNT: Tree analysis using new technology. Tucuman, Argentina. 
Gravendeel, B. 2000. Reorganising the orchid genus Coelogyne - a phylogenetic classification based on morphology and molecules. Van der Perk BV, NeuiLekkerland, The Netherlands.

Gray, A.M. 1969. Epacridaceae - Dracophyllum of Tasmania. Australian Plants 5: 208-209.

Green, P.S. 1994. Observations on the phytogeography of the New Hebrides, Lord Howe Island and Norfolk Island. Oceanic Islands. Flora of Australia 49 (1): 41-53 $\& 145$

Greuter, McNeill, J ., Barrie, F.R., Burdet, H.-M., Demoulin, V., Filgueiras, T.S., Nicolson, D.H., Silva, P.C., Skog, J.E., Trehane, P., Turland, N.J., and Hawksworth, D.L. 2000. International code of botanical nomenclature (St. Louis Code). Koeltz Scientific Books, Königstein, Germany.

Guillaumin, J.B.A. 1911. Dracophyllum vieillardii. Annales du Musee Colonial de Marseille 9 (2): 181, t.1.

Haase, P. 1986. An ecological study of the subalpine tree Dracophyllum traversii (Epacridaceae) at Arthur's Pass, South Island, New Zealand. New Zealand Journal of Botany 24: 69-78.

Hammer, O., Harper, D.A.T., and Ryan, P.D. 2009. PAST - PAlaeontological STatistics, ver. 1.90. University of Oslo. 
Hawkins, J.A., Hughes, C.E., and Scotland, R.W. 1997. Primary homology assessment, Characters and character states. Cladistics 13: 275-283.

Heather, B., and Robertson, H. 1996. Field guide to the birds of New Zealand. Viking, Auckland.

Hedberg, O. 1958. The taxonomic treatment of vicarious taxa. Systematics of today. Uppsala Universitets Arsskrift 6: 193.

Hemsley, W.B. 1896. The Flora of Lord Howe Island. Annals of Botany 10: 221-241.

Hertzer, R.H. 1998. Tectonic control of terrestrial species migration to New Zealand in the Early to Middle Miocene. Geology and genes (eds. R.A. Cooper \& C.M. Jones): 35-38. Geological Society of New Zealand Miscellaneous Publication 97. Wellington.

Heywood, V.H. 1959. A taxonomic treatment of ecotypic variation. Systematics Association Publication 3: 87-112.

Hickey, L.F. 1973. Classification of the architecture of dicotyledonous leaves. American Journal of Botany 60: 17-33.

Holmgren, P.K., Holmgren N.H., \& Barnett, L.C. 1990. Index Herbariorum. Part I: The Herbaria of the world. $8^{\text {th }}$ ed. Regnum Vegetabile 120.

Hombron, J.B., and Jacquinot, M. 1853. Voyage au Pôle Sud et dans L'Océane sur les corvettes L'Astrolobe et la Zélée 2. Gide et J. Baudry, Paris. 
Hooker, J.D. 1833. Dracophyllum secundum. Secund-flowered Dracophyllum. Curtis's Botanical Magazine 7: t. 3264.

Hooker, J.D. 1839. Transmutation of species. Annals of Natural History 2: 48-49.

Hooker, J.D. 1844a. The botany of the Antarctic voyage. Flora Antarctica 1. L. Reeve \& Co., London.

Hooker, J.D. 1844b. Catalogue of the names of a collection of plants made by Mr. Wm. Stephenson in New Zealand. Journal of Botany, London 3: 416.

Hooker, J.D. 1852. Dracophyllum milligani. Icones Plantarum 9: t. 845. London.

Hooker, J.D. 1853. Flora Novae Zelandiae 2 (1). L. Reeve \& Co., London.

Hooker, J.D. 1860. The botany of the Antarctic voyage. Flora Tasmaniae 3. L. Reeve \& Co., London.

Hooker, J.D. 1864. ERICEAE. Handbook of the New Zealand Flora. 1. L. Reeve \& Co., London.

Hutton, I. 2002. Field Guide to the Plants of Lord Howe Island. Ian Hutton, Lord Howe Island.

Jackes, B.R. 1969. Dracophyllum Labill. - Australian Plants 5: 206-209. 
Jaffré, T. 1980. Etude écologique du peuplement végétal des sols dérivés de roches ultrabasiques en Nouvelle-Calédonie. Coll. Trav. Doc. ORSTOM 124: 1-274.

Jaffré, T. 1991. Floristic and ecological diversity of the vegetation on ultramafic rocks in New Caledonia. In: A.J.M. Baker et al. Eds. The Vegetation of Ultramafic Serpentine Soils. Proceedings of the First International Conference on Serpentine Ecology

Judd, W.S., and Kron, K.A. 1993. Circumscription of Ericaceae (Ericales) as determined by preliminary cladistic analysis based on morphological, anatomical, and embryological features. Brittonia 45 (2): 99-114.

Judd, W.S., Campbell, C.S., Kellogg, E.A., and Stevens, P.F. 1999. Plant Systematics - A Phylogenetic Approach. Sinauer Ass., Inc. Sunderland, Massachusetts, U.S.A.

Judd, W.S., Campbell, C.S., Kellogg, E.A., and Stevens, P.F., and Donoghue, M.J. 2007. Plant Systematics: A Phylogenetic Approach, Third Edition. Sinauer Ass., Inc. Sunderland, Massachusetts, U.S.A.

Kershaw, A.P. 1988. Australasia. In: Vegetation History. Eds. B. Huntley and T. Webb III. : Kluwer Academic Publisher, New York.

Kirk, T. 1885. On the flowering plants of Stewart Island. Transactions and Proceedings of the New Zealand Institute 17: 223.

Kirk, T. 1889. The Forest Flora of New Zealand. New Zealand Government Printer, Wellington. 
Kirkpatrick, J.B. 1983. Treeless plant communities of the Tasmanian High Country. Proceedings of the Ecological Society of Australia 12: 61-77.

Kluge, A.G., and Farris, J.S. 1969. Quantative phyletics and the evolution of anurans. Systematic Zoology 18: 1-32.

Kron, K.A., and Chase, M.W. 1993. Systematics of the Ericaceae, Empetraceae, Epacridaceae and related taxa based on rbcL sequence data. Annals of the Missouri Botanical Garden 80 (3): 735-741.

Kron, K.A. 1996. Phylogenetic relationships of Empetraceae, Epacridaceae, Ericaceae, Monotropaceae and Pyrolaceae: evidence from nuclear ribosomal 18s sequence data. Annals of Botany 77 (4): 293-303.

Kron, K.A., Chase, M.W., and Hills, H.G. 1991. Phylogenetic relationships of Ericaceae, Empetraceae, and Epacridaceae based on rbcL sequence data and their position within the Dilleniidae. American Journal of Botany (Supplement) 78 (6): 197-198.

Kron, K.A., Fuller, R., Crayn, D.M., Gadek, P.A., and Quinn, C.J. 1996. Molecular systematics of the vaccinioids and epacrids using matK sequence data. American Journal of Botany (Supplement) 83 (6): 170.

Kron, K.A., Judd, W.S., Stevens, P.F., Crayn, D.M., Anderberg, A.A., Gadek, P.A., Quinn, C.J., and Luteyn, J.L. 2002. Phylogenetic classification of Ericaceae: molecular and morphological evidence. The Botanical Review 68 (3): 335-423. 
Labillardière, J.J.H. de, 1800. Rèlation du voyage à la recherche de la Pérouse 2: 210-221, t. 40. Paris.

Lamarck, J.B.A.P.M. de 1811. Encyclopédie Méthodique. Supplement 2: H. Agasse. Paris.

Lawrence, G.H.M., A.F.G. Buchheim, G.S. Daniels, and H. Dolezal (eds.) 1968. BotanicoPeriodicum-Huntianum. Hunt Botanical Library. Pittsburgh, Pennsylvania.

Lee, W.G. 1992. New Zealand Ultramafics. In: B.A. Roberts and J. Proctor (eds.). The ecology of areas with serpentinized rocks. A world view. Kluwer Academic Press, Dortrecht.

Le Maout, E., and Decaisne, J. 1868. ÉPACRIDÉES, EPACRIDEAE. Traité Général de Botanique descriptive et analythique. Librairie de Firmin Didot Frères, Fils et $C^{\text {ie }}$, Paris.

Lipscomb, D. 1998. Basics of cladistic analysis. George Washington University, Washington DC.

Lloyd, D.G. 1972. A revision of the New Zealand, Subantarctic, and South American species of Cotula, section Leptinella. New Zealand Journal of Botany 10: 277-372.

Luteyn, J.L. (ed.). 1995. Ericaceae Part II: The superior-ovaried genera (Monotropoideaea, Pyroloideae, Rhododendroideae, and Vaccinioideae p.p.) Monotropoideae. Flora Neotropica Monograph 66(2): 1-560. 
McGlone, M.S. 1985. Plant biogeography and the late Cenozoic history of New Zealand. New Zealand Journal of Botany 23: 723-749.

McGlone, M. S., and Topping, W. W. 1983: Late Quaternary vegetation. Tongariro region, central North Island, New Zealand. New Zealand Journal of Botany 21: 5376.

McGlone, M.S., Duncan, R.P., and Heenan, P.B. 2001. Endemism, species selection and the origin and distribution of the vascular plant flora of New Zealand. Journal of Biogeography 28: 199-216.

McGlone,M.S., Wilmhurst, J.M., and Wiser, S.K. 2000. Late glacial and Holocene vegetation and climatic change on Auckland Island, Subantarctic New Zealand. The Holocene 10(6): 719-728.

McNeill, J., Barrie, F.R., Burdet, H.M., Demoulin, V., Hawksworth, D.L., Marhold, K., Nicholson, D.H., Prado, J., Silva, P.C., Skog, J.E., Wiersema, J.H., and Turland, N.J. 2006. International Code of Botanical Nomenclature (Vienna Code). Regnum Vegetabile 146. A.R.G. Gantner Verlag KG.

Maddison, D.R. 1991. The discovery and importance of multiple islands of mostparsimonious trees. Systematic Zoology 40: 315-328.

Maddison, W.P., Donoghue, M.J., and Maddison, D.R. 1984. Outgroup analysis and parsimony. Systematic Zoology 33(1): 83-103. 
Mark, A.F., and Adams, N.M. 1986. New Zealand Alpine Plants. Reed, Wellington.

Mayr, E. 1942. Systematics and the origin of species. Columbia University Press, New York.

Mayr, E. 1969. Principles of systematic roology. McGraw-Hill, New York.

Menadue, Y., and Crowden, R.K. 2000. Taxonomic revision of Richea R. Br. (Epacridaceae). Australian Systematic Botany 13: 773-802.

Metcalf, C.R., and Chalk, L. 1950. Anatomy of the dicotyledons. 2. Clarendon Press, Oxford.

Mildenhall, D.C. 1980. New Zealand late Cretaceous and Cenozoic plant biogeography a contribution. Palaeogeography, Palaeoclimatology and Palaeoecology 31: 197-234.

Moar, N.T. 1973. Late Pleistocene vegetation and environment in southern New Zealand. In: E.M. van Zinderen-Bakker Sr. (ed.) Palaeoecology of Africa, the Surrounding Islands and Antarctica. VIII. A.A. Balkema, Cape Town.

Moore, C. 1921. Dracophyllum compactum. Journal of the Linnaean Society (Botany) 45: 349.

Moore, C., and Mueller, F.J.H. von. 1869. Epacrideae. Fragmenta Phytogeographiae Australiae 7: 27 .

Moore, L.B., and Irwin, J.B. 1978. The Oxford Book of New Zealand plants. Oxford University Press. 
Mueller, F.J.H. von. 1858. Fragmenta Phytographiae Australiae 1. Johannis Ferres, Government Printer, Melbourne.

Mueller, F.J.H. von. 1864. The Vegetation of the Chatham Islands. Johannis Ferres, Government Printer, Melbourne.

Mueller, F.J.H. von. 1867. Fragmenta Phytographiae Australiae 6. Johannis Ferres, Government Printer, Melbourne.

Mueller, F.J.H. von. 1882. Systematic census of Australian plants. Part 1 - V asculares. McCarron Bird, Melbourne.

Mueller, F.J.H. von. 1887. Dracophyllum sayeri. Botanisches Centralblatt 30: 356.

Mueller, F.J.H. von. 1889. Second systematic census of Australian plants with chronologic, literary and geographic annotations. Part 1 - V asculares. McCarron Bird, Melbourne.

Mueller, K.F. 2005. The efficiency of different search strategies in estimating parsimony jacknife, bootstrap, and Bremer support. BMC Evolutionary Biology 5: 58-59.

Nicholson, N., and Nicholson, H. 1991. Australian Rainforest Plants 3: 24.

Oliver, E.G.H. 1987. Studies in the Ericoideae (Ericaceae). VII. The placing of the genus Philippia into synonymy under Erica; the southern African species. South African Journal of Botany 53(6): 455-458. 
Oliver, E.G.H. 1988. Studies in the Ericoideae (Ericaceae). VI. The generic relationship between Erica and Philippia in southern Africa. Bothalia 18(1): 1-10.

Oliver, E.G.H. 2000. Systematics of Ericeae (Ericaceae - Ericoideae): species with dehiscent and partially dehiscent fruits. Contributions from the Bolus Herbarium 19: 1472.

Oliver, W.R.B. 1917. The Vegetation and Flora of Lord Howe Island. Transactions and Proceedings of the New Zealand Institute 49: 146.

Oliver, W.R.B. 1928. A revision of the genus Dracophyllum. Transactions and Proceedings of the New Zealand Institute 59: 678-714.

Oliver, W.R.B. 1952. A revision of the genus Dracophyllum: (Supplement). Transactions of the Royal Society of New Zealand. 80 (1): 1-17.

Paterson, B. R. 1961. Studies of floral morphology of Epacridaceae. Botanical Gazette 122: 259-279.

Patterson, H.E.H. 1985. The recognition concept of species. In: E. S. Vrba, ed. Species and Speciation, monograph no. 4. Transvaal Museum, Pretoria.

PhyloCode System. http://www.ohiou.edu/phylocode/

Poiret, J.L.M. 1811. In: Lamarck, J.B.A.P.M. de Encyclopédie Méthodique Botanique Supplément 2. Paris. 
Pole, M.S. 1993. Keeping in Touch: Vegetation prehistory on both sides of the Tasman. Australian Systematic Botany 6: 387-397.

Pole, M. S. 1994. The New Zealand flora - entirely long-distance dispersal? Journal of Biogeography 21: 625-635.

Poole, A.L. 1987. Southern Beeches. SIPC, Wellington.

Poole, A.L., and Adams, N. 1994. Trees and Shrubs of NewZealand. Manaaki Whenua Press, Lincoln.

Powell, J.M. 1983. Epacridaceae. In: B.D. Morley, and H.R. Tölken. eds. Flowering Plants in Australia. Rigby Publishers, Sydney.

Powell, J.M. 1992. Epacridaceae. In: G.J. Harden (Ed.) Flora of New South Wales 3. Royal Botanic Gardens, Sydney.

Powell, J.M., Chapman, A.R., and Doust, A.N. 1987. Classification and generic status in the Epacridaeae - a preliminary analysis. Australian Systematic Botany Society Newsletter 53: 70-78.

Powell, J.M., Crayn, D.M., Gadek, P.A., Quinn, C.J., Morrison, D.A., and Chapman, A.R. 1996. A re-assessment of relationships within Epacridaceae. Annals of Botany 77 (4): 305-315. 
Powell, J.M., Morrison, D.A., Gadek, P.A., Crayan, D.M., and Quinn, C.J. 1997.

Relationships and generic concepts within Styphelieae (Epacridaceae). Australian Systematic Botany 10: 15-29.

Primack, R.B. 1983. Insect pollination in the New Zealand mountain flora. New Zealand Journal of Botany 21: 317-333.

Quinn, C.J., Crayn, D.M., Heslewood, M.M., Brown, E.A., and Gadek, P.A. 2003. A molecular estimate of the phylogeny of Styphelieae (Ericaceae). Australian Systematic Botany 16: 581-594.

Radford, E.A., Watson, M.F., and Preston, J. 2001. Phylogenetic relationships of species of Aciphylla (Apiaceae, subfamily Apioideae) and related genera using molecular, morphological, and combined data sets. New Zealand Journal of Botany 11: 177-200.

Rauh, W. 1990. The Bromeliad Lexicon. Bok Books International.

Raven, P.H. 1973. Evolution of subalpine and alpine plant groups in New Zealand. New Zealand Journal of Botany 11: 177-200.

Raven, P.H. \& Raven, T.E. 1976. The genus Epilobium (Onagraceae) in Australasia: a systematic and evolutionary study. DSIR, Christchurch.

Rebelo, A.G., Siegfried, W.R., and Oliver, E.G.H. 1985. Pollination syndromes of Erica species in the south-western Cape. South African Journal of Botany 51(4): 270-280. 
Richard, M.A. 1832. Essai d'une Flore de la Nouvelle-Zélande (Voyage de decorvéttes de l'Astrolobe pendant les annees). Paris.

Rodway, L. 1903. The Tasmanian Flora. Government Printer, Hobart.

Roemer, J.J., and Schultes, J.A. 1819. Systema vegetabilium 4. J.G. Cottae, Stuttgardtiae.

Rollins, R.C. 1953. Cytogenetical approaches to the study of genera. Chronica Botanica 14 (3): 133-139.

Salmon, J.T. 1989. The Native Trees of New Zealand. Heinemann Reed, Auckland.

Samuelsson, G. 1913. Studien über die Entwicklungsgeschichte der Blüte einiger Bicornes-Typen. Svensk Botanisk Tidskrift 7: 97-188.

Sanderson, M.J., and Donoghue, M.J. 1989. Patterns of variation in levels of homoplasy. Evolution 43: 1781-1795.

Schlechter, R. 1907. Beiträge zur kenntnis der flora von Neu-Kaledonien. Botanische Jabrbücher 39: 220, t. 21.

Sibson, R.B. 1990. Charadriiformes. In: E.G. Turbott (Convener), Checklist of the birds of New Zealand and the Ross Dependency, Antarctica. Random Century, Auckland.

Simon, F. 1891. Beiträge zur vergleichenden Anatomie der Epacridaceae und Ericaceae. Botanische Jabrbücher 30: 15-39. 
Simpson, G. 1945. Notes and descriptions of new species. Transactions of the Royal Society of New Zealand 75 (2): 191-192.

Simpson, G. 1952. Notes on some New Zealand plants and descriptions of new species (No.5) . Transactions of the Royal Society of New Zealand 79: 434.

Simpson, G.G. 1951. The species concept. Evolution 5: 285-298.

Simpson, G.G. 1961. Principles of animal taxonomy. Columbia University Press, New York.

Sleumer, H. 1966. Ericaceae. Flora Malesiana (Ser. 1.) 6 (4): 422-444.

Smith-Dodsworth. 1991. New Zealand native shrubs and climbers. David Bateman Ltd., Auckland.

Sneath, P.A., and Sokal, R.R. 1975. Numerical Taxonomy. W.H. Freeman, San Francisco.

Specht, R.L. 1981. Foliage projective cover and standing biomass. In: A.N. Gillison \& D.J. Anderson, Vegetation classification in Australia. Canberra: CSIRO \& Australian Universal Press.

Sprengel, C. 1825. Systema Vegetabilium 1. Gottingae.

Stace, C.A. 1965. Cuticular studies as an aid to plant taxonomy. Bulletin of the British Museum (Natural History) Botany 4: 1-78. 
Stace, C.A. 1992. Plant Taxonomy and Biosystematics. Cambridge University Press.

Stafleu, F. A., and Cowan, R. S. (1976 et seq.): Taxonomic Literature, ${ }^{2 \text { nd }}$ Edition. Vols. 1-7. Bohn, Scheltema \& Holkema, Utrecht.

Stearn, W.T. 1996. Botanical Latin. ${ }^{4 \text { th }}$ Edition.David \& Charles Publishers, Devon, England.

Stchegleev, S.S. 1859. Dracophyllum setifolium. Bulletin de la Société Imperiale des Naturalistes de Moscou. Moscow. 32 (1): 23.

St. George, I. 1999. The nature guide to New Zealand native orchids. Godwit, Auckland.

Stevens, P.F. 1971. A classification of the Ericaceae: subfamilies and tribes. Botanical Journal of the Linnean Society 64: 1-53.

Streiber, N., Brown, E.A., Conn, B.J., and Quinn, C.J. 1999. Systematic studies in Dracophyllum (Epacridaceae) 1. Morphometric analyses of Dracophyllum secundum senso lato. Telopea 8 (3): 381-391.

Stuessy, T.F. 1990. Plant Taxonomy: The systematic evaluation of comparative data. Columbia University Press, New York.

Sweet, R. 1827. Flora Australasica - or a selection of handsome or curious plants, native of New Holland, and the South Sea Islands. James Ridgway. 
Sweet, R. 1830. Sweet's Hortus Britannicus. Piccadilly, London.

Systematics Agenda. 2000. Charting the Biosphere. Technical Report. Herbarium, New York Botanical Garden, USA.

Takhtajan, A. 1986. Floristic regions of the world. (trans. T.J. Crovello). University of California Press, Berkeley.

Tarboton, W.R., Kemp, M.I., and Kemp, A.C. 1987. Birds of the Transvaal. Transvaal Museum, Pretoria.

Thorne, R.F. 1992. Classification and geography of the flowering plants. Botanical Review 58: $225-348$.

Thorne, R.F. 2000. Classification and geography of the flowering plants. Botanical Review 66(4): 441-647.

Tölken, H.R. 1977. A revision of the genus Crassula in Southern Africa. Contributions from the Bolus Herbarium 8(1): 1-331.

Truswell, E.M., and Harros, W.K. 1982. The Cainozoic palaeobotanical record in arid Australia: fossil evidence from the origins of an arid-adapted flora. In: Evolution of the Flora and Fauna of Arid Australia. Eds. W.R. Barker \& P.J.M. Greenslade. Peacock Publications, Southern Australia. 
Turbott, E. G. (Conv.) 1990. Checklist of the birds of New Zealand and the Ross Dependancy, Antartica. Random Century \& Ornithological Society of New Zealand.

Van Emden, H.E. 2008. Statistics for Terrified Biologists. Blackwell Publishing. Carlton.

Van Steenis, C.G.G.J. 1984. A synopsis of Alseuosmiaceae in New Zealand, New Caledonia, Australia and New Guinea. Blumea 29: 387-394.

Van Valen, L. 1976. Ecological species, multispecies, and Oaks. Taxon 25: 233-239.

Van Welzen, P.C. 1998. Phylogenetic versus Linnaean taxonomy, the continuing story. Taxon 47: 413-423.

Venter, S. 2002. Dracophyllum marmoricola and Dracophyllum ophioliticum (Ericaceae), two new species from north-west Nelson, New Zealand. New Zealand Journal of Botany 40 (1): 39-47.

Venter, S. 2004a. Dracophyllum elegantissimum (Ericaceae), a new species from north-west Nelson, New Zealand. New Zealand Journal of Botany 42: 37-43.

Venter, S. 2004b. Dracophyllum mackeeanum (Ericaceae), a new species from New Caledonia. New Zealand Journal of Botany 42 (4): 37-43.

Virot, R. 1975. Epacridacées. Flora de la Nouvelle Calédonie et Dépendances 6. Museum National d'Histoire Naturelle, Paris. 
Wagstaff, S.J. \& Garnock-Jones, P.J. 1998. Evolution and biogeography of the Hebe complex (Scrophulariaceae) inferred from ITS sequences. New Zealand Journal of Botany 36: 425-437.

Wagstaff, S.J. \& Garnock-Jones, P.J. 2000. Patterns of diversification in Chionohebe and Parahebe (Scrophulariaceae) inferred from ITS sequences. New Zealand Journal of Botany. 38: 389-407.

Wagstaff, S.J., Bayly, M.J., Garnock-Jones, P.J., and Albach, D.C. 2002. Classification, Origin, and diversification of the New Zealand Hebes (Scrophulariaceae). Annals of the Missouri Botanical Garden. 89: 38-63.

Wardle, P. 1978. Origin of the New Zealand mountain flora, with special reference to trans-Tasman relationships. New Zealand Journal of Botany 16: 535-550.

Wardle, P. 1987. Dracophyllum (Epacridaceae) in the Chatham and sub Antarctic islands of New Zealand. New Zealand Journal of Botany 25: 107-114.

Wardle, P. 2002. Vegetation of New Zealand. The Blackburn Press, Caldwell, New Jersey.

Watson, L. 1962. The taxonomic significance of stomatal distribution and morphology in Epacridaceae. New Phytologist 61: 36-40.

Watson, L. 1967. Taxonomic implications of a comparative anatomical study of Epacridaceae. New Phytologist 66: 495-504. 
Watson, L., Williams, W.T., and Lance, G.N. 1967. A mixed-data numerical approach to angiosperm taxonomy: the classification of Ericales. Proceedings of the Society of London 178 (1): 25-35.

Webb, C.J., and Simpson, M.J.A. 2001. Seeds of New Zealand-gymnosperms \& dicotyledons. Manuka Press, New Zealand.

Weiller, C.M., Crowden, R.K., and Powell, J.M. 1994. Morphology and taxonomic significance of leaf epicuticular waxes in the Epacridaceae. Australian Systematic Botany 7(2): 125-152.

White, M.E. 1999. Reading the rocks: animals and plants in prehistoric Australia and New Zealand. Kangaroo Press, NSW.

Wiley, E.O. 1978. The evolutionary species concept reconsidered. Systematic Zoology 27: $17-26$.

Wiley, E.O. 1981. Phylogenetics: the theory and practise of phylogenetic systematics. John Wiley and Sons, New York.

Wilkin, P. 1999. A morphological cladistic analysis of the Ipomoeeae (Convolvulaceae). Kew Bulletin 54: 853-876.

Williams, B. 1993. Biostatistics. Chapman \& Hall Australia, Melbourne. 
Wilson, C.M., and Given, D.R. 1989. Threatened plants of New Zealand. DSIR Publishing, Wellington.

Wilson, H. D. 1987. Vegetation of Stewart Island, New Zealand: a supplement to New Zealand journal of botany. Wellington, DSIR Science Information Publishing Centre.

Wilton, A.D. 1999. Phenetic library for S-Plus 4.5 (r2). Unpublished computer routines, 23 March 1999, Landcare Research, Lincoln, New Zealand.

Winston, J.E. 1999. Describing species: practical taxonomic procedures for biologists. New York, Columbia University Press.

Woodroffe, C.D., Kennedy, D.M., Brooke, B.P., and Dickson, M.E. 2006.

Geomorphological evolution of Lord Howe Island and carbonate production at the latitudinal limit to reef growth. Journal of Coastal Research 22: 188-201. 


\section{APPENDICES}

Appendix 1. Material used for leaf anatomical and epicuticular wax studies.

\begin{tabular}{|c|c|c|c|c|c|}
\hline \multirow{2}{*}{\multicolumn{6}{|c|}{$\begin{array}{c}\text { Species } \\
\text { Dracophyllum }\end{array}$}} \\
\hline & & & & & \\
\hline D. alticola & Mt. Humboldt & 19.ix.1980. & Hoff & 2645 & $P$ \\
\hline D. balansae & River Bleue & 7.xii.1965 & Schmidt & 824 & $P$ \\
\hline D. cosmelioides & Plain des Lacs & 25.vi.1963 & Blanchon & 207 & $P$ \\
\hline D. elegantissimum & Rameka Track & 28.i.2001. & Venter & 13827 & $\mathrm{CHR}$ \\
\hline D. fiordense & Alex Knob & 19.iii.2000. & Venter & 13801 & $\mathrm{CHR}$ \\
\hline D. fitzgeraldii & Mt. Gower & 17.xi.1998 & Parkes & s.n. & $\mathrm{CHR}$ \\
\hline D. involucratum & Ouenarou & 22.ii.1970 & MacKee & 21621 & L \\
\hline D. latifolium & Mt. Kaitarakihi & 12.ii. 1999. & Venter & 13764 & $\mathrm{CHR}$ \\
\hline D. mackeeanum & Gallieni Mine & 25.xii.1960 & MacKee & 7745 & L \\
\hline D. menziesii & Mt. Anglem & 11.i.2000. & Venter & 13788 & $\mathrm{CHR}$ \\
\hline D. milliganii & Mt. Humboldt & 17.i.1978 & Jarman & s.n. & $\mathrm{HO}$ \\
\hline D. oceanicum & Jervis Bay & 9.ix.1997 & Brown et al. & 97/82 & $\mathrm{HO}$ \\
\hline D. ouaiemense & Roche Ouaièmense & 13.vii.1968. & MacKee & 19135 & $P$ \\
\hline D. ramosum & Thio & 18.iii.1968 & Vieillon & 1651 & $P$ \\
\hline D. sayeri & Mt. Bellenden-Ker & 12.iv.1949 & Selling & s.n. & $S$ \\
\hline D. secundum & Pointer Gap, Milton & 9.viii.1978 & Barnsley & 214 & L \\
\hline D. strictum & Turangi, along river & 09.ii.1999. & Venter & 13760 & $\mathrm{CHR}$ \\
\hline D. townsonii & Knuckle Hill & 28.iii.1999. & Venter & 13777 & $\mathrm{CHR}$ \\
\hline D. traversii & Mt. Arthur & 10.xii. 1989. & Venter & 13734 & $\mathrm{CHR}$ \\
\hline D. verticillatum & Ile Neba & 8.x.1970 & MacKee & 22736 & Z \\
\hline \multicolumn{6}{|l|}{ Oreothamnus } \\
\hline D. acerosum & Foggy Peak & 28.i.1999. & Venter & 13753 & $\mathrm{CHR}$ \\
\hline D. arboreum & Chatham Island & xii.1961 & Bell & s.n. & $\mathrm{CHR}$ \\
\hline D. cockayneanum & Campbell Island & 23.xi.1966. & Robertse & s.n. & WELTU \\
\hline D. densum & Mt. Rochfort & 07.i.1999. & Venter & 13746 & $\mathrm{CHR}$ \\
\hline D. filifolium & Egmont National Park & 10.ii. 1999. & Venter & 13762 & $\mathrm{CHR}$ \\
\hline D. frondosum & Deep Stream & 23.iii.2000. & Venter & 13817 & $\mathrm{CHR}$ \\
\hline D. kirkii & Hooker Valley & 12.xi.1967 & Mark & s.n. & OTA \\
\hline D. lessonianum & Karikari Peninsula & 14.ii.1999. & Venter & 13767 & $\mathrm{CHR}$ \\
\hline D. longifolium & Christmas Village & 11.i.2000. & Venter & 13787 & $\mathrm{CHR}$ \\
\hline D. marmoricola & Mt. Arthur & 02.i.1999. & Venter & 13739 & $\mathrm{CHR}$ \\
\hline D. minimum & Lakes Col Nat. Park & xii.1928 & Campher & s.n. & K \\
\hline D. muscoides & End Peak, Mnt. Harris & 17.i. 1950 & McNeur & s.n. & $\mathrm{CHR}$ \\
\hline D. oliveri & Mt. Rochfort & 26.iii.2000. & Venter & 13820 & $\mathrm{CHR}$ \\
\hline D. ophioliticum & Asbestos Creek & 22.iv.2000. & Venter & 13822 & $\mathrm{CHR}$ \\
\hline D. palustris & Lewis Pass & 20.ii.1975 & Simpson & 7427 & $\mathrm{CHR}$ \\
\hline D. patens & Mt. Rowe, Thames & 16.ii.1999. & Venter & 13771 & $\mathrm{CHR}$ \\
\hline D. pearsonii & Mt. Anglem & 11.i.2000. & Venter & 13790 & $\mathrm{CHR}$ \\
\hline D. politum & Mt. Anglem & 11.i. 2000. & Venter & 13789 & $\mathrm{CHR}$ \\
\hline D. pronum & Foggy Peak & 28.i.1999. & Venter & 13755 & $\mathrm{CHR}$ \\
\hline D. prostratum & Lake Harris & 21.iii.2000. & Venter & 13807 & $\mathrm{CHR}$ \\
\hline D. pubescens & Mt. Mytton & 11.xii. 1989. & Venter & 13736 & $\mathrm{CHR}$ \\
\hline D. recurvum & Mt. Ruapehu & 08.ii.1999. & Venter & 13757 & $\mathrm{CHR}$ \\
\hline D. rosmarinifolium & Alex Knob & 21.iii.2000. & Venter & 13803 & $\mathrm{CHR}$ \\
\hline D. scoparium & Campbell Island & ii. 1976 & Given & 9167 & $\mathrm{HO}$ \\
\hline D. septentrionale & Mt. Maharahara & 07.ii.1999. & Venter & 13756 & $\mathrm{CHR}$ \\
\hline D. sinclairii & Black Jack Road & 13.ii. 1999. & Venter & 13766 & $\mathrm{CHR}$ \\
\hline D. subulatum & Rangipo Desert & 09.ii.1999. & Venter & 13761 & $\mathrm{CHR}$ \\
\hline D. trimorphum & Echo Point & 12.xii. 1989. & Venter & 13738 & $\mathrm{CHR}$ \\
\hline D. urvilleanum & Freshwater Cove & 02.iii.2000. & Venter & 13799 & $\mathrm{CHR}$ \\
\hline
\end{tabular}


Appendix 2. Material for SEM pollen studies.

\begin{tabular}{|c|c|c|c|c|c|}
\hline Species & Locality & Date & Collector & Coll. no. & Herbarium \\
\hline $\begin{array}{l}\text { Subgenus Dracophyllum } \\
\text { D. alticola } \\
\text { D. ramosum }\end{array}$ & $\begin{array}{l}\text { Mt. Humboldt } \\
\text { Thio }\end{array}$ & $\begin{array}{l}\text { 19.ix.1980 } \\
\text { 18.iii.1968 }\end{array}$ & $\begin{array}{l}\text { Hoff } \\
\text { Vieillon }\end{array}$ & & $\begin{array}{l}P \\
P\end{array}$ \\
\hline $\begin{array}{l}\text { Subgenus Oreothamnus } \\
\text { D. filifolium } \\
\text { D. septentrionale }\end{array}$ & $\begin{array}{l}\text { Waimarino Stream } \\
\text { Takapari }\end{array}$ & $\begin{array}{c}\text { i. } 1965 . \\
-\end{array}$ & $\begin{array}{l}\text { Druce } \\
\text { Druce }\end{array}$ & $\begin{array}{l}\text { s.n. } \\
\text { s.n. }\end{array}$ & $\begin{array}{l}\text { CHR } 131361 \\
\text { CHR } 366362\end{array}$ \\
\hline
\end{tabular}

Appendix 3. Lamina measurements (length divided by width) in $\mathrm{mm}$ for 10 leaves per plant from a single plant in 10 widely separated populations of Oreothamnus rosmarinifolius.

\begin{tabular}{|l|l|c|c|c|c|c|c|c|c|c|c|}
\hline Voucher & Altitude & Plant 1 & Plant 2 & Plant 3 & Plant 4 & Plant 5 & Plant 6 & Plant 7 & Plant 8 & Plant 9 & Plant 10 \\
\hline Forster s.n. (O) & $400 \mathrm{~m}$ & 30.17 & 25.2 & 15.23 & 18.91 & 21.26 & 14.85 & 14.62 & 19.84 & 18.4 & 19.73 \\
\hline Venter 13786a (CHR) & $500 \mathrm{~m}$ & 22.03 & 30.47 & 31.39 & 34.61 & 29.52 & 21.69 & 29.18 & 22.27 & 27.71 & 21.97 \\
\hline Venter 13811 (CHR) & $885 \mathrm{~m}$ & 30.72 & 27.71 & 24.71 & 32.16 & 27.26 & 29.49 & 33.65 & 43.19 & 31.58 & 32.71 \\
\hline Venter 13729 (CHR) & $1000 \mathrm{~m}$ & 27.52 & 32.56 & 35.22 & 39.87 & 31.26 & 35.45 & 31.25 & 44.77 & 43.57 & 32.52 \\
\hline Venter 13803 (CHR) & $1200 \mathrm{~m}$ & 27.52 & 35.56 & 35.22 & 39.87 & 31.26 & 35.45 & 31.25 & 44.77 & 43.57 & 32.52 \\
\hline Venter 13776 (CHR) & $1400 \mathrm{~m}$ & 19.02 & 19.92 & 20.09 & 20.43 & 20.63 & 25.09 & 16.85 & 19.71 & 16.39 & 28.1 \\
\hline
\end{tabular}

Appendix 4. Lamina measurements (length divided by width) in $\mathrm{mm}$ for 10 leaves per plant from 9 individual plants $(\mathrm{A}-\mathrm{J})$ in a population of Oreothamnus rosmarinifolius from Fiordland (Venter 13806).

\begin{tabular}{|c|c|c|c|c|c|c|c|c|c|}
\hline Plant A & Plant B & Plant C & Pland D & Plant E & Plant F & Plant G & Plant H & Plant I & Plant J \\
\hline 15.4 & 18.3 & 28.4 & 28.4 & 20.1 & 11.1 & 11.7 & 17.4 & 14.7 & 18.8 \\
\hline 20.2 & 21.1 & 28.4 & 28.5 & 20.3 & 12.4 & 13 & 17.9 & 18.3 & 20.7 \\
\hline 20.5 & 22.7 & 28.5 & 28.9 & 22.3 & 13.2 & 13.1 & 18 & 24 & 24.9 \\
\hline 20.7 & 23.5 & 29.3 & 30.5 & 23.8 & 13.9 & 13.4 & 18.3 & 26.7 & 27.8 \\
\hline 20.7 & 27.3 & 31 & 31.3 & 24.7 & 14.4 & 13.5 & 18.6 & 27 & 28 \\
\hline 21 & 28.5 & 31.7 & 31.6 & 26.3 & 14.5 & 14 & 19.3 & 28.1 & 29 \\
\hline 21.3 & 29.2 & 34.2 & 32.2 & 26.4 & 14.6 & 14.1 & 19.4 & 29.5 & 29 \\
\hline 21.4 & 29.3 & 35.1 & 32.4 & 27.1 & 15.1 & 14.3 & 19.7 & 30 & 29.2 \\
\hline 23.1 & 30 & 37.1 & 33.2 & 27.1 & 15.1 & 14.5 & 21.1 & 30 & 30 \\
\hline 24.1 & 31.2 & 38.4 & 33.7 & 28.5 & 16.2 & 14.8 & 22 & 30.1 & 30.5 \\
\hline
\end{tabular}


Appendix 5. Lamina measurements ( $\mathrm{mm}$ ) for 95 leaves of Oreothamnus rosmarinifolius from a single population at Mt. Arthur (Venter 13796).

\begin{tabular}{|c|c|c|c|c|c|c|c|c|c|c|}
\hline Length & 16.92 & 18.47 & 21.24 & 19.18 & 16.3 & 21.53 & 20.87 & 21.95 & 14.42 & 14.41 \\
\hline Width & 1.0 & 0.9 & 0.9 & 0.65 & 1.09 & 0.72 & 0.59 & 1.36 & 0.99 & 0.85 \\
\hline Length & 13.51 & 16.84 & 13.59 & 15.63 & 23.41 & 20.4 & 13.49 & 17.4 & 14 & 8.84 \\
\hline Width & 0.82 & 1.1 & 0.87 & 0.92 & 0.82 & 0.69 & 0.91 & 1.02 & 0.94 & 0.82 \\
\hline Length & 11.33 & 12.78 & 20 & 13.74 & 13.8 & 14.56 & 14.97 & 15.37 & 15.84 & 17.31 \\
\hline Width & 0.84 & 0.68 & 0.93 & 0.75 & 0.82 & 0.83 & 0.76 & 0.81 & 0.91 & 0.98 \\
\hline Length & 26.12 & 12.6 & 10.99 & 13.93 & 11.14 & 19.73 & 21.12 & 20.92 & 19.65 & 20.43 \\
\hline Width & 0.91 & 0.79 & 0.8 & 1.1 & 0.62 & 1.0 & 0.9 & 0.83 & 1.29 & 1.08 \\
\hline Length & 22.75 & 21.24 & 14.62 & 23.81 & 20.24 & 18.24 & 20.93 & 28.95 & 29.2 & 30.81 \\
\hline Width & 1.07 & 1.43 & 1.0 & 1.2 & 1.1 & 0.83 & 0.95 & 0.95 & 0.93 & 0.89 \\
\hline Length & 28.05 & 26.69 & 23.35 & 21.83 & 30.21 & 33.17 & 31.03 & 28.27 & 28.42 & 27.98 \\
\hline Width & 0.95 & 1.23 & 0.8 & 0.98 & 1.09 & 1.03 & 1.01 & 1.02 & 1.15 & 0.87 \\
\hline Length & 30.54 & 29.49 & 37.36 & 38.01 & 35.06 & 32.2 & 29.73 & 28.33 & 31.7 & 28.31 \\
\hline Width & 1.12 & 1.0 & 1.11 & 0.88 & 1.11 & 0.99 & 1.08 & 0.87 & 0.9 & 0.71 \\
\hline Length & 31.26 & 32.62 & 28.13 & 33.13 & 30.5 & 19.7 & 19.54 & 24.34 & 25.81 & 27.33 \\
\hline Width & 1.0 & 0.92 & 0.9 & 0.74 & 0.7 & 0.6 & 0.63 & 0.64 & 0.67 & 0.66 \\
\hline Length & 21.52 & 22.97 & 28.18 & 25.9 & 27.44 & 13.77 & 14.08 & 13.15 & 14.87 & 14.92 \\
\hline Width & 0.74 & 0.65 & 0.63 & 0.51 & 0.6 & 0.7 & 0.74 & 0.66 & 0.74 & 0.73 \\
\hline Length & 13.62 & 16.06 & 11.46 & 13.21 & 12.13 & - & - & - & - & - \\
\hline Width & 0.66 & 0.64 & 0.68 & 0.67 & 0.74 & - & - & - & - & - \\
\hline & & & & & & & & & & \\
\hline
\end{tabular}

Appendix 6. Oreothamnus urvilleanus. Leaf measurements $(\mathrm{mm})$ for 37 leaves from the Kaiteriteri population and 11 leaves from the Whangamoa Saddle population.

\begin{tabular}{|l|c|c|c|c|c|c|c|c|c|c|c|}
\hline Kaiteriteri population \\
\hline Length & 110 & 87 & 96 & 48 & 129 & 117 & 64 & 80 & 94 & 61 & \\
\hline Width & 0.63 & 0.88 & 0.59 & 0.65 & 0.76 & 0.94 & 0.91 & 1.06 & 0.93 & 0.68 & \\
\hline Length & 61.2 & 117 & 118 & 81.1 & 74 & 69 & 86.2 & 75 & 55.8 & 42.2 & \\
\hline Width & 0.85 & 0.88 & 0.55 & 1.06 & 0.7 & 0.8 & 1.02 & 0.71 & 0.42 & 0.84 & \\
\hline Length & 111 & 60 & 73 & 115 & 92 & 82 & 70 & 94.1 & 84 & 83 & \\
\hline Width & 1.08 & 0.69 & 0.74 & 0.76 & 1.24 & 1.12 & 0.83 & 0.54 & 0.74 & 0.93 & \\
\hline Length & 111 & 89 & 80 & 107 & 65 & 61 & 72.2 & & & & \\
\hline Width & 1.01 & 0.75 & 1.05 & 1.05 & 0.94 & 1.04 & 0.88 & & & & \\
\hline \\
Whangame & 09 & & & & & & & & \\
\hline Saddle population & & & & & & & \\
\hline Length & 101 & 156 & 119 & 131 & 121 & 105 & 119 & 116 & 111 & 117 & 127 \\
\hline Width & 1.05 & 0.93 & 1.19 & 1.02 & 0.99 & 0.92 & 0.81 & 0.98 & 0.96 & 0.97 & 1.05 \\
\hline
\end{tabular}


Appendix 7. Oreothamnus pronus. Leaf measurements $(\mathrm{mm})$ for 15 leaves from Dun Mountain (Venter 13786) and 15 leaves from Foggy Peak (Venter 13755).

\begin{tabular}{|c|c|c|c|c|c|c|c|}
\hline \multicolumn{3}{|c|}{ Dun Mountain } & \multicolumn{3}{|c|}{ Foggy Peak } & & \\
\hline Length & Width & $\mathrm{I}: \mathrm{w}$ & Length & Width & $\mathrm{I}: \mathrm{w}$ & & \\
\hline & & & & & & Mean & 8.686666667 \\
\hline 17.7 & 0.87 & 20.34 & 7.8 & 0.7 & 11.14 & Standard Error & 0.404697026 \\
\hline 18.7 & 1.23 & 15.2 & 6.4 & 0.6 & 10.66 & Median & 8.71 \\
\hline 16 & 0.9 & 17.77 & 5 & 1 & 5 & Mode & 7 \\
\hline 18.15 & 0.79 & 22.97 & 7 & 1 & 7 & Standard Deviation & 1.56738484 \\
\hline 17.4 & 1.07 & 16.26 & 5.9 & 0.7 & 8.42 & Sample Variance & 2.456695238 \\
\hline 18 & 1.24 & 14.51 & 6.8 & 0.7 & 9.71 & Kurtosis & 0.921335891 \\
\hline 13.3 & 0.85 & 15.64 & 6.4 & 0.7 & 9.14 & Skewness & -0.716978886 \\
\hline 15.7 & 0.76 & 20.65 & 6.1 & 0.7 & 8.71 & Range & 6.14 \\
\hline 16.2 & 0.73 & 22.19 & 8 & 1 & 8 & Minimum & 5 \\
\hline 18.6 & 0.82 & 22.68 & 5.2 & 0.6 & 8.66 & Maximum & 11.14 \\
\hline 16 & 0.7 & 22.85 & 8 & 1 & 8 & Sum & 130.3 \\
\hline 15.3 & 0.7 & 21.85 & 7 & 1 & 7 & Count & 15 \\
\hline 21.8 & 0.79 & 27.59 & 7.9 & 0.8 & 9.87 & Largest(1) & 11.14 \\
\hline 15 & 0.8 & 18.75 & 5.9 & 0.6 & 9.83 & Smallest(1) & 5 \\
\hline 20 & 0.8 & 25 & 5.5 & 0.6 & 9.16 & Confidence Level(95.0\%) & 0.867989565 \\
\hline
\end{tabular}

Appendix 8. Cladistic data matrix.

Andersonia
Cosmelia
Sprengelia
acerosus
alticola
arboreus
balansae
cosmelioides
densus
filifolius
fiordense
fit_geraldii
frondosus
elegantissimum
involucratum
kirkii
latifolium
lessonianus
cockayneanus
longifolius
mackeeanum
macrantbum
marmoricola
menziesii
milliganii
minimus

0000- 00000 0010- 0000000010000000 0000- 00000 0010- 0000000000000100 0000- 00000 1010- 0000000010000000 $00010110002110-000000010-000100$ 0100-00100201111111101111100001 $001101100021110000000010-000100$ 0100-0010021111011110111110010 1 0000- 00110011110111101111100001 $10011100100110-00000$ 0010- 001100 $000111000021110000000010-000100$ 0000- 00100210110111101111100101 0000-0010121111011110111110001 1 0001110000 2110- $000000010-001100$ 0000- 00100211110111101111100121 0000- 00100211110111111011100121 0010010000 2100- $000000010-001100$ 0000-0010021111011110111110012 1 $001111000021110000000010-000100$ $001111100021110000000010-000100$ $001111000021110000000010-000100$ 0100- 01100211110111101111100101 0000- 00100211110111101111100001 $100111100021110000000010-001100$ 0000-00100210110111101111 100101 0000- 00101211111111101111100021 $10011100101110-00000$ 0010- 001100 


muscoides
oceanicum
oliveri
ophioliticus
ouaiemense
palustris
patens
pearsonii
politus
pronus
prostratus
pubescens
ramosum
recurvus
rosmarinifolius
sayeri
scoparius
secundum
septentrionalis
sinclairii
strictum
subulatus
townsonii
traversii
trimorphus
urvillianus
verticillatum
Scapitatum
Sdracophylloides
Sdrummondii
Sgracilis
Sparviflora
Ssquarrosa
Racerosa
Ralpina
Rcontinentis
Rdracophylla
Rgunnii
Rmilligunnii
Rpandanifolia
Rprocera
Rscoparia
Rsprengelioides
Rvictoriana

$10011100101110-000000010-001100$ 0000-00100211110111101111100101 $001111000021110000000010-000100$ $000111100021110000000010-000100$ 0000-00100211110111101111100101 0001110010 2110- 00000 0010- 000100 $001001100021110000000010-000100$ 00011100002101000000 0010- 001100 $10011100101110-000000010-001100$ 1001110000 2110- $000000010-001100$ $10011100101110-00000$ 0010- 001100 $001001100021110000000010-000100$ 0000- 00100211110111101111100101 $000111100021110000000010-000100$ 0001110000 2010- 00000 0010- 001100 0000- 00100211110111101111100121 $000111101021110000000010-000100$ 0000-00100211110111101111100001 $001111100021010000000010-000100$ $001111000021110000000010-000100$ 0010-00100211110111101111100101 $001110001021110000000010-000100$ 0000- 00100210110111101111100121 0000-00100211110111101111100121 $001111100021110000000010-000100$ $000111000021110000000010-000100$ 0000- 00100211110111111111100121 0000- 00100 2010- 0000000111000100 0000- 00100 2010- 0000000111000100 0000- 00100 2010- 0000000111000100 0000- 00100 2010- 0000000111000100 0000- 00100 2010- 0000000111000100 0000- 00100 2010- 0000000111000100 0000- 00100 2000- 0001000110010020 0000- 00100211110111100110110020 0000- 00100201110111100110110020 0000- 00100211110111100110110020 0000- 00100200110111100110110020 0000- 00100 2000- 0011000110010020 0000- 00100211110111100110110020 0000- $001002110-0011000110010020$ 0000- 00100200110111100110110020 0000- 00100 2000- 0011000110010020 0000-00100200110111100110110020 